\title{
RESPONSE TO MANAGEMENT STRATEGIES IN YOUNG- GROWTH GIANT SEQUOIA STANDS AT MOUNTAIN HOME DEMONSTRATION STATE FOREST - REMEASUREMENT TWENTY YEARS AFTER TREATMENT
}

\author{
A Thesis \\ presented to \\ the Faculty of California Polytechnic State University, \\ San Luis Obispo
}

\author{
In Partial Fulfillment \\ of the Requirements for the Degree \\ Master of Science in Forestry Sciences
}

by

Joshua Soderlund

December, 2011 
(C) 2011

Joshua Soderlund

ALL RIGHTS RESERVED

Page ii 
TITLE:

AUTHOR:

DATE SUBMITTED:

COMMITTEE CHAIR:

COMMITTEE MEMBER:

COMMITTEE MEMBER:
Response to Management Strategies in YoungGrowth Giant Sequoia Stands at Mountain Home Demonstration State Forest - Remeasurement Twenty Years After Treatment

Joshua Soderlund

December, 2011

Dr. Douglas D. Piirto, Department Head Natural Resources Management and Environmental Sciences Department

Dr. Samantha J. Gill, Professor

Natural Resources Management and Environmental Sciences Department

Dr. Scott L. Stephens, Associate Professor Environmental Science, Policy and Management Department, University California, Berkeley 


\begin{abstract}
Response to Management Strategies in Young-Growth Giant Sequoia Stands at Mountain Home Demonstration State Forest - Remeasurement Twenty Years After Treatment Joshua Soderlund
\end{abstract}

There is limited information on how young-growth giant sequoia (Sequoiadendron giganteum [Lindl.] Buchholz)/mixed conifer stands respond to forest management strategies. An applied research study was initiated in 1989 when 35 approximately 0.1 acre (0.04 hectare) plots were installed in six young-growth giant sequoia/mixed conifer stands. The objective of this study was to determine if there was a difference after 20 years between treatments (a) thin only, (b) thin and prescribe burn, and (c) control in terms of the effect on overstory growth and yield, understory plants, tree regeneration and downed woody debris. Analysis of variance (ANOVA) for cubicfoot growth over 20 years showed significant difference $(p=0.016)$ between the three treatments. Three diversity indices (richness, evenness, and heterogeneity) showed varied results with environmental factors of slope and elevation major variables affecting plant diversity. Regeneration study showed significant seedlings per acre difference ( $p=$ 0.010) between treatment (b) and treatments (a) and (c) with white fir (Abies concolor [Gord. \& Glend.] Lindl. ex Hildebr.) the majority at 87\%. These collected and analyzed data will benefit Mountain Home Demonstration State Forest along with other forest managers who actively manage giant sequoia stands, whether natural or plantation. 


\section{ACKNOWLEDGMENTS}

This project was made possible by funding from California Department of Forestry and Fire Protection. I would like to thank Helge Eng for guidance and for securing the funding necessary for this project. I would like to thank Jim Kral, the manager at Mountain Home Demonstration State Forest, for the use of the barracks and trailer, and especially forestry technicians Eric Hedge, Damian Bean, Steve Ricchiazzi, and Nick Estrada who helped me collect all of the data.

I would like to thank my committee chairman Dr. Douglas Piirto for all of his support, guidance, and direction for this project. I am thankful for our weekly meeting where we discussed research issues and sometimes just talked about life.

I would like to thank my other committee members Drs. Samantha Gill and Scott Stephens for research help and answering my many questions. I would like to thank Gary Roller for helping me find many of the research plots and responding to my questions. I would like to thank Lori Ann Walters for all of her formatting work and for dealing with my long awkward sentences.

I thank my wife Ruth most of all, for she inspired me to pursue my master's degree and has experienced all the joys and frustrations of graduate school along with me. 


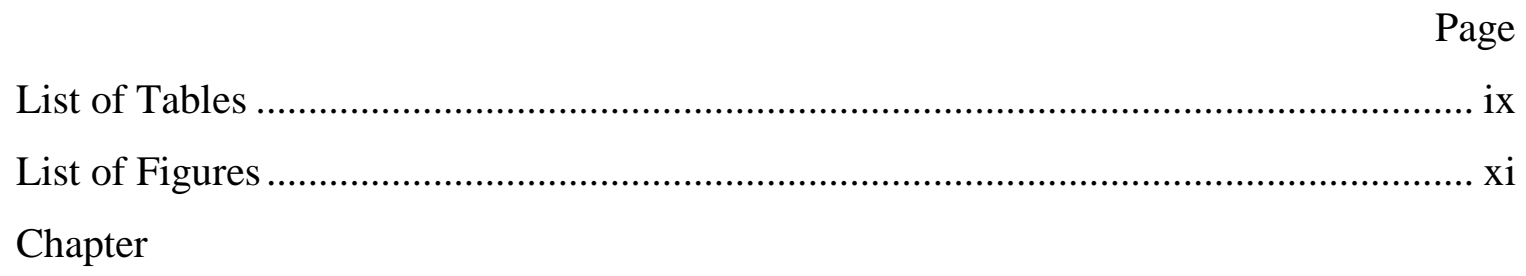

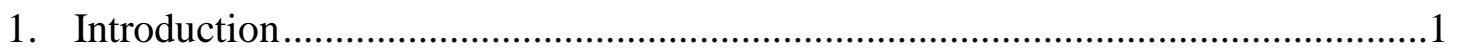

Objective/ Hypothesis Statement .......................................................................

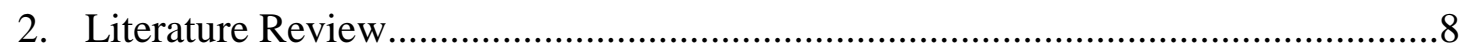

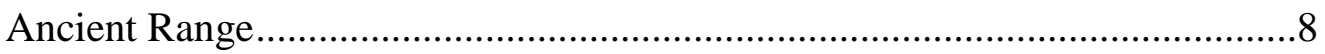

Cultivation Outside Natural Range................................................................9

Ecological Restoration .............................................................................10

Forest Growth .......................................................................................11

Understory Vegetation .............................................................................13

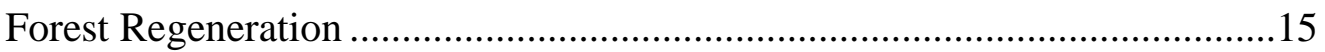

Downed Woody Debris...................................................................................16

3. Methods and Materials.......................................................................................18

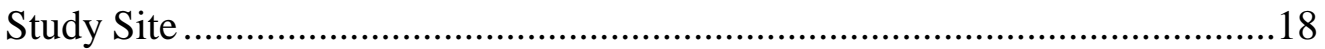

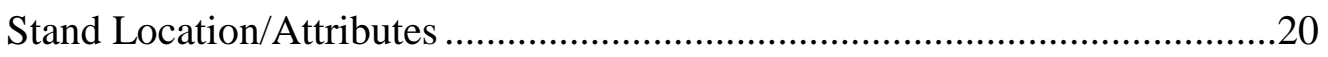

Treatments (Experimental Design) ...................................................................22

Data Collection/Measurement .....................................................................23

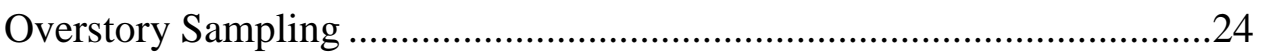

Understory Sampling ...........................................................................26

Regeneration/ Seedlings Sampling .........................................................28

Downed Woody Debris Sampling ............................................................29

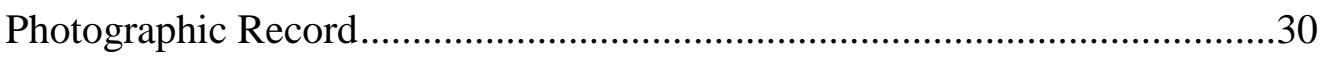

Statistical Analysis ........................................................................................ 
TABLE OF CONTENTS (continued)

Chapter $\quad$ Page

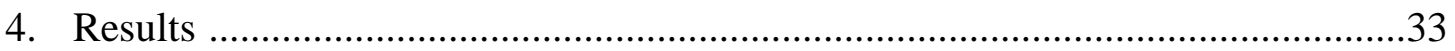

Overstory Growth and Yield Response ...........................................................33

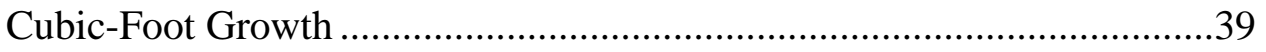

Board-Foot Growth ......................................................................................

Cubic-Foot/ Board-Foot Yield....................................................................44

Periodic Annual Increment Trend 1989-2009 .............................................48

Understory Plant Response ............................................................................49

Understory Plant Functional Groups …………………………………....54

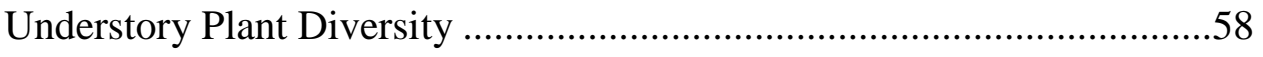

Regeneration/ Seedlings Response ...............................................................61

Downed Woody Debris Response ......................................................................64

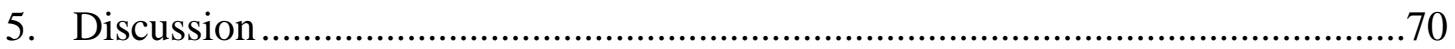

Overstory Growth and Yield Response ..........................................................70

Understory Plant Response ............................................................................73

Regeneration/ Seedlings Response ................................................................76

Downed Woody Debris Response ...................................................................78

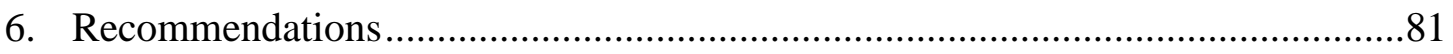

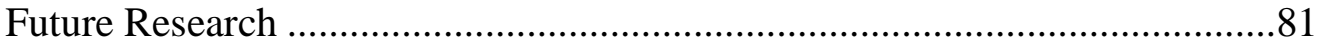

Mountain Home Demonstration State Forest ....................................................82

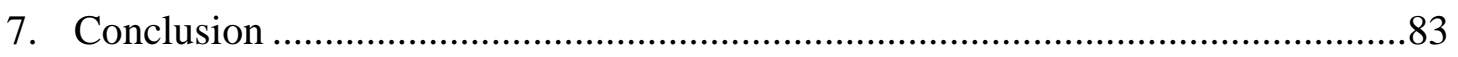

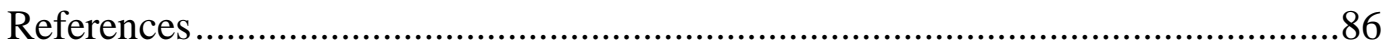

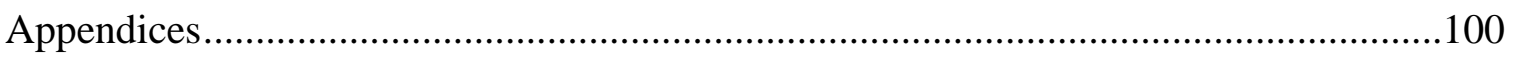

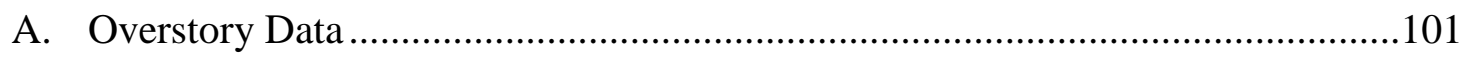

B. DBH Distribution Graphs/Stand Tables .............................................................175

Page vii 


\section{TABLE OF CONTENTS (continued)}

\section{Appendices}

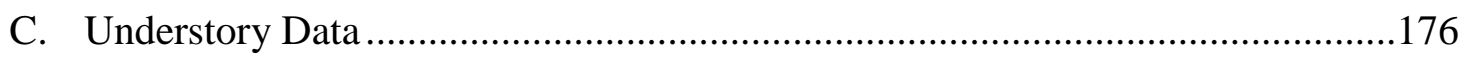

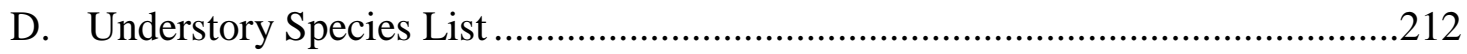

E. Downed Woody Debris Data .........................................................................216

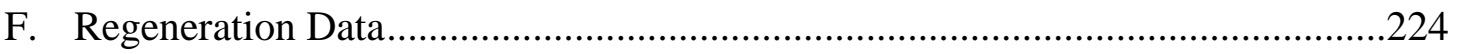

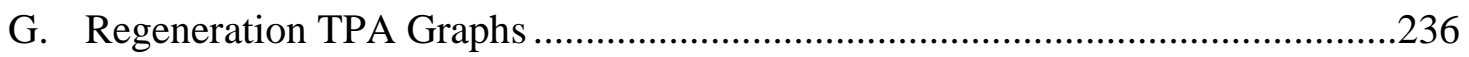

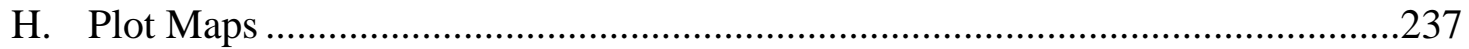

I. Pre/Post Treatment Plot Pictures .....................................................................244

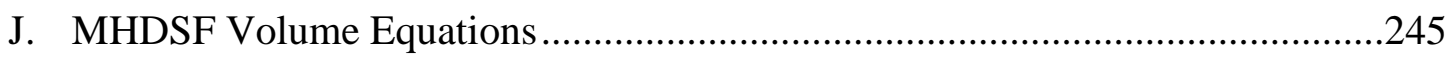

K. Special Investigation of Observed Second-Growth Giant Sequoia Mortality .....247 


\section{LIST OF TABLES}

Table

Page

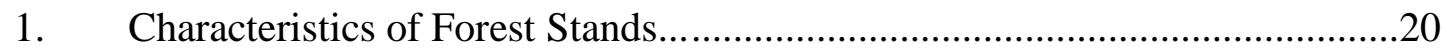

2. Transformations of datasets to meet assumptions for ANOVA ....................32

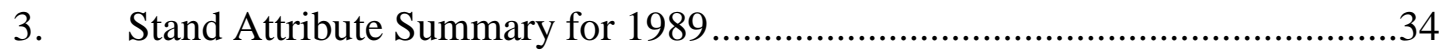

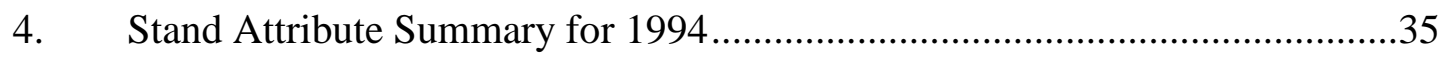

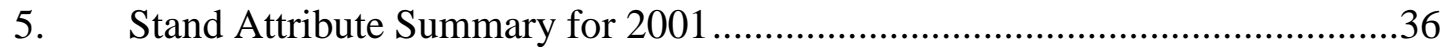

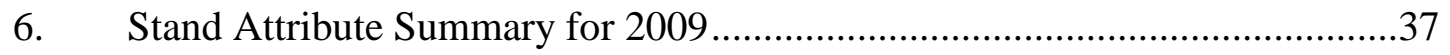

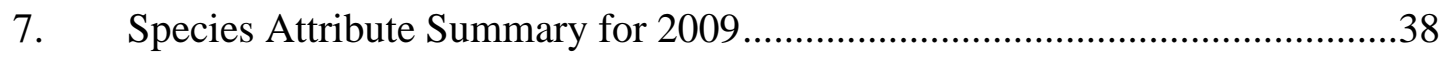

8. Parameter Summary of Significance ….....................................................39

9. Summary Statistics for Cubic-Foot Growth/Acre.........................................40

10. Results of ANOVA for Cubic-Foot Growth from 2001-2009........................40

11. Results of Pairwise Comparison for Cubic-Foot Growth from 2001-2009 ....41

12. Results of ANOVA for Cubic-Foot Growth from 1989-2009........................41

13. Results of Pairwise Comparison for Cubic-Foot Growth from 1989-2009 .....42

14. Summary Statistics for Board-Foot Growth/Acre .....................................43

15. Results of ANOVA for Board-Foot Growth from 2001-2009.......................43

16. Results of ANOVA for Board-Foot Growth from 1989-2009........................44

17. Results of Pairwise Comparison for Board-Foot Growth from 1989-2009....44

18. Summary Statistics for Cubic-Foot Yield/Acre and Board-Foot Yield/Acre

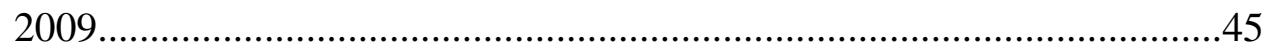

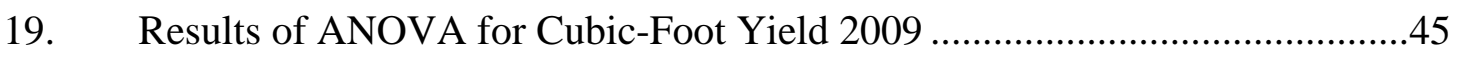

20. Results of Pairwise Comparison for Cubic-Foot Yield 2009 .........................46

21. Results of ANOVA for Board-Foot Yield 2009 ........................................46

22. Results of Pairwise Comparison for Board-Foot Yield 2009 .......................47

23. Percent Volume Growth Between Treatments from 1989-2009 ....................47 


\section{LIST OF TABLES (continued)}

Table

24. Understory Plant Species: Frequency (Number of Plot Occurrences

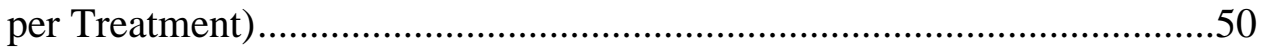

25. Understory Plant Species: Density (Average Stems per Acre Per

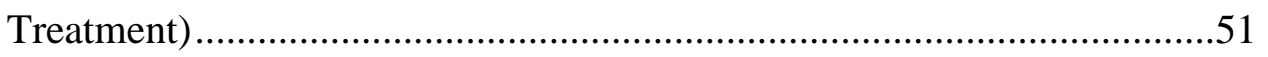

26. Understory Plant Species: Abundance (Average Percent Cover per

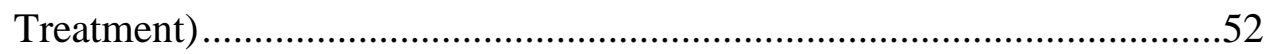

27. Understory Plant Species Aggregated by Functional Group per Treatment

and Year (standard errors in parentheses) ..............................................55

28. 2009 Summary Table Diversity Indices by Treatment

(standard errors in parentheses) .........................................................58

29. 2009 Control Summary Table for Diversity Indices by Stand

(standard errors in parentheses) .......................................................59

30. Summary Statistics for Seedlings per Acre 2009 .....................................61

31. Results of ANOVA for Seedlings per Acre 2009 .....................................62

32. Results of Pairwise Comparison for Seedlings per Acre 2009 ......................62

33. Summary Table Downed Woody Debris and Litter Levels per Treatment

by Year (standard errors in parentheses) .............................................66 


\section{LIST OF FIGURES}

Figure

1. Location of Giant Sequoia Groves..........................................................

2. Mountain Home Demonstration State Forest Location Map...........................19

3. Mountain Home Demonstration State Forest Stands Map .............................21

4. Periodic Annual Increment (ft. ${ }^{3}$ /acre/year) from 1989-2009 ...........................48

5. Periodic Annual Mortality (ft. ${ }^{3}$ /acre/year) from 1994-2009 ............................49

6. Frequency of Understory Plant Functional Groups by Treatment and Year ...56

7. Species Richness vs. Elevation (m) and Slope (\%) ...................................60

8. Evenness: Berger-Parker Index vs. Elevation (m) and Slope (\%) ..................60

9. Heterogeneity: Simpson Index vs. Elevation (m) and Slope (\%) ...................60

10. Percent Seedling Composition in Seedlings per Acre 2009 ..........................63

11. Seedlings per Acre on Thin Only, Thin and Burn, and Control Plots .............64

12. Downed Woody Debris - Surface (1, 10, 100 hr.) Fuels in 2009 (columns with same letters do not differ at the 0.05 level). .................................66

13. Downed Woody Debris on Thin Only Plots in 2001 and 2009 .....................68

14. Downed Woody Debris on Thin/Burn Plots in 2001 and 2009 .....................68

15. Downed Woody Debris on Control Plots in 2001 and 2009 (asterisk indicates difference between 2001 and 2009 value at 0.05 level)

16. Change in Shrub Abundance (percent cover) and Density (stems per acre) on the same Thin and Burn Plot comparing 1989 (A) and 2009 (B) at

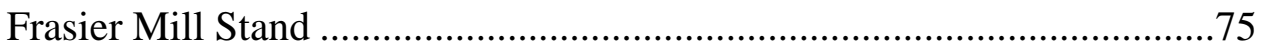

17. Second-Growth Giant Sequoia Mortality Poster ......................................249 


\section{CHAPTER 1}

Introduction

The giant sequoia, big tree, sierra redwood (Sequoiadendron giganteum [Lindl.] Buchholz) (syn. Sequoia gigantea [Lindl.] Decne) is a tree that has captured the admiration of society in general, and John Muir in particular when he wrote, "Do behold the King in his glory, King Sequoia! Behold! Behold! seems all I can say” (Muir, 1870). These long lived trees, reaching ages of 2,000 to 3,000 years, can grow to heights of 250 feet $(76 \mathrm{~m})$ and diameters of 20 feet $(610 \mathrm{~cm})$. The largest recorded giant sequoia is the General Sherman Tree located within Sequoia National Park’s Giant Forest with a height of 274.9 feet $(83.8 \mathrm{~m})$ and circumference of 102.6 feet $(31.3 \mathrm{~m})$, for a total volume of 52,508 cubic-feet (Flint, 2002; Rigg, 2001; Schubert, 1957). The physical characteristics of this evergreen is a decurrent growth form having a young conical and old irregular crown of green awl-like foliage, red-brown fibrous bark, and small 1.6 - 3.5 inches $(4-9$ cm) elliptical cones (Hickman, 1993). The requirements for regeneration and growth of giant sequoia are adequate sunlight and soil moisture as well as mineral soil free of debris plus a seed source. Fires can provide an adequate seed bed and growth conditions by removing duff and competing vegetation (Shellhammer and Shellhammer, 2006;

Stephens et al., 1999). Giant sequoia’s sacred object status and its limited natural range have restricted research using active stand management (Piirto et al., 1997). 
Giant sequoia trees naturally occur in 65 to 75 isolated groves, according to different authorities Rundel (1972b) and Willard (1994), (Figure 1) located within a 270 miles (420 km) long and about 15 miles (24 km) wide strip in the mixed-conifer forest on the west-facing slope of the Sierra Nevada Mountains of California. The northern limit is the small Placer County Grove on the Middle Fork of the American River, Tahoe National Forest, Placer County, and the southern limit is the Starvation Creek Grove on Starvation Creek (Deer Creek watershed), Sequoia National Forest, Tulare County (Rundel, 1972b; Schubert, 1957; Willard, 1994).

Society has shown that it values the giant sequoia as an important element of the environment both scientifically and socially beginning as early as 1864, just 12 years after its discovery, with the protection of the Mariposa Grove in Yosemite (Basey and Basey, 1998). These early protective tendencies did not stop the aggressive logging of giant sequoia starting in 1856 thru 1935 and continuing less aggressively until the 1950s. The commitment of California's citizens to giant sequoia protection circa late 1880s resulted in formation of Sequoia, General Grant, and Yosemite Parks in 1890. Between 1900 and 1975 the remaining groves that are on public land were acquired, notably Calaveras Big Trees in 1909, Nelder Grove in 1928, Converse Basin in 1935, Redwood Mountain Grove in 1940, and Mountain Home in 1946 (Leisz, 1992; Tweed, 1992). Presently, approximately $90 \%$ of giant sequoia groves are on public land where they are preserved and protected from logging and fire (Hartesvelt, 1975). Agency and percentage managed are as follows: federal (United States Forest Service 49\%, National Park Service 28\%, Bureau of Land Management $<1 \%$ ), state and county (Cal Fire, State 


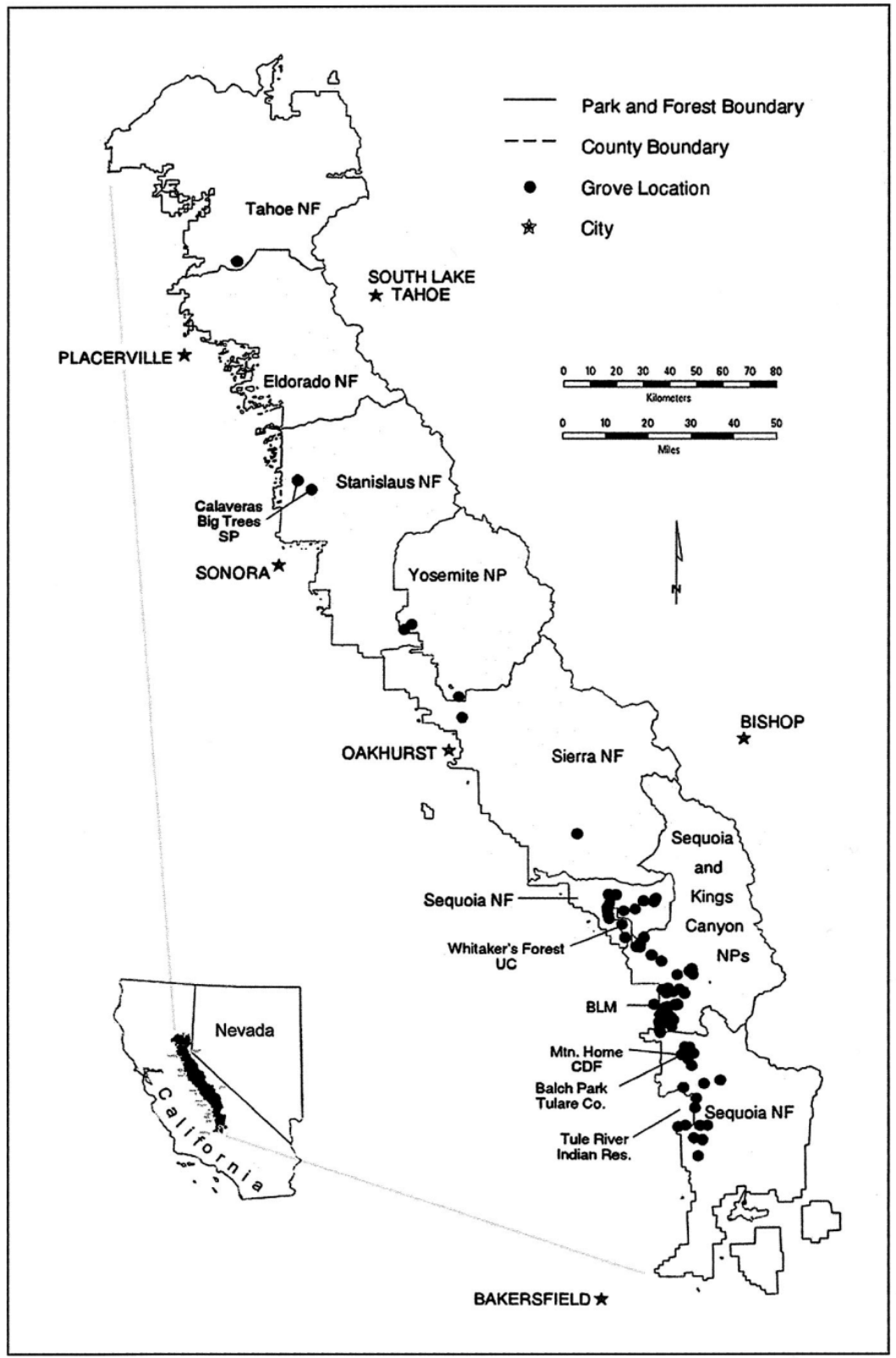

Fig. 1. Location of Giant Sequoia Groves (from Aubert, 1996). 
Parks and Recreation, University of California and Tulare County 11\%) and tribal (Tule Indian Reservation 4\%) (Willard, 1994).

People from around the world travel to the Sierra Nevada Mountains of California and stand in awe of the old-growth giant sequoia trees. In order for future generations to have the same privilege, the groves must continue to produce old-growth trees. Foresters agree that regeneration is crucial, yet recommend many different methods to provide the mineral soil conditions and canopy openings; essential elements for seedling establishment and growth (Piirto et al., 1997). Giant sequoia grove management involving prescribed fire started in the National Park Service as early as the 1960s (Piirto and Rogers, 1999). Throughout the 1980s the Forest Service grove management included prescribed fire and timber harvests, which caused public outcry within the environmental community and led to a Mediated Settlement Agreement (MSA) for Sequoia National Forest in 1990 (Piirto et al., 1997). The (MSA) agreement ceased timber harvests in the groves and provided a general objective "to protect, preserve, and restore the groves for the benefit and enjoyment of the present and future generations” (USDA Forest Service, 1990).

The present management of giant sequoia ranges from custodial protection (i.e., fire suppression and controlling recreational impacts), to stand management (i.e., the selective removal of trees followed by prescribed burning, or prescribed burning only) (Benson, 1986; Fontaine, 1986; Harrison, 1986; Heald, 1986; Parsons and Nichols, 1986; Rogers, 1986; Roller, 2004). A trend toward ecosystem management instead of stand management is occurring which takes into consideration biological, physical, and social/cultural dimensions to reach desired condition (Piirto and Rogers, 2002). What are 
the best management practices for the perpetuation of giant sequoia from seedling to specimen tree? Much remains to be determined and that is why sound scientific research is important.

One of the few long-term studies investigating how young-growth giant sequoia stands will react to different management treatments is the "Response to Management Strategies in Giant Sequoia Forests” study first established by Dr. Robert E. Martin and Mr. Donald P. Gasser in 1989 at Mountain Home Demonstration State Forest, Tulare County, California. Their initial proposal submitted to the California Department of Forestry and Fire Protection sought funding to initiate long-term studies evaluating the effect of three treatments: a) thinning only, no burning; b) thinning then burning; and c) control, no thinning, no burning) on overstory growth and yield, understory vegetation, downed woody debris, and regeneration. Funding was approved and six young-growth giant sequoia stands at Mountain Home Demonstration State Forest were partially thinned and burned in a controlled study in the fall of 1989 and spring and fall of 1990. Inventory plots were established and measured within the six stands during this same time frame. Overstory and understory data were collected, yet the initial downed woody debris dataset was incomplete. Regeneration data were not measured until 2001 and 2009 (Martin and Gasser, 1989; Roller, 2001).

There have been three subsequent remeasurements of these data. The 1994 data are presented in Todd Bates’ 1998 master's thesis which focused on diameter and height growth. There was significant difference in diameter growth between the treatments with average of 0.34 inch $(0.86 \mathrm{~cm})$ of diameter growth per year and the control with average of 0.12 inch $(0.30 \mathrm{~cm})$ of diameter growth per year. The height growth was significantly 
different between the treatments with average of 1.5 feet $(0.46 \mathrm{~m})$ per year and the control with average of 0.9 feet $(0.27 \mathrm{~m})$ per year. The understory plant data were collected but incomplete and downed woody debris data were not collected (Bates, 1998). The 2001 data are presented in Gary Roller’s 2004 master’s thesis and his 2001 senior project which compiled the 1989, 1994, and 2001 raw data. Roller focused on growth and yield and found that the cubic-foot and board-foot growth over the 12 year period were both significantly different for both treatments compared to control. Understory plant data were collected but not fully analyzed. Roller initiated the regeneration study and found that seedlings per acre were significantly greater on the thin and burn plots compared to the thin and control plots. Roller found that the 1, 10, $100 \mathrm{hr}$ fuel levels were significantly different between thin only and both thin and burn and control (Roller, 2001; Roller, 2004). The 2009 data are presented in Joshua Soderlund's 2011 master’s thesis. 


\section{Objective/Hypothesis Statement}

The objectives of this study are to conduct a 20 year remeasurement of younggrowth giant sequoia stands' response to different management treatments: a) thinning only, b) thinning and prescribed burning, and c) control, no thinning or prescribed burning; specifically, to determine the treatments' effects upon the overstory growth and yield response of young growth giant sequoia and other mixed conifer species, the understory plant response, downed woody debris response, and the regeneration response of giant sequoia and other mixed conifer species. Data from this fourth measurement will be compared with past measurements done in 1989, 1994, and 2001 to determine whether or not trends are developing.

The null hypothesis is that there will be no significant difference between treatment and control in relation to overstory growth and yield, understory plant response, downed woody debris levels, and tree regeneration; $\mathrm{H}_{0}$ : treatment $=$ control and $\mathrm{H}_{\mathrm{A}}$ : treatment $\neq$ control. 


\section{CHAPTER 2}

\section{Literature Review}

A review of key literature related to giant sequoia and its management is needed to lay a foundation for the present study. Key findings of previous studies are in relation to the topics of ancient range, cultivation outside natural range, ecological restoration, forest growth, understory vegetation, forest regeneration, and downed woody debris.

\section{Ancient Range}

The genus Sequoiadendron/Sequoia was once widely spread across North America, Europe, and Asia Minor during the Tertiary period, and fossils within coal have been found in Montana, central Europe, Croatia, and Turkey (Kayac1k et al., 1995; Muller-Stoll, 1947; Spoljaric, 1952; Wilson and Webster, 1946). The closest ancestral species with similar foliage and reproductive structures to S. giganteum was Sequoiadendron chaneyi of the late Tertiary period. S. chaneyi was located in western Nevada within a plant community that has fossil associates similar to those of the present giant sequoia/mixed-conifer community. The migration of the ancient big tree communities westward to the eastern slope, then the summit, and then to the western slope of the Sierra was due to climatic changes in western Nevada. The typical precipitation during the summer of the Tertiary was being replaced by winter precipitation of snow due to cooler winters, while the summer was becoming hot and dry 
during the Quaternary (Axelrod, 1959). S. giganteum pollen from Mono Lake east of the Sierra Nevada showed a decline starting during the transition from the late glacial Pleistocene to the early Holocene (11,000 ya) with the last occurrence during the hot and dry middle Holocene (7,800 ya) (Davis, 1999a). These hot temperatures segregated the big trees to higher elevations with less evaporation and sufficient ground water throughout the year provided by the snow pack (Anderson and Smith, 1994). Prior to the early Holocene (9,000 ya), S. giganteum was abundant at lower elevations along streams that flowed into Tule Lake yet by the middle Holocene they had disappeared (Davis, 1999b; Cole, 1983). Even within its present range area S. giganteum was rare prior to the late Holocene (4,500 ya) when the climate changed to a cooler and wetter regime which allowed for the development of the sequoia-mixed conifer forest (Anderson, 1994; Anderson and Smith, 1994). This perhaps continuous big tree forest was thought to be disturbed by the glaciation of the Sierra Nevada with an absence of big trees where the glaciers carved valleys and canyons. This would have isolated the remaining groves in the refugia areas in between (Muir, 1876). The more recent theory is that during the hot period of the early and middle Holocene the giant sequoia's range retreated to mesic areas for refuge and then slowly expanded during the late Holocene creating the isolated nature of groves (Anderson, 1994; Anderson and Smith, 1994).

\section{Cultivation Outside Natural Range}

Many S. giganteum have been planted outside its limited natural range, primarily as an ornamental in parks and botanical gardens across the United States and many countries around the world, especially across Europe from England to the Black Sea 
region of USSR (Hartesvelt et al., 1975). The giant sequoia had its first exposure outside the United States within London’s Gardeners’ Chronicle in 1853 (Lindley, 1853). Trials were planted in the Crimea and Trans-Caucasus regions of USSR as early as 1858 (Molotkov, 1958; Jaroslavcev, 1963) and a plantation was started in Gottweig, Austria in 1880 (Rannert, 1955). The first true giant sequoia stands in Europe were planted around the turn of the $20^{\text {th }}$ century with the first in Weinheim, Germany, the second at Groenendaal Experiment Station in Belle Etoile, Belgium, and the third at the Domaine Royal in Tervuren, Belgium (Kleinschmit, 1984, as cited in Knigge, 1994). Subsequently during the $20^{\text {th }}$ century, plantations were established and research concerning commercial viability was done in Europe (Afanasijev, 1951; Antipova, 1952; Bonev, 1966; Commonwealth Agriculture Bureaux, 1949-1950; Holubčík, 1960; Jaroslavcev, 1963; Knigge, 1994; Radler, 1956).

\section{Ecological Restoration}

To what reference or natural condition is the forest or landscape being restored and what methods will be applied? The reference condition for the giant sequoia ecosystem is either that of no human influence or pre-Euro-American contact. The National Park Service and many resource managers are using the pre-Euro-American contact as a reference condition (Stephenson, 1999).

Two elements of the ecosystem that are compared to reference condition for restoration are fire regimes and forest structure (species composition, age, size, and arrangement) (Stephenson, 1999). The pre-Euro-American forest condition for giant sequoia ecosystems within Giant Forest, Sequoia National Park had a frequent fire 
regime of approximately two years (Swetnam et al., 2009). The Sierran mixed-conifer forest structure of Teakettle Experimental Forest within Sierra National Forest in 1865 had 67 stems/ha with species composition of 51\% shade tolerant and $49 \%$ shade intolerant. Fire exclusion has caused the forest structure to change at Teakettle to be 469 stems/ha with species composition of $84 \%$ shade tolerant and $14 \%$ shade intolerant in 2000 (North et al., 2007).

The process of restoring the ecosystem to the natural condition is a debate between structural restoration, which uses fire only after forest structure is restored mechanically, and process restoration, which says only fire is necessary. The use of fire without any prior mechanical removal may restore the pre-Euro-American structure of sequoia groves (Stephenson, 1999). A study comparing stand structure for mixed-conifer forest using combinations of thinning, overstory and understory, and burning treatments against a reconstruction of the same forest as it would have looked in 1865 was done at Teakettle Experimental Forest. The study found that the treatment of understory thinning and prescribed burn produced a spatial pattern closest to historical conditions (North et al., 2007).

\section{Forest Growth}

Management treatments such as prescribed burning and mechanical thinning can affect the continued growth after regeneration has been established. The continued height growth for giant sequoia is dependent on elevated light levels (Shellhammer and Shellhammer, 2006). Comparison of 0.1 to 1.0 ha openings after three years of sapling growth showed an increase in height growth as opening size increased with giant sequoia 
having the highest mean height compared to other species; incense cedar (Calocedrus decurrens Torr.), Douglas-fir (Pseudotsuga menziesii [Mirb.] Franco), ponderosa pine (Pinus ponderosa Dougl. Ex Laws.), white fir (Abies concolor [Gord. \& Glend.] Lindl. ex Hildebr.) and sugar pine (Pinus lambertiana Dougl.). Height growth for giant sequoia was correlated to light availability and water (York et al., 2003). Between 7 and 20 foot spacing significantly affected the early height growth development of giant sequoia. A positive linear relationship between spacing and height, crown diameter, and stem diameter was observed. At year seven, the 14 - 20 foot spacing had trees with 45 - 78\% greater diameter growth and 29 - 67\% greater height compared with trees at 7 - 10 foot spacing, evidence of less inter tree competition for light, moisture, and nutrients (Heald and Barrett, 1999).

A similar study by Perraca and O’Hara (2008) showing relationship between tree growth components and tree growing space for three species; giant sequoia, ponderosa pine, and Douglas-fir had varied growing space per tree from $4.1 \mathrm{ft}^{2}$ to $411.0 \mathrm{ft}^{2}$. A significant relationship for all three species were observed between tree growing space and tree height, diameter and live crown ratio; all increased as space increased. Giant sequoia had its greatest volume with growing space of $103.2 \mathrm{ft}^{2}$ while Douglas-fir and ponderosa pine had greatest volume with growing space of $26.0 \mathrm{ft}^{2}$ and $10.3 \mathrm{ft}^{2}$ (Perraca and O'Hara et al., 2008). There is very little information on how natural young-growth giant sequoia stands respond to management strategies. 


\section{Understory Vegetation}

Species diversity and its relationship to forest management have been an important topic for the last 35 years since the National Forest Management Act of 1976 stated that the provision of plant and animal community diversity should be a main concern of the USDA Forest Service (Lewis et al., 1988; Roberts and Gilliam, 1995). The northern hemisphere temperate forests, including the mixed conifer forest of California’s Sierra Nevada Mountains, have a rich amount of plant species and the majority are within the understory plant community (Halpern and Spies, 1995; Shevock, 1996). These forests on private lands are actively managed for timber production involving activities ranging from clearcuts to selective single tree harvest along with site preparation and regeneration planting (Battles et al., 2001). How is understory plant diversity measured and how do these management techniques affect the understory plant diversity?

The three approaches to measuring species diversity are species richness, evenness, and heterogeneity (Krebs, 1999). Species richness describes the number of species in the area or community to be measured (McIntosh, 1967). Evenness means measuring the quantity of each species and then comparing those numbers against a community with all species quantities equalized (Magurran, 1988; Krebs, 1999). Heterogeneity combines species richness and evenness stating that a community with five species having equal quantity has greater diversity than that same community of five species with one dominant species having the majority of quantity (Krebs, 1999). Understory plant diversity has been assessed in relation to specific treatments of thinning 
prescriptions, prescribed burning techniques, and various combinations of each. For example management regimes of plantation, shelterwood, group selection, and single-tree had greater average species richness and Simpson index values compared to reserve/control at a study conducted at Blodgett Forest Research Station, with significantly greater diversity values for plantation and shelterwood than for reserve/control (Battles et al., 2001). Another study at Teakettle Experimental Forest within the mixed conifer forest type showed that the burn and understory thin treatment produced significantly greater species richness than the control, burn only, understory thin only, and overstory thin only treatments (Wayman and North, 2007). Green tree retention treatment, leaving 5 to 60 large trees per hectare, had significantly greater average species richness compared to intact forest/control along with highest BergerParker evenness value representing more evenly distributed species (North et al., 1996). A prescribed burn study showed one year after late season burn there was no significant difference in species richness compared to unburned control, while one year after early season burn there was significantly greater species richness compared to unburned control (Knapp et al., 2007). A mixed conifer study at Grand Canyon National Park found a significant difference in species richness between burned plots with greater richness and unburned plots with lesser richness (Huisinga et al., 2005). The general disturbance created by different treatments has positive effects upon species diversity by providing regeneration conditions for many species, yet specific regeneration conditions are needed for giant sequoia (Rundel, 1972a). 


\section{Forest Regeneration}

The requirements for regeneration of giant sequoia are adequate sunlight and soil moisture as well as mineral soil free of debris plus a seed source. Fires can provide an adequate seed bed and growth conditions by removing duff and competing vegetation, and providing canopy openings (Hartesveldt et al., 1975; Shellhammer and Shellhammer, 2006; Stephens et al., 1999). The average seedling survival rate 34 and 35 years later for a study done in Kings Canyon National Park between the surface treatments of burn pile and non-burn pile was 19\% to 1\%, respectively (Shellhammer and Shellhammer, 2006). Another study having burn and non-burn treatments showed regeneration was low in broadcast burn and tractor pile and burn plots while absent in the lop-and-scatter plots (Stephens et al., 1999). The variables affecting primarily the establishment and height growth of giant sequoia after experimental burn were soil moisture measured with a moisture meter (Model 200, Aquaterr) and light levels measured with a light meter (Model 250, Li-Cor) (Shellhammer and Shellhammer, 2006). Burn pile seedlings with higher soil moisture and light levels were significantly taller than non-burn pile seedlings with similar soil moisture and light levels (Shellhammer and Shellhammer, 2006). Planted seedlings initial growth was greater on burned substrate than unburned or bare substrate (York et al., 2011). A comparison study with opening sizes small (15m), medium (30m), and large $(61 \mathrm{~m})$ all had a low number of giant sequoia seedlings yet it showed a trend of large openings with the most and small opening with the least seedlings but no significant difference was detected based on opening sizes (Stephens et al., 1999). Seedling height and basal diameter growth increased as gap size increased 
(York et al., 2011). Survival and growth of giant sequoia regeneration requires site disturbance whether provided by natural or human means (Stephenson et al., 1991; York et al., 2011).

\section{Downed Woody Debris}

The fire regime of the giant sequoia mixed-conifer forest type prior to the $1870 \mathrm{~s}$ was high frequency and low intensity small acreage fires (Kilgore and Taylor, 1979). A Redwood Mountain study found that between 1700 and 1875 the fire return interval within a given drainage was two to three years and as area scale decreased the fire return interval increased to 11 to 39 years on individual trees (Kilgore and Taylor, 1979). A recent study at Giant Forest developed a 3,000 year chronology and found a fire return interval of 2.2 years for grove scale that increased to 15.5 years for tree scale (Swetnam et al., 2009). These frequent low intensity fires kept fuel levels low by consuming litter

and downed woody debris, also killing understory tree regeneration which minimized risk of crown fire. Since 1900 with the policy of fire suppression, these low intensity fires have been replaced by high intensity fires over large areas due to accumulation of fuel loads and understory shade tolerant trees (Kilgore and Taylor, 1979).

The fuel load accumulations due to fire suppression vary throughout areas of the giant sequoia mixed-conifer forest. Sixty years of fuel accumulation at Kings Canyon National Park led to 55.89 tons per acre for downed woody debris and 29.1 tons per acre for litter and duff (Parson, 1978). Other studies within Sequoia and Kings Canyon National Parks showed accumulation of between 35.16 and 49.39 tons per acre for downed woody debris and between 52.95 and 55.63 tons per acre for litter and duff 
(Keifer, 1998; Keifer et al., 2006). A predominantly giant sequoia stand at Mountain Home Demonstration State Forest having no fires since 1900 had 3.0 tons per acre for downed woody debris and 33.1 tons per acre for forest floor loads relative equivalent to litter and duff loads. A giant sequoia mixed-conifer stand, predominantly white fir and incense-cedar, with no recorded fire history and having been selectively logged with lopping for slash treatment had 72.4 tons per acre for downed woody debris and 34.0 tons per acre for forest floor loads (Weise et al., 1997). Studies have been done that reintroduced fire into these systems to reduce the heavy fuel loads and dense understory trees which can cause high intensity and damaging fires (Kilgore, 1973).

Prescribed burn studies have recorded the reduction of fuel loads and tracked the accumulation of fuels after the treatment. The Kings Canyon National Park study showed a reduction of $88 \%$ for downed woody fuels and $92 \%$ for litter and duff levels and within seven years the downed woody fuels and litter/duff levels reached 54\% and $45 \%$ of pre-fire levels, which are sufficient levels to support fire (Parson, 1978). Another study showed a total fuel load (downed woody debris, litter and duff) reduction of 75\% immediately after treatment, and ten years later the total fuel load was $66 \%$ of pre-fire level (Keifer et al., 2006). After a prescribed burn the live crown weight of the lower 55 feet $(16.8 \mathrm{~m})$ of stand was reduced from 7.2 to 3.1 tons per acre and the mean height crown base was increased from 3 to 16 feet ( 0.9 to $4.9 \mathrm{~m})$, thus reducing the ladder fuels and risk of a crown fire (Kilgore and Sando, 1975). 


\section{CHAPTER 3}

Methods and Materials

\section{Study Site}

The study site is located at Mountain Home Demonstration State Forest (MHDSF) established in 1946 as the first state forest after land was purchased from the Michigan Trust Company for $\$ 548,762$. The California Department of Forestry and Fire Protection manages the forest with regard to Public Resource Code (PRC) 4631 - 4658 and 4701 - 4703 granting maximum sustainable timber production while providing for public recreation the primary land use at Mountain Home. MHDSF is located in the southern Sierra Nevada Mountain Range in Tulare County, California, northeast of Porterville (36 ${ }^{\circ} 14^{\prime} 23.71$ ” N and $118^{\circ} 40^{\prime} 23.71^{\prime}$ W) (Figure 2). This MHDSF mixedconifer forest is approximately 4,858 acres (1966 ha) located within the drainages of the North Fork of the Tule River and the North Fork of the Middle Fork of the Tule River. The elevation ranges from 4,800 to 7,600 feet (1463 to $2316 \mathrm{~m}$ ). The climate is Mediterranean with dry, warm summers and cold, wet winters along with an average precipitation of 42 inches (1067 mm) per year (CDF, 2010).

Common trees species within MHDSF other than giant sequoia are: incense cedar (Calocedrus decurrens Torr.), white fir (Abies concolor [Gord. \& Glend.] Lindl. ex 


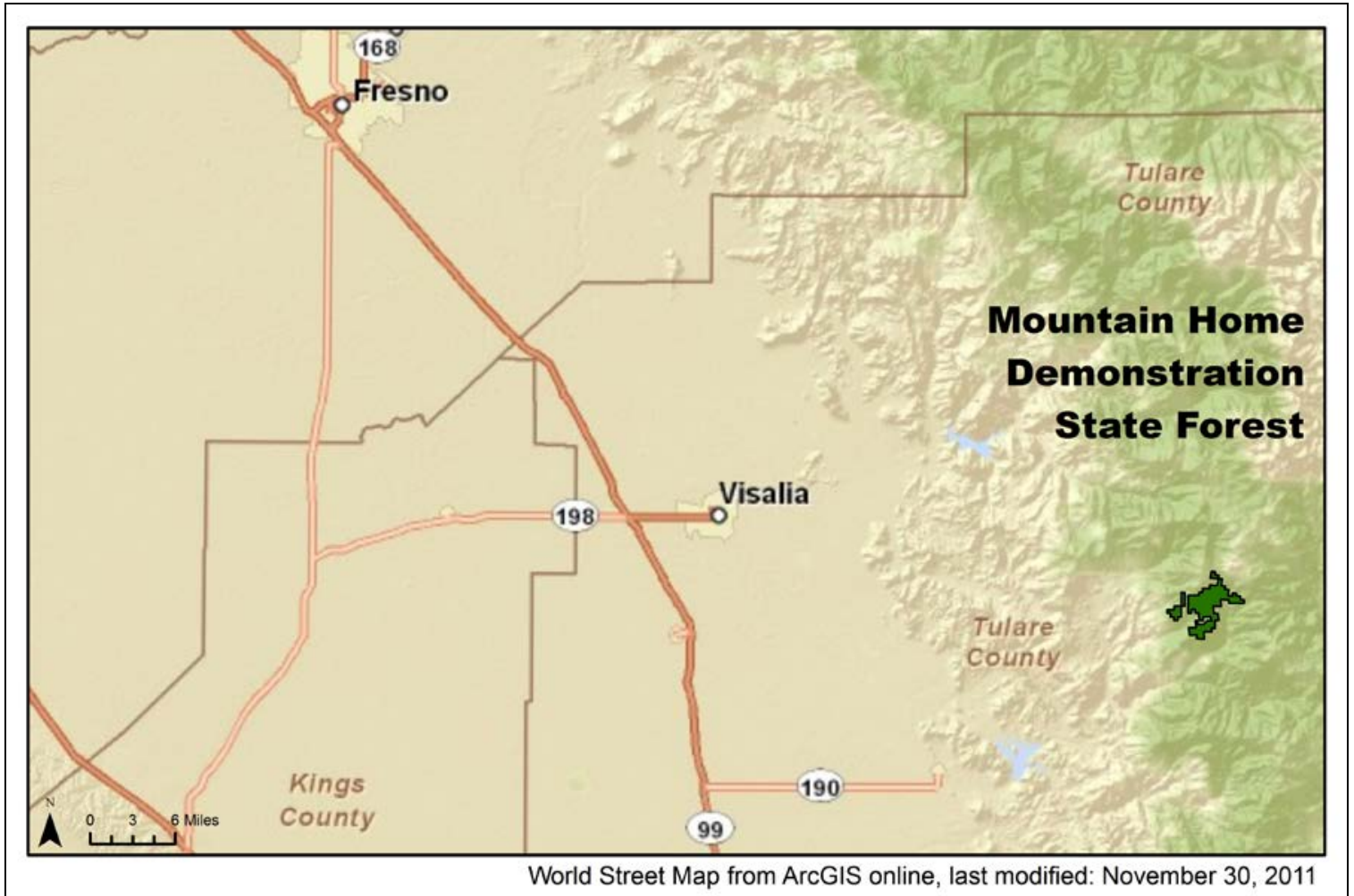

Fig. 2. Mountain Home Demonstration State Forest Location Map.

Hildebr.), red fir (Abies magnifica A. Murr.), ponderosa pine (Pinus ponderosa Dougl. Ex Laws.), sugar pine (Pinus lambertiana Dougl.), black oak (Quercus kelloggii), Jeffrey pine (Pinus jeffreyi), canyon live oak (Quercus chrysolepsis), and white alder (Alnus rhombifolia).

The common understory species are: mountain whitethorn (Ceanothus cordulatus), deerbrush (Ceanothus integerrimus), dogwood (Cornus nuttalli), sierra gooseberry (Ribes roezlii), sierra currant (Ribes nevadense), blackcap raspberry (Rubus leucodermis), thimbleberry (Rubus parviflorus), mountain misery (Chamaebatia foliosa), bracken fern (Pteridium aquilinum) and various species of lotus (Lotus spp.), lupine (Lupinus spp.), and manzanita (Acrtostaphylos spp.) (CDF, 2010). 


\section{Stand Location/Attributes}

The two principal investigators of the original study, Dr. Robert E. Martin and Mr.

Donald P. Gasser (1989), located young-growth giant sequoia stands that met the

following criteria: 1.) include relatively a significant component of young-growth giant sequoia; 2.) contain no old-growth giant sequoia trees; 3.) be accessible for the removal of cut trees; and 4.) represent the natural variability of growth conditions at MHDSF. Six young-growth giant sequoia stands were found with the above criteria and named in relation to historical or natural features (Table 1 and Figure 3) (Martin and Gasser, 1989; Roller, 2004). Plot maps can be found in Appendix H.

Table 1. Characteristics of Forest Stands

\begin{tabular}{|c|c|c|c|c|c|}
\hline Name & Aspect/Slope & $\begin{array}{l}\text { Legal Land } \\
\text { Description }\end{array}$ & Latitude & Longitude & Elevation \\
\hline $\begin{array}{l}\text { Bogus } \\
\text { Meadow }\end{array}$ & $\begin{array}{l}\text { southwest } \\
\text { aspect with } \\
20 \% \text { slopes }\end{array}$ & $\begin{array}{c}\text { T19S R30E } \\
\text { SW } 1 / 4 \text { of } \\
\text { section } 25 \\
\end{array}$ & $36^{\circ} 14^{\prime} 24.3 ”$ & $118^{\circ} 41^{\prime} 21.0^{\prime \prime}$ & $\begin{array}{l}6,289 \mathrm{ft} . \\
1,920 \mathrm{~m}\end{array}$ \\
\hline Frasier Mill & $\begin{array}{l}\text { southwest } \\
\text { aspect with } \\
20 \% \text { slopes }\end{array}$ & $\begin{array}{l}\text { T19S R30E } \\
\text { SE } 1 / 4 \text { of } \\
\text { section } 26\end{array}$ & $36^{\circ} 14^{\prime} 21.0^{\prime \prime}$ & $118^{\circ} 41^{\prime} 26.7^{\prime \prime}$ & $\begin{array}{l}6,250 \mathrm{ft} . \\
1,905 \mathrm{~m}\end{array}$ \\
\hline Headquarters & $\begin{array}{l}\text { southwest } \\
\text { aspect with } \\
20 \% \text { slopes }\end{array}$ & $\begin{array}{c}\text { T20S R30E } \\
\text { NW } 1 / 4 \text { of } \\
\text { section } 1 \\
\end{array}$ & $36^{\circ} 12^{\prime} 53.9^{\prime \prime}$ & $118^{\circ} 41^{\prime} 2.5^{\prime \prime}$ & $\begin{array}{l}6,167 \mathrm{ft} . \\
1,880 \mathrm{~m}\end{array}$ \\
\hline Indian Bath & $\begin{array}{c}\text { southeast aspect } \\
\text { with } 30 \% \\
\text { slopes }\end{array}$ & $\begin{array}{l}\text { T19S R30E } \\
\text { SE } 1 / 4 \text { of } \\
\text { section } 26\end{array}$ & $36^{\circ} 14^{\prime} 25.8^{\prime \prime}$ & $118^{\circ} 41^{\prime} 54.9^{\prime \prime}$ & $\begin{array}{l}6,725 \mathrm{ft} . \\
2,050 \mathrm{~m}\end{array}$ \\
\hline Methuselah & $\begin{array}{c}\text { northwest } \\
\text { aspect with } \\
\text { 20\% slopes } \\
\end{array}$ & $\begin{array}{l}\text { T20S R30E } \\
\text { SW } 1 / 4 \text { of } \\
\text { section } 1 \\
\end{array}$ & $36^{\circ} 12^{\prime} 28.2^{\prime \prime}$ & $118^{\circ} 40^{\prime} 56.0^{\prime \prime}$ & $\begin{array}{l}6,259 \mathrm{ft} . \\
1,908 \mathrm{~m}\end{array}$ \\
\hline Tub Flats & $\begin{array}{l}\text { southwest } \\
\text { aspect with } \\
35 \% \text { slopes }\end{array}$ & $\begin{array}{l}\text { T19S R30E } \\
\text { NW 1/4 of } \\
\text { section } 25\end{array}$ & $36^{\circ} 14^{\prime} 55.2^{\prime \prime}$ & $118^{\circ} 40^{\prime} 55.9 ”$ & $\begin{array}{l}6,916 \mathrm{ft} . \\
2,108 \mathrm{~m}\end{array}$ \\
\hline
\end{tabular}




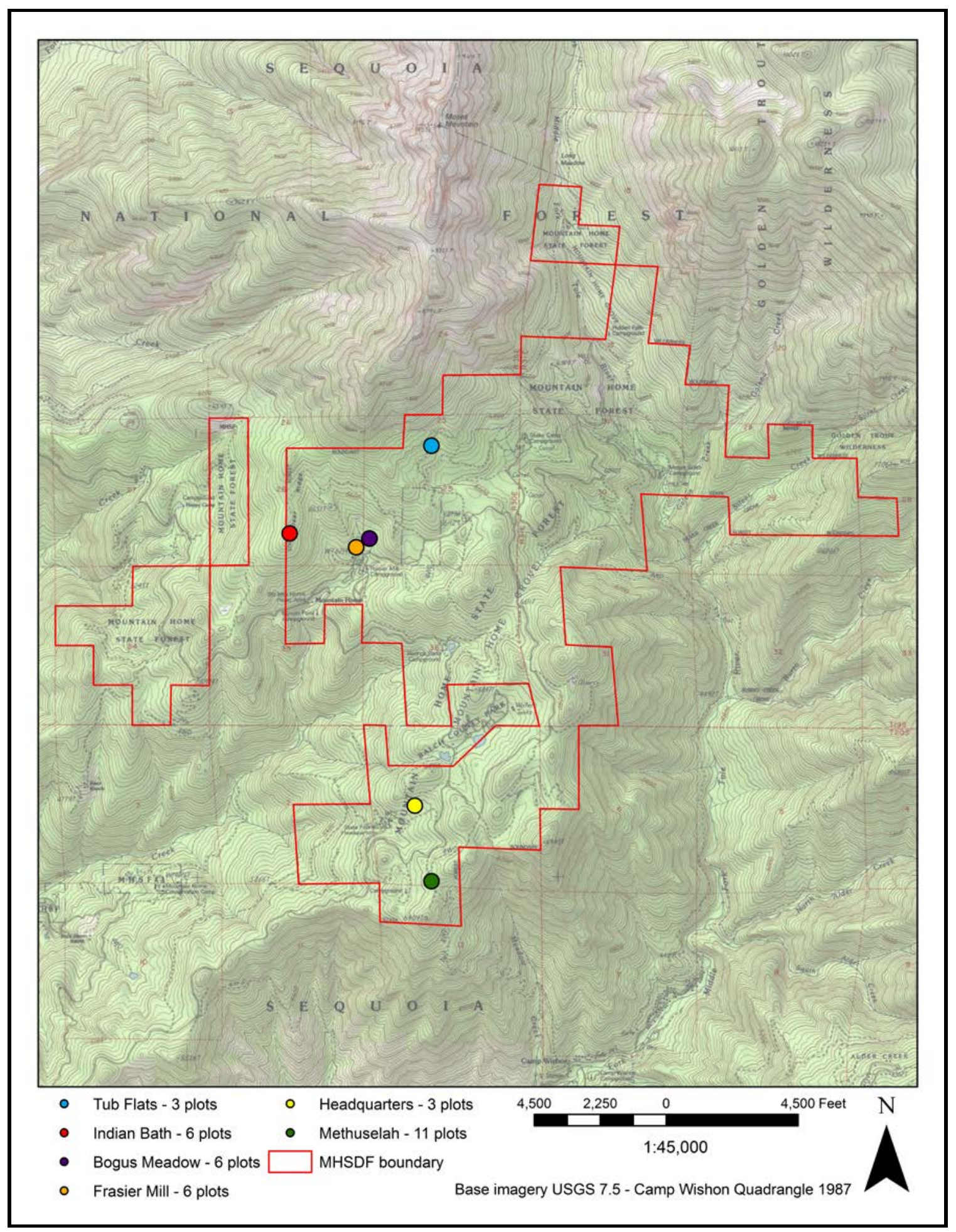

Fig. 3. Mountain Home Demonstration State Forest Stand Map. 


\section{Treatments (Experimental Design)}

The original planned design was a complete block design with 54 plots but this was not possible due to different size and shapes of suitable giant sequoia stands. This study is a not a completely random design but assume random for practical purposes of simple random analysis approach with the experimental unit represented by forest stands and the sampling units represented by inventory plots. Each of the six stands represents an experimental unit having all three treatments established by Martin and Gasser (1989). The 35 inventory plots representing a sampling unit were chosen randomly to receive treatment with the constraint that treatment plots are near a skid trail to allow tree removal. Headquarters and Tub Flats each had three plots total with one for each treatment; Bogus Meadow, Frasier Mill, and Indian Bath had six plots total with two plots for each treatment; and Methuselah had eleven plots total with four plots of thinning only and thinning and prescribed burning yet with only three control plots. The reason for the omission of a fourth control plot for Methuselah was unknown. The treatments were given an alphanumerical code: (A) thinning only, (B) thinning and burning, and (C) control, no thinning or burning. The location, size, and shape of suitable young-growth giant sequoia stands caused the variation in number of plots per stand (Martin and Gasser, 1989).

The specific thinning type used was low thinning or thinning from below which removes the smaller suppressed trees and poor intermediates that would have been lost to natural mortality and leaves the larger dominant and co-dominant trees with more room to grow (Nyland, 2002). The study kept the larger dominant and co-dominant giant 
sequoia along with an occasional dominant secondary species. To reduce edge effect, 66 feet $(20 \mathrm{~m})$ beyond the thinned plots was thinned to comparable residual basal area. Similarly, most of the control plots were grouped together in order for establishment of a surrounding buffer strip to help reduce any potential edge effect (Martin and Gasser, 1989). The thin and burn plots utilized prescribed fire defined as using fire as a management tool within a predetermined area. The burning schedule developed constraints due to weather, time and prescribed burning logistics permitting all stand plots except Indian Bath to be burned in late fall of 1989 and summer of 1990. The Indian Bath plots were burned in 1991. This difference of a year was not expected to cause significant result differences compared to plots burned earlier (Martin and Gasser, 1989; Roller, 2004; Stoddard and Stoddard, 1987).

\section{Data Collection/Measurement}

Each inventory plot is permanently monumented with a piece of rebar pounded flush to the ground at plot center and given an alphanumeric code. A five-foot (1.5 m) piece of aluminum conduit with the top two feet $(0.6 \mathrm{~m})$ painted neon orange was placed next to the rebar to aid in locating the plots. The plots are approximately 0.1 acre (0.04 ha) in size with a radius of 39.37 feet (12 m). The alphanumeric code starts with two digits represented by the first letter of each word for the stand name. The second two digits are represented by the treatment type and treatment plot number. For example, FM-B1 represents Frasier Mill stand, thin and burn treatment, and plot \#1 (Roller, 2004). The number of treatment plots for each of the six stands is:

- Bogus Meadow (BM) with 2 Thin only, 2 Thin and Burn, 2 Control. 
- Frasier Mill (FM) with 2 Thin only, 2 Thin and Burn, 2 Control.

- Headquarters (HQ) with 1 Thin only, 1 Thin and Burn, 1 Control.

- Indian Bath (IB) with 2 Thin only, 2 Thin and Burn, 2 Control.

- Methuselah (ME) with 4 Thin only, 4 Thin and Burn, 3 Control.

- Tub Flats (TF) with 1 Thin only, 1 Thin and Burn, 1 Control.

There was some misnaming of plots within the Frasier Mill and Indian Bath stands for unknown reasons in 1989 with plots FM-A2 and IB-A2 as thinned and burned and plots FM-B1 and IB-B1 as thinned only. These plots were field verified in 2001 by Roller and in 2008 by Roller, Piirto, and Soderlund by observed scorch marks on remaining trees. Original plot names were kept and data collection and analysis were done appropriately taking into consideration the misnaming issue (Roller, 2004).

\section{Overstory Sampling}

In 1989 all trees within the plots were tagged and measured for height and diameter at breast height $(\mathrm{DBH}) 4.5$ feet $(1.37 \mathrm{~m})$ above ground creating the original data set. The tags were placed with aluminum nails at DBH marking where DBH was measured and should be measured in the future. The tags faced plot center and trees were sequentially numbered clockwise from due north, which should help future researchers locate and identify trees with missing tags. The 2001 study re-established all tags and replaced missing tags with blue aluminum circular tags. The 2009 measurement utilized the same tags when replacing due to missing or bark enveloped tags since the 2001 measurement (Martin and Gasser, 1989; Roller, 2004). 
The overstory data of total height and DBH were collected for all trees within the entire 0.1 acre inventory plot. The diameter was measured with a standard diameter tape at DBH indicated by the tag. The height was measured with a Vertex III manufactured by Haglof ( $\odot$ Inc., which was calibrated in the morning before field work and in the afternoon to ensure accurate reading. Overstory data measurements for 1989, 1994, 2001 and 2009 can be found in Appendix A. Graphs and stand tables for DBH distribution can be found in Appendix B.

In order to distinguish trees from the regeneration portion of the study, only trees with a DBH threshold of at least one inch were measured as in-growth trees. The Roller 2001 measurement chose the one inch minimum threshold because it represented an established tree that was able to be tagged and had measurable basal area (Roller, 2004).

Some trees experienced negative height growth at some time during the 20 years since the first measurement. Trees with negative growth since last measurement were measured twice to ensure correct measurement and104 of the 802 trees measured had negative height growth. Fifty-seven of the 104 trees had negative growth due to broken, deformed or forked tops. The remaining 47 trees, only $5 \%$ of the total, had negative growth for unknown reasons. These differences in tree height could be attributed to using tape and a clinometer for the first two measurements; a method that may yield less precise results than using a hypsometer. The present study, like the Roller 2001 study, is concentrating on the volume growth and yield, so negative height trees are not a significant concern. There is always some degree of measurement error both underestimating and overestimating, so negative growth trees are kept in the data set. 
Removing these trees could cause upward bias in heights since only the underestimated trees are removed (Roller, 2004).

The location data set of all overstory trees within the plots relative to plot center was first collected during the Roller 2001 measurement. Spatial maps were created by Roller (2004) which show tree diameter and location relative to plot center and each other. This data set aided in the location and identification of trees with missing tags. The in-growth trees of 2009 were added to this dataset by taking bearing from plot center with a hand compass and distance from plot center to middle of tree with a cloth tape.

After remeasuring the distance from plot center to the residual trees the Roller 2001 study found 5 trees greater than the 39.37 feet $(12 \mathrm{~m})$ radius from plot center. These trees were identified within the dataset and not used in summary tables or statistical analysis. During this remeasurement 9 trees not measured during the previous studies located within the 39.37 feet $(12 \mathrm{~m})$ radius plot were measured and added to the dataset.

\section{Understory Sampling}

Understory study utilized nine subplots in a 3 x 3 grid pattern with 19.7 feet $(6 \mathrm{~m})$ spacing, setting the center subplots as the center of the inventory plots, as established by Martin and Gasser (1989). The subplots were marked at plot center with a piece of rebar stake. A metal detector was especially helpful in finding rebar stakes that had been buried in litter and duff. Missing rebar stakes were re-established in approximately the original position by measuring from adjacent subplots and plot center. 
Each subplot was 21.5 square feet $(2.0 \mathrm{sq}$. $\mathrm{m})$ with a radius of 2.6 feet $(0.8 \mathrm{~m})$. The understory vegetation was measured by a total count of each stem per species and an ocular estimate of percent cover for each species for each subplot. Graminoid and unidentified forb stems were counted by number and estimated for ocular percent cover only and not assessed by species (Roller, 2004). The 2009 data added lady fern (Athyrum filix-femina [L.] Roth var. cyclosorum Rupr.), sedge (Carex sp.), chinkapin (Castanopsis sempervirens [Kellogg] Hjelmq.), paintbrush (Castilleja sp.), deer brush (Ceanothus integerrimus Hook. \& Arn.), California hazelnut (Corylus cornuta Marsh. var californica [A. DC.] W. Sharp), horsetail (Equisetum sp.), iris (Iris sp.), wintergreen (Pyrola picta Smith), false Solomon's seal (Smilacina racemosa [L.] Link), and violet (Viola sp.) to the shrub/herbaceous plant species list. The added herbaceous plant species that related to the graminoids and unidentified forbs were lumped into these categorizes in order to compare with 1989 dataset. They are recorded in the footnotes of the data sheets located in Appendix C. Duff and litter measurements were taken at two random spots within each subplot. Understory vegetation species list and dataset are located in Appendices D and C (Martin and Gasser, 1989; Roller, 2004).

Understory plant data of species and stem counts (number of individuals) for each inventory plot were entered into Diversity Calculator 4.0 (Zippi, 2003) that calculates 11 diversity indices. The two used were species richness and Simpson Index. Richness was analyzed using raw species richness which is represented by $S$ (the number of species recorded in each inventory plot). Evenness as related to dominance was analyzed with the Berger-Parker index, which uses $N$ (the sum total of the individuals of all $\mathrm{S}$ species) and $N_{\max }$ (the sum total of the individuals of the most abundant species). The reciprocal 
form of Berger-Parker index is expressed as $1 / d$ so that an increase in value accompanies an increase in diversity/evenness (Berger and Parker, 1970; May, 1975).

$$
d=N_{\max } / N
$$

Heterogeneity (the combination of richness and evenness) was analyzed with Simpson Index of Diversity which uses $n_{i}$ (number of individuals in the ith species) and $N$ (sum total of the individuals of all S species). The reciprocal form of Simpson's Index is expressed as $1 / D$ so that value increases with increasing diversity. This index gives the probability that two individuals collected randomly and independently from a population will be from different species/plants. This index is most sensitive to changes in the more abundant species within the study (Magurran, 1988; Simpson, 1949).

$$
D=\sum\left(\frac{n_{i}\left(n_{i}-1\right)}{\mathrm{N}(\mathrm{N}-1)}\right)
$$

\section{Regeneration/Seedlings Sampling}

The regeneration seedling survey was first done by Roller (2001) to address Dr. Piirto's concern that there was no data related to new seedlings within the plots in response to the management strategies and this study contains the second regeneration seedling survey. The seedling data were collected by conducting a 100\% count of seedling species. The seedlings were counted inside a nested plot with a 19.7 feet $(6 \mathrm{~m})$ radius from the inventory plot center, approximately 0.03 acres ( $0.01 \mathrm{ha})$. Every seedling less than 1 inch DBH was counted by species and by one-foot height classes: $0=(0.0$ 0.9 feet $) ; 1=(1.0-1.9$ feet $) ; 2=(2.0-2.9$ feet $) ; 3=(3.0-3.9$ feet $) ; 4=(4.0-4.9$ feet $)$ 
and $5=$ (over 5.0 feet). Trees that were one inch and greater in diameter represented an ingrowth tree and were counted in the overstory sampling (Roller, 2004). Regeneration data is located in Appendix F of this thesis and trees per acre graphs for regeneration are located in Appendix G of this thesis.

Downed Woody Debris Sampling

The fuel data were determined by measuring downed woody debris using the planar intersect method (Brown, 1974). In each of the four cardinal directions a 33 foot (10 m) transect line was established from plot center. A go-no-go gauge was used to inventory the downed woody debris along the transect line classifying them as $1,10,100$, or 1,000 hour fuels based on diameter:

- up to 0.25 inch $(0.64 \mathrm{~cm})$ in diameter are 1-hour fuels;

- greater than 0.25 inch to less than 1.0 inch $(2.54 \mathrm{~cm})$ in diameter are 10 -hour fuels;

- greater than 1.0 inch to less than 3 inches $(7.62 \mathrm{~cm})$ in diameter are 100 -hour fuels; and

- greater than 3.0 inches in diameter are 1,000-hour fuels.

The 1 and 10 hour fuels are recorded from plot center to 6.5 feet $(2 \mathrm{~m}), 100$ hour fuels from plot center to 10 feet $(3 \mathrm{~m})$ and 1,000 hour fuels from plot center to 33 feet (10 m) along each transect line. The 1,000 hour fuels also had the diameter measured and determined if sound or rotten. The litter layer depth was measured at 10 feet $(3 \mathrm{~m})$ and 33 feet (10 m) along the transect (Brown, 1974). The downed woody debris dataset was 
incomplete in 1989, not collected in 1994, and fully collected in 2001. For the 2009 dataset refer to Appendix E (Roller, 2004).

Photographic Record

The 2009 study took digital photographs of each plot to record present stand conditions. The 2001 general photograph protocol was followed with photographs taken in each of the four cardinal directions from plot center facing out and a canopy photograph taken from plot center with lens facing straight up. Plot photos of 1989 pretreatment, 2001, and 2009 are located in Appendix I. The group of photos for each plot can themselves tell a story involving the changes in understory vegetation, fuel load, and light infiltration in relation to the different treatments. Progression photos can show the chronological changes occurring in the plots (Roller, 2004).

Statistical Analysis

The data were analyzed as a random design using descriptive statistics, analysis of variance (ANOVA) and Tukey’s multiple pairwise comparison test generated by SAS/STAT ${ }^{\circledR}$ software, version 9.2 of the SAS system for Windows 7. Copyright $@$ 2002-2008 SAS Institute Inc. SAS and all other SAS Institute Inc. product or service names are registered trademarks or trademarks of SAS Institute Inc., Cary, NC, USA. The standard assumptions for an (ANOVA) are: 1) Independence - each sampling unit randomly assigned treatment (a), (b) or (c); 2) Populations have equal variances - accept $\mathrm{H}_{0}$ : Variances are equal if homogeneity of variance test result is a p-value greater than $\alpha$ $=0.05$, Levene's test was used; 3) Population has a normal distribution - accept $\mathrm{H}_{0}$ : 
Normal Population if normality test result is a p-value greater than $\alpha=0.05$, AndersonDarling test was used.

The data met the assumptions for an (ANOVA) with the following data sets needing transformations (Table 2). The following data sets did not meet the assumptions of variance after many transformations so the (ANOVA) could not be done: understory plant study functional groups - all frequency data, control shrubs abundance by year, control and thin and thin/burn graminoids abundance by year, thin trees abundance by year and 2009 control diversity indices by stand.

One way analysis of variance (ANOVA) with a significance level of 0.05 was used to determine if there are statistically significant differences between treatments. Tukey's multiple pairwise comparison tests with $\alpha=0.05$ were used to determine which specific treatments were significantly different from each other if the (ANOVA) determined a significant difference existed. 
Table 2. Transformations of datasets to meet assumptions for ANOVA.

\begin{tabular}{|c|c|}
\hline Transformations & Datasets \\
\hline Ln(dataset) & $\begin{array}{l}\text { Board-foot growth from } 2001 \text { - } 2009 \text { by treatment, } 2009 \\
\text { cubic-foot yield by treatment, } 2009 \text { board-foot yield by } \\
\text { treatment, } 2001 \text { total fuel tons per acre by treatment, } 2001 \\
\text { litter tons per acre by treatment, Thin/burn litter tons per acre } \\
\text { by year }\end{array}$ \\
\hline Ln(dataset - 1) & 2009 total fuel tons per acre by treatment \\
\hline Ln(dataset - 400) & Cubic-foot growth from $2001-2009$ by treatment \\
\hline Ln(dataset +0.1$)$ & 2009 Trees abundance by treatment, \\
\hline Ln(dataset +0.2$)$ & 20011,000 hr. fuel tons per acre by treatment \\
\hline Ln(dataset +0.25$)$ & 2009 Thin/burn trees abundance by year \\
\hline Ln(dataset +0.5$)$ & 2009 Graminoids density by treatments \\
\hline Ln(dataset +1.0$)$ & $\begin{array}{l}2009 \text { Seedlings per acre by treatment, } 2009 \text { shrubs density } \\
\text { by treatment, } 2009 \text { graminoids abundance by treatment, Thin } \\
\text { shrub density by year, Thin/burn shrubs density by year, } \\
\text { Thin/burn trees density by year, Thin shrubs abundance by } \\
\text { year, Thin/burn shrubs abundance by year, Thin forbs } \\
\text { abundance by year, Thin/burn forbs abundance by year, } 2009 \\
1,000 \mathrm{hr} \text {. fuel tons per acre by treatment, Thin } 1,000 \mathrm{hr} \text {. fuel } \\
\text { tons per acre by year, Thin/burn } 1,000 \mathrm{hr} \text {. fuel tons per acre } \\
\text { by year, Thin total fuel tons per acre by year, Thin/burn fuel } \\
\text { tons per acre by year, }\end{array}$ \\
\hline Ln(dataset +2.0$)$ & Thin trees density by year \\
\hline Ln(dataset +10$)$ & 2009 Forb abundance by treatment \\
\hline $\operatorname{Ln}($ dataset +50$)$ & 2009 Forbs density by treatment, \\
\hline$\sqrt{ }($ dataset $)$ & $\begin{array}{l}2009 \text { Shrubs abundance by treatment, Control shrub density } \\
\text { by year, Control trees density by year, Control forbs } \\
\text { abundance by year, Control trees abundance by year }\end{array}$ \\
\hline$\sqrt{ }($ dataset +5.0$)$ & Thin litter tons per acre by year \\
\hline $\arcsin ($ dataset) & $\begin{array}{l}2009 \text { Species richness by treatment, } 2009 \text { Simpson Index by } \\
\text { treatment }\end{array}$ \\
\hline
\end{tabular}




\title{
CHAPTER 4
}

\author{
Results
}

\section{Overstory Growth and Yield Response}

The overstory data were analyzed using board-foot per acre and cubic-foot per acre parameters. The analysis was separated into stand volume growth and stand volume yield using the local volume equations created for Mountain Home Demonstration State Forest refer to Appendix J (Pillsbury et al., 1990, 1991). Each measurement year - 1989, 1994, 2001, and 2009 has a stand attribute summary table comparing the treatments (A) thinned, (B) thin and burn, and (C) control in relation to average and maximum diameter breast height (DBH), average and maximum height, average basal area, average trees per acre, average cubic-foot volume per acre, and average board-foot volume per acre (Tables 3, 4, 5 and 6). The volume range varies in relation to stands with 2009 Bogus Meadow (A) thinned at 19,617 cubic-feet/acre compared to 2009 Tub Flats (A) thinned at 7,498 cubic-feet/acre, 2009 Bogus Meadow (B) thin and burn at 26,758 cubic-feet/acre compared to Methuselah (B) thin and burn at 7,114 cubic-feet/acre, and Frasier Mill (C) control at 44,182 cubic-feet/acre compared to Tub Flats (C) control at 13,586 cubicfeet/acre (Table 6). The overstory species composition across all treatments shows giant sequoia with $90 \%$ of the cubic-foot volume yield validating that these mixed-conifer stands are primary young-growth giant sequoia (Table 7). The summary of significance 
for parameters of growth and yield across years and treatments are represented with overall significance relating to (ANOVA) and significance between treatments to Tukey's pairwise comparison (Table 8).

Table 3. Stand Attribute Summary for 1989.

\begin{tabular}{|r|c|c|c|c|c|c|}
\hline & $\begin{array}{c}\text { Bogus } \\
\text { Meadow }\end{array}$ & $\begin{array}{c}\text { Frasier } \\
\text { Mill }\end{array}$ & Headquarters & $\begin{array}{c}\text { Indian } \\
\text { Bath }\end{array}$ & Methuselah & $\begin{array}{c}\text { Tub } \\
\text { Flats }\end{array}$ \\
Elevation & $6,289 \mathrm{ft}$. & $6,250 \mathrm{ft}$. & $6,167 \mathrm{ft}$. & $6,725 \mathrm{ft}$. & $6,259 \mathrm{ft}$. & $6,916 \mathrm{ft}$. \\
Aspect & SW & SW & SW & SE & NW & SE \\
\# of Thinned Plots (A) & 2 & 2 & 1 & 2 & 4 & 1 \\
\# of Thin \& Burn Plots (B) & 2 & 2 & 1 & 2 & 4 & 1 \\
\# of Control Plots (C) & 2 & 2 & 1 & 2 & 3 & 1 \\
Total Plots & 6 & 6 & 3 & 6 & 11 & 3 \\
\hline Avg. DBH (A plots) & 35.1 & 24.8 & 18.0 & 15.9 & 17.7 & 11.4 \\
Avg. DBH (B plots) & 27.9 & 24.2 & 19.9 & 13.4 & 16.6 & 13.8 \\
Avg. DBH (C plots) & 13.3 & 15.7 & 14.4 & 13.3 & 12.2 & 9.5 \\
Max. DBH (A plots) & 52.3 & 46.3 & 33.7 & 24.7 & 28.9 & 20.9 \\
Max. DBH (B plots) & 49.4 & 35.7 & 27.1 & 29.3 & 28.8 & 20.5 \\
Max. DBH (C plots) & 46.9 & 52.5 & 31.4 & 36.0 & 31.0 & 23.5 \\
Avg. Height (A plots) & 152 & 118 & 76 & 77 & 65 & 57 \\
Avg. Height (B plots) & 120 & 107 & 89 & 77 & 64 & 69 \\
Avg. Height (C plots) & 64 & 75 & 68 & 59 & 53 & 47 \\
Max. Height (A plots) & 173 & 159 & 129 & 100 & 96 & 92 \\
Max. Height (B plots) & 169 & 145 & 112 & 105 & 108 & 86 \\
Max. Height (C plots) & 164 & 165 & 108 & 134 & 95 & 103 \\
Avg. Basal Area (A plots) & 289 & 259 & 175 & 235 & 134 & 139 \\
Avg. Basal Area (B plots) & 427 & 241 & 207 & 240 & 130 & 130 \\
Avg. Basal Area (C plots) & 532 & 887 & 521 & 621 & 307 & 369 \\
Avg. Trees per Acre (A) & 41 & 64 & 73 & 164 & 82 & 173 \\
Avg. Trees per Acre (B) & 77 & 59 & 91 & 223 & 77 & 119 \\
Avg. Trees per Acre (C) & 346 & 419 & 328 & 497 & 296 & 538 \\
Avg. CF Volume (A plots) & 10,970 & 8,980 & 4,835 & 5,702 & 2,703 & 3,027 \\
Avg. CF Volume (B plots) & 15,203 & 8,017 & 5,263 & 6,412 & 2,701 & 3,743 \\
Avg. CF Volume (C plots) & 16,713 & 29,539 & 13,360 & 16,472 & 6,420 & 8,584 \\
Avg. BF Volume (A plots) & 68,492 & 51,211 & 25,401 & 26,769 & 12,093 & 13,680 \\
Avg. BF Volume (B plots) & 92,357 & 45,749 & 25,902 & 30,840 & 12,089 & 19,576 \\
Avg. BF Volume (C plots) & 95,492 & 171,776 & 64,901 & 83,806 & 28,186 & 40,885 \\
\hline
\end{tabular}


Table 4. Stand Attribute Summary for 1994.

\begin{tabular}{|r|c|c|c|c|c|c|}
\hline & $\begin{array}{c}\text { Bogus } \\
\text { Meadow }\end{array}$ & $\begin{array}{c}\text { Frasier } \\
\text { Mill }\end{array}$ & Headquarters & $\begin{array}{c}\text { Indian } \\
\text { Bath }\end{array}$ & Methuselah & $\begin{array}{c}\text { Tub } \\
\text { Flats }\end{array}$ \\
Elevation & $6,289 \mathrm{ft}$. & $6,250 \mathrm{ft}$ & $6,167 \mathrm{ft}$. & $6,725 \mathrm{ft}$. & $6,259 \mathrm{ft.}$ & $6,916 \mathrm{ft}$. \\
Aspect & SW & SW & SW & SE & NW & SE \\
\# of Thinned Plots (A) & 2 & 2 & 1 & 2 & 4 & 1 \\
\# of Thin \& Burn Plots (B) & 2 & 2 & 1 & 2 & 4 & 1 \\
\# of Control Plots (C) & 2 & 2 & 1 & 2 & 3 & 1 \\
Total Plots & 6 & 6 & 3 & 6 & 11 & 3 \\
\hline Avg. DBH (A plots) & 37.9 & 26.0 & 20.0 & 16.9 & 19.9 & 12.3 \\
Avg. DBH (B plots) & 29.6 & 25.3 & 21.4 & 14.1 & 19.5 & 14.7 \\
Avg. DBH (C plots) & 14.1 & 16.5 & 15.3 & 13.9 & 13.2 & 9.9 \\
Max. DBH (A plots) & 56.0 & 47.6 & 37.5 & 26.2 & 32.0 & 22.6 \\
Max. DBH (B plots) & 51.1 & 36.9 & 29.7 & 31.3 & 31.2 & 22.3 \\
Max. DBH (C plots) & 47.2 & 54.1 & 33.3 & 36.4 & 31.7 & 24.3 \\
Avg. Height (A plots) & 164 & 123 & 84 & 79 & 71 & 61 \\
Avg. Height (B plots) & 137 & 122 & 102 & 82 & 77 & 71 \\
Avg. Height (C plots) & 67 & 78 & 73 & 60 & 60 & 51 \\
Max. Height (A plots) & 188 & 164 & 138 & 102 & 98 & 97 \\
Max. Height (B plots) & 186 & 158 & 120 & 115 & 111 & 87 \\
Max. Height (C plots) & 152 & 175 & 123 & 142 & 101 & 105 \\
Avg. Basal Area (A plots) & 338 & 282 & 220 & 269 & 164 & 163 \\
Avg. Basal Area (B plots) & 467 & 235 & 241 & 267 & 149 & 149 \\
Avg. Basal Area (C plots) & 556 & 965 & 567 & 656 & 354 & 404 \\
Avg. Trees per Acre (A) & 41 & 64 & 73 & 182 & 75 & 173 \\
Avg. Trees per Acre (B) & 77 & 55 & 91 & 223 & 68 & 119 \\
Avg. Trees per Acre (C) & 346 & 419 & 328 & 497 & 298 & 538 \\
Avg. CF Volume (A plots) & 13,607 & 10,085 & 6,661 & 6,589 & 3,545 & 3,636 \\
Avg. CF Volume (B plots) & 18,273 & 9,223 & 6,926 & 7,450 & 3,383 & 4,021 \\
Avg. CF Volume (C plots) & 17,522 & 32,400 & 16,035 & 17,977 & 7,980 & 9,649 \\
Avg. BF Volume (A plots) & 87,861 & 58,494 & 36,901 & 31,370 & 16,392 & 16,816 \\
Avg. BF Volume (B plots) & 115,718 & 54,205 & 36,059 & 36,742 & 16,073 & 20,915 \\
Avg. BF Volume (C plots) & 99,514 & 191,620 & 82,674 & 93,024 & 36,127 & 46,777 \\
\hline
\end{tabular}


Table 5. Stand Attribute Summary for 2001.

\begin{tabular}{|r|c|c|c|c|c|c|}
\hline & $\begin{array}{c}\text { Bogus } \\
\text { Meadow }\end{array}$ & $\begin{array}{c}\text { Frasier } \\
\text { Mill }\end{array}$ & Headquarters & $\begin{array}{c}\text { Indian } \\
\text { Bath }\end{array}$ & Methuselah & $\begin{array}{c}\text { Tub } \\
\text { Flats }\end{array}$ \\
Elevation & $6,289 \mathrm{ft}$. & $6,250 \mathrm{ft.}$ & $6,167 \mathrm{ft}$. & $6,725 \mathrm{ft.}$ & $6,259 \mathrm{ft.}$ & $6,916 \mathrm{ft.}$ \\
Aspect & SW & SW & SW & SE & NW & SE \\
\# of Thinned Plots (A) & 2 & 2 & 1 & 2 & 4 & 1 \\
\# of Thin \& Burn Plots (B) & 2 & 2 & 1 & 2 & 4 & 1 \\
\# of Control Plots (C) & 2 & 2 & 1 & 2 & 3 & 1 \\
Total Plots & 6 & 6 & 3 & 6 & 11 & 3 \\
\hline Avg. DBH (A plots) & 41.4 & 28.6 & 23.0 & 18.6 & 22.4 & 14.1 \\
Avg. DBH (B plots) & 32.2 & 28.8 & 24.2 & 15.6 & 23.2 & 17.0 \\
Avg. DBH (C plots) & 15.5 & 18.0 & 16.3 & 15.4 & 14.3 & 11.0 \\
Max. DBH (A plots) & 59.9 & 51.2 & 41.8 & 28.5 & 36.3 & 25.6 \\
Max. DBH (B plots) & 54.2 & 40.3 & 33.7 & 33.7 & 35.7 & 23.7 \\
Max. DBH (C plots) & 48.4 & 56.8 & 34.1 & 38.6 & 35.7 & 22.1 \\
Avg. Height (A plots) & 167 & 133 & 94 & 91 & 83 & 66 \\
Avg. Height (B plots) & 139 & 126 & 107 & 93 & 91 & 79 \\
Avg. Height (C plots) & 74 & 85 & 79 & 72 & 69 & 57 \\
Max. Height (A plots) & 189 & 168 & 149 & 117 & 114 & 102 \\
Max. Height (B plots) & 200 & 159 & 123 & 129 & 123 & 95 \\
Max. Height (C plots) & 187 & 192 & 139 & 156 & 114 & 110 \\
Avg. Basal Area (A plots) & 400 & 355 & 333 & 353 & 207 & 219 \\
Avg. Basal Area (B plots) & 550 & 361 & 306 & 314 & 201 & 197 \\
Avg. Basal Area (C plots) & 659 & 1,052 & 623 & 751 & 419 & 435 \\
Avg. Trees per Acre (A) & 46 & 73 & 109 & 187 & 116 & 182 \\
Avg. Trees per Acre (B) & 87 & 77 & 91 & 214 & 66 & 119 \\
Avg. Trees per Acre (C) & 337 & 433 & 328 & 488 & 340 & 556 \\
Avg. CF Volume (A plots) & 16,092 & 12,604 & 11,057 & 9,630 & 5,126 & 5,200 \\
Avg. CF Volume (B plots) & 21,935 & 12,439 & 8,897 & 9,607 & 5,141 & 5,465 \\
Avg. CF Volume (C plots) & 22,694 & 37,817 & 19,341 & 22,896 & 10,588 & 10,778 \\
Avg. BF Volume (A plots) & 105,381 & 75,053 & 64,486 & 48,474 & 25,419 & 25,277 \\
Avg. BF Volume (B plots) & 141,812 & 73,467 & 47,396 & 49,661 & 26,091 & 28,913 \\
Avg. BF Volume (C plots) & 135,679 & 230,071 & 104,902 & 124,736 & 50,674 & 51,990 \\
\hline
\end{tabular}


Table 6. Stand Attribute Summary for 2009.

\begin{tabular}{|c|c|c|c|c|c|c|}
\hline & $\begin{array}{l}\text { Bogus } \\
\text { Meadow }\end{array}$ & $\begin{array}{l}\text { Frasier } \\
\text { Mill }\end{array}$ & Headquarters & $\begin{array}{l}\text { Indian } \\
\text { Bath }\end{array}$ & Methuselah & $\begin{array}{l}\text { Tub } \\
\text { Flats }\end{array}$ \\
\hline Elevation & $\begin{array}{c}6,289 \mathrm{ft} . \\
\text { SW }\end{array}$ & 6,250 ft. & $\begin{array}{c}6,167 \mathrm{ft} . \\
\text { sw }\end{array}$ & $\begin{array}{c}6,725 \mathrm{ft} . \\
\mathrm{SF}\end{array}$ & 6,259 ft. & 6,916 ft. \\
\hline \# of Thinned Plots (A) & 2 & 2 & 1 & 2 & 4 & 1 \\
\hline \# of Thin \& Burn Plots (B) & 2 & 2 & 1 & 2 & 4 & 1 \\
\hline \# of Control Plots (C) & 2 & 2 & 1 & 2 & 3 & 1 \\
\hline Total Plots & 6 & 6 & 3 & 6 & 11 & 3 \\
\hline Avg. DBH (A plots) & 42.0 & 30.7 & 21.1 & 20.7 & 18.8 & 15.4 \\
\hline Avg. DBH (B plots) & 34.3 & 31.3 & 28.3 & 16.9 & 26.2 & 19.2 \\
\hline Avg. DBH (C plots) & 16.1 & 19.2 & 18.1 & 17.3 & 14.1 & 11.6 \\
\hline Max. DBH (A plots) & 64.7 & 52.3 & 50.5 & 30.8 & 39.8 & 29.0 \\
\hline Max. DBH (B plots) & 59.3 & 44.0 & 41.1 & 36.6 & 39.7 & 24.8 \\
\hline Max. DBH (C plots) & 49.1 & 60.0 & 39.3 & 40.7 & 38.8 & 23.9 \\
\hline Avg. Height (A plots) & 157 & 142 & 81 & 101 & 69 & 76 \\
\hline Avg. Height (B plots) & 141 & 136 & 121 & 102 & 103 & 93 \\
\hline Avg. Height (C plots) & 77 & 94 & 88 & 81 & 67 & 62 \\
\hline Max. Height (A plots) & 188 & 178 & 156 & 126 & 127 & 117 \\
\hline Max. Height (B plots) & 202 & 166 & 140 & 138 & 135 & 107 \\
\hline Max. Height (C plots) & 182 & 192 & 150 & 162 & 118 & 110 \\
\hline Avg. Basal Area (A plots) & 491 & 404 & 463 & 424 & 280 & 277 \\
\hline Avg. Basal Area (B plots) & 661 & 421 & 420 & 368 & 254 & 249 \\
\hline Avg. Basal Area (C plots) & 725 & 1,141 & 768 & 817 & 502 & 505 \\
\hline Avg. Trees per Acre (A) & 59 & 73 & 164 & 187 & 203 & 201 \\
\hline Avg. Trees per Acre (B) & 105 & 82 & 91 & 219 & 75 & 119 \\
\hline Avg. Trees per Acre (C) & 369 & 474 & 346 & 479 & 368 & 538 \\
\hline Avg. CF Volume (A plots) & 19,617 & 15,132 & 15,704 & 12,460 & 7,510 & 7,498 \\
\hline Avg. CF Volume (B plots) & 26,758 & 15,264 & 13,383 & 12,102 & 7,114 & 7,660 \\
\hline Avg. CF Volume (C plots) & 26,257 & 44,182 & 25,807 & 26,332 & 13,588 & 13,586 \\
\hline Avg. BF Volume (A plots) & 129,951 & 92,625 & 94,883 & 65,489 & 39,439 & 38,501 \\
\hline Avg. BF Volume (B plots) & 176,202 & 92,910 & 75,784 & 65,060 & 37,941 & 42,025 \\
\hline Avg. BF Volume (C plots) & 160,311 & 277,016 & 147,154 & 148,122 & 67,725 & 68,157 \\
\hline
\end{tabular}


Table 7. Species Attribute Summary for $2009^{1}$.

\begin{tabular}{|r|c|c|c|c|c|}
\hline Species & $\begin{array}{c}\text { Sequoiadendron } \\
\text { giganteum }\end{array}$ & $\begin{array}{c}\text { Abies } \\
\text { concolor }\end{array}$ & $\begin{array}{c}\text { Calocedrus } \\
\text { decurrens }\end{array}$ & $\begin{array}{c}\text { Pinus } \\
\text { lambertiana }\end{array}$ & $\begin{array}{c}\text { Pinus } \\
\text { ponderosa }\end{array}$ \\
\hline Avg. Dbh (A plots) & 27.6 & 3.5 & 10.3 & & 3.2 \\
Avg. Dbh (B plots) & 27.6 & 11.0 & 1.1 & 29.0 & \\
Avg. Dbh (C plots) & 19.2 & 8.4 & 6.0 & 13.6 & 20.9 \\
\cline { 2 - 6 } Max Dbh (A plots) & 64.7 & 18.7 & 32.9 & & 3.2 \\
Max Dbh (B plots) & 53.0 & 24.8 & 1.1 & 36.6 & \\
Max Dbh (C plots) & 51.9 & 49.1 & 33.3 & 22.9 & 20.9 \\
\cline { 2 - 6 } Avg. Ht. (A plots) & 116 & 17 & 36 & & 14 \\
Avg. Ht. (B plots) & 120 & 50 & 10 & 125 & \\
Avg. Ht. (C plots) & 92 & 41 & 26 & 64 & 109 \\
\cline { 2 - 6 } Max Ht. (A plots) & 188 & 99 & 94 & & 14 \\
Max Ht. (B plots) & 202 & 170 & 10 & 150 & \\
Max Ht. (C plots) & 191 & 182 & 99 & 93 & 109 \\
\cline { 2 - 6 } Avg. Basal Area (A plots) & 362 & 4 & 9 & & 0.04 \\
Avg. Basal Area (B plots) & 358 & 13 & 0.01 & 11 & \\
Avg. Basal Area (C plots) & 661 & 45 & 26 & 7 & 2 \\
\cline { 2 - 6 } Avg. Trees per Acre (A plots) & 88 & 37 & 20 & & 1 \\
Avg. Trees per Acre (B plots) & 92 & 13 & 1 & 2 & \\
Avg. Trees per Acre (C plots) & 278 & 62 & 43 & 5 & 1 \\
\cline { 2 - 6 } Avg. CF/acre Volume (A plots) & 12,002 & 120 & 215 & & 0.3 \\
Avg. CF/acre Volume (B plots) & 12,396 & 491 & 0.04 & 403 & \\
Avg. CF/acre Volume (C plots) & 22,202 & 1,859 & 568 & 181 & 71 \\
\cline { 2 - 6 } Avg. BF/acre Volume (A plots) & 70,774 & 701 & 921 & & 0.35 \\
Avg. BF/acre Volume (B plots) & 73,609 & 3,097 & 0.03 & 2,301 & \\
Avg. BF/acre Volume (C plots) & 128,825 & 12,533 & 2,054 & 756 & 320 \\
\hline
\end{tabular}

${ }^{1}$ Did not include hardwoods due to only 4 trees of insufficient size and frequency. 
Table 8. Parameter Summary of Significance.

\begin{tabular}{|c|c|c|c|c|c|}
\hline \multirow[b]{2}{*}{ Parameter } & \multirow[b]{2}{*}{$\begin{array}{c}\text { Overall } \\
\text { Significance }^{1}\end{array}$} & \multirow[b]{2}{*}{$P$ - value } & \multicolumn{3}{|c|}{$\begin{array}{c}\text { Significance Between } \\
\text { Treatments }^{2}\end{array}$} \\
\hline & & & A vs. C & B vs. C & A vs. B \\
\hline Cubic-Foot Volume Growth 2001-2009 & $\mathrm{Y}$ & 0.0324 & $\mathrm{~N}$ & $\mathrm{~N}$ & $\mathrm{~N}$ \\
\hline Cubic-Foot Volume Growth 1989-2009 & $\mathrm{Y}$ & 0.0164 & $\mathrm{Y}$ & $\mathrm{Y}$ & $\mathrm{N}$ \\
\hline Board-Foot Volume Growth 2001-2009 & $\mathrm{N}$ & 0.0611 & $\mathrm{~N}$ & $\mathrm{~N}$ & $\mathrm{~N}$ \\
\hline Board-Foot Volume Growth 1989-2009 & $\mathrm{Y}$ & 0.0437 & $\mathrm{~N}$ & $\mathrm{~N}$ & $\mathrm{~N}$ \\
\hline Cubic-Foot Yield 1989 & $\mathrm{Y}$ & 0.0009 & $\mathrm{Y}$ & $\mathrm{Y}$ & $\mathrm{N}$ \\
\hline Cubic-Foot Yield 1994 & $\mathrm{Y}$ & 0.0013 & $\mathrm{Y}$ & $\mathrm{Y}$ & $\mathrm{N}$ \\
\hline Cubic-Foot Yield 2001 & $\mathrm{Y}$ & 0.0016 & $\mathrm{Y}$ & $\mathrm{Y}$ & $\mathrm{N}$ \\
\hline Cubic-Foot Yield 2009 & $\mathrm{Y}$ & 0.0018 & $\mathrm{Y}$ & $\mathrm{Y}$ & $\mathrm{N}$ \\
\hline Board-Foot Yield 1989 & $\mathrm{Y}$ & 0.0058 & $\mathrm{Y}$ & $\mathrm{Y}$ & $\mathrm{N}$ \\
\hline Board-Foot Yield 1994 & $\mathrm{Y}$ & 0.0078 & $\mathrm{Y}$ & $\mathrm{Y}$ & $\mathrm{N}$ \\
\hline Board-Foot Yield 2001 & $\mathrm{Y}$ & 0.0089 & $\mathrm{Y}$ & $\mathrm{Y}$ & $\mathrm{N}$ \\
\hline Board-Foot Yield 2009 & $\mathrm{Y}$ & 0.0106 & $\mathrm{Y}$ & $\mathrm{Y}$ & $\mathrm{N}$ \\
\hline
\end{tabular}

${ }^{1}$ (ANOVA) shows significant difference between the three treatments if $\mathrm{p}$-value $\leq 0.05$.

${ }^{2}$ Tukey's pairwise comparison shows significant difference between specific treatments at 0.05 level.

\section{Cubic-Foot Growth}

This inherent variability is also apparent when observing the range of cubic-foot growth per acre (Table 9). The measurement year intervals for this analysis are 2001 2009 and 1989 - 2009 looking at overall cubic-foot volume growth difference between treatments. The prior year intervals of 1989 - 1994, 1994 - 2001, and 1989 - 2001 were analyzed by Roller (2004). 
Table 9. Summary Statistics for Cubic-Foot Growth/Acre.

\begin{tabular}{|l|c|c|c|c|c|}
\hline \multicolumn{7}{|c|}{$2001-2009$} \\
\hline Treatment & Mean & SE $^{1}$ & Max & Min & $N$ \\
\hline A - Thinned & $2,853.93 \mathrm{a}^{2}$ & 243.36 & $4,647.69$ & $1,789.63$ & 12 \\
\hline B - Thin\Burn & $2,921.78 \mathrm{a}$ & 343.19 & $5,625.81$ & $1,818.14$ & 12 \\
\hline C - Control & $4,092.75 \mathrm{a}$ & 476.63 & $7,006.34$ & $2,582.55$ & 11 \\
\hline \multicolumn{5}{|c|}{$1989-2009$} \\
\hline Treatment & Mean & SE & Max & Min & $N$ \\
\hline A - Thinned & $6,460.44 \mathrm{a}$ & 661.39 & $10,869.18$ & $3,540.17$ & 12 \\
\hline B - Thin\Burn & $6,667.78 \mathrm{a}$ & 802.72 & $12,874.96$ & $3,912.52$ & 12 \\
\hline C - Control & $9,731.05 \mathrm{~b}$ & $1,028.19$ & $17,419.64$ & $5,002.71$ & 11 \\
\hline
\end{tabular}

${ }^{1} \mathrm{SE}=$ Standard Error.

${ }^{2}$ Means followed by the same letter do not differ at the 0.05 level.

The 2001 - 2009 ANOVA result shows a significant difference $(p=0.0324)$ in volume between the three treatments (Table 10). Tukey's pairwise comparison is not able to show which treatments are significantly different from each other (Table 11).

Table 10. Results of ANOVA for Cubic-Foot Growth from 2001-2009.

\begin{tabular}{|l|c|c|c|c|c|}
\hline Source & DF & SS & MS & F Value & $\operatorname{Pr}>$ F \\
\hline Model & 2 & 1.13821393 & 0.56910697 & 3.83 & 0.0324 \\
\hline Error & 32 & 4.75993705 & 0.14874803 & & \\
\hline Corrected Total & 34 & 5.89815098 & & & \\
\hline
\end{tabular}


Table 11. Results of Pairwise Comparison for Cubic-Foot Growth from 2001-2009.

$$
\begin{aligned}
& \text { Tukey’s Studentized Range (HSD) Test } \\
& \text { Critical Value of Studentized Range } 3.47525
\end{aligned}
$$

\begin{tabular}{|c|c|cc|}
\hline $\begin{array}{c}\text { Treatment } \\
\text { Comparison }\end{array}$ & $\begin{array}{c}\text { Difference } \\
\text { Between Means }\end{array}$ & Simultaneous 95\% Confidence Limits \\
\hline C - A & 0.3856 & -0.0100 & 0.7812 \\
\hline C - B & 0.3912 & -0.0044 & 0.7868 \\
\hline A - C & -0.3856 & -0.7812 & 0.0100 \\
\hline A - B & 0.0056 & -0.3813 & 0.3925 \\
\hline B - C & -0.3912 & -0.7868 & 0.0044 \\
\hline B - A & -0.0056 & -0.3925 & 0.3813 \\
\hline
\end{tabular}

The 1989 - 2009 ANOVA result shows a significant difference $(p=0.0164)$ in volume between the three treatments (Table 12). Tukey’s pairwise comparison shows that there was a significant difference between the thin only treatment and the control and also between the thin and burn treatment and the control. However there was no significant difference between the thin only and the thin and burn treatments (Table 13).

Table 12. Results of ANOVA for Cubic-Foot Growth from 1989-2009.

\begin{tabular}{|l|c|r|r|r|c|}
\hline Source & DF & SS & MS & F Value & Pr $>$ F \\
\hline Model & 2 & 75908865.4 & 37954432.7 & 4.69 & 0.0164 \\
\hline Error & 32 & 259087430.7 & 8096482.2 & & \\
\hline $\begin{array}{l}\text { Corrected } \\
\text { Total }\end{array}$ & 34 & 334996296.0 & & & \\
\hline
\end{tabular}


Table 13. Results of Pairwise Comparison for Cubic-Foot Growth from 1989-2009.

Tukey’s Studentized Range (HSD) Test
Critical Value of Studentized Range 3.47525
Comparisons significant at the 0.05 level are indicated by ***.

\begin{tabular}{|c|c|cc|}
\hline $\begin{array}{c}\text { Treatment } \\
\text { Comparison }\end{array}$ & $\begin{array}{c}\text { Difference } \\
\text { Between Means }\end{array}$ & \multicolumn{2}{|c|}{ Simultaneous 95\% Confidence Limits } \\
\hline C - B & 3,063 & 145 & $5,982 * * *$ \\
\hline C - A & 3,271 & 352 & $6,189 * * *$ \\
\hline B - C & $-3,063$ & $-5,982$ & $-145 * * *$ \\
\hline B - A & 207 & $-2,647$ & 3,062 \\
\hline A - C & $-3,271$ & $-6,189$ & $-352 * * *$ \\
\hline A - B & -207 & $-3,062$ & 2,647 \\
\hline
\end{tabular}

\section{Board-Foot Growth}

This inherent variability is also apparent when observing the range of board-foot growth per acre (Table 14). The measurement year intervals for this analysis are 2001 2009 and 1989 - 2009 looking at overall board-foot volume growth difference between treatments. The prior year intervals of 1989 - 1994, 1994 - 2001 and 1989 - 2001 were analyzed by Roller (2004).

The 2001 - 2009 ANOVA result shows no significant difference $(p=0.0611)$ in volume between the treatments (Table 15). Tukey’s pairwise comparison is not necessary since the ANOVA shows no significant differences between the treatments. 
Table 14. Summary Statistics for Board-Foot Growth/Acre.

\begin{tabular}{|c|c|c|c|c|c|}
\hline \multicolumn{6}{|c|}{$2001-2009$} \\
\hline Treatment & Mean & $\mathrm{SE}^{1}$ & Max & Min & $N$ \\
\hline A - Thinned & $18,167.79 \mathrm{a}^{2}$ & $1,867.01$ & $30,397.14$ & $10,907.31$ & 12 \\
\hline B - Thin \Burn & $18,947.12$ a & $2,647.08$ & $40,275.83$ & $9,922.74$ & 12 \\
\hline C - Control & $27,227.01 \mathrm{a}$ & $3,801.81$ & $51,475.14$ & $14,632.06$ & 11 \\
\hline \multicolumn{6}{|c|}{$1989-2009$} \\
\hline Treatment & Mean & SE & Max & Min & $N$ \\
\hline A - Thinned & $40,572.66 \mathrm{a}$ & $5,001.72$ & $69,482.52$ & $19,633.16$ & 12 \\
\hline B - Thin\Burn & $42,633.59$ a & $6,460.90$ & $93,894.19$ & 21,799.90 & 12 \\
\hline C - Control & $63,353.83 \mathrm{a}$ & $8,433.75$ & $125,026.24$ & $27,277.09$ & 11 \\
\hline
\end{tabular}

${ }^{1} \mathrm{SE}=$ Standard Error. $\quad{ }^{2}$ Means followed by the same letter do not differ at the 0.05 level.

Table 15. Results of ANOVA for Board-Foot Growth from 2001-2009.

\begin{tabular}{|l|c|c|c|c|c|}
\hline Source & DF & SS & MS & F Value & Pr $>$ F \\
\hline Model & 2 & 1.01519911 & 0.50759956 & 3.05 & 0.0611 \\
\hline Error & 32 & 5.31914808 & 0.16622338 & & \\
\hline Corrected Total & 34 & 6.33434719 & & & \\
\hline
\end{tabular}

The 1989 - 2009 ANOVA result shows a significant difference $(\mathrm{p}=0.0437)$ in volume between the three treatments (Table 16). Tukey's pairwise comparison is not able to show which groups are significantly different from each other (Table 17). 
Table 16. Results of ANOVA for Board-Foot Growth from 1989-2009.

\begin{tabular}{|l|c|r|r|r|c|}
\hline Source & DF & SS & MS & F Value & Pr $>$ F \\
\hline Model & 2 & 3593959414 & 1796979707 & 3.46 & 0.0437 \\
\hline Error & 32 & 16636478055 & 519889939 & & \\
\hline $\begin{array}{l}\text { Corrected } \\
\text { Total }\end{array}$ & 34 & 20230437469 & & & \\
\hline
\end{tabular}

Table 17. Results of Pairwise Comparison for Board-Foot Growth from 1989-2009.

\begin{tabular}{|c|c|cc|}
\hline \multicolumn{3}{|l|}{$\begin{array}{l}\text { Tukey's Studentized Range (HSD) Test } \\
\text { Critical Value of Studentized Range 3.47525 }\end{array}$} \\
\hline $\begin{array}{c}\text { Treatment } \\
\text { Comparison }\end{array}$ & $\begin{array}{c}\text { Difference } \\
\text { Between Means }\end{array}$ & Simultaneous 95\% Confidence Limits \\
\hline C - B & 20,720 & $-2,668$ & 44,109 \\
\hline C - A & 22,781 & -607 & 46,170 \\
\hline B - C & $-20,720$ & $-44,109$ & 2,668 \\
\hline B - A & 2,061 & $-20,814$ & 24,935 \\
\hline A - C & $-22,781$ & $-46,170$ & 607 \\
\hline A - B & $-2,061$ & $-24,935$ & 20,814 \\
\hline
\end{tabular}

\section{Cubic-Foot/Board-Foot Yield}

This inherent variability is also apparent when observing the range of cubic-foot yield per acre and board-foot yield per acre (Table 18). The cubic-foot per acre and board-foot per acre yield measurement year for this analysis is 2009. The prior years of 1989, 1994, and 2001 were analyzed by Roller (2004). 
Table 18. Summary Statistics for Cubic-Foot Yield/Acre and Board-Foot Yield/Acre 2009.

\begin{tabular}{|c|c|c|c|c|c|}
\hline \multicolumn{6}{|c|}{ Cubic-Feet/Acre } \\
\hline Treatment & Mean & $\mathrm{SE}^{1}$ & Max & Min & $N$ \\
\hline A - Thinned & $12,305.09 a^{2}$ & $1,606.18$ & $21,887.86$ & $5,735.79$ & 12 \\
\hline B - Thin $\backslash$ Burn & $13,252.51 \mathrm{a}$ & $2,095.55$ & $30,835.35$ & $6,520.29$ & 12 \\
\hline C - Control & $24,881.51$ b & $3,769.60$ & $55,881.52$ & $11,532.14$ & 11 \\
\hline \multicolumn{6}{|c|}{ Board-Feet/Acre } \\
\hline Treatment & Mean & SE & Max & Min & $N$ \\
\hline A - Thinned & $72,272.54 \mathrm{a}$ & $11,470.81$ & $143,959.09$ & $29,421.00$ & 12 \\
\hline B - Thin \Burn & $78,159.84$ a & $14,977.51$ & $203,475.33$ & 29,299.74 & 12 \\
\hline C - Control & $144,489.60 \mathrm{~b}$ & $25,050.90$ & $342,108.40$ & $57,399.09$ & 11 \\
\hline
\end{tabular}

${ }^{1} \mathrm{SE}=$ Standard Error. $\quad{ }^{2}$ Means followed by the same letter do not differ at the 0.05 level.

The 2009 cubic-feet yield/acre ANOVA result shows a significant difference $(\mathrm{p}=0.0018)$ in volume between the three treatments (Table 19). Tukey’s pairwise comparison shows that there was a significant difference between the thin only treatment and the control and also between the thin and burn treatment and the control. However there was no significant difference between the thin only and the thin and burn treatments (Table 20).

Table 19. Results of ANOVA for Cubic-Foot Yield 2009.

\begin{tabular}{|l|c|c|c|c|c|}
\hline Source & DF & SS & MS & F Value & Pr $>$ F \\
\hline Model & 2 & 3.38825360 & 1.69412680 & 7.75 & 0.0018 \\
\hline Error & 32 & 6.99522772 & 0.21860087 & & \\
\hline Corrected Total & 34 & 10.38348131 & & & \\
\hline
\end{tabular}


Table 20. Results of Pairwise Comparison for Cubic-Foot Yield 2009.

Tukey’s Studentized Range (HSD) Test

Critical Value of Studentized Range 3.47525

Comparisons significant at the 0.05 level are indicated by ***.

\begin{tabular}{|c|c|cc|}
\hline $\begin{array}{c}\text { Treatment } \\
\text { Comparison }\end{array}$ & $\begin{array}{c}\text { Difference } \\
\text { Between Means }\end{array}$ & Simultaneous 95\% Confidence Limits \\
\hline C - B & 0.6436 & 0.1640 & $1.1232 * * *$ \\
\hline C - A & 0.6938 & 0.2143 & $1.1734 * * *$ \\
\hline B - C & -0.6436 & -1.1232 & $-0.1640 * * *$ \\
\hline B - A & 0.0503 & -0.4188 & 0.5193 \\
\hline A - C & -0.6938 & -1.1734 & $-0.2143^{* * *}$ \\
\hline A - B & -0.0503 & -0.5193 & 0.4188 \\
\hline
\end{tabular}

The 2009 board-foot yield/acre ANOVA result shows a significant difference $(\mathrm{p}=0.0106)$ in volume between the three treatments (Table 21). Tukey’s pairwise comparison shows that there was a significant difference between the thin only treatment and the control and also between the thin and burn treatment and the control. However there was no significant difference between the thin only and the thin and burn treatments (Table 22).

Table 21. Results of ANOVA for Board-Foot Yield 2009.

\begin{tabular}{|l|c|c|c|c|c|}
\hline Source & DF & SS & MS & F Value & Pr $>$ F \\
\hline Model & 2 & 3.32618649 & 1.66309325 & 5.26 & 0.0106 \\
\hline Error & 32 & 10.12354398 & 0.31636075 & & \\
\hline Corrected Total & 34 & 13.44973047 & & & \\
\hline
\end{tabular}


Table 22. Results of Pairwise Comparison for Board-Foot Yield 2009.

Tukey’s Studentized Range (HSD) Test
Critical Value of Studentized Range 3.47525
Comparisons significant at the 0.05 level are indicated by ***.

\begin{tabular}{|c|c|cc|}
\hline $\begin{array}{c}\text { Treatment } \\
\text { Comparison }\end{array}$ & $\begin{array}{c}\text { Difference } \\
\text { Between Means }\end{array}$ & Simultaneous 95\% Confidence Limits \\
\hline C - B & 0.6421 & 0.0652 & 1.2191 *** \\
\hline C - A & 0.6839 & 0.1069 & $1.2608 * * *$ \\
\hline B - C & -0.6421 & -1.2191 & $-0.0652 * * *$ \\
\hline B - A & 0.0417 & -0.5225 & 0.6060 \\
\hline A - C & -0.6839 & -1.2608 & $-0.1069 * * *$ \\
\hline A - B & -0.0417 & -0.6060 & 0.5225 \\
\hline
\end{tabular}

The 1989 - 2009 control cubic-feet and board-feet volume growth was greater than the thin only and thin and burn treatments (Table 9 and 14). However the 20 year growth of the thin only and thin and burn treatment plots expressed as percentage of posttreatment volume was greater than the growth of the control plots (Table 23). The thinned only plots added $110.5 \%$ of the cubic-feet volume that was on the post-treatment thinned plots in 1989 and the control plots added $65.0 \%$ of the cubic-feet volume that was on the control plots in 1989.

Table 23. Percent Volume Growth Between Treatments from 1989-2009.

\begin{tabular}{|c|c|c|c|}
\cline { 2 - 4 } \multicolumn{1}{c|}{} & Thinned (\%) & Thin/Burn (\%) & Control (\%) \\
\hline Cubic-Feet & 110.5 & 101.3 & 65.0 \\
\hline Board-Feet & 128.0 & 120.0 & 79.3 \\
\hline
\end{tabular}


The cubic-feet periodic annual increment (PAI) for the three time periods 1989 1994, 1994 - 2001, and 2001 - 2009 within the 20 year study were calculated. The 20 year (PAI) showed control with the highest at $487 \mathrm{ft}^{2}$ per acre per year. The results showed an upward or increasing volume trend for all treatments from 1989 through 2001. The thin only and thin and burn both showed this increasing volume trend starting to level off for the time period 2001 through 2009. The control has started to show a decrease volume trend for the time period 2001 through 2009 (Figure 4). In contrast the PAI mortality per acre per year for the control plots had increasing trend from 25.3 for $1994-2001$ to 41.1 for 2001 - 2009 (Figure 5).

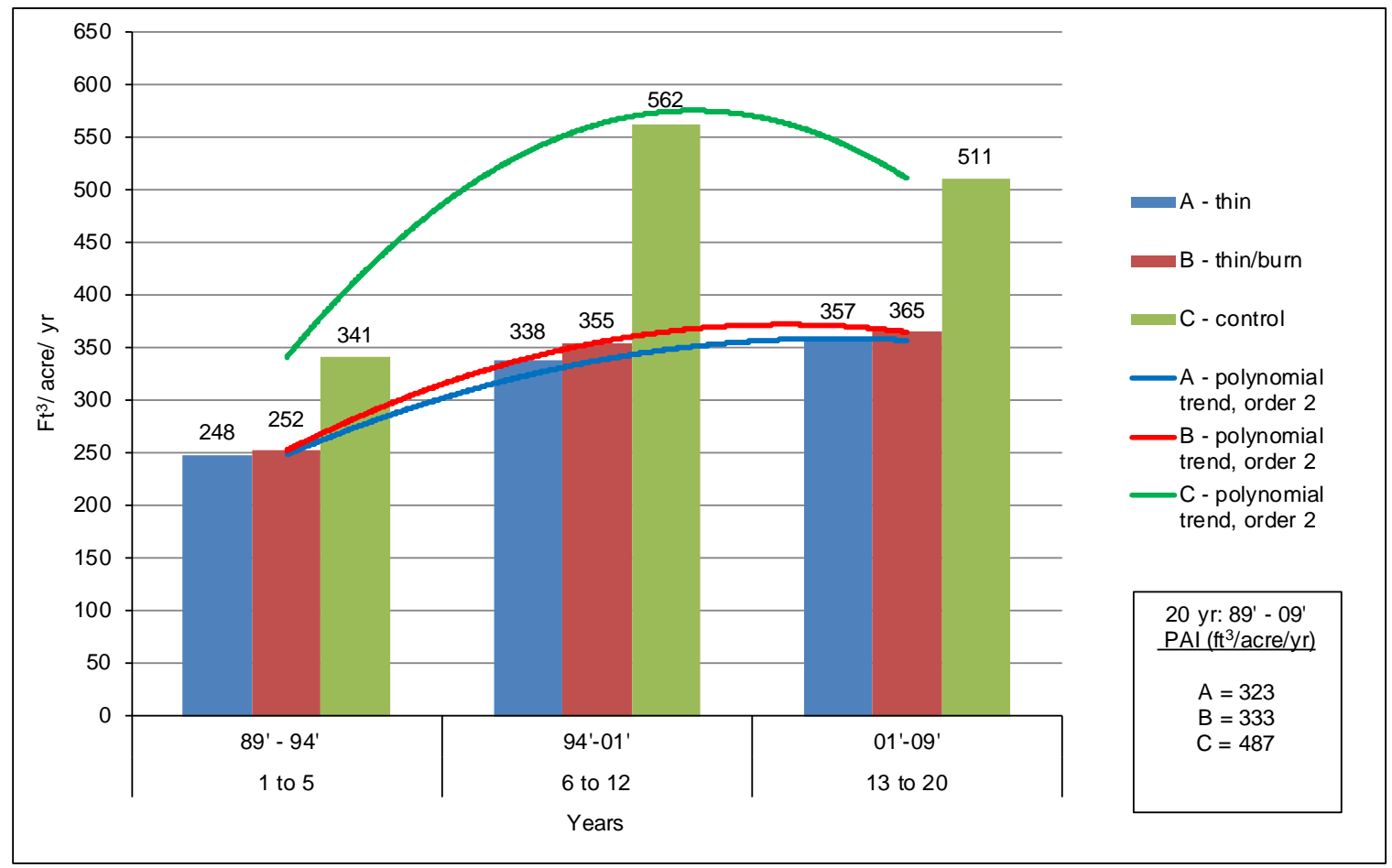

Fig. 4. Periodic Annual Increment (ft. ${ }^{3} /$ acre/year) from 1989-2009. 


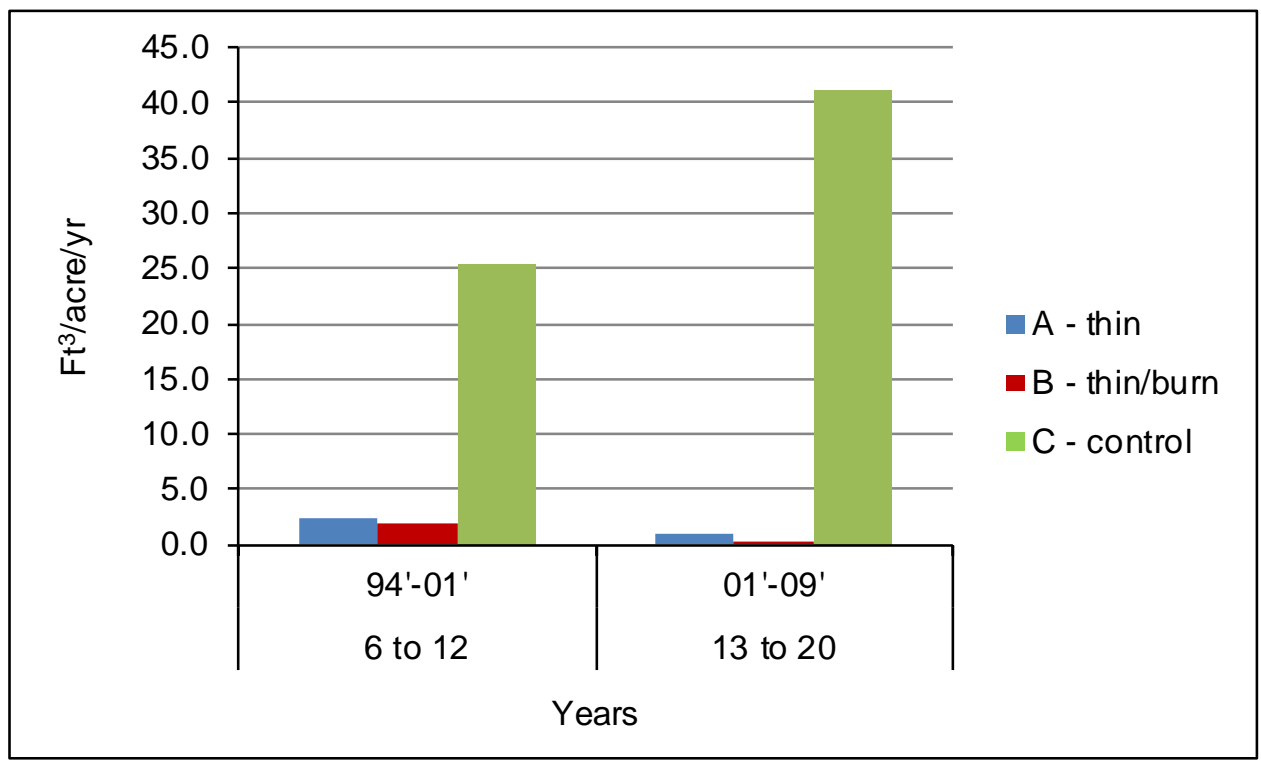

Fig. 5. Periodic Annual Mortality (ft. ${ }^{3}$ /acre/year) from 1994-2009.

\section{Understory Plant Response}

The understory plant species raw data are displayed in frequency (number of plot occurrences), density (average stems per acre), and abundance (average percent cover) tables in relation to the different treatments and years 1989 and 2009 (Tables 24 - 26). There are 26 different plants represented with 23 species, ferns (Bracken and Lady Ferns lumped together), graminoids (grasses, sedges and rushes lumped together), and unidentified forbs (lumped together) with the top half of occurrences for 2009 above the double line. Frequency is the presence or absence of a specific plant per inventory plot leading to the total number of inventory plot occurrences in relation to treatment and year. All plants above the double line for 2009 occur in all treatments and only the top five plants occur in approximately $50 \%$ or greater of the total 35 plots with Abies 
Table 24. Understory Plant Species: Frequency (Number of Plot Occurrences per Treatment) ${ }^{1}$

\begin{tabular}{|c|c|c|c|c|c|c|c|c|}
\hline \multirow[t]{2}{*}{ Species } & \multirow[t]{2}{*}{ Common Name } & \multirow{2}{*}{$\begin{array}{c}\text { Growth }^{7} \\
\text { Form } \\
\text { Category }\end{array}$} & \multicolumn{3}{|c|}{$\begin{array}{c}1989^{2} \\
\text { Treatments }^{3}\end{array}$} & \multicolumn{3}{|c|}{$\begin{array}{c}2009^{2} \\
\text { Treatments }\end{array}$} \\
\hline & & & A & $\mathrm{B}$ & $\mathrm{C}$ & A & $\mathrm{B}$ & $\mathrm{C}$ \\
\hline Abies concolor & white fir & $\mathrm{T}$ & 6 & 5 & 6 & 12 & 12 & 9 \\
\hline Unidentified Forbs ${ }^{4}$ & unidentified forbs & $\mathrm{F}$ & 5 & 8 & 8 & 10 & 11 & 9 \\
\hline Ribes roezlii & sierra gooseberry & S & 6 & 6 & 5 & 11 & 9 & 7 \\
\hline Graminoids $^{5}$ & grasses, sedges and rushes & G & 2 & 1 & 4 & 9 & 10 & 6 \\
\hline Ferns $^{6}$ & bracken fern and lady fern & $\mathrm{F}$ & 5 & 5 & 4 & 6 & 6 & 5 \\
\hline Calocedrus decurrens & incense-cedar & $\mathrm{T}$ & 3 & 4 & 5 & 4 & 6 & 5 \\
\hline Galium trifidum & threepetal bedstraw & $\mathrm{F}$ & 0 & 0 & 0 & 5 & 5 & 5 \\
\hline Adenocaulon bicolor & trail plant & $\mathrm{F}$ & 0 & 0 & 0 & 5 & 4 & 4 \\
\hline Cornus nuttallii & western dogwood & $\mathrm{T}$ & 1 & 2 & 0 & 2 & 3 & 4 \\
\hline Quercus kelloggii & california black oak & $\mathrm{T}$ & 3 & 3 & 3 & 2 & 2 & 4 \\
\hline Rosa californica & california wild rose & S & 2 & 4 & 1 & 2 & 4 & 2 \\
\hline Pinus lambertiana & sugar pine & $\mathrm{T}$ & 3 & 1 & 1 & 2 & 7 & 2 \\
\hline Corylus cornuta & california hazelnut & $\mathrm{S}$ & 1 & 0 & 1 & 2 & 2 & 3 \\
\hline Chamaebatia foliolosa & bear clover/ mountain misery & S & 1 & 0 & 1 & 3 & 1 & 2 \\
\hline Arctostaphylos patula & greenleaf manzanita & S & 0 & 0 & 0 & 3 & 3 & 0 \\
\hline Ribes nevadense & mountain pink currant & S & 0 & 2 & 1 & 1 & 2 & 2 \\
\hline Lupinus polyphyllus & bigleaf lupine & $\mathrm{F}$ & 0 & 0 & 0 & 2 & 3 & 0 \\
\hline Ceanothus cordulatus & mountain whitethorn & S & 0 & 0 & 1 & 1 & 3 & 0 \\
\hline Ceanothus integerrimus & deer brush & $\mathrm{S}$ & 0 & 1 & 0 & 1 & 3 & 0 \\
\hline Ceanothus parvifolius & littleleaf ceanothus & $S$ & 0 & 0 & 0 & 3 & 1 & 0 \\
\hline Lotus crassifolius & big deervetch & $\mathrm{F}$ & 0 & 0 & 0 & 0 & 4 & 0 \\
\hline Prunus emarginata & bitter cherry & $\mathrm{S}$ & 0 & 2 & 0 & 0 & 2 & 1 \\
\hline Rubus leucodermis & blackcap/ western raspberry & $S$ & 0 & 0 & 0 & 1 & 2 & 0 \\
\hline Rubus parviflorus & thimbleberry & $S$ & 0 & 0 & 1 & 0 & 0 & 2 \\
\hline Sequoiadendron giganteum & giant sequoia & $\mathrm{T}$ & 1 & 0 & 1 & 0 & 0 & 1 \\
\hline Chrysolepsis sempervirens & evergreen/bush chinquapin & $\mathrm{S}$ & 0 & 2 & 0 & 0 & 1 & 0 \\
\hline
\end{tabular}

${ }^{1}$ Top 50\% occurrence for 2009 are those species above the double line.

${ }^{2} 1989$ is pretreatment, 2009 is 20 years after treatment.

${ }^{3}$ Treatments: $\mathrm{A}=$ thin only, 12 plots; $\mathrm{B}=$ thin and burn, 12 plots; $\mathrm{C}=$ control, no thin or burn, 11 plots.

${ }^{4}$ Unidentified Forbs: Forbs where possible were identified while other forbs were lumped into this category.

${ }^{5}$ Graminoids: Poaceae, Cyperaceae and Juncaceae.

${ }^{6}$ Ferns: Pteridium aquilinum and Athyrum filix-femina var cyclosorum.

${ }^{7}$ Growth Form Category: $\mathrm{T}$ = tree, $\mathrm{F}=$ Forb/Herb/Fern, $\mathrm{S}=$ shrub, $\mathrm{G}=$ graminoid. 
Table 25. Understory Plant Species: Density (Average Stems Per Acre per Treatment) ${ }^{1}$.

\begin{tabular}{|c|c|c|c|c|c|c|c|c|}
\hline \multirow[t]{2}{*}{ Species } & \multirow[t]{2}{*}{ Common Name } & \multirow{2}{*}{$\begin{array}{c}\text { Growth }^{7} \\
\text { Form } \\
\text { Category }\end{array}$} & \multicolumn{3}{|c|}{$\begin{array}{c}1989^{2} \\
\text { Treatments }^{3}\end{array}$} & \multicolumn{3}{|c|}{$\begin{array}{c}2009^{2} \\
\text { Treatments }\end{array}$} \\
\hline & & & A & $\mathrm{B}$ & $\mathrm{C}$ & A & $\mathrm{B}$ & $\mathrm{C}$ \\
\hline Abies concolor & white fir & $\mathrm{T}$ & 356.0 & 224.8 & 224.8 & $1,742.4$ & $4,833.8$ & $2,268.7$ \\
\hline Unidentified Forbs ${ }^{4}$ & unidentified forbs & $\mathrm{F}$ & $\mathrm{n} / \mathrm{a}$ & $\mathrm{n} / \mathrm{a}$ & $\mathrm{n} / \mathrm{a}$ & $59,222.9$ & $76,178.5$ & $53,529.0$ \\
\hline Ribes roezlii & sierra gooseberry & S & $2,360.7$ & $1,049.2$ & $1,267.2$ & $3,915.7$ & $2,154.6$ & $1,246.8$ \\
\hline Graminoids $^{5}$ & grasses, sedges and rushes & G & $\mathrm{n} / \mathrm{a}$ & $\mathrm{n} / \mathrm{a}$ & $\mathrm{n} / \mathrm{a}$ & $10,585.6$ & $22,089.1$ & $2,779.7$ \\
\hline Ferns ${ }^{6}$ & bracken fern and lady fern & $\mathrm{F}$ & $2,042.2$ & $2,079.6$ & $2,084.7$ & $5,470.8$ & $4,234.2$ & $2,350.5$ \\
\hline Calocedrus decurrens & incense-cedar & $\mathrm{T}$ & 187.4 & 168.6 & 183.9 & 187.4 & 393.4 & 286.1 \\
\hline Galium trifidum & threepetal bedstraw & $\mathrm{F}$ & 0.0 & 0.0 & 0.0 & $18,210.9$ & $8,899.4$ & $18,129.1$ \\
\hline Adenocaulon bicolor & trail plant & $\mathrm{F}$ & 0.0 & 0.0 & 0.0 & $1,236.5$ & 112.4 & $12,242.8$ \\
\hline Cornus nuttallii & western dogwood & $\mathrm{T}$ & 37.5 & 74.9 & 0.0 & 37.5 & 224.8 & 306.6 \\
\hline Quercus kelloggii & california black oak & $\mathrm{T}$ & 149.9 & 131.1 & 183.9 & 206.1 & 74.9 & 224.8 \\
\hline Rosa californica & california wild rose & S & $1,180.3$ & 693.2 & 633.6 & $3,784.6$ & $2,510.6$ & $1,921.2$ \\
\hline Pinus lambertiana & sugar pine & $\mathrm{T}$ & 56.2 & 18.7 & 20.4 & 56.2 & 131.1 & 102.2 \\
\hline Corylus cornuta & california hazelnut & $\mathrm{S}$ & 18.7 & 0.0 & 61.3 & 56.2 & 393.4 & 163.5 \\
\hline Chamaebatia foliolosa & bear clover/ mountain misery & $\mathrm{S}$ & 149.9 & 0.0 & 143.1 & $11,522.3$ & 74.9 & $2,779.7$ \\
\hline Arctostaphylos patula & greenleaf manzanita & $S$ & 0.0 & 0.0 & 0.0 & 74.9 & 168.6 & 0.0 \\
\hline Ribes nevadense & mountain pink currant & $\mathrm{S}$ & 0.0 & 318.5 & 347.5 & 187.4 & 449.7 & 388.3 \\
\hline Lupinus polyphyllus & bigleaf lupine & $\mathrm{F}$ & 0.0 & 0.0 & 0.0 & $5,845.5$ & $6,688.6$ & 0.0 \\
\hline Ceanothus cordulatus & mountain whitethorn & $S$ & 0.0 & 0.0 & 20.4 & 18.7 & $2,454.3$ & 0.0 \\
\hline Ceanothus integerrimus & deer brush & $\mathrm{S}$ & 0.0 & 37.5 & 0.0 & 18.7 & 430.9 & 0.0 \\
\hline Ceanothus parvifolius & littleleaf ceanothus & $\mathrm{S}$ & 0.0 & 0.0 & 0.0 & 112.4 & 37.5 & 0.0 \\
\hline Lotus crassifolius & big deervetch & $\mathrm{F}$ & 0.0 & 0.0 & 0.0 & 0.0 & 880.6 & 0.0 \\
\hline Prunus emarginata & bitter cherry & S & 0.0 & 243.6 & 0.0 & 0.0 & 805.6 & 20.4 \\
\hline Rubus leucodermis & blackcap/ western raspberry & $S$ & 0.0 & 0.0 & 0.0 & 524.6 & 337.2 & 0.0 \\
\hline Rubus parviflorus & thimbleberry & $\mathrm{S}$ & 0.0 & 0.0 & 40.9 & 0.0 & 0.0 & 449.7 \\
\hline Sequoiadendron giganteum & giant sequoia & $\mathrm{T}$ & 18.7 & 0.0 & 20.4 & 0.0 & 0.0 & 20.4 \\
\hline Chrysolepsis sempervirens & evergreen/bush chinquapin & $\mathrm{S}$ & 0.0 & 37.5 & 0.0 & 0.0 & 37.5 & 0.0 \\
\hline
\end{tabular}

${ }^{1}$ Top 50\% occurrence for 2009 are those species above the double line.

${ }^{2} 1989$ is pretreatment, 2009 is 20 years after treatment.

${ }^{3}$ Treatments: $\mathrm{A}=$ thin only, 12 plots; $\mathrm{B}=$ thin and burn, 12 plots; $\mathrm{C}=$ control, no thin or burn, 11 plots.

${ }^{4}$ Unidentified Forbs: Forbs where possible were identified while other forbs were lumped into this category.

${ }^{5}$ Graminoids: Poaceae, Cyperaceae and Juncaceae.

${ }^{6}$ Ferns: Pteridium aquilinum and Athyrum filix-femina var cyclosorum.

${ }^{7}$ Growth Form Category: $\mathrm{T}=$ tree, $\mathrm{F}=$ Forb/Herb/Fern, $\mathrm{S}=$ shrub, $\mathrm{G}=$ graminoid. 
Table 26. Understory Plant Species: Abundance (Average Percent Cover per Treatment) ${ }^{1}$.

\begin{tabular}{|c|c|c|c|c|c|c|c|c|}
\hline \multirow[t]{2}{*}{ Species } & \multirow[t]{2}{*}{ Common Name } & \multirow{2}{*}{$\begin{array}{c}\text { Growth }^{7} \\
\text { Form } \\
\text { Category }\end{array}$} & \multicolumn{3}{|c|}{$\begin{array}{c}1989^{2} \\
\text { Treatments } \\
\end{array}$} & \multicolumn{3}{|c|}{$\begin{array}{c}2009^{2} \\
\text { Treatments }{ }^{4}\end{array}$} \\
\hline & & & A & $\mathrm{B}$ & $\mathrm{C}$ & A & $\mathrm{B}$ & $\mathrm{C}$ \\
\hline Abies concolor & white fir & $\mathrm{T}$ & 0.57 & 0.14 & 0.18 & 2.00 & 3.40 & 1.10 \\
\hline Unidentified Forbs ${ }^{4}$ & unidentified forbs & $\mathrm{F}$ & 2.39 & 2.33 & 3.93 & 2.90 & 3.30 & 2.50 \\
\hline Ribes roezlii & sierra gooseberry & S & 0.56 & 0.44 & 0.64 & 1.30 & 0.70 & 0.30 \\
\hline Graminoids $^{5}$ & grasses, sedges and rushes & G & 0.20 & 0.07 & 0.21 & 0.30 & 0.40 & 0.10 \\
\hline Ferns ${ }^{6}$ & bracken fern and lady fern & $\mathrm{F}$ & 2.30 & 2.40 & 2.40 & 5.70 & 5.60 & 2.80 \\
\hline Calocedrus decurrens & incense-cedar & $\mathrm{T}$ & 0.26 & 0.38 & 0.41 & 0.40 & 0.10 & 0.40 \\
\hline Galium trifidum & threepetal bedstraw & $\mathrm{F}$ & 0.00 & 0.00 & 0.00 & 0.50 & 0.30 & 0.40 \\
\hline Adenocaulon bicolor & trail plant & $\mathrm{F}$ & 0.00 & 0.00 & 0.00 & 0.20 & 0.03 & 1.40 \\
\hline Cornus nuttallii & western dogwood & $\mathrm{T}$ & 0.04 & 0.27 & 0.00 & 0.01 & 1.30 & 0.10 \\
\hline Quercus kelloggii & california black oak & $\mathrm{T}$ & 0.42 & 0.03 & 0.18 & 0.20 & 0.10 & 0.30 \\
\hline Rosa californica & california wild rose & S & 0.31 & 0.14 & 0.33 & 0.40 & 0.20 & 0.40 \\
\hline Pinus lambertiana & sugar pine & $\mathrm{T}$ & 0.01 & 0.005 & 0.01 & 0.03 & 0.10 & 0.10 \\
\hline Corylus cornuta & california hazelnut & $\mathrm{S}$ & 0.02 & 0.00 & 0.06 & 0.02 & 0.20 & 0.20 \\
\hline Chamaebatia foliolosa & bear clover/ mountain misery & $\bar{S}$ & 0.05 & 0.00 & 0.11 & 2.30 & 0.01 & 0.80 \\
\hline Arctostaphylos patula & greenleaf manzanita & S & 0.00 & 0.00 & 0.00 & 0.30 & 0.20 & 0.00 \\
\hline Ribes nevadense & mountain pink currant & S & 0.00 & 0.21 & 0.30 & 0.30 & 0.10 & 0.50 \\
\hline Lupinus polyphyllus & bigleaf lupine & $\mathrm{F}$ & 0.00 & 0.00 & 0.00 & 0.70 & 1.40 & 0.00 \\
\hline Ceanothus cordulatus & mountain whitethorn & S & 0.00 & 0.00 & 0.01 & 0.02 & 2.60 & 0.00 \\
\hline Ceanothus integerrimus & deer brush & S & 0.00 & 0.02 & 0.00 & 0.02 & 3.40 & 0.00 \\
\hline Ceanothus parvifolius & littleleaf ceanothus & S & 0.00 & 0.00 & 0.00 & 0.40 & 0.10 & 0.00 \\
\hline Lotus crassifolius & big deervetch & $\mathrm{F}$ & 0.00 & 0.00 & 0.00 & 0.00 & 0.60 & 0.00 \\
\hline Prunus emarginata & bitter cherry & S & 0.00 & 0.28 & 0.00 & 0.00 & 0.50 & 0.01 \\
\hline Rubus leucodermis & blackcap/ western raspberry & S & 0.00 & 0.00 & 0.00 & 0.10 & 0.20 & 0.00 \\
\hline Rubus parviflorus & thimbleberry & S & 0.00 & 0.00 & 0.22 & 0.00 & 0.00 & 0.30 \\
\hline Sequoiadendron giganteum & giant sequoia & $\mathrm{T}$ & 0.10 & 0.00 & 0.03 & 0.00 & 0.00 & 0.03 \\
\hline Chrysolepsis sempervirens & evergreen/bush chinquapin & $\mathrm{S}$ & 0.00 & 0.02 & 0.00 & 0.00 & 0.10 & 0.00 \\
\hline
\end{tabular}

${ }^{1}$ Top 50\% occurrence for 2009 are those species above the double line.

${ }^{2} 1989$ is pretreatment, 2009 is 20 years after treatment.

3 Treatments: $\mathrm{A}=$ thin only, 12 plots; $\mathrm{B}=$ thin and burn, 12 plots; $\mathrm{C}=$ control, no thin or burn, 11 plots.

${ }^{4}$ Unidentified Forbs: Forbs where possible were identified while other forbs were lumped into this category.

${ }^{5}$ Graminoids: Poaceae, Cyperaceae and Juncaceae.

${ }^{6}$ Ferns: Pteridium aquilinum and Athyrum filix-femina var cyclosorum.

${ }^{7}$ Growth Form Category: $\mathrm{T}=$ tree, $\mathrm{F}=$ Forb/Herb/Fern, $\mathrm{S}=$ shrub, $\mathrm{G}=$ graminoid. 
concolor, unidentified forbs, and Ribes roezlii in greater than $75 \%$. When aggregated by treatment, thin shows the top five plants occur in $50 \%$ or greater of the plots, thin/burn shows the top six plants plus Pinus lambertiana occur in 50\% or greater of the plots, and control shows the top four plants occur in $50 \%$ or greater of the plots (Table 24). Density is the average stems per acre for each plant in relation to treatment and year. A. concolor is the 2009 understory tree with the greatest stems per acre across all the treatments compared with other understory trees and the thin/burn plots having the most with 4,833 stems per acre. Galium trifidum is the 2009 understory herbaceous species having the greatest average stems per acre; the thin only having the most with 18,210 stems per acre. Adenocaulon bicolor is the 2009 understory herbaceous species having the second greatest average stems per acre yet the density in relation to treatment ranges from 12,242 stems per acre for control plots to 112 stems per acre for thin/burn plots. The graminoids 2009 greatest density is 22,089 stems per acre on the thin/burn plots (Table 25).

Abundance is the average percent cover for each plant in relation to treatment and year. The percent cover for 2009 understory trees A. concolor and Conus nuttallii are greatest on thin/burn plots. The ferns have similar percent cover in 1989 and then in 2009 the thin and thin/burn plots have the greatest values. The percent cover and stems per acre for 2009 shrub Ribes roezlii are greatest on the thin plots (Table 26).

Whereas the focus is the species above the double line some below showed interesting results. The 2009 shrubs Ceanothus cordulatus and Ceanothus intergerrimus and 2009 forb Lupinus polyphyllus are only found on treatment plots with the greatest values for percent cover and stems per acre on thin/burn plots. The 2009 shrub 
Chamaebatia foliolosa stems and percent cover per acre are greatest on the thin plots (Tables 25 and 26).

\section{Understory Plant Functional Groups}

The plants were aggregated into functional groups: shrubs (woody plants), Forbs/Herbs (flowering and non-flowering herbaceous plants), graminoids (grasses, sedges, or rushes) and trees (all tree species $<1$ inch DBH) with frequency, density, and percent cover calculated by treatment and year. Twenty years after treatment there was a significant difference between treatments and control for some functional groups (Table 27). The frequency data for the functional groups show a greater increase between 1989 and 2009 for the treatment plots compared with the control plots except by Forbs/Herbs on thin/burn plots (Figure 6).

The 2009 ANOVA results for functional groups density show no significant difference for shrubs $(p=0.271)$ and forb/herbs $(p=0.774)$ between the treatments and the control while there is a significant difference at 0.10 level for graminoids $(\mathrm{p}=0.086)$, and at the 0.05 level for trees $(\mathrm{p}=0.011)$. Tukey's pairwise comparison for graminoid density at $\alpha=0.1$ shows a significant difference between thin/burn and control while no significant difference between thin and thin/burn or thin and control. Tukey’s pairwise comparison for tree density at $\alpha=0.05$ shows a significant difference between thin/burn and both thin and control, which is similar to the regeneration results later in this study (Table 27).

The 2009 ANOVA results for functional groups abundance show no significance for shrubs $(p=0.128)$, forb/herbs $(p=0.542)$ and trees $(p=0.110)$ between the 
Table 27. Understory Plant Species Aggregated by Functional Group per Treatment and Year (standard errors in parentheses).

\begin{tabular}{|c|c|c|c|c|c|c|c|c|}
\hline \multirow{3}{*}{$\begin{array}{l}\text { Functional } \\
\text { Groups }\end{array}$} & \multicolumn{6}{|c|}{ Frequency (number of plot occurrences per treatment) } & \multirow{3}{*}{2009} & \multirow{3}{*}{$\begin{array}{c}\text { 2009-1989 comparison } \\
\text { A, B, C } \\
\text { p-values }^{5}\end{array}$} \\
\hline & \multicolumn{3}{|c|}{$\begin{array}{l}1989^{1} \\
\text { Treatments }^{2} \\
\end{array}$} & \multicolumn{3}{|c|}{$\begin{array}{c}2009^{1} \\
\text { Treatments }^{3,4} \\
\end{array}$} & & \\
\hline & A & B & $\mathrm{C}$ & A & B & $\mathrm{C}$ & & \\
\hline Shrubs & 6.0 & 7.0 & 6.0 & 11.0 & 11.0 & 7.0 & $\mathrm{n} / \mathrm{a}$ & $\mathrm{n} / \mathrm{a}$ \\
\hline Forbs/Herbs ${ }^{6}$ & 6.0 & 10.0 & 8.0 & 10.0 & 11.0 & 9.0 & $\mathrm{n} / \mathrm{a}$ & $\mathrm{n} / \mathrm{a}$ \\
\hline Graminoids $^{7}$ & 2.0 & 1.0 & 4.0 & 9.0 & 10.0 & 6.0 & $\mathrm{n} / \mathrm{a}$ & $\mathrm{n} / \mathrm{a}$ \\
\hline \multirow[t]{4}{*}{ Trees $^{8}$} & 7.0 & 6.0 & 9.0 & 12.0 & 12.0 & 10.0 & $\mathrm{n} / \mathrm{a}$ & $\mathrm{n} / \mathrm{a}$ \\
\hline & \multicolumn{6}{|c|}{ Density (average stems per acre per treatment) } & & \\
\hline & \multicolumn{3}{|c|}{ Treatments } & \multicolumn{3}{|c|}{ Treatments } & & \\
\hline & $\mathrm{A}$ & $\mathrm{B}$ & $\mathrm{C}$ & $\mathrm{A}$ & $\mathrm{B}$ & $\mathrm{C}$ & & \\
\hline Shrubs & $\begin{array}{c}3,709.6 \\
(1,861.9)\end{array}$ & $\begin{array}{c}2,379.4 \\
(1,215.3)\end{array}$ & $\begin{array}{c}2,514.0 \\
(1,182.2)\end{array}$ & $\begin{array}{c}20,215.6 a^{*} \\
(8,721.4)\end{array}$ & $\begin{array}{l}9,854.9 \mathrm{a}^{*} \\
(2,715.3)\end{array}$ & $\begin{array}{c}6,969.6 \mathrm{a} \\
(2,993.7)\end{array}$ & 0.271 & {$[0.018][0.007][0.231]$} \\
\hline Forbs/Herbs & $\mathrm{n} / \mathrm{a}$ & $\mathrm{n} / \mathrm{a}$ & $\mathrm{n} / \mathrm{a}$ & $\begin{array}{c}89,986.5 \text { a } \\
(33,830.7)\end{array}$ & $\begin{array}{c}96,993.6 \text { a } \\
(31,256.6)\end{array}$ & $\begin{array}{l}86,251.4 \mathrm{a} \\
(33,371.4)\end{array}$ & 0.774 & $\mathrm{n} / \mathrm{a}$ \\
\hline Graminoids & $\mathrm{n} / \mathrm{a}$ & $\mathrm{n} / \mathrm{a}$ & $\mathrm{n} / \mathrm{a}$ & $\begin{array}{l}10,585.5 \mathrm{ab} \\
(4,388.0)\end{array}$ & $\begin{array}{c}22,089.1 \mathrm{a} \\
(8,272.4)\end{array}$ & $\begin{array}{c}2,779.7 \text { b } \\
(1,464.7)\end{array}$ & 0.086 & $\mathrm{n} / \mathrm{a}$ \\
\hline \multirow[t]{4}{*}{ Trees } & $\begin{array}{c}805.6 \\
(342.8)\end{array}$ & $\begin{array}{c}618.3 \\
(291.7) \\
\end{array}$ & $\begin{array}{c}633.6 \\
(288.9)\end{array}$ & $\begin{array}{c}2,229.5 b^{*} \\
(366.6)\end{array}$ & $\begin{array}{c}5,658.1 \mathrm{a}^{*} \\
(975.2)\end{array}$ & $\begin{array}{c}3,208.9 b^{*} \\
(895.3)\end{array}$ & 0.011 & {$[0.001][<0.0001][0.011]$} \\
\hline & \multicolumn{6}{|c|}{ Abundance (average percent cover (avg of subplots) per treatment) } & & \\
\hline & \multicolumn{3}{|c|}{ Treatments } & \multicolumn{3}{|c|}{ Treatments } & & \\
\hline & A & $\mathrm{B}$ & $\mathrm{C}$ & A & $\mathrm{B}$ & $\mathrm{C}$ & & \\
\hline Shrubs & $\begin{array}{c}0.90 \\
(0.50)\end{array}$ & $\begin{array}{c}1.10 \\
(0.70)\end{array}$ & $\begin{array}{c}1.70 \\
(0.70)\end{array}$ & $\begin{array}{l}5.30 \mathrm{a}^{*} \\
(1.90)\end{array}$ & $\begin{array}{l}8.40 a^{*} \\
(2.70)\end{array}$ & $\begin{array}{l}2.40 \mathrm{a} \\
(1.00)\end{array}$ & 0.128 & {$[0.008][0.003][\mathrm{n} / \mathrm{a}]$} \\
\hline Forbs/Herbs & $\begin{array}{c}4.70 \\
(2.50)\end{array}$ & $\begin{array}{c}4.70 \\
(2.00)\end{array}$ & $\begin{array}{c}6.30 \\
(2.20)\end{array}$ & $\begin{array}{l}10.10 \mathrm{a}^{*} \\
(2.70)\end{array}$ & $\begin{array}{l}11.20 \mathrm{a} \\
(4.40)\end{array}$ & $\begin{array}{l}7.20 \mathrm{a} \\
(3.00)\end{array}$ & 0.542 & {$[0.044][0.152][0.932]$} \\
\hline Graminoids & $\begin{array}{c}0.20 \\
(0.20)\end{array}$ & $\begin{array}{c}0.10 \\
(0.06)\end{array}$ & $\begin{array}{c}0.20 \\
(0.18)\end{array}$ & $\begin{array}{l}0.30 \mathrm{ab} \\
(0.10)\end{array}$ & $\begin{array}{l}0.40 \mathrm{a} \\
(0.10)\end{array}$ & $\begin{array}{l}0.10 \mathrm{~b} \\
(0.03)\end{array}$ & 0.035 & $\mathrm{n} / \mathrm{a}$ \\
\hline Trees & $\begin{array}{c}1.30 \\
(0.60) \\
\end{array}$ & $\begin{array}{c}0.80 \\
(0.50) \\
\end{array}$ & $\begin{array}{c}0.80 \\
(0.30) \\
\end{array}$ & $\begin{array}{l}2.60 \mathrm{a} \\
(1.20)\end{array}$ & $\begin{array}{l}5.00 \mathrm{a}^{*} \\
(1.60)\end{array}$ & $\begin{array}{l}2.00 \mathrm{a} \\
(0.80) \\
\end{array}$ & 0.110 & {$[\mathrm{n} / \mathrm{a}][0.002][0.156]$} \\
\hline
\end{tabular}

${ }^{1} 1989$ is pretreatment, 2009 is 20 years after treatment.

2 Treatments: $\mathrm{A}=$ thin only, 12 plots; $\mathrm{B}=$ thin and burn, 12 plots; $\mathrm{C}=$ control, no thin or burn, 11 plots.

${ }^{3} 2009$ values followed by the same letter do not differ at the 0.10 level (Tukey's pairwise comparison).

${ }^{4} 2009$ value with an asterisk differs from 1989 value at the 0.10 level.

${ }^{5} \mathrm{p}$-value from analysis of variance (ANOVA).

${ }^{6}$ Forbs/Herbs/Ferns: Flowering and Nonflowering herbaceous plants lumped together.

${ }^{7}$ Graminoids: Grasses, Sedges or Rushes.

${ }^{8}$ Trees: All tree species < 1inch DBH. 


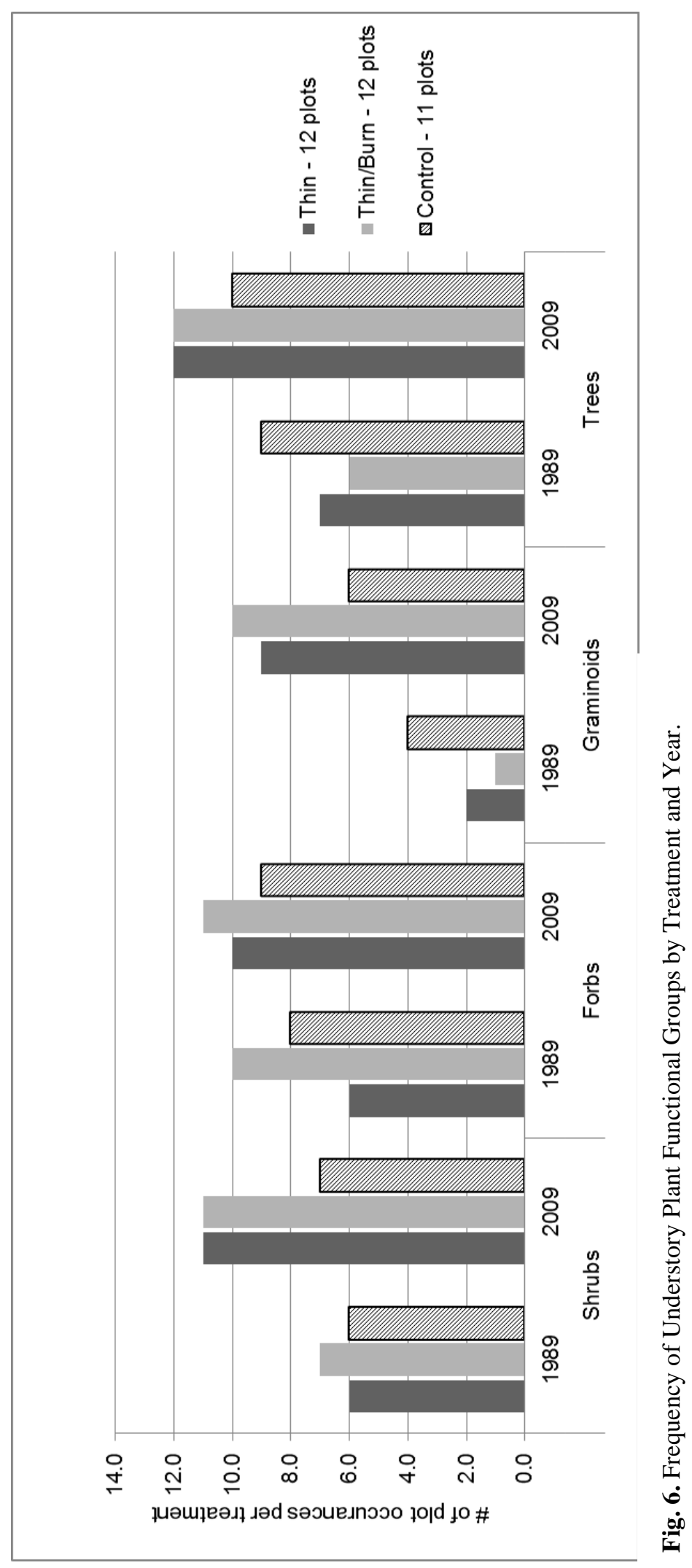

Page 56 
treatments and the control, while there is significance for graminoids $(\mathrm{p}=0.035)$.

Tukey’s pairwise comparison for graminoid abundance at $\alpha=0.05$ shows a significant difference between thin/burn and control while no significant difference between thin and thin/burn or thin and control (Table 27).

A significant difference for the density and abundance values between 2009 and 1989 were found for some functional groups. The ANOVA results for shrubs density show a significant difference between 2009 and 1989 for thin $(\mathrm{p}=0.018)$ and thin/burn $(p=0.007)$ but not for control $(0.231)$. The ANOVA results for trees density show a significant difference between 2009 and 1989 for thin $(p=0.001)$, thin/burn $(p=<0.001)$ and control $(\mathrm{p}=0.011)$. The density comparison between 2009 and 1989 was not possible for forbs/herbs and graminoids because the 1989 data did not record density for unidentified forbs and graminoids (Table 27).

The ANOVA results for shrubs abundance show a significant difference between 2009 and 1989 for thin $(p=0.008)$ and thin/burn $(p=0.003)$. The ANOVA results for forbs/herbs abundance show a significant difference between 2009 and 1989 for thin (p = 0.044) but not for control ( $p=0.932)$ or thin/burn $(\mathrm{p}=0.152)$, even with its similar value difference. The ANOVA results for trees abundance show a significant difference between 2009 and 1989 for thin/burn $(p=0.002)$ but not for thin $(p=n / a)$ or control $(p=$ 0.156) (Table 27). 


\section{Understory Plant Diversity}

The 2009 ANOVA results for the diversity indices show no significant difference for $S$ - species richness $(\mathrm{p}=0.453)$, Berger-Parker Index $(\mathrm{p}=0.721)$, or Simpson Index $(p=0.807)$ between the treatments and the control, likely due to variability caused by different environmental conditions throughout the stands (Table 28). The control plots' values for $S$ - species richness, Berger-Parker Index, and Simpson Index vary by stand (Table 29). A principle components analysis (PCA) shows that slope and elevation are the most influential of the environmental conditions. All three diversity indices display a negative slope trend showing that as elevation and slope values increase the indices' values decrease with $S$-species richness the most pronounced, Berger-Parker Index the least pronounced, and Simpson Index in the middle (Figures 7 - 9).

Table 28. 2009 Summary Table Diversity Indices by Treatment (standard errors in parentheses) ${ }^{1}$.

\begin{tabular}{|l|c|c|c|}
\hline \multirow{4}{*}{ Treatment } & Richness & Evenness & Heterogeneity \\
\cline { 2 - 4 } & $\begin{array}{c}\text { Species } \\
\text { Richness }\end{array}$ & $\begin{array}{c}\text { Berger - Parker } \\
\text { Index }\end{array}$ & $\begin{array}{c}\text { Simpson } \\
\text { Index }\end{array}$ \\
\hline A -Thinned & $7.3 \mathrm{a}^{2}$ & $1.8 \mathrm{a}$ & $53.1 \mathrm{a}$ \\
B - Thin/Burn & $(0.9)$ & $(0.1)$ & $(5.6)$ \\
& $8.5 \mathrm{a}$ & $1.9 \mathrm{a}$ & $52.1 \mathrm{a}$ \\
C - Control & $(1.0)$ & $(0.2)$ & $(7.2)$ \\
& $6.6 \mathrm{a}$ & $1.7 \mathrm{a}$ & $46.1 \mathrm{a}$ \\
& $(1.2)$ & $(0.2)$ & $(8.0)$ \\
\hline P - value & 0.453 & 0.721 & 0.807 \\
\hline
\end{tabular}

${ }^{1}$ Richness- number of species per sample, Evenness- measure of the relative abundance of the different species making up richness, Heterogeneity- accounts for both richness and evenness.

${ }^{2}$ Means followed by the same letter do not differ at the 0.05 level (Tukey's pairwise comparison).

${ }^{3} \mathrm{p}$-value from analysis of variance (ANOVA). 
Table 29. 2009 Control Summary Table for Diversity Indices by Stand (standard errors in parentheses) ${ }^{1}$.

\begin{tabular}{|l|c|c|c|}
\hline \multirow{4}{*}{ Stand } & Richness & Evenness & Heterogeneity \\
\cline { 2 - 4 } & $\begin{array}{c}\text { Species } \\
\text { Richness }\end{array}$ & $\begin{array}{c}\text { Berger - Parker } \\
\text { Index }\end{array}$ & $\begin{array}{c}\text { Simpson } \\
\text { Index }\end{array}$ \\
\hline Bogus Meadow & 9.0 & 2.5 & 68.7 \\
Frasier Mill & $(0.0)$ & $(0.1)$ & $(0.5)$ \\
& 5.0 & 1.8 & 57.1 \\
Headquarters & $(0.0)$ & $(0.2)$ & $(7.6)$ \\
& 12.0 & 1.3 & 40.3 \\
Indian Bath & $(0.0)$ & $(0.0)$ & $(0.0)$ \\
& 1.0 & 1.0 & 0.0 \\
Methuselah & $(0.0)$ & $(0.0)$ & $(0.0)$ \\
& 9.7 & 2.0 & 62.7 \\
Tub Flats & $(0.3)$ & $(0.4)$ & $(7.0)$ \\
& 2.0 & 1.2 & 27.8 \\
& $(0.0)$ & $(0.0)$ & $(0.0)$ \\
\hline
\end{tabular}

${ }^{1}$ Richness- number of species per sample, Evenness- measure of the relative abundance of the different species making up richness, Heterogeneity- accounts for both richness and evenness. 

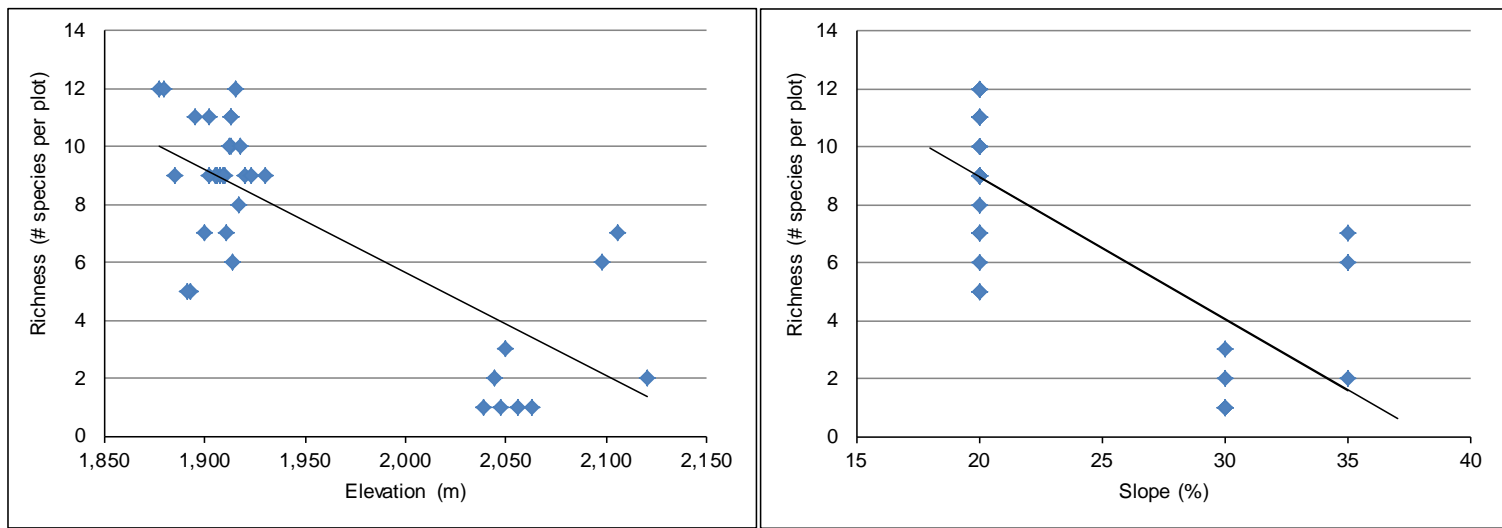

Fig. 7. Species Richness vs. Elevation (m) and Slope (\%).
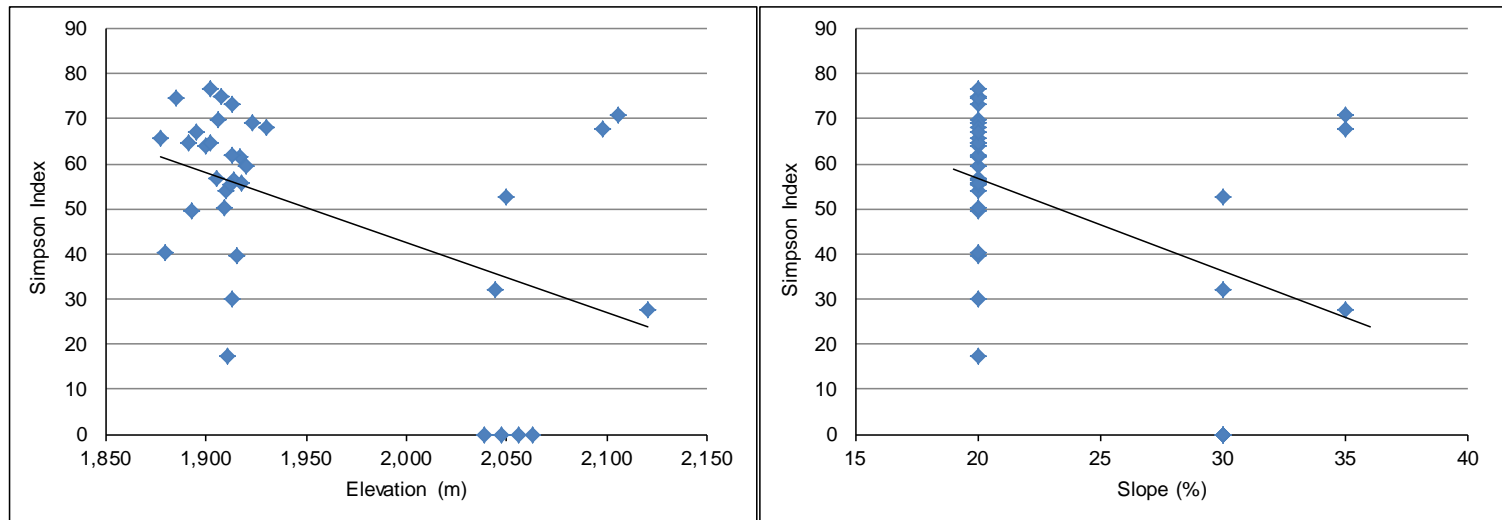

Fig. 8. Heterogeneity: Simpson Index vs. Elevation (m) and Slope (\%).
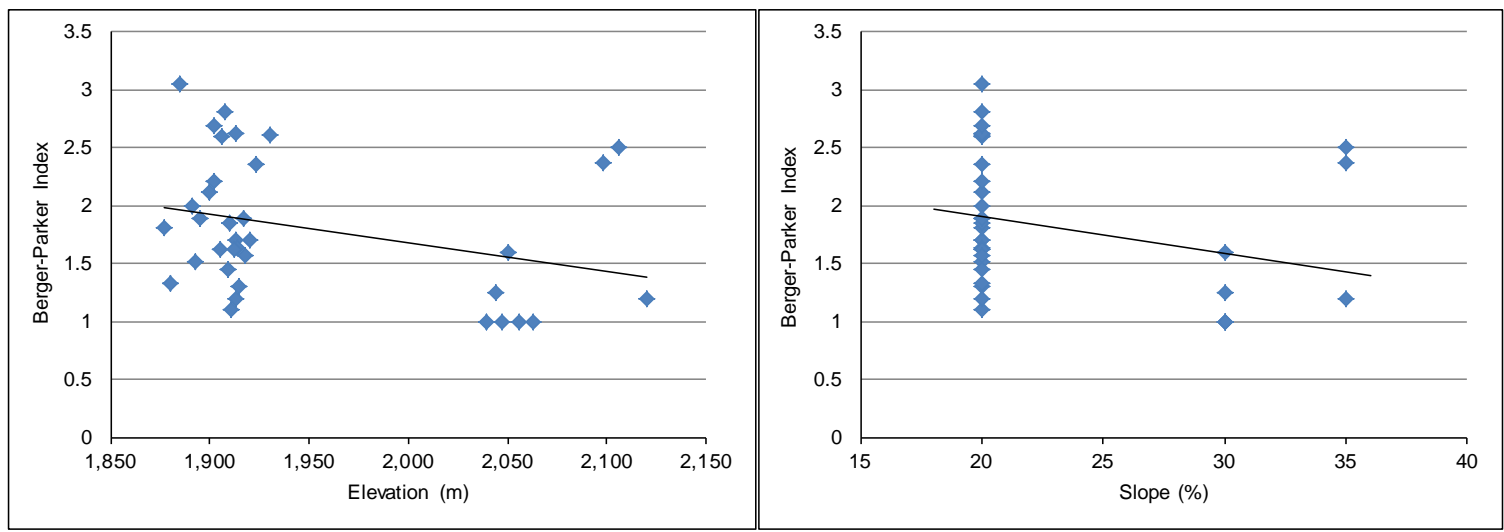

Fig. 9. Evenness: Berger-Parker vs. Elevation (m) and Slope (\%). 


\section{Regeneration/Seedlings Response}

The natural regeneration data were analyzed using seedlings per acre parameters. The number of seedlings per acre range varies in relation to stands with 2009 Methuselah (A) thinned at 2,140.50 seedlings/acre compared to 2009 Indian Baths (A) thinned at 242.65 seedlings/acre, 2009 Headquarters (B) thin and burn at 8,596.66 seedlings/acre compared to Methuselah (B) thin and burn at 1,785.19 seedlings/acre, and Methuselah (C) control at 3,408.62 seedlings/acre compared to Frasier Mill (C) control at 207.98 seedlings/acre. This inherent variability is also apparent when observing the range of seedlings per acre (Table 30).

Table 30. Summary Statistics for Seedlings Per Acre 2009.

\begin{tabular}{|l|c|c|c|c|c|}
\hline \multicolumn{7}{|c|}{2009} \\
\hline Treatment & Mean & SE $^{1}$ & Max & Min & $N$ \\
\hline A - Thinned & $1,250.79 \mathrm{a}^{2}$ & 280.01 & $3,085.09$ & 242.65 & 12 \\
\hline B - Thin\Burn & $4,341.66 \mathrm{~b}$ & 957.49 & $8,908.63$ & $1,005.25$ & 12 \\
\hline C - Control & $1,654.42 \mathrm{a}$ & 501.87 & $5,407.58$ & 0.00 & 11 \\
\hline
\end{tabular}

${ }^{1} \mathrm{SE}=$ Standard Error.

${ }^{2}$ Means followed by the same letter do not differ at the 0.05 level.

The 2009 ANOVA result shows a significant difference $(p=0.0100)$ in density between the three treatments (Table 31). Tukey's pairwise comparison shows that there was a significant difference between the thin and burn treatment and the control and also 
between the thin and burn treatment and the thin only treatment. However, there was no significant difference between the thin only and the control treatments (Table 32). The results of Roller's (2004) study were similar having a p-value of 0.005 and Tukey’s pairwise comparison yielding a significant difference between thin only treatment and thin and burn treatment and control and thin and burn treatment. The thin only treatment and the control likewise were not significantly different (Roller, 2004).

Table 31. Results of ANOVA for Seedlings per Acre 2009.

\begin{tabular}{|l|c|c|c|c|c|}
\hline Source & DF & SS & MS & F Value & Pr $>$ F \\
\hline Model & 2 & 12.07548545 & 6.03774272 & 5.34 & 0.0100 \\
\hline Error & 32 & 36.19811813 & 1.13119119 & & \\
\hline Corrected Total & 34 & 48.27360357 & & & \\
\hline
\end{tabular}

Table 32. Results of Pairwise Comparison for Seedlings per Acre 2009.

\section{Tukey’s Studentized Range (HSD) Test}

Critical Value of Studentized Range 3.47525

Comparisons significant at the 0.05 level are indicated by $* * *$.

\begin{tabular}{|c|c|cc|}
\hline $\begin{array}{c}\text { Treatment } \\
\text { Comparison }\end{array}$ & $\begin{array}{c}\text { Difference } \\
\text { Between Means }\end{array}$ & Simultaneous 95\% Confidence Limits \\
\hline B - A & 1.2182 & 0.1512 & $2.2852 * * *$ \\
\hline B - C & 1.2575 & 0.1666 & $2.3485 * * *$ \\
\hline A - B & -1.2182 & -2.2852 & $-0.1512 * * *$ \\
\hline A - C & 0.0394 & -1.0516 & 1.1304 \\
\hline C - B & -1.2575 & -2.3485 & $-0.1666 * * *$ \\
\hline C - A & -0.0394 & -1.1304 & 1.0516 \\
\hline
\end{tabular}


The percent seedling composition per acre across all treatments shows white fir with $78 \%$, then incense-cedar with $6 \%$, black oak with $4 \%$, sugar pine with $3 \%$, and giant sequoia and ponderosa pine both having less than 1\% (Figure 10). These results are similar with Roller's (2004), the only difference being that incense-cedar was $8 \%$ and black oak was $2 \%$.

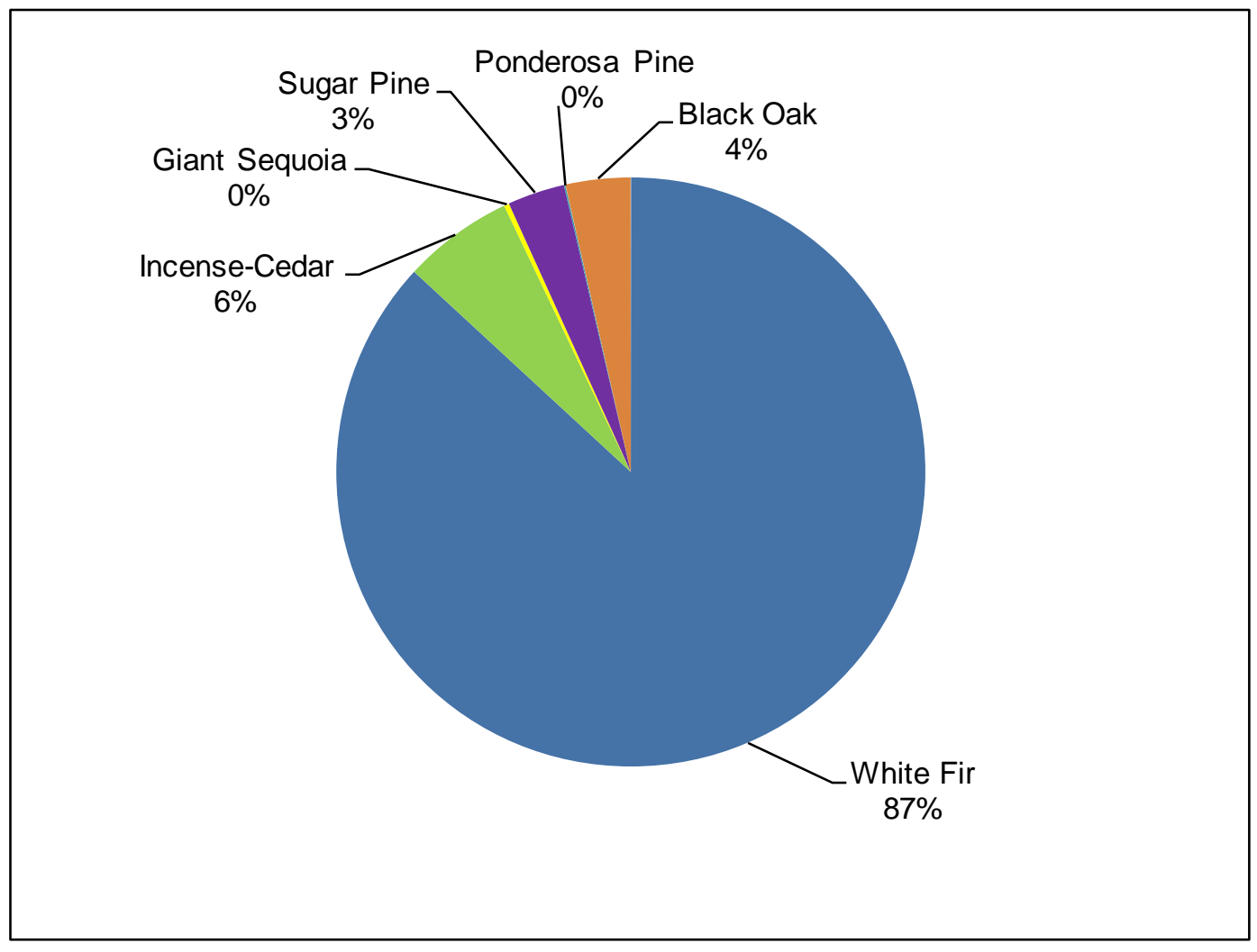

Fig. 10. Percent Seedling Composition in 2009.

The seedlings per acre by treatment also show white fir the greatest across all treatments (Figure 11), which agree with Roller’s 2004 results. This study’s results for Page 63 
giant sequoia concur with Roller (2004) both having the thinned only treatment with the most seedlings per acre, yet 2009 results show no seedlings for the thinned and burned and control treatments (Figure 11).

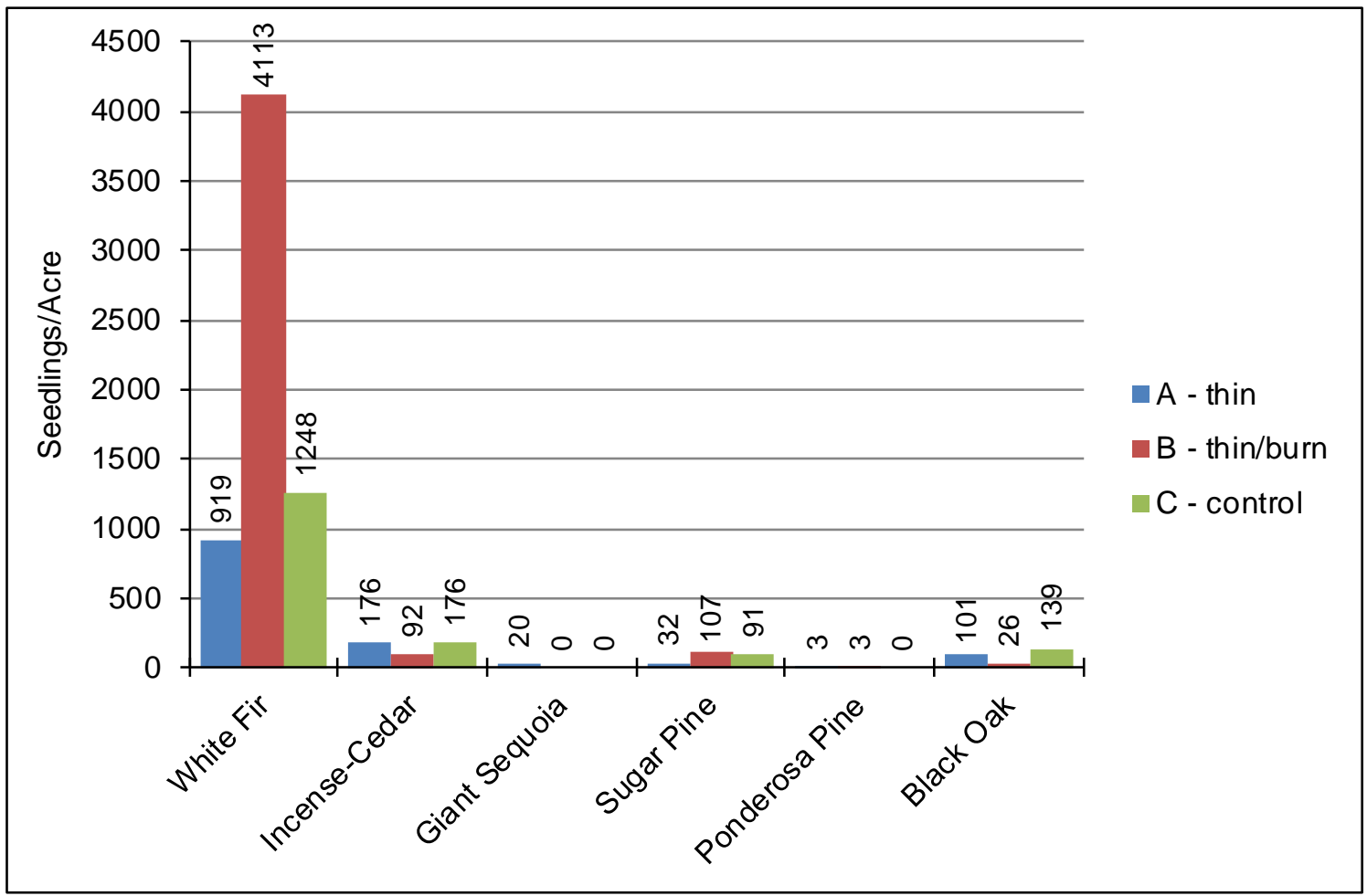

Fig. 11. Seedlings per Acre on Thin Only, Thin and Burn, and Control Plots.

\section{Downed Woody Debris Response}

The following results for downed woody debris are presented in tons per acre calculated using van Wagtendonk, Benedict and Sydoriak (1996) coefficients and aggregated by fine surface (1 hr., 10 hr., 100 hr.) fuels, 1,000 hr. fuels and total fuels. Litter is presented in tons per acre calculated using van Wagtendonk, Benedict and Sydoriak (1998) coefficients. Only the data for the years 2001 and 2009 are represented 
because no fuel data were collected in 1994 and the 1989 fuel data are incomplete. The 1989 fuel data has two data sets - the pre-treatment measurements and the post-treatment measurements, one of which is incomplete and due to the lack of dates on the data sheets there is no certainty on the identity of either data set.

The 2001 ANOVA results for fine surface (1 hr., $10 \mathrm{hr} ., 100 \mathrm{hr}$.) fuels tons per acre shows a significant difference $(\mathrm{p}=0.0001)$ between the three treatments (Table 33). The 2009 ANOVA results for surface fuel (1 hr., 10 hr., 100 hr.) tons per acre shows a significant difference $(\mathrm{p}=0.008)$ between the three treatments (Table 33). Tukey’s pairwise comparison for 2001 shows a significant difference between thin only and both thin/burn and control, but no significant difference between thin and burn and control (Table 33). Tukey’s pairwise comparison for 2009 shows a significant difference between thin and burn and both thin only and control, but no significant difference between thin only and control (Table 33, Figure 12).

The 2001 ANOVA results for 1,000 hr. fuels tons per acre show no significant difference $(p=0.103)$ between the three treatments (Table 33). The 2009 ANOVA results for $1,000 \mathrm{hr}$. fuels tons per acre show a significant difference $(\mathrm{p}=0.041)$ between the three treatments with Tukey's pairwise comparison showing a significant difference between thin and burn and control, but no significant difference between thin only and control or thin only and thin and burn, yet the raw data values show thin only is greater than thin and burn (Table 33).

The 2001 ANOVA results for total fuels tons per acre show a significant difference $(p=0.017)$ between the three treatments with Tukey's pairwise comparison showing a significant difference between thin only and control, but not significant 
Table 33. Summary Table Downed Woody Debris Levels and Litter per Treatment by Year (standard errors in parentheses).

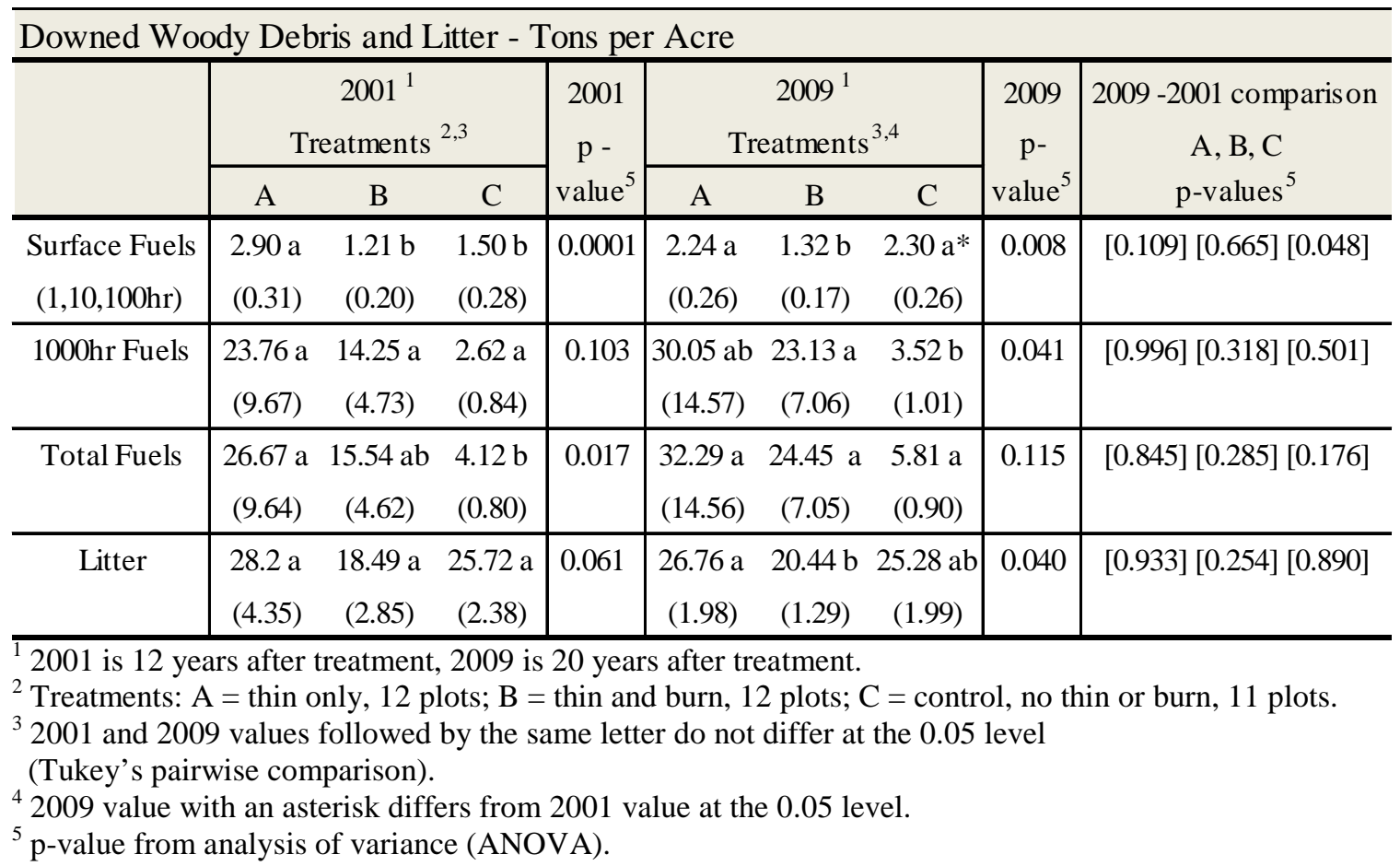

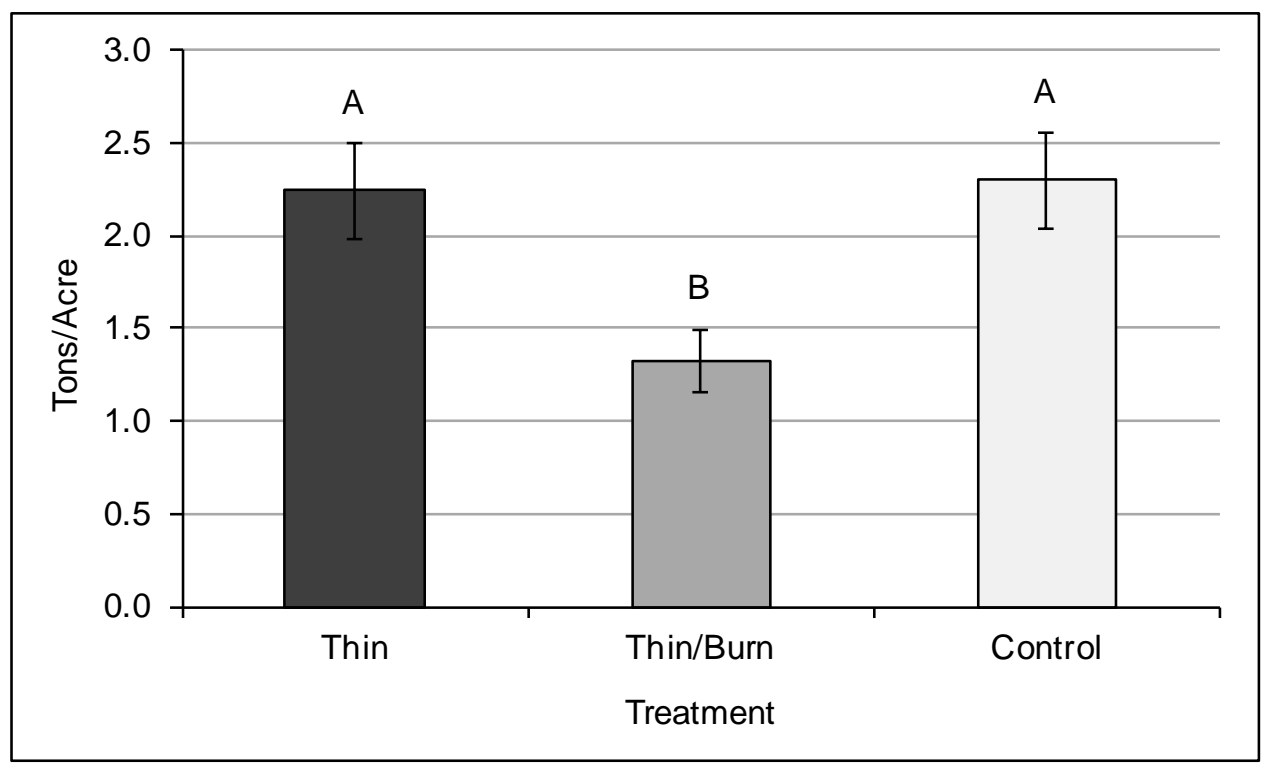

Fig. 12. Downed Woody Debris - Surface (1, 10, 100 hr.) Fuels in 2009 (columns with same letters do not differ at the 0.05 level). 
difference between thin only and thin and burn or thin and burn and control (Table 33). The 2009 ANOVA results for total fuels tons per acre show no significant difference $(\mathrm{p}=$ 0.115) between the three treatments (Table 33).

The ANOVA results for surface ( $1 \mathrm{hr} ., 10 \mathrm{hr} ., 100 \mathrm{hr}$.) fuels tons per acre show a significant difference comparing 2009 to 2001 for control plots $(\mathrm{p}=$ 0.048) but not for thin only $(\mathrm{p}=0.109)$ and thin and burn $(\mathrm{p}=0.665)$. The ANOVA results for 1,000 hr. fuels and total fuels tons per acre show no significant difference comparing 2009 to 2001 for thin only ( $\mathrm{p}=0.996$ and 0.845$)$, thin and burn ( $\mathrm{p}=0.318$ and 0.285$)$, or control $(\mathrm{p}=$ 0.501 and 0.174 ) (Table 33, Figures 13 - 15).

The 2001 ANOVA results for litter tons per acre show no significant difference (p $=0.061$ ) between the three treatments (Table 33). The 2009 ANOVA results for litter tons per acre show significant difference $(p=0.040)$ between the three treatments with Tukey's pairwise comparison showing a significant difference between thin only and thin and burn, but no significant difference between control and thin only or control and thin and burn (Table 33). The ANOVA results for litter tons per acre show no significant difference between 2009 and 2001 for thin only $(p=0.933)$, thin and burn $(p=0.540)$ or control $(\mathrm{p}=0.890)($ Table 33). 


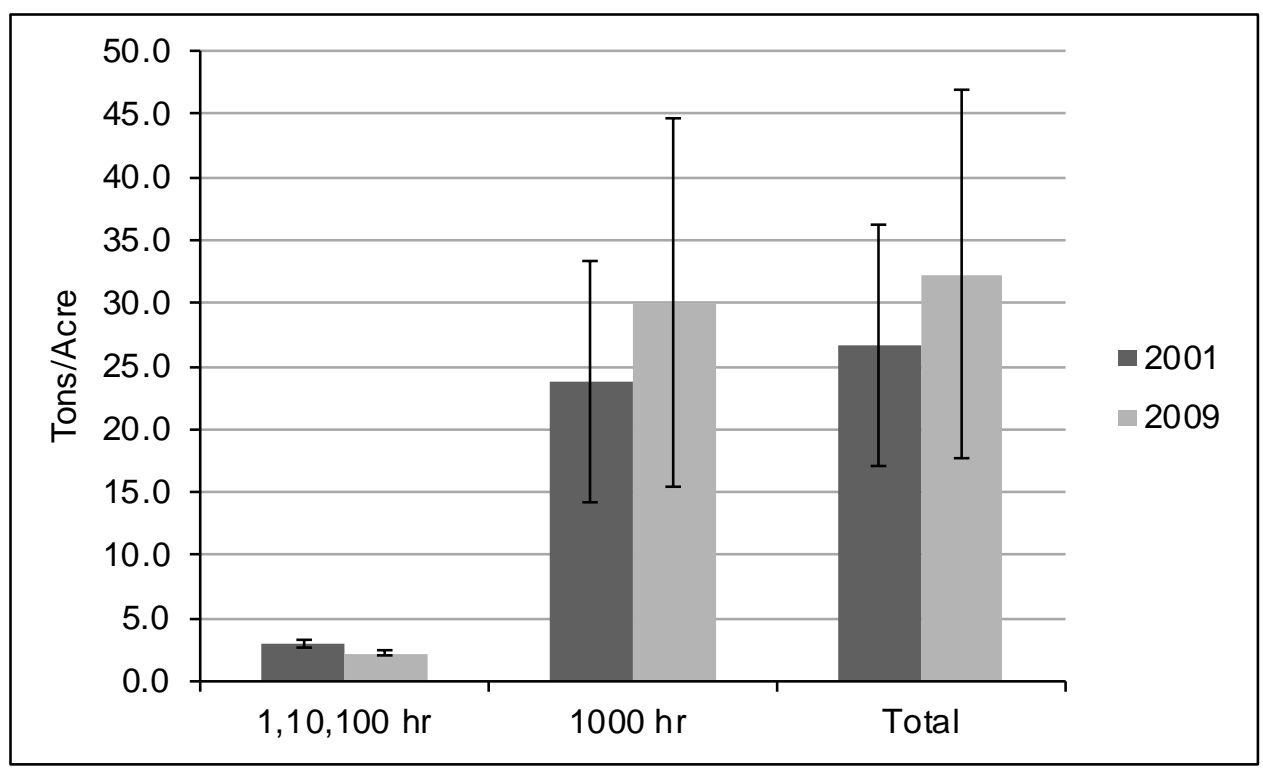

Fig. 13. Downed Woody Debris on Thin Only Plots in 2001 and 2009.

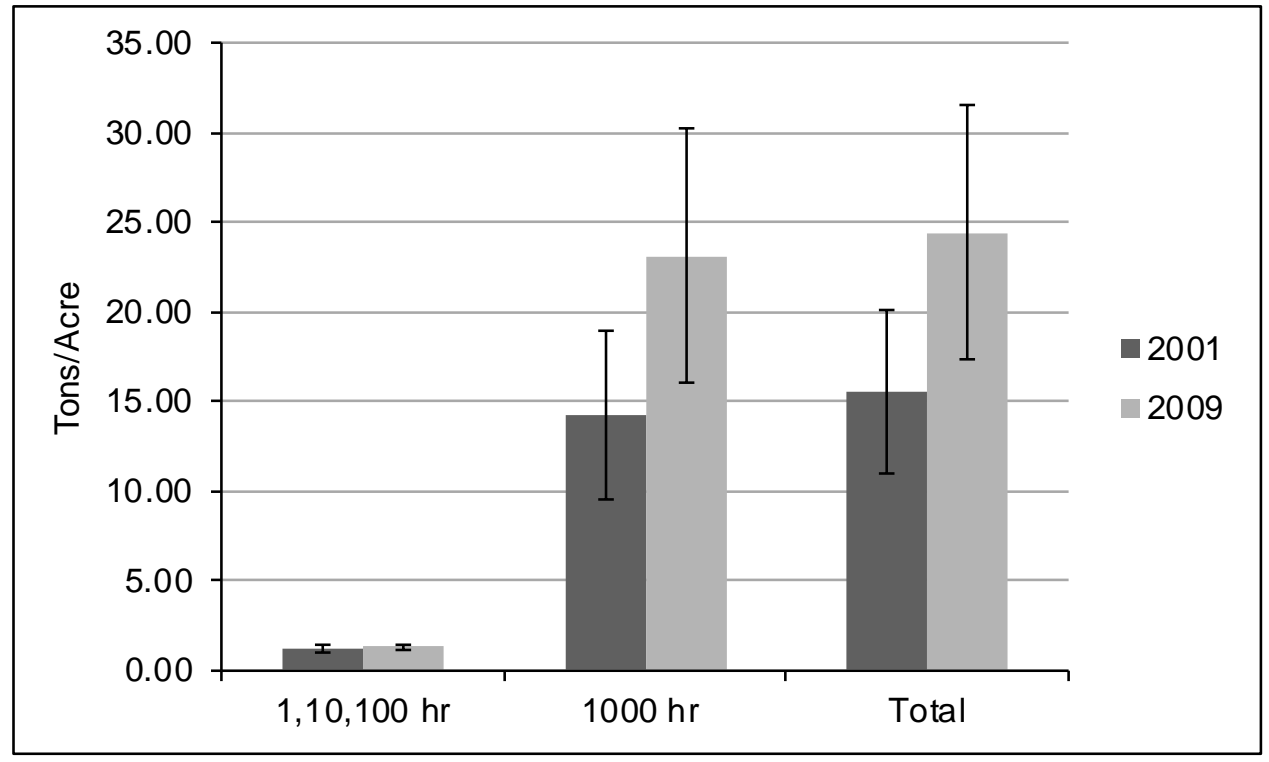

Fig. 14. Downed Woody Debris on Thin/Burn Plots in 2001 and 2009. 


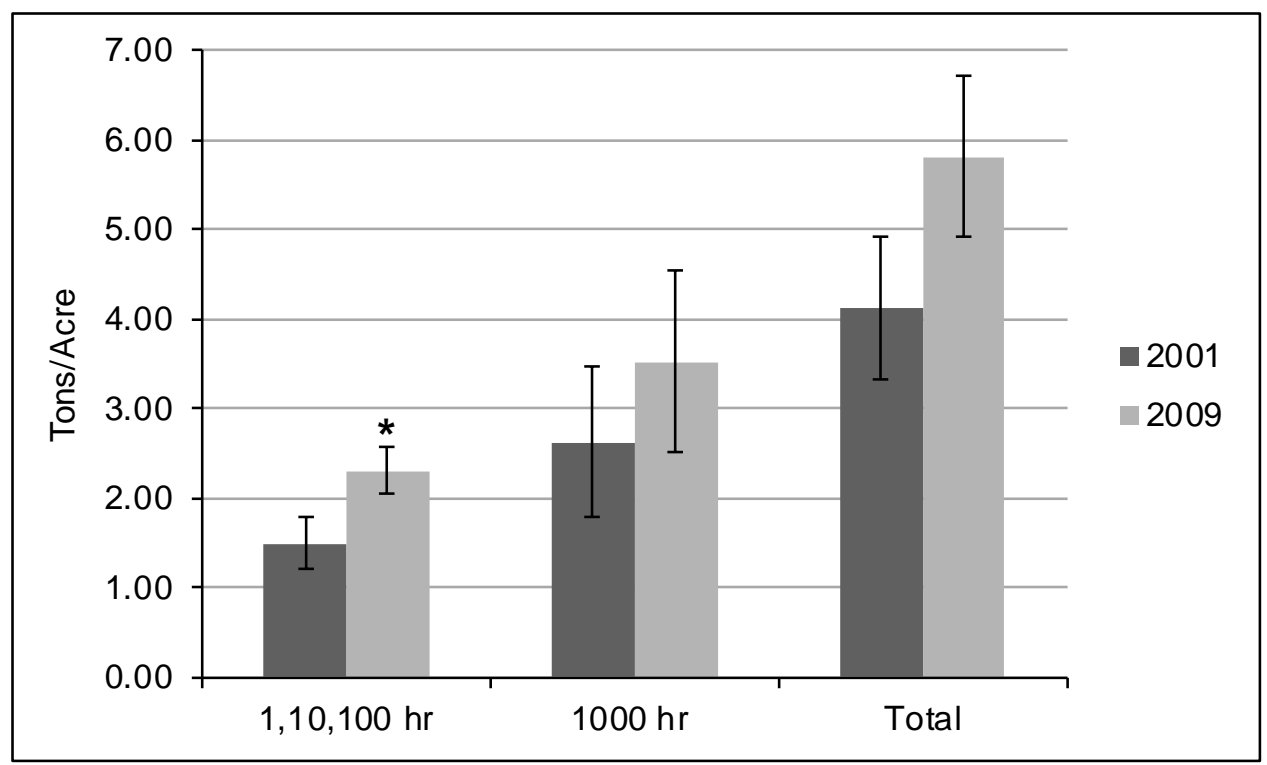

Fig. 15. Downed Woody Debris on Control Plots in 2001 and 2009 (asterisk indicates difference between 2001 and 2009 value at 0.05 level). 


\section{CHAPTER 5}

Discussion

\section{Overstory Growth and Yield Response}

The growth and yield data for these primarily young-growth giant sequoia mixed conifer stands show extremely high values, especially for the control stands. The average growth for 1989 - 2009 was 9,731 cubic-feet per acre with a (PAI) of 487 cubic-feet per acre per year, and the 2009 yield was 24,881 cubic-feet per acre for the control plots. The average growth for 1989 - 2009 was 63,354 board-feet per acre with PAI of 3,168 board-feet per acre per year and 2009 yield of 144,490 board-feet per acre. A growth study from MHDSF of a primary young-growth giant sequoia 86 year old stand presented in Forestry Note no. 113 demonstrates the ability of high growth and yield. Its results showed a total volume yield of 26,080 cubic-feet per acre with greatest PAI of 541cubicfeet/acre/year during a three year period of the study and 147,002 board-feet per acre with a greatest PAI of 3,012 board-feet/acre/year during a one year period of the study (Dulitz and Medina, 2000). Our study averaged a 2009 yield for control plots of 24,881 cubic-feet per acre and 144,490 board-feet per acre and PAI of 562 cubic-feet per acre per year (1994 - 2001) and 511 cubic-feet per acre per year (2001 - 2009) and 3,685 board-feet per acre per year (1994 - 2001) and 3,403 board-feet per acre per year (2001 2009). Most giant sequoia/ mixed conifer forests stabilize at 400 square feet basal area 
(BA) per acre shown from inventory plots on Whitaker Forest, yet stands of primary young growth giant sequoia stands are able to hold high levels of growing stock. The 500 - 600 square feet per acre (BA) for the control plots at the beginning of this study could not be achieved by other species before stagnation of growth (Gasser, 1992).

The overall cubic-foot volume growth per acre for the 20 year period of 1989 2009 was significantly different $(p=0.0140$ ) between the two treatments and the control. The pairwise comparison showed that the treatments were significantly different than the control yet not significantly different from each other. Our study showed combining prescribed burning with thinning produced no significant effect on cubic-foot volume growth. A ponderosa pine/Douglas-Fir stand manipulation study showed no significant difference in quadratic mean diameter between thin only and thin and burn treatments, yet there was significant difference when compared to the control (Fiedler et al., 2010). Our study's control plots have greater trees per acre, BA, PAI, and volume growth and yield compared to the treatments plots still after 20 years. A thinning/ stocking study of coast redwood showed 17 years after treatment that the growth of the different spaced thinned stands had transferred to the residual trees in that there was no significant difference between the control (no cut) in respect to cubic-foot per acre volume yield, PAI and BA (Lindquist, 2004). A ponderosa pine thinning study suggested that cubicfoot volume yield decreased linearly as spacing increased and board-foot volume yield varied as spacing increased (Cochran and Barrett, 1999). The ability of giant sequoia to continue in volume growth even with high levels of growing stock perhaps explains the greater total volume in our study's control plots compared to treatment plots even after 20 years. Yet, the percent of post-treatment volume growth between 1989 and 2009 is 
greater for the treatments then the control. The treatment plots grew back approximately 106\% of the post-treatment 1989 cubic-feet volume and the control approximately 65\% of the 1989 cubic-feet volume. The thinning aspect of treatments provide more growing space allowing greater average 20 year volume growth per tree, 60 - 68 cubic-feet per tree, compared to 23 cubic-feet per tree of the control. The management objective will determine whether the result is large trees with low stand volume or small trees with high stand volume (Peracca and O’Hara, 2008).

The giant sequoia growth trend shows the PAI between years 6 and 12 after treatment greater than the PAI of the first five years after treatment for both treatment and control plots (Figure 4). A coast redwood stocking study similarly showed the PAI between years 6 and 17 greater than the PAI of the first five years after thinning treatments for both treatment and uncut (control) plots (Lindquist, 2004). This increase for the treatment plots in this study is perhaps due to a delayed release response after the thinning treatment. Another possible reason for the increase of both treatment and control plots in this study is a below average winter precipitation the five years following the treatment and then an above average winter precipitation from years 6 to 12 after the treatment (York et al., 2010). The PAI between years 12 and 20 of this study tell a different story.

The last eight years, 2001 - 2009, of this study shows a decrease in PAI of 51 cubic-feet per acre per year on the control plots (Figure 4). The control cubic-feet mortality per acre per year increased from 25.3 to 41.1 during the last eight years due to competition within the stand. Study by Stohlgren (1993) found that dead sequoia trees with diameter less than 6.5 in $(16.6 \mathrm{~cm})$ had significantly greater crowding index in 
relation to overlapped root system and mean number of live neighbor trees compared to live trees of similar diameter. The treatment plots are starting to level off in growth for the last eight years of study; thus, the culmination of PAI is being prolonged due to the thinning.

\section{Understory Plant Response}

There are 26 different plants represented in this study with 23 species, ferns (Bracken and Lady Ferns lumped together), graminoids (grasses, sedges and rushes lumped together), and unidentified forbs (lumped together); other studies within the giant sequoia mixed conifer forest type have found many of the same plants (Biswell, 1966; Roy and Vankat, 1999; Vankat, 1982; Vankat and Major, 1978; Wayman and North, 2007). The treatments, whether thin or thin and burn, had positive effects upon many species when looking at frequency, density, and abundance. Earlier understory plant studies of Biswell (1966) and Wayman and North (2007) found that $R$. roezlii has been shown to have greater frequency in burn or thin and burn plots and our study shows similar results with actually the thin only plots having the greatest values for frequency, density, and abundance. Some species in this study such as Lotus crassifolius were only found on thin and burn plots and a study at Teakettle Experimental Forest found similar results; thin and burn treatments were preferred (Wayman and North, 2007).

Shrub species such as Arctostaphylos patula and Ceanothus cordulatus, $C$. integerrimus, and Prunus emarginata within the giant sequoia mixed-conifer forest have decreased, probably due to lack of fire needed for seed germination (Biswell et al., 1966; Vankat and Major, 1978). This study showed that the above species were only found in 
the treatment plots with the thin and burn plots having the greatest frequency and density, reinforcing the importance of disturbance, especially fire (Tables 24 and 25). The disturbance caused by the treatments in relation to the shrubs shows an almost doubling in frequency from 1989 to 2009 (Figure 6) and a significant increase in density and abundance from 1989 to 2009 on the treatment plots (Figure 16 and Table 27).

The trees' density for treatment thin and burn was significantly greater than thin only and control which is similar to this study's and Roller's (2001) regeneration results. White fir density trees per acre were the highest among the tree species across all treatments and higher for thin and burn treatment compared to thin only and control. A study in southern Sierra Nevada showed similar results with white fir having the highest density among tree species (height: $\leq 5$ feet) across treatments and higher density where treatment included burning (Meyer and Safford, 2011). This study shows that after combining all treatments, the rank from greatest to least density is: white fir, incensecedar, black oak, sugar pine and giant sequoia. Sugar pine had lowest density on thin only plots, preferring thin and burn or control for both understory and regeneration studies. Giant sequoia density was low across all the treatments. Study at Giant Sequoia National Monument showed giant sequoia seedling density was significantly greater for high- and moderate-severity fire compared to control and not significantly different between low-severity fire compared to control (Meyer and Safford, 2011). This study's prescribed fire severity was not high enough to establish sufficient amounts of giant sequoia seedlings on thin and burn plots due to low seed release from closed cones since fire intensity was relatively low. 
1989

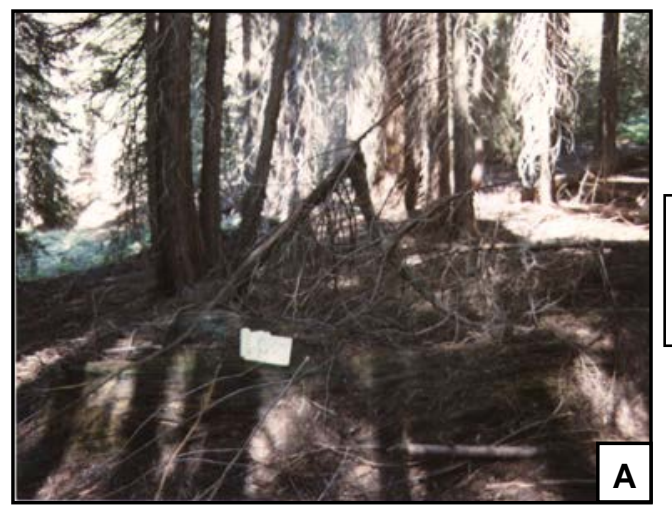

2009

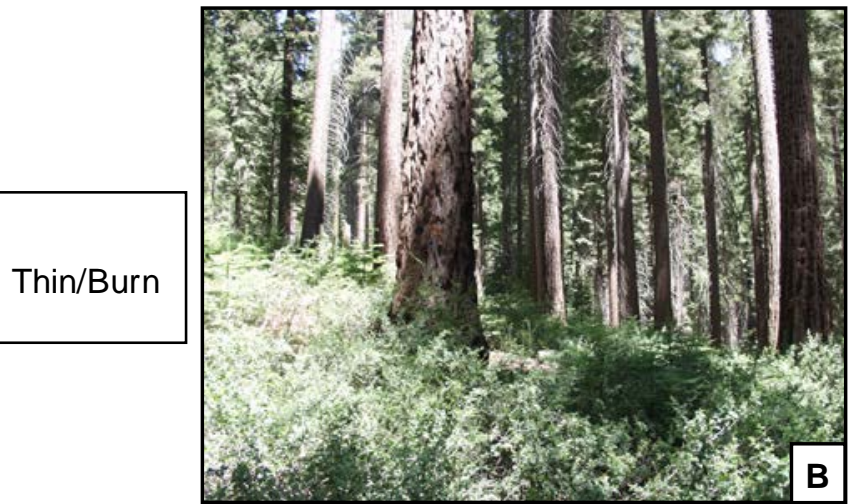

Fig. 16. Change in Shrub Abundance (percent cover) and Density (stems per acre) on the same Thin and Burn Plot comparing 1989 (A) and 2009 (B) at Frasier Mill Stand.

Twenty years after initial treatment, control plots lagged behind the treatment plots of thin only and thin and burn when comparing average species richness, species evenness using the Berger-Parker index, and species diversity using Simpson index values. Battles et al. (2001) study showed management regimes that include thinning such as plantation, shelterwood, group selection, and single-tree had greater average species richness and Simpson index values compared to reserve/control, with plantation and shelterwood values significantly greater than reserve/control. Study at Teakettle Experimental Forest showed the burn and understory thin treatment produced significantly greater species richness than the control, burn only, understory thin only, and overstory thin only treatments (Wayman and North, 2007). The variability due to environmental conditions within the sites is great enough to influence the treatment effect causing no significant difference between treatment plots and control plots. The stands were shown to have varying species richness, Berger-Parker index values, and Simpson 
index values (Table 29), so a PCA was done to determine which environmental conditions were most influential.

Understory plant diversity was shown to be most influenced by environmental conditions with those of elevation and slope being the most influential. The diversity indices’ values for species richness and Simpson index decreased as elevation values increased (Figures 7 and 9), showing results similar to a woody species study at Sequoia National Park in white fir forest vegetation type containing S. giganteum within similar elevation range (Vankat, 1982). A study in the Siskiyou Mountains, Oregon showed that as elevation increased from 5,000 feet $(1,524 \mathrm{~m})$ to 6,500 feet $(1,981 \mathrm{~m})$ the number of species decreased (Whittaker, 1960). Another study in Arizona’s Santa Catalina Mountains documented that as elevation increased the species richness decreased (Whittaker, 1965; Whittaker and Niering, 1965).

\section{Regeneration/ Seedlings Response}

This study was not set up as a regeneration study yet in 2001 it was determined to assess the effects of the treatments on natural regeneration. The number of seedlings per acre for the 20 year period of 1989 - 2009 was significantly different $(p=0.010)$ between the thin and burn treatment compared to the control and thin only treatment. These results are similar to Roller’s (2001) 12 year period of 1989 - 2001 with significant difference $(p=0.005)$ of seedlings per acre between thin and burn treatment compared to control and thin only treatment. This study and Roller (2001) both show control and thin only not significantly different from each other. Early growth plots at MHDSF showed reproduction after five years in descending order with white fir, sugar pine, incense- 
cedar, ponderosa pine and giant sequoia (Beechel, 1960). The 2001 and 2009 conifer seedling species composition is similar in descending order with white fir, incense-cedar, sugar pine, giant sequoia and ponderosa pine. Both 2001 and 2009 measurements showed white fir seedlings with over $85 \%$ of the regeneration having 3,927 out of a total 4,589 mixed conifer and hardwood seedlings in 2001 and 6,280 out of a total 7,245 mixed conifer and hardwood seedlings in 2009 (Roller, 2004). A seedlings study done within the mixed conifer forest at Challenge Experimental Forest showed white fir with approximately 1,000 seedlings per acre in 9-meter openings out of a total of about 4,300 mixed conifer seedlings. Sugar pine, ponderosa, and giant sequoia seedlings - all shade intolerant trees, were less than $5 \%$ of total mixed conifer seedlings for this study. The ponderosa pine seedlings at the Challenge Experimental Forest study showed a significant height increase with 27-meter openings, suggesting small openings and thinning the stand is not enough for a shade intolerant species such as ponderosa pine to maintain adequate growth (McDonald and Abbott, 1994; McDonald and Reynolds, 1999). A study done at Blodgett Experimental Forest found that canopy gaps/openings above 0.3 to 0.5 ha best facilitated seedling height growth and height in general also increased as distance from edge increased (York et al., 2004; York and Battles, 2008). A regeneration study at MHDSF with openings ranging from approximately 15 to 61 meters in diameter found that all canopy openings had low giant sequoia seedling density with no significant difference between opening sizes, yet the smallest openings had the least amount of seedlings (Stephens et al., 1999). A study at Whitaker's Forest Research Station showed no influence of gap size which ranged from 1/8 to 1 acre on seedling survival (York, 2010). The treatment of thinning the stand in this study yielded low giant 
sequoia seedling density showing that thinning do not facilitate high seedling density or good regeneration. The prescribed fire severity was too low for adequate seed dispersal and establishment of giant sequoia seedlings. Study at Giant Sequoia National Monument found that giant sequoia seedling density was significantly greater for highand moderate-severity fire compared to control and not significantly different between low-severity fire compared to control (Meyer and Safford, 2011).

\section{Downed Woody Debris Response}

Due to the incomplete nature of the 1989 pre-treatment data, only the 2001 and 2009 data, 12 and 20 years after treatment, could be examined. The rate of accumulation could be determined since the values of two separate time periods were known. A 1997 fuel study by Weise et al. (1997) at Mountain Home Demonstration State Forest showed a control plot with comparable trees per acre and majority giant sequoia composition having an average fuel loading of 3.0 tons per acre for total downed woody debris. The annual accumulation trend rate for total downed woody debris for this study's control plots using 2001 and 2009 data was 0.211 tons per acre per year. This results in a 12 year, 1997 to 2009, accumulation of 2.53 tons per acre with a predicted fuel load of 5.53 tons per acre in 2009, which is close to our study's 2009 control fuel load of 5.81 tons per acre. These rates were determined to be reasonable values for young-growth giant sequoia control stands at Mountain Home Demonstration State Forest.

Parson’s 1978 study at Kings Canyon National Park determined that seven years after a prescribed burn, the surface $(1,10,100 \mathrm{hr}$.) fuels levels were $86 \%$ of pre-burned levels. This study at Mountain Home Demonstration State Forest indicates that 12 years 
after treatment, surface $(1,10,100 \mathrm{hr}$.) fuels levels show no significant difference between control and thin and burn plots, which have returned to pre-treatment levels. Fuels levels on thin only plots were significantly greater than control and thin and burn plots since they had not been reduced by fire (Table 33). Twenty years after treatment the dynamics of the surface $(1,10,100 \mathrm{hr}$.) fuels levels have changed with the thin only and control plots significantly greater than the thin and burn plots but not different from each other (Table 33 and Figure 12). This increase in fine surface (1, 10, $100 \mathrm{hr}$.$) fuels$ levels for control plots between 2001 and 2009 was significant (Table 33 and Figure 15) due to increased mortality caused by suppression initiating fuel build-up when dead materials fall to the forest floor (Parson, 1978; USDA, 2010).

Litter levels seven years after a prescribed burn were only $45 \%$ of unburned levels for a Kings Canyon National Park study and another study within the Sequoia Kings Canyon National Parks exhibited 50\% of unburned levels ten years after treatment (Keifer et al., 2006; Parson, 1978). This study showed that after 12 years, the litter levels for thin and burn plots were not significantly different than control plots, showing a return to pre-treatment levels; after 20 years the plots had the same statistical outcome with the litter values even closer together.

Coarse woody debris average levels after thin only treatment were higher than after thin and burn treatment for a mixed-conifer forest study at Teakettle Experiment Forest, yet due to variability they were not significantly different (Innes et al., 2006). This study found that the 2001 and 2009 thin only 1,000 hr. fuels levels were higher than thin and burn 1,000 hr. fuels levels, yet because of variability they were not significantly different (Table 33). The 2001 and 2009 1,000 hr. fuels levels for thin only and thin and 
burn plots were higher than control plots by between 11 to 27 tons per acre (Table 33). This may be caused by large remnant giant sequoia logs within the treatment plots long before the study was established.

Variability when calculating total tons per acre for downed woody fuels may account for the following inconsistencies. 2009 calculations determined no significant differences between any of the treatments. 2001 calculations, however, showed a significant difference between thin only (26.67 tons per acre) and control (4.12 tons per acre) plots, but no significant difference between thin and burn (15.54 tons per acre) and control (4.12 tons per acre) plots (Table 33). 


\section{CHAPTER 6}

Recommendations

\section{Future Research}

Research involving growth and yield will need to continue if giant sequoia is ever to become a viable commercial timber species in the future. The rapid growth of young giant sequoia is known but the specific thinning prescriptions in relation to trees per acre and basal area for maximum wood production need to be researched. This study has shown that young growth giant sequoia stands are capable of heavy stocking levels before growth starts to decline. Studies have been done on the favorable wood properties of young growth giant sequoia and research needs to continue, especially related to the production of decay resistant heartwood (Piirto, 1986). Growth and yield studies involving giant sequoia plantations are being done at University of California, Berkeley’s Blodgett Experimental Forest in Eldorado County, California. Sierra Pacific Industries of California has giant sequoia planted in 460 plantations from 3 to 57 years in age. Giant sequoia wood is incorporated with incense-cedar wood at fencing material plant. A study at 136 plantations evaluating giant sequoia growth compared to native conifers was potentially completed fall 2010, presently no published results. This needs to be a longterm study to further the understanding of giant sequoia’s commercial potential both outside and within its natural range. 


\section{Mountain Home Demonstration State Forest}

This understory plant study was able to identify 32 separate plants with 27 to species level and 5 to genus level (Appendix D). All species present within plots were not identified. This caused an underestimating of species richness across all treatments due to the unknown amount of species within the unidentified forbs and graminoids growth form category. It is recommended that the next time an understory plant diversity study is done that a botanist is hired to aid in plant identification. The study's results showed that average species richness for treatments was greater than control but not significantly greater due to variability. The site conditions of elevation and slope had the strongest effect upon this variability. It is recommended that research plots are located within areas of similar slope and elevation values to control for variability. 


\section{CHAPTER 7}

\section{Conclusion}

This study is one of the few, if only, involving stand manipulation of natural young-growth giant sequoia stands and needs to be remeasured perhaps every 10 years. When Martin and Gasser first initiated this study in 1989 an objective was a continued measurement and observation of these stands. Long-term status has been secured with the 20 year remeasurement of the original plots to observe the effects of thinning and prescribed fire on overstory growth and yield, understory plant growth and diversity, fuel load, and tree regeneration.

The overstory growth and yield study has shown that even 20 years after management strategies there is a significant difference between treatments and control. The ability of giant sequoia to continue the increase of volume growth even with high levels of growing stock perhaps explains the greater total volume in control plots compared to treatment plots even after 20 years. The dense control stands have more volume growth than the treatment stands yet the post-treatment percent volume growth over 20 years is greater in the treatment stands. The last eight years of this study show the PAI of the control stands starting to decrease while the treatment stands PAI are starting to level off. When will the treatment plots PAI intersect with the control plots PAI? 
All young-growth giant sequoia stands are not alike for there are differences in species richness and evenness using Berger-Parker Index and homogeneity using Simpson Index due to environmental conditions related to stand location. The variability due to site conditions was a strong enough influence to null the treatment effects. The diversity was driven by the environmental conditions elevation and slope; as these values increased the diversity indices values decreased. Management strategies such as stand manipulation within these young-growth giant sequoia stands did not negatively affect diversity. When observing functional groups and/or species there are positive effects related to frequency, density, and abundance, shrubs preferred treatment plots having significantly more stems per acre and percent cover after 20 years.

The regeneration study showed that the thin and burn treatment had significantly greater seedlings per acre compared to thin only and control. The next cohort within these stands will be majority white fir which had the highest seedlings per acre count across all management strategies. Giant sequoia did not have adequate regeneration. Study results found that successful giant sequoia regeneration requires large enough multiple canopy openings distributed throughout the stand to provide adequate sunlight, and a high- to moderate-severity fire that burns off the litter layer to expose mineral soil and opens cones to produce a large seed source.

Stand manipulation treatments such as thinning, and thinning and burning effect downed woody debris and litter within young-growth giant sequoia stands even 20 years after treatment. The thin and burn plots had significantly reduced surface (1, 10, $100 \mathrm{hr}$.) fuels and litter tons per acre compared to thin only and control treatments. The Kings Canyon National Park study found that seven years after prescribed burn the total fuel 
level including litter/duff and downed woody debris of 45.0 tons per acre was a sufficient level to support intense fire (Parson, 1978). This study's total fuel levels including litter and downed woody debris after 20 years for the treatments thin only and thin/burn are 59.05 and 44.89 tons per acre. These levels would be adequate to support a prescribed fire intense enough to provide Mountain Home Demonstration Forest's objectives of reducing fuel load to provide seedbed for seeds released from heat opened giant sequoia cones (CDF, 2010). The treatments removed those ladder fuels in the lower 55 feet (16.8 m) of the stand, minimizing the potential of a crown fire while some control plots have $50 \%$ of the trees made up of these ladder fuels, increasing the potential of a crown fire (Kilgore and Sando, 1975).

The results provided by this study will hopefully yield insight into the management of giant sequoia into the future. When this study began it was mentioned at the 1992 symposium, Giant Sequoias: Their Place in the Ecosystem and Society; perhaps it will be mentioned at a future symposium; "Do behold the King in his glory, King Sequoia! Behold! Behold! seems all I can say” (Muir, 1870). 


\section{References}

Afanasijev, D. 1951. Establishment of fast-growing stands (abstract). Sum. List. 75(12):387-392.

Anderson, R.S. 1994. Paleohistory of giant sequoia grove: The record from log meadow, Sequoia National Park. Gen. Tech. Rep. PSW-151 USDA Forest Service, Pacific Southwest Research Station. Albany, CA.

Anderson, R.S. and S.J. Smith. 1994. Paleoclimate interpretation of meadow sediment and pollen stratigraphies from California. Geology. 22(9):723-726.

Antipova, V.I. 1952. Cultivation of Sequoia in Yalta forest district (abstract). Lesn. Hoz. 5(6):79.

Aubert, J. 1996. Figure 55.2. 1434. In: Sierra Nevada Ecosystem Project, Final report to Congress, vol. II, Assessments and scientific basis for management options, Ch 55, Davis: University of California, Centers for Water and Wildland Resources.

Axelrod, D.I. 1959. Late cenozoic evolution of the sierra bigtree forest. Society for the Study of Evolution. 13(1):9-23.

Basey, H.E. and J.M. Basey. 1998. Basey’s Sierra Nevada Journal. $1^{\text {st }}$ ed. The Robin Works, Groveland, CA.

Bates, T.R. 1998. Response of young growth giant sequoia to management strategies. University of California, Berkeley. Master’s Thesis.

Battles, J.J., A.J. Shlisky, R.H. Barrett, R.C. Heald and B.H. Allen-Diaz. 2001. The effects of forest management on plant species diversity in a Sierran conifer forest. Forest Ecology and Management. 146:211-222. 
Beechel, K. 1960. Growth plots on Mountain Home State Forest. California Forestry Note No. 1. California Department of Forestry and Fire Protection. Sacramento, California.

Benson, N.J. 1986. Management of giant sequoia on Mountain Home Demonstration State Forest. Proceedings of the workshop on management of giant sequoia, May 24-25, 1985, Reedley, California. Gen. Tech. Rep. PSW-95 USDA Forest Service, Pacific Southwest Forest and Range Experiment Station. Berkeley, CA.

Berger W.H. and F.L. Parker. 1970. Diversity of planktonic foraminifera in deep-sea sediments. Science 168(3937):1345-1347.

Biswell, H.H., H. Buchanan and R.P. Gibbens. 1966. Ecology of the vegetation of a second-growth sequoia forest. Ecology. 47(4):630-634.

Bonev, I. 1966. Sequoia gigantea abroad and in Bulgaria (abstract). Gorsko Stopanstvo. 22(1):15-19.

Brown, J.K. 1974. Handbook for inventorying downed woody material. USDA Forest Service General Technical Report, INT-16. Intermountain Forest and Range Experiment Station, Ogden, UT.

California Department of Forestry and Fire Protection (CDF), The Natural Resources Agency. 2010. Mountain Home Demonstration State Forest, Management Plan. California Southern Region. Tulare County California. Revised by James Kral. Cochran, P.H. and J.W. Barrett. 1999. Thirty-five-year growth of ponderosa pine saplings in response to thinning and understory removal. Research Paper. PNW-RP-512. Portland, OR: Department of Agriculture, Forest Service, Pacific Northwest Research Station. 
Cole, K.L. 1983. Late Pleistocene vegetation of Kings Canyon, Sierra Nevada, California (abstract). Quaternary Research. 19:117-129.

Commonwealth Agriculture Bureaux. 1949-1950. Forestry the World Over, USSR. Forestry Abstracts. 11(4):588-593.

Davis, O.K. 1999a. Pollen analysis of a late-glacial and Holocene sediment core from Mono Lake, Mono County, California. Quaternary Research. 52:243-249.

Davis, O.K. 1999b. Pollen analysis of Tulare Lake, California: Great Basin-like vegetation in central California during the full-glacial and early Holocene. Review of Palaeobotany and Palynology. 107(3/4):249-257.

DeLeon, D. 1952. Insects associated with Sequoia sempervirens and Sequoia gigantea in California. The Pan-Pacific Entomologist. 23(2):75-92.

Dulitz, D.J. and J.M. Medina. 2000. Growth of young giant sequoia stands on Mountain Home Demonstration State Forest. California Forestry Note No. 113. California Department of Forestry and Fire Protection. Sacramento, CA.

Fiedler, C.E., K.L. Metlen and E.K. Dobson. 2010. Restoration treatment effects on stand structure, tree growth, and fire hazard in a Ponderosa Pine/Douglas-Fir forest in Montana. Forest Science. 56(1):18-31.

Flint, W.D. 2002. To find the biggest tree. Three Rivers, CA: Sequoia Natural History Association.

Fontaine, J. 1986. Recommendations from the Sierra Club for managing giant sequoia. Proceedings of the workshop on management of giant sequoia, May 24-25, 1985, Reedley, California. Gen. Tech. Rep. PSW-95 USDA Forest Service, Pacific Southwest Forest and Range Experiment Station. Berkeley, CA. 
Gasser, D.P. 1992. Young growth management of giant sequoia. Proceedings of the Symposium on Giant Sequoia: Their Place in the Ecosystem and Society. Visalia, California. USDA Forest Service, PSW-GTR-151. 1994.

Halpern, C.B. and T.A. Spies. 1995. Plant species diversity in natural and managed forests of the Pacific Northwest. Ecological Applications. 5(4):913-934

Harrison, W. 1986. Management of giant sequoia at Calaveras Big Trees State Park. Proceedings of the workshop on management of giant sequoia, May 24-25, 1985, Reedley, California. Gen. Tech. Rep. PSW-95 USDA Forest Service, Pacific Southwest Forest and Range Experiment Station. Berkeley, CA.

Hartesveldt, R.J., H.T. Harvey, H.S. Shellhammer, and R.E. Stecker. 1975. The giant sequoia of the Sierra Nevada. U.S. Department of the Interior, National Park Service, Washington, DC.

Heald, R.C. 1986. Management of giant sequoia at Blodgett Forest Research Station. Proceedings of the workshop on management of giant sequoia, May 24-25, 1985, Reedley, California. Gen. Tech. Rep. PSW-95 USDA Forest Service, Pacific Southwest Forest and Range Experiment Station. Berkeley, CA.

Heald, R.C. and T.M. Barrett 1999. Effects of planting density on early growth of giant sequoia (Sequoiadendron giganteum). Western Journal of Applied Forestry 14:65-72.

Hickman, J.C. (ed.). 1993. The Jepson manual: Higher plants of California. University of California Press, Berkeley and Los Angeles, California.

Holubčík, M. 1960. Raising exotics in Czechoslovak stands (abstract). Lesn. Căs. 6(1):64-75. 
Huisinga, K.D., D.C. Laughlin, P.Z. Fulé, J.D. Springer, and C.M. McGlone. 2005. Effects of an intense prescribed fire on understory vegetation in a mixed conifer forest. Journal of the Torrey Botanical Society. 132(4):590-601.

Innes, J.C., M.P. North and N. Williamson. 2006. Effect of thinning and prescribed fire restoration treatments on woody debris and snag dynamics in a sierra old-growth, mixed conifer forest. Canadian Journal of Forest Research 36:3183-3193.

Jaroslavcev, G.D. 1963. Sequoia gigantea in plantations in the Crimea (abstract). Lesn. Ž., Arhangel'sk. 6(1):43-45.

Kayacık, H., B. Aytuğ, F. Yaltırık, İ. Şanlı, A. Efe, Ü. Akkemik, and M. İnan. 1995 (publ.1999) (abstract). Sequoiadendron giganteum trees lived near Istanbul in late Tertiary. İstanbul Üniversitesi Orman Fakültesi Dergisi. Seri A, 45(1):15-22.

Keifer, M. 1998. Fuel load and tree density changes following prescribed fire in the giant sequoia-mixed conifer forest: the first 14 years of fire monitoring. Proceedings of the Tall Timbers Fire Ecology Conference 20:306-309.

Keifer, M., J.W. van Wagtendonk and M. Buhler. 2006. Long-term surface fuel accumulation in burned and unburned mixed-conifer forests of the central and southern Sierra Nevada, CA (USA). Fire Ecology 2(1):53-72.

Kilgore, B.M. 1973. Impact of prescribed burning on a sequoia-mixed conifer forest. Proceedings of the Tall Timbers Fire Ecology Conference 12:345-375.

Kilgore, B.M and R.W. Sando. 1975. Crown-fire potential in sequoia forest after prescribed burning. Forest Science 21(1):83-87.

Kilgore, B.M. and D. Taylor. 1979. Fire history of a sequoia-mixed conifer forest. Ecology 60(1):129-142. 
Knapp, E.E., D.W. Schwilk, J.M. Kane, and J.E. Kelley. 2007. Role of burning season on initial understory vegetation response to prescribed fire in a mixed conifer forest. Canadian Journal of Forest Research. 37(1):11-22.

Knigge, W. 1994. Giant sequoia (Sequoiadendron giganteum (Lindl.) Buchholz) in Europe. Gen. Tech. Rep. PSW-151 USDA Forest Service, Pacific Southwest Research Station. Albany, CA.

Krebs, C.J. 1999. Ecological methodology. $2^{\text {nd }}$ ed. Benjamin/Cummings. Menlo Park, California. 620 pp.

Leisz, D.R. 1992. Remarks for the Giant Sequoia Symposium. Proceedings of the Symposium on Giant Sequoia: Their Place in the Ecosystem and Society. Visalia, California. USDA Forest Service, PSW-GTR-151. 1994.

Lewis, C.E., B.F. Swindel and G.W. Tanner. 1988. Species diversity and diversity profiles: Concept, measurement and application to timber and range management. Journal of Range Management. 41(6):466-469.

Lindley, J. (Ed.). 1853, December 24. The Gardeners’ Chronicle and Agricultural Gazette, 52, 819-820.

Lindquist, J.L. 2004. Precommercial stocking control of Coast Redwood a seventeen-year status report (1981-1998). California Forestry Report No. 2. California Department of Forestry and Fire Protection, Sacramento, CA.

Magurran, A.E. 1988. Ecological diversity and its measurement. Princeton University Press, Princeton, NJ. 
Martin R.E. and D.P. Gasser. 1989. Response to management strategies in giant sequoia forests, research proposal. California Department of Forestry and Fire Protection, Sacramento, CA. Unpublished document.

May R.M. 1975. Patterns of species abundances and diversity. In: Cody M.L., Diamond J.M. (eds.). Ecology and Evolution of Communities. Belknap Press of Harvard University Press, Cambridge, MA. pp 81-120.

McDonald, P.M. and C.S. Abbott. 1994. Seedfall, regeneration, and seedling development in small group-selection openings. USDA Forest Service Pacific Southwest Research Station. Research Paper. PSW-RP-220.

McDonald, P.M. and P.E. Reynolds. 1999. Plant community development after 28 years in small group-selection openings. USDA Forest Service Pacific Southwest Research Station. Research Paper. PSW-RP-241.

McIntosh, R.P. 1967. An index of diversity and the relation of certain concepts to diversity. Ecology. 48(3):392-404.

Meyer M.D. and H.D. Safford. 2011. Giant Sequoia regeneration in groves exposed to wildfire and retention harvest. Fire Ecology. 7(2):2-16.

Molotkov, P.I. 1958. Sequoia gigantea in Transcaucasia (abstract) Lesn. Hoz. 11(12):74. Muir, J. 1870. Letter from [John Muir] to [Jeanne C.] Carr, [1870 Fall]. John Muir Correspondence. Holt-Atherton Special Collections. University of the Pacific.

Muir, J. 1876. On the post-glacial history of Sequoia gigantea. Proc. Amer. Assoc. Adv. Sci., 25:242-253.

Muller-Stoll, H. 1947. The durability of wood of trees and shrubs of the Tertiary period (abstract). Senckenbergiana, Frankfurt a.M. 28(1/3):67-94. 
North, M., J. Chen, G. Smith, L. Krakowiak, and J. Franklin. 1996. Initial response of understory plant diversity and overstory tree diameter growth to a green tree retention harvest. Northwest Science. 70(1):24-35.

North, M., J. Innes and H. Zald. 2007. Comparison of thinning and prescribed fire restoration treatments to Sierran mixed-conifer historic conditions. Canadian Journal of Forest Research 37(2):331-342.

Nyland, R.D. 2002. Silviculture concepts and applications. $2^{\text {nd }}$ ed. Waveland Press, Inc., Long Grove, IL.

Parson, D.J. 1978. Fire and fuel accumulation in a giant sequoia forest. Journal of Forestry 76(2):104-105.

Parsons, D.J. and H.T. Nichols. 1986. Management of giant sequoia in the national parks of the Sierra Nevada, California. Proceedings of the workshop on management of giant sequoia, May 24-25, 1985, Reedley, California. Gen. Tech. Rep. PSW-95 USDA Forest Service, Pacific Southwest Forest and Range Experiment Station. Berkeley, CA.

Peracca, G.G. and K.L. O’Hara. 2008. Effects of growing space on growth for 20-yearold giant sequoia, ponderosa pine, and Douglas-fir in the Sierra Nevada. Western Journal of Applied Forestry 23:156-165.

Piirto, D.D. 1986. Wood of giant sequoia: Properties and unique characteristics. Proceedings of the workshop on management of giant sequoia, May 24-25, 1985, Reedley, California. Gen. Tech. Rep. PSW-95 USDA Forest Service, Pacific Southwest Forest and Range Experiment Station. Berkeley, CA. 
Piirto, D. and R. Rogers. 2002. An ecological basis for managing giant sequoia ecosystems. Environmental Management 30:110-128.

Piirto, D. and R. Rogers. 1999. An ecological foundation for management of national forest giant sequoia ecosystems. USDA Forest Service Pacific Southwest Region, R5-EM-TP-005.

Piirto, D., R. Rogers and M.C. Bethke. 1997. Communicating the role of science in managing giant sequoia groves. Reprinted from: Communicating the Role of Silviculture in Managing the National Forests, Proceedings of the National Silviculture Workshop. General Technical Report \#238. Northeastern Forest Experimental Station. USDA Forest Service.

Pillsbury, N.H., M.J. De Lasaux and D. Dulitz. 1991. Young-growth sierra redwood volume equations for Mountain Home Demonstration State Forest. California Forestry Note No. 103. California Department of Forestry and Fire Protection. Sacramento, CA.

Pillsbury, N.H. and J.P. Joseph. 1990. Volume equations for young growth softwood species at Mountain Home Demonstration State Forest. Natural Resources Management Department, California Polytechnic State University, San Luis Obispo, California.

Radler, F. 1956. Trials with Sequoia gigantea in Lower Rhine region (abstract). Hoz-Zbl. 82(6):55-56.

Rannert, H. 1955. On the stem form and volume of Sequoia gigantea (abstract). Zbl. Ges. Forstw. 74(1):19-26. 
Rigg, C.M. 2001. Orchestrating ecosystem management: Challenges and lessons from Sequoia National Forest. Conservation Biology 15:78-90.

Roberts, M.R. and F.S. Gilliam. 1995. Patterns and mechanisms of plant diversity in forested ecosystems: Implications for forest management. Ecological Applications 5(4):969-977.

Rogers, R.R. 1986. Management of giant sequoia in the national forests of the Sierra Nevada, California. Proceedings of the workshop on management of giant sequoia, May 24-25, 1985, Reedley, California. Gen. Tech. Rep. PSW-95 USDA Forest Service, Pacific Southwest Forest and Range Experiment Station. Berkeley, CA.

Roller, G. 2001. A twelve-year remeasurement of growth response of young growth giant sequoia trees to silvicultural manipulation. California Polytechnic State University, San Luis Obispo. Senior Project.

Roller, G. 2004. Young growth giant sequoia response to management strategies at Mountain Home State Forest. Master’s thesis. California Polytechnic State University, San Luis Obispo, CA.

Roy, D.G. and J.L. Vankat. 1999. Reversal of human-induced vegetation changes in Sequoia National Park, California. Canadian Journal of Forest Research 29(4):399-412.

Rundel, P.W. 1972a. Habitat restriction in giant sequoia: The environmental control of grove boundaries. American Midland Naturalist 87(1):81-99.

Rundel, P.W. 1972b. An annotated list of the groves of Sequoiadendron giganteum in the Sierra Nevada -Part 1. Madroño. 21(5):319-328. 
Schubert, G.H. 1957. Silvicultural characteristics of giant sequoia. Technical Paper \#20. California Forest and Range Experimental Station, Berkeley California. USDA Forest Service.

Shellhammer, H.S. and T.H. Shellhammer. 2006. Giant sequoia (Sequoiadendron giganteum [taxodiaceae]) seedling survival and growth in the first four decades following managed fires. Madroño 53:342-350.

Shevock, J.R. 1996. Status of rare and endangered plants. In: Sierra Nevada Ecosystem Project: Final Report to Congress, Vol. II. Centers for Water and Wildland Resources, University of California, Davis, pp. 691-707.

Simpson, E.H. 1949. Measurement of diversity. Nature 163:688.

Spoljaric, Z. 1952. Anatomic and pollen-analytic investigations on some lignites from northern Croatia (abstract). Jugaslavenska Akademija Znanosti I Umjetnosti, Zagreb. p 98.

Stephens, S.L., D.J. Dulitz, and R.E. Martin. 1999. Giant sequoia regeneration in group selection openings in the southern Sierra Nevada. Forest Ecology and Management 120:89-95.

Stephenson, N.L. 1999. Reference conditions for giant sequoia forest restoration: Structure, process, and precision. Ecological Applications 9:1253-1265.

Stephenson, S.L., D.L. Parsons, and T.W. Swetnam. 1991. Restoring natural fire to the sequoia-mixed conifer forest should intense fire play a role? Proceedings of the $18^{\text {th }}$ Tall Timbers Fire Ecology Conference, May 18-21, 1989: High Intensity Fire in Wildlands: Management Challenges and Options. pp.321-337. 
Stoddard, C.H. and G.M. Stoddard. 1987. Essentials of forestry practice. $4^{\text {th }}$ ed. John Wiley \& Sons, Inc., New York.

Stohlgren, T.J., 1993. Intra-specific competition (crowding) of giant sequoias

(Sequoiadendron giganteum). Forestry Ecology and Management. 59(1-2):127148.

Swetnam, T.W., C.H. Baisan, A.C. Caprio, P.M. Brown, R. Touchan, R.S. Anderson and D.J. Hallett. 2009. Multi-millennial fire history of the Giant Forest, Sequoia National Park, California, USA. Fire Ecology 5(3):120-150.

Tweed, W. 1992. Public perceptions of giant sequoia over time. Proceedings of the Symposium on Giant Sequoia: Their Place in the Ecosystem and Society. Visalia, California. USDA Forest Service, PSW-GTR-151. 1994.

USDA Forest Service. 1990. Sequoia National Forest Mediated Settlement Agreement. Unpublished administrative document, Porterville, CA.

USDA Forest Service. 2010. Giant sequoia national monument draft environmental impact statement (DEIS), volume 1, chapter 3. Sequoia National Forest, Porterville, CA.

Vankat, J.L. 1982. A gradient perspective on the vegetation of Sequoia National Park, California. Madroño. 29:200-214.

Vankat, J.L. and J. Major. Vegetation changes in Sequoia National Park, California. Journal of Biogeography. 5:377-402.

van Wagtendonk, J.W., J.M. Benedict and W.M. Sydoriak. 1996. Physical properties of woody fuel particles of Sierra Nevada conifers. International Journal of Wildland Fire. 6(3):117-123. 
van Wagtendonk, J.W., J.M. Benedict and W.M. Sydoriak. 1998. Fuel bed characteristics of Sierra Nevada conifers. Western Journal of Applied Forestry. 13(3):73-84.

Wayman, R.B. and M. North. 2007. Initial response of a mixed-conifer understory plant community to burning and thinning restoration treatments. Forest Ecology and Management. 239:32-44.

Weise, D.R.; A. Gelobter, S.M. Haase and S.S. Sackett. 1997. Photo series for quantifying fuels and assessing fire risk in giant sequoia groves. General Technical Report \#163. Pacific Southwest Research Station. USDA Forest Service.

Whittaker, R.H. 1960. Vegetation of the Siskiyou Mountains, Oregon and California. Ecological Monographs. 30(3):279-338.

Whittaker, R.H. 1965. Dominance and diversity in land plant communities. Science. 147(3655):250-260.

Whittaker, R.H. and W.A. Niering. 1965. Vegetation of the Santa Catalina Mountains, Arizona: A gradient analysis of the south slope. Ecology. 46(4):429-452.

Willard, D. 1994. The natural giant sequoia (Sequoiadendron giganteum) groves of the Sierra Nevada, California - an updated annotated list. General Technical Report \#151. Pacific Southwest Research Station. USDA Forest Service.

Wilson, L.R. and R.M. Webster. 1946. Plant microfossils from a Fort Union coal of Montana (abstract). American Journal of Botany. 33(4):271-278. 
York, R.A. 2010. Update on giant sequoia research and management at UC Center for Forestry Properties. Meeting: Long term management of giant sequoia in California in light of potential climate change and fire risk. Sacramento, California.

York, R.A. and J.J. Battles. 2008. Growth response of mature trees versus seedlings to gaps associated with group selection management in the Sierra Nevada, California. Western Journal of Applied Forestry. 23(2):94-98.

York, R.A., J.J. Battles, A.K. Eschtruth, and F.G. Schurr. 2011. Giant sequoia (Sequoiadendron giganteum) regeneration in experimental canopy gaps. Restoration Ecology. 19(1):14-23.

York, R.A., J.J. Battles, and R.C. Heald. 2003. Edge effects in mixed conifer group selection openings: Tree height response to resource gradients. Forest Ecology and Management 179:107-121.

York, R.A., D. Fuchs, J.J. Battles and S.L. Stephens. 2010. Radial growth responses to gap creation in large, old Sequoiadendron giganteum. Applied Vegetation Science. 13(4):498-509.

York, R.A., R.C. Heald, J.J. Battles, and J.D. York. 2004. Group selection management in conifer forests: Relationships between opening size and tree growth. Canadian Journal of Forestry Res. 34:630-641.

Zippi, P. 2003. Diversity calculator 4.0 PAZ Software, Garland, TX. 


\section{Appendices}
A. Overstory Data
p. 101
B. DBH Distribution Graphs/Stand Tables
p. 175
C. Understory Data
p. 176
D. Understory Species List
p. 212
E. Downed Woody Debris Data
p. 216
F. Regeneration Data
p. 224
G. Regeneration TPA Graphs
p. 236
H. Plot Maps
p. 237
I. Pre/Post Treatment Plot Pictures
p. 244
J. MHDSF Volume Equations
p. 245
K. Special Investigation of Observed Second-Growth Giant Sequoia Mortality
p. 247 
APPENDIX A

Overstory Data

Page 101 
MHDSF Young-Growth Giant Sequoia Management Strategies Study 2009 - Overstory Summary Data (39.37 ft. (12m) Plot)

$\begin{array}{lllll}\text { Stand: Bogus Meadow } & \text { Treatment: Thinned } & \text { Measured By: } & 1989 \text { Bates, Masser } \\ & & \text { Measured By: } & 1994 \text { Ganz } \\ \text { Block: A } & \text { Plot \# :1 } & \text { Measured By: } & 2001 \text { Roller, Rueter } \\ & & \text { Measured By: } & 2009 \text { Soderlund, Ricchiazzi }\end{array}$

\begin{tabular}{cc|cc|cc|cc|cc|}
\cline { 3 - 9 } \multicolumn{1}{c|}{} & & \multicolumn{2}{|c|}{1989 Data } & \multicolumn{2}{c|}{ 1994 Data } & \multicolumn{2}{c|}{ 2001 Data } & \multicolumn{2}{c|}{ 2009 Data } \\
Tree \# & Species & DBH & Height & DBH & Height & DBH & Height & DBH & Height \\
\hline \hline 16 & GS & 38.2 & 160.0 & 41.0 & 174.0 & 43.9 & 173.1 & 47.7 & 172.8 \\
17 & GS & 28.7 & 145.0 & 33.6 & 167.0 & 38.2 & 168.9 & 42.3 & 170.8 \\
18 & GS & 26.9 & 111.0 & 29.0 & 122.0 & 31.9 & 115.8 & 35.1 & 129.8 \\
19 & GS & 52.3 & 160.0 & 56.0 & 168.0 & 59.9 & 180.9 & 64.7 & 177.8 \\
20 & GS & 30.6 & 172.0 & 33.4 & 183.0 & 38.3 & 189.2 & 44.1 & 181.2 \\
\hline \hline AVG. & & 35.3 & 149.6 & 38.6 & 162.8 & 42.4 & 165.6 & 46.8 & 166.5
\end{tabular}

2009 - Overstory Summary Growth Data (39.37 ft. (12m) Plot)

\begin{tabular}{|c|c|c|c|c|c|c|c|c|c|c|c|c|c|}
\hline \multirow[b]{2}{*}{ Tree \# } & \multirow[b]{2}{*}{ Species } & \multicolumn{2}{|c|}{$\begin{array}{c}\text { Change } \\
\text { 1989-1994 }\end{array}$} & \multicolumn{2}{|c|}{$\begin{array}{c}\text { Change } \\
\text { 1994-2001 }\end{array}$} & \multicolumn{2}{|c|}{$\begin{array}{c}\text { Change } \\
\text { 1989-2001 }\end{array}$} & \multicolumn{2}{|c|}{$\begin{array}{c}\text { Change } \\
\text { 1994-2009 }\end{array}$} & \multicolumn{2}{|c|}{$\begin{array}{l}\text { Change } \\
\text { 2001-2009 }\end{array}$} & \multicolumn{2}{|c|}{$\begin{array}{c}\text { Change } \\
\text { 1989-2009 }\end{array}$} \\
\hline & & $\mathrm{DBH}$ & Height & $\mathrm{DBH}$ & Height & $\mathrm{DBH}$ & Height & $\mathrm{DBH}$ & Height & $\mathrm{DBH}$ & Height & $\mathrm{DBH}$ & Height \\
\hline 16 & GS & 2.8 & 14.0 & 2.9 & -0.9 & 5.7 & 13.1 & 6.7 & -1.2 & 3.8 & -0.3 & 9.5 & 12.8 \\
\hline 17 & GS & 4.9 & 22.0 & 4.6 & 1.9 & 9.5 & 23.9 & 8.7 & 3.8 & 4.1 & 1.9 & 13.6 & 25.8 \\
\hline 18 & GS & 2.1 & 11.0 & 2.9 & -6.2 & 5.0 & 4.8 & 6.1 & 7.8 & 3.2 & 14.0 & 8.2 & 18.8 \\
\hline 19 & GS & 3.7 & 8.0 & 3.9 & 12.9 & 7.6 & 20.9 & 8.7 & 9.8 & 4.8 & -3.1 & 12.4 & 17.8 \\
\hline 20 & GS & 2.8 & 11.0 & 4.9 & 6.2 & 7.7 & 17.2 & 10.7 & -1.8 & 5.8 & -8.0 & 13.5 & 9.2 \\
\hline AVG. & & 3.3 & 13.2 & 3.8 & 2.8 & 7.1 & 16.0 & 8.2 & 3.7 & 4.3 & 0.9 & 11.4 & 16.9 \\
\hline
\end{tabular}

Tree $\quad 18$ Broken Top in 2001 
MHDSF Young-Growth Giant Sequoia Management Strategies Study 2009 - Overstory Summary Data (39.37 ft. (12m) Plot)

$\begin{array}{lllll}\text { Stand: Bogus Meadow } & \text { Treatment: Thinned } & \text { Measured By: } & 1990 \text { Rodgers, Eagen } \\ & & \text { Measured By: } & 1994 \text { Ganz } \\ \text { Block: A } & \text { Plot \# :2 } & \text { Measured By: } & 2001 \text { Roller, Rueter } \\ & & \text { Measured By: } & 2009 \text { Soderlund, Ricchiazzi }\end{array}$

\begin{tabular}{cc|cc|cc|cc|cc|}
\cline { 3 - 9 } \multicolumn{1}{c|}{} & \multicolumn{2}{c|}{ 1989 Data } & \multicolumn{2}{c|}{ 1994 Data } & \multicolumn{2}{c|}{ 2001 Data } & \multicolumn{2}{c|}{2009 Data } \\
Tree \# & Species & DBH & Height & DBH & Height & DBH & Height & DBH & Height \\
\hline \hline 58 & GS & 32.0 & 159.0 & 34.5 & 161.0 & 36.7 & 165.3 & 41.1 & 183.1 \\
59 & GS & 37.8 & 156.0 & 40.9 & 176.0 & 41.6 & 181.4 & 46.5 & 184.4 \\
60 & GS & 27.9 & 130.0 & 29.8 & 137.0 & 34.6 & 138.6 & 39.7 & 162.4 \\
61 & GS & 41.4 & 173.0 & 43.9 & 188.0 & 48.4 & 186.6 & 53.4 & 188.2 \\
62 & WF & $* * *$ & $* * *$ & $* * *$ & $* * *$ & 2.4 & 13.0 & 4.9 & 23.6 \\
63 & WF & $* * *$ & $* * *$ & $* * *$ & $* * *$ & $* * *$ & $* * *$ & 1.7 & 10.1 \\
64 & WF & $* * *$ & $* * *$ & $* * *$ & $* * *$ & $* * *$ & $* * *$ & 1.0 & 7.7 \\
65 & WF & $* * *$ & $* * *$ & $* * *$ & $* * *$ & $* * *$ & $* * *$ & 1.1 & 7.8 \\
\hline \hline AVG. & & 34.8 & 154.5 & 37.3 & 165.5 & 32.7 & 137.0 & 23.7 & 95.9
\end{tabular}

2009 - Overstory Summary Growth Data (39ft. (12m) Plot)

\begin{tabular}{|c|c|c|c|c|c|c|c|c|c|c|c|c|c|}
\hline \multirow[b]{2}{*}{ Tree \# } & \multirow[b]{2}{*}{ Species } & \multicolumn{2}{|c|}{$\begin{array}{c}\text { Change } \\
\text { 1989-1994 }\end{array}$} & \multicolumn{2}{|c|}{$\begin{array}{c}\text { Change } \\
1994-2001\end{array}$} & \multicolumn{2}{|c|}{$\begin{array}{l}\text { Change } \\
\text { 1989-2001 }\end{array}$} & \multicolumn{2}{|c|}{$\begin{array}{c}\text { Change } \\
\text { 1994-2009 }\end{array}$} & \multicolumn{2}{|c|}{$\begin{array}{l}\text { Change } \\
\text { 2001-2009 }\end{array}$} & \multicolumn{2}{|c|}{$\begin{array}{c}\text { Change } \\
\text { 1989-2009 }\end{array}$} \\
\hline & & DBH & Height & DBH & Height & DBH & Height & DBH & Height & DBH & Height & $\mathrm{DBH}$ & Height \\
\hline 58 & GS & 2.5 & 2.0 & 2.2 & $\begin{array}{l}4.3 \\
\end{array}$ & 4.7 & 6.3 & 6.6 & 22.1 & 4.4 & $\begin{array}{l}17.8 \\
\end{array}$ & 9.1 & 24.1 \\
\hline 59 & GS & 3.1 & 20.0 & 0.7 & 5.4 & 3.8 & 25.4 & 5.6 & 8.4 & 4.9 & 3.0 & 8.7 & 28.4 \\
\hline 60 & GS & 1.9 & 7.0 & 4.8 & 1.6 & 6.7 & 8.6 & 9.9 & 25.4 & 5.1 & 23.8 & 11.8 & 32.4 \\
\hline 61 & GS & 2.5 & 15.0 & 4.5 & -1.4 & 7.0 & 13.6 & 9.5 & 0.2 & 5.0 & 1.6 & 12.0 & 15.2 \\
\hline 62 & WF & $* * *$ & $* * *$ & $* * *$ & $* * *$ & $* * *$ & $* * *$ & $* * *$ & $* * *$ & 2.5 & 10.6 & $* * *$ & $* * *$ \\
\hline 63 & WF & $* * *$ & $* * *$ & $* * *$ & $* * *$ & $* * *$ & $* * *$ & $* * *$ & $* * *$ & $* * *$ & $* * *$ & $* * *$ & $* * *$ \\
\hline 64 & WF & $* * *$ & $* * *$ & $* * *$ & $* * *$ & $* * *$ & $* * *$ & $* * *$ & $* * *$ & $* * *$ & $* * *$ & $* * *$ & $* * *$ \\
\hline 65 & WF & $* * *$ & $* * *$ & $* * *$ & $* * *$ & $* * *$ & $* * *$ & $* * *$ & $* * *$ & $* * *$ & $* * *$ & $* * *$ & $* * *$ \\
\hline AVG. & & 2.5 & 11.0 & 3.1 & 2.5 & 5.6 & 13.5 & 7.9 & 14.0 & 4.4 & 11.4 & 10.4 & 25.0 \\
\hline
\end{tabular}

Tree $62 \quad$ Ingrowth in 2001

Trees 63,64,65 Ingrowth in 2009 
MHDSF Young-Growth Giant Sequoia Management Strategies Study 2009 - Overstory Summary Data (39.37 ft. (12m) Plot)

$\begin{array}{llll}\text { Stand: Bogus Meadow } & \text { Treatment: Thinned/Burned } & \text { Measured By: } & 1989 \text { Bates, Masser } \\ & & \text { Measured By: } & 1994 \text { Ganz } \\ \text { Block: B } & \text { Plot \# :1 } & \text { Measured By: } & 2001 \text { Roller, Rueter } \\ & & \text { Measured By: } & 2009 \text { Soderlund, Ricchiazzi }\end{array}$

\begin{tabular}{cc|cc|cc|cc|cc|}
\cline { 3 - 9 } \multicolumn{1}{c|}{} & \multirow{2}{*}{ Tree \# } & Species & DB89 Data & \multicolumn{2}{c|}{ 1994 Data } & \multicolumn{2}{c|}{ 2001 Data } & \multicolumn{2}{c|}{ 2009 Data } \\
\hline \hline 9 & SP & 23.5 & 143.0 & 24.6 & 154.0 & 27.3 & 156.8 & 29.7 & 150.4 \\
10 & GS & 12.5 & 80.0 & 13.5 & 88.0 & 16.1 & 99.1 & 19.5 & 106.0 \\
11 & GS & 25.0 & 134.0 & 26.0 & 139.0 & 29.8 & 149.4 & 34.5 & 154.7 \\
12 & GS & 40.1 & 169.0 & 41.7 & 186.0 & 45.8 & 199.7 & 50.4 & 202.0 \\
13 & GS & 33.8 & 150.0 & 36.1 & 167.0 & 40.4 & 172.0 & 44.1 & 181.4 \\
14 & GS & 33.2 & 148.0 & 37.0 & 161.0 & 38.2 & 180.9 & 41.5 & 174.9 \\
15 & GS & 40.2 & 140.0 & 42.7 & 147.0 & 45.5 & 152.4 & 48.4 & 171.2 \\
16 & WF & $* * *$ & $* * *$ & $* * *$ & $* * *$ & $* * *$ & $* * *$ & 2.1 & 11.7 \\
17 & WF & $* * *$ & $* * *$ & $* * *$ & $* * *$ & $* * *$ & $* * *$ & 2.0 & 12.3 \\
18 & IC & $* * *$ & $* * *$ & $* * *$ & $* * *$ & $* * *$ & $* * *$ & 1.1 & 9.5 \\
\hline \hline
\end{tabular}

2009 - Overstory Summary Growth Data (39ft. (12m) Plot)

\begin{tabular}{|c|c|c|c|c|c|c|c|c|c|c|c|c|c|}
\hline \multirow[b]{2}{*}{ Tree \# } & \multirow[b]{2}{*}{ Species } & \multicolumn{2}{|c|}{$\begin{array}{c}\text { Change } \\
1989-1994\end{array}$} & \multicolumn{2}{|c|}{$\begin{array}{c}\text { Change } \\
\text { 1994-2001 }\end{array}$} & \multicolumn{2}{|c|}{$\begin{array}{c}\text { Change } \\
\text { 1989-2001 }\end{array}$} & \multicolumn{2}{|c|}{$\begin{array}{c}\text { Change } \\
\text { 1994-2009 }\end{array}$} & \multicolumn{2}{|c|}{$\begin{array}{c}\text { Change } \\
\text { 2001-2009 }\end{array}$} & \multicolumn{2}{|c|}{$\begin{array}{c}\text { Change } \\
1989-2009\end{array}$} \\
\hline & & DBH & Height & DBH & Height & DBH & Height & $\mathrm{DBH}$ & Height & $\mathrm{DBH}$ & Height & $\mathrm{DBH}$ & Height \\
\hline 9 & SP & 21.1 & 11.0 & 2.7 & 2.8 & 3.8 & 13.8 & 5.1 & -3.6 & 2.4 & -6.4 & 6.2 & 7.4 \\
\hline 10 & GS & 1.0 & 8.0 & 2.6 & 11.1 & 3.6 & 19.1 & 6.0 & 18.0 & 3.4 & 6.9 & 7.0 & 26.0 \\
\hline 11 & GS & 1.0 & 5.0 & 3.8 & 10.4 & 4.8 & 15.4 & 8.5 & 15.7 & 4.7 & 5.3 & 9.5 & 20.7 \\
\hline 12 & GS & 1.6 & 17.0 & 4.1 & 13.7 & 5.7 & 30.7 & 8.7 & 16.0 & 4.6 & 2.3 & 10.3 & 33.0 \\
\hline 13 & GS & 2.3 & 17.0 & 4.3 & 5.0 & 6.6 & 22.0 & 8.0 & 14.4 & 3.7 & 9.4 & 10.3 & 31.4 \\
\hline 14 & GS & 3.8 & 13.0 & 1.2 & 19.9 & 5.0 & 32.9 & 4.5 & 13.9 & 3.3 & -6.0 & 8.3 & 26.9 \\
\hline 15 & GS & 2.5 & 7.0 & 2.8 & 5.4 & 5.3 & 12.4 & 5.7 & 24.2 & 2.9 & 18.8 & 8.2 & 31.2 \\
\hline 16 & WF & $* * *$ & $* * *$ & $* * *$ & $* * *$ & $* * *$ & $* * *$ & $* * *$ & $* * *$ & $* * *$ & $* * *$ & $* * *$ & $* * *$ \\
\hline 17 & WF & $* * *$ & $* * *$ & $* * *$ & $* * *$ & $* * *$ & $* * *$ & $* * *$ & $* * *$ & $* * *$ & $* * *$ & $* * *$ & $* * *$ \\
\hline 18 & IC & $* * *$ & $* * *$ & $* * *$ & $* * *$ & $* * *$ & $* * *$ & $* * *$ & $* * *$ & $* * *$ & $* * *$ & $* * *$ & $* * *$ \\
\hline AVG. & & 1.9 & 11.1 & 3.1 & 9.8 & 5.0 & 20.9 & 6.6 & 14.1 & 3.6 & 4.3 & 8.5 & 25.2 \\
\hline
\end{tabular}

Tree $\quad 13$ Diameter measured 4in above dbh due to stems growing together in 2009

Tree 14 Diameter measured 6in above dbh due to stems growing together in 2009

Tree 16,17,18 Ingrowth in 2009 
MHDSF Young-Growth Giant Sequoia Management Strategies Study 2009 - Overstory Summary Data (39.37 ft. (12m) Plot)

$\begin{array}{llll}\text { Stand: Bogus Meadow } & \text { Treatment: Thinned/Burned } & \text { Measured By: } & 1990 \text { Rodgers, Eagen } \\ & & \text { Measured By: } & 1994 \text { Ganz } \\ \text { Block: B } & \text { Plot \# :2 } & \text { Measured By: } & 2001 \text { Roller, Rueter } \\ & & \text { Measured By: } & 2009 \text { Soderlund, Ricchiazzi }\end{array}$

\begin{tabular}{cc|cc|cc|cc|cc|}
\cline { 3 - 9 } \multicolumn{1}{c|}{} & & \multicolumn{2}{c|}{1989 Data } & \multicolumn{2}{c|}{ 1994 Data } & \multicolumn{2}{c|}{ 2001 Data } & \multicolumn{2}{c|}{ 2009 Data } \\
Tree \# & Species & DBH & Height & DBH & Height & DBH & Height & DBH & Height \\
\hline \hline 47 & GS & 31.4 & 160.0 & 33.8 & 177.0 & 38.3 & 179.0 & 42.7 & 183.7 \\
48 & GS & 46.1 & 161.0 & 45.1 & 179.0 & 48.5 & 191.3 & 52.6 & 183.3 \\
49 & WF & 6.6 & 24.0 & 7.9 & 34.0 & 10.0 & 40.7 & 11.3 & 52.7 \\
50 & GS & 32.7 & 140.0 & 36.2 & 154.0 & 38.8 & 160.3 & 43.3 & 163.9 \\
51 & GS & 49.4 & 147.0 & 51.1 & 172.0 & 54.2 & 171.1 & 59.3 & 174.2 \\
52 & GS & 24.0 & 107.0 & 24.0 & 120.0 & 25.4 & 123.3 & 28.9 & 136.2 \\
53 & WF & 19.7 & 68.0 & 20.0 & 79.0 & 20.5 & 90.5 & 21.3 & 116.4 \\
54 & GS & 43.3 & 139.0 & 44.7 & 152.0 & 48.5 & 153.4 & 53.0 & 181.3 \\
55 & GS & 29.4 & 154.0 & 30.9 & 168.0 & 33.7 & 168.7 & 35.9 & 170.5 \\
56 & WF & 1.0 & 16.0 & 3.6 & 21.0 & 3.6 & 16.3 & 5.2 & 25.7 \\
57 & WF & 3.0 & 6.0 & $* * *$ & $* * *$ & 5.6 & 26.3 & 7.9 & 36.6 \\
58 & WF & $* * *$ & $* * *$ & $* * *$ & $* * *$ & 1.1 & 6.8 & 2.1 & 12.3 \\
59 & WF & $* * *$ & $* * *$ & $* * *$ & $* * *$ & $* * *$ & $* * *$ & 1.6 & 7.3 \\
\hline \hline AVG. & & 26.1 & 102.0 & 29.7 & 125.6 & 27.4 & 110.6 & 28.1 & 111.1
\end{tabular}

2009 - Overstory Summary Growth Data (39ft. (12m) Plot)

\begin{tabular}{|c|c|c|c|c|c|c|c|c|c|c|c|c|c|}
\hline \multirow[b]{2}{*}{ Tree \# } & \multirow[b]{2}{*}{ Species } & \multicolumn{2}{|c|}{$\begin{array}{c}\text { Change } \\
1989-1994\end{array}$} & \multicolumn{2}{|c|}{$\begin{array}{c}\text { Change } \\
1994-2001\end{array}$} & \multicolumn{2}{|c|}{$\begin{array}{c}\text { Change } \\
1989-2001\end{array}$} & \multicolumn{2}{|c|}{$\begin{array}{c}\text { Change } \\
1994-2009\end{array}$} & \multicolumn{2}{|c|}{$\begin{array}{c}\text { Change } \\
2001-2009\end{array}$} & \multicolumn{2}{|c|}{$\begin{array}{c}\text { Change } \\
1989-2009\end{array}$} \\
\hline & & $\mathrm{DBH}$ & Height & $\mathrm{DBH}$ & Height & $\mathrm{DBH}$ & Height & $\mathrm{DBH}$ & Height & $\mathrm{DBH}$ & Height & $\mathrm{DBH}$ & Height \\
\hline 47 & GS & 2.4 & 17.0 & 4.5 & 2.0 & 6.9 & 19.0 & 8.9 & 6.7 & 4.4 & 4.7 & 11.3 & 23.7 \\
\hline 48 & GS & -1.0 & 18.0 & 3.4 & 12.3 & 2.4 & 30.3 & 7.5 & 4.3 & 4.1 & -8.0 & 6.5 & 22.3 \\
\hline 49 & WF & 1.3 & 10.0 & 2.1 & 6.7 & 3.4 & 16.7 & 3.4 & 18.7 & 1.3 & 12.0 & 4.7 & 28.7 \\
\hline 50 & GS & 3.5 & 14.0 & 2.6 & 6.3 & 6.1 & 20.3 & 7.1 & 9.9 & 4.5 & 3.6 & 10.6 & 23.9 \\
\hline 51 & GS & 1.7 & 25.0 & 3.1 & -0.9 & 4.8 & 24.1 & 8.2 & 2.2 & 5.1 & 3.1 & 9.9 & 27.2 \\
\hline 52 & GS & 0.0 & 13.0 & 1.4 & 3.3 & 1.4 & 16.3 & 4.9 & 16.2 & 3.5 & 12.9 & 4.9 & 29.2 \\
\hline 53 & WF & 0.3 & 11.0 & 0.5 & 11.5 & 0.8 & 22.5 & 1.3 & 37.4 & 0.8 & 25.9 & 1.6 & 48.4 \\
\hline 54 & GS & 1.4 & 13.0 & 3.8 & 1.4 & 5.2 & 14.4 & 8.3 & 29.3 & 4.5 & 27.9 & 9.7 & 42.3 \\
\hline 55 & GS & 1.5 & 14.0 & 2.8 & 0.7 & 4.3 & 14.7 & 5.0 & 2.5 & 2.2 & 1.8 & 6.5 & 16.5 \\
\hline 56 & WF & 2.6 & 5.0 & 0.0 & -4.7 & 2.6 & 0.3 & 1.6 & 4.7 & 1.6 & 9.4 & 4.2 & 9.7 \\
\hline 57 & WF & $* * *$ & $* * *$ & $* * *$ & $* * *$ & 2.6 & 20.3 & $* * *$ & $* * *$ & 2.3 & 10.3 & 4.9 & 30.6 \\
\hline 58 & WF & $* * *$ & $* * *$ & $* * *$ & $* * *$ & $* * *$ & $* * *$ & $* * *$ & $* * *$ & 1.0 & 5.5 & $* * *$ & $* * *$ \\
\hline 59 & WF & $* * *$ & $* * *$ & $* * *$ & $* * *$ & $* * *$ & $* * *$ & $* * *$ & $* * *$ & $* * *$ & $* * *$ & $* * *$ & $* * *$ \\
\hline AVG. & & 1.4 & 14.0 & 2.4 & 3.9 & 3.7 & 18.1 & 5.6 & 13.2 & 2.9 & 9.1 & 6.8 & 27.5 \\
\hline
\end{tabular}

$\begin{array}{lll}\text { Tree } & 57 & \text { Dead in } 1994 \\ \text { Tree } & 57 & \text { Is Alive in } 2001 \\ \text { Tree } & 58 & \text { Ingrowth in } 2001 \\ \text { Tree } & 59 & \text { Ingrowth in } 2009\end{array}$


MHDSF Young-Growth Giant Sequoia Management Strategies Study 2009 - Overstory Summary Data (39ft. (12m) Plot)

$\begin{array}{lllll}\text { Stand: Bogus Meadow } & \text { Treatment: Control } & \text { Measured By: } & 1989 & \text { Bates, Scott, Masser } \\ & & \text { Measured By: } & 1994 & \text { Ganz \& CDF } \\ \text { Block: C } & \text { Plot \# :1 } & \text { Measured By: } & 2001 & \text { Roller, Rueter } \\ & & \text { Measured By: } & 2009 & \text { Soderlund, Ricchiazzi }\end{array}$

\begin{tabular}{|c|c|c|c|c|c|c|c|c|c|}
\hline \multirow[b]{2}{*}{ Tree \# } & \multirow[b]{2}{*}{ Species } & \multicolumn{2}{|c|}{1989 Data } & \multicolumn{2}{|c|}{1994 Data } & \multicolumn{2}{|c|}{2001 Data } & \multicolumn{2}{|c|}{2009 Data } \\
\hline & & $\mathrm{DBH}$ & Height & $\mathrm{DBH}$ & Height & $\mathrm{DBH}$ & Height & $\mathrm{DBH}$ & Height \\
\hline 37 & GS & 25.1 & 124.0 & 26.5 & 135.0 & 39.5 & 149.8 & 32.7 & 156.6 \\
\hline 38 & WF & 11.1 & 58.0 & $* * *$ & $* * *$ & $* * *$ & $* * *$ & $* * *$ & $* * *$ \\
\hline 39 & GS & 4.1 & 27.0 & 4.1 & 28.0 & $* * *$ & $* * *$ & $* * *$ & $* * *$ \\
\hline 40 & GS & 6.2 & 25.0 & 6.2 & 28.0 & 6.2 & 29.1 & 6.3 & 27.1 \\
\hline 41 & GS & 21.2 & 117.0 & 22.3 & 116.0 & 23.8 & 119.1 & 25.5 & 141.8 \\
\hline 42 & WF & 8.0 & 58.0 & 8.0 & 73.0 & 8.2 & 47.1 & $* * *$ & $* * *$ \\
\hline 43 & GS & 17.7 & 84.0 & 17.6 & 98.0 & 18.0 & 91.0 & 18.0 & 89.5 \\
\hline 44 & GS & 21.9 & 118.0 & 22.9 & 130.0 & 25.4 & 145.7 & 27.8 & 152.1 \\
\hline 45 & GS & 10.0 & 65.0 & 9.9 & 67.0 & 9.9 & 70.5 & 9.8 & 62.3 \\
\hline 46 & GS & 24.0 & 112.0 & 25.2 & 103.0 & 27.0 & 126.3 & 29.0 & 146.8 \\
\hline 47 & GS & 9.5 & 27.0 & 9.5 & 49.0 & 9.6 & 50.2 & 9.6 & 52.6 \\
\hline 48 & GS & 1.9 & 8.0 & $* * *$ & $* * *$ & $* * *$ & $* * *$ & $* * *$ & $* * *$ \\
\hline 49 & GS & 17.9 & 112.0 & 19.2 & 115.0 & 21.6 & 138.8 & 24.4 & 146.9 \\
\hline 50 & WF & 6.5 & 45.0 & 6.3 & 44.0 & 6.5 & 49.4 & 6.8 & 50.6 \\
\hline 51 & GS & 19.1 & 121.0 & 20.3 & 118.0 & 23.2 & 126.9 & 25.0 & 144.4 \\
\hline 52 & WF & 9.9 & 72.0 & 10.0 & 76.0 & $* * *$ & $* * *$ & $* * *$ & $* * *$ \\
\hline 53 & WF & 4.3 & 36.0 & 4.4 & 40.0 & 4.4 & 38.9 & $* * *$ & $* * *$ \\
\hline 54 & GS & 14.0 & 73.0 & 14.7 & 75.0 & 15.4 & 84.7 & 16.2 & 87.6 \\
\hline 55 & WF & 10.5 & 80.0 & 10.5 & 74.0 & 10.7 & 81.8 & 11.1 & 87.8 \\
\hline 56 & GS & 27.5 & 115.0 & 29.6 & 124.0 & 32.4 & 142.3 & 45.6 & 152.4 \\
\hline 57 & WF & 4.2 & 31.0 & 4.1 & 31.0 & $* * *$ & $* * *$ & $* * *$ & $* * *$ \\
\hline 58 & GS & 5.9 & 21.0 & 6.1 & 24.0 & 6.5 & 24.2 & 7.0 & 25.3 \\
\hline 59 & GS & 26.4 & 118.0 & 27.7 & 116.0 & 30.3 & 130.4 & 33.2 & 142.5 \\
\hline 60 & GS & 6.5 & 26.0 & 6.5 & 28.0 & 6.5 & 28.1 & 6.5 & 27.8 \\
\hline 61 & GS & 6.0 & 22.0 & 6.0 & 21.0 & 6.0 & 23.9 & 6.0 & 24.2 \\
\hline 62 & GS & 2.7 & 12.0 & 2.7 & 10.0 & 2.7 & 11.2 & 2.6 & $* * *$ \\
\hline 63 & GS & 15.4 & 94.0 & 16.0 & 93.0 & 17.2 & 86.8 & 18.3 & 89.6 \\
\hline 64 & GS & 14.3 & 36.0 & 14.6 & 41.0 & 15.1 & 37.9 & 15.0 & 42.5 \\
\hline 65 & WF & 4.2 & 19.0 & 5.0 & 22.0 & 6.3 & 31.9 & 7.4 & 38.2 \\
\hline 66 & GS & 7.5 & 38.0 & 8.0 & 38.0 & 8.6 & 40.3 & 8.9 & 43.7 \\
\hline 67 & GS & 12.1 & 50.0 & 12.4 & 55.0 & 13.2 & 51.0 & 13.8 & 54.3 \\
\hline 68 & GS & 6.6 & 32.0 & 6.5 & 34.0 & 6.4 & 33.5 & 6.4 & 33.5 \\
\hline 69 & GS & 13.1 & 72.0 & 13.4 & 91.0 & 13.7 & 76.1 & 14.3 & 80.8 \\
\hline 70 & GS & 9.4 & 82.0 & 9.5 & 75.0 & 9.9 & 83.8 & 10.0 & 96.1 \\
\hline 71 & GS & 17.2 & 72.0 & 17.9 & 75.0 & 18.9 & 89.7 & 20.1 & 100.5 \\
\hline 72 & WF & 5.0 & 32.0 & 5.1 & 39.0 & 5.5 & 38.5 & 5.6 & 40.2 \\
\hline 73 & SP & 11.5 & 63.0 & 11.9 & 70.0 & 13.0 & 79.9 & 14.4 & 71.6 \\
\hline 74 & GS & 11.6 & 45.0 & 12.1 & 53.0 & 12.4 & 46.8 & 12.4 & 46.9 \\
\hline 75 & WF & 18.0 & 67.0 & 18.6 & 65.0 & 20.0 & 85.4 & 20.9 & 97.9 \\
\hline 76 & GS & 12.7 & 70.0 & 12.9 & 81.0 & 13.7 & 80.9 & 14.3 & 81.5 \\
\hline 77 & WF & 46.9 & 164.0 & 47.2 & 152.0 & 48.4 & 187.3 & 49.1 & 182.4 \\
\hline 78 & SP & 6.8 & 38.0 & $* * *$ & $* * *$ & $* * *$ & $* * *$ & $* * *$ & $* * *$ \\
\hline
\end{tabular}


MHDSF Young-Growth Giant Sequoia Management Strategies Study 2009 - Overstory Summary Data (39ft. (12m) Plot)

$\begin{array}{lllll}\text { Stand: Bogus Meadow } & \text { Treatment: Control } & \text { Measured By: } & 1989 & \text { Bates, Scott, Masser } \\ & & \text { Measured By: } & 1994 & \text { Ganz \& CDF } \\ \text { Block: C } & \text { Plot \# :1 } & \text { Measured By: } & 2001 \text { Roller, Rueter } \\ & & \text { Measured By: } & 2009 \text { Soderlund, Ricchiazzi }\end{array}$

\begin{tabular}{|c|c|c|c|c|c|c|c|c|c|}
\hline \multirow[b]{2}{*}{ Tree \# } & \multirow[b]{2}{*}{ Species } & \multicolumn{2}{|c|}{1989 Data } & \multicolumn{2}{|c|}{1994 Data } & \multicolumn{2}{|c|}{2001 Data } & 2009 Data & Data \\
\hline & & $\mathrm{DBH}$ & Height & $\mathrm{DBH}$ & Height & $\mathrm{DBH}$ & Height & $\mathrm{DBH}$ & Height \\
\hline 79 & GS & 6.6 & 36.0 & 6.6 & 35.0 & 6.6 & 37.9 & 6.6 & 34.6 \\
\hline 80 & GS & 6.2 & 21.0 & 6.2 & 19.0 & 6.3 & 22.4 & 6.3 & 22.7 \\
\hline 81 & GS & 8.5 & 42.0 & 8.8 & 42.0 & 8.9 & 45.2 & 8.8 & 45.1 \\
\hline 82 & GS & 2.9 & 12.0 & 2.8 & 11.0 & 2.7 & 13.2 & 2.7 & 13.0 \\
\hline 83 & WF & $* * *$ & $* * *$ & $* * *$ & $* * *$ & $* * *$ & $* * *$ & 4.5 & 19.3 \\
\hline 84 & WF & $* * *$ & $* * *$ & $* * *$ & $* * *$ & $* * *$ & $* * *$ & 2.2 & 13.4 \\
\hline 85 & GS & $* * *$ & $* * *$ & $* * *$ & $* * *$ & $* * *$ & $* * *$ & 22.3 & $* * *$ \\
\hline AVG. & & 12.1 & 60.7 & 12.9 & 65.4 & 14.5 & 71.9 & 15.3 & 76.1 \\
\hline Trees & $38,48,78$ & & & Dead in & 1994 & & & & \\
\hline Trees & $39,52,78$ & & & Dead/D & own in 20 & & & & \\
\hline Trees & 38, 57 & & & Dead/S & anding in & 2001 & & & \\
\hline Trees & $42,45,64$ & & & Broken & Top in 20 & & & & \\
\hline Tree & 71 & & & Forked & top-heigh & at high & st fork in & 2001, 2 & 009 \\
\hline Trees & 74,79 & & & Deform & ed/Bowe & Tops i & 2001 & & \\
\hline Tree & 37 & & & A tree & ell into pl & t rippin & bark off & and dec & reasing dbh in 2009 \\
\hline Tree & 83 & & & Tree in & plot $37.8 \mathrm{f}$ & from $p$ & ot center & and tag & ged, no data in 1994 or 2001. \\
\hline Trees & $38,42,53,57$ & & & Dead/D & own in 20 & & & & \\
\hline Tree & 62 & & & Dead/S & anding in & 2009 & & & \\
\hline Tree & 85 & & & Dead/S & anding in & 2009, n & data in 1 & 989,19 & 94 or 2001. \\
\hline Trees & $40,43,47,60$ & $0,68,74,81$ & & Deform & ed top in & 2009 & & & \\
\hline Trees & $45,73,77$ & & & Broken & top in 200 & & & & \\
\hline Tree & 82 & & & Dead to & $\mathrm{p}$ in 2009 & & & & \\
\hline Tree & 79 & & & Deform & ed/Bowe & in 200 & & & \\
\hline
\end{tabular}


MHDSF Young-Growth Giant Sequoia Management Strategies Study 2009 - Overstory Summary Growth Data (39.37 ft. (12m) Plot)

$\begin{array}{lllll}\text { Stand: Bogus Meadow } & \text { Treatment: Control } & \text { Measured By: } & 1989 & \text { Bates, Scott, Masser } \\ & & \text { Measured By: } & 1994 & \text { Ganz \& CDF } \\ \text { Block: C } & \text { Plot \# : } 1 & \text { Measured By: } & 2001 \text { Roller, Rueter } \\ & & \text { Measured By: } & 2009 \text { Soderlund, Ricchiazzi }\end{array}$

\begin{tabular}{|c|c|c|c|c|c|c|c|c|c|c|c|c|c|}
\hline \multirow[b]{2}{*}{ Tree \# } & \multirow[b]{2}{*}{ Species } & \multicolumn{2}{|c|}{$\begin{array}{c}\text { Change } \\
\text { 1989-1994 }\end{array}$} & \multicolumn{2}{|c|}{$\begin{array}{c}\text { Change } \\
\text { 1994-2001 }\end{array}$} & \multicolumn{2}{|c|}{$\begin{array}{c}\text { Change } \\
1989-2001\end{array}$} & \multicolumn{2}{|c|}{$\begin{array}{c}\text { Change } \\
1994-2009\end{array}$} & \multicolumn{2}{|c|}{$\begin{array}{c}\text { Change } \\
\text { 2001-2009 }\end{array}$} & \multicolumn{2}{|c|}{$\begin{array}{c}\text { Change } \\
1989-2009\end{array}$} \\
\hline & & $\mathrm{DBH}$ & Height & $\mathrm{DBH}$ & Height & DBH & Height & DBH & Height & $\mathrm{DBH}$ & Height & $\mathrm{DBH}$ & Height \\
\hline 37 & GS & 1.4 & 11.0 & 13.0 & 14.8 & 14.4 & 25.8 & 6.2 & 21.6 & -6.8 & 6.8 & 7.6 & 32.6 \\
\hline 38 & WF & $* * *$ & $* * *$ & $* * *$ & $* * *$ & $* * *$ & $* * *$ & $* * *$ & $* * *$ & $* * *$ & $* * *$ & $* * *$ & $* * *$ \\
\hline 39 & GS & 0.0 & 1.0 & $* * *$ & $* * *$ & $* * *$ & $* * *$ & $* * *$ & $* * *$ & $* * *$ & $* * *$ & $* * *$ & $* * *$ \\
\hline 40 & GS & 0.0 & 3.0 & 0.0 & 1.1 & 0.0 & 4.1 & 0.1 & -0.9 & 0.1 & -2.0 & 0.1 & 2.1 \\
\hline 41 & GS & 1.1 & -1.0 & 1.5 & 3.1 & 2.6 & 2.1 & 3.2 & 25.8 & 1.7 & 22.7 & 4.3 & 24.8 \\
\hline 42 & WF & 0.0 & 15.0 & 0.2 & -25.9 & 0.2 & -10.9 & $* * *$ & $* * *$ & $* * *$ & $* * *$ & $* * *$ & $* * *$ \\
\hline 43 & GS & -0.1 & 14.0 & 0.4 & -7.0 & 0.3 & 7.0 & 0.4 & -8.5 & 0.0 & -1.5 & 0.3 & 5.5 \\
\hline 44 & GS & 1.0 & 12.0 & 2.5 & 15.7 & 3.5 & 27.7 & 4.9 & 22.1 & 2.4 & 6.4 & 5.9 & 34.1 \\
\hline 45 & GS & -0.1 & 2.0 & 0.0 & 3.5 & -0.1 & 5.5 & -0.1 & -4.7 & -0.1 & -8.2 & -0.2 & -2.7 \\
\hline 46 & GS & 1.2 & -9.0 & 1.8 & 23.3 & 3.0 & 14.3 & 3.8 & 43.8 & 2.0 & 20.5 & 5.0 & 34.8 \\
\hline 47 & GS & 0.0 & 22.0 & 0.1 & 1.2 & 0.1 & 23.2 & 0.1 & 3.6 & 0.0 & 2.4 & 0.1 & 25.6 \\
\hline 48 & GS & $* * *$ & $* * *$ & $* * *$ & $* * *$ & $* * *$ & $* * *$ & $* * *$ & $* * *$ & $* * *$ & $* * *$ & $* * *$ & $* * *$ \\
\hline 49 & GS & 1.3 & 3.0 & 2.4 & 23.8 & 3.7 & 26.8 & 5.2 & 31.9 & 2.8 & 8.1 & 6.5 & 34.9 \\
\hline 50 & WF & -0.2 & -1.0 & 0.2 & 5.4 & 0.0 & 4.4 & 0.5 & 6.6 & 0.3 & 1.2 & 0.3 & 5.6 \\
\hline 51 & GS & 1.2 & -3.0 & 2.9 & 8.9 & 4.1 & 5.9 & 4.7 & 26.4 & 1.8 & 17.5 & 5.9 & 23.4 \\
\hline 52 & WF & 0.1 & 4.0 & $* * *$ & $* * *$ & $* * *$ & $* * *$ & $* * *$ & $* * *$ & $* * *$ & $* * *$ & $* * *$ & $* * *$ \\
\hline 53 & WF & 0.1 & 4.0 & 0.0 & -1.1 & 0.1 & 2.9 & $* * *$ & $* * *$ & $* * *$ & $* * *$ & $* * *$ & $* * *$ \\
\hline 54 & GS & 0.7 & 2.0 & 0.7 & 9.7 & 1.4 & 11.7 & 1.5 & 12.6 & 0.8 & 2.9 & 2.2 & 14.6 \\
\hline 55 & WF & 0.0 & -6.0 & 0.2 & 7.8 & 0.2 & 1.8 & 0.6 & 13.8 & 0.4 & 6.0 & 0.6 & 7.8 \\
\hline 56 & GS & 2.1 & 9.0 & 2.8 & 18.3 & 4.9 & 27.3 & 16.0 & 28.4 & 13.2 & 10.1 & 18.1 & 37.4 \\
\hline 57 & WF & -0.1 & 0.0 & $* * *$ & $* * *$ & $* * *$ & $* * *$ & $* * *$ & $* * *$ & $* * *$ & $* * *$ & $* * *$ & $* * *$ \\
\hline 58 & GS & 0.2 & 3.0 & 0.4 & 0.2 & 0.6 & 3.2 & 0.9 & 1.3 & 0.5 & 1.1 & 1.1 & 4.3 \\
\hline 59 & GS & 1.3 & -2.0 & 2.6 & 14.4 & 3.9 & 12.4 & 5.5 & 26.5 & 2.9 & 12.1 & 6.8 & 24.5 \\
\hline 60 & GS & 0.0 & 2.0 & 0.0 & 0.1 & 0.0 & 2.1 & 0.0 & -0.2 & 0.0 & -0.3 & 0.0 & 1.8 \\
\hline 61 & GS & 0.0 & -1.0 & 0.0 & 2.9 & 0.0 & 1.9 & 0.0 & 3.2 & 0.0 & 0.3 & 0.0 & 2.2 \\
\hline 62 & GS & 0.0 & -2.0 & 0.0 & 1.2 & 0.0 & -0.8 & -0.1 & $* * *$ & -0.1 & $* * *$ & -0.1 & $* * *$ \\
\hline 63 & GS & 0.6 & -1.0 & 1.2 & -6.2 & 1.8 & -7.2 & 2.3 & -3.4 & 1.1 & 2.8 & 2.9 & -4.4 \\
\hline 64 & GS & 0.3 & 5.0 & 0.5 & -3.1 & 0.8 & 1.9 & 0.4 & 1.5 & -0.1 & 4.6 & 0.7 & 6.5 \\
\hline 65 & WF & 0.8 & 3.0 & 1.3 & 9.9 & 2.1 & 12.9 & 2.4 & 16.2 & 1.1 & 6.3 & 3.2 & 19.2 \\
\hline 66 & GS & 0.5 & 0.0 & 0.6 & 2.3 & 1.1 & 2.3 & 0.9 & 5.7 & 0.3 & 3.4 & 1.4 & 5.7 \\
\hline 67 & GS & 0.3 & 5.0 & 0.8 & -4.0 & 1.1 & 1.0 & 1.4 & -0.7 & 0.6 & 3.3 & 1.7 & 4.3 \\
\hline 68 & GS & -0.1 & 2.0 & -0.1 & -0.5 & -0.2 & 1.5 & -0.1 & -0.5 & 0.0 & 0.0 & -0.2 & 1.5 \\
\hline 69 & GS & 0.3 & 19.0 & 0.3 & -14.9 & 0.6 & 4.1 & 0.9 & -10.2 & 0.6 & 4.7 & 1.2 & 8.8 \\
\hline 70 & GS & 0.1 & -7.0 & 0.4 & 8.8 & 0.5 & 1.8 & 0.5 & 21.1 & 0.1 & 12.3 & 0.6 & 14.1 \\
\hline 71 & GS & 0.7 & 3.0 & 1.0 & 14.7 & 1.7 & 17.7 & 2.2 & 25.5 & 1.2 & 10.8 & 2.9 & 28.5 \\
\hline 72 & WF & 0.1 & 7.0 & 0.4 & -0.5 & 0.5 & 6.5 & 0.5 & 1.2 & 0.1 & 1.7 & 0.6 & 8.2 \\
\hline 73 & $\mathrm{SP}$ & 0.4 & 7.0 & 1.1 & 9.9 & 1.5 & 16.9 & 2.5 & 1.6 & 1.4 & -8.3 & 2.9 & 8.6 \\
\hline 74 & GS & 0.5 & 8.0 & 0.3 & -6.2 & 0.8 & 1.8 & 0.3 & -6.1 & 0.0 & 0.1 & 0.8 & 1.9 \\
\hline 75 & WF & 0.6 & -2.0 & 1.4 & 20.4 & 2.0 & 18.4 & 2.3 & 32.9 & 0.9 & 12.5 & 2.9 & 30.9 \\
\hline 76 & GS & 0.2 & 11.0 & 0.8 & -0.1 & 1.0 & 10.9 & 1.4 & 0.5 & 0.6 & 0.6 & 1.6 & 11.5 \\
\hline 77 & WF & 0.3 & -12.0 & 1.2 & 35.3 & 1.5 & 23.3 & 1.9 & 30.4 & 0.7 & -4.9 & 2.2 & 18.4 \\
\hline 78 & SP & $* * *$ & $* * *$ & $* * *$ & $* * *$ & $* * *$ & $* * *$ & $* * *$ & $* * *$ & $* * *$ & $* * *$ & $* * *$ & $* * *$ \\
\hline
\end{tabular}


MHDSF Young-Growth Giant Sequoia Management Strategies Study 2009 - Overstory Summary Growth Data (39.37 ft. (12m) Plot)

$\begin{array}{lllll}\text { Stand: Bogus Meadow } & \text { Treatment: Control } & \text { Measured By: } & 1989 & \text { Bates, Scott, Masser } \\ & & \text { Measured By: } & 1994 & \text { Ganz \& CDF } \\ \text { Block: C } & \text { Plot \# : } 1 & \text { Measured By: } & 2001 & \text { Roller, Rueter } \\ & & \text { Measured By: } & 2009 \text { Soderlund, Ricchiazzi }\end{array}$

\begin{tabular}{|c|c|c|c|c|c|c|c|c|c|c|c|c|c|}
\hline \multirow[b]{2}{*}{ Tree \# } & \multirow[b]{2}{*}{ Species } & \multicolumn{2}{|c|}{$\begin{array}{c}\text { Change } \\
1989-1994\end{array}$} & \multicolumn{2}{|c|}{$\begin{array}{c}\text { Change } \\
1994-2001\end{array}$} & \multicolumn{2}{|c|}{$\begin{array}{c}\text { Change } \\
1989-2001\end{array}$} & \multicolumn{2}{|c|}{$\begin{array}{c}\text { Change } \\
\text { 1994-2009 }\end{array}$} & \multicolumn{2}{|c|}{$\begin{array}{c}\text { Change } \\
\text { 2001-2009 }\end{array}$} & \multicolumn{2}{|c|}{$\begin{array}{c}\text { Change } \\
\text { 1989-2009 }\end{array}$} \\
\hline & & DBH & Height & $\mathrm{DBH}$ & Height & $\mathrm{DBH}$ & Height & $\mathrm{DBH}$ & Height & $\mathrm{DBH}$ & Height & $\mathrm{DBH}$ & Height \\
\hline 79 & GS & 0.0 & -1.0 & 0.0 & 2.9 & 0.0 & 1.9 & 0.0 & -0.4 & 0.0 & -3.3 & 0.0 & -1.4 \\
\hline 80 & GS & 0.0 & -2.0 & 0.1 & 3.4 & 0.1 & 1.4 & 0.1 & 3.7 & 0.0 & 0.3 & 0.1 & 1.7 \\
\hline 81 & GS & 0.3 & 0.0 & 0.1 & 3.2 & 0.4 & 3.2 & 0.0 & 3.1 & -0.1 & -0.1 & 0.3 & 3.1 \\
\hline 82 & GS & -0.1 & -1.0 & -0.1 & 2.2 & -0.2 & 1.2 & -0.1 & 2.0 & 0.0 & -0.2 & -0.2 & 1.0 \\
\hline 83 & WF & $* * *$ & $* * *$ & $* * *$ & $* * *$ & $* * *$ & $* * *$ & $* * *$ & $* * *$ & $* * *$ & $* * *$ & $* * *$ & $* * *$ \\
\hline 84 & WF & $* * *$ & $* * *$ & $* * *$ & $* * *$ & $* * *$ & $* * *$ & $* * *$ & $* * *$ & $* * *$ & $* * *$ & $* * *$ & $* * *$ \\
\hline 85 & GS & $* * *$ & $* * *$ & $* * *$ & $* * *$ & $* * *$ & $* * *$ & $* * *$ & $* * *$ & $* * *$ & $* * *$ & $* * *$ & $* * *$ \\
\hline AVG. & & 0.4 & 2.9 & 1.1 & 5.0 & 1.5 & 8.0 & 1.9 & 10.2 & 0.8 & 4.1 & 2.4 & 13.0 \\
\hline Trees & $38,48,78$ & & & Dead in & 1994 & & & & & & & & \\
\hline Trees & $39,52,78$ & & & Dead/D & wn in 20 & & & & & & & & \\
\hline Trees & 38, 57 & & & Dead/St & anding in & 2001 & & & & & & & \\
\hline Trees & $42,45,64$ & & & Broken & Гop in 20 & & & & & & & & \\
\hline Tree & 71 & & & Forked & op-height & at highe & st fork in & 2001, 2 & 009 & & & & \\
\hline Trees & 74,79 & & & Deform & d/Bowec & Tops il & 2001 & & & & & & \\
\hline Tree & 37 & & & A tree $f$ & ll into pl & trippin & bark off & and dec & reasing $\mathrm{c}$ & bh in 20 & & & \\
\hline Tree & 83 & & & Tree in & lot $37.8 \mathrm{f}$ & from $p$ & ot center & and tag & sed, no di & ta in 19 & 94 or 200 & & \\
\hline Trees & $38,42,53,57$ & & & Dead/D & wn in 20 & & & & & & & & \\
\hline Tree & 62 & & & Dead/St & anding in & 2009 & & & & & & & \\
\hline Tree & 85 & & & Dead/St & anding in & 2009, n & data in & 989,19 & 4 or 200 & & & & \\
\hline Trees & $40,43,47,60$ & 0,68,74,81 & & Deform & $\mathrm{d}$ top in & 2009 & & & & & & & \\
\hline Trees & 45,73,77 & & & Broken & op in 200 & & & & & & & & \\
\hline Tree & 82 & & & Dead to & in 2009 & & & & & & & & \\
\hline Tree & 79 & & & Deform & $\mathrm{d} /$ Bowec & in $200 s$ & & & & & & & \\
\hline
\end{tabular}


MHDSF Young-Growth Giant Sequoia Management Strategies Study 2009 - Overstory Summary Data (39.37 ft. (12m) Plot)

$\begin{array}{lllll}\text { Stand: Bogus Meadow } & \text { Treatment: Control } & \text { Measured By: } & 1990 & \text { Bates, Scott, Masser, Johannis } \\ & & \text { Measured By: } & 1994 & \text { Ganz \& CDF } \\ \text { Block: C } & \text { Plot \# :2 } & \text { Measured By: } & 2001 \text { Roller, Rueter } \\ & & \text { Measured By: } & 2009 \text { Soderlund, Ricchiazzi }\end{array}$

\begin{tabular}{|c|c|c|c|c|c|c|c|c|c|}
\hline \multirow[b]{2}{*}{ Tree \# } & \multirow[b]{2}{*}{ Species } & \multicolumn{2}{|c|}{1989 Data } & \multicolumn{2}{|c|}{1994 Data } & \multicolumn{2}{|c|}{2001 Data } & \multicolumn{2}{|c|}{2009 Data } \\
\hline & & $\mathrm{DBH}$ & Height & $\mathrm{DBH}$ & Height & DBH & Height & DBH & Height \\
\hline 1 & GS & 36.2 & 127.0 & 38.0 & 130.0 & 41.3 & 152.3 & 44.5 & 168.2 \\
\hline 2 & WF & 2.2 & 12.0 & 2.4 & 12.0 & 2.7 & 12.7 & 2.7 & 13.0 \\
\hline 3 & GS & 2.9 & 14.0 & $* * *$ & $* * *$ & $* * *$ & $* * *$ & $* * *$ & $* * *$ \\
\hline 5 & WF & 7.2 & 41.0 & 7.2 & 41.0 & 7.5 & 44.6 & 7.7 & 44.9 \\
\hline 6 & GS & 4.7 & 13.0 & 4.7 & 25.0 & 4.8 & 18.6 & 4.8 & 19.2 \\
\hline 7 & WF & 3.9 & 19.0 & 4.2 & 20.0 & 4.4 & 23.2 & 4.6 & 26.0 \\
\hline 8 & GS & 25.1 & 123.0 & 27.0 & 128.0 & 30.1 & 133.7 & 32.8 & 149.1 \\
\hline 9 & GS & 7.7 & 30.0 & 7.7 & 31.0 & 7.8 & 34.9 & 7.6 & 30.9 \\
\hline 10 & GS & 17.3 & 95.0 & 18.0 & 95.0 & 19.1 & 107.8 & 20.0 & 111.8 \\
\hline 11 & WF & 2.5 & 14.0 & 2.8 & 16.0 & 3.2 & 15.8 & 3.4 & 16.1 \\
\hline 12 & GS & 20.3 & 97.0 & 21.7 & 103.0 & 23.9 & 119.1 & 26.0 & 132.3 \\
\hline 13 & WF & 1.8 & 12.0 & 1.9 & 12.0 & 2.3 & 14.8 & 2.4 & 15.3 \\
\hline 14 & GS & 12.4 & 53.0 & 12.8 & 53.0 & 13.8 & 61.4 & 14.7 & 59.5 \\
\hline 15 & WF & 7.6 & 46.0 & 8.2 & 47.0 & 9.1 & 52.7 & 10.5 & 53.2 \\
\hline 16 & WF & 28.0 & 134.0 & 28.0 & 138.0 & 28.6 & 139.3 & 28.4 & $* * *$ \\
\hline 17 & GS & 7.0 & 38.0 & 7.0 & 41.0 & 7.3 & 40.1 & 7.7 & 38.4 \\
\hline 18 & GS & 8.2 & 28.0 & 8.2 & 28.0 & 8.3 & 27.1 & 8.4 & 30.4 \\
\hline 19 & GS & 5.1 & 13.0 & 5.3 & 14.0 & 5.7 & 17.5 & 6.0 & 18.7 \\
\hline 20 & GS & 3.3 & 12.0 & 3.7 & 12.0 & 4.2 & 12.3 & 4.7 & 14.6 \\
\hline 21 & GS & 6.3 & 25.0 & 6.6 & 27.0 & 6.5 & 33.4 & 7.0 & 37.3 \\
\hline 22 & GS & 25.3 & 112.0 & 27.1 & 115.0 & 30.6 & 136.5 & 34.0 & 150.6 \\
\hline 23 & GS & 23.3 & 108.0 & 24.5 & 111.0 & 25.7 & 132.1 & 28.0 & 144.7 \\
\hline 24 & GS & 12.9 & 103.0 & 13.1 & 107.0 & 13.3 & 109.9 & 13.3 & 110.6 \\
\hline 25 & GS & 9.9 & 52.0 & 9.9 & 52.0 & 10.1 & 52.4 & 10.2 & 53.5 \\
\hline 26 & GS & 29.1 & 131.0 & 30.9 & 133.0 & 33.6 & 142.2 & 36.3 & 163.7 \\
\hline 27 & GS & 19.6 & 98.0 & 19.6 & 102.0 & 22.2 & 115.9 & 24.2 & 131.0 \\
\hline 28 & GS & 23.6 & 127.0 & 24.5 & 127.0 & 26.4 & 152.1 & 28.2 & 153.7 \\
\hline 29 & GS & 6.4 & 34.0 & 6.5 & 34.0 & 6.5 & 33.5 & 6.5 & 33.5 \\
\hline 30 & GS & 10.4 & 73.0 & 10.5 & 75.0 & 10.5 & 72.5 & 10.6 & 75.6 \\
\hline 31 & GS & 18.1 & 77.0 & 18.3 & 86.0 & 18.6 & 87.6 & 18.9 & 90.3 \\
\hline 32 & GS & 5.7 & 24.0 & 5.7 & 24.0 & 5.8 & 26.0 & 5.7 & 26.2 \\
\hline 33 & GS & 29.5 & 103.0 & 31.0 & 104.0 & 33.2 & 119.5 & 34.7 & 144.7 \\
\hline 34 & GS & 33.7 & 123.0 & 34.8 & 126.0 & 37.2 & 138.6 & 39.9 & 153.8 \\
\hline 35 & GS & 13.6 & 45.0 & $* * *$ & $* * *$ & $* * *$ & $* * *$ & 13.1 & $* * *$ \\
\hline 36 & GS & 36.8 & 116.0 & 38.4 & 119.0 & 40.8 & 148.0 & 43.4 & 160.9 \\
\hline 37 & WF & $* * *$ & $* * *$ & $* * *$ & $* * *$ & 1.1 & 8.1 & 2.3 & 12.2 \\
\hline 38 & IC & $* * *$ & $* * *$ & $* * *$ & $* * *$ & $* * *$ & $* * *$ & 9.5 & $* * *$ \\
\hline 39 & WF & $* * *$ & $* * *$ & $* * *$ & $* * *$ & $* * *$ & $* * *$ & 1.4 & 8.7 \\
\hline 40 & WF & $* * *$ & $* * *$ & $* * *$ & $* * *$ & $* * *$ & $* * *$ & 1.3 & 8.7 \\
\hline 41 & WF & $* * *$ & $* * *$ & $* * *$ & $* * *$ & $* * *$ & $* * *$ & 1.4 & 8.4 \\
\hline 42 & WF & $* * *$ & $* * *$ & $* * *$ & $* * *$ & $* * *$ & $* * *$ & 1.5 & 7.9 \\
\hline AVG. & & 14.5 & 64.9 & 15.5 & 69.3 & 16.1 & 74.6 & 15.2 & 70.7 \\
\hline
\end{tabular}

Page 110 


\section{MHDSF Young-Growth Giant Sequoia Management Strategies Study 2009 - Overstory Summary Data (39.37 ft. (12m) Plot)}

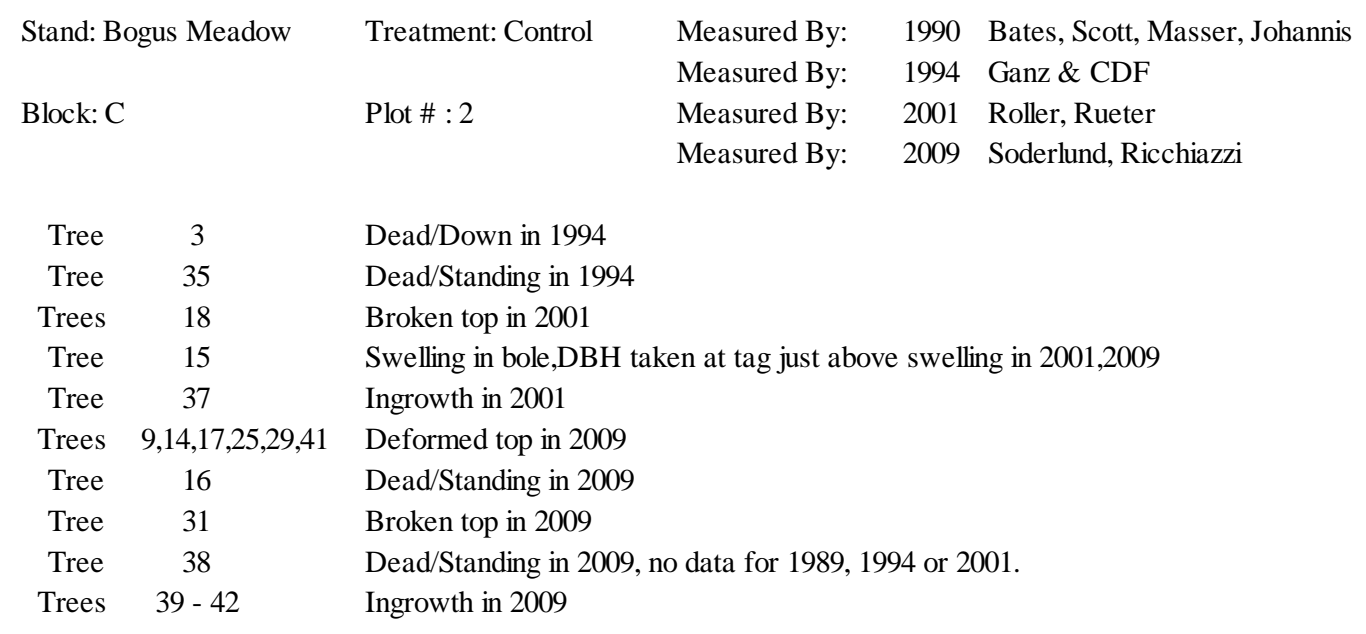


MHDSF Young-Growth Giant Sequoia Management Strategies Study 2009 - Overstory Summary Growth Data (39.37 ft. (12m) Plot)

$\begin{array}{lllll}\text { Stand: Bogus Meadow } & \text { Treatment: Control } & \text { Measured By: } & 1990 & \text { Bates, Scott, Masser, Johannis } \\ & & \text { Measured By: } & 1994 & \text { Ganz \& CDF } \\ \text { Block: C } & \text { Plot \# :2 } & \text { Measured By: } & 2001 & \text { Roller, Rueter } \\ & & \text { Measured By: } & 2009 & \text { Soderlund, Ricchiazzi }\end{array}$

\begin{tabular}{|c|c|c|c|c|c|c|c|c|c|c|c|c|c|}
\hline \multirow[b]{2}{*}{ Tree \# } & \multirow[b]{2}{*}{ Species } & \multicolumn{2}{|c|}{$\begin{array}{c}\text { Change } \\
\text { 1989-1994 }\end{array}$} & \multicolumn{2}{|c|}{$\begin{array}{c}\text { Change } \\
\text { 1994-2001 }\end{array}$} & \multicolumn{2}{|c|}{$\begin{array}{c}\text { Change } \\
\text { 1989-2001 }\end{array}$} & \multicolumn{2}{|c|}{$\begin{array}{c}\text { Change } \\
\text { 1994-2009 }\end{array}$} & \multicolumn{2}{|c|}{$\begin{array}{c}\text { Change } \\
\text { 2001-2009 }\end{array}$} & \multicolumn{2}{|c|}{$\begin{array}{c}\text { Change } \\
\text { 1989-2009 }\end{array}$} \\
\hline & & $\mathrm{DBH}$ & Height & DBH & Height & $\mathrm{DBH}$ & Height & $\mathrm{DBH}$ & Height & $\mathrm{DBH}$ & Height & $\mathrm{DBH}$ & Height \\
\hline 1 & GS & 1.8 & 3.0 & 3.3 & 22.3 & 5.1 & 25.3 & 6.5 & 38.2 & 3.2 & 15.9 & 8.3 & 41.2 \\
\hline 2 & WF & 0.2 & 0.0 & 0.3 & 0.7 & 0.5 & 0.7 & 0.3 & 1.0 & 0.0 & 0.3 & 0.5 & 1.0 \\
\hline 3 & GS & $* * *$ & $* * *$ & $* * *$ & $* * *$ & $* * *$ & $* * *$ & $* * *$ & $* * *$ & $* * *$ & $* * *$ & $* * *$ & $* * *$ \\
\hline 5 & WF & 0.0 & 0.0 & 0.3 & 3.6 & 0.3 & 3.6 & 0.5 & 3.9 & 0.2 & 0.3 & 0.5 & 3.9 \\
\hline 6 & GS & 0.0 & 12.0 & 0.1 & -6.4 & 0.1 & 5.6 & 0.1 & -5.8 & 0.0 & 0.6 & 0.1 & 6.2 \\
\hline 7 & WF & 0.3 & 1.0 & 0.2 & 3.2 & 0.5 & 4.2 & 0.4 & 6.0 & 0.2 & 2.8 & 0.7 & 7.0 \\
\hline 8 & GS & 1.9 & 5.0 & 3.1 & 5.7 & 5.0 & 10.7 & 5.8 & 21.1 & 2.7 & 15.4 & 7.7 & 26.1 \\
\hline 9 & GS & 0.0 & 1.0 & 0.1 & 3.9 & 0.1 & 4.9 & -0.1 & -0.1 & -0.2 & -4.0 & -0.1 & 0.9 \\
\hline 10 & GS & 0.7 & 0.0 & 1.1 & 12.8 & 1.8 & 12.8 & 2.0 & 16.8 & 0.9 & 4.0 & 2.7 & 16.8 \\
\hline 11 & WF & 0.3 & 2.0 & 0.4 & -0.2 & 0.7 & 1.8 & 0.6 & 0.1 & 0.2 & 0.3 & 0.9 & 2.1 \\
\hline 12 & GS & 1.4 & 6.0 & 2.2 & 16.1 & 3.6 & 22.1 & 4.3 & 29.3 & 2.1 & 13.2 & 5.7 & 35.3 \\
\hline 13 & WF & 0.1 & 0.0 & 0.4 & 2.8 & 0.5 & 2.8 & 0.5 & 3.3 & 0.1 & 0.5 & 0.6 & 3.3 \\
\hline 14 & GS & 0.4 & 0.0 & 1.0 & 8.4 & 1.4 & 8.4 & 1.9 & 6.5 & 0.9 & -1.9 & 2.3 & 6.5 \\
\hline 15 & WF & 0.6 & 1.0 & 0.9 & 5.7 & 1.5 & 6.7 & 2.3 & 6.2 & 1.4 & 0.5 & 2.9 & 7.2 \\
\hline 16 & WF & 0.0 & 4.0 & 0.6 & 1.3 & 0.6 & 5.3 & 0.4 & $* * *$ & -0.2 & $* * *$ & 0.4 & $* * *$ \\
\hline 17 & GS & 0.0 & 3.0 & 0.3 & -0.9 & 0.3 & 2.1 & 0.7 & -2.6 & 0.4 & -1.7 & 0.7 & 0.4 \\
\hline 18 & GS & 0.0 & 0.0 & 0.1 & -0.9 & 0.1 & -0.9 & 0.2 & 2.4 & 0.1 & 3.3 & 0.2 & 2.4 \\
\hline 19 & GS & 0.2 & 1.0 & 0.4 & 3.5 & 0.6 & 4.5 & 0.7 & 4.7 & 0.3 & 1.2 & 0.9 & 5.7 \\
\hline 20 & GS & 0.4 & 0.0 & 0.5 & 0.3 & 0.9 & 0.3 & 1.0 & 2.6 & 0.5 & 2.3 & 1.4 & 2.6 \\
\hline 21 & GS & 0.3 & 2.0 & -0.1 & 6.4 & 0.2 & 8.4 & 0.4 & 10.3 & 0.5 & 3.9 & 0.7 & 12.3 \\
\hline 22 & GS & 1.8 & 3.0 & 3.5 & 21.5 & 5.3 & 24.5 & 6.9 & 35.6 & 3.4 & 14.1 & 8.7 & 38.6 \\
\hline 23 & GS & 1.2 & 3.0 & 1.2 & 21.1 & 2.4 & 24.1 & 3.5 & 33.7 & 2.3 & 12.6 & 4.7 & 36.7 \\
\hline 24 & GS & 0.2 & 4.0 & 0.2 & 2.9 & 0.4 & 6.9 & 0.2 & 3.6 & 0.0 & 0.7 & 0.4 & 7.6 \\
\hline 25 & GS & 0.0 & 0.0 & 0.2 & 0.4 & 0.2 & 0.4 & 0.3 & 1.5 & 0.1 & 1.1 & 0.3 & 1.5 \\
\hline 26 & GS & 1.8 & 2.0 & 2.7 & 9.2 & 4.5 & 11.2 & 5.4 & 30.7 & 2.7 & 21.5 & 7.2 & 32.7 \\
\hline 27 & GS & 0.0 & 4.0 & 2.6 & 13.9 & 2.6 & 17.9 & 4.6 & 29.0 & 2.0 & 15.1 & 4.6 & 33.0 \\
\hline 28 & GS & 0.9 & 0.0 & 1.9 & 25.1 & 2.8 & 25.1 & 3.7 & 26.7 & 1.8 & 1.6 & 4.6 & 26.7 \\
\hline 29 & GS & 0.1 & 0.0 & 0.0 & -0.5 & 0.1 & -0.5 & 0.0 & -0.5 & 0.0 & 0.0 & 0.1 & -0.5 \\
\hline 30 & GS & 0.1 & 2.0 & 0.0 & -2.5 & 0.1 & -0.5 & 0.1 & 0.6 & 0.1 & 3.1 & 0.2 & 2.6 \\
\hline 31 & GS & 0.2 & 9.0 & 0.3 & 1.6 & 0.5 & 10.6 & 0.6 & 4.3 & 0.3 & 2.7 & 0.8 & 13.3 \\
\hline 32 & GS & 0.0 & 0.0 & 0.1 & 2.0 & 0.1 & 2.0 & 0.0 & 2.2 & -0.1 & 0.2 & 0.0 & 2.2 \\
\hline 33 & GS & 1.5 & 1.0 & 2.2 & 15.5 & 3.7 & 16.5 & 3.7 & 40.7 & 1.5 & 25.2 & 5.2 & 41.7 \\
\hline 34 & GS & 1.1 & 3.0 & 2.4 & 12.6 & 3.5 & 15.6 & 5.1 & 27.8 & 2.7 & 15.2 & 6.2 & 30.8 \\
\hline 35 & GS & $* * *$ & $* * *$ & $* * *$ & $* * *$ & $* * *$ & $* * *$ & $* * *$ & $* * *$ & $* * *$ & $* * *$ & $* * *$ & $* * *$ \\
\hline 36 & GS & 1.6 & 3.0 & 2.4 & 29.0 & 4.0 & 32.0 & 5.0 & 41.9 & 2.6 & 12.9 & 6.6 & 44.9 \\
\hline 37 & WF & $* * *$ & $* * *$ & $* * *$ & $* * *$ & $* * *$ & $* * *$ & $* * *$ & $* * *$ & 1.2 & 4.1 & $* * *$ & $* * *$ \\
\hline 38 & IC & $* * *$ & $* * *$ & $* * *$ & $* * *$ & $* * *$ & $* * *$ & $* * *$ & $* * *$ & $* * *$ & $* * *$ & $* * *$ & $* * *$ \\
\hline 39 & WF & $* * *$ & $* * *$ & $* * *$ & $* * *$ & $* * *$ & $* * *$ & $* * *$ & $* * *$ & $* * *$ & $* * *$ & $* * *$ & $* * *$ \\
\hline 40 & WF & $* * *$ & $* * *$ & $* * *$ & $* * *$ & $* * *$ & $* * *$ & $* * *$ & $* * *$ & $* * *$ & $* * *$ & $* * *$ & $* * *$ \\
\hline 41 & WF & $* * *$ & $* * *$ & $* * *$ & $* * *$ & $* * *$ & $* * *$ & $* * *$ & $* * *$ & $* * *$ & $* * *$ & $* * *$ & $* * *$ \\
\hline 42 & WF & $* * *$ & $* * *$ & $* * *$ & $* * *$ & $* * *$ & $* * *$ & $* * *$ & $* * *$ & $* * *$ & $* * *$ & $* * *$ & $* * *$ \\
\hline
\end{tabular}

Page 112 
MHDSF Young-Growth Giant Sequoia Management Strategies Study 2009 - Overstory Summary Growth Data (39.37 ft. (12m) Plot)

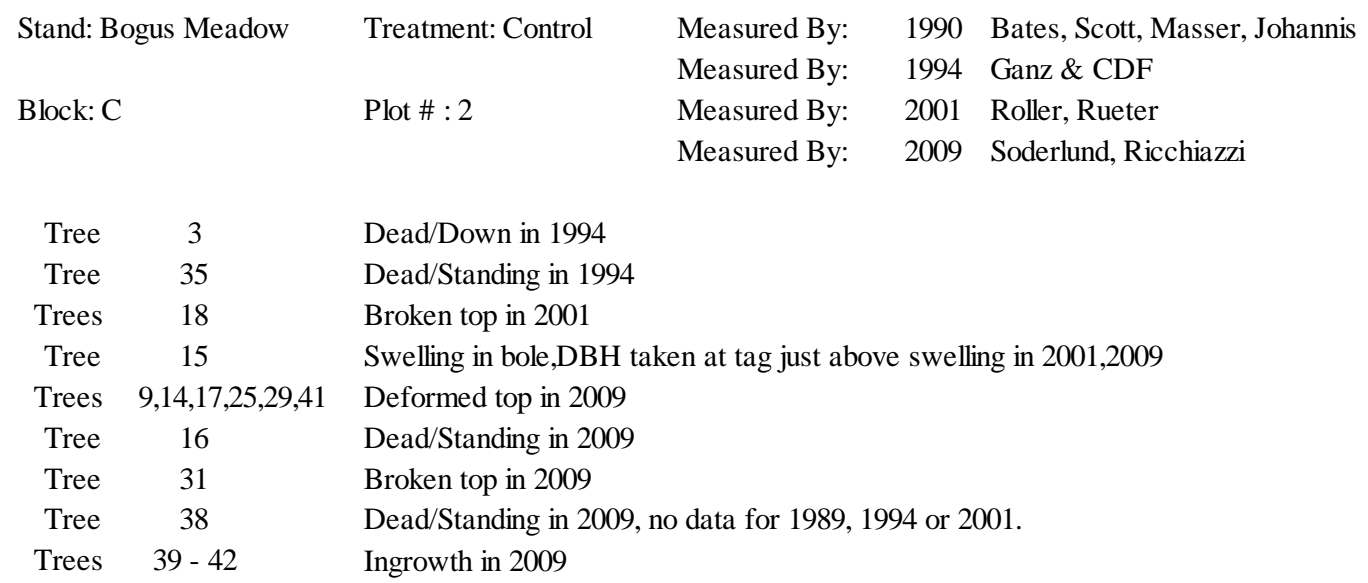


MHDSF Young-Growth Giant Sequoia Management Strategies Study 2009 - Overstory Summary Data (39.37 ft. (12m) Plot)

$\begin{array}{lllll}\text { Stand: Frasier Mill } & \text { Treatment: Thinned } & \text { Measured By: } & 1990 \text { Joe, Domingo, Mary } \\ & & \text { Measured By: } & 1994 \text { Ganz } \\ \text { Block: A } & \text { Plot \# :1 } & \text { Measured By: } & 2001 \text { Roller, McLoed } \\ & & \text { Measured By: } & 2009 \text { Soderlund, Ricchiazzi }\end{array}$

\begin{tabular}{cc|cc|cc|cc|cc|}
\cline { 3 - 9 } \multicolumn{1}{c|}{} & & \multicolumn{2}{|c|}{1990 Data } & \multicolumn{2}{c|}{ 1994 Data } & \multicolumn{2}{c|}{ 2001 Data } & \multicolumn{2}{c|}{ 2009 Data } \\
Tree \# & Species & DBH & Height & DBH & Height & DBH & Height & DBH & Height \\
\hline \hline 24 & GS & 11.8 & 82.0 & 12.7 & 88.0 & 14.8 & 100.8 & 16.7 & 109.4 \\
25 & GS & 16.0 & 91.0 & 17.6 & 95.0 & 20.2 & 122.3 & 22.5 & 134.4 \\
26 & GS & 20.8 & 115.0 & 21.8 & 128.0 & 23.3 & 128.3 & 24.9 & 138.5 \\
27 & GS & 23.9 & 132.0 & 25.0 & 134.0 & 27.3 & 148.6 & 29.7 & 148.7 \\
28 & GS & 22.7 & 125.0 & 23.8 & 125.0 & 25.9 & 143.5 & 28.2 & 153.2 \\
29 & GS & 13.7 & 88.0 & 14.1 & 90.0 & 15.6 & 94.3 & 16.8 & 102.0 \\
30 & GS & 21.7 & 106.0 & 23.0 & 110.0 & 25.6 & 115.7 & 28.3 & 124.4 \\
31 & GS & 21.6 & 119.0 & 23.0 & 122.0 & 25.3 & 131.9 & 27.6 & 144.8 \\
\hline \hline AVG. & & 19.0 & 107.3 & 20.1 & 111.5 & 22.3 & 123.2 & 24.3 & 131.9
\end{tabular}

2009 - Overstory Summary Growth Data (39ft. (12m) Plot)

\begin{tabular}{|c|c|c|c|c|c|c|c|c|c|c|c|c|c|}
\hline \multirow[b]{2}{*}{ Tree \# } & \multirow[b]{2}{*}{ Species } & \multicolumn{2}{|c|}{$\begin{array}{c}\text { Change } \\
\text { 1990-1994 }\end{array}$} & \multicolumn{2}{|c|}{$\begin{array}{c}\text { Change } \\
\text { 1994-2001 }\end{array}$} & \multicolumn{2}{|c|}{$\begin{array}{c}\text { Change } \\
\text { 1990-2001 }\end{array}$} & \multicolumn{2}{|c|}{$\begin{array}{c}\text { Change } \\
\text { 1994-2009 }\end{array}$} & \multicolumn{2}{|c|}{$\begin{array}{l}\text { Change } \\
\text { 2001-2009 }\end{array}$} & \multicolumn{2}{|c|}{$\begin{array}{c}\text { Change } \\
\text { 1990-2009 }\end{array}$} \\
\hline & & $\mathrm{DBH}$ & Height & $\mathrm{DBH}$ & Height & $\mathrm{DBH}$ & Height & $\mathrm{DBH}$ & Height & $\mathrm{DBH}$ & Height & $\mathrm{DBH}$ & Height \\
\hline 24 & GS & 0.9 & 6.0 & 2.1 & 12.8 & 3.0 & 18.8 & 4.0 & 21.4 & 1.9 & 8.6 & 4.9 & 27.4 \\
\hline 25 & GS & 1.6 & 4.0 & 2.6 & 27.3 & 4.2 & 31.3 & 4.9 & 39.4 & 2.3 & 12.1 & 6.5 & 43.4 \\
\hline 26 & GS & 1.0 & 13.0 & 1.5 & 0.3 & 2.5 & 13.3 & 3.1 & 10.5 & 1.6 & 10.2 & 4.1 & 23.5 \\
\hline 27 & GS & 1.1 & 2.0 & 2.3 & 14.6 & 3.4 & 16.6 & 4.7 & 14.7 & 2.4 & 0.1 & 5.8 & 16.7 \\
\hline 28 & GS & 1.1 & 0.0 & 2.1 & 18.5 & 3.2 & 18.5 & 4.4 & 28.2 & 2.3 & 9.7 & 5.5 & 28.2 \\
\hline 29 & GS & 0.4 & 2.0 & 1.5 & 4.3 & 1.9 & 6.3 & 2.7 & 12.0 & 1.2 & 7.7 & 3.1 & 14.0 \\
\hline 30 & GS & 1.3 & 4.0 & 2.6 & 5.7 & 3.9 & 9.7 & 5.3 & 14.4 & 2.7 & 8.7 & 6.6 & 18.4 \\
\hline 31 & GS & 1.4 & 3.0 & 2.3 & 9.9 & 3.7 & 12.9 & 4.6 & 22.8 & 2.3 & 12.9 & 6.0 & 25.8 \\
\hline AVG. & & 1.1 & 4.3 & 2.1 & 11.7 & 3.2 & 15.9 & 4.2 & 20.4 & 2.1 & 8.8 & 5.3 & 24.7 \\
\hline
\end{tabular}

Tree $\quad 27 \quad$ Deformed Top in 2009 
MHDSF Young-Growth Giant Sequoia Management Strategies Study 2009 - Overstory Summary Data (39.37 ft. (12m) Plot)

$\begin{array}{lllll}\text { Stand: Frasier Mill } & \text { Treatment: Thinned/Burned } & \text { Measured By: } & 1990 \text { Joe, Domingo, Mary } \\ & & \text { Measured By: } & 1994 \text { Ganz } \\ \text { Block: A } & \text { Plot \# :2 } & \text { Measured By: } & 2001 \text { Roller, McLoed } \\ & & \text { Measured By: } & 2009 \text { Soderlund, Ricchiazzi }\end{array}$

\begin{tabular}{cc|cc|cc|cc|cc|}
\cline { 3 - 9 } \multicolumn{1}{c|}{} & & \multicolumn{2}{c|}{1990 Data } & \multicolumn{2}{c|}{ 1994 Data } & \multicolumn{2}{c|}{2001 Data } & \multicolumn{2}{c|}{ 2009 Data } \\
Tree \# & Species & DBH & Height & DBH & Height & DBH & Height & DBH & Height \\
\hline \hline 17 & GS & 11.9 & 100.0 & 12.2 & 102.0 & 35.3 & 151.6 & 39.1 & 161.8 \\
18 & GS & $* * *$ & $* * *$ & $* * *$ & $* * *$ & $* * *$ & $* * *$ & $* * *$ & $* * *$ \\
19 & GS & 20.7 & 105.0 & 21.5 & 127.0 & 24.5 & 130.6 & 26.8 & 140.0 \\
20 & GS & 34.5 & 145.0 & 35.8 & 154.0 & 39.4 & 158.7 & 42.3 & 166.4 \\
21 & GS & 32.0 & 140.0 & 33.0 & 143.0 & 38.1 & 148.0 & 43.0 & 155.7 \\
22 & GS & 35.7 & 141.0 & 36.9 & 158.0 & 40.3 & 159.3 & 44.0 & 166.2 \\
23 & GS & 29.4 & 140.0 & 31.8 & 156.0 & $* * *$ & $* * *$ & $* * *$ & $* * *$ \\
24 & GS & $* * *$ & $* * *$ & $* * *$ & $* * *$ & 22.4 & 125.0 & 24.9 & 132.1 \\
25 & GS & $* * *$ & $* * *$ & $* * *$ & $* * *$ & 9.4 & 69.5 & 9.8 & 70.4 \\
26 & GS & $* * *$ & $* * *$ & $* * *$ & $* * *$ & $* * *$ & $* * *$ & 7.6 & $* * *$ \\
\hline \hline AVG. & & 27.4 & 128.5 & 28.5 & 140.0 & 29.9 & 134.7 & 29.7 & 141.8
\end{tabular}

2009 - Overstory Summary Growth Data (39.37 ft. (12m) Plot)

\begin{tabular}{|c|c|c|c|c|c|c|c|c|c|c|c|c|c|}
\hline \multirow[b]{2}{*}{ Tree \# } & \multirow[b]{2}{*}{ Species } & \multicolumn{2}{|c|}{$\begin{array}{c}\text { Change } \\
\text { 1990-1994 }\end{array}$} & \multicolumn{2}{|c|}{$\begin{array}{c}\text { Change } \\
\text { 1994-2001 }\end{array}$} & \multicolumn{2}{|c|}{$\begin{array}{c}\text { Change } \\
\text { 1990-2001 }\end{array}$} & \multicolumn{2}{|c|}{$\begin{array}{c}\text { Change } \\
\text { 1994-2009 }\end{array}$} & \multicolumn{2}{|c|}{$\begin{array}{c}\text { Change } \\
\text { 2001-2009 }\end{array}$} & \multicolumn{2}{|c|}{$\begin{array}{c}\text { Change } \\
1990-2009\end{array}$} \\
\hline & & $\mathrm{DBH}$ & Height & $\mathrm{DBH}$ & Height & $\mathrm{DBH}$ & Height & $\mathrm{DBH}$ & Height & $\mathrm{DBH}$ & Height & $\mathrm{DBH}$ & Height \\
\hline 17 & GS & $\begin{array}{c}0.3 \\
\end{array}$ & 2.0 & 23.1 & 49.6 & 23.4 & 51.6 & 26.9 & 59.8 & 3.8 & 10.2 & 27.2 & 61.8 \\
\hline 18 & GS & $* * *$ & $* * *$ & $* * *$ & $* * *$ & $* * *$ & $* * *$ & $* * *$ & $* * *$ & $* * *$ & $* * *$ & $* * *$ & $* * *$ \\
\hline 19 & GS & 0.8 & 22.0 & 3.0 & 3.6 & 3.8 & 25.6 & 5.3 & 13.0 & 2.3 & 9.4 & 6.1 & 35.0 \\
\hline 20 & GS & 1.3 & 9.0 & 3.6 & 4.7 & 4.9 & 13.7 & 6.5 & 12.4 & 2.9 & 7.7 & 7.8 & 21.4 \\
\hline 21 & GS & 1.0 & 3.0 & 5.1 & 5.0 & 6.1 & 8.0 & 10.0 & 12.7 & 4.9 & 7.7 & 11.0 & 15.7 \\
\hline 22 & GS & 1.2 & 17.0 & 3.4 & 1.3 & 4.6 & 18.3 & 7.1 & 8.2 & 3.7 & 6.9 & 8.3 & 25.2 \\
\hline 23 & GS & 2.4 & 16.0 & $* * *$ & $* * *$ & $* * *$ & $* * *$ & $* * *$ & $* * *$ & $* * *$ & $* * *$ & $* * *$ & $* * *$ \\
\hline 24 & GS & $* * *$ & $* * *$ & $* * *$ & $* * *$ & $* * *$ & $* * *$ & $* * *$ & $* * *$ & 2.5 & 7.1 & $* * *$ & $* * *$ \\
\hline 25 & GS & $* * *$ & $* * *$ & $* * *$ & $* * *$ & $* * *$ & $* * *$ & $* * *$ & $* * *$ & 0.4 & 0.9 & $* * *$ & $* * *$ \\
\hline 26 & GS & $* * *$ & $* * *$ & $* * *$ & $* * *$ & $* * *$ & $* * *$ & $* * *$ & $* * *$ & $* * *$ & $* * *$ & $* * *$ & $* * *$ \\
\hline AVG. & & 1.17 & 11.50 & 7.64 & 12.84 & 8.56 & 23.44 & 11.16 & 21.22 & 2.93 & 7.13 & 12.08 & 31.82 \\
\hline
\end{tabular}

Tree 18 Dead 1994. No plot center stake. Reestablished as close as possible.

Tree \#18 is dead/down in 2001

Tree $\quad 23 \quad$ There was no tree alive or dead in plot that was the size reported in 1994 that could have been \#23. Missing in 2001,2009

Tree 24 With the new plot center another tree was added to become a new tree \#24 in 2001

Tree $\quad 25 \quad$ Not previously measured in 1989 or 1994

Tree 26 Dead/Standing in 2009, not previously measured in 1994 or 2001. 
MHDSF Young-Growth Giant Sequoia Management Strategies Study 2009 - Overstory Summary Data (39.37 ft. (12m) Plot)

$\begin{array}{lllll}\text { Stand: Frasier Mill } & \text { Treatment: Thinned } & \text { Measured By: } & 1990 \text { Joe, Sandy, Mary } \\ & & \text { Measured By: } & 1994 & \text { Ganz } \\ \text { Block: B } & \text { Plot \# :1 } & \text { Measured By: } & 2001 & \text { Roller, McLoed } \\ & & \text { Measured By: } & 2009 \text { Soderlund, Ricchiazzi }\end{array}$

\begin{tabular}{cc|cc|cc|cc|cc|}
\cline { 3 - 9 } \multicolumn{1}{c|}{} & & \multicolumn{2}{c|}{1990 Data } & \multicolumn{2}{c|}{1994 Data } & \multicolumn{2}{c|}{2001 Data } & \multicolumn{2}{c|}{2009 Data } \\
Tree \# & Species & DBH & Height & DBH & Height & DBH & Height & DBH & Height \\
\hline \hline 1 & GS & 23.8 & 110.0 & 24.6 & 112.0 & 27.0 & 122.9 & 29.3 & 128.2 \\
2 & GS & 29.4 & 129.0 & 30.4 & 132.0 & 33.8 & 129.7 & 34.6 & 142.8 \\
3 & GS & 46.3 & 159.0 & 47.6 & 164.0 & 51.2 & 168.2 & 52.3 & 178.0 \\
4 & GS & 29.5 & 119.0 & 30.4 & 128.0 & 33.3 & 136.7 & 35.6 & 147.7 \\
5 & GS & 32.4 & 132.0 & 33.8 & 141.0 & 37.3 & 152.5 & 40.8 & 163.5 \\
6 & GS & 27.1 & 132.0 & 28.3 & 134.0 & 31.0 & 148.3 & 33.7 & 161.9 \\
7 & GS & 26.0 & 124.0 & 27.1 & 130.0 & 29.8 & 135.9 & 32.4 & 143.4 \\
8 & GS & 30.6 & 127.0 & 32.7 & 135.0 & 36.2 & 140.4 & 37.8 & 149.0 \\
\hline \hline AVG. & & 30.6 & 129.0 & 31.9 & 134.5 & 35.0 & 141.8 & 37.1 & 151.8 \\
\hline
\end{tabular}

2009 - Overstory Summary Growth Data (39.37 ft. (12m) Plot)

\begin{tabular}{|c|c|c|c|c|c|c|c|c|c|c|c|c|c|}
\hline \multirow[b]{2}{*}{ Tree \# } & \multirow[b]{2}{*}{ Species } & \multicolumn{2}{|c|}{$\begin{array}{c}\text { Change } \\
\text { 1989-1994 }\end{array}$} & \multicolumn{2}{|c|}{$\begin{array}{c}\text { Change } \\
\text { 1994-2001 }\end{array}$} & \multicolumn{2}{|c|}{$\begin{array}{c}\text { Change } \\
\text { 1989-2001 }\end{array}$} & \multicolumn{2}{|c|}{$\begin{array}{c}\text { Change } \\
\text { 1994-2009 }\end{array}$} & \multicolumn{2}{|c|}{$\begin{array}{c}\text { Change } \\
\text { 2001-2009 }\end{array}$} & \multicolumn{2}{|c|}{$\begin{array}{c}\text { Change } \\
1989-2009\end{array}$} \\
\hline & & DBH & Height & DBH & Height & DBH & Height & DBH & Height & DBH & Height & $\mathrm{DBH}$ & Height \\
\hline 1 & GS & 0.8 & 2.0 & 2.4 & 10.9 & 3.2 & 12.9 & 4.7 & 16.2 & 2.3 & 5.3 & 5.5 & 18.2 \\
\hline 2 & GS & 1.0 & 3.0 & 3.4 & -2.3 & 4.4 & 0.7 & 4.2 & 10.8 & 0.8 & 13.1 & 5.2 & 13.8 \\
\hline 3 & GS & 1.3 & 5.0 & 3.6 & 4.2 & 4.9 & 9.2 & 4.7 & 14.0 & 1.1 & 9.8 & 6.0 & 19.0 \\
\hline 4 & GS & 0.9 & 9.0 & 2.9 & 8.7 & 3.8 & 17.7 & 5.2 & 19.7 & 2.3 & 11.0 & 6.1 & 28.7 \\
\hline 5 & GS & 1.4 & 9.0 & 3.5 & 11.5 & 4.9 & 20.5 & 7.0 & 22.5 & 3.5 & 11.0 & 8.4 & 31.5 \\
\hline 6 & GS & 1.2 & 2.0 & 2.7 & 14.3 & 3.9 & 16.3 & 5.4 & 27.9 & 2.7 & 13.6 & 6.6 & 29.9 \\
\hline 7 & GS & 1.1 & 6.0 & 2.7 & 5.9 & 3.8 & 11.9 & 5.3 & 13.4 & 2.6 & 7.5 & 6.4 & 19.4 \\
\hline 8 & GS & 2.1 & 8.0 & 3.5 & 5.4 & 5.6 & 13.4 & 5.1 & 14.0 & 1.6 & 8.6 & 7.2 & 22.0 \\
\hline AVG. & & 1.2 & 5.5 & 3.1 & 7.3 & 4.3 & 12.8 & 5.2 & 17.3 & 2.1 & 10.0 & 6.4 & 22.8 \\
\hline
\end{tabular}


MHDSF Young-Growth Giant Sequoia Management Strategies Study 2009 - Overstory Summary Data (39.37 ft. (12m) Plot)

$\begin{array}{lllll}\text { Stand: Frasier Mill } & \text { Treatment: Thinned/Burned } & \text { Measured By: } & 1990 \text { Joe, Sandy, Mary } \\ & & \text { Measured By: } & 1994 \text { Ganz } \\ \text { Block: B } & \text { Plot \# :2 } & \text { Measured By: } & 2001 \text { Roller, McLoed } \\ & & \text { Measured By: } & 2009 \text { Soderlund, Ricchiazzi }\end{array}$

\begin{tabular}{cc|cc|cc|cc|cc|}
\cline { 3 - 10 } \multicolumn{1}{c|}{} & & \multicolumn{2}{c|}{1990 Data } & \multicolumn{2}{c|}{1994 Data } & \multicolumn{2}{c|}{ 2001 Data } & \multicolumn{2}{c|}{2009 Data } \\
Tree \# & Species & DBH & Height & DBH & Height & DBH & Height & DBH & Height \\
\hline \hline 9 & GS & 23.5 & 112.0 & 25.1 & 119.0 & 27.5 & 119.6 & 29.5 & 129.1 \\
10 & GS & 31.8 & 115.0 & 32.4 & 120.0 & 33.8 & 124.2 & 35.3 & 125.5 \\
11 & GS & 22.5 & 120.0 & 23.1 & 127.0 & 25.8 & 129.5 & 28.2 & 142.5 \\
12 & GS & 24.1 & 124.0 & 25.2 & 130.0 & 27.4 & 132.0 & 29.6 & 146.1 \\
13 & GS & 35.4 & 133.0 & 36.1 & 138.0 & 38.7 & 139.6 & 40.9 & 151.1 \\
14 & GS & 14.6 & 100.0 & 15.6 & 101.0 & 17.3 & 103.4 & 18.6 & 107.5 \\
15 & GS & $* * *$ & $* * *$ & $* * *$ & $* * *$ & 29.1 & 126.1 & 31.8 & 140.7 \\
16 & GS & 25.5 & 120.0 & 26.7 & 129.0 & 27.3 & 137.0 & 29.7 & 157.5 \\
17 & GS & $* * *$ & $* * *$ & $* * *$ & $* * *$ & 14.6 & 66.8 & 17.1 & 80.9 \\
18 & GS & $* * *$ & $* * *$ & $* * *$ & $* * *$ & 35.7 & 128.9 & 35.8 & 137.3 \\
\hline \hline AVG. & & 25.3 & 117.7 & 26.3 & 123.4 & 27.7 & 120.7 & 29.7 & 131.8
\end{tabular}

2009 - Overstory Summary Growth Data (39.37 ft. (12m) Plot)

\begin{tabular}{|c|c|c|c|c|c|c|c|c|c|c|c|c|c|}
\hline \multirow[b]{2}{*}{ Tree \# } & \multirow[b]{2}{*}{ Species } & \multicolumn{2}{|c|}{$\begin{array}{c}\text { Change } \\
\text { 1989-1994 }\end{array}$} & \multicolumn{2}{|c|}{$\begin{array}{c}\text { Change } \\
1994-2001\end{array}$} & \multicolumn{2}{|c|}{$\begin{array}{c}\text { Change } \\
1989-2001\end{array}$} & \multicolumn{2}{|c|}{$\begin{array}{c}\text { Change } \\
1994-2009\end{array}$} & \multicolumn{2}{|c|}{$\begin{array}{c}\text { Change } \\
\text { 2001-2009 }\end{array}$} & \multicolumn{2}{|c|}{$\begin{array}{c}\text { Change } \\
1989-2009\end{array}$} \\
\hline & & $\mathrm{DBH}$ & Height & $\mathrm{DBH}$ & Height & $\mathrm{DBH}$ & Height & $\mathrm{DBH}$ & Height & $\mathrm{DBH}$ & Height & $\mathrm{DBH}$ & Height \\
\hline 9 & GS & 1.6 & 7.0 & 2.4 & 0.6 & 4.0 & 7.6 & 4.4 & 10.1 & 2.0 & 9.5 & 6.0 & 17.1 \\
\hline 10 & GS & 0.6 & 5.0 & 1.4 & 4.2 & 2.0 & 9.2 & 2.9 & 5.5 & 1.5 & 1.3 & 3.5 & 10.5 \\
\hline 11 & GS & 0.6 & 7.0 & 2.7 & 2.5 & 3.3 & 9.5 & 5.1 & 15.5 & 2.4 & 13.0 & 5.7 & 22.5 \\
\hline 12 & GS & 1.1 & 6.0 & 2.2 & 2.0 & 3.3 & 8.0 & 4.4 & 16.1 & 2.2 & 14.1 & 5.5 & 22.1 \\
\hline 13 & GS & 0.7 & 5.0 & 2.6 & 1.6 & 3.3 & 6.6 & 4.8 & 13.1 & 2.2 & 11.5 & 5.5 & 18.1 \\
\hline 14 & GS & 1.0 & 1.0 & 1.7 & 2.4 & 2.7 & 3.4 & 3.0 & 6.5 & 1.3 & 4.1 & 4.0 & 7.5 \\
\hline 15 & GS & $* * *$ & $* * *$ & $* * *$ & $* * *$ & $* * *$ & $* * *$ & $* * *$ & $* * *$ & 2.7 & 14.6 & $* * *$ & $* * *$ \\
\hline 16 & GS & 1.2 & 9.0 & 0.6 & 8.0 & 1.8 & 17.0 & 3.0 & 28.5 & 2.4 & 20.5 & 4.2 & 37.5 \\
\hline 17 & GS & $* * *$ & $* * *$ & $* * *$ & $* * *$ & $* * *$ & $* * *$ & $* * *$ & $* * *$ & 2.5 & 14.1 & $* * *$ & $* * *$ \\
\hline 18 & GS & $* * *$ & $* * *$ & $* * *$ & $* * *$ & $* * *$ & $* * *$ & $* * *$ & $* * *$ & 0.1 & 8.4 & $* * *$ & $* * *$ \\
\hline AVG. & & 1.0 & 5.7 & 1.9 & 3.0 & 2.9 & 8.8 & 3.9 & 13.6 & 1.9 & 11.1 & 4.9 & 19.3 \\
\hline Tree & 15 & Missing & in 1989, & & & & & & & & & & \\
\hline Tree & 12 & Previou & ly meast & red but & s out of & lot at 4 & 5 feet & $\mathrm{m}$ plo & enter. & & & & \\
\hline Tree & 17,18 & Not pre & jiously m & easured & but clear & in plo & ind add & to dat & & & & & \\
\hline Tree & 10 & Deform & ed Top in & 2009 & & & & & & & & & \\
\hline
\end{tabular}


MHDSF Young-Growth Giant Sequoia Management Strategies Study 2009 - Overstory Summary Data (39.37 ft. (12m) Plot)

$\begin{array}{lllll}\text { Stand: Frasier Mill } & \text { Treatment: Control } & \text { Measured By: } & 1990 & \text { Joe, Domingo, Mary } \\ & & \text { Measured By: } & 1994 & \text { Ganz } \\ \text { Block: C } & \text { Plot \# :1 } & \text { Measured By: } & 2001 & \text { Roller, McLoed } \\ & & \text { Measured By: } & 2009 & \text { Soderlund, Ricchiazzi }\end{array}$

\begin{tabular}{|c|c|c|c|c|c|c|c|c|c|}
\hline \multirow[b]{2}{*}{ Tree \# } & \multirow[b]{2}{*}{ Species } & \multicolumn{2}{|c|}{1989 Data } & \multicolumn{2}{|c|}{1994 Data } & \multicolumn{2}{|c|}{2001 Data } & \multicolumn{2}{|c|}{2009 Data } \\
\hline & & $\mathrm{DBH}$ & Height & $\mathrm{DBH}$ & Height & $\mathrm{DBH}$ & Height & $\mathrm{DBH}$ & Height \\
\hline 1 & "WF & 1.5 & 8.0 & 1.9 & 9.0 & 2.2 & 10.8 & 2.5 & 12.3 \\
\hline 2 & WF & 32.4 & 144.0 & 32.4 & 145.0 & 36.0 & 149.4 & 37.6 & 165.6 \\
\hline 3 & WF & 7.8 & 42.0 & 8.3 & 43.0 & 8.8 & 44.4 & 9.2 & 48.8 \\
\hline 4 & WF & 3.1 & 15.0 & 3.3 & 16.0 & $* * *$ & $* * *$ & $* * *$ & $* * *$ \\
\hline 69 & GS & 32.5 & 134.0 & 33.4 & 162.0 & 34.2 & 151.9 & 35.9 & 165.5 \\
\hline 70 & GS & 14.6 & 80.0 & 14.9 & 80.0 & 14.9 & 82.5 & 14.8 & 79.8 \\
\hline 71 & GS & 32.2 & 149.0 & 32.9 & 150.0 & 34.5 & 155.2 & 36.5 & 181.0 \\
\hline 72 & GS & 19.7 & 81.0 & 20.0 & 82.0 & 20.7 & 80.8 & 21.0 & 88.1 \\
\hline 73 & WF & 3.5 & 15.0 & 3.9 & 17.0 & 4.3 & 20.7 & 4.6 & 23.0 \\
\hline 74 & WF & 5.8 & 25.0 & 6.0 & 26.0 & 6.2 & 38.3 & 6.4 & 42.7 \\
\hline 75 & GS & 33.0 & 149.0 & 33.6 & 152.0 & 35.2 & 156.4 & 36.7 & 173.3 \\
\hline 76 & GS & $* * *$ & $* * *$ & $* * *$ & $* * *$ & 23.9 & $* * *$ & 23.3 & $* * *$ \\
\hline 77 & GS & 46.4 & 158.0 & 47.5 & 159.0 & 48.3 & 173.8 & 51.9 & 190.8 \\
\hline 78 & GS & $* * *$ & $* * *$ & $* * *$ & $* * *$ & 24.5 & $* * *$ & 25.0 & $* * *$ \\
\hline 79 & GS & 19.2 & 103.0 & 19.8 & 116.0 & 20.3 & 115.0 & 20.8 & 117.3 \\
\hline 80 & GS & 7.1 & 47.0 & 7.1 & 51.0 & 7.1 & 53.5 & 7.0 & $* * *$ \\
\hline 81 & GS & $* * *$ & $* * *$ & $* * *$ & $* * *$ & 7.3 & $* * *$ & 7.1 & $* * *$ \\
\hline 82 & GS & $* * *$ & $* * *$ & $* * *$ & $* * *$ & $* * *$ & $* * *$ & 5.2 & $* * *$ \\
\hline 83 & GS & $* * *$ & $* * *$ & $* * *$ & $* * *$ & $* * *$ & $* * *$ & 8.4 & $* * *$ \\
\hline 84 & GS & $* * *$ & $* * *$ & $* * *$ & $* * *$ & $* * *$ & $* * *$ & $* * *$ & $* * *$ \\
\hline 85 & GS & 17.0 & 120.0 & 17.2 & 129.0 & 17.8 & 123.5 & 17.8 & 131.3 \\
\hline 86 & GS & 9.9 & 33.0 & 10.1 & 33.0 & 9.7 & 36.0 & 9.4 & $* * *$ \\
\hline 87 & GS & 14.5 & 58.0 & 14.5 & 58.0 & 14.7 & 59.3 & 15.0 & 67.2 \\
\hline 88 & GS & 17.3 & 148.0 & 18.1 & 151.0 & 18.4 & 140.6 & 19.4 & 137.6 \\
\hline 89 & GS & 15.6 & 66.0 & 15.8 & 72.0 & 15.7 & 58.3 & 15.5 & 70.5 \\
\hline 90 & WF & 5.8 & 40.0 & 6.0 & 40.0 & 6.3 & 46.2 & 6.6 & 48.5 \\
\hline 91 & WF & 3.7 & 18.0 & 3.9 & 19.0 & $* * *$ & $* * *$ & $* * *$ & $* * *$ \\
\hline 92 & WF & 4.8 & 32.0 & 5.8 & 32.0 & $* * *$ & $* * *$ & $* * *$ & $* * *$ \\
\hline 93 & WF & 4.9 & 34.0 & 5.3 & 36.0 & 6.1 & 40.2 & 6.1 & 40.9 \\
\hline 94 & WF & 5.1 & 25.0 & 5.5 & 27.0 & 5.6 & 26.0 & 5.5 & $* * *$ \\
\hline 95 & GS & $* * *$ & $* * *$ & 33.5 & 40.0 & 33.8 & 45.0 & 33.8 & 88.0 \\
\hline 96 & WF & 5.6 & 35.0 & 6.1 & 36.0 & 6.2 & 37.5 & 6.5 & 39.7 \\
\hline 97 & WF & 2.1 & 9.0 & 2.1 & 9.0 & $* * *$ & $* * *$ & $* * *$ & $* * *$ \\
\hline 98 & WF & 3.5 & 10.0 & 3.6 & 10.0 & 3.7 & 12.1 & 4.2 & 12.9 \\
\hline 99 & GS & 52.5 & 165.0 & 54.1 & 175.0 & 56.8 & 182.8 & 60.0 & 191.5 \\
\hline 100 & WF & 12.7 & 64.0 & 13.5 & 69.0 & 14.2 & 76.9 & 14.7 & 83.3 \\
\hline 102 & GS & $* * *$ & $* * *$ & $* * *$ & $* * *$ & $* * *$ & $* * *$ & 28.5 & 176.2 \\
\hline 103 & GS & $* * *$ & $* * *$ & $* * *$ & $* * *$ & $* * *$ & $* * *$ & 8.5 & $* * *$ \\
\hline AVG. & & 15.0 & 69.2 & 16.0 & 71.5 & 18.5 & 81.4 & 18.3 & 99.0 \\
\hline
\end{tabular}

Trees 76,78,81,82,83,84 Dead in 1994, no values. Roller 2004 thesis has values for 1994: \#81-DBH 7.4; \#82-DBH 5.6; \#83-DBH 8.8; \#84-DBH 25.7

Tree $\quad 95$ Broken top in 1994, no values. Roller 2004 thesis has values for 1994: \#95-DBH 33.5,Ht 40.0

Trees 76,78,81 Dead/Standing in 2001 


\begin{tabular}{ccccc}
\multicolumn{5}{c}{ MHDSF Young-Growth Giant Sequoia Management Strategies Study } \\
2009 - Overstory Summary Data (39.37 ft. (12m) Plot)
\end{tabular}

Page 119 
MHDSF Young-Growth Giant Sequoia Management Strategies Study

2009 - Overstory Summary Growth Data (39.37 ft. (12m) Plot)

$\begin{array}{lllll}\text { Stand: Frasier Mill } & \text { Treatment: Control } & \text { Measured By: } & 1990 & \text { Joe, Domingo, Mary } \\ & & \text { Measured By: } & 1994 & \text { Ganz } \\ \text { Block: C } & \text { Plot \# : } 1 & \text { Measured By: } & 2001 & \text { Roller, McLoed } \\ & & \text { Measured By: } & 2009 & \text { Soderlund, Ricchiazzi }\end{array}$

\begin{tabular}{|c|c|c|c|c|c|c|c|c|c|c|c|c|c|}
\hline \multirow[b]{2}{*}{ Tree \# } & \multirow[b]{2}{*}{ Species } & \multicolumn{2}{|c|}{$\begin{array}{c}\text { Change } \\
\text { 1989-1994 }\end{array}$} & \multicolumn{2}{|c|}{$\begin{array}{c}\text { Change } \\
\text { 1994-2001 }\end{array}$} & \multicolumn{2}{|c|}{$\begin{array}{c}\text { Change } \\
\text { 1989-2001 }\end{array}$} & \multicolumn{2}{|c|}{$\begin{array}{c}\text { Change } \\
1994-2009\end{array}$} & \multicolumn{2}{|c|}{$\begin{array}{l}\text { Change } \\
\text { 2001-2009 }\end{array}$} & \multicolumn{2}{|c|}{$\begin{array}{c}\text { Change } \\
1989-2009\end{array}$} \\
\hline & & $\mathrm{DBH}$ & Height & $\mathrm{DBH}$ & Height & $\mathrm{DBH}$ & Height & DBH & Height & DBH & Height & $\mathrm{DBH}$ & Height \\
\hline 1 & WF & 0.4 & 1.0 & 0.3 & 1.8 & 0.7 & 2.8 & 0.6 & 3.3 & 0.3 & 1.5 & 1.0 & 4.3 \\
\hline 2 & WF & 0.0 & 1.0 & 3.6 & 4.4 & 3.6 & 5.4 & 5.2 & 20.6 & 1.6 & 16.2 & 5.2 & 21.6 \\
\hline 3 & WF & 0.5 & 1.0 & 0.5 & 1.4 & 1.0 & 2.4 & 0.9 & 5.8 & 0.4 & 4.4 & 1.4 & 6.8 \\
\hline 4 & WF & 0.2 & 1.0 & $* * *$ & $* * *$ & $* * *$ & $* * *$ & $* * *$ & $* * *$ & $* * *$ & $* * *$ & $* * *$ & $* * *$ \\
\hline 69 & GS & 0.9 & 28.0 & 0.8 & -10.1 & 1.7 & 17.9 & 2.5 & 3.5 & 1.7 & 13.6 & 3.4 & 31.5 \\
\hline 70 & GS & 0.3 & 0.0 & 0.0 & 2.5 & 0.3 & 2.5 & -0.1 & -0.2 & -0.1 & -2.7 & 0.2 & -0.2 \\
\hline 71 & GS & 0.7 & 1.0 & 1.6 & 5.2 & 2.3 & 6.2 & 3.6 & 31.0 & 2.0 & 25.8 & 4.3 & 32.0 \\
\hline 72 & GS & 0.3 & 1.0 & 0.7 & -1.2 & 1.0 & -0.2 & 1.0 & 6.1 & 0.3 & 7.3 & 1.3 & 7.1 \\
\hline 73 & WF & 0.4 & 2.0 & 0.4 & 3.7 & 0.8 & 5.7 & 0.7 & 6.0 & 0.3 & 2.3 & 1.1 & 8.0 \\
\hline 74 & WF & 0.2 & 1.0 & 0.2 & 12.3 & 0.4 & 13.3 & 0.4 & 16.7 & 0.2 & 4.4 & 0.6 & 17.7 \\
\hline 75 & GS & 0.6 & 3.0 & 1.6 & 4.4 & 2.2 & 7.4 & 3.1 & 21.3 & 1.5 & 16.9 & 3.7 & 24.3 \\
\hline 76 & GS & $* * *$ & $* * *$ & $* * *$ & $* * *$ & $* * *$ & $* * *$ & $* * *$ & $* * *$ & -0.6 & $* * *$ & $* * *$ & $* * *$ \\
\hline 77 & GS & 1.1 & 1.0 & 0.8 & 14.8 & 1.9 & 15.8 & 4.4 & 31.8 & 3.6 & 17.0 & 5.5 & 32.8 \\
\hline 78 & GS & $* * *$ & $* * *$ & $* * *$ & $* * *$ & $* * *$ & $* * *$ & $* * *$ & $* * *$ & 0.5 & $* * *$ & $* * *$ & $* * *$ \\
\hline 79 & GS & 0.6 & 13.0 & 0.5 & -1.0 & 1.1 & 12.0 & 1.0 & 1.3 & 0.5 & 2.3 & 1.6 & 14.3 \\
\hline 80 & GS & 0.0 & 4.0 & 0.0 & 2.5 & 0.0 & 6.5 & -0.1 & $* * *$ & -0.1 & $* * *$ & -0.1 & $* * *$ \\
\hline 81 & GS & $* * *$ & $* * *$ & $* * *$ & $* * *$ & $* * *$ & $* * *$ & $* * *$ & $* * *$ & -0.2 & $* * *$ & $* * *$ & $* * *$ \\
\hline 82 & GS & $* * *$ & $* * *$ & $* * *$ & $* * *$ & $* * *$ & $* * *$ & $* * *$ & $* * *$ & $* * *$ & $* * *$ & $* * *$ & $* * *$ \\
\hline 83 & GS & $* * *$ & $* * *$ & $* * *$ & $* * *$ & $* * *$ & $* * *$ & $* * *$ & $* * *$ & $* * *$ & $* * *$ & $* * *$ & $* * *$ \\
\hline 84 & GS & $* * *$ & $* * *$ & $* * *$ & $* * *$ & $* * *$ & $* * *$ & $* * *$ & $* * *$ & $* * *$ & $* * *$ & $* * *$ & $* * *$ \\
\hline 85 & GS & 0.2 & 9.0 & 0.6 & -5.5 & 0.8 & 3.5 & 0.6 & 2.3 & 0.0 & 7.8 & 0.8 & 11.3 \\
\hline 86 & GS & 0.2 & 0.0 & -0.4 & 3.0 & -0.2 & 3.0 & -0.7 & $* * *$ & -0.3 & $* * *$ & -0.5 & $* * *$ \\
\hline 87 & GS & 0.0 & 0.0 & 0.2 & 1.3 & 0.2 & 1.3 & 0.5 & 9.2 & 0.3 & 7.9 & 0.5 & 9.2 \\
\hline 88 & GS & 0.8 & 3.0 & 0.3 & -10.4 & 1.1 & -7.4 & 1.3 & -13.4 & 1.0 & -3.0 & 2.1 & -10.4 \\
\hline 89 & GS & 0.2 & 6.0 & -0.1 & -13.7 & 0.1 & -7.7 & -0.3 & -1.5 & -0.2 & 12.2 & -0.1 & 4.5 \\
\hline 90 & WF & 0.2 & 0.0 & 0.3 & 6.2 & 0.5 & 6.2 & 0.6 & 8.5 & 0.3 & 2.3 & 0.8 & 8.5 \\
\hline 91 & WF & 0.2 & 1.0 & $* * *$ & $* * *$ & $* * *$ & $* * *$ & $* * *$ & $* * *$ & $* * *$ & $* * *$ & $* * *$ & $* * *$ \\
\hline 92 & WF & 1.0 & 0.0 & $* * *$ & $* * *$ & $* * *$ & $* * *$ & $* * *$ & $* * *$ & $* * *$ & $* * *$ & $* * *$ & $* * *$ \\
\hline 93 & WF & 0.4 & 2.0 & 0.8 & 4.2 & 1.2 & 6.2 & 0.8 & 4.9 & 0.0 & 0.7 & 1.2 & 6.9 \\
\hline 94 & WF & 0.4 & 2.0 & 0.1 & -1.0 & 0.5 & 1.0 & 0.0 & $* * *$ & -0.1 & $* * *$ & 0.4 & $* * *$ \\
\hline 95 & GS & $* * *$ & $* * *$ & 0.3 & 5.0 & $* * *$ & $* * *$ & 0.3 & 48.0 & 0.0 & 43.0 & $* * *$ & $* * *$ \\
\hline 96 & WF & 0.5 & 1.0 & 0.1 & 1.5 & 0.6 & 2.5 & 0.4 & 3.7 & 0.3 & 2.2 & 0.9 & 4.7 \\
\hline 97 & WF & 0.0 & 0.0 & $* * *$ & $* * *$ & $* * *$ & $* * *$ & $* * *$ & $* * *$ & $* * *$ & $* * *$ & $* * *$ & $* * *$ \\
\hline 98 & WF & 0.1 & 0.0 & 0.1 & 2.1 & 0.2 & 2.1 & 0.6 & 2.9 & 0.5 & 0.8 & 0.7 & 2.9 \\
\hline 99 & GS & 1.6 & 10.0 & 2.7 & 7.8 & 4.3 & 17.8 & 5.9 & 16.5 & 3.2 & 8.7 & 7.5 & 26.5 \\
\hline 100 & WF & 0.8 & 5.0 & 0.7 & 7.9 & 1.5 & 12.9 & 1.2 & 14.3 & 0.5 & 6.4 & 2.0 & 19.3 \\
\hline 102 & GS & $* * *$ & $* * *$ & $* * *$ & $* * *$ & $* * *$ & $* * *$ & $* * *$ & $* * *$ & $* * *$ & $* * *$ & $* * *$ & $* * *$ \\
\hline 103 & GS & $* * *$ & $* * *$ & $* * *$ & $* * *$ & $* * *$ & $* * *$ & $* * *$ & $* * *$ & $* * *$ & $* * *$ & $* * *$ & $* * *$ \\
\hline AV & & 0.4 & 3.3 & 0.6 & 1.9 & 1.1 & 5.6 & 1.3 & 10.5 & 0.6 & 8.6 & 1.8 & 12.9 \\
\hline
\end{tabular}

Trees $\quad 76,78,81,82,83,84$

Tree 95
Dead in 1994, no values. Roller 2004 thesis has values for 1994: \#81-DBH 7.4; \#82-DBH 5.6; \#83-DBH 8.8; \#84-DBH 25.7

Broken top in 1994 
MHDSF Young-Growth Giant Sequoia Management Strategies Study 2009 - Overstory Summary Growth Data (39.37 ft. (12m) Plot)

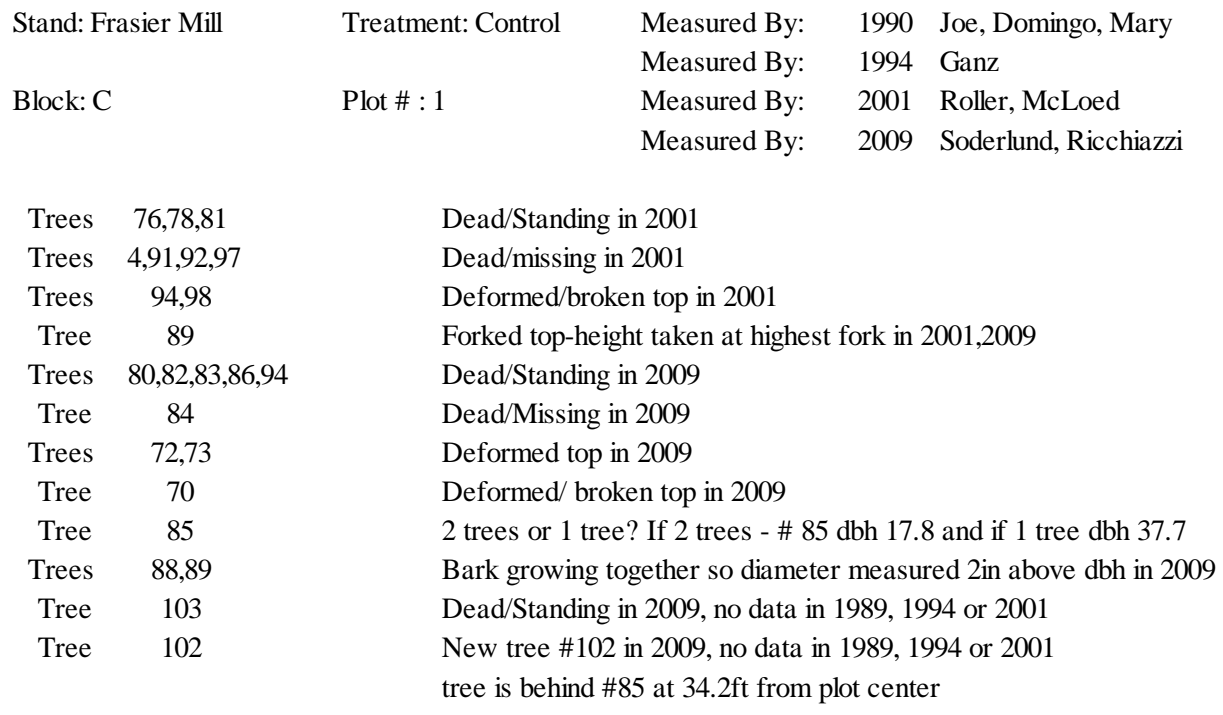


MHDSF Young-Growth Giant Sequoia Management Strategies Study 2009 - Overstory Summary Data (39.37 ft. (12m) Plot)

$\begin{array}{lllll}\text { Stand: Frasier Mill } & \text { Treatment: Control } & \text { Measured By: } & 1989 & \text { Bates, Masser, Johannis } \\ & & \text { Measured By: } & 1994 & \text { ??? } \\ \text { Block: C } & \text { Plot \# :2 } & \text { Measured By: } & 2001 \text { Roller, McLoed } \\ & & \text { Measured By: } & 2009 \text { Soderlund, Ricchiazzi }\end{array}$

\begin{tabular}{|c|c|c|c|c|c|c|c|c|c|}
\hline \multirow[b]{2}{*}{ Tree \# } & \multirow[b]{2}{*}{ Species } & \multicolumn{2}{|c|}{1989 Data } & \multicolumn{2}{|c|}{1994 Data } & \multicolumn{2}{|c|}{2001 Data } & \multicolumn{2}{|c|}{2009 Data } \\
\hline & & DBH & Height & DBH & Height & DBH & Height & DBH & Height \\
\hline 1 & WF & 2.1 & 8.0 & 2.5 & 10.0 & 3.0 & 13.6 & 3.6 & 15.9 \\
\hline 2 & WF & 2.5 & 10.0 & 2.6 & 11.0 & 2.6 & 15.5 & 3.0 & 15.1 \\
\hline 3 & GS & 29.0 & 141.0 & 30.2 & 144.0 & 31.5 & 150.5 & 33.8 & 165.8 \\
\hline 4 & WF & 3.8 & 12.0 & 3.9 & 13.0 & 3.9 & 15.9 & 4.0 & 17.3 \\
\hline 5 & GS & 21.7 & 140.0 & 22.4 & 142.0 & 23.3 & 148.9 & 23.9 & 155.3 \\
\hline 6 & GS & 32.3 & 123.0 & 33.1 & 126.0 & 34.6 & 139.2 & 36.2 & 148.5 \\
\hline 7 & GS & 25.1 & 119.0 & 26.2 & 122.0 & 27.4 & 127.0 & 28.3 & 138.0 \\
\hline 8 & GS & 34.9 & 133.0 & 35.5 & 146.0 & 38.1 & 141.8 & 39.2 & 153.7 \\
\hline 9 & WF & 7.5 & 24.0 & 7.7 & 31.0 & 8.0 & 26.7 & 8.1 & 27.2 \\
\hline 10 & GS & 14.7 & 63.0 & 15.3 & 66.0 & 15.8 & 63.2 & 16.3 & 66.9 \\
\hline 11 & GS & 13.4 & 41.0 & 13.9 & 41.0 & 14.6 & 42.6 & 15.4 & 69.4 \\
\hline 12 & WF & 4.9 & 15.0 & 6.1 & 16.0 & 7.0 & 17.1 & 7.4 & 19.0 \\
\hline 13 & GS & 9.7 & 82.0 & 9.7 & 82.0 & 9.8 & 74.5 & 9.7 & 81.3 \\
\hline 14 & GS & 14.2 & 94.0 & 14.4 & 104.0 & 14.8 & 93.1 & 14.8 & 106.0 \\
\hline 15 & GS & 8.7 & 63.0 & 9.0 & 65.0 & 9.1 & 60.4 & 9.3 & 65.1 \\
\hline 16 & GS & 16.1 & 84.0 & 16.8 & 87.0 & 17.2 & 84.0 & 16.7 & 92.3 \\
\hline 17 & GS & 8.3 & 64.0 & 8.4 & 65.0 & 8.6 & 59.9 & 8.5 & 67.4 \\
\hline 18 & GS & 15.2 & 75.0 & 15.4 & 80.0 & 15.8 & 73.0 & 15.6 & 77.9 \\
\hline 19 & GS & 19.0 & 60.0 & 19.0 & 64.0 & 19.5 & 58.8 & 19.2 & 61.8 \\
\hline 20 & GS & 8.1 & 62.0 & 8.1 & 62.0 & 8.1 & 78.2 & 7.8 & 69.8 \\
\hline 21 & GS & 7.9 & 29.0 & 8.0 & 59.0 & 8.0 & 29.8 & 7.8 & 29.1 \\
\hline 22 & GS & 5.0 & 21.0 & 5.1 & 24.0 & 5.1 & 21.8 & 5.0 & 21.6 \\
\hline 23 & GS & 12.3 & 70.0 & 12.3 & 76.0 & 12.4 & 75.1 & 12.2 & 65.2 \\
\hline 24 & GS & 25.8 & 122.0 & 26.9 & 125.0 & 28.1 & 136.7 & 29.9 & 145.9 \\
\hline 25 & GS & 32.3 & 118.0 & 33.7 & 121.0 & 35.5 & 142.2 & 38.1 & 155.5 \\
\hline 26 & GS & 11.3 & 46.0 & 11.7 & 48.0 & 12.0 & 51.7 & 11.9 & 55.8 \\
\hline 27 & GS & 5.8 & 34.0 & 5.8 & 38.0 & 5.9 & 31.5 & 5.7 & $* * *$ \\
\hline 28 & GS & 20.7 & 109.0 & 21.8 & 128.0 & 23.3 & 143.3 & 24.6 & 150.8 \\
\hline 29 & GS & 11.6 & 60.0 & 12.0 & 64.0 & 12.2 & 59.4 & 12.6 & 64.2 \\
\hline 30 & GS & 3.6 & 18.0 & 3.6 & 18.0 & 3.6 & 18.7 & 3.6 & 18.9 \\
\hline 31 & GS & 10.8 & 60.0 & 11.1 & 79.0 & 11.4 & 60.8 & 11.3 & 67.0 \\
\hline 32 & GS & 7.1 & 38.0 & 7.1 & 48.0 & 7.2 & 45.7 & 7.0 & 42.3 \\
\hline 33 & GS & 9.4 & 39.0 & 9.5 & 40.0 & 9.5 & 47.2 & 9.3 & 42.9 \\
\hline 34 & GS & 20.5 & 105.0 & 21.8 & 108.0 & 22.4 & 128.9 & 23.4 & 140.3 \\
\hline 35 & WF & 2.8 & 13.0 & 3.1 & 14.0 & 3.3 & 17.2 & 4.6 & 17.7 \\
\hline 36 & GS & $* * *$ & $* * *$ & $* * *$ & $* * *$ & 9.4 & 35.4 & 9.3 & 37.5 \\
\hline 37 & GS & 25.1 & 104.0 & 26.6 & 106.0 & 28.7 & 120.6 & 29.9 & 136.9 \\
\hline 38 & GS & 5.7 & 27.0 & 5.8 & 27.0 & 6.0 & 32.2 & 5.8 & 28.7 \\
\hline 39 & GS & 7.6 & 32.0 & 8.0 & 33.0 & 8.3 & 35.3 & 8.5 & 35.2 \\
\hline 40 & GS & 22.5 & 114.0 & 23.4 & 117.0 & 25.0 & 157.9 & 26.6 & 163.7 \\
\hline 41 & GS & 37.6 & 147.0 & 38.9 & 149.0 & 42.2 & 162.4 & 43.7 & 175.0 \\
\hline 42 & GS & 1.8 & 6.0 & 1.9 & 7.0 & 2.0 & 9.1 & 2.0 & 7.9 \\
\hline 43 & GS & 24.4 & 121.0 & 25.3 & 124.0 & 26.1 & 142.9 & 26.5 & 156.0 \\
\hline 44 & GS & 12.1 & 46.0 & 12.6 & 48.0 & 13.1 & 48.9 & 13.3 & 49.9 \\
\hline
\end{tabular}

Page 122 
MHDSF Young-Growth Giant Sequoia Management Strategies Study 2009 - Overstory Summary Data (39.37 ft. (12m) Plot)

$\begin{array}{lllll}\text { Stand: Frasier Mill } & \text { Treatment: Control } & \text { Measured By: } & 1989 & \text { Bates, Masser, Johannis } \\ & & \text { Measured By: } & 1994 & \text { ??? } \\ \text { Block: C } & \text { Plot \# :2 } & \text { Measured By: } & 2001 & \text { Roller, McLoed } \\ & & \text { Measured By: } & 2009 \text { Soderlund, Ricchiazzi }\end{array}$

\begin{tabular}{|c|c|c|c|c|c|c|c|c|c|}
\hline \multirow[b]{2}{*}{ Tree \# } & \multirow[b]{2}{*}{ Species } & \multicolumn{2}{|c|}{1989 Data } & \multicolumn{2}{|c|}{1994 Data } & \multicolumn{2}{|c|}{2001 Data } & \multicolumn{2}{|c|}{2009 Data } \\
\hline & & $\mathrm{DBH}$ & Height & $\mathrm{DBH}$ & Height & $\mathrm{DBH}$ & Height & $\mathrm{DBH}$ & Height \\
\hline 45 & WF & 1.0 & 7.0 & 2.0 & 9.0 & 2.1 & 11.6 & 3.7 & 12.8 \\
\hline 46 & GS & 17.7 & 128.0 & 18.2 & 135.0 & 18.8 & 141.1 & 19.5 & 153.5 \\
\hline 47 & GS & 11.1 & 70.0 & 11.2 & 78.0 & 12.4 & 83.3 & 11.4 & 76.2 \\
\hline 48 & GS & 4.5 & 14.0 & 4.5 & 15.0 & 4.5 & 13.7 & 4.5 & 13.9 \\
\hline 49 & GS & 37.1 & 136.0 & 37.3 & 139.0 & 40.0 & 151.1 & 42.0 & 170.8 \\
\hline 50 & GS & 25.9 & 143.0 & 26.7 & 147.0 & 28.2 & 154.4 & 28.8 & 148.6 \\
\hline 51 & GS & 20.6 & 122.0 & 20.9 & 126.0 & 21.2 & 133.9 & 21.1 & 133.4 \\
\hline 52 & GS & $* * *$ & $* * *$ & $* * *$ & $* * *$ & $* * *$ & $* * *$ & $* * *$ & $* * *$ \\
\hline 53 & GS & 33.6 & 140.0 & 34.4 & 143.0 & 36.0 & 174.6 & 37.6 & 181.2 \\
\hline 54 & GS & 25.9 & 143.0 & 26.5 & 158.0 & 27.3 & 154.4 & 27.6 & 158.5 \\
\hline 55 & GS & 17.5 & 146.0 & 17.6 & 147.0 & 17.6 & 134.5 & 17.4 & 127.8 \\
\hline 56 & GS & 12.1 & 60.0 & 12.1 & 66.0 & 12.5 & 70.0 & 12.3 & 57.2 \\
\hline 57 & GS & 33.1 & 160.0 & 34.2 & 161.0 & 36.1 & 176.5 & 36.7 & 186.7 \\
\hline 58 & GS & 9.6 & 76.0 & 9.9 & 78.0 & 9.7 & 92.0 & 9.5 & 88.7 \\
\hline 59 & GS & 30.5 & 149.0 & 31.5 & 168.0 & 33.0 & 192.1 & 34.3 & 173.4 \\
\hline 60 & GS & 15.1 & 104.0 & 15.5 & 117.0 & 16.5 & 119.9 & 15.6 & 107.6 \\
\hline 61 & GS & $* * *$ & $* * *$ & $* * *$ & $* * *$ & $* * *$ & $* * *$ & $* * *$ & $* * *$ \\
\hline 62 & GS & 30.4 & 134.0 & 31.3 & 137.0 & 32.5 & 157.5 & 34.1 & 164.6 \\
\hline 63 & GS & 17.0 & 68.0 & 17.0 & 68.0 & 17.3 & 69.6 & 17.1 & $* * *$ \\
\hline 64 & GS & 12.0 & 62.0 & 12.1 & 63.0 & 12.0 & 63.6 & 11.9 & 65.2 \\
\hline 65 & GS & 32.9 & 145.0 & 33.3 & 147.0 & 34.1 & 160.0 & 35.9 & 164.1 \\
\hline 66 & GS & 34.1 & 150.0 & 35.2 & 158.0 & 36.7 & 173.3 & 38.3 & 175.2 \\
\hline 67 & GS & $* * *$ & $* * *$ & $* * *$ & $* * *$ & $* * *$ & $* * *$ & $* * *$ & $* * *$ \\
\hline 68 & GS & $* * *$ & $* * *$ & $* * *$ & $* * *$ & $* * *$ & $* * *$ & $* * *$ & $* * *$ \\
\hline 69 & WF & $* * *$ & $* * *$ & $* * *$ & $* * *$ & 1.4 & 8.7 & 2.0 & 11.4 \\
\hline 70 & WF & $* * *$ & $* * *$ & $* * *$ & $* * *$ & 1.1 & 7.0 & 2.7 & 8.8 \\
\hline 71 & WF & $* * *$ & $* * *$ & $* * *$ & $* * *$ & 1.0 & 9.1 & 1.4 & 10.8 \\
\hline 72 & WF & $* * *$ & $* * *$ & $* * *$ & $* * *$ & $* * *$ & $* * *$ & 1.6 & 10.1 \\
\hline 73 & GS & $* * *$ & $* * *$ & $* * *$ & $* * *$ & $* * *$ & $* * *$ & 2.7 & $* * *$ \\
\hline 74 & GS & $* * *$ & $* * *$ & $* * *$ & $* * *$ & $* * *$ & $* * *$ & 1.9 & $* * *$ \\
\hline AVG. & & 16.5 & 80.1 & 16.9 & 84.7 & 16.8 & 84.9 & 16.6 & 88.2 \\
\hline Trees & $36,52,61$, & 7,68 & & Dead in & 1994 & & & & \\
\hline Trees & $9,10,18,2$ & $36,42,4$ & & Broken & op in 20 & & & & \\
\hline Tree & $19,22,32$ & & & Bowed & Deforme & in 2001 & & & \\
\hline Tree & 36 & & & Is Alive & broken t & $\mathrm{p}$ in 200 & & & \\
\hline Tree & 54 & & & Forked & Top in 20 & & & & \\
\hline Tree & $69,70,71$ & & & Ingrow & in 2001 & & & & \\
\hline Trees & $9,16,20,5$ & 51,64 & & Broken & op in 20 & & & & \\
\hline Trees & 27,63 & & & Dead/S & anding in & 2009 & & & \\
\hline Trees & $18,23,33$ & 7,55,58, & 9,60 & Deform & dop in & 2009 & & & \\
\hline Tree & 48 & & & Dead tc & in 2009 & & & & \\
\hline Tree & 56 & & & Broken & Dead tor & in 2009 & & & \\
\hline Tree & 72 & & & Ingrow & in 2009 & & & & \\
\hline Trees & 73,74 & & & Dead/S & anding ir & 2009, n & t & $\mathrm{d}$ in 19 & 1 or? \\
\hline
\end{tabular}

Page 123 
MHDSF Young-Growth Giant Sequoia Management Strategies Study 2009 - Overstory Summary Growth Data (39.37 ft. (12m) Plot)

$\begin{array}{lllll}\text { Stand: Frasier Mill } & \text { Treatment: Control } & \text { Measured By: } & 1989 & \text { Bates, Masser, Johannis } \\ & & \text { Measured By: } & 1994 & \text { ??? } \\ \text { Block: C } & \text { Plot \# :2 } & \text { Measured By: } & 2001 & \text { Roller, McLoed } \\ & & \text { Measured By: } & 2009 \text { Soderlund, Ricchiazzi }\end{array}$

\begin{tabular}{|c|c|c|c|c|c|c|c|c|c|c|c|c|c|}
\hline \multirow[b]{2}{*}{ Tree \# } & \multirow[b]{2}{*}{ Species } & \multicolumn{2}{|c|}{$\begin{array}{c}\text { Change } \\
\text { 1989-1994 }\end{array}$} & \multicolumn{2}{|c|}{$\begin{array}{c}\text { Change } \\
\text { 1994-2001 }\end{array}$} & \multicolumn{2}{|c|}{$\begin{array}{c}\text { Change } \\
\text { 1989-2001 }\end{array}$} & \multicolumn{2}{|c|}{$\begin{array}{c}\text { Change } \\
\text { 1994-2009 }\end{array}$} & \multicolumn{2}{|c|}{$\begin{array}{c}\text { Change } \\
\text { 2001-2009 }\end{array}$} & \multicolumn{2}{|c|}{$\begin{array}{c}\text { Change } \\
\text { 1989-2009 }\end{array}$} \\
\hline & & $\mathrm{DBH}$ & Height & DBH & Height & $\mathrm{DBH}$ & Height & $\mathrm{DBH}$ & Height & DBH & Height & DBH & Height \\
\hline 1 & WF & 0.4 & 2.0 & 0.5 & 3.6 & 0.9 & 5.6 & 1.1 & 5.9 & 0.6 & 2.3 & 1.5 & 7.9 \\
\hline 2 & WF & 0.1 & 1.0 & 0.0 & 4.5 & 0.1 & 5.5 & 0.4 & 4.1 & 0.4 & -0.4 & 0.5 & 5.1 \\
\hline 3 & GS & 1.2 & 3.0 & 1.3 & 6.5 & 2.5 & 9.5 & 3.6 & 21.8 & 2.3 & 15.3 & 4.8 & 24.8 \\
\hline 4 & WF & 0.1 & 1.0 & 0.0 & 2.9 & 0.1 & 3.9 & 0.1 & 4.3 & 0.1 & 1.4 & 0.2 & 5.3 \\
\hline 5 & GS & 0.7 & 2.0 & 0.9 & 6.9 & 1.6 & 8.9 & 1.5 & 13.3 & 0.6 & 6.4 & 2.2 & 15.3 \\
\hline 6 & GS & 0.8 & 3.0 & 1.5 & 13.2 & 2.3 & 16.2 & 3.1 & 22.5 & 1.6 & 9.3 & 3.9 & 25.5 \\
\hline 7 & GS & 1.1 & 3.0 & 1.2 & 5.0 & 2.3 & 8.0 & 2.1 & 16.0 & 0.9 & 11.0 & 3.2 & 19.0 \\
\hline 8 & GS & 0.6 & 13.0 & 2.6 & -4.2 & 3.2 & 8.8 & 3.7 & 7.7 & 1.1 & 11.9 & 4.3 & 20.7 \\
\hline 9 & WF & 0.2 & 7.0 & 0.3 & -4.3 & 0.5 & 2.7 & 0.4 & -3.8 & 0.1 & 0.5 & 0.6 & 3.2 \\
\hline 10 & GS & 0.6 & 3.0 & 0.5 & -2.8 & 1.1 & 0.2 & 1.0 & 0.9 & 0.5 & 3.7 & 1.6 & 3.9 \\
\hline 11 & GS & 0.5 & 0.0 & 0.7 & 1.6 & 1.2 & 1.6 & 1.5 & 28.4 & 0.8 & 26.8 & 2.0 & 28.4 \\
\hline 12 & WF & 1.2 & 1.0 & 0.9 & 1.1 & 2.1 & 2.1 & 1.3 & 3.0 & 0.4 & 1.9 & 2.5 & 4.0 \\
\hline 13 & GS & 0.0 & 0.0 & 0.1 & -7.5 & 0.1 & -7.5 & 0.0 & -0.7 & -0.1 & 6.8 & 0.0 & -0.7 \\
\hline 14 & GS & 0.2 & 10.0 & 0.4 & -10.9 & 0.6 & -0.9 & 0.4 & 2.0 & 0.0 & 12.9 & 0.6 & 12.0 \\
\hline 15 & GS & 0.3 & 2.0 & 0.1 & -4.6 & 0.4 & -2.6 & 0.3 & 0.1 & 0.2 & 4.7 & 0.6 & 2.1 \\
\hline 16 & GS & 0.7 & 3.0 & 0.4 & -3.0 & 1.1 & 0.0 & -0.1 & 5.3 & -0.5 & 8.3 & 0.6 & 8.3 \\
\hline 17 & GS & 0.1 & 1.0 & 0.2 & -5.1 & 0.3 & -4.1 & 0.1 & 2.4 & -0.1 & 7.5 & 0.2 & 3.4 \\
\hline 18 & GS & 0.2 & 5.0 & 0.4 & -7.0 & 0.6 & -2.0 & 0.2 & -2.1 & -0.2 & 4.9 & 0.4 & 2.9 \\
\hline 19 & GS & 0.0 & 4.0 & 0.5 & -5.2 & 0.5 & -1.2 & 0.2 & -2.2 & -0.3 & 3.0 & 0.2 & 1.8 \\
\hline 20 & GS & 0.0 & 0.0 & 0.0 & 16.2 & 0.0 & 16.2 & -0.3 & 7.8 & -0.3 & -8.4 & -0.3 & 7.8 \\
\hline 21 & GS & 0.1 & 30.0 & 0.0 & -29.2 & 0.1 & 0.8 & -0.2 & -29.9 & -0.2 & -0.7 & -0.1 & 0.1 \\
\hline 22 & GS & 0.1 & 3.0 & 0.0 & -2.2 & 0.1 & 0.8 & -0.1 & -2.4 & -0.1 & -0.2 & 0.0 & 0.6 \\
\hline 23 & GS & 0.0 & 6.0 & 0.1 & -0.9 & 0.1 & 5.1 & -0.1 & -10.8 & -0.2 & -9.9 & -0.1 & -4.8 \\
\hline 24 & GS & 1.1 & 3.0 & 1.2 & 11.7 & 2.3 & 14.7 & 3.0 & 20.9 & 1.8 & 9.2 & 4.1 & 23.9 \\
\hline 25 & GS & 1.4 & 3.0 & 1.8 & 21.2 & 3.2 & 24.2 & 4.4 & 34.5 & 2.6 & 13.3 & 5.8 & 37.5 \\
\hline 26 & GS & 0.4 & 2.0 & 0.3 & 3.7 & 0.7 & 5.7 & 0.2 & 7.8 & -0.1 & 4.1 & 0.6 & 9.8 \\
\hline 27 & GS & 0.0 & 4.0 & 0.1 & -6.5 & 0.1 & -2.5 & -0.1 & $* * *$ & -0.2 & $* * *$ & -0.1 & $* * *$ \\
\hline 28 & GS & 1.1 & 19.0 & 1.5 & 15.3 & 2.6 & 34.3 & 2.8 & 22.8 & 1.3 & 7.5 & 3.9 & 41.8 \\
\hline 29 & GS & 0.4 & 4.0 & 0.2 & -4.6 & 0.6 & -0.6 & 0.6 & 0.2 & 0.4 & 4.8 & 1.0 & 4.2 \\
\hline 30 & GS & 0.0 & 0.0 & 0.0 & 0.7 & 0.0 & 0.7 & 0.0 & 0.9 & 0.0 & 0.2 & 0.0 & 0.9 \\
\hline 31 & GS & 0.3 & 19.0 & 0.3 & -18.2 & 0.6 & 0.8 & 0.2 & -12.0 & -0.1 & 6.2 & 0.5 & 7.0 \\
\hline 32 & GS & 0.0 & 10.0 & 0.1 & -2.3 & 0.1 & 7.7 & -0.1 & -5.7 & -0.2 & -3.4 & -0.1 & 4.3 \\
\hline 33 & GS & 0.1 & 1.0 & 0.0 & 7.2 & 0.1 & 8.2 & -0.2 & 2.9 & -0.2 & -4.3 & -0.1 & 3.9 \\
\hline 34 & GS & 1.3 & 3.0 & 0.6 & 20.9 & 1.9 & 23.9 & 1.6 & 32.3 & 1.0 & 11.4 & 2.9 & 35.3 \\
\hline 35 & WF & 0.3 & 1.0 & 0.2 & 3.2 & 0.5 & 4.2 & 1.5 & 3.7 & 1.3 & 0.5 & 1.8 & 4.7 \\
\hline 36 & GS & $* * *$ & $* * *$ & $* * *$ & $* * *$ & $* * *$ & $* * *$ & $* * *$ & $* * *$ & -0.1 & 2.1 & $* * *$ & $* * *$ \\
\hline 37 & GS & 1.5 & 2.0 & 2.1 & 14.6 & 3.6 & 16.6 & 3.3 & 30.9 & 1.2 & 16.3 & 4.8 & 32.9 \\
\hline 38 & GS & 0.1 & 0.0 & 0.2 & 5.2 & 0.3 & 5.2 & 0.0 & 1.7 & -0.2 & -3.5 & 0.1 & 1.7 \\
\hline 39 & GS & 0.4 & 1.0 & 0.3 & 2.3 & 0.7 & 3.3 & 0.5 & 2.2 & 0.2 & -0.1 & 0.9 & 3.2 \\
\hline 40 & GS & 0.9 & 3.0 & 1.6 & 40.9 & 2.5 & 43.9 & 3.2 & 46.7 & 1.6 & 5.8 & 4.1 & 49.7 \\
\hline 41 & GS & 1.3 & 2.0 & 3.3 & 13.4 & 4.6 & 15.4 & 4.8 & 26.0 & 1.5 & 12.6 & 6.1 & 28.0 \\
\hline 42 & GS & 0.1 & 1.0 & 0.1 & 2.1 & 0.2 & 3.1 & 0.1 & 0.9 & 0.0 & -1.2 & 0.2 & 1.9 \\
\hline 43 & GS & 0.9 & 3.0 & 0.8 & 18.9 & 1.7 & 21.9 & 1.2 & 32.0 & 0.4 & 13.1 & 2.1 & 35.0 \\
\hline 44 & GS & 0.5 & 2.0 & 0.5 & 0.9 & 1.0 & 2.9 & 0.7 & 1.9 & 0.2 & 1.0 & 1.2 & 3.9 \\
\hline
\end{tabular}


MHDSF Young-Growth Giant Sequoia Management Strategies Study 2009 - Overstory Summary Growth Data (39.37 ft. (12m) Plot)

$\begin{array}{lllll}\text { Stand: Frasier Mill } & \text { Treatment: Control } & \text { Measured By: } & 1989 & \text { Bates, Masser, Johannis } \\ & & \text { Measured By: } & 1994 & \text { ??? } \\ \text { Block: C } & \text { Plot \# :2 } & \text { Measured By: } & 2001 & \text { Roller, McLoed } \\ & & \text { Measured By: } & 2009 & \text { Soderlund, Ricchiazzi }\end{array}$

\begin{tabular}{|c|c|c|c|c|c|c|c|c|c|c|c|c|c|}
\hline \multirow[b]{2}{*}{ Tree \# } & \multirow[b]{2}{*}{ Species } & \multicolumn{2}{|c|}{$\begin{array}{c}\text { Change } \\
\text { 1989-1994 }\end{array}$} & \multicolumn{2}{|c|}{$\begin{array}{c}\text { Change } \\
\text { 1994-2001 }\end{array}$} & \multicolumn{2}{|c|}{$\begin{array}{c}\text { Change } \\
\text { 1989-2001 }\end{array}$} & \multicolumn{2}{|c|}{$\begin{array}{c}\text { Change } \\
\text { 1994-2009 }\end{array}$} & \multicolumn{2}{|c|}{$\begin{array}{c}\text { Change } \\
\text { 2001-2009 }\end{array}$} & \multicolumn{2}{|c|}{$\begin{array}{l}\text { Change } \\
\text { 1989-2009 }\end{array}$} \\
\hline & & $\mathrm{DBH}$ & Height & DBH & Height & $\mathrm{DBH}$ & Height & $\mathrm{DBH}$ & Height & DBH & Height & DBH & Height \\
\hline 45 & "WF & " 1.0 & 20 & 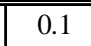 & 2.6 & 1.1 & 4.6 & 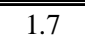 & 3.8 & 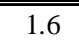 & 1.2 & 2.7 & 5.8 \\
\hline 46 & GS & 0.5 & 7.0 & 0.6 & 6.1 & 1.1 & 13.1 & 1.3 & 18.5 & 0.7 & 12.4 & 1.8 & 25.5 \\
\hline 47 & GS & 0.1 & 8.0 & 1.2 & 5.3 & 1.3 & 13.3 & 0.2 & -1.8 & -1.0 & -7.1 & 0.3 & 6.2 \\
\hline 48 & GS & 0.0 & 1.0 & 0.0 & -1.3 & 0.0 & -0.3 & 0.0 & -1.1 & 0.0 & 0.2 & 0.0 & -0.1 \\
\hline 49 & GS & 0.2 & 3.0 & 2.7 & 12.1 & 2.9 & 15.1 & 4.7 & 31.8 & 2.0 & 19.7 & 4.9 & 34.8 \\
\hline 50 & GS & 0.8 & 4.0 & 1.5 & 7.4 & 2.3 & 11.4 & 2.1 & 1.6 & 0.6 & -5.8 & 2.9 & 5.6 \\
\hline 51 & GS & 0.3 & 4.0 & 0.3 & 7.9 & 0.6 & 11.9 & 0.2 & 7.4 & -0.1 & -0.5 & 0.5 & 11.4 \\
\hline 52 & GS & $* * *$ & $* * *$ & $* * *$ & $* * *$ & $* * *$ & $* * *$ & $* * *$ & $* * *$ & $* * *$ & $* * *$ & $* * *$ & $* * *$ \\
\hline 53 & GS & 0.8 & 3.0 & 1.6 & 31.6 & 2.4 & 34.6 & 3.2 & 38.2 & 1.6 & 6.6 & 4.0 & 41.2 \\
\hline 54 & GS & 0.6 & 15.0 & 0.8 & -3.6 & 1.4 & 11.4 & 1.1 & 0.5 & 0.3 & 4.1 & 1.7 & 15.5 \\
\hline 55 & GS & 0.1 & 1.0 & 0.0 & -12.5 & 0.1 & -11.5 & -0.2 & -19.2 & -0.2 & -6.7 & -0.1 & -18.2 \\
\hline 56 & GS & 0.0 & 6.0 & 0.4 & 4.0 & 0.4 & 10.0 & 0.2 & -8.8 & -0.2 & -12.8 & 0.2 & -2.8 \\
\hline 57 & GS & 1.1 & 1.0 & 1.9 & 15.5 & 3.0 & 16.5 & 2.5 & 25.7 & 0.6 & 10.2 & 3.6 & 26.7 \\
\hline 58 & GS & 0.3 & 2.0 & -0.2 & 14.0 & 0.1 & 16.0 & -0.4 & 10.7 & -0.2 & -3.3 & -0.1 & 12.7 \\
\hline 59 & GS & 1.0 & 19.0 & 1.5 & 24.1 & 2.5 & 43.1 & 2.8 & 5.4 & 1.3 & -18.7 & 3.8 & 24.4 \\
\hline 60 & GS & 0.4 & 13.0 & 1.0 & 2.9 & 1.4 & 15.9 & 0.1 & -9.4 & -0.9 & -12.3 & 0.5 & 3.6 \\
\hline 61 & GS & $* * *$ & $* * *$ & $* * *$ & $* * *$ & $* * *$ & $* * *$ & $* * *$ & $* * *$ & $* * *$ & $* * *$ & $* * *$ & $* * *$ \\
\hline 62 & GS & 0.9 & 3.0 & 1.2 & 20.5 & 2.1 & 23.5 & 2.8 & 27.6 & 1.6 & 7.1 & 3.7 & 30.6 \\
\hline 63 & GS & 0.0 & 0.0 & 0.3 & 1.6 & 0.3 & 1.6 & 0.1 & $* * *$ & -0.2 & $* * *$ & 0.1 & $* * *$ \\
\hline 64 & GS & 0.1 & 1.0 & -0.1 & 0.6 & 0.0 & 1.6 & -0.2 & 2.2 & -0.1 & 1.6 & -0.1 & 3.2 \\
\hline 65 & GS & 0.4 & 2.0 & 0.8 & 13.0 & 1.2 & 15.0 & 2.6 & 17.1 & 1.8 & 4.1 & 3.0 & 19.1 \\
\hline 66 & GS & 1.1 & 8.0 & 1.5 & 15.3 & 2.6 & 23.3 & 3.1 & 17.2 & 1.6 & 1.9 & 4.2 & 25.2 \\
\hline 67 & GS & $* * *$ & $* * *$ & $* * *$ & $* * *$ & $* * *$ & $* * *$ & $* * *$ & $* * *$ & $* * *$ & $* * *$ & $* * *$ & $* * *$ \\
\hline 68 & GS & $* * *$ & $* * *$ & $* * *$ & $* * *$ & $* * *$ & $* * *$ & $* * *$ & $* * *$ & $* * *$ & $* * *$ & $* * *$ & $* * *$ \\
\hline 69 & WF & $* * *$ & $* * *$ & $* * *$ & $* * *$ & $* * *$ & $* * *$ & $* * *$ & $* * *$ & 0.6 & 2.7 & $* * *$ & $* * *$ \\
\hline 70 & WF & $* * *$ & $* * *$ & $* * *$ & $* * *$ & $* * *$ & $* * *$ & $* * *$ & $* * *$ & 1.6 & 1.8 & $* * *$ & $* * *$ \\
\hline 71 & WF & $* * *$ & $* * *$ & $* * *$ & $* * *$ & $* * *$ & $* * *$ & $* * *$ & $* * *$ & 0.4 & 1.7 & $* * *$ & $* * *$ \\
\hline 72 & WF & $* * *$ & $* * *$ & $* * *$ & $* * *$ & $* * *$ & $* * *$ & $* * *$ & $* * *$ & $* * *$ & $* * *$ & $* * *$ & $* * *$ \\
\hline 73 & GS & $* * *$ & $* * *$ & $* * *$ & $* * *$ & $* * *$ & $* * *$ & $* * *$ & $* * *$ & $* * *$ & $* * *$ & $* * *$ & $* * *$ \\
\hline 74 & GS & $* * *$ & $* * *$ & $* * *$ & $* * *$ & $* * *$ & $* * *$ & $* * *$ & $* * *$ & $* * *$ & $* * *$ & $* * *$ & $* * *$ \\
\hline AVG. & & 0.5 & 4.6 & 0.7 & 4.6 & 1.2 & 9.2 & 1.2 & 8.4 & 0.5 & 3.4 & 1.7 & 13.1 \\
\hline Trees & $36,52,61,6$ & 7,68 & & Dead il & 1994 & & & & & & & & \\
\hline Trees & $9,10,18,21$ & ,36,42,48 & 3,63 & Broken & top in 20 & & & & & & & & \\
\hline Tree & $19,22,32$ & & & Bowed & Deforme & $\mathrm{d}$ in 2001 & & & & & & & \\
\hline Tree & 36 & & & Is Alive & broken t & op in 200 & & & & & & & \\
\hline Tree & 54 & & & Forked & Гор in 20 & & & & & & & & \\
\hline Tree & $69,70,71$ & & & Ingrow & h in 2001 & & & & & & & & \\
\hline Trees & $9,16,20,50$ & $, 51,64$ & & Broken & top in 20 & & & & & & & & \\
\hline Trees & 27,63 & & & Dead/s & anding in & 2009 & & & & & & & \\
\hline Trees & $18,23,33,4$ & 7,55,58,5 & 59,60 & Deforn & ed top in & 2009 & & & & & & & \\
\hline Tree & 48 & & & Dead t & $p$ in 2009 & & & & & & & & \\
\hline Tree & 56 & & & Broken & Dead top & in 2009 & & & & & & & \\
\hline Tree & 72 & & & Ingrow & h in 2009 & & & & & & & & \\
\hline Trees & 73,74 & & & Dead/s & anding in & 2009, no & t recorde & $d$ in 19 & 4 or 200 & data & & & \\
\hline
\end{tabular}


MHDSF Young-Growth Giant Sequoia Management Strategies Study 2009 - Overstory Summary Data (39.37 ft. (12m) Plot)

$\begin{array}{lllll}\text { Stand: Headquarters } & \text { Treatment: Thinned } & \text { Measured By: } & 1989 & \text { ??? } \\ & & \text { Measured By: } & 1994 & \text { Ganz } \\ \text { Block: A } & \text { Plot \# : } 1 & \text { Measured By: } & 2001 & \text { Roller, Kong } \\ & & \text { Measured By: } & 2009 & \text { Soderlund, Estrada }\end{array}$

\begin{tabular}{|c|c|c|c|c|c|c|c|c|c|}
\hline \multirow[b]{2}{*}{ Tree \# } & \multirow[b]{2}{*}{ Species } & \multicolumn{2}{|c|}{1989 Data } & \multicolumn{2}{|c|}{1994 Data } & \multicolumn{2}{|c|}{2001 Data } & \multicolumn{2}{|c|}{2009 Data } \\
\hline & & $\mathrm{DBH}$ & Height & DBH & Height & $\mathrm{DBH}$ & Height & DBH & Height \\
\hline 11 & GS & 33.7 & 112.0 & 37.5 & 126.0 & 441.8 & 136.8 & 50.5 & 145.5 \\
\hline 12 & GS & 24.4 & 103.0 & 27.0 & 115.0 & 33.1 & 128.8 & 39.1 & 145.2 \\
\hline 13 & GS & 25.3 & 103.0 & 28.6 & 119.0 & 33.3 & 133.6 & 39.0 & 139.6 \\
\hline 14 & IC & 3.3 & 14.0 & 3.8 & 15.0 & 4.5 & 18.6 & 5.2 & 22.2 \\
\hline 15 & GS & 24.4 & 98.0 & 26.8 & 112.0 & 30.4 & 116.1 & 33.7 & 130.4 \\
\hline 16 & IC & 0.3 & 5.0 & 0.9 & 8.0 & 2.5 & 13.0 & 3.9 & 22.6 \\
\hline 17 & GS & 0.8 & 8.0 & 1.3 & 8.0 & 1.7 & 10.9 & 2.4 & 15.4 \\
\hline 18 & GS & 23.4 & 113.0 & 26.9 & 123.0 & 30.1 & 141.2 & 35.2 & 156.3 \\
\hline 19 & IC & $* * *$ & $* * *$ & $* * *$ & $* * *$ & 1.5 & 9.1 & 2.5 & 13.7 \\
\hline 20 & IC & $* * *$ & $* * *$ & $* * *$ & $* * *$ & 1.3 & 9.1 & 2.4 & 14.2 \\
\hline 21 & WF & $* * *$ & $* * *$ & $* * *$ & $* * *$ & 1.8 & 11.4 & 4.1 & 16.5 \\
\hline 22 & GS & $* * *$ & $* * *$ & $* * *$ & $* * *$ & 29.7 & 149.0 & 35.1 & 144.8 \\
\hline 23 & IC & $* * *$ & $* * *$ & $* * *$ & $* * *$ & $* * *$ & $* * *$ & 2.9 & 15.3 \\
\hline 24 & WF & $* * *$ & $* * *$ & $* * *$ & $* * *$ & $* * *$ & $* * *$ & 1.3 & 9.0 \\
\hline 25 & WF & $* * *$ & $* * *$ & $* * *$ & $* * *$ & $* * *$ & $* * *$ & 1.4 & 10.2 \\
\hline 26 & WF & $* * *$ & $* * *$ & $* * *$ & $* * *$ & $* * *$ & $* * *$ & 2.1 & 11.9 \\
\hline 27 & WF & $* * *$ & $* * *$ & $* * *$ & $* * *$ & $* * *$ & $* * *$ & 1.4 & 8.8 \\
\hline 28 & WF & $* * *$ & $* * *$ & $* * *$ & $* * *$ & $* * *$ & $* * *$ & 2.4 & 13.4 \\
\hline AVG. & & 17.0 & 69.5 & 19.1 & 78.3 & 17.6 & 73.1 & 14.7 & 57.5 \\
\hline Trees & \multicolumn{3}{|l|}{$19,20,21$} & \multicolumn{4}{|c|}{ Ingrowth in 2001} & & \\
\hline Tree & \multicolumn{2}{|c|}{22} & & \multirow{2}{*}{\multicolumn{4}{|c|}{$\begin{array}{l}\text { Not previously mea } \\
\text { Ingrowth in } 2009\end{array}$}} & 1994. & Measure \\
\hline Trees & $23,24,25,2$ & $6,27,28$ & & & & & & & \\
\hline
\end{tabular}

Page 126 
MHDSF Young-Growth Giant Sequoia Management Strategies Study 2009 - Overstory Summary Data (39.37 ft. (12m) Plot)

$\begin{array}{lllll}\text { Stand: Headquarters } & \text { Treatment: Thinned } & \text { Measured By: } & 1989 & \text { ??? } \\ & & \text { Measured By: } & 1994 & \text { Ganz } \\ \text { Block: A } & \text { Plot \# :1 } & \text { Measured By: } & 2001 \text { Roller, Kong } \\ & & \text { Measured By: } & 2009 \text { Soderlund, Estrada }\end{array}$

\begin{tabular}{|c|c|c|c|c|c|c|c|c|c|c|c|c|c|}
\hline \multirow[b]{2}{*}{ Tree \# } & \multirow[b]{2}{*}{ Species } & \multicolumn{2}{|c|}{$\begin{array}{c}\text { Change } \\
\text { 1989-1994 }\end{array}$} & \multicolumn{2}{|c|}{$\begin{array}{c}\text { Change } \\
\text { 1994-2001 }\end{array}$} & \multicolumn{2}{|c|}{$\begin{array}{c}\text { Change } \\
1989-2001\end{array}$} & \multicolumn{2}{|c|}{$\begin{array}{c}\text { Change } \\
\text { 1994-2009 }\end{array}$} & \multicolumn{2}{|c|}{$\begin{array}{c}\text { Change } \\
\text { 2001-2009 }\end{array}$} & \multicolumn{2}{|c|}{$\begin{array}{c}\text { Change } \\
\text { 1989-2009 }\end{array}$} \\
\hline & & $\mathrm{DBH}$ & Height & $\mathrm{DBH}$ & Height & $\mathrm{DBH}$ & Height & DBH & Height & $\mathrm{DBH}$ & Height & $\mathrm{DBH}$ & Height \\
\hline 11 & GS & 3.8 & 14.0 & 4.3 & 10.8 & 8.1 & 24.8 & 13.0 & 19.5 & 8.7 & 8.7 & 16.8 & 33.5 \\
\hline 12 & GS & 2.6 & 12.0 & 6.1 & 13.8 & 8.7 & 25.8 & 12.1 & 30.2 & 6.0 & 16.4 & 14.7 & 42.2 \\
\hline 13 & GS & 3.3 & 16.0 & 4.7 & 14.6 & 8.0 & 30.6 & 10.4 & 20.6 & 5.7 & 6.0 & 13.7 & 36.6 \\
\hline 14 & IC & 0.5 & 1.0 & 0.7 & 3.6 & 1.2 & 4.6 & 1.4 & 7.2 & 0.7 & 3.6 & 1.9 & 8.2 \\
\hline 15 & GS & 2.4 & 14.0 & 3.6 & 4.1 & 6.0 & 18.1 & 6.9 & 18.4 & 3.3 & 14.3 & 9.3 & 32.4 \\
\hline 16 & IC & 0.6 & 3.0 & 1.6 & 5.0 & 2.2 & 8.0 & 3.0 & 14.6 & 1.4 & 9.6 & 3.6 & 17.6 \\
\hline 17 & GS & 0.5 & 0.0 & 0.4 & 2.9 & 0.9 & 2.9 & 1.1 & 7.4 & 0.7 & 4.5 & 1.6 & 7.4 \\
\hline 18 & GS & 3.5 & 10.0 & 3.2 & 18.2 & 6.7 & 28.2 & 8.3 & 33.3 & 5.1 & 15.1 & 11.8 & 43.3 \\
\hline 19 & IC & $* * *$ & $* * *$ & $* * *$ & $* * *$ & $* * *$ & $* * *$ & $* * *$ & $* * *$ & 1.0 & 4.6 & $* * *$ & $* * *$ \\
\hline 20 & IC & $* * *$ & $* * *$ & $* * *$ & $* * *$ & $* * *$ & $* * *$ & $* * *$ & $* * *$ & 1.1 & 5.1 & $* * *$ & $* * *$ \\
\hline 21 & WF & $* * *$ & $* * *$ & $* * *$ & $* * *$ & $* * *$ & $* * *$ & $* * *$ & $* * *$ & 2.3 & 5.1 & $* * *$ & $* * *$ \\
\hline 22 & GS & $* * *$ & $* * *$ & $* * *$ & $* * *$ & $* * *$ & $* * *$ & $* * *$ & $* * *$ & 5.4 & -4.2 & $* * *$ & $* * *$ \\
\hline 23 & IC & $* * *$ & $* * *$ & $* * *$ & $* * *$ & $* * *$ & $* * *$ & $* * *$ & $* * *$ & $* * *$ & $* * *$ & $* * *$ & $* * *$ \\
\hline 24 & WF & $* * *$ & $* * *$ & $* * *$ & $* * *$ & $* * *$ & $* * *$ & $* * *$ & $* * *$ & $* * *$ & $* * *$ & $* * *$ & $* * *$ \\
\hline 25 & WF & $* * *$ & $* * *$ & $* * *$ & $* * *$ & $* * *$ & $* * *$ & $* * *$ & $* * *$ & $* * *$ & $* * *$ & $* * *$ & $* * *$ \\
\hline 26 & WF & $* * *$ & $* * *$ & $* * *$ & $* * *$ & $* * *$ & $* * *$ & $* * *$ & $* * *$ & $* * *$ & $* * *$ & $* * *$ & $* * *$ \\
\hline 27 & WF & $* * *$ & $* * *$ & $* * *$ & $* * *$ & $* * *$ & $* * *$ & $* * *$ & $* * *$ & $* * *$ & $* * *$ & $* * *$ & $* * *$ \\
\hline 28 & WF & $* * *$ & $* * *$ & $* * *$ & $* * *$ & $* * *$ & $* * *$ & $* * *$ & $* * *$ & $* * *$ & $* * *$ & $* * *$ & $* * *$ \\
\hline \multicolumn{2}{|l|}{ AVG. } & 2.2 & 8.8 & 3.1 & 9.1 & 5.2 & 17.9 & 7.0 & 18.9 & 3.5 & 7.4 & 9.2 & 27.7 \\
\hline Trees & \multicolumn{3}{|l|}{$19,20,21$} & \multicolumn{10}{|c|}{ Ingrowth in 2001} \\
\hline Tree & \multicolumn{3}{|c|}{22} & \multicolumn{10}{|c|}{ Not previously measured in 1989 or 1994 . Measured in 2001} \\
\hline Trees & \multicolumn{3}{|c|}{$23,24,25,26,27,28$} & \multicolumn{10}{|c|}{ Ingrowth in 2009} \\
\hline
\end{tabular}

Page 127 
MHDSF Young-Growth Giant Sequoia Management Strategies Study 2009 - Overstory Summary Data (39.37 ft. (12m) Plot)

$\begin{array}{lllll}\text { Stand: Headquarters } & \text { Treatment: Thinned/Burned } & \text { Measured By: } & 1989 \text { ??? } \\ & & \text { Measured By: } & 1994 \text { Ganz } \\ \text { Block: B } & \text { Plot \# :1 } & \text { Measured By: } & 2001 \text { Roller, Kong } \\ & & \text { Measured By: } & 2009 \text { Soderlund, Estrada }\end{array}$

\begin{tabular}{c|c|cc|cc|cc|cc|}
\cline { 3 - 9 } \multicolumn{1}{c|}{} & \multicolumn{2}{c|}{ 1989 Data } & \multicolumn{2}{c|}{ 1994 Data } & \multicolumn{2}{c|}{ 2001 Data } & \multicolumn{2}{c|}{ 2009 Data } \\
\multicolumn{1}{c|}{ Tree \# } & Species & DBH & Height & DBH & Height & DBH & Height & DBH & Height \\
\hline \hline 1 & GS & 14.2 & 67.0 & 15.4 & 85.0 & 18.8 & 96.6 & 21.2 & 109.7 \\
2 & GS & 16.5 & 82.0 & 17.0 & 94.0 & 17.2 & 86.3 & 19.9 & 90.7 \\
3 & GS & 14.8 & 73.0 & 16.3 & 89.0 & 19.9 & 90.9 & 23.7 & 107.5 \\
4 & GS & 25.7 & 93.0 & 27.2 & 105.0 & 30.2 & 111.6 & 34.5 & 125.5 \\
5 & GS & 15.5 & 84.0 & 16.8 & 97.0 & 18.9 & 104.9 & 21.5 & 119.3 \\
6 & GS & 19.0 & 92.0 & 20.5 & 109.0 & 23.1 & 113.9 & 26.3 & 130.6 \\
7 & GS & 25.4 & 97.0 & 27.4 & 116.0 & 30.0 & 116.6 & 34.1 & 133.7 \\
8 & GS & 19.4 & 88.0 & 20.3 & 96.0 & 22.7 & 105.9 & 27.2 & 124.5 \\
9 & GS & 21.5 & 112.0 & 23.7 & 120.0 & 27.6 & 122.7 & 33.1 & 139.5 \\
10 & GS & 27.1 & 99.0 & 29.7 & 111.0 & 33.7 & 116.8 & 41.1 & 131.5 \\
\hline \hline AVG. & & 19.9 & 88.7 & 21.4 & 102.2 & 24.2 & 106.6 & 28.3 & 121.3
\end{tabular}

2009 - Overstory Summary Growth Data (39.37 ft. (12m) Plot)

\begin{tabular}{|c|c|c|c|c|c|c|c|c|c|c|c|c|c|}
\hline \multirow[b]{2}{*}{ Tree \# } & \multirow[b]{2}{*}{ Species } & \multicolumn{2}{|c|}{$\begin{array}{c}\text { Change } \\
\text { 1989-1994 }\end{array}$} & \multicolumn{2}{|c|}{$\begin{array}{c}\text { Change } \\
1994-2001\end{array}$} & \multicolumn{2}{|c|}{$\begin{array}{c}\text { Change } \\
1989-2001\end{array}$} & \multicolumn{2}{|c|}{$\begin{array}{c}\text { Change } \\
1994-2009\end{array}$} & \multicolumn{2}{|c|}{$\begin{array}{c}\text { Change } \\
\text { 2001-2009 }\end{array}$} & \multicolumn{2}{|c|}{$\begin{array}{c}\text { Change } \\
1989-2009\end{array}$} \\
\hline & & DBH & Height & DBH & Height & DBH & Height & DBH & Height & $\mathrm{DBH}$ & Height & DBH & Height \\
\hline 1 & GS & 1.2 & 18.0 & 3.4 & 11.6 & 4.6 & 29.6 & 5.8 & 24.7 & 2.4 & "13.1 & 7.0 & $\begin{array}{l}42.7 \\
\end{array}$ \\
\hline 2 & GS & 0.5 & 12.0 & 0.2 & -7.7 & 0.7 & 4.3 & 2.9 & -3.3 & 2.7 & 4.4 & 3.4 & 8.7 \\
\hline 3 & GS & 1.5 & 16.0 & 3.6 & 1.9 & 5.1 & 17.9 & 7.4 & 18.5 & 3.8 & 16.6 & 8.9 & 34.5 \\
\hline 4 & GS & 1.5 & 12.0 & 3.0 & 6.6 & 4.5 & 18.6 & 7.3 & 20.5 & 4.3 & 13.9 & 8.8 & 32.5 \\
\hline 5 & GS & 1.3 & 13.0 & 2.1 & 7.9 & 3.4 & 20.9 & 4.7 & 22.3 & 2.6 & 14.4 & 6.0 & 35.3 \\
\hline 6 & GS & 1.5 & 17.0 & 2.6 & 4.9 & 4.1 & 21.9 & 5.8 & 21.6 & 3.2 & 16.7 & 7.3 & 38.6 \\
\hline 7 & GS & 2.0 & 19.0 & 2.6 & 0.6 & 4.6 & 19.6 & 6.7 & 17.7 & 4.1 & 17.1 & 8.7 & 36.7 \\
\hline 8 & GS & 0.9 & 8.0 & 2.4 & 9.9 & 3.3 & 17.9 & 6.9 & 28.5 & 4.5 & 18.6 & 7.8 & 36.5 \\
\hline 9 & GS & 2.2 & 8.0 & 3.9 & 2.7 & 6.1 & 10.7 & 9.4 & 19.5 & 5.5 & 16.8 & 11.6 & 27.5 \\
\hline 10 & GS & 2.6 & 12.0 & 4.0 & 5.8 & 6.6 & 17.8 & 11.4 & 20.5 & 7.4 & 14.7 & 14.0 & 32.5 \\
\hline$\overline{\text { AVG. }}$ & & 1.5 & 13.5 & 2.8 & 4.4 & 4.3 & 17.9 & 6.8 & $\begin{array}{l}19.1 \\
\end{array}$ & 4.1 & 14.6 & 8.4 & 32.6 \\
\hline
\end{tabular}

Page 128 
MHDSF Young-Growth Giant Sequoia Management Strategies Study 2009 - Overstory Summary Data (39.37 ft. (12m) Plot)

$\begin{array}{lllll}\text { Stand: Headquarters } & \text { Treatment: Control } & \text { Measured By: } & 1989 & \text { ??? } \\ & & \text { Measured By: } & 1994 & \text { Ganz } \\ \text { Block: C } & \text { Plot \# : } 1 & \text { Measured By: } & 2001 & \text { Roller, Kong } \\ & & \text { Measured By: } & 2009 \text { Soderlund, Estrada }\end{array}$

\begin{tabular}{|c|c|c|c|c|c|c|c|c|c|}
\hline \multirow[b]{2}{*}{ Tree \# } & \multirow[b]{2}{*}{ Species } & \multicolumn{2}{|c|}{1989 Data } & \multicolumn{2}{|c|}{1994 Data } & \multicolumn{2}{|c|}{2001 Data } & \multicolumn{2}{|c|}{2009 Data } \\
\hline & & $\mathrm{DBH}$ & Height & $\mathrm{DBH}$ & Height & $\mathrm{DBH}$ & Height & $\mathrm{DBH}$ & Height \\
\hline 35 & GS & 20.0 & 999.0 & 21.8 & 1116.0 & 23.4 & 122.9 & 27.4 & 133.8 \\
\hline 36 & GS & 20.0 & 100.0 & 21.1 & 113.0 & 22.5 & 113.9 & 25.4 & 125.4 \\
\hline 65 & GS & 20.0 & 90.0 & 20.7 & 105.0 & 21.5 & 102.0 & 23.0 & 120.2 \\
\hline 66 & GS & 12.7 & 97.0 & 13.4 & 99.0 & 13.9 & 112.5 & 15.1 & 126.5 \\
\hline 67 & GS & 21.6 & 102.0 & 23.0 & 111.0 & 24.5 & 114.3 & 27.5 & 129.0 \\
\hline 68 & GS & 17.1 & 94.0 & 18.1 & 110.0 & 19.0 & 119.9 & 20.6 & 132.4 \\
\hline 69 & GS & 4.4 & 22.0 & 4.5 & 18.0 & 4.5 & 24.4 & 4.4 & 24.0 \\
\hline 70 & GS & 13.0 & 77.0 & 13.5 & 79.0 & 13.6 & 82.4 & 14.2 & 79.3 \\
\hline 71 & GS & 6.0 & 35.0 & 6.4 & 36.0 & 6.4 & 39.1 & 6.6 & 38.8 \\
\hline 72 & GS & 12.9 & 74.0 & 13.9 & 83.0 & 14.8 & 93.9 & 17.6 & 122.5 \\
\hline 73 & GS & 7.2 & 18.0 & 7.6 & 19.0 & 7.5 & 19.3 & 7.6 & 22.3 \\
\hline 74 & GS & 13.8 & 80.0 & 15.3 & 94.0 & 17.3 & 121.0 & 19.4 & 126.3 \\
\hline 75 & IC & 18.8 & 69.0 & 19.1 & 78.0 & 19.5 & 87.0 & 20.2 & 88.6 \\
\hline 76 & GS & 9.7 & 68.0 & 10.4 & 75.0 & 10.6 & 88.0 & 11.7 & 90.7 \\
\hline 77 & SP & 13.2 & 103.0 & $* * *$ & $* * *$ & $* * *$ & $* * *$ & $* * *$ & $* * *$ \\
\hline 78 & GS & 19.8 & 102.0 & 21.2 & 111.0 & 23.1 & 122.0 & 26.6 & 137.8 \\
\hline 79 & & 9.6 & 65.0 & 10.0 & 7.0 & 10.3 & $* * *$ & 10.3 & $* * *$ \\
\hline 80 & GS & 24.3 & 100.0 & 26.2 & 108.0 & 27.2 & 132.2 & 29.7 & 139.6 \\
\hline 81 & GS & 7.4 & 36.0 & 7.8 & 39.0 & 7.8 & 36.6 & 7.9 & 36.4 \\
\hline 82 & GS & 11.2 & 87.0 & 11.6 & 94.0 & 11.5 & $* * *$ & 11.5 & $* * *$ \\
\hline 83 & GS & 28.5 & 107.0 & 30.8 & 119.0 & 34.1 & 138.8 & 37.9 & 150.4 \\
\hline 84 & IC & 0.6 & 7.0 & 0.6 & 7.0 & 1.4 & 9.5 & 1.7 & 10.0 \\
\hline 85 & GS & 28.9 & 90.0 & 30.8 & 101.0 & 33.5 & 123.1 & 36.6 & 132.7 \\
\hline 86 & GS & 27.1 & 106.0 & 29.0 & 119.0 & 30.9 & 135.0 & 34.3 & 150.5 \\
\hline 87 & IC & 8.0 & 32.0 & 8.7 & 36.0 & 9.0 & 31.7 & 9.4 & 37.6 \\
\hline 88 & GS & 4.5 & 20.0 & 4.8 & 18.0 & 4.6 & 18.5 & 4.6 & 20.8 \\
\hline 89 & & 3.0 & 18.0 & 3.1 & 17.0 & 3.0 & 12.0 & 3.1 & 15.1 \\
\hline 90 & GS & 5.2 & 12.0 & 5.3 & 13.0 & 5.1 & 12.3 & 5.1 & 20.9 \\
\hline 91 & GS & 12.8 & 60.0 & 13.4 & 65.0 & 13.6 & 69.8 & 13.6 & 67.7 \\
\hline 92 & GS & 8.1 & 33.0 & 8.4 & 38.0 & 8.4 & 34.5 & 8.4 & 37.5 \\
\hline 93 & GS & 31.4 & 102.0 & 33.3 & 114.0 & 34.0 & 120.3 & 39.3 & 144.5 \\
\hline 94 & GS & 26.5 & 105.0 & 27.8 & 118.0 & 29.6 & 136.7 & 33.5 & 142.3 \\
\hline 95 & GS & 25.3 & 108.0 & 26.9 & 123.0 & 27.2 & 129.7 & 31.1 & 138.8 \\
\hline 96 & GS & 11.1 & 63.0 & 11.4 & 69.0 & 11.3 & 62.1 & 11.6 & 62.6 \\
\hline 97 & IC & 22.0 & 74.0 & 22.3 & 81.0 & 22.5 & 82.0 & 24.3 & 98.6 \\
\hline 98 & SP & 12.7 & 85.0 & $* * *$ & $* * *$ & $* * *$ & $* * *$ & $* * *$ & $* * *$ \\
\hline 99 & GS & 3.9 & 22.0 & 4.1 & 22.0 & 4.1 & 23.2 & 4.1 & 22.2 \\
\hline 100 & GS & 3.1 & 15.0 & 3.3 & 15.0 & 3.3 & 16.6 & $* * *$ & $* * *$ \\
\hline 101 & GS & $* * *$ & $* * *$ & $* * *$ & $* * *$ & 12.4 & 48.2 & 13.4 & 49.2 \\
\hline 102 & WF & $* * *$ & $* * *$ & $* * *$ & $* * *$ & $* * *$ & $* * *$ & 1.2 & 8.6 \\
\hline 103 & WF & $* * *$ & $* * *$ & $* * *$ & $* * *$ & $* * *$ & $* * *$ & 1.9 & 11.1 \\
\hline AVG. & & 14.4 & 67.8 & 15.3 & 73.1 & 15.9 & 78.2 & 16.9 & 83.2 \\
\hline
\end{tabular}

Page 129 
MHDSF Young-Growth Giant Sequoia Management Strategies Study 2009 - Overstory Summary Data (39.37 ft. (12m) Plot)

$\begin{array}{ccll}\text { Stand: Headquarters } & \text { Treatment: Control } & \begin{array}{l}\text { Me } \\ \text { Me }\end{array} \\ \text { Block: C } & & \text { Plot \# :1 } & \text { Me } \\ & & & \\ & & & \\ \text { Tree } & 77 & \text { Dead in 1994 } \\ \text { Tree } & 98 & \text { Dead/Standing in 1994 } \\ \text { Trees } & 79,82 & \text { Dead/Standing in 2001 } \\ \text { Trees } & 89,90 & \text { Damaged/Deformed in 2001 } \\ \text { Trees } & 102,103 & \text { Ingrowth in 2009 } \\ \text { Trees } & 98,100 & \text { Dead/Missing in 2009 } \\ \text { Tree } & 90 & \text { Deformed/Bowed in 2009 } \\ \text { Trees } & 69,70,99 & \text { Deformed Top in 2009 }\end{array}$

Page 130 
MHDSF Young-Growth Giant Sequoia Management Strategies Study 2009 - Overstory Summary Growth Data (39.37 ft. (12m) Plot)

$\begin{array}{lllll}\text { Stand: Headquarters } & \text { Treatment: Control } & \text { Measured By: } & 1989 & \text { ??? } \\ & & \text { Measured By: } & 1994 & \text { Ganz } \\ \text { Block: C } & \text { Plot \# : } 1 & \text { Measured By: } & 2001 & \text { Roller, Kong } \\ & & \text { Measured By: } & 2009 \text { Soderlund, Estrada }\end{array}$

\begin{tabular}{|c|c|c|c|c|c|c|c|c|c|c|c|c|c|}
\hline \multirow[b]{2}{*}{ Tree \# } & \multirow[b]{2}{*}{ Species } & \multicolumn{2}{|c|}{$\begin{array}{c}\text { Change } \\
\text { 1989-1994 }\end{array}$} & \multicolumn{2}{|c|}{$\begin{array}{c}\text { Change } \\
\text { 1994-2001 }\end{array}$} & \multicolumn{2}{|c|}{$\begin{array}{c}\text { Change } \\
\text { 1989-2001 }\end{array}$} & \multicolumn{2}{|c|}{$\begin{array}{c}\text { Change } \\
\text { 1994-2009 }\end{array}$} & \multicolumn{2}{|c|}{$\begin{array}{c}\text { Change } \\
\text { 2001-2009 }\end{array}$} & \multicolumn{2}{|c|}{$\begin{array}{c}\text { Change } \\
\text { 1989-2009 }\end{array}$} \\
\hline & & $\mathrm{DBH}$ & Height & DBH & Height & $\mathrm{DBH}$ & Height & $\mathrm{DBH}$ & Height & $\mathrm{DBH}$ & Height & $\mathrm{DBH}$ & Height \\
\hline 35 & GS & 101.8 & 1717.0 & 1.6 & 6.9 & 3.4 & 23.9 & 5.6 & 17.8 & 4.0 & 10.9 & 7.4 & 34.8 \\
\hline 36 & GS & 1.1 & 13.0 & 1.4 & 0.9 & 2.5 & 13.9 & 4.3 & 12.4 & 2.9 & 11.5 & 5.4 & 25.4 \\
\hline 65 & GS & 0.7 & 15.0 & 0.8 & -3.0 & 1.5 & 12.0 & 2.3 & 15.2 & 1.5 & 18.2 & 3.0 & 30.2 \\
\hline 66 & GS & 0.7 & 2.0 & 0.5 & 13.5 & 1.2 & 15.5 & 1.7 & 27.5 & 1.2 & 14.0 & 2.4 & 29.5 \\
\hline 67 & GS & 1.4 & 9.0 & 1.5 & 3.3 & 2.9 & 12.3 & 4.5 & 18.0 & 3.0 & 14.7 & 5.9 & 27.0 \\
\hline 68 & GS & 1.0 & 16.0 & 0.9 & 9.9 & 1.9 & 25.9 & 2.5 & 22.4 & 1.6 & 12.5 & 3.5 & 38.4 \\
\hline 69 & GS & 0.1 & -4.0 & 0.0 & 6.4 & 0.1 & 2.4 & -0.1 & 6.0 & -0.1 & -0.4 & 0.0 & 2.0 \\
\hline 70 & GS & 0.5 & 2.0 & 0.1 & 3.4 & 0.6 & 5.4 & 0.7 & 0.3 & 0.6 & -3.1 & 1.2 & 2.3 \\
\hline 71 & GS & 0.4 & 1.0 & 0.0 & 3.1 & 0.4 & 4.1 & 0.2 & 2.8 & 0.2 & -0.3 & 0.6 & 3.8 \\
\hline 72 & GS & 1.0 & 9.0 & 0.9 & 10.9 & 1.9 & 19.9 & 3.7 & 39.5 & 2.8 & 28.6 & 4.7 & 48.5 \\
\hline 73 & GS & 0.4 & 1.0 & -0.1 & 0.3 & 0.3 & 1.3 & 0.0 & 3.3 & 0.1 & 3.0 & 0.4 & 4.3 \\
\hline 74 & GS & 1.5 & 14.0 & 2.0 & 27.0 & 3.5 & 41.0 & 4.1 & 32.3 & 2.1 & 5.3 & 5.6 & 46.3 \\
\hline 75 & IC & 0.3 & 9.0 & 0.4 & 9.0 & 0.7 & 18.0 & 1.1 & 10.6 & 0.7 & 1.6 & 1.4 & 19.6 \\
\hline 76 & GS & 0.7 & 7.0 & 0.2 & 13.0 & 0.9 & 20.0 & 1.3 & 15.7 & 1.1 & 2.7 & 2.0 & 22.7 \\
\hline 77 & SP & $* * *$ & $* * *$ & $* * *$ & $* * *$ & $* * *$ & $* * *$ & $* * *$ & $* * *$ & $* * *$ & $* * *$ & $* * *$ & $* * *$ \\
\hline 78 & GS & 1.4 & 9.0 & 1.9 & 11.0 & 3.3 & 20.0 & 5.4 & 26.8 & 3.5 & 15.8 & 6.8 & 35.8 \\
\hline 79 & GS & 0.4 & 2.0 & $* * *$ & $* * *$ & $* * *$ & $* * *$ & $* * *$ & $* * *$ & $* * *$ & $* * *$ & $* * *$ & $* * *$ \\
\hline 80 & GS & 1.9 & 8.0 & 1.0 & 24.2 & 2.9 & 32.2 & 3.5 & 31.6 & 2.5 & 7.4 & 5.4 & 39.6 \\
\hline 81 & GS & 0.4 & 3.0 & 0.0 & -2.4 & 0.4 & 0.6 & 0.1 & -2.6 & 0.1 & -0.2 & 0.5 & 0.4 \\
\hline 82 & GS & 0.4 & 7.0 & $* * *$ & $* * *$ & $* * *$ & $* * *$ & $* * *$ & $* * *$ & $* * *$ & $* * *$ & $* * *$ & $* * *$ \\
\hline 83 & GS & 2.3 & 12.0 & 3.3 & 19.8 & 5.6 & 31.8 & 7.1 & 31.4 & 3.8 & 11.6 & 9.4 & 43.4 \\
\hline 84 & IC & 0.0 & 0.0 & 0.8 & 2.5 & 0.8 & 2.5 & 1.1 & 3.0 & 0.3 & 0.5 & 1.1 & 3.0 \\
\hline 85 & GS & 1.9 & 11.0 & 2.7 & 22.1 & 4.6 & 33.1 & 5.8 & 31.7 & 3.1 & 9.6 & 7.7 & 42.7 \\
\hline 86 & GS & 1.9 & 13.0 & 1.9 & 16.0 & 3.8 & 29.0 & 5.3 & 31.5 & 3.4 & 15.5 & 7.2 & 44.5 \\
\hline 87 & IC & 0.7 & 4.0 & 0.3 & -4.3 & 1.0 & -0.3 & 0.7 & 1.6 & 0.4 & 5.9 & 1.4 & 5.6 \\
\hline 88 & GS & 0.3 & -2.0 & -0.2 & 0.5 & 0.1 & -1.5 & -0.2 & 2.8 & 0.0 & 2.3 & 0.1 & 0.8 \\
\hline 89 & GS & 0.1 & -1.0 & -0.1 & -5.0 & 0.0 & -6.0 & 0.0 & -1.9 & 0.1 & 3.1 & 0.1 & -2.9 \\
\hline 90 & GS & 0.1 & 1.0 & -0.2 & -0.7 & -0.1 & 0.3 & -0.2 & 7.9 & 0.0 & 8.6 & -0.1 & 8.9 \\
\hline 91 & GS & 0.6 & 5.0 & 0.2 & 4.8 & 0.8 & 9.8 & 0.2 & 2.7 & 0.0 & -2.1 & 0.8 & 7.7 \\
\hline 92 & GS & 0.3 & 5.0 & 0.0 & -3.5 & 0.3 & 1.5 & 0.0 & -0.5 & 0.0 & 3.0 & 0.3 & 4.5 \\
\hline 93 & GS & 1.9 & 12.0 & 0.7 & 6.3 & 2.6 & 18.3 & 6.0 & 30.5 & 5.3 & 24.2 & 7.9 & 42.5 \\
\hline 94 & GS & 1.3 & 13.0 & 1.8 & 18.7 & 3.1 & 31.7 & 5.7 & 24.3 & 3.9 & 5.6 & 7.0 & 37.3 \\
\hline 95 & GS & 1.6 & 15.0 & 0.3 & 6.7 & 1.9 & 21.7 & 4.2 & 15.8 & 3.9 & 9.1 & 5.8 & 30.8 \\
\hline 96 & GS & 0.3 & 6.0 & -0.1 & -6.9 & 0.2 & -0.9 & 0.2 & -6.4 & 0.3 & 0.5 & 0.5 & -0.4 \\
\hline 97 & IC & 0.3 & 7.0 & 0.2 & 1.0 & 0.5 & 8.0 & 2.0 & 17.6 & 1.8 & 16.6 & 2.3 & 24.6 \\
\hline 98 & SP & $* * *$ & $* * *$ & $* * *$ & $* * *$ & $* * *$ & $* * *$ & $* * *$ & $* * *$ & $* * *$ & $* * *$ & $* * *$ & $* * *$ \\
\hline 99 & GS & 0.2 & 0.0 & 0.0 & 1.2 & 0.2 & 1.2 & 0.0 & 0.2 & 0.0 & -1.0 & 0.2 & 0.2 \\
\hline 100 & GS & 0.2 & 0.0 & 0.0 & 1.6 & 0.2 & 1.6 & $* * *$ & $* * *$ & $* * *$ & $* * *$ & $* * *$ & $* * *$ \\
\hline 101 & GS & $* * *$ & $* * *$ & $* * *$ & $* * *$ & $* * *$ & $* * *$ & $* * *$ & $* * *$ & 1.0 & 1.0 & $* * *$ & $* * *$ \\
\hline 102 & WF & $* * *$ & $* * *$ & $* * *$ & $* * *$ & $* * *$ & $* * *$ & $* * *$ & $* * *$ & $* * *$ & $* * *$ & $* * *$ & $* * *$ \\
\hline 103 & WF & $* * *$ & $* * *$ & $* * *$ & $* * *$ & $* * *$ & $* * *$ & $* * *$ & $* * *$ & $* * *$ & $* * *$ & $* * *$ & $* * *$ \\
\hline 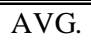 & & "0.8 & "6.7 & 0.7 & "6.4 & 1.6 & 13.2 & 2.4 & 14.3 & "1.6 & 7.5 & 3.3 & 21.3 \\
\hline
\end{tabular}


MHDSF Young-Growth Giant Sequoia Management Strategies Study 2009 - Overstory Summary Growth Data (39.37 ft. (12m) Plot)

$\begin{array}{lllll}\text { Stand: Headquarters } & \text { Treatment: Control } & \text { Measured By: } & 1989 & \text { ??? } \\ & & \text { Measured By: } & 1994 & \text { Ganz } \\ \text { Block: C } & \text { Plot \# : } 1 & \text { Measured By: } & 2001 & \text { Roller, Kong } \\ & & \text { Measured By: } & 2009 & \text { Soderlund, Estrada }\end{array}$

$\begin{array}{ccl}\text { Tree } & 77 & \text { Dead in 1994 } \\ \text { Tree } & 98 & \text { Dead/Standing in 1994 } \\ \text { Trees } & 79,82 & \text { Dead/Standing in 2001 } \\ \text { Trees } & 89,90 & \text { Damaged/Deformed in } 2001 \\ \text { Trees } & \text { 102,103 } & \text { Ingrowth in 2009 } \\ \text { Trees } & 98,100 & \text { Missing in 2009 } \\ \text { Tree } & 90 & \text { Deformed/Bowed in } 2009 \\ \text { Trees } & 69,70,99 & \text { Deformed Top in 2009 }\end{array}$


MHDSF Young-Growth Giant Sequoia Management Strategies Study 2009 - Overstory Summary Data (39.37 ft. (12m) Plot)

$\begin{array}{lllll}\text { Stand: Indian Bath } & \text { Treatment: Thinned } & \text { Measured By: } & 1989 \text { Rodgers, Johannis } \\ & & \text { Measured By: } & 1994 \text { Ganz } \\ \text { Block: A } & \text { Plot \# :1 } & \text { Measured By: } & 2001 \text { Roller, Arrowsmith } \\ & & \text { Measured By: } & 2009 \text { Soderlund, Ricchiazzi }\end{array}$

\begin{tabular}{|c|c|c|c|c|c|c|c|c|c|}
\hline \multirow[b]{2}{*}{ Tree \# } & \multirow[b]{2}{*}{ Species } & \multicolumn{2}{|c|}{1989 Data } & \multicolumn{2}{|c|}{1994 Data } & \multicolumn{2}{|c|}{2001 Data } & 2009 Data & Data \\
\hline & & $\mathrm{DBH}$ & Height & $\mathrm{DBH}$ & Height & $\mathrm{DBH}$ & Height & $\mathrm{DBH}$ & Height \\
\hline 19 & GS & 19.7 & 92.0 & 20.8 & 96.0 & 22.8 & 105.2 & 25.0 & 117.1 \\
\hline 20 & GS & 18.2 & 91.0 & 20.5 & 95.0 & 23.3 & 103.6 & 25.9 & 115.4 \\
\hline 21 & GS & 13.7 & 81.0 & 14.7 & 80.0 & 15.2 & 96.8 & 16.5 & 109.4 \\
\hline 22 & GS & 15.1 & 84.0 & 16.4 & 88.0 & 18.8 & 107.3 & 20.6 & 115.5 \\
\hline 23 & GS & 19.0 & 100.0 & 20.4 & 102.0 & 21.5 & 101.7 & 23.5 & 115.4 \\
\hline 24 & GS & 12.7 & 79.0 & 13.5 & 83.0 & 14.6 & 84.8 & 15.6 & 96.9 \\
\hline 25 & GS & 18.9 & 92.0 & 20.4 & 91.0 & 22.8 & 100.6 & 24.9 & 110.5 \\
\hline 26 & GS & 11.1 & 69.0 & 11.6 & 71.0 & 12.3 & 85.9 & 13.1 & 92.1 \\
\hline 27 & GS & 19.0 & 87.0 & 19.5 & 90.0 & 21.3 & 103.5 & 22.9 & 112.8 \\
\hline 28 & GS & 9.9 & 67.0 & 10.8 & 69.0 & 10.9 & 44.7 & 10.4 & $* * *$ \\
\hline 29 & GS & 20.3 & 96.0 & 21.7 & 98.0 & 23.5 & 116.9 & 26.3 & 126.1 \\
\hline 30 & GS & 16.6 & 81.0 & 18.2 & 84.0 & 20.6 & 99.4 & 22.8 & 110.4 \\
\hline 31 & GS & 8.5 & 68.0 & 9.3 & 68.0 & $* * *$ & $* * *$ & $* * *$ & $* * *$ \\
\hline 32 & GS & 9.0 & 60.0 & 9.7 & 61.0 & 11.0 & 70.9 & 11.9 & 94.3 \\
\hline 33 & GS & 15.9 & 71.0 & 17.3 & 73.0 & 19.6 & 89.8 & 22.0 & 101.7 \\
\hline 34 & GS & 11.5 & 70.0 & 12.2 & 74.0 & 13.8 & 83.4 & 15.1 & 96.9 \\
\hline 35 & GS & 14.3 & 89.0 & 15.7 & 84.0 & 17.2 & 97.8 & 18.7 & 110.0 \\
\hline 36 & GS & 14.4 & 84.0 & 15.9 & 80.0 & 18.0 & 100.5 & 20.4 & 112.8 \\
\hline 37 & GS & 8.2 & 58.0 & 9.1 & 63.0 & 10.1 & 72.1 & 10.8 & 79.5 \\
\hline 38 & GS & 10.7 & 85.0 & 11.6 & 82.0 & 13.3 & 97.7 & 14.9 & 103.9 \\
\hline 39 & GS & 14.2 & 85.0 & 15.5 & 82.0 & 17.2 & 86.4 & 18.8 & 99.2 \\
\hline 40 & GS & 8.3 & 75.0 & 9.0 & 70.0 & 8.9 & $* * *$ & 8.8 & $* * *$ \\
\hline 41 & GS & 12.9 & 76.0 & 13.8 & 75.0 & 15.4 & 92.7 & 16.7 & 101.5 \\
\hline 42 & GS & 10.0 & 69.0 & 10.9 & 68.0 & 12.0 & 85.5 & 13.5 & 92.7 \\
\hline 43 & GS & $* * *$ & $* * *$ & $* * *$ & $* * *$ & 11.2 & 60.9 & 11.4 & 68.2 \\
\hline 44 & GS & $* * *$ & $* * *$ & $* * *$ & $* * *$ & 12.5 & 91.9 & 13.4 & 100.6 \\
\hline AVG. & & 13.8 & 79.5 & 14.9 & 80.3 & $\begin{array}{l}16.3 \\
\end{array}$ & 90.8 & $\begin{array}{l}17.8 \\
\end{array}$ & 103.6 \\
\hline Tree & 28 & Broken & Гоp in 20 & & & & & & \\
\hline Tree & 31 & Dead/L & own in 20 & & & & & & \\
\hline Tree & 40 & Dead/S & anding in & 2001 & & & & & \\
\hline Tree & 43 & $\begin{array}{l}\text { Deform } \\
\text { Roller } 2\end{array}$ & $\begin{array}{l}\text { Top, } \mathrm{T} \\
04 \text { thesis }\end{array}$ & $\begin{array}{l}\text { agged t } \\
\text { has val }\end{array}$ & $\begin{array}{l}\text { ee but no } \\
\text { ue for } 19\end{array}$ & $\begin{array}{l}\text { t count } \\
94: \# 43\end{array}$ & $\begin{array}{l}\mathrm{d} \text { in } 1989 \\
\mathrm{DBH} 10 .\end{array}$ & $\begin{array}{l}1994 \text { da } \\
\text { 3,Ht } 56\end{array}$ & ta. Measured - 2001,2009 \\
\hline Tree & 44 & Tagged & tree but $\mathrm{r}$ & lot coun & ed in 198 & 9 or 19 & 4 data. & Ieasurec & in 2001, 2009 \\
\hline Tree & 28 & Dead/S & anding in & 2009 & & & & & \\
\hline Tree & 18 & $\begin{array}{l}\text { 1989: D } \\
\text { exclude }\end{array}$ & $\begin{array}{l}3 \mathrm{H} 10.8, \\
\text { from } 20\end{array}$ & $\begin{array}{l}\text { Ht 82. E } \\
01 \text { and } 2\end{array}$ & $\begin{array}{l}\text { xcluded } \mathrm{f} \\
009 \text { stud }\end{array}$ & $\begin{array}{l}\text { rom } 199 \\
\text { es for c }\end{array}$ & $\begin{array}{l}4 \text { study } \mathrm{f} \\
\text { onsistenc }\end{array}$ & r unkno & wn reason, and \\
\hline
\end{tabular}

Page 133 
MHDSF Young-Growth Giant Sequoia Management Strategies Study 2009 - Overstory Summary Growth Data (39.37 ft. (12m) Plot)

$\begin{array}{lllll}\text { Stand: Indian Bath } & \text { Treatment: Thinned } & \text { Measured By: } & 1989 \text { Rodgers, Johannis } \\ & & \text { Measured By: } & 1994 \text { Ganz } \\ \text { Block: A } & \text { Plot \# :1 } & \text { Measured By: } & 2001 \text { Roller, Arrowsmith } \\ & & \text { Measured By: } & 2009 \text { Soderlund, Ricchiazzi }\end{array}$

\begin{tabular}{|c|c|c|c|c|c|c|c|c|c|c|c|c|c|}
\hline \multirow[b]{2}{*}{ Tree \# } & \multirow[b]{2}{*}{ Species } & \multicolumn{2}{|c|}{$\begin{array}{c}\text { Change } \\
\text { 1989-1994 }\end{array}$} & \multicolumn{2}{|c|}{$\begin{array}{c}\text { Change } \\
1994-2001\end{array}$} & \multicolumn{2}{|c|}{$\begin{array}{c}\text { Change } \\
1989-2001\end{array}$} & \multicolumn{2}{|c|}{$\begin{array}{c}\text { Change } \\
\text { 1994-2009 }\end{array}$} & \multicolumn{2}{|c|}{$\begin{array}{c}\text { Change } \\
\text { 2001-2009 }\end{array}$} & \multicolumn{2}{|c|}{$\begin{array}{c}\text { Change } \\
\text { 1989-2009 }\end{array}$} \\
\hline & & DBH & Height & DBH & Height & DBH & Height & DBH & Height & DBH & Height & DBH & Height \\
\hline 19 & GS & 1.1 & 4.0 & 2.0 & 9.2 & 3.1 & 13.2 & 4.2 & 21.1 & 2.2 & 11.9 & 5.3 & 25.1 \\
\hline 20 & GS & 2.3 & 4.0 & 2.8 & 8.6 & 5.1 & 12.6 & 5.4 & 20.4 & 2.6 & 11.8 & 7.7 & 24.4 \\
\hline 21 & GS & 1.0 & -1.0 & 0.5 & 16.8 & 1.5 & 15.8 & 1.8 & 29.4 & 1.3 & 12.6 & 2.8 & 28.4 \\
\hline 22 & GS & 1.3 & 4.0 & 2.4 & 19.3 & 3.7 & 23.3 & 4.2 & 27.5 & 1.8 & 8.2 & 5.5 & 31.5 \\
\hline 23 & GS & 1.4 & 2.0 & 1.1 & -0.3 & 2.5 & 1.7 & 3.1 & 13.4 & 2.0 & 13.7 & 4.5 & 15.4 \\
\hline 24 & GS & 0.8 & 4.0 & 1.1 & 1.8 & 1.9 & 5.8 & 2.1 & 13.9 & 1.0 & 12.1 & 2.9 & 17.9 \\
\hline 25 & GS & 1.5 & -1.0 & 2.4 & 9.6 & 3.9 & 8.6 & 4.5 & 19.5 & 2.1 & 9.9 & 6.0 & 18.5 \\
\hline 26 & GS & 0.5 & 2.0 & 0.7 & 14.9 & 1.2 & 16.9 & 1.5 & 21.1 & 0.8 & 6.2 & 2.0 & 23.1 \\
\hline 27 & GS & 0.5 & 3.0 & 1.8 & 13.5 & 2.3 & 16.5 & 3.4 & 22.8 & 1.6 & 9.3 & 3.9 & 25.8 \\
\hline 28 & GS & 0.9 & 2.0 & 0.1 & -24.3 & 1.0 & -22.3 & -0.4 & $* * *$ & -0.5 & $* * *$ & 0.5 & $* * *$ \\
\hline 29 & GS & 1.4 & 2.0 & 1.8 & 18.9 & 3.2 & 20.9 & 4.6 & 28.1 & 2.8 & 9.2 & 6.0 & 30.1 \\
\hline 30 & GS & 1.6 & 3.0 & 2.4 & 15.4 & 4.0 & 18.4 & 4.6 & 26.4 & 2.2 & 11.0 & 6.2 & 29.4 \\
\hline 31 & GS & 0.8 & 0.0 & $* * *$ & $* * *$ & $* * *$ & $* * *$ & $* * *$ & $* * *$ & $* * *$ & $* * *$ & $* * *$ & $* * *$ \\
\hline 32 & GS & 0.7 & 1.0 & 1.3 & 9.9 & 2.0 & 10.9 & 2.2 & 33.3 & 0.9 & 23.4 & 2.9 & 34.3 \\
\hline 33 & GS & 1.4 & 2.0 & 2.3 & 16.8 & 3.7 & 18.8 & 4.7 & 28.7 & 2.4 & 11.9 & 6.1 & 30.7 \\
\hline 34 & GS & 0.7 & 4.0 & 1.6 & 9.4 & 2.3 & 13.4 & 2.9 & 22.9 & 1.3 & 13.5 & 3.6 & 26.9 \\
\hline 35 & GS & 1.4 & -5.0 & 1.5 & 13.8 & 2.9 & 8.8 & 3.0 & 26.0 & 1.5 & 12.2 & 4.4 & 21.0 \\
\hline 36 & GS & 1.5 & -4.0 & 2.1 & 20.5 & 3.6 & 16.5 & 4.5 & 32.8 & 2.4 & 12.3 & 6.0 & 28.8 \\
\hline 37 & GS & 0.9 & 5.0 & 1.0 & 9.1 & 1.9 & 14.1 & 1.7 & 16.5 & 0.7 & 7.4 & 2.6 & 21.5 \\
\hline 38 & GS & 0.9 & -3.0 & 1.7 & 15.7 & 2.6 & 12.7 & 3.3 & 21.9 & 1.6 & 6.2 & 4.2 & 18.9 \\
\hline 39 & GS & 1.3 & -3.0 & 1.7 & 4.4 & 3.0 & 1.4 & 3.3 & 17.2 & 1.6 & 12.8 & 4.6 & 14.2 \\
\hline 40 & GS & 0.7 & -5.0 & -0.1 & $* * *$ & 0.6 & $* * *$ & -0.2 & $* * *$ & -0.1 & $* * *$ & 0.5 & $* * *$ \\
\hline 41 & GS & 0.9 & -1.0 & 1.6 & 17.7 & 2.5 & 16.7 & 2.9 & 26.5 & 1.3 & 8.8 & 3.8 & 25.5 \\
\hline 42 & GS & 0.9 & -1.0 & 1.1 & 17.5 & 2.0 & 16.5 & 2.6 & 24.7 & 1.5 & 7.2 & 3.5 & 23.7 \\
\hline 43 & GS & $* * *$ & $* * *$ & $* * *$ & $* * *$ & $* * *$ & $* * *$ & $* * *$ & $* * *$ & 0.2 & 7.3 & $* * *$ & $* * *$ \\
\hline 44 & GS & $* * *$ & $* * *$ & $* * *$ & $* * *$ & $* * *$ & $* * *$ & $* * *$ & $* * *$ & 0.9 & 8.7 & $* * *$ & $* * *$ \\
\hline AVG. & & 1.1 & 0.8 & 1.5 & 10.8 & 2.6 & 11.9 & 3.0 & 23.5 & 1.4 & 10.8 & 4.2 & 24.5 \\
\hline
\end{tabular}

\begin{tabular}{|c|c|c|}
\hline Tree & 28 & Broken Top in 2001 \\
\hline Tree & 31 & Dead/Down in 2001 \\
\hline Tree & 40 & Dead/Standing in 2001 \\
\hline Tree & 43 & $\begin{array}{l}\text { Deformed Top, Tagged tree but not counted in 1989,1994 data. Measured - 2001,2009 } \\
\text { Roller } 2004 \text { thesis has value for 1994: \#43-DBH 10.8,Ht } 56\end{array}$ \\
\hline Tree & 44 & Tagged tree but not counted in 1989 or 1994 data. Measured in 2001, 2009 \\
\hline Tree & 28 & Dead/Standing in 2009 \\
\hline Tree & 18 & $\begin{array}{l}\text { 1989: DBH 10.8,Ht 82. Excluded from } 1994 \text { study for unknown reason, and } \\
\text { excluded from } 2001 \text { and } 2009 \text { studies for consistency. }\end{array}$ \\
\hline
\end{tabular}




\begin{tabular}{lllll}
\multicolumn{5}{c}{ MHDSF Young-Growth Giant Sequoia Management Strategies Study } \\
\\
2009 - Overstory Summary Data (39.37 ft. (12m) Plot) & \\
Stand: Indian Bath & Treatment: Thinned/Burned & Measured By: & 1989 Rodgers, Johannis \\
& & Measured By: & 1994 Ganz \\
Block: A & Plot \# :2 & Measured By: & 2001 Roller, Arrowsmith \\
& & Measured By: & 2009 Soderlund, Ricchiazzi
\end{tabular}

\begin{tabular}{|c|c|c|c|c|c|c|c|c|c|}
\hline \multirow[b]{2}{*}{ Tree \# } & \multirow[b]{2}{*}{ Species } & \multicolumn{2}{|c|}{1989 Data } & \multicolumn{2}{|c|}{1994 Data } & \multicolumn{2}{|c|}{2001 Data } & \multicolumn{2}{|c|}{2009 Data } \\
\hline & & $\mathrm{DBH}$ & Height & $\mathrm{DBH}$ & Height & $\mathrm{DBH}$ & Height & $\mathrm{DBH}$ & Height \\
\hline 55 & GS & 21.4 & 90.0 & 222.5 & 96.0 & 23.9 & 112.9 & 26.1 & 12124.4 \\
\hline 56 & GS & 18.6 & 102.0 & 18.7 & 106.0 & 20.3 & 116.6 & 21.9 & 130.5 \\
\hline 57 & GS & 22.3 & 103.0 & 23.4 & 110.0 & 26.0 & 110.7 & 28.3 & 124.1 \\
\hline 58 & GS & 17.9 & 94.0 & 18.5 & 101.0 & 20.5 & 106.7 & 22.7 & 121.3 \\
\hline 59 & GS & 14.9 & 80.0 & 15.4 & 86.0 & 16.6 & 88.5 & 18.0 & 101.7 \\
\hline 60 & GS & 12.0 & 79.0 & 12.5 & 78.0 & 14.0 & 90.7 & 15.8 & 102.7 \\
\hline 61 & GS & 7.3 & 39.0 & 7.4 & 46.0 & 7.6 & 45.0 & 7.8 & 46.0 \\
\hline 62 & GS & 8.1 & 52.0 & 8.8 & 51.0 & 10.0 & 54.9 & 10.2 & 60.8 \\
\hline 63 & GS & 13.5 & 81.0 & 14.4 & 81.0 & 15.6 & 94.3 & 17.0 & 105.6 \\
\hline 64 & GS & 13.5 & 82.0 & 14.3 & 85.0 & 16.0 & 95.1 & 17.4 & 102.4 \\
\hline 65 & GS & 11.4 & 75.0 & 12.4 & 79.0 & 13.8 & 90.2 & 15.1 & 98.3 \\
\hline 66 & GS & 18.0 & 89.0 & 18.8 & 84.0 & 20.5 & 104.5 & 22.3 & 108.9 \\
\hline 67 & GS & 15.8 & 87.0 & 16.7 & 91.0 & 19.1 & 110.6 & 21.1 & 121.1 \\
\hline 68 & GS & 9.3 & 68.0 & 9.9 & 69.0 & 10.2 & 80.7 & 10.5 & 86.7 \\
\hline 69 & GS & 17.8 & 87.0 & 18.8 & 94.0 & 20.3 & 106.4 & 22.2 & 114.2 \\
\hline 70 & GS & 12.5 & 82.0 & 13.3 & 85.0 & 14.5 & 95.9 & 15.7 & 108.8 \\
\hline 71 & GS & 11.7 & 71.0 & 12.4 & 78.0 & 13.5 & 96.3 & 14.5 & 108.5 \\
\hline 72 & GS & 15.5 & 97.0 & 16.3 & 101.0 & 17.4 & 114.8 & 18.5 & 121.6 \\
\hline 73 & GS & 15.1 & 94.0 & 16.2 & 97.0 & 17.7 & 111.6 & 19.4 & 123.7 \\
\hline 74 & GS & 21.8 & 105.0 & 23.0 & 115.0 & 25.2 & 129.0 & 27.2 & 138.3 \\
\hline 75 & GS & 12.6 & 90.0 & 13.5 & 93.0 & 15.8 & 112.6 & 16.2 & 121.7 \\
\hline AVG. & & 14.8 & 83.2 & 15.6 & 87.0 & 17.1 & 98.5 & 18.5 & 108.2 \\
\hline
\end{tabular}


MHDSF Young-Growth Giant Sequoia Management Strategies Study 2009 - Overstory Summary Growth Data (39.37 ft. (12m) Plot)

$\begin{array}{lllll}\text { Stand: Indian Bath } & \text { Treatment: Thinned/Burned } & \text { Measured By: } & 1989 \text { Rodgers, Johannis } \\ & & \text { Measured By: } & 1994 \text { Ganz } \\ \text { Block: A } & \text { Plot \# :2 } & \text { Measured By: } & 2001 \text { Roller, Arrowsmith } \\ & & \text { Measured By: } & 2009 \text { Soderlund, Ricchiazzi }\end{array}$

\begin{tabular}{|c|c|c|c|c|c|c|c|c|c|c|c|c|c|}
\hline \multirow[b]{2}{*}{ Tree \# } & \multirow[b]{2}{*}{ Species } & \multicolumn{2}{|c|}{$\begin{array}{c}\text { Change } \\
1989-1994\end{array}$} & \multicolumn{2}{|c|}{$\begin{array}{c}\text { Change } \\
\text { 1994-2001 }\end{array}$} & \multicolumn{2}{|c|}{$\begin{array}{c}\text { Change } \\
\text { 1989-2001 }\end{array}$} & \multicolumn{2}{|c|}{$\begin{array}{c}\text { Change } \\
\text { 1994-2009 }\end{array}$} & \multicolumn{2}{|c|}{$\begin{array}{c}\text { Change } \\
2001-2009\end{array}$} & \multicolumn{2}{|c|}{$\begin{array}{c}\text { Change } \\
1989-2009\end{array}$} \\
\hline & & DBH & Height & DBH & Height & DBH & Height & $\mathrm{DBH}$ & Height & DBH & Height & $\mathrm{DBH}$ & Height \\
\hline 55 & GS & 1.1 & 6.0 & 1.4 & 16.9 & 2.5 & 22.9 & 3.6 & 28.4 & 2.2 & 11.5 & 4.7 & 34.4 \\
\hline 56 & GS & 0.1 & 4.0 & 1.6 & 10.6 & 1.7 & 14.6 & 3.2 & 24.5 & 1.6 & 13.9 & 3.3 & 28.5 \\
\hline 57 & GS & 1.1 & 7.0 & 2.6 & 0.7 & 3.7 & 7.7 & 4.9 & 14.1 & 2.3 & 13.4 & 6.0 & 21.1 \\
\hline 58 & GS & 0.6 & 7.0 & 2.0 & 5.7 & 2.6 & 12.7 & 4.2 & 20.3 & 2.2 & 14.6 & 4.8 & 27.3 \\
\hline 59 & GS & 0.5 & 6.0 & 1.2 & 2.5 & 1.7 & 8.5 & 2.6 & 15.7 & 1.4 & 13.2 & 3.1 & 21.7 \\
\hline 60 & GS & 0.5 & -1.0 & 1.5 & 12.7 & 2.0 & 11.7 & 3.3 & 24.7 & 1.8 & 12.0 & 3.8 & 23.7 \\
\hline 61 & GS & 0.1 & 7.0 & 0.2 & -1.0 & 0.3 & 6.0 & 0.4 & 0.0 & 0.2 & 1.0 & 0.5 & 7.0 \\
\hline 62 & GS & 0.7 & -1.0 & 1.2 & 3.9 & 1.9 & 2.9 & 1.4 & 9.8 & 0.2 & 5.9 & 2.1 & 8.8 \\
\hline 63 & GS & 0.9 & 0.0 & 1.2 & 13.3 & 2.1 & 13.3 & 2.6 & 24.6 & 1.4 & 11.3 & 3.5 & 24.6 \\
\hline 64 & GS & 0.8 & 3.0 & 1.7 & 10.1 & 2.5 & 13.1 & 3.1 & 17.4 & 1.4 & 7.3 & 3.9 & 20.4 \\
\hline 65 & GS & 1.0 & 4.0 & 1.4 & 11.2 & 2.4 & 15.2 & 2.7 & 19.3 & 1.3 & 8.1 & 3.7 & 23.3 \\
\hline 66 & GS & 0.8 & -5.0 & 1.7 & 20.5 & 2.5 & 15.5 & 3.5 & 24.9 & 1.8 & 4.4 & 4.3 & 19.9 \\
\hline 67 & GS & 0.9 & 4.0 & 2.4 & 19.6 & 3.3 & 23.6 & 4.4 & 30.1 & 2.0 & 10.5 & 5.3 & 34.1 \\
\hline 68 & GS & 0.6 & 1.0 & 0.3 & 11.7 & 0.9 & 12.7 & 0.6 & 17.7 & 0.3 & 6.0 & 1.2 & 18.7 \\
\hline 69 & GS & 1.0 & 7.0 & 1.5 & 12.4 & 2.5 & 19.4 & 3.4 & 20.2 & 1.9 & 7.8 & 4.4 & 27.2 \\
\hline 70 & GS & 0.8 & 3.0 & 1.2 & 10.9 & 2.0 & 13.9 & 2.4 & 23.8 & 1.2 & 12.9 & 3.2 & 26.8 \\
\hline 71 & GS & 0.7 & 7.0 & 1.1 & 18.3 & 1.8 & 25.3 & 2.1 & 30.5 & 1.0 & 12.2 & 2.8 & 37.5 \\
\hline 72 & GS & 0.8 & 4.0 & 1.1 & 13.8 & 1.9 & 17.8 & 2.2 & 20.6 & 1.1 & 6.8 & 3.0 & 24.6 \\
\hline 73 & GS & 1.1 & 3.0 & 1.5 & 14.6 & 2.6 & 17.6 & 3.2 & 26.7 & 1.7 & 12.1 & 4.3 & 29.7 \\
\hline 74 & GS & 1.2 & 10.0 & 2.2 & 14.0 & 3.4 & 24.0 & 4.2 & 23.3 & 2.0 & 9.3 & 5.4 & 33.3 \\
\hline 75 & GS & 0.9 & 3.0 & 2.3 & 19.6 & 3.2 & 22.6 & 2.7 & 28.7 & 0.4 & 9.1 & 3.6 & 31.7 \\
\hline AVG. & & 0.8 & 3.8 & 1.5 & 11.5 & 2.3 & 15.3 & 2.9 & 21.2 & 1.4 & 9.7 & 3.7 & 25.0 \\
\hline
\end{tabular}


MHDSF Young-Growth Giant Sequoia Management Strategies Study 2009 - Overstory Summary Data (39ft. (12m) Plot)

$\begin{array}{lllll}\text { Stand: Indian Bath } & \text { Treatment: Thinned } & \text { Measured By: } & 1989 & \text { Rodgers, Johannis } \\ & & \text { Measured By: } & 1994 & \text { Ganz } \\ \text { Block: B } & \text { Plot \# :1 } & \text { Measured By: } & 2001 & \text { Roller, Arrowsmith } \\ & & \text { Measured By: } & 2009 & \text { Soderlund, Ricchiazzi }\end{array}$

\begin{tabular}{cc|cc|cc|cc|cc|}
\cline { 3 - 10 } Tree \# & Species & \multicolumn{2}{|c|}{1989 Data } & \multicolumn{2}{c|}{1994 Data } & \multicolumn{2}{c|}{ 2001 Data } & \multicolumn{2}{c|}{ 2009 Data } \\
\hline \hline 43 & GS & 24.7 & 95.0 & 26.2 & 96.0 & 28.5 & 106.8 & 30.8 & 123.1 \\
44 & GS & 24.3 & 92.0 & 25.5 & 93.0 & 27.8 & 109.7 & 29.9 & 116.8 \\
45 & GS & 17.4 & 66.0 & 18.1 & 72.0 & 20.1 & 83.1 & 22.4 & 95.5 \\
46 & GS & 20.7 & 82.0 & 21.9 & 83.0 & 23.2 & 94.8 & 27.9 & 100.2 \\
47 & GS & 21.2 & 90.0 & 22.9 & 91.0 & 25.0 & 107.7 & 27.2 & 112.7 \\
48 & GS & 10.5 & 39.0 & 12.1 & 43.0 & 13.3 & 56.1 & 15.3 & 70.9 \\
49 & GS & 22.5 & 89.0 & 24.2 & 96.0 & 27.1 & 107.8 & 29.7 & 119.5 \\
50 & GS & 17.7 & 79.0 & 18.7 & 88.0 & 21.1 & 103.7 & 23.7 & 109.0 \\
51 & GS & 24.1 & 91.0 & 25.7 & 97.0 & 28.0 & 109.1 & 30.5 & 116.3 \\
52 & GS & 8.2 & 47.0 & 8.7 & 48.0 & 9.5 & 62.9 & 10.4 & 63.2 \\
53 & GS & 16.9 & 82.0 & 17.7 & 87.0 & 16.8 & 84.3 & 17.5 & 92.3 \\
54 & GS & 15.4 & 78.0 & 16.1 & 79.0 & 19.0 & 93.3 & 20.2 & 101.3 \\
55 & GS & $* * *$ & $* * *$ & $* * *$ & $* * *$ & 24.4 & 106.0 & 26.5 & 112.8 \\
56 & GS & $* * *$ & $* * *$ & $* * *$ & $* * *$ & 9.2 & 37.6 & 9.8 & 39.2 \\
57 & GS & $* * *$ & $* * *$ & $* * *$ & $* * *$ & 19.4 & 90.3 & 21.4 & 97.9 \\
58 & GS & $* * *$ & $* * *$ & $* * *$ & $* * *$ & 2.7 & 7.8 & 2.2 & $* * *$ \\
\hline \hline AVG. & & 18.6 & 77.5 & 19.8 & 81.1 & 19.7 & 85.1 & 21.6 & 98.0 \\
\hline
\end{tabular}

2009 - Overstory Summary Growth Data (39ft. (12m) Plot)

\begin{tabular}{|c|c|c|c|c|c|c|c|c|c|c|c|c|c|}
\hline \multirow[b]{2}{*}{ Tree \# } & \multirow[b]{2}{*}{ Species } & \multicolumn{2}{|c|}{$\begin{array}{c}\text { Change } \\
\text { 1989-1994 }\end{array}$} & \multicolumn{2}{|c|}{$\begin{array}{c}\text { Change } \\
\text { 1994-2001 }\end{array}$} & \multicolumn{2}{|c|}{$\begin{array}{c}\text { Change } \\
\text { 1989-2001 }\end{array}$} & \multicolumn{2}{|c|}{$\begin{array}{c}\text { Change } \\
\text { 1994-2009 }\end{array}$} & \multicolumn{2}{|c|}{$\begin{array}{c}\text { Change } \\
\text { 2001-2009 }\end{array}$} & \multicolumn{2}{|c|}{$\begin{array}{c}\text { Change } \\
\text { 1989-2009 }\end{array}$} \\
\hline & & DBH & Height & DBH & Height & DBH & Height & $\mathrm{DBH}$ & Height & DBH & Height & DBH & Height \\
\hline 40 & GS & 1.5 & 1.0 & 2.3 & 10.8 & 3.8 & 11.8 & 4.6 & 27.1 & 2.3 & 1616.3 & 6.1 & 28.1 \\
\hline 44 & GS & 1.2 & 1.0 & 2.3 & 16.7 & 3.5 & 17.7 & 4.4 & 23.8 & 2.1 & 7.1 & 5.6 & 24.8 \\
\hline 45 & GS & 0.7 & 6.0 & 2.0 & 11.1 & 2.7 & 17.1 & 4.3 & 23.5 & 2.3 & 12.4 & 5.0 & 29.5 \\
\hline 46 & GS & 1.2 & 1.0 & 1.3 & 11.8 & 2.5 & 12.8 & 6.0 & 17.2 & 4.7 & 5.4 & 7.2 & 18.2 \\
\hline 47 & GS & 1.7 & 1.0 & 2.1 & 16.7 & 3.8 & 17.7 & 4.3 & 21.7 & 2.2 & 5.0 & 6.0 & 22.7 \\
\hline 48 & GS & 1.6 & 4.0 & 1.2 & 13.1 & 2.8 & 17.1 & 3.2 & 27.9 & 2.0 & 14.8 & 4.8 & 31.9 \\
\hline 49 & GS & 1.7 & 7.0 & 2.9 & 11.8 & 4.6 & 18.8 & 5.5 & 23.5 & 2.6 & 11.7 & 7.2 & 30.5 \\
\hline 50 & GS & 1.0 & 9.0 & 2.4 & 15.7 & 3.4 & 24.7 & 5.0 & 21.0 & 2.6 & 5.3 & 6.0 & 30.0 \\
\hline 51 & GS & 1.6 & 6.0 & 2.3 & 12.1 & 3.9 & 18.1 & 4.8 & 19.3 & 2.5 & 7.2 & 6.4 & 25.3 \\
\hline 52 & GS & 0.5 & 1.0 & 0.8 & 14.9 & 1.3 & 15.9 & 1.7 & 15.2 & 0.9 & 0.3 & 2.2 & 16.2 \\
\hline 53 & GS & 0.8 & 5.0 & -0.9 & -2.7 & -0.1 & 2.3 & -0.2 & 5.3 & 0.7 & 8.0 & 0.6 & 10.3 \\
\hline 54 & GS & 0.7 & 1.0 & 2.9 & 14.3 & 3.6 & 15.3 & 4.1 & 22.3 & 1.2 & 8.0 & 4.8 & 23.3 \\
\hline 55 & GS & $* * *$ & $* * *$ & $* * *$ & $* * *$ & $* * *$ & $* * *$ & $* * *$ & $* * *$ & 2.1 & 6.8 & $* * *$ & $* * *$ \\
\hline 56 & GS & $* * *$ & $* * *$ & $* * *$ & $* * *$ & $* * *$ & $* * *$ & $* * *$ & $* * *$ & 0.6 & 1.6 & $* * *$ & $* * *$ \\
\hline 57 & GS & $* * *$ & $* * *$ & $* * *$ & $* * *$ & $* * *$ & $* * *$ & $* * *$ & $* * *$ & 2.0 & 7.6 & $* * *$ & $* * *$ \\
\hline 58 & GS & $* * *$ & $* * *$ & $* * *$ & $* * *$ & $* * *$ & $* * *$ & $* * *$ & $* * *$ & -0.5 & $* * *$ & $* * *$ & $* * *$ \\
\hline AVG. & & 1.2 & 3.6 & 1.8 & 12.2 & 3.0 & 15.8 & 4.0 & 20.7 & 1.9 & 7.8 & 5.2 & 24.2 \\
\hline Trees & $55,56,57$ & $\begin{array}{l}\text { Taggec } \\
\text { has va }\end{array}$ & $\begin{array}{l}\text { ees but } \\
\text { for } 1\end{array}$ & $\begin{array}{l}\text { ot col } \\
4: \# 5\end{array}$ & $\begin{array}{l}\text { ted in } 1 \\
\text { DBH } 2\end{array}$ & $\begin{array}{l}9 \text { or } 1 \\
\text { Ht } 9\end{array}$ & $\begin{array}{l}4 \text { data. } \\
\# 56-\mathrm{DI}\end{array}$ & leasu & $\begin{array}{l}\mathrm{d} \text { in } 200 \\
37 ; \# 5\end{array}$ & $\begin{array}{l}2009.1 \\
\text { DBH } 1\end{array}$ & oller 20 & thesis & \\
\hline Tree & 58 & Ingrow & in 2001 & Dead/s & tanding & 2009 & & & & & & & \\
\hline
\end{tabular}

Page 137 
MHDSF Young-Growth Giant Sequoia Management Strategies Study 2009 - Overstory Summary Data (39.37ft. (12m) Plot)

$\begin{array}{lllll}\text { Stand: Indian Bath } & \text { Treatment: Thinned/Burned } & \text { Measured By: } & 1989 & \text { Bates, Maddson } \\ & & \text { Measured By: } & 1994 & \text { Ganz } \\ \text { Block: B } & \text { Plot \# : } 2 & \text { Measured By: } & 2001 & \text { Roller, Arrowsmith } \\ & & \text { Measured By: } & 2009 & \text { Soderlund, Ricchiazzi }\end{array}$

\begin{tabular}{cc|cc|cc|cc|cc|}
\cline { 3 - 9 } Tree \# & Species & DBH & Height & DBH & Height & DBH & Height & DBH & Height \\
\hline \hline 19 & GS & 8.1 & 56.0 & 8.6 & 68.0 & 8.9 & 73.4 & 9.3 & 74.6 \\
20 & GS & 12.4 & 78.0 & 13.0 & 82.0 & 14.4 & 90.6 & 15.8 & 101.3 \\
21 & GS & 8.0 & 49.0 & 8.4 & 59.0 & 8.2 & $* * *$ & 8.0 & $* * *$ \\
22 & GS & 20.8 & 93.0 & 22.3 & 96.0 & 24.6 & 107.5 & 26.9 & 118.7 \\
23 & GS & 16.7 & 93.0 & 16.9 & 97.0 & 17.9 & 95.2 & 19.5 & 106.3 \\
24 & GS & 11.6 & 77.0 & 11.8 & 80.0 & 12.6 & 91.9 & 13.5 & 101.9 \\
25 & GS & 13.2 & 71.0 & 13.5 & 75.0 & 14.2 & 81.5 & 15.1 & 95.0 \\
26 & GS & 7.8 & 55.0 & 8.0 & 57.0 & 8.4 & 70.9 & 8.9 & 79.9 \\
27 & GS & 11.7 & 78.0 & 11.8 & 85.0 & 12.9 & 93.8 & 14.0 & 103.7 \\
28 & GS & 12.8 & 78.0 & 13.2 & 86.0 & 14.3 & 85.6 & 15.0 & 92.9 \\
29 & GS & 12.2 & 83.0 & 12.2 & 88.0 & 13.3 & 94.4 & 14.6 & 107.3 \\
30 & GS & 7.0 & 62.0 & 7.8 & 69.0 & $* * *$ & $* * *$ & $* * *$ & $* * *$ \\
31 & GS & 10.2 & 71.0 & 10.7 & 75.0 & 11.7 & 80.2 & 12.7 & 87.8 \\
32 & GS & 7.2 & 53.0 & 7.6 & 58.0 & 8.3 & 67.7 & 8.8 & 74.7 \\
33 & GS & 8.8 & 58.0 & 9.4 & 64.0 & 10.2 & 72.1 & 10.8 & 78.1 \\
34 & SP & 29.3 & 100.0 & 31.3 & 107.0 & 33.7 & 117.1 & 36.6 & 124.2 \\
35 & GS & 11.0 & 64.0 & 11.6 & 69.0 & 12.5 & 89.0 & 13.7 & 95.8 \\
36 & GS & 8.2 & 59.0 & 8.9 & 64.0 & 9.8 & 80.5 & 10.5 & 87.8 \\
37 & GS & 10.0 & 71.0 & 11.0 & 72.0 & 12.3 & 89.2 & 13.5 & 99.8 \\
38 & WF & 11.5 & 71.0 & 12.6 & 74.0 & 14.3 & 84.5 & 15.4 & 89.8 \\
39 & GS & 10.0 & 72.0 & 11.0 & 74.0 & 12.1 & 88.2 & 12.9 & 96.4 \\
40 & GS & 9.8 & 62.0 & 11.0 & 67.0 & 12.1 & 82.1 & 12.9 & 90.6 \\
41 & GS & 10.3 & 64.0 & 11.0 & 69.0 & 12.0 & 82.7 & 13.1 & 93.5 \\
42 & GS & 9.5 & 73.0 & 10.2 & 77.0 & 11.6 & 89.4 & 12.9 & 100.1 \\
43 & GS & 9.8 & 76.0 & 10.6 & 79.0 & 11.9 & 91.0 & 13.0 & 101.8 \\
44 & GS & 9.4 & 73.0 & 10.3 & 83.0 & 11.5 & 86.7 & 12.4 & 96.8 \\
45 & WF & 21.0 & 84.0 & 22.3 & 89.0 & 23.5 & 93.4 & 24.5 & 98.0 \\
46 & GS & 16.9 & 86.0 & 18.6 & 92.0 & 20.3 & 102.8 & 21.8 & 112.1 \\
\hline \hline AVG. & & 12.0 & 71.8 & 12.7 & 77.0 & 14.0 & 87.7 & 15.0 & 96.5 \\
Tree & 21 & Dead/Standing in 2001 & & & & & \\
Tree & 30 & Dead/Down in 2001 & & & & & \\
& & & & & & & & &
\end{tabular}


MHDSF Young-Growth Giant Sequoia Management Strategies Study 2009 - Overstory Summary Growth Data (39.37ft. (12m) Plot)

\begin{tabular}{|c|c|c|c|c|}
\hline Stand: Indian Bath & Treatment: Thinned/Burned & Measured By: & 1989 & Bates, Maddson \\
\hline & & Measured By: & 1994 & Ganz \\
\hline Block: B & Plot \# : 2 & Measured By: & 2001 & Roller, Arrowsmith \\
\hline & & Measured By: & 2009 & Soderlund, Ricchiaz \\
\hline
\end{tabular}

\begin{tabular}{|c|c|c|c|c|c|c|c|c|c|c|c|c|c|}
\hline \multirow[b]{2}{*}{ Tree \# } & \multirow[b]{2}{*}{ Species } & \multicolumn{2}{|c|}{$\begin{array}{c}\text { Change } \\
\text { 1989-1994 }\end{array}$} & \multicolumn{2}{|c|}{$\begin{array}{c}\text { Change } \\
\text { 1994-2001 }\end{array}$} & \multicolumn{2}{|c|}{$\begin{array}{c}\text { Change } \\
\text { 1989-2001 }\end{array}$} & \multicolumn{2}{|c|}{$\begin{array}{c}\text { Change } \\
\text { 1994-2009 }\end{array}$} & \multicolumn{2}{|c|}{$\begin{array}{c}\text { Change } \\
\text { 2001-2009 }\end{array}$} & \multicolumn{2}{|c|}{$\begin{array}{c}\text { Change } \\
\text { 1989-2009 }\end{array}$} \\
\hline & & $\mathrm{DBH}$ & Height & $\mathrm{DBH}$ & Height & $\mathrm{DBH}$ & Height & $\mathrm{DBH}$ & Height & DBH & Height & $\mathrm{DBH}$ & Height \\
\hline 19 & GS & 0.5 & 12.0 & 0.3 & 5.4 & 0.8 & 17.4 & 0.7 & 6.6 & 0.4 & 1.2 & 1.2 & 18.6 \\
\hline 20 & GS & 0.6 & 4.0 & 1.4 & 8.6 & 2.0 & 12.6 & 2.8 & 19.3 & 1.4 & 10.7 & 3.4 & 23.3 \\
\hline 21 & GS & 0.4 & 10.0 & -0.2 & $* * *$ & 0.2 & $* * *$ & -0.4 & $* * *$ & -0.2 & $* * *$ & 0.0 & $* * *$ \\
\hline 22 & GS & 1.5 & 3.0 & 2.3 & 11.5 & 3.8 & 14.5 & 4.6 & 22.7 & 2.3 & 11.2 & 6.1 & 25.7 \\
\hline 23 & GS & 0.2 & 4.0 & 1.0 & -1.8 & 1.2 & 2.2 & 2.6 & 9.3 & 1.6 & 11.1 & 2.8 & 13.3 \\
\hline 24 & GS & 0.2 & 3.0 & 0.8 & 11.9 & 1.0 & 14.9 & 1.7 & 21.9 & 0.9 & 10.0 & 1.9 & 24.9 \\
\hline 25 & GS & 0.3 & 4.0 & 0.7 & 6.5 & 1.0 & 10.5 & 1.6 & 20.0 & 0.9 & 13.5 & 1.9 & 24.0 \\
\hline 26 & GS & 0.2 & 2.0 & 0.4 & 13.9 & 0.6 & 15.9 & 0.9 & 22.9 & 0.5 & 9.0 & 1.1 & 24.9 \\
\hline 27 & GS & 0.1 & 7.0 & 1.1 & 8.8 & 1.2 & 15.8 & 2.2 & 18.7 & 1.1 & 9.9 & 2.3 & 25.7 \\
\hline 28 & GS & 0.4 & 8.0 & 1.1 & -0.4 & 1.5 & 7.6 & 1.8 & 6.9 & 0.7 & 7.3 & 2.2 & 14.9 \\
\hline 29 & GS & 0.0 & 5.0 & 1.1 & 6.4 & 1.1 & 11.4 & 2.4 & 19.3 & 1.3 & 12.9 & 2.4 & 24.3 \\
\hline 30 & GS & 0.8 & 7.0 & $* * *$ & $* * *$ & $* * *$ & $* * *$ & $* * *$ & $* * *$ & $* * *$ & $* * *$ & $* * *$ & $* * *$ \\
\hline 31 & GS & 0.5 & 4.0 & 1.0 & 5.2 & 1.5 & 9.2 & 2.0 & 12.8 & 1.0 & 7.6 & 2.5 & 16.8 \\
\hline 32 & GS & 0.4 & 5.0 & 0.7 & 9.7 & 1.1 & 14.7 & 1.2 & 16.7 & 0.5 & 7.0 & 1.6 & 21.7 \\
\hline 33 & GS & 0.6 & 6.0 & 0.8 & 8.1 & 1.4 & 14.1 & 1.4 & 14.1 & 0.6 & 6.0 & 2.0 & 20.1 \\
\hline 34 & SP & 2.0 & 7.0 & 2.4 & 10.1 & 4.4 & 17.1 & 5.3 & 17.2 & 2.9 & 7.1 & 7.3 & 24.2 \\
\hline 35 & GS & 0.6 & 5.0 & 0.9 & 20.0 & 1.5 & 25.0 & 2.1 & 26.8 & 1.2 & 6.8 & 2.7 & 31.8 \\
\hline 36 & GS & 0.7 & 5.0 & 0.9 & 16.5 & 1.6 & 21.5 & 1.6 & 23.8 & 0.7 & 7.3 & 2.3 & 28.8 \\
\hline 37 & GS & 1.0 & 1.0 & 1.3 & 17.2 & 2.3 & 18.2 & 2.5 & 27.8 & 1.2 & 10.6 & 3.5 & 28.8 \\
\hline 38 & WF & 1.1 & 3.0 & 1.7 & 10.5 & 2.8 & 13.5 & 2.8 & 15.8 & 1.1 & 5.3 & 3.9 & 18.8 \\
\hline 39 & GS & 1.0 & 2.0 & 1.1 & 14.2 & 2.1 & 16.2 & 1.9 & 22.4 & 0.8 & 8.2 & 2.9 & 24.4 \\
\hline 40 & GS & 1.2 & 5.0 & 1.1 & 15.1 & 2.3 & 20.1 & 1.9 & 23.6 & 0.8 & 8.5 & 3.1 & 28.6 \\
\hline 41 & GS & 0.7 & 5.0 & 1.0 & 13.7 & 1.7 & 18.7 & 2.1 & 24.5 & 1.1 & 10.8 & 2.8 & 29.5 \\
\hline 42 & GS & 0.7 & 4.0 & 1.4 & 12.4 & 2.1 & 16.4 & 2.7 & 23.1 & 1.3 & 10.7 & 3.4 & 27.1 \\
\hline 43 & GS & 0.8 & 3.0 & 1.3 & 12.0 & 2.1 & 15.0 & 2.4 & 22.8 & 1.1 & 10.8 & 3.2 & 25.8 \\
\hline 44 & GS & 0.9 & 10.0 & 1.2 & 3.7 & 2.1 & 13.7 & 2.1 & 13.8 & 0.9 & 10.1 & 3.0 & 23.8 \\
\hline 45 & WF & 1.3 & 5.0 & 1.2 & 4.4 & 2.5 & 9.4 & 2.2 & 9.0 & 1.0 & 4.6 & 3.5 & 14.0 \\
\hline 46 & GS & 1.7 & 6.0 & 1.7 & 10.8 & 3.4 & 16.8 & 3.2 & 20.1 & 1.5 & 9.3 & 4.9 & 26.1 \\
\hline
\end{tabular}

Tree 21 Dead/Standing in 2001

Tree $\quad 30 \quad$ Dead/Down in 2001 
MHDSF Young-Growth Giant Sequoia Management Strategies Study 2009 - Overstory Summary Data (39ft. (12m) Plot)

$\begin{array}{lllll}\text { Stand: Indian Bath } & \text { Treatment: Control } & \text { Measured By: } & 1989 & \text { Bates, Maddson } \\ & & \text { Measured By: } & 1994 & \text { Gasser, Ganz, Bothof } \\ \text { Block: C } & \text { Plot \# :1 } & \text { Measured By: } & 2001 & \text { Roller, Arrowsmith } \\ & & \text { Measured By: } & 2009 & \text { Soderlund, Ricchiazzi }\end{array}$

\begin{tabular}{|c|c|c|c|c|c|c|c|c|c|}
\hline \multirow[b]{2}{*}{ Tree \# } & \multirow[b]{2}{*}{ Species } & \multicolumn{2}{|c|}{1989 Data } & \multicolumn{2}{|c|}{1994 Data } & \multicolumn{2}{|c|}{2001 Data } & \multicolumn{2}{|c|}{2009 Data } \\
\hline & & DBH & Height & $\mathrm{DBH}$ & Height & $\mathrm{DBH}$ & Height & DBH & Height \\
\hline 4 & IC & 11.1 & 443.0 & 111.2 & 443.0 & 111.6 & $4 \quad 47.8$ & 11.5 & $4 \quad 47.7$ \\
\hline 5 & IC & 10.5 & 32.0 & 10.5 & 31.0 & 10.8 & 36.2 & 10.4 & 34.3 \\
\hline 6 & IC & 12.1 & 48.0 & 12.4 & 48.0 & 12.9 & 59.2 & 13.2 & 54.3 \\
\hline 7 & WF & 13.9 & 74.0 & 15.2 & 77.0 & 17.9 & 91.7 & 19.4 & 95.3 \\
\hline 8 & IC & 5.5 & 18.0 & 5.5 & 19.0 & 5.7 & 20.6 & 5.7 & $* * *$ \\
\hline 9 & IC & 6.4 & 30.0 & 6.7 & 30.0 & 7.1 & 34.6 & 7.2 & 36.6 \\
\hline 10 & GS & 23.5 & 89.0 & 24.2 & 88.0 & 25.9 & 108.8 & 27.8 & 111.1 \\
\hline 11 & IC & 2.6 & 10.0 & 2.8 & 9.0 & 3.0 & 12.6 & 3.2 & 13.7 \\
\hline 12 & GS & 6.5 & 32.0 & 6.7 & 32.0 & 6.9 & 33.7 & 7.3 & 33.3 \\
\hline 13 & GS & 10.8 & 64.0 & 10.2 & 67.0 & 10.7 & 71.4 & 11.1 & 74.9 \\
\hline 14 & GS & 31.8 & 112.0 & 32.5 & 109.0 & 35.1 & 120.1 & 36.8 & 130.9 \\
\hline 15 & SP & 19.2 & 66.0 & 19.7 & 60.0 & 21.2 & 76.4 & 22.9 & 84.9 \\
\hline 16 & IC & 3.4 & 13.0 & 3.5 & 10.0 & 3.5 & 14.3 & 3.4 & 15.3 \\
\hline 17 & IC & 6.2 & 23.0 & 6.3 & 22.0 & 6.4 & 26.1 & 6.4 & 26.6 \\
\hline 18 & GS & 21.1 & 83.0 & 21.7 & 86.0 & 22.4 & 105.7 & 23.8 & 109.9 \\
\hline 19 & GS & 9.6 & 60.0 & 9.8 & 60.0 & 10.3 & 70.5 & 10.5 & 64.3 \\
\hline 20 & GS & 10.6 & 58.0 & 10.7 & 60.0 & 11.0 & 62.8 & 11.1 & 65.7 \\
\hline 21 & IC & 2.3 & 11.0 & 2.1 & 10.0 & $* * *$ & $* * *$ & $* * *$ & $* * *$ \\
\hline 22 & IC & 1.4 & 8.0 & $* * *$ & $* * *$ & 1.9 & $* * *$ & 1.8 & $* * *$ \\
\hline 23 & IC & 1.5 & 8.0 & $* * *$ & $* * *$ & $* * *$ & $* * *$ & $* * *$ & $* * *$ \\
\hline 24 & GS & 5.6 & 13.0 & $* * *$ & $* * *$ & 5.5 & $* * *$ & 5.3 & $* * *$ \\
\hline 25 & IC & 3.9 & 15.0 & 4.0 & 11.0 & 3.8 & $* * *$ & 3.8 & $* * *$ \\
\hline 26 & GS & 29.0 & 104.0 & 29.7 & 102.0 & 31.8 & 115.5 & 33.3 & 119.6 \\
\hline 27 & IC & 3.7 & 14.0 & $* * *$ & $* * *$ & 3.8 & $* * *$ & 3.8 & $* * *$ \\
\hline 28 & GS & 27.0 & 94.0 & 27.8 & 101.0 & 30.2 & 111.6 & 32.0 & 119.6 \\
\hline 29 & GS & 24.7 & 107.0 & 25.2 & 106.0 & 27.6 & 121.9 & 29.4 & 128.4 \\
\hline 30 & IC & 6.3 & 41.0 & 6.3 & 25.0 & 6.3 & 35.1 & 6.2 & $* * *$ \\
\hline 31 & IC & 4.2 & 15.0 & 4.2 & 18.0 & 3.8 & $* * *$ & 3.8 & $* * *$ \\
\hline 32 & IC & 5.5 & 25.0 & 5.4 & 34.0 & 5.5 & 28.5 & 5.5 & 29.1 \\
\hline 33 & GS & 15.5 & 89.0 & 16.0 & 91.0 & 17.3 & 107.8 & 18.6 & 110.3 \\
\hline 34 & GS & 9.7 & 36.0 & 9.7 & 37.0 & 9.7 & 44.6 & 9.6 & 42.4 \\
\hline 35 & IC & 7.1 & 26.0 & 7.2 & 28.0 & 8.6 & 32.8 & 7.4 & 31.6 \\
\hline 36 & IC & 2.0 & 8.0 & 2.0 & 7.0 & 2.0 & 9.7 & 1.9 & $* * *$ \\
\hline 37 & IC & 7.7 & 29.0 & 7.7 & 33.0 & 7.9 & 36.0 & 8.0 & 33.4 \\
\hline 38 & GS & 15.2 & 92.0 & 15.7 & 98.0 & 17.2 & 107.7 & 18.7 & 111.6 \\
\hline 39 & IC & 5.7 & 21.0 & 5.7 & 20.0 & 5.6 & 21.0 & 5.4 & $* * *$ \\
\hline 40 & GS & 14.3 & 86.0 & 14.3 & 95.0 & 15.0 & 105.2 & 15.3 & 107.9 \\
\hline 41 & IC & 3.3 & 14.0 & 3.3 & 12.0 & $* * *$ & $* * *$ & $* * *$ & $* * *$ \\
\hline 42 & GS & 13.7 & 80.0 & 14.1 & 96.0 & 15.3 & 94.0 & 16.2 & 100.6 \\
\hline 43 & GS & 16.6 & 96.0 & 17.1 & 100.0 & 18.5 & 95.0 & 19.4 & 107.1 \\
\hline 44 & IC & 3.1 & 15.0 & 3.2 & 11.0 & $* * *$ & $* * *$ & $* * *$ & $* * *$ \\
\hline 45 & GS & 5.1 & 22.0 & 5.2 & 19.0 & 5.2 & 21.2 & 5.1 & 22.1 \\
\hline 46 & IC & 1.6 & 7.0 & $* * *$ & $* * *$ & $* * *$ & $* * *$ & $* * *$ & $* * *$ \\
\hline 47 & GS & 2.9 & 12.0 & 2.8 & 12.0 & $* * *$ & $* * *$ & $* * *$ & $* * *$ \\
\hline
\end{tabular}

Page 140 
MHDSF Young-Growth Giant Sequoia Management Strategies Study 2009 - Overstory Summary Data (39ft. (12m) Plot)

$\begin{array}{lllll}\text { Stand: Indian Bath } & \text { Treatment: Control } & \text { Measured By: } & 1989 & \text { Bates, Maddson } \\ & & \text { Measured By: } & 1994 & \text { Gasser, Ganz, Bothof } \\ \text { Block: C } & \text { Plot \# :1 } & \text { Measured By: } & 2001 \text { Roller, Arrowsmith } \\ & & \text { Measured By: } & 2009 \text { Soderlund, Ricchiazzi }\end{array}$

\begin{tabular}{|c|c|c|c|c|c|c|c|c|c|}
\hline \multirow[b]{2}{*}{ Tree \# } & \multirow[b]{2}{*}{ Species } & \multicolumn{2}{|c|}{1989 Data } & \multicolumn{2}{|c|}{1994 Data } & \multicolumn{2}{|c|}{2001 Data } & \multicolumn{2}{|c|}{2009 Data } \\
\hline & & $\mathrm{DBH}$ & Height & DBH & Height & DBH & Height & $\mathrm{DBH}$ & Height \\
\hline 40 & IC & 25.1 & 24.0 & 25.1 & 22.0 & 25.5 & 24.6 & 5.4 & 24.2 \\
\hline 49 & IC & 2.8 & 12.0 & 2.8 & 10.0 & 2.9 & 15.5 & 3.0 & 13.2 \\
\hline 50 & IC & 6.4 & 23.0 & 6.4 & 24.0 & 6.7 & 25.2 & 6.8 & 25.4 \\
\hline 51 & IC & 8.4 & 29.0 & 8.7 & 29.0 & 9.5 & 35.6 & 9.8 & 38.0 \\
\hline 52 & GS & 2.6 & 8.0 & 2.6 & 9.0 & 3.7 & 9.8 & $* * *$ & $* * *$ \\
\hline 53 & GS & 14.6 & 76.0 & 14.9 & 78.0 & 15.5 & 88.6 & 15.5 & 65.0 \\
\hline 54 & GS & 11.6 & 77.0 & 12.0 & 79.0 & 12.5 & 70.7 & 12.5 & 73.5 \\
\hline 55 & GS & 6.2 & 21.0 & 6.4 & 20.0 & 6.5 & 22.5 & 6.5 & 23.5 \\
\hline 56 & GS & 18.8 & 90.0 & 19.6 & 89.0 & 22.1 & 98.0 & 24.2 & 111.8 \\
\hline 57 & GS & 15.0 & 80.0 & 15.4 & 79.0 & 16.6 & 98.7 & 17.9 & 101.5 \\
\hline 58 & GS & 8.0 & 40.0 & 8.0 & 41.0 & 8.0 & 43.9 & 7.9 & 41.6 \\
\hline 59 & GS & 14.8 & 87.0 & 15.3 & 86.0 & 16.6 & 103.8 & 17.6 & 109.5 \\
\hline 60 & IC & 3.9 & 19.0 & 3.8 & 20.0 & $* * *$ & $* * *$ & $* * *$ & $* * *$ \\
\hline 61 & IC & 1.7 & 8.0 & 1.5 & 8.0 & $* * *$ & $* * *$ & $* * *$ & $* * *$ \\
\hline 62 & GS & 6.4 & 27.0 & 6.6 & 27.0 & 6.8 & 31.8 & 6.9 & 32.2 \\
\hline 63 & GS & 12.7 & 71.0 & 13.0 & 68.0 & 13.6 & 82.0 & 13.8 & 90.2 \\
\hline 64 & GS & 7.0 & 21.0 & 7.1 & 21.0 & 7.2 & 23.1 & 7.1 & 22.7 \\
\hline 65 & GS & 11.6 & 72.0 & 12.0 & 72.0 & 13.4 & 80.4 & 12.7 & 85.2 \\
\hline 66 & GS & 19.0 & 91.0 & 19.6 & 99.0 & 21.4 & 110.3 & 22.6 & 118.1 \\
\hline 67 & WF & 4.8 & 28.0 & 4.9 & 26.0 & 4.8 & 27.7 & 4.8 & $* * *$ \\
\hline 68 & IC & 4.0 & 12.0 & 4.0 & 13.0 & 3.8 & 13.6 & $* * *$ & $* * *$ \\
\hline 69 & IC & 4.8 & 17.0 & 4.8 & 16.0 & 4.9 & 19.8 & 4.8 & 20.2 \\
\hline 70 & IC & 6.7 & 18.0 & 6.8 & 21.0 & 6.6 & 25.1 & 6.5 & $* * *$ \\
\hline 71 & WF & $* * *$ & $* * *$ & $* * *$ & $* * *$ & 20.3 & 101.3 & 22.1 & 103.9 \\
\hline 72 & GS & 26.2 & 59.0 & 26.7 & 98.0 & 28.4 & 103.0 & 29.8 & 116.2 \\
\hline 73 & IC & 5.1 & 18.0 & 5.1 & 18.0 & 5.0 & 24.7 & 4.9 & $* * *$ \\
\hline 74 & IC & 8.5 & 33.0 & 8.5 & 34.0 & 8.5 & 40.0 & 8.3 & $* * *$ \\
\hline 75 & IC & 9.7 & 38.0 & 9.8 & 39.0 & 10.2 & 44.9 & 10.1 & 42.6 \\
\hline 76 & WF & 9.1 & 57.0 & 9.4 & 58.0 & 9.8 & 65.1 & 9.9 & 68.4 \\
\hline 77 & WF & 4.1 & 18.0 & 4.1 & 11.0 & 4.2 & 17.2 & 4.1 & $* * *$ \\
\hline 78 & GS & 25.6 & 100.0 & 26.3 & 102.0 & 28.3 & 115.7 & 29.5 & 122.0 \\
\hline 79 & WF & 10.4 & 58.0 & 10.7 & 63.0 & 11.1 & 44.8 & 11.2 & 49.8 \\
\hline 80 & GS & 26.1 & 102.0 & 27.6 & 104.0 & 30.0 & 116.7 & 31.5 & 125.5 \\
\hline 81 & SP & 18.0 & 64.0 & 18.5 & 73.0 & 20.0 & 81.0 & 20.3 & 76.2 \\
\hline 82 & IC & 2.4 & 11.0 & 2.2 & 13.0 & 2.1 & $* * *$ & 2.0 & $* * *$ \\
\hline 83 & IC & 4.8 & 16.0 & 4.6 & 18.0 & 4.3 & $* * *$ & 4.3 & $* * *$ \\
\hline 84 & IC & 4.8 & 18.0 & 4.7 & 18.0 & 4.7 & 20.4 & 4.7 & 17.6 \\
\hline 85 & IC & 4.5 & 14.0 & 2.1 & 12.0 & 1.9 & 21.0 & 1.8 & $* * *$ \\
\hline 86 & IC & 2.1 & 12.0 & 4.5 & 14.0 & 4.5 & 20.4 & 4.3 & $* * *$ \\
\hline 87 & IC & $* * *$ & $* * *$ & $* * *$ & $* * *$ & $* * *$ & $* * *$ & 5.8 & $* * *$ \\
\hline AVG. & & 9.8 & 42.8 & 10.4 & $\begin{array}{c}46.1 \\
\end{array}$ & 11.6 & " 58.0 & 12.1 & $\begin{array}{l}68.7 \\
\end{array}$ \\
\hline
\end{tabular}

Page 141 
MHDSF Young-Growth Giant Sequoia Management Strategies Study 2009 - Overstory Summary Data (39ft. (12m) Plot)

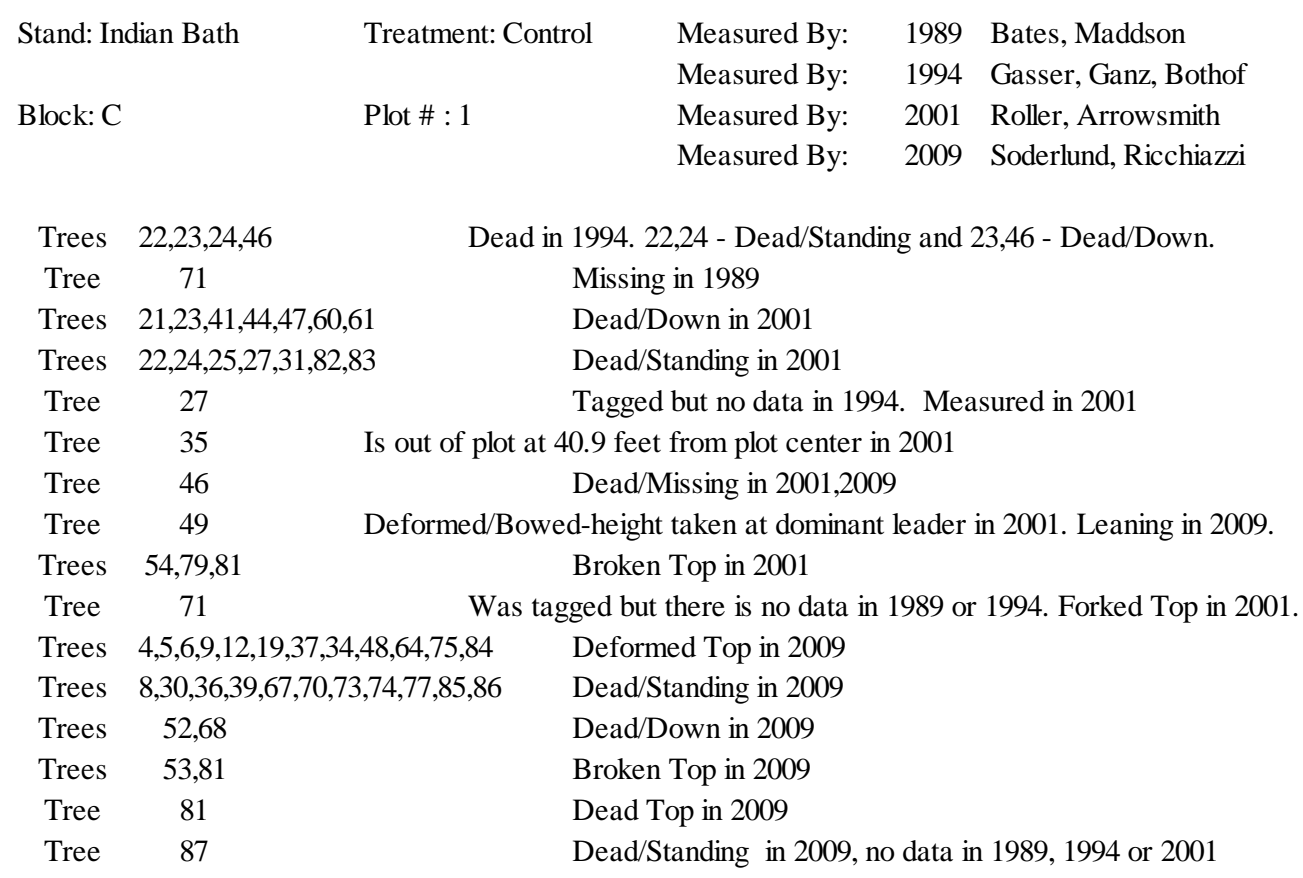


MHDSF Young-Growth Giant Sequoia Management Strategies Study 2009 - Overstory Summary Growth Data (39ft. (12m) Plot)

$\begin{array}{lllll}\text { Stand: Indian Bath } & \text { Treatment: Control } & \text { Measured By: } & 1989 & \text { Bates, Maddson } \\ & & \text { Measured By: } & 1994 & \text { Gasser, Ganz, Bothof } \\ \text { Block: C } & \text { Plot \# :1 } & \text { Measured By: } & 2001 & \text { Roller, Arrowsmith } \\ & & \text { Measured By: } & 2009 & \text { Soderlund, Ricchiazzi }\end{array}$

\begin{tabular}{|c|c|c|c|c|c|c|c|c|c|c|c|c|c|}
\hline \multirow[b]{2}{*}{ Tree \# } & \multirow[b]{2}{*}{ Species } & \multicolumn{2}{|c|}{$\begin{array}{c}\text { Change } \\
\text { 1989-1994 }\end{array}$} & \multicolumn{2}{|c|}{$\begin{array}{c}\text { Change } \\
\text { 1994-2001 }\end{array}$} & \multicolumn{2}{|c|}{$\begin{array}{c}\text { Change } \\
\text { 1989-2001 }\end{array}$} & \multicolumn{2}{|c|}{$\begin{array}{c}\text { Change } \\
\text { 1994-2009 }\end{array}$} & \multicolumn{2}{|c|}{$\begin{array}{c}\text { Change } \\
\text { 2001-2009 }\end{array}$} & \multicolumn{2}{|c|}{$\begin{array}{c}\text { Change } \\
\text { 1989-2009 }\end{array}$} \\
\hline & & $\mathrm{DBH}$ & Height & DBH & Height & DBH & Height & DBH & Height & $\mathrm{DBH}$ & Height & DBH & Height \\
\hline 4 & IC & 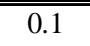 & 0.0 & 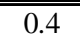 & 4.8 & 0.5 & 4 & 0.3 & 4 & $\begin{array}{c}-0.1 \\
\end{array}$ & -0.1 & 0.4 & 4.7 \\
\hline 5 & IC & 0.0 & -1.0 & 0.3 & 5.2 & 0.3 & 4.2 & -0.1 & 3.3 & -0.4 & -1.9 & -0.1 & 2.3 \\
\hline 6 & IC & 0.3 & 0.0 & 0.5 & 11.2 & 0.8 & 11.2 & 0.8 & 6.3 & 0.3 & -4.9 & 1.1 & 6.3 \\
\hline 7 & WF & 1.3 & 3.0 & 2.7 & 14.7 & 4.0 & 17.7 & 4.2 & 18.3 & 1.5 & 3.6 & 5.5 & 21.3 \\
\hline 8 & IC & 0.0 & 1.0 & 0.2 & 1.6 & 0.2 & 2.6 & 0.2 & $* * *$ & 0.0 & $* * *$ & 0.2 & $* * *$ \\
\hline 9 & IC & 0.3 & 0.0 & 0.4 & 4.6 & 0.7 & 4.6 & 0.5 & 6.6 & 0.1 & 2.0 & 0.8 & 6.6 \\
\hline 10 & GS & 0.7 & -1.0 & 1.7 & 20.8 & 2.4 & 19.8 & 3.6 & 23.1 & 1.9 & 2.3 & 4.3 & 22.1 \\
\hline 11 & IC & 0.2 & -1.0 & 0.2 & 3.6 & 0.4 & 2.6 & 0.4 & 4.7 & 0.2 & 1.1 & 0.6 & 3.7 \\
\hline 12 & GS & 0.2 & 0.0 & 0.2 & 1.7 & 0.4 & 1.7 & 0.6 & 1.3 & 0.4 & -0.4 & 0.8 & 1.3 \\
\hline 13 & GS & -0.6 & 3.0 & 0.5 & 4.4 & -0.1 & 7.4 & 0.9 & 7.9 & 0.4 & 3.5 & 0.3 & 10.9 \\
\hline 14 & GS & 0.7 & -3.0 & 2.6 & 11.1 & 3.3 & 8.1 & 4.3 & 21.9 & 1.7 & 10.8 & 5.0 & 18.9 \\
\hline 15 & SP & 0.5 & -6.0 & 1.5 & 16.4 & 2.0 & 10.4 & 3.2 & 24.9 & 1.7 & 8.5 & 3.7 & 18.9 \\
\hline 16 & IC & 0.1 & -3.0 & 0.0 & 4.3 & 0.1 & 1.3 & -0.1 & 5.3 & -0.1 & 1.0 & 0.0 & 2.3 \\
\hline 17 & IC & 0.1 & -1.0 & 0.1 & 4.1 & 0.2 & 3.1 & 0.1 & 4.6 & 0.0 & 0.5 & 0.2 & 3.6 \\
\hline 18 & GS & 0.6 & 3.0 & 0.7 & 19.7 & 1.3 & 22.7 & 2.1 & 23.9 & 1.4 & 4.2 & 2.7 & 26.9 \\
\hline 19 & GS & 0.2 & 0.0 & 0.5 & 10.5 & 0.7 & 10.5 & 0.7 & 4.3 & 0.2 & -6.2 & 0.9 & 4.3 \\
\hline 20 & GS & 0.1 & 2.0 & 0.3 & 2.8 & 0.4 & 4.8 & 0.4 & 5.7 & 0.1 & 2.9 & 0.5 & 7.7 \\
\hline 21 & IC & -0.2 & -1.0 & $* * *$ & $* * *$ & $* * *$ & $* * *$ & $* * *$ & $* * *$ & $* * *$ & $* * *$ & $* * *$ & $* * *$ \\
\hline 22 & IC & $* * *$ & $* * *$ & $* * *$ & $* * *$ & $* * *$ & $* * *$ & $* * *$ & $* * *$ & -0.1 & $* * *$ & 0.4 & $* * *$ \\
\hline 23 & IC & $* * *$ & $* * *$ & $* * *$ & $* * *$ & $* * *$ & $* * *$ & $* * *$ & $* * *$ & $* * *$ & $* * *$ & $* * *$ & $* * *$ \\
\hline 24 & GS & $* * *$ & $* * *$ & $* * *$ & $* * *$ & $* * *$ & $* * *$ & $* * *$ & $* * *$ & -0.2 & $* * *$ & -0.3 & $* * *$ \\
\hline 25 & IC & 0.1 & -4.0 & -0.2 & $* * *$ & -0.1 & $* * *$ & -0.2 & $* * *$ & 0.0 & $* * *$ & -0.1 & $* * *$ \\
\hline 26 & GS & 0.7 & -2.0 & 2.1 & 13.5 & 2.8 & 11.5 & 3.6 & 17.6 & 1.5 & 4.1 & 4.3 & 15.6 \\
\hline 27 & IC & $* * *$ & $* * *$ & $* * *$ & $* * *$ & $* * *$ & $* * *$ & $* * *$ & $* * *$ & 0.0 & $* * *$ & 0.1 & $* * *$ \\
\hline 28 & GS & 0.8 & 7.0 & 2.4 & 10.6 & 3.2 & 17.6 & 4.2 & 18.6 & 1.8 & 8.0 & 5.0 & 25.6 \\
\hline 29 & GS & 0.5 & -1.0 & 2.4 & 15.9 & 2.9 & 14.9 & 4.2 & 22.4 & 1.8 & 6.5 & 4.7 & 21.4 \\
\hline 30 & IC & 0.0 & -16.0 & 0.0 & 10.1 & 0.0 & -5.9 & -0.1 & $* * *$ & -0.1 & $* * *$ & -0.1 & $* * *$ \\
\hline 31 & IC & 0.0 & 3.0 & -0.4 & $* * *$ & -0.4 & $* * *$ & -0.4 & $* * *$ & 0.0 & $* * *$ & -0.4 & $* * *$ \\
\hline 32 & IC & -0.1 & 9.0 & 0.1 & -5.5 & 0.0 & 3.5 & 0.1 & -4.9 & 0.0 & 0.6 & 0.0 & 4.1 \\
\hline 33 & GS & 0.5 & 2.0 & 1.3 & 16.8 & 1.8 & 18.8 & 2.6 & 19.3 & 1.3 & 2.5 & 3.1 & 21.3 \\
\hline 34 & GS & 0.0 & 1.0 & 0.0 & 7.6 & 0.0 & 8.6 & -0.1 & 5.4 & -0.1 & -2.2 & -0.1 & 6.4 \\
\hline 35 & IC & 0.1 & 2.0 & 1.4 & 4.8 & 1.5 & 6.8 & 0.2 & 3.6 & -1.2 & -1.2 & 0.3 & 5.6 \\
\hline 36 & IC & 0.0 & -1.0 & 0.0 & 2.7 & 0.0 & 1.7 & -0.1 & $* * *$ & -0.1 & $* * *$ & -0.1 & $* * *$ \\
\hline 37 & IC & 0.0 & 4.0 & 0.2 & 3.0 & 0.2 & 7.0 & 0.3 & 0.4 & 0.1 & -2.6 & 0.3 & 4.4 \\
\hline 38 & GS & 0.5 & 6.0 & 1.5 & 9.7 & 2.0 & 15.7 & 3.0 & 13.6 & 1.5 & 3.9 & 3.5 & 19.6 \\
\hline 39 & IC & 0.0 & -1.0 & -0.1 & 1.0 & -0.1 & 0.0 & -0.3 & $* * *$ & -0.2 & $* * *$ & -0.3 & $* * *$ \\
\hline 40 & GS & 0.0 & 9.0 & 0.7 & 10.2 & 0.7 & 19.2 & 1.0 & 12.9 & 0.3 & 2.7 & 1.0 & 21.9 \\
\hline 41 & IC & 0.0 & -2.0 & $* * *$ & $* * *$ & $* * *$ & $* * *$ & $* * *$ & $* * *$ & $* * *$ & $* * *$ & $* * *$ & $* * *$ \\
\hline 42 & GS & 0.4 & 16.0 & 1.2 & -2.0 & 1.6 & 14.0 & 2.1 & 4.6 & 0.9 & 6.6 & 2.5 & 20.6 \\
\hline 43 & GS & 0.5 & 4.0 & 1.4 & -5.0 & 1.9 & -1.0 & 2.3 & 7.1 & 0.9 & 12.1 & 2.8 & 11.1 \\
\hline 44 & IC & 0.1 & -4.0 & $* * *$ & $* * *$ & $* * *$ & $* * *$ & $* * *$ & $* * *$ & $* * *$ & $* * *$ & $* * *$ & $* * *$ \\
\hline 45 & GS & 0.1 & -3.0 & 0.0 & 2.2 & 0.1 & -0.8 & -0.1 & 3.1 & -0.1 & 0.9 & 0.0 & 0.1 \\
\hline 46 & IC & $* * *$ & $* * *$ & $* * *$ & $* * *$ & $* * *$ & $* * *$ & $* * *$ & $* * *$ & $* * *$ & $* * *$ & $* * *$ & $* * *$ \\
\hline
\end{tabular}


MHDSF Young-Growth Giant Sequoia Management Strategies Study 2009 - Overstory Summary Growth Data (39ft. (12m) Plot)

$\begin{array}{lllll}\text { Stand: Indian Bath } & \text { Treatment: Control } & \text { Measured By: } & 1989 & \text { Bates, Maddson } \\ & & \text { Measured By: } & 1994 & \text { Gasser, Ganz, Bothof } \\ \text { Block: C } & \text { Plot \# : } 1 & \text { Measured By: } & 2001 & \text { Roller, Arrowsmith } \\ & & \text { Measured By: } & 2009 & \text { Soderlund, Ricchiazzi }\end{array}$

\begin{tabular}{|c|c|c|c|c|c|c|c|c|c|c|c|c|c|}
\hline \multirow[b]{2}{*}{ Tree \# } & \multirow[b]{2}{*}{ Species } & \multicolumn{2}{|c|}{$\begin{array}{c}\text { Change } \\
1989-1994\end{array}$} & \multicolumn{2}{|c|}{$\begin{array}{c}\text { Change } \\
\text { 1994-2001 }\end{array}$} & \multicolumn{2}{|c|}{$\begin{array}{c}\text { Change } \\
1989-2001\end{array}$} & \multicolumn{2}{|c|}{$\begin{array}{c}\text { Change } \\
\text { 1994-2009 }\end{array}$} & \multicolumn{2}{|c|}{$\begin{array}{c}\text { Change } \\
\text { 2001-2009 }\end{array}$} & \multicolumn{2}{|c|}{$\begin{array}{c}\text { Change } \\
1989-2009\end{array}$} \\
\hline & & DBH & Height & DBH & Height & $\mathrm{DBH}$ & Height & DBH & Height & DBH & Height & DBH & Height \\
\hline 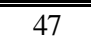 & GS & " -0.1 & 0.0 & "*** & " $* * *$ & "*** & " $* * *$ & "*** & " $* * *$ & "*** & " $* * *$ & "*** & " $* * *$ \\
\hline 48 & IC & 0.0 & -2.0 & 0.4 & 2.6 & 0.4 & 0.6 & 0.3 & 2.2 & -0.1 & -0.4 & 0.3 & 0.2 \\
\hline 49 & IC & 0.0 & -2.0 & 0.1 & 5.5 & 0.1 & 3.5 & 0.2 & 3.2 & 0.1 & -2.3 & 0.2 & 1.2 \\
\hline 50 & IC & 0.0 & 1.0 & 0.3 & 1.2 & 0.3 & 2.2 & 0.4 & 1.4 & 0.1 & 0.2 & 0.4 & 2.4 \\
\hline 51 & IC & 0.3 & 0.0 & 0.8 & 6.6 & 1.1 & 6.6 & 1.1 & 9.0 & 0.3 & 2.4 & 1.4 & 9.0 \\
\hline 52 & GS & 0.0 & 1.0 & 1.1 & 0.8 & 1.1 & 1.8 & $* * *$ & $* * *$ & $* * *$ & $* * *$ & $* * *$ & $* * *$ \\
\hline 53 & GS & 0.3 & 2.0 & 0.6 & 10.6 & 0.9 & 12.6 & 0.6 & -13.0 & 0.0 & -23.6 & 0.9 & -11.0 \\
\hline 54 & GS & 0.4 & 2.0 & 0.5 & -8.3 & 0.9 & -6.3 & 0.5 & -5.5 & 0.0 & 2.8 & 0.9 & -3.5 \\
\hline 55 & GS & 0.2 & -1.0 & 0.1 & 2.5 & 0.3 & 1.5 & 0.1 & 3.5 & 0.0 & 1.0 & 0.3 & 2.5 \\
\hline 56 & GS & 0.8 & -1.0 & 2.5 & 9.0 & 3.3 & 8.0 & 4.6 & 22.8 & 2.1 & 13.8 & 5.4 & 21.8 \\
\hline 57 & GS & 0.4 & -1.0 & 1.2 & 19.7 & 1.6 & 18.7 & 2.5 & 22.5 & 1.3 & 2.8 & 2.9 & 21.5 \\
\hline 58 & GS & 0.0 & 1.0 & 0.0 & 2.9 & 0.0 & 3.9 & -0.1 & 0.6 & -0.1 & -2.3 & -0.1 & 1.6 \\
\hline 59 & GS & 0.5 & -1.0 & 1.3 & 17.8 & 1.8 & 16.8 & 2.3 & 23.5 & 1.0 & 5.7 & 2.8 & 22.5 \\
\hline 60 & IC & -0.1 & 1.0 & $* * *$ & $* * *$ & $* * *$ & $* * *$ & $* * *$ & $* * *$ & $* * *$ & $* * *$ & $* * *$ & $* * *$ \\
\hline 61 & IC & -0.2 & 0.0 & $* * *$ & $* * *$ & $* * *$ & $* * *$ & $* * *$ & $* * *$ & $* * *$ & $* * *$ & $* * *$ & $* * *$ \\
\hline 62 & GS & 0.2 & 0.0 & 0.2 & 4.8 & 0.4 & 4.8 & 0.3 & 5.2 & 0.1 & 0.4 & 0.5 & 5.2 \\
\hline 63 & GS & 0.3 & -3.0 & 0.6 & 14.0 & 0.9 & 11.0 & 0.8 & 22.2 & 0.2 & 8.2 & 1.1 & 19.2 \\
\hline 64 & GS & 0.1 & 0.0 & 0.1 & 2.1 & 0.2 & 2.1 & 0.0 & 1.7 & -0.1 & -0.4 & 0.1 & 1.7 \\
\hline 65 & GS & 0.4 & 0.0 & 1.4 & 8.4 & 1.8 & 8.4 & 0.7 & 13.2 & -0.7 & 4.8 & 1.1 & 13.2 \\
\hline 66 & GS & 0.6 & 8.0 & 1.8 & 11.3 & 2.4 & 19.3 & 3.0 & 19.1 & 1.2 & 7.8 & 3.6 & 27.1 \\
\hline 67 & WF & 0.1 & -2.0 & -0.1 & 1.7 & 0.0 & -0.3 & -0.1 & $* * *$ & 0.0 & $* * *$ & 0.0 & $* * *$ \\
\hline 68 & IC & 0.0 & 1.0 & -0.2 & 0.6 & -0.2 & 1.6 & $* * *$ & $* * *$ & $* * *$ & $* * *$ & $* * *$ & $* * *$ \\
\hline 69 & IC & 0.0 & -1.0 & 0.1 & 3.8 & 0.1 & 2.8 & 0.0 & 4.2 & -0.1 & 0.4 & 0.0 & 3.2 \\
\hline 70 & IC & 0.1 & 3.0 & -0.2 & 4.1 & -0.1 & 7.1 & -0.3 & $* * *$ & -0.1 & $* * *$ & -0.2 & $* * *$ \\
\hline 71 & WF & $* * *$ & $* * *$ & $* * *$ & $* * *$ & $* * *$ & $* * *$ & $* * *$ & $* * *$ & 1.8 & 2.6 & $* * *$ & $* * *$ \\
\hline 72 & GS & 0.5 & 39.0 & 1.7 & 5.0 & 2.2 & 44.0 & 3.1 & 18.2 & 1.4 & 13.2 & 3.6 & 57.2 \\
\hline 73 & IC & 0.0 & 0.0 & -0.1 & 6.7 & -0.1 & 6.7 & -0.2 & $* * *$ & -0.1 & $* * *$ & -0.2 & $* * *$ \\
\hline 74 & IC & 0.0 & 1.0 & 0.0 & 6.0 & 0.0 & 7.0 & -0.2 & $* * *$ & -0.2 & $* * *$ & -0.2 & $* * *$ \\
\hline 75 & IC & 0.1 & 1.0 & 0.4 & 5.9 & 0.5 & 6.9 & 0.3 & 3.6 & -0.1 & -2.3 & 0.4 & 4.6 \\
\hline 76 & WF & 0.3 & 1.0 & 0.4 & 7.1 & 0.7 & 8.1 & 0.5 & 10.4 & 0.1 & 3.3 & 0.8 & 11.4 \\
\hline 77 & WF & 0.0 & -7.0 & 0.1 & 6.2 & 0.1 & -0.8 & 0.0 & $* * *$ & -0.1 & $* * *$ & 0.0 & $* * *$ \\
\hline 78 & GS & 0.7 & 2.0 & 2.0 & 13.7 & 2.7 & 15.7 & 3.2 & 20.0 & 1.2 & 6.3 & 3.9 & 22.0 \\
\hline 79 & WF & 0.3 & 5.0 & 0.4 & -18.2 & 0.7 & -13.2 & 0.5 & -13.2 & 0.1 & 5.0 & 0.8 & -8.2 \\
\hline 80 & GS & 1.5 & 2.0 & 2.4 & 12.7 & 3.9 & 14.7 & 3.9 & 21.5 & 1.5 & 8.8 & 5.4 & 23.5 \\
\hline 81 & SP & 0.5 & 9.0 & 1.5 & 8.0 & 2.0 & 17.0 & 1.8 & 3.2 & 0.3 & -4.8 & 2.3 & 12.2 \\
\hline 82 & IC & -0.2 & 2.0 & -0.1 & $* * *$ & -0.3 & $* * *$ & -0.2 & $* * *$ & -0.1 & $* * *$ & -0.4 & $* * *$ \\
\hline 83 & IC & -0.2 & 2.0 & -0.3 & $* * *$ & -0.5 & $* * *$ & -0.3 & $* * *$ & 0.0 & $* * *$ & -0.5 & $* * *$ \\
\hline 84 & IC & -0.1 & 0.0 & 0.0 & 2.4 & -0.1 & 2.4 & 0.0 & -0.4 & 0.0 & -2.8 & -0.1 & -0.4 \\
\hline 85 & IC & -2.4 & -2.0 & -0.2 & 9.0 & -2.6 & 7.0 & -0.3 & $* * *$ & -0.1 & $* * *$ & -2.7 & $* * *$ \\
\hline 86 & IC & 2.4 & 2.0 & 0.0 & 6.4 & 2.4 & 8.4 & -0.2 & $* * *$ & -0.2 & $* * *$ & 2.2 & $* * *$ \\
\hline 87 & IC & $* * *$ & $* * *$ & $* * *$ & $* * *$ & $* * *$ & $* * *$ & $* * *$ & $* * *$ & $* * *$ & $* * *$ & $* * *$ & $* * *$ \\
\hline AVG. & & 0.2 & 1.1 & 0.7 & 6.4 & 0.9 & 7.8 & 1.1 & 9.1 & 0.4 & 2.2 & 1.3 & 11.1 \\
\hline
\end{tabular}


MHDSF Young-Growth Giant Sequoia Management Strategies Study 2009 - Overstory Summary Growth Data (39ft. (12m) Plot)

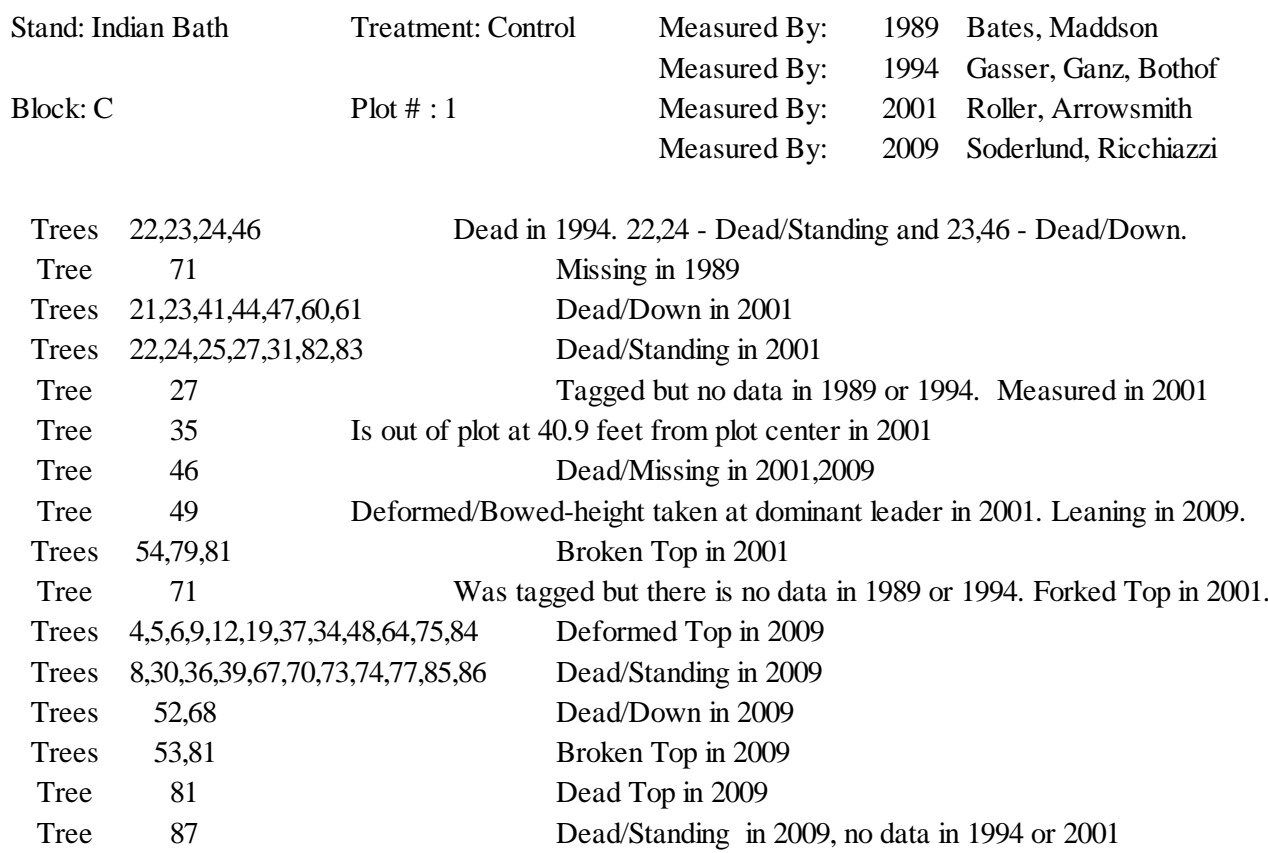




\begin{tabular}{|c|c|c|c|c|}
\hline \multirow[t]{2}{*}{ Stand: Indian Bath } & Treatment: Control & Measured By: & 1989 & Scott, Eagan \\
\hline & & Measured By: & 1994 & Gasser, Ganz, Bothof \\
\hline \multirow[t]{2}{*}{ Block: C } & Plot \# : 2 & Measured By: & 2001 & Roller, Arrowsmith \\
\hline & & Measured By: & 2009 & Soderlund, Ricchiazzi \\
\hline
\end{tabular}

\begin{tabular}{|c|c|c|c|c|c|c|c|c|c|}
\hline \multirow[b]{2}{*}{ Tree \# } & \multirow[b]{2}{*}{ Species } & \multicolumn{2}{|c|}{1989 Data } & \multicolumn{2}{|c|}{1994 Data } & \multicolumn{2}{|c|}{2001 Data } & \multicolumn{2}{|c|}{2009 Data } \\
\hline & & $\mathrm{DBH}$ & Height & $\mathrm{DBH}$ & Height & $\mathrm{DBH}$ & Height & $\mathrm{DBH}$ & Height \\
\hline 37 & IC & 2.2 & 11.0 & 2.4 & 11.0 & 2.5 & 14.0 & 2.7 & 14.0 \\
\hline 38 & GS & 34.2 & 134.0 & 35.4 & 142.0 & 37.6 & 156.2 & 39.7 & 161.8 \\
\hline 39 & WF & 10.2 & 53.0 & 10.6 & 57.0 & 11.2 & 65.4 & 11.7 & 68.7 \\
\hline 40 & IC & 1.0 & 7.0 & 1.2 & 8.0 & 1.4 & 8.7 & 1.4 & 9.1 \\
\hline 41 & GS & 32.5 & 118.0 & 33.1 & 130.0 & 34.9 & 141.7 & 36.5 & 153.2 \\
\hline 42 & GS & 30.1 & 113.0 & 30.0 & 115.0 & 31.5 & 120.1 & 32.7 & 138.2 \\
\hline 43 & GS & 9.1 & 42.0 & 9.1 & 39.0 & 9.3 & 41.6 & 9.4 & 40.1 \\
\hline 44 & IC & 0.9 & 8.0 & 1.1 & 8.0 & 1.3 & 9.6 & 1.4 & 13.5 \\
\hline 45 & GS & 9.0 & 47.0 & 9.1 & 47.0 & 9.3 & 48.8 & 9.3 & 50.2 \\
\hline 46 & GS & 19.6 & 114.0 & 20.1 & 115.0 & 21.8 & 129.0 & 23.2 & 140.1 \\
\hline 47 & GS & 27.5 & 118.0 & 28.2 & 119.0 & 30.1 & 128.7 & 31.8 & 139.5 \\
\hline 48 & GS & 10.9 & 113.0 & 11.0 & 76.0 & 11.0 & 79.6 & 11.0 & 74.4 \\
\hline 49 & GS & 32.5 & 114.0 & 33.5 & 112.0 & 35.5 & 129.1 & 37.6 & 136.5 \\
\hline 50 & GS & 13.5 & 88.0 & 13.6 & 92.0 & 14.2 & 107.5 & 14.3 & 107.7 \\
\hline 51 & GS & 27.7 & 115.0 & 28.4 & 118.0 & 30.7 & 124.8 & 32.3 & 135.9 \\
\hline 52 & GS & 8.8 & 41.0 & 9.0 & 41.0 & 9.4 & 37.1 & 9.4 & 38.7 \\
\hline 53 & GS & 18.3 & 80.0 & 18.8 & 105.0 & 19.9 & 109.1 & 20.4 & 116.9 \\
\hline 54 & GS & 23.3 & 105.0 & 23.8 & 111.0 & 25.6 & 124.7 & 27.4 & 133.0 \\
\hline 55 & GS & 7.5 & 23.0 & 7.6 & 23.0 & 7.8 & 23.2 & 7.6 & 24.7 \\
\hline 56 & GS & 20.7 & 103.0 & 21.3 & 109.0 & 23.1 & 124.9 & 24.4 & 133.2 \\
\hline 57 & GS & 8.8 & 48.0 & 9.0 & 45.0 & 9.3 & 57.3 & 9.3 & 52.5 \\
\hline 58 & GS & 1.9 & 7.0 & 2.0 & 8.0 & 2.0 & 8.6 & 2.1 & 8.1 \\
\hline 59 & GS & 26.3 & 99.0 & 26.8 & 103.0 & 28.6 & 118.7 & 29.8 & 127.1 \\
\hline 60 & GS & 36.0 & 127.0 & 36.4 & 127.0 & 38.6 & 139.5 & 40.7 & 150.5 \\
\hline 61 & GS & 3.8 & 10.0 & 3.9 & 10.0 & 3.8 & 13.9 & 3.9 & 13.5 \\
\hline 62 & SP & 15.5 & 77.0 & 15.8 & 80.0 & 16.7 & 97.5 & 17.1 & 92.5 \\
\hline 63 & GS & 26.3 & 128.0 & 31.1 & 131.0 & 31.9 & 155.1 & 33.6 & 155.4 \\
\hline 64 & WF & 5.7 & 27.0 & 5.9 & 28.0 & 6.3 & 32.2 & 6.6 & 32.6 \\
\hline 65 & WF & 1.4 & 9.0 & 1.5 & 9.0 & 1.5 & 10.1 & $* * *$ & $* * *$ \\
\hline 66 & GS & 31.1 & 119.0 & 31.6 & 121.0 & 32.8 & 129.8 & 34.0 & 135.3 \\
\hline 67 & GS & 24.1 & 125.0 & 25.3 & 124.0 & 27.2 & 140.8 & 29.1 & 146.0 \\
\hline 68 & WF & 5.9 & 27.0 & 6.3 & 29.0 & 7.0 & 36.6 & 7.3 & 37.7 \\
\hline AVG. & & 16.4 & 73.4 & 17.0 & 74.8 & 17.9 & 83.2 & 19.3 & 89.7 \\
\hline Trees & 45,52 & & Broken & op in 2 & & & & & \\
\hline Tree & 64 & & Is out of & plot at & $9.9 \mathrm{ft}$ fro & n plot c & nter in 2 & & \\
\hline Tree & 57,62 & & Broken & op in 2 & & & & & \\
\hline Trees & $43,45,48,5$ & 3,61 & Deform & d Top i & 2009 & & & & \\
\hline Tree & 61 & & Dead Tr & $p$ in 200 & & & & & \\
\hline Tree & 65 & & Dead/D & wn in 2 & 009 & & & & \\
\hline
\end{tabular}

Page 146 
MHDSF Young-Growth Giant Sequoia Management Strategies Study 2009 - Overstory Summary Growth Data (39ft. (12m) Plot)

$\begin{array}{lllll}\text { Stand: Indian Bath } & \text { Treatment: Control } & \text { Measured By: } & 1989 & \text { Scott, Eagan } \\ & & \text { Measured By: } & 1994 & \text { Gasser, Ganz, Bothof } \\ \text { Block: C } & \text { Plot \# :2 } & \text { Measured By: } & 2001 & \text { Roller, Arrowsmith } \\ & & \text { Measured By: } & 2009 & \text { Soderlund, Ricchiazzi }\end{array}$

\begin{tabular}{|c|c|c|c|c|c|c|c|c|c|c|c|c|c|}
\hline \multirow[b]{2}{*}{ Tree \# } & \multirow[b]{2}{*}{ Species } & \multicolumn{2}{|c|}{$\begin{array}{c}\text { Change } \\
\text { 1989-1994 }\end{array}$} & \multicolumn{2}{|c|}{$\begin{array}{c}\text { Change } \\
\text { 1994-2001 }\end{array}$} & \multicolumn{2}{|c|}{$\begin{array}{c}\text { Change } \\
\text { 1989-2001 }\end{array}$} & \multicolumn{2}{|c|}{$\begin{array}{c}\text { Change } \\
\text { 1994-2009 }\end{array}$} & \multicolumn{2}{|c|}{$\begin{array}{l}\text { Change } \\
\text { 2001-2009 }\end{array}$} & \multicolumn{2}{|c|}{$\begin{array}{c}\text { Change } \\
\text { 1989-2009 }\end{array}$} \\
\hline & & DBH & Height & $\mathrm{DBH}$ & Height & $\mathrm{DBH}$ & Height & DBH & Height & $\mathrm{DBH}$ & Height & $\mathrm{DBH}$ & Height \\
\hline 37 & IC & 0.2 & 0.0 & 0.1 & 3.0 & 0.3 & 3.0 & 0.3 & 3.0 & 0.2 & 0.0 & 0.5 & 3.0 \\
\hline 38 & GS & 1.2 & 8.0 & 2.2 & 14.2 & 3.4 & 22.2 & 4.3 & 19.8 & 2.1 & 5.6 & 5.5 & 27.8 \\
\hline 39 & WF & 0.4 & 4.0 & 0.6 & 8.4 & 1.0 & 12.4 & 1.1 & 11.7 & 0.5 & 3.3 & 1.5 & 15.7 \\
\hline 40 & IC & 0.2 & 1.0 & 0.2 & 0.7 & 0.4 & 1.7 & 0.2 & 1.1 & 0.0 & 0.4 & 0.4 & 2.1 \\
\hline 41 & GS & 0.6 & 12.0 & 1.8 & 11.7 & 2.4 & 23.7 & 3.4 & 23.2 & 1.6 & 11.5 & 4.0 & 35.2 \\
\hline 42 & GS & -0.1 & 2.0 & 1.5 & 5.1 & 1.4 & 7.1 & 2.7 & 23.2 & 1.2 & 18.1 & 2.6 & 25.2 \\
\hline 43 & GS & 0.0 & -3.0 & 0.2 & 2.6 & 0.2 & -0.4 & 0.3 & 1.1 & 0.1 & -1.5 & 0.3 & -1.9 \\
\hline 44 & IC & 0.2 & 0.0 & 0.2 & 1.6 & 0.4 & 1.6 & 0.3 & 5.5 & 0.1 & 3.9 & 0.5 & 5.5 \\
\hline 45 & GS & 0.1 & 0.0 & 0.2 & 1.8 & 0.3 & 1.8 & 0.2 & 3.2 & 0.0 & 1.4 & 0.3 & 3.2 \\
\hline 46 & GS & 0.5 & 1.0 & 1.7 & 14.0 & 2.2 & 15.0 & 3.1 & 25.1 & 1.4 & 11.1 & 3.6 & 26.1 \\
\hline 47 & GS & 0.7 & 1.0 & 1.9 & 9.7 & 2.6 & 10.7 & 3.6 & 20.5 & 1.7 & 10.8 & 4.3 & 21.5 \\
\hline 48 & GS & 0.1 & -37.0 & 0.0 & 3.6 & 0.1 & -33.4 & 0.0 & -1.6 & 0.0 & -5.2 & 0.1 & -38.6 \\
\hline 49 & GS & 1.0 & -2.0 & 2.0 & 17.1 & 3.0 & 15.1 & 4.1 & 24.5 & 2.1 & 7.4 & 5.1 & 22.5 \\
\hline 50 & GS & 0.1 & 4.0 & 0.6 & 15.5 & 0.7 & 19.5 & 0.7 & 15.7 & 0.1 & 0.2 & 0.8 & 19.7 \\
\hline 51 & GS & 0.7 & 3.0 & 2.3 & 6.8 & 3.0 & 9.8 & 3.9 & 17.9 & 1.6 & 11.1 & 4.6 & 20.9 \\
\hline 52 & GS & 0.2 & 0.0 & 0.4 & -3.9 & 0.6 & -3.9 & 0.4 & -2.3 & 0.0 & 1.6 & 0.6 & -2.3 \\
\hline 53 & GS & 0.5 & 25.0 & 1.1 & 4.1 & 1.6 & 29.1 & 1.6 & 11.9 & 0.5 & 7.8 & 2.1 & 36.9 \\
\hline 54 & GS & 0.5 & 6.0 & 1.8 & 13.7 & 2.3 & 19.7 & 3.6 & 22.0 & 1.8 & 8.3 & 4.1 & 28.0 \\
\hline 55 & GS & 0.1 & 0.0 & 0.2 & 0.2 & 0.3 & 0.2 & 0.0 & 1.7 & -0.2 & 1.5 & 0.1 & 1.7 \\
\hline 56 & GS & 0.6 & 6.0 & 1.8 & 15.9 & 2.4 & 21.9 & 3.1 & 24.2 & 1.3 & 8.3 & 3.7 & 30.2 \\
\hline 57 & GS & 0.2 & -3.0 & 0.3 & 12.3 & 0.5 & 9.3 & 0.3 & 7.5 & 0.0 & -4.8 & 0.5 & 4.5 \\
\hline 58 & GS & 0.1 & 1.0 & 0.0 & 0.6 & 0.1 & 1.6 & 0.1 & 0.1 & 0.1 & -0.5 & 0.2 & 1.1 \\
\hline 59 & GS & 0.5 & 4.0 & 1.8 & 15.7 & 2.3 & 19.7 & 3.0 & 24.1 & 1.2 & 8.4 & 3.5 & 28.1 \\
\hline 60 & GS & 0.4 & 0.0 & 2.2 & 12.5 & 2.6 & 12.5 & 4.3 & 23.5 & 2.1 & 11.0 & 4.7 & 23.5 \\
\hline 61 & GS & 0.1 & 0.0 & -0.1 & 3.9 & 0.0 & 3.9 & 0.0 & 3.5 & 0.1 & -0.4 & 0.1 & 3.5 \\
\hline 62 & SP & 0.3 & 3.0 & 0.9 & 17.5 & 1.2 & 20.5 & 1.3 & 12.5 & 0.4 & -5.0 & 1.6 & 15.5 \\
\hline 63 & GS & 4.8 & 3.0 & 0.8 & 24.1 & 5.6 & 27.1 & 2.5 & 24.4 & 1.7 & 0.3 & 7.3 & 27.4 \\
\hline 64 & WF & 0.2 & 1.0 & 0.4 & 4.2 & 0.6 & 5.2 & 0.7 & 4.6 & 0.3 & 0.4 & 0.9 & 5.6 \\
\hline 65 & WF & 0.1 & 0.0 & 0.0 & 1.1 & 0.1 & 1.1 & $* * *$ & $* * *$ & $* * *$ & $* * *$ & $* * *$ & $* * *$ \\
\hline 66 & GS & 0.5 & 2.0 & 1.2 & 8.8 & 1.7 & 10.8 & 2.4 & 14.3 & 1.2 & 5.5 & 2.9 & 16.3 \\
\hline 67 & GS & 1.2 & -1.0 & 1.9 & 16.8 & 3.1 & 15.8 & 3.8 & 22.0 & 1.9 & 5.2 & 5.0 & 21.0 \\
\hline 68 & WF & 0.4 & 2.0 & 0.7 & 7.6 & 1.1 & 9.6 & 1.0 & 8.7 & 0.3 & 1.1 & 1.4 & 10.7 \\
\hline AVG. & & 0.5 & 1.3 & 1.0 & 8.5 & 1.5 & 9.8 & 1.8 & 12.8 & 0.8 & 4.1 & 2.3 & 14.2 \\
\hline Trees & 45,52 & & Broken & op in 2 & & & & & & & & & \\
\hline Tree & 64 & & Is out of & plot at & $9.9 \mathrm{ft}$ fro & n plot & nter in 2 & & & & & & \\
\hline Tree & 57,62 & & Broken & op in 2 & & & & & & & & & \\
\hline Trees & $43,45,48,5$ & 8,61 & Deform & d Top i & 2009 & & & & & & & & \\
\hline Tree & 61 & & Dead T & $p$ in 200 & & & & & & & & & \\
\hline Tree & 65 & & Dead/D & wn in 2 & 009 & & & & & & & & \\
\hline
\end{tabular}


MHDSF Young-Growth Giant Sequoia Management Strategies Study 2009 - Overstory Summary Data (39ft. (12m) Plot)

$\begin{array}{lllll}\text { Stand: Methuselah } & \text { Treatment: Thinned } & \text { Measured By: } & 1989 & \text { Bates, Maddson } \\ & & \text { Measured By: } & 1994 & \text { Ganz } \\ \text { Block: A } & \text { Plot \# : } 1 & \text { Measured By: } & 2001 & \text { Roller, Kong } \\ & & \text { Measured By: } & 2009 & \text { Soderlund, Estrada }\end{array}$

\begin{tabular}{cc|cc|cc|cc|cc|}
\cline { 3 - 9 } Tree \# & Species & DBH & Height & DBH & Height & DBH & Height & DBH & Height \\
\hline \hline 1 & GS & 17.6 & 75.0 & 23.0 & 81.0 & 23.7 & 98.0 & 28.4 & 104.9 \\
2 & GS & 12.5 & 60.0 & 15.2 & 69.0 & 18.2 & 82.2 & 21.6 & 93.2 \\
3 & GS & 7.5 & 35.0 & 9.9 & 41.0 & 12.9 & 54.9 & 15.7 & 66.4 \\
4 & GS & $* * *$ & $* * *$ & $* * *$ & $* * *$ & $* * *$ & $* * *$ & $* * *$ & $* * *$ \\
5 & GS & 14.0 & 64.0 & 15.0 & 71.0 & 16.9 & 79.2 & 19.1 & 90.3 \\
6 & GS & 28.9 & 84.0 & 32.0 & 95.0 & 36.3 & 103.9 & 39.8 & 115.3 \\
7 & GS & 23.7 & 83.0 & 26.3 & 92.0 & 29.0 & 103.8 & 34.4 & 115.6 \\
8 & IC & 26.2 & 59.0 & 28.2 & 75.0 & 30.4 & 84.3 & 32.9 & 94.4 \\
9 & WF & $* * *$ & $* * *$ & $* * *$ & $* * *$ & 1.1 & 6.1 & 2.2 & 10.5 \\
10 & WF & $* * *$ & $* * *$ & $* * *$ & $* * *$ & $* * *$ & $* * *$ & 2.3 & 10.6 \\
11 & WF & $* * *$ & $* * *$ & $* * *$ & $* * *$ & $* * *$ & $* * *$ & 2.1 & 9.6 \\
12 & BO & $* * *$ & $* * *$ & $* * *$ & $* * *$ & $* * *$ & $* * *$ & 1.8 & 12.0 \\
13 & BO & $* * *$ & $* * *$ & $* * *$ & $* * *$ & $* * *$ & $* * *$ & 1.7 & 12.9 \\
14 & WF & $* * *$ & $* * *$ & $* * *$ & $* * *$ & $* * *$ & $* * *$ & 2.3 & 13.9 \\
15 & WF & $* * *$ & $* * *$ & $* * *$ & $* * *$ & $* * *$ & $* * *$ & 2.8 & 13.1 \\
16 & WF & $* * *$ & $* * *$ & $* * *$ & $* * *$ & $* * *$ & $* * *$ & 1.8 & 9.7 \\
17 & WF & $* * *$ & $* * *$ & $* * *$ & $* * *$ & $* * *$ & $* * *$ & 1.9 & 8.5 \\
\hline \hline
\end{tabular}

2009 - Overstory Summary Growth Data (39ft. (12m) Plot)

\begin{tabular}{|c|c|c|c|c|c|c|c|c|c|c|c|c|c|}
\hline \multirow[b]{2}{*}{ Tree \# } & \multirow[b]{2}{*}{ Species } & \multicolumn{2}{|c|}{$\begin{array}{c}\text { Change } \\
\text { 1989-1994 }\end{array}$} & \multicolumn{2}{|c|}{$\begin{array}{c}\text { Change } \\
\text { 1994-2001 }\end{array}$} & \multicolumn{2}{|c|}{$\begin{array}{c}\text { Change } \\
\text { 1989-2001 }\end{array}$} & \multicolumn{2}{|c|}{$\begin{array}{c}\text { Change } \\
\text { 1994-2009 }\end{array}$} & \multicolumn{2}{|c|}{$\begin{array}{c}\text { Change } \\
\text { 2001-2009 }\end{array}$} & \multicolumn{2}{|c|}{$\begin{array}{c}\text { Change } \\
1989-2009\end{array}$} \\
\hline & & $\mathrm{DBH}$ & Height & $\mathrm{DBH}$ & Height & $\mathrm{DBH}$ & Height & DBH & Height & $\mathrm{DBH}$ & Height & $\mathrm{DBH}$ & Height \\
\hline 1 & GS & 5.4 & 6.0 & 0.7 & 17.0 & 6.1 & 23.0 & 5.4 & 23.9 & 4.7 & 6.9 & 10.8 & 29.9 \\
\hline 2 & GS & 2.7 & 9.0 & 3.0 & 13.2 & 5.7 & 22.2 & 6.4 & 24.2 & 3.4 & 11.0 & 9.1 & 33.2 \\
\hline 3 & GS & 2.4 & 6.0 & 3.0 & 13.9 & 5.4 & 19.9 & 5.8 & 25.4 & 2.8 & 11.5 & 8.2 & 31.4 \\
\hline 4 & GS & $* * *$ & $* * *$ & $* * *$ & $* * *$ & $* * *$ & $* * *$ & $* * *$ & $* * *$ & $* * *$ & $* * *$ & $* * *$ & $* * *$ \\
\hline 5 & GS & 1.0 & 7.0 & 1.9 & 8.2 & 2.9 & 15.2 & 4.1 & 19.3 & 2.2 & 11.1 & 5.1 & 26.3 \\
\hline 6 & GS & 3.1 & 11.0 & 4.3 & 8.9 & 7.4 & 19.9 & 7.8 & 20.3 & 3.5 & 11.4 & 10.9 & 31.3 \\
\hline 7 & GS & 2.6 & 9.0 & 2.7 & 11.8 & 5.3 & 20.8 & 8.1 & 23.6 & 5.4 & 11.8 & 10.7 & 32.6 \\
\hline 8 & IC & 2.0 & 16.0 & 2.2 & 9.3 & 4.2 & 25.3 & 4.7 & 19.4 & 2.5 & 10.1 & 6.7 & 35.4 \\
\hline 9 & WF & $* * *$ & $* * *$ & $* * *$ & $* * *$ & $* * *$ & $* * *$ & $* * *$ & $* * *$ & 1.1 & 4.4 & $* * *$ & $* * *$ \\
\hline 10 & WF & $* * *$ & $* * *$ & $* * *$ & $* * *$ & $* * *$ & $* * *$ & $* * *$ & $* * *$ & $* * *$ & $* * *$ & $* * *$ & $* * *$ \\
\hline 11 & WF & $* * *$ & $* * *$ & $* * *$ & $* * *$ & $* * *$ & $* * *$ & $* * *$ & $* * *$ & $* * *$ & $* * *$ & $* * *$ & $* * *$ \\
\hline 12 & BO & $* * *$ & $* * *$ & $* * *$ & $* * *$ & $* * *$ & $* * *$ & $* * *$ & $* * *$ & $* * *$ & $* * *$ & $* * *$ & $* * *$ \\
\hline 13 & BO & $* * *$ & $* * *$ & $* * *$ & $* * *$ & $* * *$ & $* * *$ & $* * *$ & $* * *$ & $* * *$ & $* * *$ & $* * *$ & $* * *$ \\
\hline 14 & WF & $* * *$ & $* * *$ & $* * *$ & $* * *$ & $* * *$ & $* * *$ & $* * *$ & $* * *$ & $* * *$ & $* * *$ & $* * *$ & $* * *$ \\
\hline 15 & WF & $* * *$ & $* * *$ & $* * *$ & $* * *$ & $* * *$ & $* * *$ & $* * *$ & $* * *$ & $* * *$ & $* * *$ & $* * *$ & $* * *$ \\
\hline 16 & WF & $* * *$ & $* * *$ & $* * *$ & $* * *$ & $* * *$ & $* * *$ & $* * *$ & $* * *$ & $* * *$ & $* * *$ & $* * *$ & $* * *$ \\
\hline 17 & WF & $* * *$ & $* * *$ & $* * *$ & $* * *$ & $* * *$ & $* * *$ & $* * *$ & $* * *$ & $* * *$ & $* * *$ & $* * *$ & $* * *$ \\
\hline AVG. & & 2.7 & 9.1 & 2.5 & 11.8 & 5.3 & 20.9 & 6.0 & 22.3 & 3.2 & 9.8 & 8.8 & 31.4 \\
\hline
\end{tabular}


MHDSF Young-Growth Giant Sequoia Management Strategies Study 2009 - Overstory Summary Data (39ft. (12m) Plot)

$\begin{array}{lllll}\text { Stand: Methuselah } & \text { Treatment: Thinned } & \text { Measured By: } & 1989 \text { Bates, Maddson } \\ & & \text { Measured By: } & 1994 \text { Ganz } \\ \text { Block: A } & \text { Plot \# :1 } & \text { Measured By: } & 2001 \text { Roller, Kong } \\ & & \text { Measured By: } & 2009 \text { Soderlund, Estrada }\end{array}$

Tree $4 \quad$ Missing in 1994, no tree or data in 1989

Tree $\quad 9$ Ingrowth in 2001

Tree $\quad 3$ Previously measured but is out of plot at $41.0 \mathrm{ft}$ from plot center in 2001

Trees 10-17. Ingrowth in 2009 
MHDSF Young-Growth Giant Sequoia Management Strategies Study 2009 - Overstory Summary Data (39ft. (12m) Plot)

$\begin{array}{lllll}\text { Stand: Methuselah } & \text { Treatment: Thinned } & \text { Measured By: } & 1989 & \text { Bishop, Johannis } \\ & & \text { Measured By: } & 1994 & \text { Ganz } \\ \text { Block: A } & \text { Plot \# :2 } & \text { Measured By: } & 2001 & \text { Roller, Kong } \\ & & \text { Measured By: } & 2009 & \text { Soderlund, Estrada }\end{array}$

\begin{tabular}{|c|c|c|c|c|c|c|c|c|c|}
\hline \multirow[b]{2}{*}{ Tree \# } & \multirow[b]{2}{*}{ Species } & \multicolumn{2}{|c|}{1989 Data } & \multicolumn{2}{|c|}{1994 Data } & \multicolumn{2}{|c|}{2001 Data } & \multicolumn{2}{|c|}{2009 Data } \\
\hline & & $\mathrm{DBH}$ & Height & $\mathrm{DBH}$ & Height & $\mathrm{DBH}$ & Height & $\mathrm{DBH}$ & Height \\
\hline 78 & GS & 21.2 & 84.0 & 23.7 & 93.0 & 27.3 & 1110.7 & 31.3 & 121.1 \\
\hline 79 & GS & 17.4 & 69.0 & 20.4 & 66.0 & 23.4 & 94.1 & 29.2 & 106.0 \\
\hline 80 & IC & 0.9 & 7.0 & 1.0 & 7.0 & 2.1 & 8.8 & 3.3 & 13.8 \\
\hline 81 & GS & 21.4 & 74.0 & 22.6 & 76.0 & 25.4 & 95.4 & 29.3 & 106.1 \\
\hline 82 & GS & 0.8 & 6.0 & 1.2 & 7.0 & 1.4 & 7.1 & 2.1 & 8.7 \\
\hline 83 & GS & 16.9 & 71.0 & 19.0 & 73.0 & 21.3 & 89.2 & 24.1 & 103.0 \\
\hline 84 & IC & 1.6 & 10.0 & 2.1 & 11.0 & 3.3 & 13.0 & 3.7 & 14.7 \\
\hline 85 & GS & 14.5 & 62.0 & 16.0 & 68.0 & 18.3 & 78.8 & 20.8 & 93.5 \\
\hline 86 & GS & 13.0 & 60.0 & 14.3 & 64.0 & 15.7 & 76.5 & 17.3 & 87.8 \\
\hline 87 & GS & 15.9 & 51.0 & 17.8 & 54.0 & 20.0 & 67.1 & 22.5 & 76.9 \\
\hline 88 & GS & 14.3 & 59.0 & 16.2 & 66.0 & 17.9 & 77.4 & 20.4 & 87.9 \\
\hline 89 & GS & 19.2 & 74.0 & 21.0 & 81.0 & 24.2 & 96.6 & 27.7 & 107.5 \\
\hline $90 *$ & PP & 14.0 & 52.0 & $* * *$ & $* * *$ & $* * *$ & $* * *$ & $* * *$ & $* * *$ \\
\hline 90 & WF & $* * *$ & $* * *$ & $* * *$ & $* * *$ & 1.3 & 10.0 & 1.5 & 10.4 \\
\hline 91 & IC & $* * *$ & $* * *$ & $* * *$ & $* * *$ & 1.0 & 7.3 & 2.6 & 11.5 \\
\hline 92 & WF & $* * *$ & $* * *$ & $* * *$ & $* * *$ & 1.1 & 7.3 & 2.1 & 9.7 \\
\hline 93 & IC & $* * *$ & $* * *$ & $* * *$ & $* * *$ & 1.2 & 7.6 & 2.5 & 12.5 \\
\hline 94 & $\mathrm{PP}$ & $* * *$ & $* * *$ & $* * *$ & $* * *$ & 1.4 & 8.3 & 3.2 & 13.8 \\
\hline 95 & WF & $* * *$ & $* * *$ & $* * *$ & $* * *$ & 2.6 & 13.0 & 4.8 & 22.1 \\
\hline 96 & IC & $* * *$ & $* * *$ & $* * *$ & $* * *$ & 1.6 & 7.6 & 2.1 & 8.8 \\
\hline 97 & WF & $* * *$ & $* * *$ & $* * *$ & $* * *$ & 2.6 & 11.4 & 4.5 & 18.4 \\
\hline 98 & GS & $* * *$ & $* * *$ & $* * *$ & $* * *$ & 1.1 & 6.9 & 2.1 & 10.5 \\
\hline 99 & WF & $* * *$ & $* * *$ & $* * *$ & $* * *$ & $* * *$ & $* * *$ & 2.1 & 11.2 \\
\hline 100 & WF & $* * *$ & $* * *$ & $* * *$ & $* * *$ & $* * *$ & $* * *$ & 1.1 & 8.0 \\
\hline 101 & WF & $* * *$ & $* * *$ & $* * *$ & $* * *$ & $* * *$ & $* * *$ & 2.6 & 14.7 \\
\hline 102 & WF & $* * *$ & $* * *$ & $* * *$ & $* * *$ & $* * *$ & $* * *$ & 1.5 & 10.2 \\
\hline 103 & IC & $* * *$ & $* * *$ & $* * *$ & $* * *$ & $* * *$ & $* * *$ & 1.3 & 7.3 \\
\hline 104 & BO & $* * *$ & $* * *$ & $* * *$ & $* * *$ & $* * *$ & $* * *$ & 1.1 & 11.8 \\
\hline 105 & IC & $* * *$ & $* * *$ & $* * *$ & $* * *$ & $* * *$ & $* * *$ & 1.0 & 7.4 \\
\hline 106 & IC & $* * *$ & $* * *$ & $* * *$ & $* * *$ & $* * *$ & $* * *$ & 1.2 & 8.5 \\
\hline 107 & $\mathrm{BO}$ & $* * *$ & $* * *$ & $* * *$ & $* * *$ & $* * *$ & $* * *$ & 1.1 & 11.5 \\
\hline 108 & WF & $* * *$ & $* * *$ & $* * *$ & $* * *$ & $* * *$ & $* * *$ & 2.2 & 11.9 \\
\hline 109 & WF & $* * *$ & $* * *$ & $* * *$ & $* * *$ & $* * *$ & $* * *$ & 2.0 & 11.5 \\
\hline 110 & WF & $* * *$ & $* * *$ & $* * *$ & $* * *$ & $* * *$ & $* * *$ & 2.1 & 11.1 \\
\hline 111 & WF & $* * *$ & $* * *$ & $* * *$ & $* * *$ & $* * *$ & $* * *$ & 1.4 & 8.2 \\
\hline 112 & WF & $* * *$ & $* * *$ & $* * *$ & $* * *$ & $* * *$ & $* * *$ & 1.0 & 7.7 \\
\hline AVG. & & 13.2 & 52.2 & 14.6 & 55.5 & 10.2 & 42.6 & 8.0 & 33.9 \\
\hline Tree & 84 & Previou & ly measu & red but & out of $\mathrm{F}$ & lot at 4 & $9 \mathrm{ft}$ fror & plot ce & ter in 20 \\
\hline Tree & $90 *$ & Dead ir & 1994 & & & & & & \\
\hline Trees & $90-98$ & Ingrow & in 2001 & & & & & & \\
\hline Trees & 99-112 & Ingrow & in 2009 & & & & & & \\
\hline
\end{tabular}

Page 150 
MHDSF Young-Growth Giant Sequoia Management Strategies Study 2009 - Overstory Summary Growth Data (39ft. (12m) Plot)

$\begin{array}{lllll}\text { Stand: Methuselah } & \text { Treatment: Thinned } & \text { Measured By: } & 1989 \text { Bishop, Johannis } \\ & & \text { Measured By: } & 1994 \text { Ganz } \\ \text { Block: A } & \text { Plot \# :2 } & \text { Measured By: } & 2001 \text { Roller, Kong } \\ & & \text { Measured By: } & 2009 \text { Soderlund, Estrada }\end{array}$

\begin{tabular}{|c|c|c|c|c|c|c|c|c|c|c|c|c|c|}
\hline \multirow[b]{2}{*}{ Tree \# } & \multirow[b]{2}{*}{ Species } & \multicolumn{2}{|c|}{$\begin{array}{c}\text { Change } \\
\text { 1989-1994 }\end{array}$} & \multicolumn{2}{|c|}{$\begin{array}{c}\text { Change } \\
\text { 1994-2001 }\end{array}$} & \multicolumn{2}{|c|}{$\begin{array}{l}\text { Change } \\
\text { 1989-2001 }\end{array}$} & \multicolumn{2}{|c|}{$\begin{array}{c}\text { Change } \\
\text { 1994-2009 }\end{array}$} & \multicolumn{2}{|c|}{$\begin{array}{c}\text { Change } \\
\text { 2001-2009 }\end{array}$} & \multicolumn{2}{|c|}{$\begin{array}{c}\text { Change } \\
\text { 1989-2009 }\end{array}$} \\
\hline & & $\mathrm{DBH}$ & Height & $\mathrm{DBH}$ & Height & $\mathrm{DBH}$ & Height & $\mathrm{DBH}$ & Height & $\mathrm{DBH}$ & Height & $\mathrm{DBH}$ & Height \\
\hline 78 & GS & 2.5 & 9.0 & 3.6 & 17.7 & 6.1 & 26.7 & 7.6 & 28.1 & 4.0 & 10.4 & 10.1 & 37.1 \\
\hline 79 & GS & 3.0 & -3.0 & 3.0 & 28.1 & 6.0 & 25.1 & 8.8 & 40.0 & 5.8 & 11.9 & 11.8 & 37.0 \\
\hline 80 & IC & 0.1 & 0.0 & 1.1 & 1.8 & 1.2 & 1.8 & 2.3 & 6.8 & 1.2 & 5.0 & 2.4 & 6.8 \\
\hline 81 & GS & 1.2 & 2.0 & 2.8 & 19.4 & 4.0 & 21.4 & 6.7 & 30.1 & 3.9 & 10.7 & 7.9 & 32.1 \\
\hline 82 & GS & 0.4 & 1.0 & 0.2 & 0.1 & 0.6 & 1.1 & 0.9 & 1.7 & 0.7 & 1.6 & 1.3 & 2.7 \\
\hline 83 & GS & 2.1 & 2.0 & 2.3 & 16.2 & 4.4 & 18.2 & 5.1 & 30.0 & 2.8 & 13.8 & 7.2 & 32.0 \\
\hline 84 & IC & 0.5 & 1.0 & 1.2 & 2.0 & 1.7 & 3.0 & 1.6 & 3.7 & 0.4 & 1.7 & 2.1 & 4.7 \\
\hline 85 & GS & 1.5 & 6.0 & 2.3 & 10.8 & 3.8 & 16.8 & 4.8 & 25.5 & 2.5 & 14.7 & 6.3 & 31.5 \\
\hline 86 & GS & 1.3 & 4.0 & 1.4 & 12.5 & 2.7 & 16.5 & 3.0 & 23.8 & 1.6 & 11.3 & 4.3 & 27.8 \\
\hline 87 & GS & 1.9 & 3.0 & 2.2 & 13.1 & 4.1 & 16.1 & 4.7 & 22.9 & 2.5 & 9.8 & 6.6 & 25.9 \\
\hline 88 & GS & 1.9 & 7.0 & 1.7 & 11.4 & 3.6 & 18.4 & 4.2 & 21.9 & 2.5 & 10.5 & 6.1 & 28.9 \\
\hline 89 & GS & 1.8 & 7.0 & 3.2 & 15.6 & 5.0 & 22.6 & 6.7 & 26.5 & 3.5 & 10.9 & 8.5 & 33.5 \\
\hline $90 *$ & PP & $* * *$ & $* * *$ & $* * *$ & $* * *$ & $* * *$ & $* * *$ & $* * *$ & $* * *$ & $* * *$ & $* * *$ & $* * *$ & $* * *$ \\
\hline 90 & WF & $* * *$ & $* * *$ & $* * *$ & $* * *$ & $* * *$ & $* * *$ & $* * *$ & $* * *$ & 0.2 & 0.4 & $* * *$ & $* * *$ \\
\hline 91 & IC & $* * *$ & $* * *$ & $* * *$ & $* * *$ & $* * *$ & $* * *$ & $* * *$ & $* * *$ & 1.6 & 4.2 & $* * *$ & $* * *$ \\
\hline 92 & WF & $* * *$ & $* * *$ & $* * *$ & $* * *$ & $* * *$ & $* * *$ & $* * *$ & $* * *$ & 1.0 & 2.4 & $* * *$ & $* * *$ \\
\hline 93 & IC & $* * *$ & $* * *$ & $* * *$ & $* * *$ & $* * *$ & $* * *$ & $* * *$ & $* * *$ & 1.3 & 4.9 & $* * *$ & $* * *$ \\
\hline 94 & PP & $* * *$ & $* * *$ & $* * *$ & $* * *$ & $* * *$ & $* * *$ & $* * *$ & $* * *$ & 1.8 & 5.5 & $* * *$ & $* * *$ \\
\hline 95 & WF & $* * *$ & $* * *$ & $* * *$ & $* * *$ & $* * *$ & $* * *$ & $* * *$ & $* * *$ & 2.2 & 9.1 & $* * *$ & $* * *$ \\
\hline 96 & IC & $* * *$ & $* * *$ & $* * *$ & $* * *$ & $* * *$ & $* * *$ & $* * *$ & $* * *$ & 0.5 & 1.2 & $* * *$ & $* * *$ \\
\hline 97 & WF & $* * *$ & $* * *$ & $* * *$ & $* * *$ & $* * *$ & $* * *$ & $* * *$ & $* * *$ & 1.9 & 7.0 & $* * *$ & $* * *$ \\
\hline 98 & GS & $* * *$ & $* * *$ & $* * *$ & $* * *$ & $* * *$ & $* * *$ & $* * *$ & $* * *$ & 1.0 & 3.6 & $* * *$ & $* * *$ \\
\hline 99 & WF & $* * *$ & $* * *$ & $* * *$ & $* * *$ & $* * *$ & $* * *$ & $* * *$ & $* * *$ & $* * *$ & $* * *$ & $* * *$ & $* * *$ \\
\hline 100 & WF & $* * *$ & $* * *$ & $* * *$ & $* * *$ & $* * *$ & $* * *$ & $* * *$ & $* * *$ & $* * *$ & $* * *$ & $* * *$ & $* * *$ \\
\hline 101 & WF & $* * *$ & $* * *$ & $* * *$ & $* * *$ & $* * *$ & $* * *$ & $* * *$ & $* * *$ & $* * *$ & $* * *$ & $* * *$ & $* * *$ \\
\hline 102 & WF & $* * *$ & $* * *$ & $* * *$ & $* * *$ & $* * *$ & $* * *$ & $* * *$ & $* * *$ & $* * *$ & $* * *$ & $* * *$ & $* * *$ \\
\hline 103 & IC & $* * *$ & $* * *$ & $* * *$ & $* * *$ & $* * *$ & $* * *$ & $* * *$ & $* * *$ & $* * *$ & $* * *$ & $* * *$ & $* * *$ \\
\hline 104 & $\mathrm{BO}$ & $* * *$ & $* * *$ & $* * *$ & $* * *$ & $* * *$ & $* * *$ & $* * *$ & $* * *$ & $* * *$ & $* * *$ & $* * *$ & $* * *$ \\
\hline 105 & IC & $* * *$ & $* * *$ & $* * *$ & $* * *$ & $* * *$ & $* * *$ & $* * *$ & $* * *$ & $* * *$ & $* * *$ & $* * *$ & $* * *$ \\
\hline 106 & IC & $* * *$ & $* * *$ & $* * *$ & $* * *$ & $* * *$ & $* * *$ & $* * *$ & $* * *$ & $* * *$ & $* * *$ & $* * *$ & $* * *$ \\
\hline 107 & $\mathrm{BO}$ & $* * *$ & $* * *$ & $* * *$ & $* * *$ & $* * *$ & $* * *$ & $* * *$ & $* * *$ & $* * *$ & $* * *$ & $* * *$ & $* * *$ \\
\hline 108 & WF & $* * *$ & $* * *$ & $* * *$ & $* * *$ & $* * *$ & $* * *$ & $* * *$ & $* * *$ & $* * *$ & $* * *$ & $* * *$ & $* * *$ \\
\hline 109 & WF & $* * *$ & $* * *$ & $* * *$ & $* * *$ & $* * *$ & $* * *$ & $* * *$ & $* * *$ & $* * *$ & $* * *$ & $* * *$ & $* * *$ \\
\hline 110 & WF & $* * *$ & $* * *$ & $* * *$ & $* * *$ & $* * *$ & $* * *$ & $* * *$ & $* * *$ & $* * *$ & $* * *$ & $* * *$ & $* * *$ \\
\hline 111 & WF & $* * *$ & $* * *$ & $* * *$ & $* * *$ & $* * *$ & $* * *$ & $* * *$ & $* * *$ & $* * *$ & $* * *$ & $* * *$ & $* * *$ \\
\hline 112 & WF & $* * *$ & $* * *$ & $* * *$ & $* * *$ & $* * *$ & $* * *$ & $* * *$ & $* * *$ & $* * *$ & $* * *$ & $* * *$ & $* * *$ \\
\hline AVG. & & "1.5 & 3.3 & 2.1 & \begin{tabular}{c|}
12.4 \\
\end{tabular} & 3.6 & 15.6 & "4.7 & 21.8 & 2.0 & 7.2 & " 6.2 & 25.0 \\
\hline Tree & 84 & Previous & ly meası & red but & $s$ out of & ot at 4 & $.9 \mathrm{ft}$ fron & plot ce & ater in 20 & & & & \\
\hline Tree & $90 *$ & Dead in & 1994 & & & & & & & & & & \\
\hline Trees & $90-98$ & Ingrowt & a in 2001 & & & & & & & & & & \\
\hline Trees & $99-112$ & Ingrowt & 2009 in & & & & & & & & & & \\
\hline
\end{tabular}


MHDSF Young-Growth Giant Sequoia Management Strategies Study 2009 - Overstory Summary Data (39ft. (12m) Plot)

$\begin{array}{lllll}\text { Stand: Methuselah } & \text { Treatment: Thinned } & \text { Measured By: } & 1989 & \text { Bishop, Johannis } \\ & & \text { Measured By: } & 1994 & \text { Ganz } \\ \text { Block: A } & \text { Plot \# : 3 } & \text { Measured By: } & 2001 & \text { Roller, Kong } \\ & & \text { Measured By: } & 2009 & \text { Soderlund, Estrada }\end{array}$

\begin{tabular}{|c|c|c|c|c|c|c|c|c|c|}
\hline \multirow[b]{2}{*}{ Tree \# } & \multirow[b]{2}{*}{ Species } & \multicolumn{2}{|c|}{1989 Data } & \multicolumn{2}{|c|}{1994 Data } & \multicolumn{2}{|c|}{2001 Data } & \multicolumn{2}{|c|}{2009 Data } \\
\hline & & DBH & Height & $\mathrm{DBH}$ & Height & DBH & Height & DBH & Height \\
\hline 88 & IC & 17.9 & 67.0 & 19.6 & 72.0 & 20.9 & 71.8 & 23.1 & 78.6 \\
\hline 89 & GS & 26.9 & 91.0 & 29.0 & 93.0 & 31.5 & 107.4 & 37.0 & 120.2 \\
\hline 90 & GS & 14.5 & 74.0 & 17.1 & 77.0 & 20.4 & 96.8 & 24.5 & 108.8 \\
\hline 91 & GS & 11.7 & 51.0 & 13.9 & 54.0 & 16.3 & 69.9 & 19.6 & 81.5 \\
\hline 92 & GS & 11.7 & 30.0 & 13.0 & 33.0 & 15.3 & 44.2 & 17.4 & 57.4 \\
\hline 93 & GS & 19.9 & 96.0 & 22.0 & 98.0 & 25.6 & 106.5 & 29.7 & 120.9 \\
\hline 94 & IC & 8.1 & 37.0 & 9.2 & 40.0 & 11.1 & 48.2 & 13.0 & 57.5 \\
\hline 95 & WF & $* * *$ & $* * *$ & $* * *$ & $* * *$ & 1.5 & 9.0 & 3.0 & 12.5 \\
\hline 96 & WF & $* * *$ & $* * *$ & $* * *$ & $* * *$ & 1.9 & 11.8 & 3.0 & 15.6 \\
\hline 97 & WF & $* * *$ & $* * *$ & $* * *$ & $* * *$ & 1.6 & 11.3 & 2.8 & 15.7 \\
\hline 98 & WF & $* * *$ & $* * *$ & $* * *$ & $* * *$ & 2.0 & 10.8 & 4.1 & 17.8 \\
\hline 99 & WF & $* * *$ & $* * *$ & $* * *$ & $* * *$ & $* * *$ & $* * *$ & 1.9 & 9.8 \\
\hline 100 & IC & $* * *$ & $* * *$ & $* * *$ & $* * *$ & $* * *$ & $* * *$ & 1.1 & 7.4 \\
\hline 101 & WF & $* * *$ & $* * *$ & $* * *$ & $* * *$ & $* * *$ & $* * *$ & 1.5 & 8.5 \\
\hline 102 & WF & $* * *$ & $* * *$ & $* * *$ & $* * *$ & $* * *$ & $* * *$ & 1.5 & 9.9 \\
\hline 103 & WF & $* * *$ & $* * *$ & $* * *$ & $* * *$ & $* * *$ & $* * *$ & 2.0 & 11.4 \\
\hline 104 & WF & $* * *$ & $* * *$ & $* * *$ & $* * *$ & $* * *$ & $* * *$ & 2.0 & 8.6 \\
\hline 105 & IC & $* * *$ & $* * *$ & $* * *$ & $* * *$ & $* * *$ & $* * *$ & 2.4 & 13.7 \\
\hline AVG. & & 15.8 & "63.7 & $\begin{array}{l}17.7 \\
\end{array}$ & 66.7 & 13.5 & $\bar{~} 53.4$ & $\begin{array}{l}10.5 \\
\end{array}$ & 42.0 \\
\hline
\end{tabular}

2009 - Overstory Summary Growth Data (39ft. (12m) Plot)

\begin{tabular}{|c|c|c|c|c|c|c|c|c|c|c|c|c|c|}
\hline \multirow[b]{2}{*}{ Tree \# } & \multirow[b]{2}{*}{ Species } & \multicolumn{2}{|c|}{$\begin{array}{c}\text { Change } \\
\text { 1989-1994 }\end{array}$} & \multicolumn{2}{|c|}{$\begin{array}{c}\text { Change } \\
\text { 1994-2001 }\end{array}$} & \multicolumn{2}{|c|}{$\begin{array}{c}\text { Change } \\
\text { 1989-2001 }\end{array}$} & \multicolumn{2}{|c|}{$\begin{array}{c}\text { Change } \\
\text { 1994-2009 }\end{array}$} & \multicolumn{2}{|c|}{$\begin{array}{l}\text { Change } \\
\text { 2001-2009 }\end{array}$} & \multicolumn{2}{|c|}{$\begin{array}{l}\text { Change } \\
\text { 1989-2009 }\end{array}$} \\
\hline & & $\mathrm{DBH}$ & Height & $\mathrm{DBH}$ & Height & $\mathrm{DBH}$ & Height & $\mathrm{DBH}$ & Height & $\mathrm{DBH}$ & Height & $\mathrm{DBH}$ & Height \\
\hline 88 & IC & 1.7 & 5.0 & 1.3 & -0.2 & 3.0 & 4.8 & 3.5 & 6.6 & 2.2 & 6.8 & 5.2 & 11.6 \\
\hline 89 & GS & 2.1 & 2.0 & 2.5 & 14.4 & 4.6 & 16.4 & 8.0 & 27.2 & 5.5 & 12.8 & 10.1 & 29.2 \\
\hline 90 & GS & 2.6 & 3.0 & 3.3 & 19.8 & 5.9 & 22.8 & 7.4 & 31.8 & 4.1 & 12.0 & 10.0 & 34.8 \\
\hline 91 & GS & 2.2 & 3.0 & 2.4 & 15.9 & 4.6 & 18.9 & 5.7 & 27.5 & 3.3 & 11.6 & 7.9 & 30.5 \\
\hline 92 & GS & 1.3 & 3.0 & 2.3 & 11.2 & 3.6 & 14.2 & 4.4 & 24.4 & 2.1 & 13.2 & 5.7 & 27.4 \\
\hline 93 & GS & 2.1 & 2.0 & 3.6 & 8.5 & 5.7 & 10.5 & 7.7 & 22.9 & 4.1 & 14.4 & 9.8 & 24.9 \\
\hline 94 & IC & 1.1 & 3.0 & 1.9 & 8.2 & 3.0 & 11.2 & 3.8 & 17.5 & 1.9 & 9.3 & 4.9 & 20.5 \\
\hline 95 & WF & $* * *$ & $* * *$ & $* * *$ & $* * *$ & $* * *$ & $* * *$ & $* * *$ & $* * *$ & 1.5 & 3.5 & $* * *$ & $* * *$ \\
\hline 96 & WF & $* * *$ & $* * *$ & $* * *$ & $* * *$ & $* * *$ & $* * *$ & $* * *$ & $* * *$ & 1.1 & 3.8 & $* * *$ & $* * *$ \\
\hline 97 & WF & $* * *$ & $* * *$ & $* * *$ & $* * *$ & $* * *$ & $* * *$ & $* * *$ & $* * *$ & 1.2 & 4.4 & $* * *$ & $* * *$ \\
\hline 98 & WF & $* * *$ & $* * *$ & $* * *$ & $* * *$ & $* * *$ & $* * *$ & $* * *$ & $* * *$ & 2.1 & 7.0 & $* * *$ & $* * *$ \\
\hline 99 & WF & $* * *$ & $* * *$ & $* * *$ & $* * *$ & $* * *$ & $* * *$ & $* * *$ & $* * *$ & $* * *$ & $* * *$ & $* * *$ & $* * *$ \\
\hline 100 & IC & $* * *$ & $* * *$ & $* * *$ & $* * *$ & $* * *$ & $* * *$ & $* * *$ & $* * *$ & $* * *$ & $* * *$ & $* * *$ & $* * *$ \\
\hline 101 & WF & $* * *$ & $* * *$ & $* * *$ & $* * *$ & $* * *$ & $* * *$ & $* * *$ & $* * *$ & $* * *$ & $* * *$ & $* * *$ & $* * *$ \\
\hline 102 & WF & $* * *$ & $* * *$ & $* * *$ & $* * *$ & $* * *$ & $* * *$ & $* * *$ & $* * *$ & $* * *$ & $* * *$ & $* * *$ & $* * *$ \\
\hline 103 & WF & $* * *$ & $* * *$ & $* * *$ & $* * *$ & $* * *$ & $* * *$ & $* * *$ & $* * *$ & $* * *$ & $* * *$ & $* * *$ & $* * *$ \\
\hline 104 & WF & $* * *$ & $* * *$ & $* * *$ & $* * *$ & $* * *$ & $* * *$ & $* * *$ & $* * *$ & $* * *$ & $* * *$ & $* * *$ & $* * *$ \\
\hline 105 & IC & $* * *$ & $* * *$ & $* * *$ & $* * *$ & $* * *$ & $* * *$ & $* * *$ & $* * *$ & $* * *$ & $* * *$ & $* * *$ & $* * *$ \\
\hline AVG. & & 1.9 & 3.0 & 2.5 & 11.1 & 4.3 & 14.1 & 5.8 & 22.6 & 2.6 & 9.0 & 7.7 & 25.6 \\
\hline
\end{tabular}


MHDSF Young-Growth Giant Sequoia Management Strategies Study 2009 - Overstory Summary Data (39ft. (12m) Plot)

$\begin{array}{lllll}\text { Stand: Methuselah } & \text { Treatment: Thinned } & \text { Measured By: } & 1989 \text { Bishop, Johannis } \\ & & \text { Measured By: } & 1994 \text { Ganz } \\ \text { Block: A } & \text { Plot \# :3 } & \text { Measured By: } & 2001 \text { Roller, Kong } \\ & & \text { Measured By: } & 2009 \text { Soderlund, Estrada }\end{array}$

Trees 95-98 Ingrowth in 2001

Trees 99-105 Ingrowth in 2009 
MHDSF Young-Growth Giant Sequoia Management Strategies Study 2009 - Overstory Summary Data (39ft. (12m) Plot)

$\begin{array}{lllll}\text { Stand: Methuselah } & \text { Treatment: Thinned } & \text { Measured By: } & 1989 & \text { Scoot, Vickeral } \\ & & \text { Measured By: } & 1994 & \text { Ganz } \\ \text { Block: A } & \text { Plot \# :4 } & \text { Measured By: } & 2001 & \text { Roller, Kong } \\ & & \text { Measured By: } & 2009 & \text { Soderlund, Estrada }\end{array}$

\begin{tabular}{ccc|cc|cc|cc|cc|}
\cline { 3 - 10 } Tree \# & Species & \multicolumn{2}{|c|}{1989 Data } & \multicolumn{2}{c|}{1994 Data } & \multicolumn{2}{c|}{2001 Data } & \multicolumn{2}{c|}{2009 Data } \\
\hline \hline 91 & GS & 23.4 & Height & DBH & Height & DBH & Height & DBH & Height \\
92 & GS & 18.9 & 67.0 & 20.3 & 92.0 & 30.0 & 106.0 & 35.0 & 120.5 \\
93 & GS & 17.7 & 68.0 & 19.5 & 74.0 & 22.5 & 89.8 & 26.5 & 101.3 \\
94 & GS & 20.7 & 72.0 & 24.0 & 80.0 & 26.4 & 92.5 & 26.9 & 96.3 \\
95 & IC & 9.8 & 37.0 & 10.8 & 39.0 & 13.1 & 52.8 & 14.1 & 103.2 \\
96 & GS & 27.1 & 86.0 & 30.9 & 93.0 & 33.6 & 113.9 & 40.4 & 126.8 \\
97 & GS & 25.1 & 75.0 & 27.8 & 83.0 & 31.2 & 96.4 & 36.7 & 111.8 \\
98 & WF & $* * *$ & $* * *$ & $* * *$ & $* * *$ & 3.0 & 14.8 & 5.6 & 25.6 \\
99 & WF & $* * *$ & $* * *$ & $* * *$ & $* * *$ & 3.7 & 13.6 & 5.9 & 16.4 \\
100 & GS & $* * *$ & $* * *$ & $* * *$ & $* * *$ & 1.1 & 7.0 & 1.7 & 9.7 \\
101 & WF & $* * *$ & $* * *$ & $* * *$ & $* * *$ & 4.9 & 20.8 & 7.4 & 28.4 \\
102 & IC & $* * *$ & $* * *$ & $* * *$ & $* * *$ & $* * *$ & $* * *$ & 1.6 & 10.2 \\
103 & IC & $* * *$ & $* * *$ & $* * *$ & $* * *$ & $* * *$ & $* * *$ & 2.0 & 9.9 \\
104 & IC & $* * *$ & $* * *$ & $* * *$ & $* * *$ & $* * *$ & $* * *$ & 1.0 & 8.1 \\
105 & IC & $* * *$ & $* * *$ & $* * *$ & $* * *$ & $* * *$ & $* * *$ & 1.7 & 10.7 \\
106 & GS & $* * *$ & $* * *$ & $* * *$ & $* * *$ & $* * *$ & $* * *$ & 1.7 & 8.7 \\
107 & IC & $* * *$ & $* * *$ & $* * *$ & $* * *$ & $* * *$ & $* * *$ & 1.3 & 9.9 \\
108 & IC & $* * *$ & $* * *$ & $* * *$ & $* * *$ & $* * *$ & $* * *$ & 1.5 & 8.5 \\
109 & IC & $* * *$ & $* * *$ & $* * *$ & $* * *$ & $* * *$ & $* * *$ & 1.7 & 10.2 \\
110 & WF & $* * *$ & $* * *$ & $* * *$ & $* * *$ & $* * *$ & $* * *$ & 1.1 & 6.4 \\
\hline \hline AVG. & & 20.4 & 70.6 & 22.8 & 76.4 & 17.5 & 62.8 & 12.2 & 44.3
\end{tabular}

Trees 98-101 Ingrowth in 2001

Trees 102-110 Ingrowth in 2009 
MHDSF Young-Growth Giant Sequoia Management Strategies Study 2009 - Overstory Summary Growth Data (39ft. (12m) Plot)

$\begin{array}{lllll}\text { Stand: Methuselah } & \text { Treatment: Thinned } & \text { Measured By: } & 1989 & \text { Scoot, Vickeral } \\ & & \text { Measured By: } & 1994 & \text { Ganz } \\ \text { Block: A } & \text { Plot \# :4 } & \text { Measured By: } & 2001 & \text { Roller, Kong } \\ & & \text { Measured By: } & 2009 \text { Soderlund, Estrada }\end{array}$

\begin{tabular}{|c|c|c|c|c|c|c|c|c|c|c|c|c|c|}
\hline \multirow[b]{2}{*}{ Tree \# } & \multirow[b]{2}{*}{ Species } & \multicolumn{2}{|c|}{$\begin{array}{c}\text { Change } \\
\text { 1989-1994 }\end{array}$} & \multicolumn{2}{|c|}{$\begin{array}{c}\text { Change } \\
\text { 1994-2001 }\end{array}$} & \multicolumn{2}{|c|}{$\begin{array}{c}\text { Change } \\
\text { 1989-2001 }\end{array}$} & \multicolumn{2}{|c|}{$\begin{array}{c}\text { Change } \\
\text { 1994-2009 }\end{array}$} & \multicolumn{2}{|c|}{$\begin{array}{l}\text { Change } \\
\text { 2001-2009 }\end{array}$} & \multicolumn{2}{|c|}{$\begin{array}{c}\text { Change } \\
\text { 1989-2009 }\end{array}$} \\
\hline & & $\mathrm{DBH}$ & Height & $\mathrm{DBH}$ & Height & $\mathrm{DBH}$ & Height & DBH & Height & DBH & Height & DBH & Height \\
\hline 91 & GS & 2.8 & 3.0 & 3.8 & 14.0 & 6.6 & 17.0 & 8.8 & 28.5 & 5.0 & 14.5 & 11.6 & 31.5 \\
\hline 92 & GS & 1.4 & 7.0 & 2.2 & 15.8 & 3.6 & 22.8 & 6.2 & 27.3 & 4.0 & 11.5 & 7.6 & 34.3 \\
\hline 93 & GS & 1.8 & 6.0 & 4.0 & 8.5 & 5.8 & 14.5 & 7.4 & 22.3 & 3.4 & 13.8 & 9.2 & 28.3 \\
\hline 94 & GS & 3.3 & 8.0 & 2.4 & 13.0 & 5.7 & 21.0 & 6.1 & 23.2 & 3.7 & 10.2 & 9.4 & 31.2 \\
\hline 95 & IC & 1.0 & 2.0 & 2.3 & 13.8 & 3.3 & 15.8 & 4.1 & 25.2 & 1.8 & 11.4 & 5.1 & 27.2 \\
\hline 96 & GS & 3.8 & 7.0 & 2.7 & 20.9 & 6.5 & 27.9 & 9.5 & 33.8 & 6.8 & 12.9 & 13.3 & 40.8 \\
\hline 97 & GS & 2.7 & 8.0 & 3.4 & 13.4 & 6.1 & 21.4 & 8.9 & 28.8 & 5.5 & 15.4 & 11.6 & 36.8 \\
\hline 98 & WF & $* * *$ & $* * *$ & $* * *$ & $* * *$ & $* * *$ & $* * *$ & $* * *$ & $* * *$ & 2.6 & 10.8 & $* * *$ & $* * *$ \\
\hline 99 & WF & $* * *$ & $* * *$ & $* * *$ & $* * *$ & $* * *$ & $* * *$ & $* * *$ & $* * *$ & 2.2 & 2.8 & $* * *$ & $* * *$ \\
\hline 100 & GS & $* * *$ & $* * *$ & $* * *$ & $* * *$ & $* * *$ & $* * *$ & $* * *$ & $* * *$ & 0.6 & 2.7 & $* * *$ & $* * *$ \\
\hline 101 & WF & $* * *$ & $* * *$ & $* * *$ & $* * *$ & $* * *$ & $* * *$ & $* * *$ & $* * *$ & 2.5 & 7.6 & $* * *$ & $* * *$ \\
\hline 102 & IC & $* * *$ & $* * *$ & $* * *$ & $* * *$ & $* * *$ & $* * *$ & $* * *$ & $* * *$ & $* * *$ & $* * *$ & $* * *$ & $* * *$ \\
\hline 103 & IC & $* * *$ & $* * *$ & $* * *$ & $* * *$ & $* * *$ & $* * *$ & $* * *$ & $* * *$ & $* * *$ & $* * *$ & $* * *$ & $* * *$ \\
\hline 104 & IC & $* * *$ & $* * *$ & $* * *$ & $* * *$ & $* * *$ & $* * *$ & $* * *$ & $* * *$ & $* * *$ & $* * *$ & $* * *$ & $* * *$ \\
\hline 105 & IC & $* * *$ & $* * *$ & $* * *$ & $* * *$ & $* * *$ & $* * *$ & $* * *$ & $* * *$ & $* * *$ & $* * *$ & $* * *$ & $* * *$ \\
\hline 106 & GS & $* * *$ & $* * *$ & $* * *$ & $* * *$ & $* * *$ & $* * *$ & $* * *$ & $* * *$ & $* * *$ & $* * *$ & $* * *$ & $* * *$ \\
\hline 107 & IC & $* * *$ & $* * *$ & $* * *$ & $* * *$ & $* * *$ & $* * *$ & $* * *$ & $* * *$ & $* * *$ & $* * *$ & $* * *$ & $* * *$ \\
\hline 108 & IC & $* * *$ & $* * *$ & $* * *$ & $* * *$ & $* * *$ & $* * *$ & $* * *$ & $* * *$ & $* * *$ & $* * *$ & $* * *$ & $* * *$ \\
\hline 109 & IC & $* * *$ & $* * *$ & $* * *$ & $* * *$ & $* * *$ & $* * *$ & $* * *$ & $* * *$ & $* * *$ & $* * *$ & $* * *$ & $* * *$ \\
\hline 110 & WF & $* * *$ & $* * *$ & $* * *$ & $* * *$ & $* * *$ & $* * *$ & $* * *$ & $* * *$ & $* * *$ & $* * *$ & $* * *$ & $* * *$ \\
\hline AVG. & & 2.4 & 5.9 & 3.0 & 14.2 & 5.4 & 20.1 & 7.3 & 27.0 & 3.5 & 10.3 & 9.7 & 32.9 \\
\hline
\end{tabular}

Trees 98-101 Ingrowth in 2001

Trees 102-110 Ingrowth in 2009 
MHDSF Young-Growth Giant Sequoia Management Strategies Study 2009 - Overstory Summary Data (39ft. (12m) Plot)

$\begin{array}{llll}\text { Stand: Methuselah } & \text { Treatment: Thinned/Burned } & \text { Measured By: } & 1989 \text { ??? } \\ & & \text { Measured By: } & 1994 \text { Ganz } \\ \text { Block: B } & \text { Plot \# :1 } & \text { Measured By: } & 2001 \text { Roller, McLeod } \\ & & \text { Measured By: } & 2009 \text { Soderlund, Estrada }\end{array}$

\begin{tabular}{cc|cc|cc|cc|cc|}
\cline { 3 - 10 } \multicolumn{1}{c|}{} & \multicolumn{2}{c|}{1989 Data } & \multicolumn{2}{c|}{ 1994 Data } & \multicolumn{2}{c|}{ 2001 Data } & \multicolumn{2}{c|}{ 2009 Data } \\
Tree \# & Species & DBH & Height & DBH & Height & DBH & Height & DBH & Height \\
\hline \hline 11 & GS & 16.8 & 65.0 & 19.6 & 83.0 & 23.4 & 102.7 & 27.3 & 117.4 \\
12 & GS & 27.4 & 98.0 & 30.9 & 102.0 & 35.7 & 118.5 & 39.7 & 132.4 \\
13 & PP & 13.0 & 52.0 & $* * *$ & $* * *$ & $* * *$ & $* * *$ & $* * *$ & $* * *$ \\
14 & GS & 15.1 & 47.0 & 16.1 & 52.0 & 18.8 & 64.6 & 21.1 & 79.3 \\
15 & GS & 21.7 & 68.0 & 23.9 & 92.0 & 28.5 & 105.1 & 31.1 & 118.0 \\
16 & GS & 18.0 & 67.0 & 19.3 & 68.0 & 22.7 & 80.2 & 25.6 & 102.6 \\
17 & GS & 28.8 & 108.0 & 31.2 & 111.0 & 32.3 & 122.9 & 35.1 & 135.3 \\
\hline \hline AVG. & 20.1 & 72.1 & 23.5 & 84.7 & 26.9 & 99.0 & 30.0 & 114.2 \\
& $2009-$ Overstory Summary Growth Data (39ft. (12m) Plot)
\end{tabular}

\begin{tabular}{|c|c|c|c|c|c|c|c|c|c|c|c|c|c|}
\hline \multirow[b]{2}{*}{ Tree \# } & \multirow[b]{2}{*}{ Species } & \multicolumn{2}{|c|}{$\begin{array}{c}\text { Change } \\
1989-1994\end{array}$} & \multicolumn{2}{|c|}{$\begin{array}{c}\text { Change } \\
\text { 1994-2001 }\end{array}$} & \multicolumn{2}{|c|}{$\begin{array}{c}\text { Change } \\
\text { 1989-2001 }\end{array}$} & \multicolumn{2}{|c|}{$\begin{array}{c}\text { Change } \\
\text { 1994-2009 }\end{array}$} & \multicolumn{2}{|c|}{$\begin{array}{c}\text { Change } \\
\text { 2001-2009 }\end{array}$} & \multicolumn{2}{|c|}{$\begin{array}{c}\text { Change } \\
1989-2009\end{array}$} \\
\hline & & $\mathrm{DBH}$ & Height & $\mathrm{DBH}$ & Height & $\mathrm{DBH}$ & Height & $\mathrm{DBH}$ & Height & $\mathrm{DBH}$ & Height & $\mathrm{DBH}$ & Height \\
\hline 11 & GS & 2.8 & 18.0 & 3.8 & 19.7 & 6.6 .6 & 37.7 & 7.7 & 34.4 & 3.9 & 14.7 & 10.5 & 52.4 \\
\hline 12 & GS & 3.5 & 4.0 & 4.8 & 16.5 & 8.3 & 20.5 & 8.8 & 30.4 & 4.0 & 13.9 & 12.3 & 34.4 \\
\hline 13 & $\mathrm{PP}$ & $* * *$ & $* * *$ & $* * *$ & $* * *$ & $* * *$ & $* * *$ & $* * *$ & $* * *$ & $* * *$ & $* * *$ & $* * *$ & $* * *$ \\
\hline 14 & GS & 1.0 & 5.0 & 2.7 & 12.6 & 3.7 & 17.6 & 5.0 & 27.3 & 2.3 & 14.7 & 6.0 & 32.3 \\
\hline 15 & GS & 2.2 & 24.0 & 4.6 & 13.1 & 6.8 & 37.1 & 7.2 & 26.0 & 2.6 & 12.9 & 9.4 & 50.0 \\
\hline 16 & GS & 1.3 & 1.0 & 3.4 & 12.2 & 4.7 & 13.2 & 6.3 & 34.6 & 2.9 & 22.4 & 7.6 & 35.6 \\
\hline 17 & GS & 2.4 & 3.0 & 1.1 & 11.9 & 3.5 & 14.9 & 3.9 & 24.3 & 2.8 & 12.4 & 6.3 & 27.3 \\
\hline AVG. & & 2.2 & 9.2 & 3.4 & 14.3 & 5.6 & 23.5 & 6.5 & 29.5 & 3.1 & 15.2 & 8.7 & 38.7 \\
\hline
\end{tabular}

Tree 13 Dead/Missing in 1994 
MHDSF Young-Growth Giant Sequoia Management Strategies Study 2009 - Overstory Summary Data (39ft. (12m) Plot)

$\begin{array}{llll}\text { Stand: Methuselah } & \text { Treatment: Thinned/Burned } & \text { Measured By: } & 1989 \text { Rodgers, Johannis } \\ & & \text { Measured By: } & 1994 \text { Ganz } \\ \text { Block: B } & \text { Plot \# :2 } & \text { Measured By: } & 2001 \text { Roller, McLeod } \\ & & \text { Measured By: } & 2009 \text { Soderlund, Estrada }\end{array}$

\begin{tabular}{cc|ccc|cc|cc|cc|}
\cline { 3 - 9 } \multicolumn{1}{c|}{} & \multicolumn{2}{c|}{ 1989 Data } & \multicolumn{2}{c|}{1994 Data } & \multicolumn{2}{c|}{2001 Data } & \multicolumn{2}{c|}{2009 Data } \\
\hline \hline 1 & Tree \# & Species & DBH & Height & DBH & Height & DBH & Height & DBH & Height \\
\hline 2 & GS & 14.7 & 63.0 & 16.0 & 67.0 & 19.1 & 82.5 & 21.9 & 91.3 \\
3 & IC & 2.2 & 11.0 & $* * *$ & $* * *$ & $* * *$ & $* * *$ & $* * *$ & $* * *$ \\
4 & GS & 26.1 & 81.0 & 27.9 & 94.0 & 31.9 & 111.4 & 35.4 & 119.8 \\
5 & GF & 2.9 & 12.0 & $* * *$ & $* * *$ & $* * *$ & $* * *$ & $* * *$ & $* * *$ \\
6 & IC & 17.3 & 70.0 & 22.1 & 79.0 & 26.2 & 96.8 & 29.9 & 104.5 \\
7 & GS & 20.6 & 90.0 & 22.6 & 96.0 & 26.4 & 112.7 & 29.0 & 123.0 \\
8 & GS & 24.6 & 80.0 & 27.0 & 85.0 & 31.9 & 100.2 & 35.7 & 112.7 \\
9 & GS & 16.9 & 58.0 & 19.3 & 69.0 & 22.8 & 78.5 & 25.8 & 93.3 \\
10 & GS & 10.0 & 65.0 & 11.1 & 66.0 & 13.5 & 79.7 & 15.1 & 88.6 \\
\hline \hline AVG. & & 15.7 & 55.8 & 20.9 & 79.4 & 24.5 & 94.5 & 27.5 & 104.7
\end{tabular}

2009 - Overstory Summary Growth Data (39ft. (12m) Plot)

\begin{tabular}{|c|c|c|c|c|c|c|c|c|c|c|c|c|c|}
\hline \multirow[b]{2}{*}{ Tree \# } & \multirow[b]{2}{*}{ Species } & \multicolumn{2}{|c|}{$\begin{array}{c}\text { Change } \\
\text { 1989-1994 }\end{array}$} & \multicolumn{2}{|c|}{$\begin{array}{c}\text { Change } \\
\text { 1994-2001 }\end{array}$} & \multicolumn{2}{|c|}{$\begin{array}{c}\text { Change } \\
\text { 1989-2001 }\end{array}$} & \multicolumn{2}{|c|}{$\begin{array}{c}\text { Change } \\
\text { 1994-2009 }\end{array}$} & \multicolumn{2}{|c|}{$\begin{array}{l}\text { Change } \\
\text { 2001-2009 }\end{array}$} & \multicolumn{2}{|c|}{$\begin{array}{c}\text { Change } \\
\text { 1989-2009 }\end{array}$} \\
\hline & & DBH & Height & $\mathrm{DBH}$ & Height & $\mathrm{DBH}$ & Height & $\mathrm{DBH}$ & Height & $\mathrm{DBH}$ & Height & DBH & Height \\
\hline 1 & GS & $\begin{array}{l}1.3 \\
\end{array}$ & 4.0 & 3.1 & 15.5 & $4 \quad 4.4$ & 19.5 & 5.9 & 24.3 & 2.8 & 8.8 & 7 & 28.3 \\
\hline 2 & IC & $* * *$ & $* * *$ & $* * *$ & $* * *$ & $* * *$ & $* * *$ & $* * *$ & $* * *$ & $* * *$ & $* * *$ & $* * *$ & $* * *$ \\
\hline 3 & GS & 1.8 & 13.0 & 4.0 & 17.4 & 5.8 & 30.4 & 7.5 & 25.8 & 3.5 & 8.4 & 9.3 & 38.8 \\
\hline 4 & WF & $* * *$ & $* * *$ & $* * *$ & $* * *$ & $* * *$ & $* * *$ & $* * *$ & $* * *$ & $* * *$ & $* * *$ & $* * *$ & $* * *$ \\
\hline 5 & GS & 0.8 & 9.0 & 4.1 & 17.8 & 4.9 & 26.8 & 7.8 & 25.5 & 3.7 & 7.7 & 8.6 & 34.5 \\
\hline 6 & IC & $* * *$ & $* * *$ & $* * *$ & $* * *$ & $* * *$ & $* * *$ & $* * *$ & $* * *$ & $* * *$ & $* * *$ & $* * *$ & $* * *$ \\
\hline 7 & GS & 2.0 & 6.0 & 3.8 & 16.7 & 5.8 & 22.7 & 6.4 & 27.0 & 2.6 & 10.3 & 8.4 & 33.0 \\
\hline 8 & GS & 2.4 & 5.0 & 4.9 & 15.2 & 7.3 & 20.2 & 8.7 & 27.7 & 3.8 & 12.5 & 11.1 & 32.7 \\
\hline 9 & GS & 2.4 & 11.0 & 3.5 & 9.5 & 5.9 & 20.5 & 6.5 & 24.3 & 3.0 & 14.8 & 8.9 & 35.3 \\
\hline 10 & GS & 1.1 & 1.0 & 2.4 & 13.7 & 3.5 & 14.7 & 4.0 & 22.6 & 1.6 & 8.9 & 5.1 & 23.6 \\
\hline AVG. & & 1.7 & 7.0 & 3.7 & 15.1 & 5.4 & 22.1 & 6.7 & 25.3 & 3.0 & 10.2 & 8.4 & 32.3 \\
\hline Trees & $2,4,6$ & \multicolumn{12}{|c|}{ Dead in 1994} \\
\hline Trees & 2,4 & \multicolumn{12}{|c|}{ Dead/Down in 2001} \\
\hline Tree & 6 & \multicolumn{12}{|c|}{ Dead/Missing in 2001} \\
\hline Tree & 6 & \multicolumn{12}{|c|}{ Dead/Down in 2009} \\
\hline
\end{tabular}


MHDSF Young-Growth Giant Sequoia Management Strategies Study 2009 - Overstory Summary Data (39ft. (12m) Plot)

$\begin{array}{lllll}\text { Stand: Methuselah } & \text { Treatment: Thinned/Burned } & \text { Measured By: } & 1989 \text { Rodgers, Johannis } \\ & & \text { Measured By: } & 1994 \text { Ganz } \\ \text { Block: B } & \text { Plot \# : } 3 & \text { Measured By: } & 2001 \text { Roller, McLeod } \\ & & \text { Measured By: } & 2009 \text { Soderlund, Estrada }\end{array}$

\begin{tabular}{cc|cc|cc|cc|cc|}
\cline { 3 - 9 } \multicolumn{1}{c|}{} & & \multicolumn{2}{|c|}{1989 Data } & \multicolumn{2}{c|}{ 1994 Data } & \multicolumn{2}{c|}{ 2001 Data } & \multicolumn{2}{c|}{ 2009 Data } \\
Tree \# & Species & DBH & Height & DBH & Height & DBH & Height & DBH & Height \\
\hline \hline 65 & GS & 16.6 & 73 & 19.9 & 80.0 & 24.8 & 94.8 & 28.5 & 105.4 \\
66 & GS & 22.1 & 78 & 23.8 & 88.0 & 27.4 & 103.2 & 30.2 & 118.6 \\
67 & GS & 12.1 & 52 & 12.9 & 56.0 & 15.0 & 71.9 & 16.8 & 79.1 \\
68 & GS & 20 & 72 & 21.6 & 80.0 & 24.5 & 95.3 & 27.2 & 104.4 \\
69 & GS & 17.6 & 73 & 18.6 & 77.0 & 20.5 & 84.8 & 23.8 & 96.8 \\
70 & GS & 22 & 71 & 22.7 & 75.0 & 25.0 & 86.3 & 27.1 & 99.7 \\
71 & GS & 21.9 & 80 & 22.2 & 86.0 & 24.6 & 96.4 & 27.6 & 110.6 \\
72 & GS & 5.3 & 29 & 6.2 & 32.0 & $* * *$ & $* * *$ & $* * *$ & $* * *$ \\
73 & WF & $* * *$ & $* * *$ & $* * *$ & $* * *$ & $* * *$ & $* * *$ & 1.0 & 7.6 \\
74 & WF & $* * *$ & $* * *$ & $* * *$ & $* * *$ & $* * *$ & $* * *$ & 1.1 & 7.6 \\
75 & WF & $* * *$ & $* * *$ & $* * *$ & $* * *$ & $* * *$ & $* * *$ & 1.8 & 9.4 \\
76 & WF & $* * *$ & $* * *$ & $* * *$ & $* * *$ & $* * *$ & $* * *$ & 1.7 & 9.3 \\
\hline \hline
\end{tabular}

2009 - Overstory Summary Growth Data (39ft. (12m) Plot)

\begin{tabular}{|c|c|c|c|c|c|c|c|c|c|c|c|c|c|}
\hline \multirow[b]{2}{*}{ Tree \# } & \multirow[b]{2}{*}{ Species } & \multicolumn{2}{|c|}{$\begin{array}{c}\text { Change } \\
\text { 1989-1994 }\end{array}$} & \multicolumn{2}{|c|}{$\begin{array}{c}\text { Change } \\
\text { 1994-2001 }\end{array}$} & \multicolumn{2}{|c|}{$\begin{array}{l}\text { Change } \\
\text { 1989-2001 }\end{array}$} & \multicolumn{2}{|c|}{$\begin{array}{c}\text { Change } \\
\text { 1994-2009 }\end{array}$} & \multicolumn{2}{|c|}{$\begin{array}{l}\text { Change } \\
\text { 2001-2009 }\end{array}$} & \multicolumn{2}{|c|}{$\begin{array}{c}\text { Change } \\
\text { 1989-2009 }\end{array}$} \\
\hline & & DBH & Height & DBH & Height & DBH & Height & DBH & Height & DBH & Height & $\mathrm{DBH}$ & Height \\
\hline 65 & GS & 3.3 & 7.0 & 4.9 & $\begin{array}{l}14.8 \\
\end{array}$ & 8.2 & 21.8 & 8.6 & 25.4 & 3.7 & 10.6 & 11.9 & 32.4 \\
\hline 66 & GS & 1.7 & 10.0 & 3.6 & 15.2 & 5.3 & 25.2 & 6.4 & 30.6 & 2.8 & 15.4 & 8.1 & 40.6 \\
\hline 67 & GS & 0.8 & 4.0 & 2.1 & 15.9 & 2.9 & 19.9 & 3.9 & 23.1 & 1.8 & 7.2 & 4.7 & 27.1 \\
\hline 68 & GS & 1.6 & 8.0 & 2.9 & 15.3 & 4.5 & 23.3 & 5.6 & 24.4 & 2.7 & 9.1 & 7.2 & 32.4 \\
\hline 69 & GS & 1.0 & 4.0 & 1.9 & 7.8 & 2.9 & 11.8 & 5.2 & 19.8 & 3.3 & 12.0 & 6.2 & 23.8 \\
\hline 70 & GS & 0.7 & 4.0 & 2.3 & 11.3 & 3.0 & 15.3 & 4.4 & 24.7 & 2.1 & 13.4 & 5.1 & 28.7 \\
\hline 71 & GS & 0.3 & 6.0 & 2.4 & 10.4 & 2.7 & 16.4 & 5.4 & 24.6 & 3.0 & 14.2 & 5.7 & 30.6 \\
\hline 72 & GS & 0.9 & 3.0 & $* * *$ & $* * *$ & $* * *$ & $* * *$ & $* * *$ & $* * *$ & $* * *$ & $* * *$ & $* * *$ & $* * *$ \\
\hline 73 & WF & $* * *$ & $* * *$ & $* * *$ & $* * *$ & $* * *$ & $* * *$ & $* * *$ & $* * *$ & $* * *$ & $* * *$ & $* * *$ & $* * *$ \\
\hline 74 & WF & $* * *$ & $* * *$ & $* * *$ & $* * *$ & $* * *$ & $* * *$ & $* * *$ & $* * *$ & $* * *$ & $* * *$ & $* * *$ & $* * *$ \\
\hline 75 & WF & $* * *$ & $* * *$ & $* * *$ & $* * *$ & $* * *$ & $* * *$ & $* * *$ & $* * *$ & $* * *$ & $* * *$ & $* * *$ & $* * *$ \\
\hline 76 & WF & $* * *$ & $* * *$ & $* * *$ & $* * *$ & $* * *$ & $* * *$ & $* * *$ & $* * *$ & $* * *$ & $* * *$ & $* * *$ & $* * *$ \\
\hline AVG. & & 1.3 & 5.8 & 2.9 & 13.0 & 4.2 & 19.1 & 5.6 & 24.7 & 2.8 & 11.7 & 7.0 & 30.8 \\
\hline Tree & 72 & Dead/ & ing $i$ & & & & & & & & & & \\
\hline Trees & $73-76$ & Ingrov & & & & & & & & & & & \\
\hline
\end{tabular}


MHDSF Young-Growth Giant Sequoia Management Strategies Study 2009 - Overstory Summary Data (39ft. (12m) Plot)

$\begin{array}{llll}\text { Stand: Methuselah } & \text { Treatment: Thinned/Burned } & \text { Measured By: } & 1989 \text { Scott, Gasser, Johannis } \\ & & \text { Measured By: } & 1994 \text { Ganz } \\ \text { Block: B } & \text { Plot \# :4 } & \text { Measured By: } & 2001 \text { Roller, McLeod } \\ & & \text { Measured By: } & 2009 \text { Soderlund, Estrada }\end{array}$

\begin{tabular}{cc|cc|cc|cc|cc|}
\cline { 3 - 10 } \multicolumn{1}{c|}{} & & \multicolumn{2}{c|}{ 1989 Data } & \multicolumn{2}{c|}{ 1994 Data } & \multicolumn{2}{c|}{ 2001 Data } & \multicolumn{2}{c|}{ 2009 Data } \\
Tree \# & Species & DBH & Height & DBH & Height & DBH & Height & DBH & Height \\
\hline \hline 69 & GS & 11.0 & 57.0 & 12.8 & 68.0 & 15.5 & 78.1 & 17.4 & 87.9 \\
70 & GS & 17.1 & 74.0 & 19.2 & 81.0 & 22.0 & 92.1 & 25.5 & 101.0 \\
71 & SP & 12.1 & 63.0 & 14.0 & 72.0 & 17.3 & 86.4 & 20.6 & 100.9 \\
72 & GS & 4.3 & 25.0 & 5.8 & 28.0 & 7.5 & 32.8 & 9.0 & 41.4 \\
73 & GS & 13.0 & 59.0 & 15.0 & 72.0 & 17.8 & 81.4 & 20.3 & 89.1 \\
74 & GS & 13.3 & 64.0 & 16.8 & 71.0 & 21.6 & 87.6 & 24.9 & 95.4 \\
75 & GS & 11.0 & 53.0 & 12.4 & 69.0 & 15.3 & 70.8 & 18.1 & 80.8 \\
76 & GS & 19.1 & 79.0 & 19.6 & 90.0 & 24.5 & 102.3 & 28.8 & 112.5 \\
77 & GS & 18.4 & 75.0 & 20.5 & 82.0 & 23.8 & 98.8 & 27.2 & 108.2 \\
\hline \hline AVG. & & 13.3 & 61.0 & 15.1 & 70.3 & 18.4 & 81.1 & 21.3 & 90.8
\end{tabular}

2009 - Overstory Summary Growth Data (39ft. (12m) Plot)

\begin{tabular}{|c|c|c|c|c|c|c|c|c|c|c|c|c|c|}
\hline \multirow[b]{2}{*}{ Tree \# } & \multirow[b]{2}{*}{ Species } & \multicolumn{2}{|c|}{$\begin{array}{c}\text { Change } \\
1989-1994\end{array}$} & \multicolumn{2}{|c|}{$\begin{array}{c}\text { Change } \\
1994-2001\end{array}$} & \multicolumn{2}{|c|}{$\begin{array}{c}\text { Change } \\
\text { 1989-2001 }\end{array}$} & \multicolumn{2}{|c|}{$\begin{array}{c}\text { Change } \\
1989-2009\end{array}$} & \multicolumn{2}{|c|}{$\begin{array}{c}\text { Change } \\
\text { 1994-2009 }\end{array}$} & \multicolumn{2}{|c|}{$\begin{array}{c}\text { Change } \\
\text { 2001-2009 }\end{array}$} \\
\hline & & DBH & Height & DBH & Height & DBH & Height & DBH & Height & DBH & Height & DBH & Height \\
\hline 6 69 & GS & $=1.8$ & " 11.0 & 2.7 & $\begin{array}{c}10.1 \\
\end{array}$ & 4.4 .5 & 21.1 & 6 6.4 & 30.9 & $4 \quad 4.6$ & 19.9 & $=1.9$ & 9.8 \\
\hline 70 & GS & 2.1 & 7.0 & 2.8 & 11.1 & 4.9 & 18.1 & 8.4 & 27.0 & 6.3 & 20.0 & 3.5 & 8.9 \\
\hline 71 & SP & 1.9 & 9.0 & 3.3 & 14.4 & 5.2 & 23.4 & 8.5 & 37.9 & 6.6 & 28.9 & 3.3 & 14.5 \\
\hline 72 & GS & 1.5 & 3.0 & 1.7 & 4.8 & 3.2 & 7.8 & 4.7 & 16.4 & 3.2 & 13.4 & 1.5 & 8.6 \\
\hline 73 & GS & 2.0 & 13.0 & 2.8 & 9.4 & 4.8 & 22.4 & 7.3 & 30.1 & 5.3 & 17.1 & 2.5 & 7.7 \\
\hline 74 & GS & 3.5 & 7.0 & 4.8 & 16.6 & 8.3 & 23.6 & 11.6 & 31.4 & 8.1 & 24.4 & 3.3 & 7.8 \\
\hline 75 & GS & 1.4 & 16.0 & 2.9 & 1.8 & 4.3 & 17.8 & 7.1 & 27.8 & 5.7 & 11.8 & 2.8 & 10.0 \\
\hline 76 & GS & 0.5 & 11.0 & 4.9 & 12.3 & 5.4 & 23.3 & 9.7 & 33.5 & 9.2 & 22.5 & 4.3 & 10.2 \\
\hline 77 & GS & 2.1 & 7.0 & 3.3 & 16.8 & 5.4 & 23.8 & 8.8 & 33.2 & 6.7 & 26.2 & 3.4 & 9.4 \\
\hline AVG. & & 1.9 & 9.3 & 3.2 & 10.8 & 5.1 & 20.1 & 8.1 & 29.8 & 6.2 & 20.5 & 2.9 & 9.7 \\
\hline
\end{tabular}

Page 159 
MHDSF Young-Growth Giant Sequoia Management Strategies Study 2009 - Overstory Summary Data (39ft. (12m) Plot)

$\begin{array}{lllll}\text { Stand: Methuselah } & \text { Treatment: Control } & \text { Measured By: } & 1989 & \text { Bates, Maddson } \\ & & \text { Measured By: } & 1994 & \text { Ganz } \\ \text { Block: C } & \text { Plot \# : } 2 & \text { Measured By: } & 2001 & \text { Roller, McLoed } \\ & & \text { Measured By: } & 2009 & \text { Soderlund, Estrada }\end{array}$

\begin{tabular}{|c|c|c|c|c|c|c|c|c|c|}
\hline \multirow[b]{2}{*}{ Tree \# } & \multirow[b]{2}{*}{ Species } & \multicolumn{2}{|c|}{1989 Data } & \multicolumn{2}{|c|}{1994 Data } & \multicolumn{2}{|c|}{2001 Data } & \multicolumn{2}{|c|}{2009 Data } \\
\hline & & $\mathrm{DBH}$ & Height & $\mathrm{DBH}$ & Height & $\mathrm{DBH}$ & Height & $\mathrm{DBH}$ & Height \\
\hline 1 & GS & 20.4 & 81.0 & 21.9 & 88.0 & 24.2 & 100.7 & 27.0 & 112.5 \\
\hline 2 & IC & 20.0 & 32.0 & 21.0 & 59.0 & 21.5 & 69.9 & 22.2 & 67.1 \\
\hline 3 & IC & 2.4 & 43.0 & 2.8 & 14.0 & 3.4 & 14.3 & 4.0 & 16.2 \\
\hline 4 & IC & 3.1 & 20.0 & 4.2 & 15.0 & 3.9 & 13.8 & 4.2 & 15.5 \\
\hline 5 & GS & 5.4 & 58.0 & 5.8 & 37.0 & 6.4 & 37.8 & 6.8 & 36.6 \\
\hline 6 & GS & 29.8 & 87.0 & 31.6 & 101.0 & 35.7 & 104.1 & 38.8 & 117.8 \\
\hline 7 & IC & 2.0 & 6.0 & 2.0 & 13.0 & 2.3 & 12.4 & 2.6 & 14.0 \\
\hline 8 & IC & 31.0 & 67.0 & 31.7 & 70.0 & 32.6 & 76.6 & 33.3 & 82.7 \\
\hline 9 & IC & 11.1 & 24.0 & 12.0 & 52.0 & 13.4 & 49.1 & 14.8 & 55.3 \\
\hline 10 & IC & 4.2 & 11.0 & 5.3 & 28.0 & 5.4 & 21.2 & 5.9 & 21.5 \\
\hline 11 & IC & 10.8 & 30.0 & 12.0 & 49.0 & 13.4 & 55.3 & 14.9 & 62.6 \\
\hline 12 & IC & 7.5 & 17.0 & 8.5 & 28.0 & 9.7 & 37.3 & 11.0 & 43.2 \\
\hline 13 & IC & 15.5 & 44.0 & 16.1 & 61.0 & 16.9 & 52.6 & 17.6 & 54.6 \\
\hline 14 & IC & 11.0 & 39.0 & 12.6 & 47.0 & 14.3 & 52.3 & 16.1 & 62.3 \\
\hline 15 & GS & 18.8 & 79.0 & 21.5 & 88.0 & 23.6 & 99.8 & 26.8 & 111.0 \\
\hline 16 & IC & 7.3 & 28.0 & 7.8 & 40.0 & 8.1 & 41.9 & 8.3 & 39.6 \\
\hline 17 & GS & 8.5 & 34.0 & 9.3 & 45.0 & 10.3 & 47.5 & 11.1 & 49.3 \\
\hline 18 & IC & 6.1 & 31.0 & 6.6 & 37.0 & 7.0 & 42.1 & 7.2 & 47.1 \\
\hline 19 & IC & 10.8 & 42.0 & 11.8 & 52.0 & 12.7 & 54.5 & 13.8 & 56.6 \\
\hline 20 & IC & 0.7 & 6.0 & 1.0 & 9.0 & 1.2 & 9.1 & 1.3 & 9.4 \\
\hline 21 & IC & 0.7 & 7.0 & 1.3 & 10.0 & 2.0 & 10.1 & 2.4 & 10.7 \\
\hline 22 & IC & 18.3 & 46.0 & 19.4 & 49.0 & 20.7 & 58.1 & 22.1 & 60.4 \\
\hline 23 & IC & 5.4 & 24.0 & 6.0 & 27.0 & 6.5 & 26.9 & 6.9 & 27.9 \\
\hline 24 & IC & 5.3 & 37.0 & 6.0 & 30.0 & 6.2 & 28.2 & 6.6 & 26.8 \\
\hline 25 & IC & 1.2 & 8.0 & 1.4 & 9.0 & 1.4 & 8.3 & 1.6 & 8.5 \\
\hline 26 & GS & 25.0 & 94.0 & 26.5 & 97.0 & 28.8 & 113.5 & 31.9 & 115.4 \\
\hline 27 & IC & 0.6 & 7.0 & 0.8 & 9.0 & 1.1 & 8.2 & 1.2 & 7.4 \\
\hline 28 & GS & 21.7 & 79.0 & 23.9 & 83.0 & 26.4 & 101.5 & 29.1 & 102.7 \\
\hline 29 & GS & 16.8 & 78.0 & 18.2 & 80.0 & 19.9 & 97.3 & 21.8 & 103.5 \\
\hline 30 & GS & 1.5 & 9.0 & 1.8 & 9.0 & 2.0 & 9.1 & 2.1 & 9.9 \\
\hline 31 & GS & 19.3 & 74.0 & 21.0 & 85.0 & 23.0 & 89.4 & 25.5 & 100.8 \\
\hline 32 & IC & 0.8 & 6.0 & 1.2 & 8.0 & 1.7 & 10.1 & 2.3 & 12.9 \\
\hline 33 & IC & 0.7 & 5.0 & 1.0 & 7.0 & 1.5 & 7.9 & 2.0 & 9.8 \\
\hline 34 & GS & 21.4 & 80.0 & 23.3 & 84.0 & 24.7 & 96.7 & 26.5 & 104.4 \\
\hline AVG. & & 10.7 & 39.2 & 11.7 & 44.7 & 12.7 & 48.8 & 13.8 & 52.2 \\
\hline Tree & 13 & $\begin{array}{l}\text { Severel } \\
\text { branch }\end{array}$ & deforn & $\begin{array}{l}\text { d, origi } \\
\text { ow the }\end{array}$ & 1 bole $n$ & $\begin{array}{l}\text { sing, } \\
\text { eader }\end{array}$ & ight wa & $\begin{array}{l}\text { measu } \\
99\end{array}$ & d at side \\
\hline Trees & 6,8 & $1989 \mathrm{db}$ & values & oo low, & $6-6$ ar & $\# 8-9$ & sing $B$ & s 2004 & values \\
\hline
\end{tabular}


MHDSF Young-Growth Giant Sequoia Management Strategies Study 2009 - Overstory Summary Growth Data (39ft. (12m) Plot)

$\begin{array}{lllll}\text { Stand: Methuselah } & \text { Treatment: Control } & \text { Measured By: } & 1989 \text { Bates, Maddson } \\ & & \text { Measured By: } & 1994 \text { Ganz } \\ \text { Block: C } & \text { Plot \# :2 } & \text { Measured By: } & 2001 \text { Roller, McLoed } \\ & & \text { Measured By: } & 2009 \text { Soderlund, Estrada }\end{array}$

\begin{tabular}{|c|c|c|c|c|c|c|c|c|c|c|c|c|c|}
\hline \multirow[b]{2}{*}{ Tree \# } & \multirow[b]{2}{*}{ Species } & \multicolumn{2}{|c|}{$\begin{array}{c}\text { Change } \\
\text { 1989-1994 }\end{array}$} & \multicolumn{2}{|c|}{$\begin{array}{c}\text { Change } \\
\text { 1994-2001 }\end{array}$} & \multicolumn{2}{|c|}{$\begin{array}{c}\text { Change } \\
\text { 1989-2001 }\end{array}$} & \multicolumn{2}{|c|}{$\begin{array}{c}\text { Change } \\
\text { 1994-2009 }\end{array}$} & \multicolumn{2}{|c|}{$\begin{array}{c}\text { Change } \\
\text { 2001-2009 }\end{array}$} & \multicolumn{2}{|c|}{$\begin{array}{c}\text { Change } \\
\text { 1989-2009 }\end{array}$} \\
\hline & & DBH & Height & DBH & Height & $\mathrm{DBH}$ & Height & $\mathrm{DBH}$ & Height & DBH & Height & DBH & Height \\
\hline 1 & GS & 1.5 & 7.0 & 2.3 & 12.7 & 3.8 & 19.7 & 5.1 & 24.5 & 2.8 & 11.8 & 26.6 & 31.5 \\
\hline 2 & IC & 1.0 & 27.0 & 0.5 & 10.9 & 1.5 & 37.9 & 1.2 & 8.1 & 0.7 & -2.8 & 2.2 & 35.1 \\
\hline 3 & IC & 0.4 & -29.0 & 0.6 & 0.3 & 1.0 & -28.7 & 1.2 & 2.2 & 0.6 & 1.9 & 1.6 & -26.8 \\
\hline 4 & IC & 1.1 & -5.0 & -0.3 & -1.2 & 0.8 & -6.2 & 0.0 & 0.5 & 0.3 & 1.7 & 1.1 & -4.5 \\
\hline 5 & GS & 0.4 & -21.0 & 0.6 & 0.8 & 1.0 & -20.2 & 1.0 & -0.4 & 0.4 & -1.2 & 1.4 & -21.4 \\
\hline 6 & GS & 1.8 & 14.0 & 4.1 & 3.1 & 5.9 & 17.1 & 7.2 & 16.8 & 3.1 & 13.7 & 9.0 & 30.8 \\
\hline 7 & IC & 0.0 & 7.0 & 0.3 & -0.6 & 0.3 & 6.4 & 0.6 & 1.0 & 0.3 & 1.6 & 0.6 & 8.0 \\
\hline 8 & IC & 0.7 & 3.0 & 0.9 & 6.6 & 1.6 & 9.6 & 1.6 & 12.7 & 0.7 & 6.1 & 2.3 & 15.7 \\
\hline 9 & IC & 0.9 & 28.0 & 1.4 & -2.9 & 2.3 & 25.1 & 2.8 & 3.3 & 1.4 & 6.2 & 3.7 & 31.3 \\
\hline 10 & IC & 1.1 & 17.0 & 0.1 & -6.8 & 1.2 & 10.2 & 0.6 & -6.5 & 0.5 & 0.3 & 1.7 & 10.5 \\
\hline 11 & IC & 1.2 & 19.0 & 1.4 & 6.3 & 2.6 & 25.3 & 2.9 & 13.6 & 1.5 & 7.3 & 4.1 & 32.6 \\
\hline 12 & IC & 1.0 & 11.0 & 1.2 & 9.3 & 2.2 & 20.3 & 2.5 & 15.2 & 1.3 & 5.9 & 3.5 & 26.2 \\
\hline 13 & IC & 0.6 & 17.0 & 0.8 & -8.4 & 1.4 & 8.6 & 1.5 & -6.4 & 0.7 & 2.0 & 2.1 & 10.6 \\
\hline 14 & IC & 1.6 & 8.0 & 1.7 & 5.3 & 3.3 & 13.3 & 3.5 & 15.3 & 1.8 & 10.0 & 5.1 & 23.3 \\
\hline 15 & GS & 2.7 & 9.0 & 2.1 & 11.8 & 4.8 & 20.8 & 5.3 & 23.0 & 3.2 & 11.2 & 8.0 & 32.0 \\
\hline 16 & IC & 0.5 & 12.0 & 0.3 & 1.9 & 0.8 & 13.9 & 0.5 & -0.4 & 0.2 & -2.3 & 1.0 & 11.6 \\
\hline 17 & GS & 0.8 & 11.0 & 1.0 & 2.5 & 1.8 & 13.5 & 1.8 & 4.3 & 0.8 & 1.8 & 2.6 & 15.3 \\
\hline 18 & IC & 0.5 & 6.0 & 0.4 & 5.1 & 0.9 & 11.1 & 0.6 & 10.1 & 0.2 & 5.0 & 1.1 & 16.1 \\
\hline 19 & IC & 1.0 & 10.0 & 0.9 & 2.5 & 1.9 & 12.5 & 2.0 & 4.6 & 1.1 & 2.1 & 3.0 & 14.6 \\
\hline 20 & IC & 0.3 & 3.0 & 0.2 & 0.1 & 0.5 & 3.1 & 0.3 & 0.4 & 0.1 & 0.3 & 0.6 & 3.4 \\
\hline 21 & IC & 0.6 & 3.0 & 0.7 & 0.1 & 1.3 & 3.1 & 1.1 & 0.7 & 0.4 & 0.6 & 1.7 & 3.7 \\
\hline 22 & IC & 1.1 & 3.0 & 1.3 & 9.1 & 2.4 & 12.1 & 2.7 & 11.4 & 1.4 & 2.3 & 3.8 & 14.4 \\
\hline 23 & IC & 0.6 & 3.0 & 0.5 & -0.1 & 1.1 & 2.9 & 0.9 & 0.9 & 0.4 & 1.0 & 1.5 & 3.9 \\
\hline 24 & IC & 0.7 & -7.0 & 0.2 & -1.8 & 0.9 & -8.8 & 0.6 & -3.2 & 0.4 & -1.4 & 1.3 & -10.2 \\
\hline 25 & IC & 0.2 & 1.0 & 0.0 & -0.7 & 0.2 & 0.3 & 0.2 & -0.5 & 0.2 & 0.2 & 0.4 & 0.5 \\
\hline 26 & GS & 1.5 & 3.0 & 2.3 & 16.5 & 3.8 & 19.5 & 5.4 & 18.4 & 3.1 & 1.9 & 6.9 & 21.4 \\
\hline 27 & IC & 0.2 & 2.0 & 0.3 & -0.8 & 0.5 & 1.2 & 0.4 & -1.6 & 0.1 & -0.8 & 0.6 & 0.4 \\
\hline 28 & GS & 2.2 & 4.0 & 2.5 & 18.5 & 4.7 & 22.5 & 5.2 & 19.7 & 2.7 & 1.2 & 7.4 & 23.7 \\
\hline 29 & GS & 1.4 & 2.0 & 1.7 & 17.3 & 3.1 & 19.3 & 3.6 & 23.5 & 1.9 & 6.2 & 5.0 & 25.5 \\
\hline 30 & GS & 0.3 & 0.0 & 0.2 & 0.1 & 0.5 & 0.1 & 0.3 & 0.9 & 0.1 & 0.8 & 0.6 & 0.9 \\
\hline 31 & GS & 1.7 & 11.0 & 2.0 & 4.4 & 3.7 & 15.4 & 4.5 & 15.8 & 2.5 & 11.4 & 6.2 & 26.8 \\
\hline 32 & IC & 0.4 & 2.0 & 0.5 & 2.1 & 0.9 & 4.1 & 1.1 & 4.9 & 0.6 & 2.8 & 1.5 & 6.9 \\
\hline 33 & IC & 0.3 & 2.0 & 0.5 & 0.9 & 0.8 & 2.9 & 1.0 & 2.8 & 0.5 & 1.9 & 1.3 & 4.8 \\
\hline 34 & GS & 1.9 & 4.0 & 1.4 & 12.7 & 3.3 & 16.7 & 3.2 & 20.4 & 1.8 & 7.7 & 5.1 & 24.4 \\
\hline
\end{tabular}

Tree 13 Severely deformed, original bole missing, height was measured at side branch which is now the dominant leader in 2001, 2009

Trees 6,8 1989 values too low, \#6 - 6 and \#8 - 9 using Roller Thesis values 
MHDSF Young-Growth Giant Sequoia Management Strategies Study 2009 - Overstory Summary Data (39ft. (12m) Plot)

$\begin{array}{lllll}\text { Stand: Methuselah } & \text { Treatment: Control } & \text { Measured By: } & 1989 & \text { Bates, Maddson } \\ & & \text { Measured By: } & 1994 & \text { Ganz } \\ \text { Block: C } & \text { Plot \# : } 3 & \text { Measured By: } & 2001 & \text { Roller, McLoed } \\ & & \text { Measured By: } & 2009 & \text { Soderlund, Estrada }\end{array}$

\begin{tabular}{|c|c|c|c|c|c|c|c|c|c|}
\hline \multirow[b]{2}{*}{ Tree \# } & \multirow[b]{2}{*}{ Species } & \multicolumn{2}{|c|}{1989 Data } & \multicolumn{2}{|c|}{1994 Data } & \multicolumn{2}{|c|}{2001 Data } & \multicolumn{2}{|c|}{2009 Data } \\
\hline & & $\mathrm{DBH}$ & Height & $\mathrm{DBH}$ & Height & $\mathrm{DBH}$ & Height & $\mathrm{DBH}$ & Height \\
\hline 32 & GS & 12.0 & 53.0 & 13.3 & 65.0 & 15.5 & 74.5 & 17.5 & 91.2 \\
\hline 33 & GS & 12.0 & 60.0 & 13.3 & 62.0 & 15.2 & 82.3 & 17.1 & 89.1 \\
\hline 34 & GS & 15.4 & 65.0 & 16.7 & 75.0 & 18.4 & 90.5 & 20.8 & 95.3 \\
\hline 35 & WF & 25.3 & 95.0 & 26.1 & 98.0 & 27.2 & 109.2 & 29.7 & 112.5 \\
\hline 36 & GS & 11.5 & 56.0 & 11.9 & 63.0 & 12.4 & 77.4 & 13.0 & 85.8 \\
\hline 37 & GS & 14.4 & 56.0 & 15.5 & 62.0 & 15.8 & 85.4 & 18.7 & 101.7 \\
\hline 38 & GS & 24.2 & 81.0 & 25.7 & 91.0 & 26.4 & 94.8 & 30.4 & 107.0 \\
\hline 39 & GS & 13.2 & 71.0 & 14.0 & 74.0 & 14.5 & 92.3 & 16.4 & 94.5 \\
\hline 40 & GS & 11.2 & 70.0 & 12.0 & 75.0 & 13.0 & 87.1 & 14.2 & 93.3 \\
\hline 41 & GS & 11.3 & 61.0 & 12.0 & 65.0 & 12.6 & 78.6 & 13.7 & 86.3 \\
\hline 42 & GS & 10.7 & 76.0 & 11.4 & 79.0 & 11.7 & 85.0 & 12.5 & 97.5 \\
\hline 43 & GS & 15.9 & 86.0 & 17.1 & 89.0 & 18.0 & 87.7 & 19.8 & 103.7 \\
\hline 44 & GS & 12.8 & 69.0 & 13.6 & 73.0 & 14.6 & 89.8 & 15.4 & 95.3 \\
\hline 45 & GS & 11.8 & 72.0 & 12.5 & 77.0 & 13.2 & 90.8 & 13.9 & 93.0 \\
\hline 46 & GS & 11.0 & 82.0 & 11.5 & 67.0 & 12.0 & 83.7 & 12.5 & 90.8 \\
\hline 47 & GS & 14.4 & 74.0 & 15.5 & 77.0 & 17.0 & 97.2 & 18.7 & 98.3 \\
\hline 48 & GS & 14.3 & 71.0 & 15.6 & 76.0 & 16.4 & 90.0 & 17.7 & 101.1 \\
\hline 49 & GS & 13.4 & 59.0 & 14.2 & 73.0 & 15.7 & 79.2 & 16.9 & 87.6 \\
\hline 50 & GS & 13.6 & 67.0 & 14.8 & 75.0 & 15.8 & 96.3 & 17.7 & 91.7 \\
\hline 51 & GS & 15.0 & 71.0 & 16.0 & 73.0 & 18.2 & 92.6 & 19.7 & 98.8 \\
\hline 52 & GS & 10.0 & & 11.4 & 58.0 & 12.0 & 65.9 & 12.9 & 79.2 \\
\hline 53 & GS & 10.3 & 51.0 & 11.3 & 52.0 & 12.6 & 65.7 & 13.9 & 78.6 \\
\hline 54 & GS & 16.1 & 81.0 & 17.5 & 85.0 & 19.7 & 92.4 & 21.7 & 114.7 \\
\hline 55 & GS & 15.5 & 67.0 & 16.8 & 76.0 & 18.0 & 87.4 & 19.5 & 99.1 \\
\hline 56 & GS & 16.7 & 68.0 & 18.0 & 72.0 & 20.0 & 84.6 & 21.6 & 96.7 \\
\hline 57 & GS & 14.8 & 69.0 & 15.7 & 74.0 & 17.4 & 86.7 & 19.0 & 98.2 \\
\hline 58 & GS & 9.5 & 60.0 & 9.9 & 66.0 & 10.7 & 78.7 & 11.1 & 85.9 \\
\hline 59 & GS & 11.7 & & 12.7 & 61.0 & 13.9 & 73.3 & 15.1 & 80.6 \\
\hline 60 & GS & 12.5 & 68.0 & 13.9 & 74.0 & 15.5 & 86.3 & 17.2 & 99.5 \\
\hline 61 & GS & 22.0 & 75.0 & 23.4 & 80.0 & 25.8 & 93.8 & 28.1 & 102.3 \\
\hline 62 & GS & 14.1 & 72.0 & 15.5 & 75.0 & 17.2 & 89.3 & 18.6 & 98.5 \\
\hline 63 & GS & 11.8 & 65.0 & 13.1 & 71.0 & 14.7 & 77.0 & 16.1 & 93.2 \\
\hline 64 & GS & 11.4 & 64.0 & 12.4 & 72.0 & 14.2 & 74.4 & 16.1 & 89.8 \\
\hline 65 & IC & $* * *$ & $* * *$ & $* * *$ & $* * *$ & 1.3 & 8.9 & 2.4 & 11.8 \\
\hline 66 & WF & $* * *$ & $* * *$ & $* * *$ & $* * *$ & 2.0 & 12.4 & 2.4 & 12.3 \\
\hline 67 & IC & $* * *$ & $* * *$ & $* * *$ & $* * *$ & 2.2 & 11.6 & 2.7 & 14.7 \\
\hline 68 & WF & $* * *$ & $* * *$ & $* * *$ & $* * *$ & 4.1 & 15.1 & 5.3 & 16.7 \\
\hline 69 & IC & $* * *$ & $* * *$ & $* * *$ & $* * *$ & 3.0 & 11.2 & 3.1 & 13.3 \\
\hline 70 & IC & $* * *$ & $* * *$ & $* * *$ & $* * *$ & 1.6 & 9.9 & 2.1 & 11.1 \\
\hline 71 & WF & $* * *$ & $* * *$ & $* * *$ & $* * *$ & 4.4 & 23.9 & 5.5 & 31.7 \\
\hline 72 & IC & $* * *$ & $* * *$ & $* * *$ & $* * *$ & 1.0 & 7.8 & 1.4 & 9.9 \\
\hline$A V G$ & & 13.9 & 67.6 & 15.0 & 72.9 & 13.5 & 71.2 & 14.9 & 79.3 \\
\hline
\end{tabular}

Trees 65-72 Ingrowth in 2001 
MHDSF Young-Growth Giant Sequoia Management Strategies Study 2009 - Overstory Summary Growth Data (39ft. (12m) Plot)

$\begin{array}{lllll}\text { Stand: Methuselah } & \text { Treatment: Control } & \text { Measured By: } & 1989 & \text { Bates, Maddson } \\ & & \text { Measured By: } & 1994 & \text { Ganz } \\ \text { Block: C } & \text { Plot \# :3 } & \text { Measured By: } & 2001 \text { Roller, McLoed } \\ & & \text { Measured By: } & 2009 \text { Soderlund, Estrada }\end{array}$

\begin{tabular}{|c|c|c|c|c|c|c|c|c|c|c|c|c|c|}
\hline \multirow[b]{2}{*}{ Tree \# } & \multirow[b]{2}{*}{ Species } & \multicolumn{2}{|c|}{$\begin{array}{c}\text { Change } \\
1989-1994\end{array}$} & \multicolumn{2}{|c|}{$\begin{array}{c}\text { Change } \\
1994-2001\end{array}$} & \multicolumn{2}{|c|}{$\begin{array}{c}\text { Change } \\
1989-2001\end{array}$} & \multicolumn{2}{|c|}{$\begin{array}{c}\text { Change } \\
\text { 1994-2009 }\end{array}$} & \multicolumn{2}{|c|}{$\begin{array}{c}\text { Change } \\
\text { 2001-2009 }\end{array}$} & \multicolumn{2}{|c|}{$\begin{array}{c}\text { Change } \\
1989-2009\end{array}$} \\
\hline & & $\mathrm{DBH}$ & Height & DBH & Height & DBH & Height & $\mathrm{DBH}$ & Height & DBH & Height & DBH & Height \\
\hline 32 & GS & 1.3 & 12.0 & 2.2 & 9.5 & 3.5 & 21.5 & 4.2 & 26.2 & 2.0 & 16.7 & 5.5 & 38.2 \\
\hline 33 & GS & 1.3 & 2.0 & 1.9 & 20.3 & 3.2 & 22.3 & 3.8 & 27.1 & 1.9 & 6.8 & 5.1 & 29.1 \\
\hline 34 & GS & 1.3 & 10.0 & 1.7 & 15.5 & 3.0 & 25.5 & 4.1 & 20.3 & 2.4 & 4.8 & 5.4 & 30.3 \\
\hline 35 & WF & 0.8 & 3.0 & 1.1 & 11.2 & 1.9 & 14.2 & 3.6 & 14.5 & 2.5 & 3.3 & 4.4 & 17.5 \\
\hline 36 & GS & 0.4 & 7.0 & 0.5 & 14.4 & 0.9 & 21.4 & 1.1 & 22.8 & 0.6 & 8.4 & 1.5 & 29.8 \\
\hline 37 & GS & 1.1 & 6.0 & 0.3 & 23.4 & 1.4 & 29.4 & 3.2 & 39.7 & 2.9 & 16.3 & 4.3 & 45.7 \\
\hline 38 & GS & 1.5 & 10.0 & 0.7 & 3.8 & 2.2 & 13.8 & 4.7 & 16.0 & 4.0 & 12.2 & 6.2 & 26.0 \\
\hline 39 & GS & 0.8 & 3.0 & 0.5 & 18.3 & 1.3 & 21.3 & 2.4 & 20.5 & 1.9 & 2.2 & 3.2 & 23.5 \\
\hline 40 & GS & 0.8 & 5.0 & 1.0 & 12.1 & 1.8 & 17.1 & 2.2 & 18.3 & 1.2 & 6.2 & 3.0 & 23.3 \\
\hline 41 & GS & 0.7 & 4.0 & 0.6 & 13.6 & 1.3 & 17.6 & 1.7 & 21.3 & 1.1 & 7.7 & 2.4 & 25.3 \\
\hline 42 & GS & 0.7 & 3.0 & 0.3 & 6.0 & 1.0 & 9.0 & 1.1 & 18.5 & 0.8 & 12.5 & 1.8 & 21.5 \\
\hline 43 & GS & 1.2 & 3.0 & 0.9 & -1.3 & 2.1 & 1.7 & 2.7 & 14.7 & 1.8 & 16.0 & 3.9 & 17.7 \\
\hline 44 & GS & 0.8 & 4.0 & 1.0 & 16.8 & 1.8 & 20.8 & 1.8 & 22.3 & 0.8 & 5.5 & 2.6 & 26.3 \\
\hline 45 & GS & 0.7 & 5.0 & 0.7 & 13.8 & 1.4 & 18.8 & 1.4 & 16.0 & 0.7 & 2.2 & 2.1 & 21.0 \\
\hline 46 & GS & 0.5 & -15.0 & 0.5 & 16.7 & 1.0 & 1.7 & 1.0 & 23.8 & 0.5 & 7.1 & 1.5 & 8.8 \\
\hline 47 & GS & 1.1 & 3.0 & 1.5 & 20.2 & 2.6 & 23.2 & 3.2 & 21.3 & 1.7 & 1.1 & 4.3 & 24.3 \\
\hline 48 & GS & 1.3 & 5.0 & 0.8 & 14.0 & 2.1 & 19.0 & 2.1 & 25.1 & 1.3 & 11.1 & 3.4 & 30.1 \\
\hline 49 & GS & 0.8 & 14.0 & 1.5 & 6.2 & 2.3 & 20.2 & 2.7 & 14.6 & 1.2 & 8.4 & 3.5 & 28.6 \\
\hline 50 & GS & 1.2 & 8.0 & 1.0 & 21.3 & 2.2 & 29.3 & 2.9 & 16.7 & 1.9 & -4.6 & 4.1 & 24.7 \\
\hline 51 & GS & 1.0 & 2.0 & 2.2 & 19.6 & 3.2 & 21.6 & 3.7 & 25.8 & 1.5 & 6.2 & 4.7 & 27.8 \\
\hline 52 & GS & 1.4 & 10.0 & 0.6 & 7.9 & 2.0 & 17.9 & 1.5 & 21.2 & 0.9 & 13.3 & 2.9 & 31.2 \\
\hline 53 & GS & 1.0 & 1.0 & 1.3 & 13.7 & 2.3 & 14.7 & 2.6 & 26.6 & 1.3 & 12.9 & 3.6 & 27.6 \\
\hline 54 & GS & 1.4 & 4.0 & 2.2 & 7.4 & 3.6 & 11.4 & 4.2 & 29.7 & 2.0 & 22.3 & 5.6 & 33.7 \\
\hline 55 & GS & 1.3 & 9.0 & 1.2 & 11.4 & 2.5 & 20.4 & 2.7 & 23.1 & 1.5 & 11.7 & 4.0 & 32.1 \\
\hline 56 & GS & 1.3 & 4.0 & 2.0 & 12.6 & 3.3 & 16.6 & 3.6 & 24.7 & 1.6 & 12.1 & 4.9 & 28.7 \\
\hline 57 & GS & 0.9 & 5.0 & 1.7 & 12.7 & 2.6 & 17.7 & 3.3 & 24.2 & 1.6 & 11.5 & 4.2 & 29.2 \\
\hline 58 & GS & 0.4 & 6.0 & 0.8 & 12.7 & 1.2 & 18.7 & 1.2 & 19.9 & 0.4 & 7.2 & 1.6 & 25.9 \\
\hline 59 & GS & 1.0 & 14.0 & 1.2 & 12.3 & 2.2 & 26.3 & 2.4 & 19.6 & 1.2 & 7.3 & 3.4 & 33.6 \\
\hline 60 & GS & 1.4 & 6.0 & 1.6 & 12.3 & 3.0 & 18.3 & 3.3 & 25.5 & 1.7 & 13.2 & 4.7 & 31.5 \\
\hline 61 & GS & 1.4 & 5.0 & 2.4 & 13.8 & 3.8 & 18.8 & 4.7 & 22.3 & 2.3 & 8.5 & 6.1 & 27.3 \\
\hline 62 & GS & 1.4 & 3.0 & 1.7 & 14.3 & 3.1 & 17.3 & 3.1 & 23.5 & 1.4 & 9.2 & 4.5 & 26.5 \\
\hline 63 & GS & 1.3 & 6.0 & 1.6 & 6.0 & 2.9 & 12.0 & 3.0 & 22.2 & 1.4 & 16.2 & 4.3 & 28.2 \\
\hline 64 & GS & 1.0 & 8.0 & 1.8 & 2.4 & 2.8 & 10.4 & 3.7 & 17.8 & 1.9 & 15.4 & 4.7 & 25.8 \\
\hline 65 & IC & $* * *$ & $* * *$ & $* * *$ & $* * *$ & $* * *$ & $* * *$ & $* * *$ & $* * *$ & 1.1 & 2.9 & $* * *$ & $* * *$ \\
\hline 66 & WF & $* * *$ & $* * *$ & $* * *$ & $* * *$ & $* * *$ & $* * *$ & $* * *$ & $* * *$ & 0.4 & -0.1 & $* * *$ & $* * *$ \\
\hline 67 & IC & $* * *$ & $* * *$ & $* * *$ & $* * *$ & $* * *$ & $* * *$ & $* * *$ & $* * *$ & 0.5 & 3.1 & $* * *$ & $* * *$ \\
\hline 68 & WF & $* * *$ & $* * *$ & $* * *$ & $* * *$ & $* * *$ & $* * *$ & $* * *$ & $* * *$ & 1.2 & 1.6 & $* * *$ & $* * *$ \\
\hline 69 & IC & $* * *$ & $* * *$ & $* * *$ & $* * *$ & $* * *$ & $* * *$ & $* * *$ & $* * *$ & 0.1 & 2.1 & $* * *$ & $* * *$ \\
\hline 70 & IC & $* * *$ & $* * *$ & $* * *$ & $* * *$ & $* * *$ & $* * *$ & $* * *$ & $* * *$ & 0.5 & 1.2 & $* * *$ & $* * *$ \\
\hline 71 & WF & $* * *$ & $* * *$ & $* * *$ & $* * *$ & $* * *$ & $* * *$ & $* * *$ & $* * *$ & 1.1 & 7.8 & $* * *$ & $* * *$ \\
\hline 72 & IC & $* * *$ & $* * *$ & $* * *$ & $* * *$ & $* * *$ & $* * *$ & $* * *$ & $* * *$ & 0.4 & 2.1 & $* * *$ & $* * *$ \\
\hline AVG. & & 1.0 & 5.3 & 1.2 & 12.6 & 2.3 & 17.9 & 2.8 & 22.0 & 1.4 & 8.1 & 3.9 & 27.3 \\
\hline
\end{tabular}

Trees 65-72 Ingrowth in 2001 
MHDSF Young-Growth Giant Sequoia Management Strategies Study 2009 - Overstory Summary Data (39ft. (12m) Plot)

$\begin{array}{lllll}\text { Stand: Methuselah } & \text { Treatment: Control } & \text { Measured By: } & 1989 & \text { Bates, Maddson } \\ & & \text { Measured By: } & 1994 & \text { Ganz } \\ \text { Block: C } & \text { Plot \# : } 4 & \text { Measured By: } & 2001 & \text { Roller, McLoed } \\ & & \text { Measured By: } & 2009 & \text { Soderlund, Estrada }\end{array}$

\begin{tabular}{|c|c|c|c|c|c|c|c|c|c|}
\hline \multirow[b]{2}{*}{ Tree \# } & \multirow[b]{2}{*}{ Species } & \multicolumn{2}{|c|}{1989 Data } & \multicolumn{2}{|c|}{1994 Data } & \multicolumn{2}{|c|}{2001 Data } & \multicolumn{2}{|c|}{2009 Data } \\
\hline & & $\mathrm{DBH}$ & Height & DBH & Height & DBH & Height & DBH & Height \\
\hline 1 & PP & 15.4 & 75.0 & 16.7 & 83.0 & 18.9 & 93.5 & 20.9 & 108.6 \\
\hline 2 & GS & 10.8 & 50.0 & 11.7 & 70.0 & 12.8 & 73.3 & 13.8 & 84.6 \\
\hline 3 & GS & 6.7 & 28.0 & 7.3 & 33.0 & 7.6 & 37.5 & 7.6 & 35.0 \\
\hline 4 & GS & 15.0 & 76.0 & 16.0 & 78.0 & 18.0 & 103.4 & 19.8 & 99.2 \\
\hline 5 & GS & 15.4 & 70.0 & 16.9 & 72.0 & 18.1 & 91.5 & 20.3 & 95.7 \\
\hline 6 & GS & 5.9 & 48.0 & 6.3 & 53.0 & 6.6 & 50.3 & 6.8 & 49.8 \\
\hline 7 & GS & 6.2 & 25.0 & 6.8 & 27.0 & 7.1 & 28.9 & 7.2 & 29.2 \\
\hline 8 & GS & 12.6 & 69.0 & 13.5 & 74.0 & 14.5 & 78.9 & 16.0 & 88.3 \\
\hline 9 & GS & 13.4 & 76.0 & 14.5 & 81.0 & 15.8 & 93.5 & 17.2 & 99.4 \\
\hline 10 & GS & 8.8 & 48.0 & 9.5 & 46.0 & 10.2 & 65.3 & 10.5 & 70.6 \\
\hline 11 & GS & 11.9 & 51.0 & 13.2 & 55.0 & 14.9 & 74.8 & 16.5 & 79.1 \\
\hline 12 & WF & 22.6 & 85.0 & 23.4 & 92.0 & 24.5 & 99.9 & 26.0 & 105.4 \\
\hline 13 & GS & 19.4 & 73.0 & 20.9 & 72.0 & 23.1 & 90.9 & 25.7 & 97.4 \\
\hline 14 & GS & 7.2 & 51.0 & 8.0 & 56.0 & 8.8 & 69.0 & 9.9 & 71.4 \\
\hline 15 & GS & 9.3 & 61.0 & 10.2 & 64.0 & 10.5 & 81.8 & 11.0 & 89.6 \\
\hline 16 & GS & 6.2 & 36.0 & 6.7 & 37.0 & 7.0 & 43.6 & 7.1 & 43.5 \\
\hline 17 & GS & 12.6 & 65.0 & 13.9 & 71.0 & 15.7 & 85.1 & 17.6 & 92.4 \\
\hline 18 & GS & 11.7 & 58.0 & 12.9 & 65.0 & 14.4 & 75.2 & 15.7 & 88.8 \\
\hline 19 & GS & 11.4 & 47.0 & 12.3 & 52.0 & 13.5 & 65.0 & 14.7 & 78.4 \\
\hline 20 & GS & 8.9 & 53.0 & 9.6 & 57.0 & 10.8 & 73.8 & 11.7 & 71.5 \\
\hline 21 & GS & 7.9 & 31.0 & 8.5 & 31.0 & 9.1 & 26.7 & 10.1 & 54.4 \\
\hline 22 & GS & 13.9 & 50.0 & 15.3 & 68.0 & 17.8 & 83.9 & 20.3 & 95.7 \\
\hline 23 & GS & 10.2 & 52.0 & 11.6 & 63.0 & 12.9 & 70.5 & 13.9 & 83.6 \\
\hline 24 & GS & 13.0 & 61.0 & 13.6 & 66.0 & 15.4 & 76.9 & 16.5 & 92.4 \\
\hline 25 & GS & 12.7 & 62.0 & 13.4 & 65.0 & 14.1 & 74.9 & 14.8 & 88.6 \\
\hline 26 & GS & 18.4 & 70.0 & 19.9 & 87.0 & 22.1 & 89.1 & 25.0 & 97.7 \\
\hline 27 & GS & 9.5 & 57.0 & 10.4 & 64.0 & 11.1 & 75.0 & 11.9 & 84.4 \\
\hline 28 & GS & 16.5 & 62.0 & 17.3 & 71.0 & 18.9 & 78.0 & 20.9 & 92.3 \\
\hline 29 & GS & 15.7 & 68.0 & 16.9 & 76.0 & 19.0 & 85.6 & 20.7 & 95.2 \\
\hline 30 & GS & 8.7 & 32.0 & 9.3 & 41.0 & 9.7 & 40.6 & 10.2 & 46.6 \\
\hline 31 & GS & 15.6 & 77.0 & 17.0 & 79.0 & 18.9 & 93.2 & 20.9 & 102.6 \\
\hline 32 & WF & $* * *$ & $* * *$ & $* * *$ & $* * *$ & 2.2 & 11.9 & 2.4 & 13.4 \\
\hline 33 & WF & $* * *$ & $* * *$ & $* * *$ & $* * *$ & 4.3 & 22.8 & 4.9 & 26.4 \\
\hline 34 & WF & $* * *$ & $* * *$ & $* * *$ & $* * *$ & 3.3 & 16.1 & 4.8 & 18.4 \\
\hline 35 & WF & $* * *$ & $* * *$ & $* * *$ & $* * *$ & 2.3 & 12.0 & 3.1 & 13.6 \\
\hline 36 & WF & $* * *$ & $* * *$ & $* * *$ & $* * *$ & 1.2 & 8.7 & 2.0 & 11.3 \\
\hline 37 & WF & $* * *$ & $* * *$ & $* * *$ & $* * *$ & 1.7 & 10.1 & 2.8 & 14.2 \\
\hline 38 & WF & $* * *$ & $* * *$ & $* * *$ & $* * *$ & $* * *$ & $* * *$ & 1.2 & 8.2 \\
\hline 39 & WF & $* * *$ & $* * *$ & $* * *$ & $* * *$ & $* * *$ & $* * *$ & 1.3 & 6.9 \\
\hline 40 & WF & $* * *$ & $* * *$ & $* * *$ & $* * *$ & $* * *$ & $* * *$ & 1.1 & 6.9 \\
\hline 41 & SP & $* * *$ & $* * *$ & $* * *$ & $* * *$ & $* * *$ & $* * *$ & 1.2 & 8.2 \\
\hline 42 & IC & $* * *$ & $* * *$ & $* * *$ & $* * *$ & $* * *$ & $* * *$ & 1.2 & 7.6 \\
\hline 43 & SP & $* * *$ & $* * *$ & $* * *$ & $* * *$ & $* * *$ & $* * *$ & 1.2 & 9.3 \\
\hline 44 & WF & $* * *$ & $* * *$ & $* * *$ & $* * *$ & $* * *$ & $* * *$ & 1.4 & 8.1 \\
\hline 45 & WF & $* * *$ & $* * *$ & $* * *$ & $* * *$ & $* * *$ & $* * *$ & 1.0 & 7.1 \\
\hline 46 & WF & $* * *$ & $* * *$ & $* * *$ & $* * *$ & $* * *$ & $* * *$ & 1.1 & 7.9 \\
\hline AVG. & & 12.0 & 57.0 & 13.0 & 62.9 & 12.3 & 63.5 & 11.1 & 58.2 \\
\hline
\end{tabular}

Page 164 
MHDSF Young-Growth Giant Sequoia Management Strategies Study

2009 - Overstory Summary Data (39ft. (12m) Plot)

Stand: Methuselah

Block: C
Treatment: Control

Plot \# : 4
Measured By:

Measured By:

Measured By:

Measured By:
1989 Bates, Maddson

1994 Ganz

2001 Roller, McLoed

2009 Soderlund, Estrada

Trees 32-37 Ingrowth in 2001

Trees $\quad 21 \quad$ Forked Top in 2001

Trees 38-46 Ingrowth in 2009 
MHDSF Young-Growth Giant Sequoia Management Strategies Study 2009 - Overstory Summary Data (39ft. (12m) Plot)

$\begin{array}{lllll}\text { Stand: Methuselah } & \text { Treatment: Control } & \text { Measured By: } & 1989 & \text { Bates, Maddson } \\ & & \text { Measured By: } & 1994 & \text { Ganz } \\ \text { Block: C } & \text { Plot \# : } 4 & \text { Measured By: } & 2001 & \text { Roller, McLoed } \\ & & \text { Measured By: } & 2009 & \text { Soderlund, Estrada }\end{array}$

\begin{tabular}{|c|c|c|c|c|c|c|c|c|c|c|c|c|c|}
\hline \multirow[b]{2}{*}{ Tree \# } & \multirow[b]{2}{*}{ Species } & \multicolumn{2}{|c|}{$\begin{array}{c}\text { Change } \\
\text { 1989-1994 }\end{array}$} & \multicolumn{2}{|c|}{$\begin{array}{c}\text { Change } \\
1994-2001\end{array}$} & \multicolumn{2}{|c|}{$\begin{array}{c}\text { Change } \\
1989-2001\end{array}$} & \multicolumn{2}{|c|}{$\begin{array}{c}\text { Change } \\
\text { 1994-2009 }\end{array}$} & \multicolumn{2}{|c|}{$\begin{array}{l}\text { Change } \\
\text { 2001-2009 }\end{array}$} & \multicolumn{2}{|c|}{$\begin{array}{c}\text { Change } \\
\text { 1989-2009 }\end{array}$} \\
\hline & & DBH & Height & $\mathrm{DBH}$ & Height & DBH & Height & DBH & Height & DBH & Height & $\mathrm{DBH}$ & Height \\
\hline 1 & PP & $\begin{array}{l}1.3 \\
\end{array}$ & 8.0 & 2.2 & 10.5 & 3.5 & 18.5 & 4.2 & 25.6 & 2.0 & 15.1 & 5.5 & 33.6 \\
\hline 2 & GS & 0.9 & 20.0 & 1.1 & 3.3 & 2.0 & 23.3 & 2.1 & 14.6 & 1.0 & 11.3 & 3.0 & 34.6 \\
\hline 3 & GS & 0.6 & 5.0 & 0.3 & 4.5 & 0.9 & 9.5 & 0.3 & 2.0 & 0.0 & -2.5 & 0.9 & 7.0 \\
\hline 4 & GS & 1.0 & 2.0 & 2.0 & 25.4 & 3.0 & 27.4 & 3.8 & 21.2 & 1.8 & -4.2 & 4.8 & 23.2 \\
\hline 5 & GS & 1.5 & 2.0 & 1.2 & 19.5 & 2.7 & 21.5 & 3.4 & 23.7 & 2.2 & 4.2 & 4.9 & 25.7 \\
\hline 6 & GS & 0.4 & 5.0 & 0.3 & -2.7 & 0.7 & 2.3 & 0.5 & -3.2 & 0.2 & -0.5 & 0.9 & 1.8 \\
\hline 7 & GS & 0.6 & 2.0 & 0.3 & 1.9 & 0.9 & 3.9 & 0.4 & 2.2 & 0.1 & 0.3 & 1.0 & 4.2 \\
\hline 8 & GS & 0.9 & 5.0 & 1.0 & 4.9 & 1.9 & 9.9 & 2.5 & 14.3 & 1.5 & 9.4 & 3.4 & 19.3 \\
\hline 9 & GS & 1.1 & 5.0 & 1.3 & 12.5 & 2.4 & 17.5 & 2.7 & 18.4 & 1.4 & 5.9 & 3.8 & 23.4 \\
\hline 10 & GS & 0.7 & -2.0 & 0.7 & 19.3 & 1.4 & 17.3 & 1.0 & 24.6 & 0.3 & 5.3 & 1.7 & 22.6 \\
\hline 11 & GS & 1.3 & 4.0 & 1.7 & 19.8 & 3.0 & 23.8 & 3.3 & 24.1 & 1.6 & 4.3 & 4.6 & 28.1 \\
\hline 12 & WF & 0.8 & 7.0 & 1.1 & 7.9 & 1.9 & 14.9 & 2.6 & 13.4 & 1.5 & 5.5 & 3.4 & 20.4 \\
\hline 13 & GS & 1.5 & -1.0 & 2.2 & 18.9 & 3.7 & 17.9 & 4.8 & 25.4 & 2.6 & 6.5 & 6.3 & 24.4 \\
\hline 14 & GS & 0.8 & 5.0 & 0.8 & 13.0 & 1.6 & 18.0 & 1.9 & 15.4 & 1.1 & 2.4 & 2.7 & 20.4 \\
\hline 15 & GS & 0.9 & 3.0 & 0.3 & 17.8 & 1.2 & 20.8 & 0.8 & 25.6 & 0.5 & 7.8 & 1.7 & 28.6 \\
\hline 16 & GS & 0.5 & 1.0 & 0.3 & 6.6 & 0.8 & 7.6 & 0.4 & 6.5 & 0.1 & -0.1 & 0.9 & 7.5 \\
\hline 17 & GS & 1.3 & 6.0 & 1.8 & 14.1 & 3.1 & 20.1 & 3.7 & 21.4 & 1.9 & 7.3 & 5.0 & 27.4 \\
\hline 18 & GS & 1.2 & 7.0 & 1.5 & 10.2 & 2.7 & 17.2 & 2.8 & 23.8 & 1.3 & 13.6 & 4.0 & 30.8 \\
\hline 19 & GS & 0.9 & 5.0 & 1.2 & 13.0 & 2.1 & 18.0 & 2.4 & 26.4 & 1.2 & 13.4 & 3.3 & 31.4 \\
\hline 20 & GS & 0.7 & 4.0 & 1.2 & 16.8 & 1.9 & 20.8 & 2.1 & 14.5 & 0.9 & -2.3 & 2.8 & 18.5 \\
\hline 21 & GS & 0.6 & 0.0 & 0.6 & -4.3 & 1.2 & -4.3 & 1.6 & 23.4 & 1.0 & 27.7 & 2.2 & 23.4 \\
\hline 22 & GS & 1.4 & 18.0 & 2.5 & 15.9 & 3.9 & 33.9 & 5.0 & 27.7 & 2.5 & 11.8 & 6.4 & 45.7 \\
\hline 23 & GS & 1.4 & 11.0 & 1.3 & 7.5 & 2.7 & 18.5 & 2.3 & 20.6 & 1.0 & 13.1 & 3.7 & 31.6 \\
\hline 24 & GS & 0.6 & 5.0 & 1.8 & 10.9 & 2.4 & 15.9 & 2.9 & 26.4 & 1.1 & 15.5 & 3.5 & 31.4 \\
\hline 25 & GS & 0.7 & 3.0 & 0.7 & 9.9 & 1.4 & 12.9 & 1.4 & 23.6 & 0.7 & 13.7 & 2.1 & 26.6 \\
\hline 26 & GS & 1.5 & 17.0 & 2.2 & 2.1 & 3.7 & 19.1 & 5.1 & 10.7 & 2.9 & 8.6 & 6.6 & 27.7 \\
\hline 27 & GS & 0.9 & 7.0 & 0.7 & 11.0 & 1.6 & 18.0 & 1.5 & 20.4 & 0.8 & 9.4 & 2.4 & 27.4 \\
\hline 28 & GS & 0.8 & 9.0 & 1.6 & 7.0 & 2.4 & 16.0 & 3.6 & 21.3 & 2.0 & 14.3 & 4.4 & 30.3 \\
\hline 29 & GS & 1.2 & 8.0 & 2.1 & 9.6 & 3.3 & 17.6 & 3.8 & 19.2 & 1.7 & 9.6 & 5.0 & 27.2 \\
\hline 30 & GS & 0.6 & 9.0 & 0.4 & -0.4 & 1.0 & 8.6 & 0.9 & 5.6 & 0.5 & 6.0 & 1.5 & 14.6 \\
\hline 31 & GS & 1.4 & 2.0 & 1.9 & 14.2 & 3.3 & 16.2 & 3.9 & 23.6 & 2.0 & 9.4 & 5.3 & 25.6 \\
\hline 32 & WF & $* * *$ & $* * *$ & *** & $* * *$ & $* * *$ & $* * *$ & $* * *$ & $* * *$ & 0.2 & 1.5 & $* * *$ & $* * *$ \\
\hline 33 & WF & $* * *$ & $* * *$ & $* * *$ & $* * *$ & $* * *$ & $* * *$ & $* * *$ & $* * *$ & 0.6 & 3.6 & $* * *$ & $* * *$ \\
\hline 34 & WF & $* * *$ & $* * *$ & $* * *$ & $* * *$ & $* * *$ & $* * *$ & $* * *$ & $* * *$ & 1.5 & 2.3 & $* * *$ & $* * *$ \\
\hline 35 & WF & $* * *$ & $* * *$ & $* * *$ & $* * *$ & $* * *$ & $* * *$ & $* * *$ & $* * *$ & 0.8 & 1.6 & $* * *$ & $* * *$ \\
\hline 36 & WF & $* * *$ & $* * *$ & $* * *$ & $* * *$ & $* * *$ & $* * *$ & $* * *$ & $* * *$ & 0.8 & 2.6 & $* * *$ & $* * *$ \\
\hline 37 & WF & $* * *$ & $* * *$ & $* * *$ & $* * *$ & $* * *$ & $* * *$ & $* * *$ & $* * *$ & 1.1 & 4.1 & $* * *$ & $* * *$ \\
\hline 38 & WF & $* * *$ & $* * *$ & $* * *$ & $* * *$ & $* * *$ & $* * *$ & $* * *$ & $* * *$ & $* * *$ & $* * *$ & $* * *$ & $* * *$ \\
\hline 39 & WF & $* * *$ & $* * *$ & $* * *$ & $* * *$ & $* * *$ & $* * *$ & $* * *$ & $* * *$ & $* * *$ & $* * *$ & $* * *$ & $* * *$ \\
\hline 40 & WF & $* * *$ & $* * *$ & $* * *$ & $* * *$ & $* * *$ & $* * *$ & $* * *$ & $* * *$ & $* * *$ & $* * *$ & $* * *$ & $* * *$ \\
\hline 41 & SP & $* * *$ & $* * *$ & $* * *$ & $* * *$ & $* * *$ & $* * *$ & $* * *$ & $* * *$ & $* * *$ & $* * *$ & $* * *$ & $* * *$ \\
\hline 42 & IC & $* * *$ & $* * *$ & $* * *$ & $* * *$ & $* * *$ & $* * *$ & $* * *$ & $* * *$ & $* * *$ & $* * *$ & $* * *$ & $* * *$ \\
\hline 43 & SP & $* * *$ & $* * *$ & $* * *$ & $* * *$ & $* * *$ & $* * *$ & $* * *$ & $* * *$ & $* * *$ & $* * *$ & $* * *$ & $* * *$ \\
\hline 44 & WF & $* * *$ & $* * *$ & $* * *$ & $* * *$ & $* * *$ & $* * *$ & $* * *$ & $* * *$ & $* * *$ & $* * *$ & $* * *$ & $* * *$ \\
\hline 45 & WF & $* * *$ & $* * *$ & $* * *$ & $* * *$ & $* * *$ & $* * *$ & $* * *$ & $* * *$ & $* * *$ & $* * *$ & $* * *$ & $* * *$ \\
\hline 46 & WF & $* * *$ & $* * *$ & $* * *$ & $* * *$ & $* * *$ & $* * *$ & $* * *$ & $* * *$ & $* * *$ & $* * *$ & $* * *$ & $* * *$ \\
\hline$V G$ & & 1.0 & 5.9 & 1.2 & 10.3 & 2.2 & 16.2 & 2.5 & 18.1 & 1.2 & 7.0 & 3.5 & 24.0 \\
\hline
\end{tabular}

Page 166 
MHDSF Young-Growth Giant Sequoia Management Strategies Study 2009 - Overstory Summary Data (39ft. (12m) Plot)

$\begin{array}{lllll}\text { Stand: Methuselah } & \text { Treatment: Control } & \text { Measured By: } & 1989 \text { Bates, Maddson } \\ & & \text { Measured By: } & 1994 & \text { Ganz } \\ \text { Block: C } & \text { Plot \# :4 } & \text { Measured By: } & 2001 \text { Roller, McLoed } \\ & & \text { Measured By: } & 2009 \text { Soderlund, Estrada }\end{array}$

Trees 32-37 Ingrowth in 2001

Trees $\quad 21 \quad$ Forked Top in 2001

Trees 38-46 Ingrowth in 2009 
MHDSF Young-Growth Giant Sequoia Management Strategies Study 2009 - Overstory Summary Data (39ft. (12m) Plot)

$\begin{array}{lllll}\text { Stand: Tub Flats } & \text { Treatment: Thinned } & \text { Measured By: } & 1989 \text { Rodgers, Johannis, Eagan } \\ & & \text { Measured By: } & 1994 \text { Gasser, Ganz } \\ \text { Block: A } & \text { Plot \#: } 1 & \text { Measured By: } & 2001 \text { Roller, Reuter } \\ & & \text { Measured By: } & 2009 \text { Soderlund, Estrada }\end{array}$

\begin{tabular}{ccccc|cc|cc|cc|}
\cline { 3 - 10 } & & & \multicolumn{2}{c|}{1989 Data } & \multicolumn{2}{c|}{1994 Data } & \multicolumn{2}{c|}{2001 Data } & \multicolumn{2}{c|}{2009 Data } \\
Tree \# & Species & DBH & Height & DBH & Height & DBH & Height & DBH & Height \\
\hline \hline 62 & GS & 14.1 & 81.0 & 15.7 & 82.0 & 18.8 & 92.6 & 21.9 & 108.2 \\
63 & GS & 20.9 & 76.0 & 22.6 & 78.0 & 25.6 & 90.1 & 29.0 & 105.3 \\
64 & GS & 13.1 & 61.0 & 13.9 & 59.0 & 16.4 & 66.9 & 18.3 & 79.1 \\
65 & GS & 12.0 & 51.0 & 12.4 & 49.0 & 13.2 & 52.2 & 14.0 & 68.5 \\
66 & GS & 10.3 & 44.0 & 11.2 & 45.0 & 12.9 & 53.8 & 14.4 & 68.5 \\
67 & GS & 8.3 & 41.0 & 9.1 & 42.0 & 10.2 & 47.7 & 11.5 & 60.3 \\
68 & GS & 7.1 & 50.0 & 7.4 & 58.0 & 8.1 & 57.7 & 9.0 & 69.2 \\
69 & GS & 14.2 & 62.0 & 15.3 & 66.0 & 17.9 & 71.1 & 20.1 & 82.3 \\
70 & WF & 10.8 & 61.0 & 11.3 & 66.0 & 13.8 & 73.7 & 15.4 & 83.7 \\
71 & GS & 6.6 & 44.0 & 6.9 & 47.0 & 7.4 & 49.9 & 7.8 & 58.3 \\
72 & GS & 9.8 & 50.0 & 10.3 & 59.0 & 11.4 & 57.5 & 12.8 & 68.7 \\
73 & GS & 9.7 & 53.0 & 10.2 & 54.0 & 10.8 & 37.6 & 11.2 & 44.4 \\
74 & GS & 12.4 & 59.0 & 13.0 & 70.0 & 14.4 & 71.8 & 16.1 & 83.1 \\
75 & GS & 13.3 & 69.0 & 14.1 & 74.0 & 16.5 & 78.9 & 18.5 & 97.8 \\
76 & GS & 18.4 & 92.0 & 20.7 & 97.0 & 24.8 & 102.3 & 28.5 & 117.3 \\
77 & GS & 10.5 & 66.0 & 11.2 & 65.0 & 13.2 & 77.5 & 15.5 & 90.2 \\
78 & GS & 10.5 & 64.0 & 11.3 & 66.0 & 13.7 & 79.9 & 15.8 & 94.8 \\
79 & WF & 13.6 & 73.0 & 15.2 & 76.0 & 17.4 & 92.7 & 18.7 & 99.1 \\
80 & GS & $* * *$ & $* * *$ & $* * *$ & $* * *$ & 6.1 & 19.5 & 6.5 & 23.1 \\
94 & WF & 1.0 & 8.0 & 1.8 & 8.0 & 2.2 & 8.6 & 3.0 & 11.7 \\
95 & WF & $* * *$ & $* * *$ & $* * *$ & $* * *$ & $* * *$ & $* * *$ & 1.4 & 7.0 \\
96 & WF & $* * *$ & $* * *$ & $* * *$ & $* * *$ & $* * *$ & $* * *$ & 2.3 & 8.3 \\
\hline \hline AVG. & & 11.4 & 58.2 & 12.3 & 61.1 & 13.7 & 64.1 & 14.2 & 69.5 \\
Tree & 80 & Ingrowth in 2001 & & & & & & \\
Trees & 73 & Broken Top in 2001 & & & & & & \\
& & & & & & & & & \\
75 & Ingrowth in 2009 & & & & & &
\end{tabular}


MHDSF Young-Growth Giant Sequoia Management Strategies Study 2009 - Overstory Summary Growth Data (39ft. (12m) Plot)

$\begin{array}{lllll}\text { Stand: Tub Flats } & \text { Treatment: Thinned } & \text { Measured By: } & 1989 & \text { Rodgers, Johannis, Eagan } \\ & & \text { Measured By: } & 1994 & \text { Gasser, Ganz } \\ \text { Block: A } & \text { Plot \#: } 1 & \text { Measured By: } & 2001 & \text { Roller, Reuter } \\ & & \text { Measured By: } & 2009 & \text { Soderlund, Estrada }\end{array}$

\begin{tabular}{|c|c|c|c|c|c|c|c|c|c|c|c|c|c|}
\hline \multirow[b]{2}{*}{ Tree \# } & \multirow[b]{2}{*}{ Species } & \multicolumn{2}{|c|}{$\begin{array}{c}\text { Change } \\
\text { 1989-1994 }\end{array}$} & \multicolumn{2}{|c|}{$\begin{array}{c}\text { Change } \\
\text { 1994-2001 }\end{array}$} & \multicolumn{2}{|c|}{$\begin{array}{c}\text { Change } \\
\text { 1989-2001 }\end{array}$} & \multicolumn{2}{|c|}{$\begin{array}{c}\text { Change } \\
\text { 1994-2009 }\end{array}$} & \multicolumn{2}{|c|}{$\begin{array}{l}\text { Change } \\
\text { 2001-2009 }\end{array}$} & \multicolumn{2}{|c|}{$\begin{array}{c}\text { Change } \\
\text { 1989-2009 }\end{array}$} \\
\hline & & $\mathrm{DBH}$ & Height & $\mathrm{DBH}$ & Height & $\mathrm{DBH}$ & Height & $\mathrm{DBH}$ & Height & $\mathrm{DBH}$ & Height & $\mathrm{DBH}$ & Height \\
\hline 62 & GS & 1.6 & 1.0 & 3.1 & 10.6 & 4.7 & 11.6 & 6.2 & 26.2 & 3.1 & 15.6 & 7.8 & 27.2 \\
\hline 63 & GS & 1.7 & 2.0 & 3.0 & 12.1 & 4.7 & 14.1 & 6.4 & 27.3 & 3.4 & 15.2 & 8.1 & 29.3 \\
\hline 64 & GS & 0.8 & -2.0 & 2.5 & 7.9 & 3.3 & 5.9 & 4.4 & 20.1 & 1.9 & 12.2 & 5.2 & 18.1 \\
\hline 65 & GS & 0.4 & -2.0 & 0.8 & 3.2 & 1.2 & 1.2 & 1.6 & 19.5 & 0.8 & 16.3 & 2.0 & 17.5 \\
\hline 66 & GS & 0.9 & 1.0 & 1.7 & 8.8 & 2.6 & 9.8 & 3.2 & 23.5 & 1.5 & 14.7 & 4.1 & 24.5 \\
\hline 67 & GS & 0.8 & 1.0 & 1.1 & 5.7 & 1.9 & 6.7 & 2.4 & 18.3 & 1.3 & 12.6 & 3.2 & 19.3 \\
\hline 68 & GS & 0.3 & 8.0 & 0.7 & -0.3 & 1.0 & 7.7 & 1.6 & 11.2 & 0.9 & 11.5 & 1.9 & 19.2 \\
\hline 69 & GS & 1.1 & 4.0 & 2.6 & 5.1 & 3.7 & 9.1 & 4.8 & 16.3 & 2.2 & 11.2 & 5.9 & 20.3 \\
\hline 70 & WF & 0.5 & 5.0 & 2.5 & 7.7 & 3.0 & 12.7 & 4.1 & 17.7 & 1.6 & 10.0 & 4.6 & 22.7 \\
\hline 71 & GS & 0.3 & 3.0 & 0.5 & 2.9 & 0.8 & 5.9 & 0.9 & 11.3 & 0.4 & 8.4 & 1.2 & 14.3 \\
\hline 72 & GS & 0.5 & 9.0 & 1.1 & -1.5 & 1.6 & 7.5 & 2.5 & 9.7 & 1.4 & 11.2 & 3.0 & 18.7 \\
\hline 73 & GS & 0.5 & 1.0 & 0.6 & -16.4 & 1.1 & -15.4 & 1.0 & -9.6 & 0.4 & 6.8 & 1.5 & -8.6 \\
\hline 74 & GS & 0.6 & 11.0 & 1.4 & 1.8 & 2.0 & 12.8 & 3.1 & 13.1 & 1.7 & 11.3 & 3.7 & 24.1 \\
\hline 75 & GS & 0.8 & 5.0 & 2.4 & 4.9 & 3.2 & 9.9 & 4.4 & 23.8 & 2.0 & 18.9 & 5.2 & 28.8 \\
\hline 76 & GS & 2.3 & 5.0 & 4.1 & 5.3 & 6.4 & 10.3 & 7.8 & 20.3 & 3.7 & 15.0 & 10.1 & 25.3 \\
\hline 77 & GS & 0.7 & -1.0 & 2.0 & 12.5 & 2.7 & 11.5 & 4.3 & 25.2 & 2.3 & 12.7 & 5.0 & 24.2 \\
\hline 78 & GS & 0.8 & 2.0 & 2.4 & 13.9 & 3.2 & 15.9 & 4.5 & 28.8 & 2.1 & 14.9 & 5.3 & 30.8 \\
\hline 79 & WF & 1.6 & 3.0 & 2.2 & 16.7 & 3.8 & 19.7 & 3.5 & 23.1 & 1.3 & 6.4 & 5.1 & 26.1 \\
\hline 80 & GS & $* * *$ & $* * *$ & $* * *$ & $* * *$ & $* * *$ & $* * *$ & $* * *$ & $* * *$ & 0.4 & 3.6 & $* * *$ & $* * *$ \\
\hline 94 & WF & 0.8 & 0.0 & 0.4 & 0.6 & 1.2 & 0.6 & 1.2 & 3.7 & 0.8 & 3.1 & 2.0 & 3.7 \\
\hline 95 & WF & $* * *$ & $* * *$ & $* * *$ & $* * *$ & $* * *$ & $* * *$ & $* * *$ & $* * *$ & $* * *$ & $* * *$ & $* * *$ & $* * *$ \\
\hline 96 & WF & $* * *$ & $* * *$ & $* * *$ & $* * *$ & $* * *$ & $* * *$ & $* * *$ & $* * *$ & $* * *$ & $* * *$ & $* * *$ & $* * *$ \\
\hline AVG. & & 0.9 & 2.9 & 1.8 & 5.3 & 2.7 & 8.3 & 3.6 & 17.3 & 1.7 & 11.6 & 4.5 & 20.3 \\
\hline
\end{tabular}

Tree $\quad 80 \quad$ Ingrowth in 2001

Tree 73 Broken Top in 2001

Trees 95,96 Ingrowth in 2009 
MHDSF Young-Growth Giant Sequoia Management Strategies Study 2009 - Overstory Summary Data (39ft. (12m) Plot)

Stand: Tub Flats

Block: B
Treatment: Thinned/Burned

Plot \#: 1
Measured By: Measured By: Measured By: Measured By:
1990 Rodgers, Johannis, Eagan

1994 Gasser, Ganz

2001 Roller, Reuter

2009 Soderlund, Estrada

\begin{tabular}{cc|cc|cc|cc|cc|}
\cline { 3 - 9 } \multicolumn{1}{c|}{} & & \multicolumn{2}{c|}{ 1989 Data } & \multicolumn{2}{c|}{ 1994 Data } & \multicolumn{2}{c|}{ 2001 Data } & \multicolumn{2}{c|}{2009 Data } \\
Tree \# & Species & DBH & Height & DBH & Height & DBH & Height & DBH & Height \\
\hline \hline 80 & WF & 20.5 & 80.0 & 22.3 & 82.0 & 23.7 & 83.8 & 24.8 & 94.2 \\
81 & GS & 11.8 & 55.0 & 11.8 & 57.0 & 13.2 & 69.6 & 16.2 & 86.1 \\
82 & WF & 13.4 & 80.0 & $* * *$ & $* * *$ & $* * *$ & $* * *$ & $* * *$ & $* * *$ \\
83 & GS & 13.0 & 79.0 & 13.4 & 80.0 & 16.6 & 89.2 & 19.2 & 99.4 \\
84 & GS & 9.8 & 56.0 & 10.3 & 57.0 & 12.2 & 69.1 & 13.9 & 86.9 \\
85 & GS & 11.1 & 64.0 & 12.0 & 67.0 & 14.2 & 75.4 & 16.7 & 85.4 \\
86 & WF & 15.5 & 65.0 & 17.1 & 65.0 & 19.1 & 75.6 & 20.6 & 84.1 \\
87 & GS & 14.8 & 72.0 & 15.9 & 78.0 & 19.3 & 82.4 & 22.4 & 103.1 \\
88 & GS & 11.4 & 64.0 & 11.9 & 66.0 & 13.7 & 71.5 & 15.6 & 90.7 \\
89 & GS & 10.6 & 55.0 & 11.1 & 53.0 & 12.8 & 67.8 & 15.2 & 83.5 \\
90 & GS & 10.0 & 57.0 & 10.1 & 64.0 & 12.2 & 65.4 & 14.6 & 81.5 \\
91 & WF & 19.6 & 86.0 & 20.8 & 87.0 & 22.5 & 94.7 & 23.8 & 104.4 \\
92 & GS & 15.1 & 72.0 & 16.8 & 77.0 & 20.2 & 90.2 & 23.8 & 107.3 \\
93 & GS & 15.9 & 78.0 & 18.2 & 85.0 & 21.1 & 90.4 & 23.4 & 107.3 \\
\hline \hline AVG. & & 13.8 & 68.8 & 14.7 & 70.6 & 17.0 & 78.9 & 19.2 & 93.4
\end{tabular}

2009 - Overstory Summary Growth Data (39ft. (12m) Plot)

\begin{tabular}{|c|c|c|c|c|c|c|c|c|c|c|c|c|c|}
\hline \multirow[b]{2}{*}{ Tree \# } & \multirow[b]{2}{*}{ Species } & \multicolumn{2}{|c|}{$\begin{array}{c}\text { Change } \\
\text { 1989-1994 }\end{array}$} & \multicolumn{2}{|c|}{$\begin{array}{c}\text { Change } \\
\text { 1994-2001 }\end{array}$} & \multicolumn{2}{|c|}{$\begin{array}{c}\text { Change } \\
1989-2001\end{array}$} & \multicolumn{2}{|c|}{$\begin{array}{c}\text { Change } \\
\text { 1994-2009 }\end{array}$} & \multicolumn{2}{|c|}{$\begin{array}{l}\text { Change } \\
\text { 2001-2009 }\end{array}$} & \multicolumn{2}{|c|}{$\begin{array}{c}\text { Change } \\
\text { 1989-2009 }\end{array}$} \\
\hline & & $\mathrm{DBH}$ & Height & DBH & Height & $\mathrm{DBH}$ & Height & DBH & Height & $\mathrm{DBH}$ & Height & $\mathrm{DBH}$ & Height \\
\hline 80 & WF & 1.8 & 2.0 & 1.4 & 10 & 3.2 & 3.8 & 2.5 & (12.2 & 1.1 & $\begin{array}{l}10.4 \\
\end{array}$ & 4.3 & 14.2 \\
\hline 81 & GS & 0.0 & 2.0 & 1.4 & 12.6 & 1.4 & 14.6 & 4.4 & 29.1 & 3.0 & 16.5 & 4.4 & 31.1 \\
\hline 82 & WF & $* * *$ & $* * *$ & $* * *$ & $* * *$ & $* * *$ & $* * *$ & $* * *$ & $* * *$ & $* * *$ & $* * *$ & $* * *$ & $* * *$ \\
\hline 83 & GS & 0.4 & 1.0 & 3.2 & 9.2 & 3.6 & 10.2 & 5.8 & 19.4 & 2.6 & 10.2 & 6.2 & 20.4 \\
\hline 84 & GS & 0.5 & 1.0 & 1.9 & 12.1 & 2.4 & 13.1 & 3.6 & 29.9 & 1.7 & 17.8 & 4.1 & 30.9 \\
\hline 85 & GS & 0.9 & 3.0 & 2.2 & 8.4 & 3.1 & 11.4 & 4.7 & 18.4 & 2.5 & 10.0 & 5.6 & 21.4 \\
\hline 86 & WF & 1.6 & 0.0 & 2.0 & 10.6 & 3.6 & 10.6 & 3.5 & 19.1 & 1.5 & 8.5 & 5.1 & 19.1 \\
\hline 87 & GS & 1.1 & 6.0 & 3.4 & 4.4 & 4.5 & 10.4 & 6.5 & 25.1 & 3.1 & 20.7 & 7.6 & 31.1 \\
\hline 88 & GS & 0.5 & 2.0 & 1.8 & 5.5 & 2.3 & 7.5 & 3.7 & 24.7 & 1.9 & 19.2 & 4.2 & 26.7 \\
\hline 89 & GS & 0.5 & -2.0 & 1.7 & 14.8 & 2.2 & 12.8 & 4.1 & 30.5 & 2.4 & 15.7 & 4.6 & 28.5 \\
\hline 90 & GS & 0.1 & 7.0 & 2.1 & 1.4 & 2.2 & 8.4 & 4.5 & 17.5 & 2.4 & 16.1 & 4.6 & 24.5 \\
\hline 91 & WF & 1.2 & 1.0 & 1.7 & 7.7 & 2.9 & 8.7 & 3.0 & 17.4 & 1.3 & 9.7 & 4.2 & 18.4 \\
\hline 92 & GS & 1.7 & 5.0 & 3.4 & 13.2 & 5.1 & 18.2 & 7.0 & 30.3 & 3.6 & 17.1 & 8.7 & 35.3 \\
\hline 93 & GS & 2.3 & 7.0 & 2.9 & 5.4 & 5.2 & 12.4 & 5.2 & 22.3 & 2.3 & 16.9 & 7.5 & 29.3 \\
\hline AVG. & & 1.0 & 2.7 & 2.2 & 8.2 & 3.2 & 10.9 & 4.5 & 22.8 & 2.3 & 14.5 & 5.5 & 25.5 \\
\hline Tree & 82 & Dead/N & sing il & 994 & & & & & & & & & \\
\hline Tree & 86 & Raptor & est in 2 & & & & & & & & & & \\
\hline
\end{tabular}


MHDSF Young-Growth Giant Sequoia Management Strategies Study 2009 - Overstory Summary Data (39ft. (12m) Plot)

$\begin{array}{llll}\text { Stand: Tub Flats } & \text { Treatment: Control } & \text { Measured By: } & 1990 \text { Scott, Johannis } \\ & & \text { Measured By: } & 1994 \text { Gasser, CDF } \\ \text { Block: C } & \text { Plot \#: } 1 & \text { Measured By: } & 2001 \text { Roller, Reuter } \\ & & \text { Measured By: } & 2009 \text { Soderlund, Estrada }\end{array}$

\begin{tabular}{|c|c|c|c|c|c|c|c|c|c|}
\hline \multirow[b]{2}{*}{ Tree \# } & \multirow[b]{2}{*}{ Species } & \multicolumn{2}{|c|}{1989 Data } & \multicolumn{2}{|c|}{1994 Data } & \multicolumn{2}{|c|}{2001 Data } & \multicolumn{2}{|c|}{2009 Data } \\
\hline & & $\mathrm{DBH}$ & Height & $\mathrm{DBH}$ & Height & $\mathrm{DBH}$ & Height & $\mathrm{DBH}$ & Height \\
\hline 1 & WF & 11.3 & 49.0 & 12.2 & 56.0 & 13.6 & 70.6 & 15.1 & 85.9 \\
\hline 2 & WF & 6.2 & 19.0 & 6.6 & 24.0 & 6.9 & 18.6 & 7.4 & 24.2 \\
\hline 3 & GS & 15.1 & 73.0 & 15.7 & 71.0 & 17.9 & 81.0 & 19.5 & 93.6 \\
\hline 4 & GS & 9.3 & 60.0 & 9.8 & 65.0 & $* * *$ & $* * *$ & 9.6 & $* * *$ \\
\hline 5 & GS & 14.5 & 69.0 & 16.0 & 72.0 & 17.9 & 88.0 & 20.1 & 95.7 \\
\hline 6 & GS & 11.5 & 64.0 & 12.2 & 64.0 & 13.4 & 70.3 & 14.7 & 80.1 \\
\hline 7 & GS & 10.5 & 58.0 & 10.7 & 61.0 & 11.1 & 65.9 & 11.4 & 72.7 \\
\hline 8 & GS & 11.6 & 60.0 & 12.3 & 64.0 & 13.4 & 74.1 & 14.4 & 83.2 \\
\hline 9 & GS & 1.6 & 8.0 & 1.5 & 7.0 & 1.6 & 7.7 & 2.7 & 8.3 \\
\hline 10 & GS & 11.2 & 64.0 & 11.7 & 71.0 & 12.5 & 76.0 & 13.3 & 86.3 \\
\hline 11 & GS & 16.3 & 83.0 & 17.0 & 90.0 & 18.6 & 91.5 & 20.6 & 108.3 \\
\hline 12 & WF & 14.8 & 85.0 & 15.9 & 95.0 & 17.4 & 109.8 & 18.6 & 110.3 \\
\hline 13 & GS & 14.2 & 75.0 & 15.2 & 77.0 & 17.4 & 89.5 & 19.2 & 98.1 \\
\hline 14 & WF & 9.0 & 53.0 & 9.3 & 66.0 & 9.8 & 55.5 & 10.1 & 59.4 \\
\hline 15 & GS & 16.3 & 71.0 & 17.0 & 72.0 & 18.7 & 82.7 & 20.8 & 96.8 \\
\hline 16 & GS & 10.5 & 70.0 & 11.1 & 72.0 & 11.6 & 84.9 & 12.0 & 88.4 \\
\hline 17 & WF & 15.3 & 77.0 & 16.5 & 84.0 & 18.4 & 90.9 & 20.2 & 100.8 \\
\hline 18 & WF & 12.0 & 63.0 & 12.5 & 65.0 & 13.0 & 48.7 & 13.3 & 64.3 \\
\hline 19 & WF & 23.5 & 103.0 & 24.3 & 105.0 & $* * *$ & $* * *$ & $* * *$ & $* * *$ \\
\hline 20 & GS & 10.6 & 68.0 & 11.3 & 72.0 & 12.2 & 75.0 & 13.0 & 84.7 \\
\hline 21 & GS & 14.3 & 83.0 & 15.3 & 94.0 & 16.9 & 104.7 & 18.4 & 97.2 \\
\hline 22 & GS & 12.2 & 58.0 & 12.8 & 58.0 & 14.0 & 62.2 & 15.4 & 71.8 \\
\hline 23 & GS & 19.4 & 77.0 & 20.2 & 76.0 & 22.1 & 92.0 & 23.9 & 103.2 \\
\hline 24 & GS & 10.8 & 69.0 & 11.4 & 71.0 & 12.1 & 84.9 & 13.0 & 87.7 \\
\hline 25 & GS & 12.3 & 71.0 & 12.9 & 76.0 & 14.2 & 83.6 & 15.1 & 89.6 \\
\hline 26 & GS & 3.2 & 15.0 & 3.3 & 13.0 & 3.3 & 13.0 & 3.4 & 14.0 \\
\hline 27 & GS & 5.4 & 19.0 & 5.1 & 22.0 & 5.2 & 21.5 & 5.2 & 21.6 \\
\hline 28 & GS & 1.9 & 10.0 & 1.4 & 9.0 & $* * *$ & $* * *$ & 1.4 & $* * *$ \\
\hline 29 & GS & 12.9 & 64.0 & 13.4 & 59.0 & 14.1 & 79.6 & 14.7 & 83.1 \\
\hline 30 & GS & 0.9 & 7.0 & 1.0 & 6.0 & 1.0 & 6.6 & 1.0 & 6.9 \\
\hline 31 & GS & 11.2 & 69.0 & 11.5 & 67.0 & 12.5 & 75.9 & 13.4 & 79.8 \\
\hline 32 & GS & 11.1 & 68.0 & 11.7 & 63.0 & 12.7 & 78.9 & 13.5 & 79.8 \\
\hline 33 & WF & 3.4 & 19.0 & 3.6 & 17.0 & 4.1 & 18.8 & 4.5 & 21.2 \\
\hline 34 & GS & 18.1 & 75.0 & 18.9 & 65.0 & 20.8 & 85.5 & 22.5 & 94.9 \\
\hline 35 & GS & 12.0 & 67.0 & 12.4 & 76.0 & 13.2 & 76.0 & 14.0 & 81.3 \\
\hline 36 & GS & 14.3 & 72.0 & 14.9 & 68.0 & 15.8 & 75.2 & 16.8 & 87.7 \\
\hline 37 & GS & 4.4 & 25.0 & 4.5 & 24.0 & 4.6 & 21.9 & 4.7 & 20.5 \\
\hline 38 & GS & 15.1 & 75.0 & 15.5 & 78.0 & 17.0 & 78.3 & 18.4 & 88.7 \\
\hline 39 & GS & 10.7 & 65.0 & 10.9 & 71.0 & 11.3 & 70.5 & 11.6 & 76.8 \\
\hline 40 & GS & 10.5 & 77.0 & 11.1 & 70.0 & 11.7 & 80.2 & 12.5 & 88.2 \\
\hline 41 & GS & 5.6 & 36.0 & 5.5 & 35.0 & 5.5 & 35.4 & 5.6 & 34.4 \\
\hline 42 & GS & 9.9 & 41.0 & 10.0 & 47.0 & 10.5 & 47.6 & 11.0 & 53.3 \\
\hline 43 & GS & 8.6 & 48.0 & 9.1 & 56.0 & 9.7 & 65.3 & 10.5 & 72.4 \\
\hline 44 & GS & 5.6 & 33.0 & 5.8 & 38.0 & 5.9 & 31.5 & 6.0 & 32.5 \\
\hline
\end{tabular}


MHDSF Young-Growth Giant Sequoia Management Strategies Study 2009 - Overstory Summary Data (39ft. (12m) Plot)

$\begin{array}{lllll}\text { Stand: Tub Flats } & \text { Treatment: Control } & \text { Measured By: } & 1990 & \text { Scott, Johannis } \\ & & \text { Measured By: } & 1994 & \text { Gasser, CDF } \\ \text { Block: C } & \text { Plot \#: } 1 & \text { Measured By: } & 2001 & \text { Roller, Reuter } \\ & & \text { Measured By: } & 2009 & \text { Soderlund, Estrada }\end{array}$

\begin{tabular}{cc|cc|cc|cc|cc|}
\cline { 3 - 10 } Tree \# & Species & DBH & Height & DBH & Height & DBH & Height & DBH & Height \\
\hline \hline 45 & GS & 3.4 & 10.0 & 3.3 & 8.0 & 3.4 & $* * *$ & 3.3 & $* * *$ \\
46 & GS & 10.9 & 67.0 & 11.4 & 78.0 & 12.4 & 82.9 & 13.4 & 86.5 \\
47 & GS & 15.4 & 68.0 & 16.0 & 69.0 & 17.5 & 77.4 & 18.9 & 85.9 \\
48 & GS & 15.4 & 72.0 & 15.8 & 74.0 & 17.3 & 79.8 & 18.8 & 92.3 \\
49 & GS & 2.0 & 10.0 & 2.0 & 10.0 & 2.0 & $* * *$ & 1.9 & $* * *$ \\
50 & GS & 8.0 & 26.0 & 8.0 & 26.0 & 8.5 & 28.5 & 8.7 & 26.3 \\
51 & GS & 1.7 & 9.0 & 1.8 & 9.0 & 1.9 & $* * *$ & 1.8 & 6.1 \\
52 & GS & 10.2 & 61.0 & 10.6 & 67.0 & 11.4 & 69.7 & 12.3 & 80.8 \\
53 & GS & 4.4 & 16.0 & 4.7 & 14.0 & 5.0 & 18.6 & 5.5 & 21.2 \\
54 & GS & 3.7 & 15.0 & 3.9 & 12.0 & 4.0 & 15.2 & 4.2 & 15.3 \\
55 & GS & 1.5 & 7.0 & 1.6 & 7.0 & 1.7 & 7.6 & 1.7 & 6.9 \\
56 & GS & 11.5 & 65.0 & 12.1 & 77.0 & 12.8 & 70.5 & 13.7 & 77.9 \\
57 & GS & 7.0 & 24.0 & 7.0 & 16.0 & 7.3 & 21.3 & 7.4 & 22.7 \\
58 & GS & 7.9 & 41.0 & 8.4 & 46.0 & 9.0 & 48.0 & 9.6 & 56.5 \\
59 & GS & 6.0 & 34.0 & 6.2 & 39.0 & 6.7 & 41.5 & 7.0 & 35.4 \\
60 & GS & 2.3 & 8.0 & 2.3 & 8.0 & 2.4 & 8.4 & 2.4 & 8.0 \\
61 & GS & 3.4 & 14.0 & 3.2 & 11.0 & 3.3 & 12.5 & 3.4 & 11.5 \\
62 & GS & 4.6 & 19.0 & 4.8 & 21.0 & 4.9 & 24.6 & 5.0 & 22.5 \\
63 & GS & 6.4 & 30.0 & 6.7 & 30.0 & 6.9 & 34.0 & 7.0 & 29.4 \\
64 & WF & 2.6 & 12.0 & 3.0 & 13.0 & 3.4 & 17.9 & 3.8 & 19.9 \\
\hline \hline AVG. & & 9.5 & 48.8 & 9.9 & 50.7 & 10.6 & 57.4 & 11.1 & 61.6
\end{tabular}

$\begin{array}{ccl}\text { Trees } & 2,45,49,51 & \text { Deformed/Bowed in 2001,2009 } \\ \text { Trees } & 4,28 & \text { Dead/Standing in 2001 } \\ \text { Tree } & 18 & \text { Broken Top in 2001 } \\ \text { Tree } & 19 & \text { Dead/Down in 2001 } \\ \text { Trees } & 9,30,60 & \text { Dead top in 2009 } \\ \text { Trees } & 45,49 & \text { Dead/Standing in 2009 } \\ \text { Tree } & 21 & \text { Broken Top in 2009 }\end{array}$


MHDSF Young-Growth Giant Sequoia Management Strategies Study

2009 - Overstory Summary Growth Data (39ft. (12m) Plot)

$\begin{array}{lllll}\text { Stand: Tub Flats } & \text { Treatment: Control } & \text { Measured By: } & 1990 & \text { Scott, Johannis } \\ & & \text { Measured By: } & 1994 & \text { Gasser, CDF } \\ \text { Block: C } & \text { Plot \#: } 1 & \text { Measured By: } & 2001 \text { Roller, Reuter } \\ & & \text { Measured By: } & 2009 \text { Soderlund, Estrada }\end{array}$

\begin{tabular}{|c|c|c|c|c|c|c|c|c|c|c|c|c|c|}
\hline \multirow[b]{2}{*}{ Tree \# } & \multirow[b]{2}{*}{ Species } & \multicolumn{2}{|c|}{$\begin{array}{c}\text { Change } \\
\text { 1989-1994 }\end{array}$} & \multicolumn{2}{|c|}{$\begin{array}{c}\text { Change } \\
\text { 1994-2001 }\end{array}$} & \multicolumn{2}{|c|}{$\begin{array}{c}\text { Change } \\
\text { 1989-2001 }\end{array}$} & \multicolumn{2}{|c|}{$\begin{array}{c}\text { Change } \\
\text { 1994-2009 }\end{array}$} & \multicolumn{2}{|c|}{$\begin{array}{c}\text { Change } \\
\text { 2001-2009 }\end{array}$} & \multicolumn{2}{|c|}{$\begin{array}{c}\text { Change } \\
\text { 1989-2009 }\end{array}$} \\
\hline & & DBH & Height & DBH & Height & DBH & Height & DBH & Height & DBH & Height & DBH & Height \\
\hline 1 & WF & 0.9 & 7.0 & 1.4 & 14.6 & 2.3 & 21.6 & 2.9 & 29.9 & 1.5 & 15.3 & 3.8 & 36.9 \\
\hline 2 & WF & 0.4 & 5.0 & 0.3 & -5.4 & 0.7 & -0.4 & 0.8 & 0.2 & 0.5 & 5.6 & 1.2 & 5.2 \\
\hline 3 & GS & 0.6 & -2.0 & 2.2 & 10.0 & 2.8 & 8.0 & 3.8 & 22.6 & 1.6 & 12.6 & 4.4 & 20.6 \\
\hline 4 & GS & 0.5 & 5.0 & $* * *$ & $* * *$ & $* * *$ & $* * *$ & -0.2 & $* * *$ & $* * *$ & $* * *$ & 0.3 & $* * *$ \\
\hline 5 & GS & 1.5 & 3.0 & 1.9 & 16.0 & 3.4 & 19.0 & 4.1 & 23.7 & 2.2 & 7.7 & 5.6 & 26.7 \\
\hline 6 & GS & 0.7 & 0.0 & 1.2 & 6.3 & 1.9 & 6.3 & 2.5 & 16.1 & 1.3 & 9.8 & 3.2 & 16.1 \\
\hline 7 & GS & 0.2 & 3.0 & 0.4 & 4.9 & 0.6 & 7.9 & 0.7 & 11.7 & 0.3 & 6.8 & 0.9 & 14.7 \\
\hline 8 & GS & 0.7 & 4.0 & 1.1 & 10.1 & 1.8 & 14.1 & 2.1 & 19.2 & 1.0 & 9.1 & 2.8 & 23.2 \\
\hline 9 & GS & -0.1 & -1.0 & 0.1 & 0.7 & 0.0 & -0.3 & 1.2 & 1.3 & 1.1 & 0.6 & 1.1 & 0.3 \\
\hline 10 & GS & 0.5 & 7.0 & 0.8 & 5.0 & 1.3 & 12.0 & 1.6 & 15.3 & 0.8 & 10.3 & 2.1 & 22.3 \\
\hline 11 & GS & 0.7 & 7.0 & 1.6 & 1.5 & 2.3 & 8.5 & 3.6 & 18.3 & 2.0 & 16.8 & 4.3 & 25.3 \\
\hline 12 & WF & 1.1 & 10.0 & 1.5 & 14.8 & 2.6 & 24.8 & 2.7 & 15.3 & 1.2 & 0.5 & 3.8 & 25.3 \\
\hline 13 & GS & 1.0 & 2.0 & 2.2 & 12.5 & 3.2 & 14.5 & 4.0 & 21.1 & 1.8 & 8.6 & 5.0 & 23.1 \\
\hline 14 & WF & 0.3 & 13.0 & 0.5 & -10.5 & 0.8 & 2.5 & 0.8 & -6.6 & 0.3 & 3.9 & 1.1 & 6.4 \\
\hline 15 & GS & 0.7 & 1.0 & 1.7 & 10.7 & 2.4 & 11.7 & 3.8 & 24.8 & 2.1 & 14.1 & 4.5 & 25.8 \\
\hline 16 & GS & 0.6 & 2.0 & 0.5 & 12.9 & 1.1 & 14.9 & 0.9 & 16.4 & 0.4 & 3.5 & 1.5 & 18.4 \\
\hline 17 & WF & 1.2 & 7.0 & 1.9 & 6.9 & 3.1 & 13.9 & 3.7 & 16.8 & 1.8 & 9.9 & 4.9 & 23.8 \\
\hline 18 & WF & 0.5 & 2.0 & 0.5 & -16.3 & 1.0 & -14.3 & 0.8 & -0.7 & 0.3 & 15.6 & 1.3 & 1.3 \\
\hline 19 & WF & 0.8 & 2.0 & $* * *$ & $* * *$ & $* * *$ & $* * *$ & $* * *$ & $* * *$ & $* * *$ & $* * *$ & $* * *$ & $* * *$ \\
\hline 20 & GS & 0.7 & 4.0 & 0.9 & 3.0 & 1.6 & 7.0 & 1.7 & 12.7 & 0.8 & 9.7 & 2.4 & 16.7 \\
\hline 21 & GS & 1.0 & 11.0 & 1.6 & 10.7 & 2.6 & 21.7 & 3.1 & 3.2 & 1.5 & -7.5 & 4.1 & 14.2 \\
\hline 22 & GS & 0.6 & 0.0 & 1.2 & 4.2 & 1.8 & 4.2 & 2.6 & 13.8 & 1.4 & 9.6 & 3.2 & 13.8 \\
\hline 23 & GS & 0.8 & -1.0 & 1.9 & 16.0 & 2.7 & 15.0 & 3.7 & 27.2 & 1.8 & 11.2 & 4.5 & 26.2 \\
\hline 24 & GS & 0.6 & 2.0 & 0.7 & 13.9 & 1.3 & 15.9 & 1.6 & 16.7 & 0.9 & 2.8 & 2.2 & 18.7 \\
\hline 25 & GS & 0.6 & 5.0 & 1.3 & 7.6 & 1.9 & 12.6 & 2.2 & 13.6 & 0.9 & 6.0 & 2.8 & 18.6 \\
\hline 26 & GS & 0.1 & -2.0 & 0.0 & 0.0 & 0.1 & -2.0 & 0.1 & 1.0 & 0.1 & 1.0 & 0.2 & -1.0 \\
\hline 27 & GS & -0.3 & 3.0 & 0.1 & -0.5 & -0.2 & 2.5 & 0.1 & -0.4 & 0.0 & 0.1 & -0.2 & 2.6 \\
\hline 28 & GS & -0.5 & -1.0 & $* * *$ & $* * *$ & $* * *$ & $* * *$ & 0.0 & $* * *$ & $* * *$ & $* * *$ & -0.5 & $* * *$ \\
\hline 29 & GS & 0.5 & -5.0 & 0.7 & 20.6 & 1.2 & 15.6 & 1.3 & 24.1 & 0.6 & 3.5 & 1.8 & 19.1 \\
\hline 30 & GS & 0.1 & -1.0 & 0.0 & 0.6 & 0.1 & -0.4 & 0.0 & 0.9 & 0.0 & 0.3 & 0.1 & -0.1 \\
\hline 31 & GS & 0.3 & -2.0 & 1.0 & 8.9 & 1.3 & 6.9 & 1.9 & 12.8 & 0.9 & 3.9 & 2.2 & 10.8 \\
\hline 32 & GS & 0.6 & -5.0 & 1.0 & 15.9 & 1.6 & 10.9 & 1.8 & 16.8 & 0.8 & 0.9 & 2.4 & 11.8 \\
\hline 33 & WF & 0.2 & -2.0 & 0.5 & 1.8 & 0.7 & -0.2 & 0.9 & 4.2 & 0.4 & 2.4 & 1.1 & 2.2 \\
\hline 34 & GS & 0.8 & -10.0 & 1.9 & 20.5 & 2.7 & 10.5 & 3.6 & 29.9 & 1.7 & 9.4 & 4.4 & 19.9 \\
\hline 35 & GS & 0.4 & 9.0 & 0.8 & 0.0 & 1.2 & 9.0 & 1.6 & 5.3 & 0.8 & 5.3 & 2.0 & 14.3 \\
\hline 36 & GS & 0.6 & -4.0 & 0.9 & 7.2 & 1.5 & 3.2 & 1.9 & 19.7 & 1.0 & 12.5 & 2.5 & 15.7 \\
\hline 37 & GS & 0.1 & -1.0 & 0.1 & -2.1 & 0.2 & -3.1 & 0.2 & -3.5 & 0.1 & -1.4 & 0.3 & -4.5 \\
\hline 38 & GS & 0.4 & 3.0 & 1.5 & 0.3 & 1.9 & 3.3 & 2.9 & 10.7 & 1.4 & 10.4 & 3.3 & 13.7 \\
\hline 39 & GS & 0.2 & 6.0 & 0.4 & -0.5 & 0.6 & 5.5 & 0.7 & 5.8 & 0.3 & 6.3 & 0.9 & 11.8 \\
\hline 40 & GS & 0.6 & -7.0 & 0.6 & 10.2 & 1.2 & 3.2 & 1.4 & 18.2 & 0.8 & 8.0 & 2.0 & 11.2 \\
\hline 41 & GS & -0.1 & -1.0 & 0.0 & 0.4 & -0.1 & -0.6 & 0.1 & -0.6 & 0.1 & -1.0 & 0.0 & -1.6 \\
\hline 42 & GS & 0.1 & 6.0 & 0.5 & 0.6 & 0.6 & 6.6 & 1.0 & 6.3 & 0.5 & 5.7 & 1.1 & 12.3 \\
\hline 43 & GS & 0.5 & 8.0 & 0.6 & 9.3 & 1.1 & 17.3 & 1.4 & 16.4 & 0.8 & 7.1 & 1.9 & 24.4 \\
\hline 44 & GS & 0.2 & 5.0 & 0.1 & -6.5 & 0.3 & -1.5 & 0.2 & -5.5 & 0.1 & 1.0 & 0.4 & -0.5 \\
\hline
\end{tabular}

Page 173 


$\begin{array}{lllll}\text { Stand: Tub Flats } & \text { Treatment: Control } & \text { Measured By: } & 1990 & \text { Scott, Johannis } \\ & & \text { Measured By: } & 1994 & \text { Gasser, CDF } \\ \text { Block: C } & \text { Plot \#: } 1 & \text { Measured By: } & 2001 \text { Roller, Reuter } \\ & & \text { Measured By: } & 2009 \text { Soderlund, Estrada }\end{array}$

\begin{tabular}{|c|c|c|c|c|c|c|c|c|c|c|c|c|c|}
\hline \multirow[b]{2}{*}{ Tree \# } & \multirow[b]{2}{*}{ Species } & \multicolumn{2}{|c|}{$\begin{array}{c}\text { Change } \\
\text { 1989-1994 }\end{array}$} & \multicolumn{2}{|c|}{$\begin{array}{c}\text { Change } \\
1994-2001\end{array}$} & \multicolumn{2}{|c|}{$\begin{array}{c}\text { Change } \\
\text { 1989-2001 }\end{array}$} & \multicolumn{2}{|c|}{$\begin{array}{c}\text { Change } \\
\text { 1994-2009 }\end{array}$} & \multicolumn{2}{|c|}{$\begin{array}{c}\text { Change } \\
\text { 2001-2009 }\end{array}$} & \multicolumn{2}{|c|}{$\begin{array}{c}\text { Change } \\
\text { 1989-2009 }\end{array}$} \\
\hline & & $\mathrm{DBH}$ & Height & DBH & Height & DBH & Height & DBH & Height & DBH & Height & DBH & Height \\
\hline 245 & GS & $\begin{array}{c}-0.1 \\
\end{array}$ & $\begin{array}{l}-2.0 \\
\end{array}$ & ב 0.1 & " & $\begin{array}{c}0.0 \\
\end{array}$ & " & $\begin{array}{c}0.0 \\
\end{array}$ & " & $\begin{array}{c}-0.1 \\
\end{array}$ & " & " & " \\
\hline 46 & GS & 0.5 & 11.0 & 1.0 & 4.9 & 1.5 & 15.9 & 2.0 & 8.5 & 1.0 & 3.6 & 2.5 & 19.5 \\
\hline 47 & GS & 0.6 & 1.0 & 1.5 & 8.4 & 2.1 & 9.4 & 2.9 & 16.9 & 1.4 & 8.5 & 3.5 & 17.9 \\
\hline 48 & GS & 0.4 & 2.0 & 1.5 & 5.8 & 1.9 & 7.8 & 3.0 & 18.3 & 1.5 & 12.5 & 3.4 & 20.3 \\
\hline 49 & GS & 0.0 & 0.0 & 0.0 & $* * *$ & 0.0 & $* * *$ & -0.1 & $* * *$ & -0.1 & $* * *$ & -0.1 & $* * *$ \\
\hline 50 & GS & 0.0 & 0.0 & 0.5 & 2.5 & 0.5 & 2.5 & 0.7 & 0.3 & 0.2 & -2.2 & 0.7 & 0.3 \\
\hline 51 & GS & 0.1 & 0.0 & 0.1 & $* * *$ & 0.2 & $* * *$ & 0.0 & -2.9 & -0.1 & $* * *$ & 0.1 & -2.9 \\
\hline 52 & GS & 0.4 & 6.0 & 0.8 & 2.7 & 1.2 & 8.7 & 1.7 & 13.8 & 0.9 & 11.1 & 2.1 & 19.8 \\
\hline 53 & GS & 0.3 & -2.0 & 0.3 & 4.6 & 0.6 & 2.6 & 0.8 & 7.2 & 0.5 & 2.6 & 1.1 & 5.2 \\
\hline 54 & GS & 0.2 & -3.0 & 0.1 & 3.2 & 0.3 & 0.2 & 0.3 & 3.3 & 0.2 & 0.1 & 0.5 & 0.3 \\
\hline 55 & GS & 0.1 & 0.0 & 0.1 & 0.6 & 0.2 & 0.6 & 0.1 & -0.1 & 0.0 & -0.7 & 0.2 & -0.1 \\
\hline 56 & GS & 0.6 & 12.0 & 0.7 & -6.5 & 1.3 & 5.5 & 1.6 & 0.9 & 0.9 & 7.4 & 2.2 & 12.9 \\
\hline 57 & GS & 0.0 & -8.0 & 0.3 & 5.3 & 0.3 & -2.7 & 0.4 & 6.7 & 0.1 & 1.4 & 0.4 & -1.3 \\
\hline 58 & GS & 0.5 & 5.0 & 0.6 & 2.0 & 1.1 & 7.0 & 1.2 & 10.5 & 0.6 & 8.5 & 1.7 & 15.5 \\
\hline 59 & GS & 0.2 & 5.0 & 0.5 & 2.5 & 0.7 & 7.5 & 0.8 & -3.6 & 0.3 & -6.1 & 1.0 & 1.4 \\
\hline 60 & GS & 0.0 & 0.0 & 0.1 & 0.4 & 0.1 & 0.4 & 0.1 & 0.0 & 0.0 & -0.4 & 0.1 & 0.0 \\
\hline 61 & GS & -0.2 & -3.0 & 0.1 & 1.5 & -0.1 & -1.5 & 0.2 & 0.5 & 0.1 & -1.0 & 0.0 & -2.5 \\
\hline 62 & GS & 0.2 & 2.0 & 0.1 & 3.6 & 0.3 & 5.6 & 0.2 & 1.5 & 0.1 & -2.1 & 0.4 & 3.5 \\
\hline 63 & GS & 0.3 & 0.0 & 0.2 & 4.0 & 0.5 & 4.0 & 0.3 & -0.6 & 0.1 & -4.6 & 0.6 & -0.6 \\
\hline 64 & WF & 0.4 & 1.0 & 0.4 & 4.9 & 0.8 & 5.9 & 0.8 & 6.9 & 0.4 & 2.0 & 1.2 & 7.9 \\
\hline AVG. & & 0.4 & 1.9 & 0.8 & 5.0 & 1.2 & 7.0 & 120.7 & 9.9 & $\begin{array}{l}0.8 \\
\end{array}$ & 5.1 & 1.9 & 111.9 \\
\hline
\end{tabular}

$\begin{array}{ccl}\text { Trees } & 2,45,49,51 & \text { Deformed/Bowed in 2001,2009 } \\ \text { Trees } & 4,28 & \text { Dead/Standing in 2001 } \\ \text { Tree } & 18 & \text { Broken Top in 2001 } \\ \text { Tree } & 19 & \text { Dead/Down in 2001 } \\ \text { Trees } & 9,30,60 & \text { Dead top in 2009 } \\ \text { Trees } & 45,49 & \text { Dead/Standing in 2009 } \\ \text { Tree } & 21 & \text { Broken Top in 2009 }\end{array}$




\section{APPENDIX B}

DBH Distribution Graphs/Stand Tables

Located in Supplementary Files

Page 175 
APPENDIX C

Understory Data

Page 176 


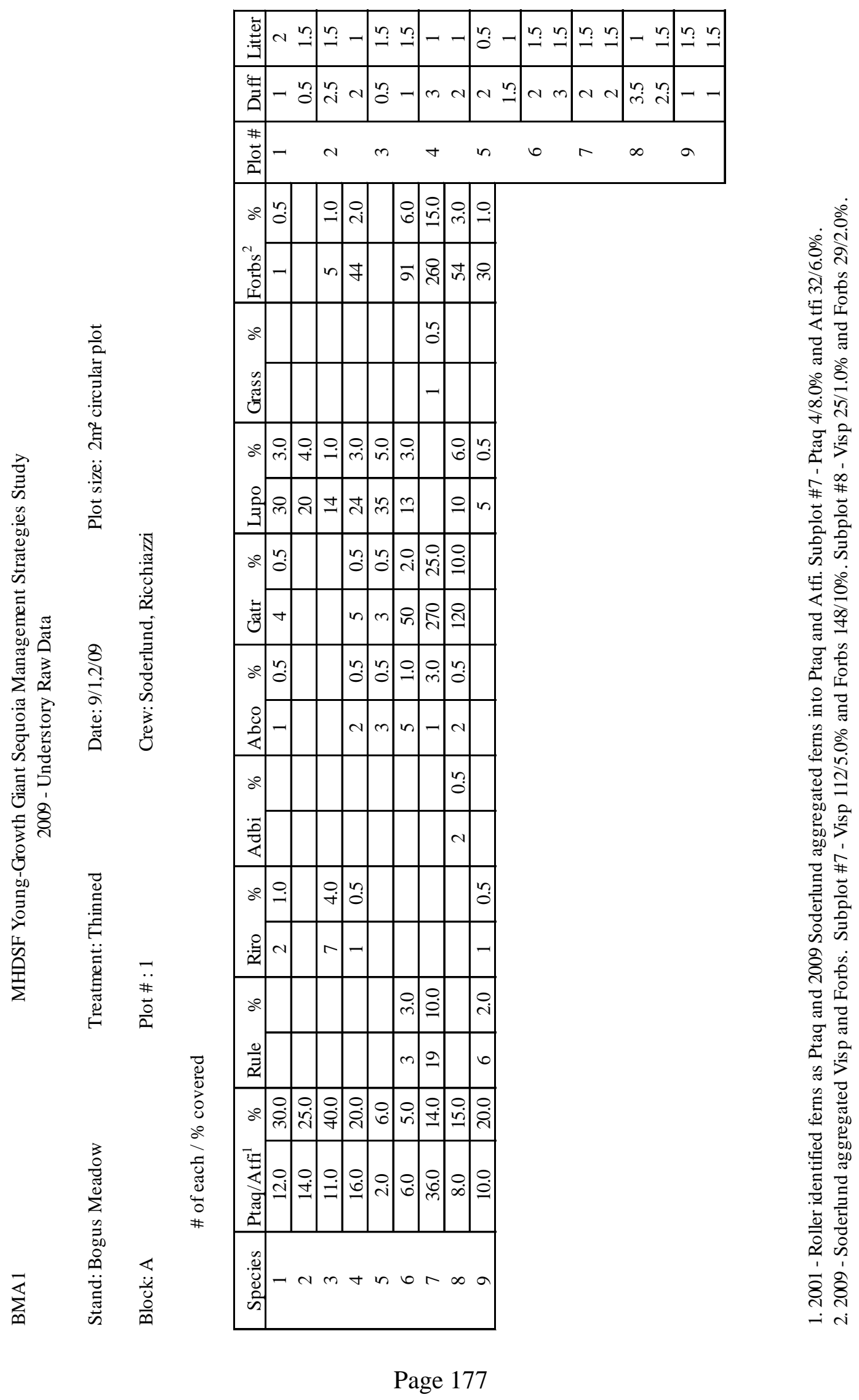




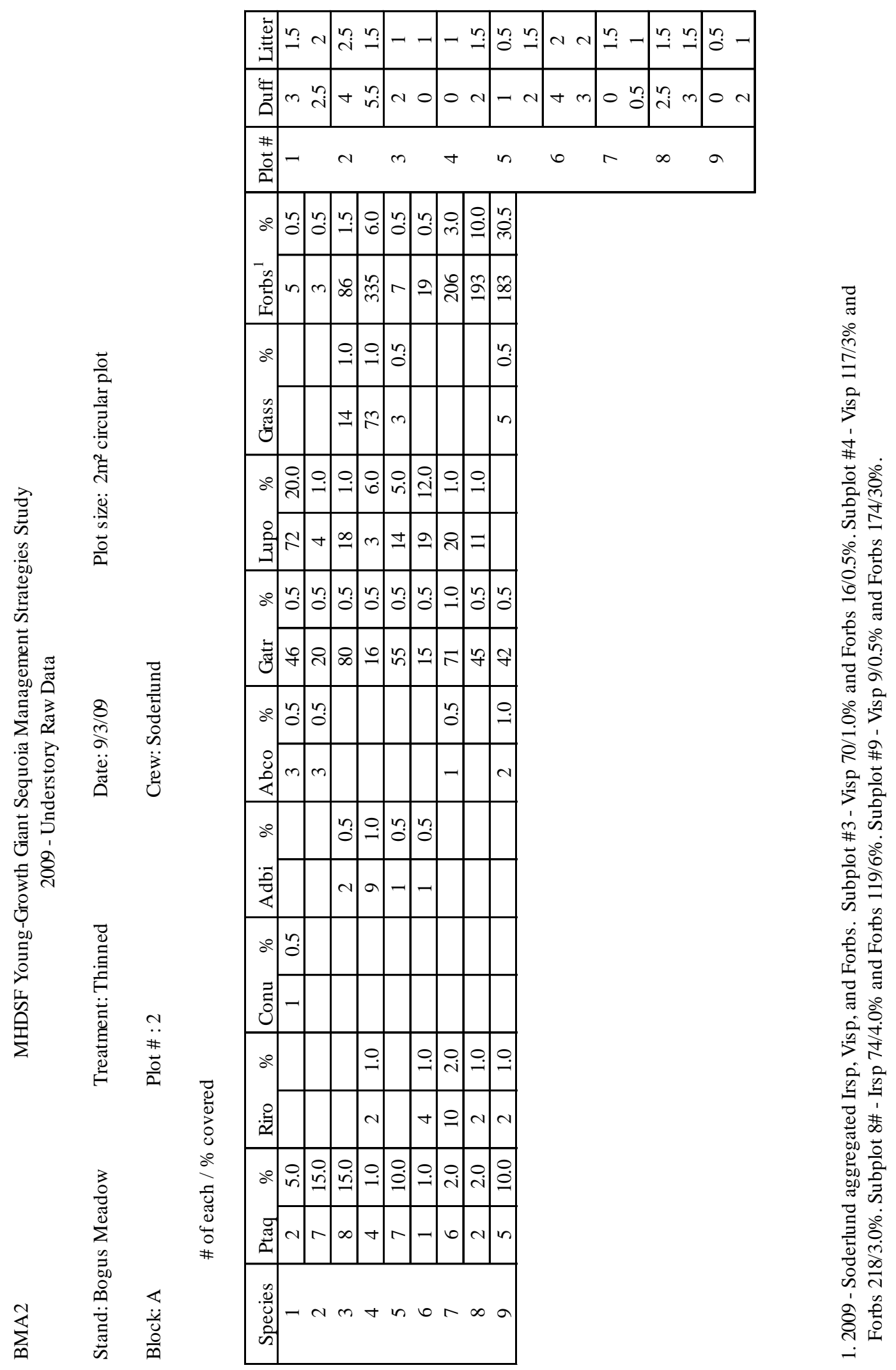

Page 178 


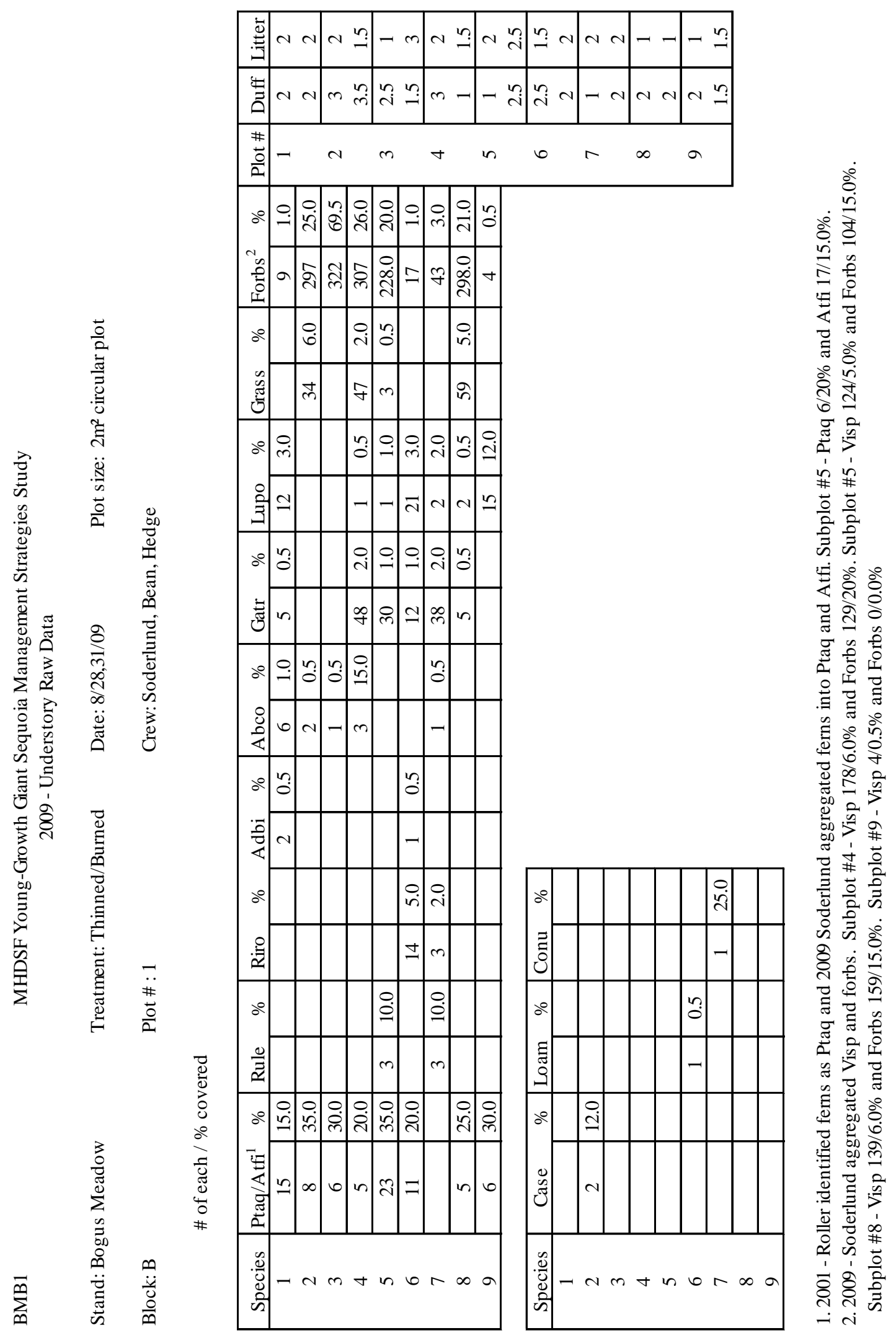

Page 179 


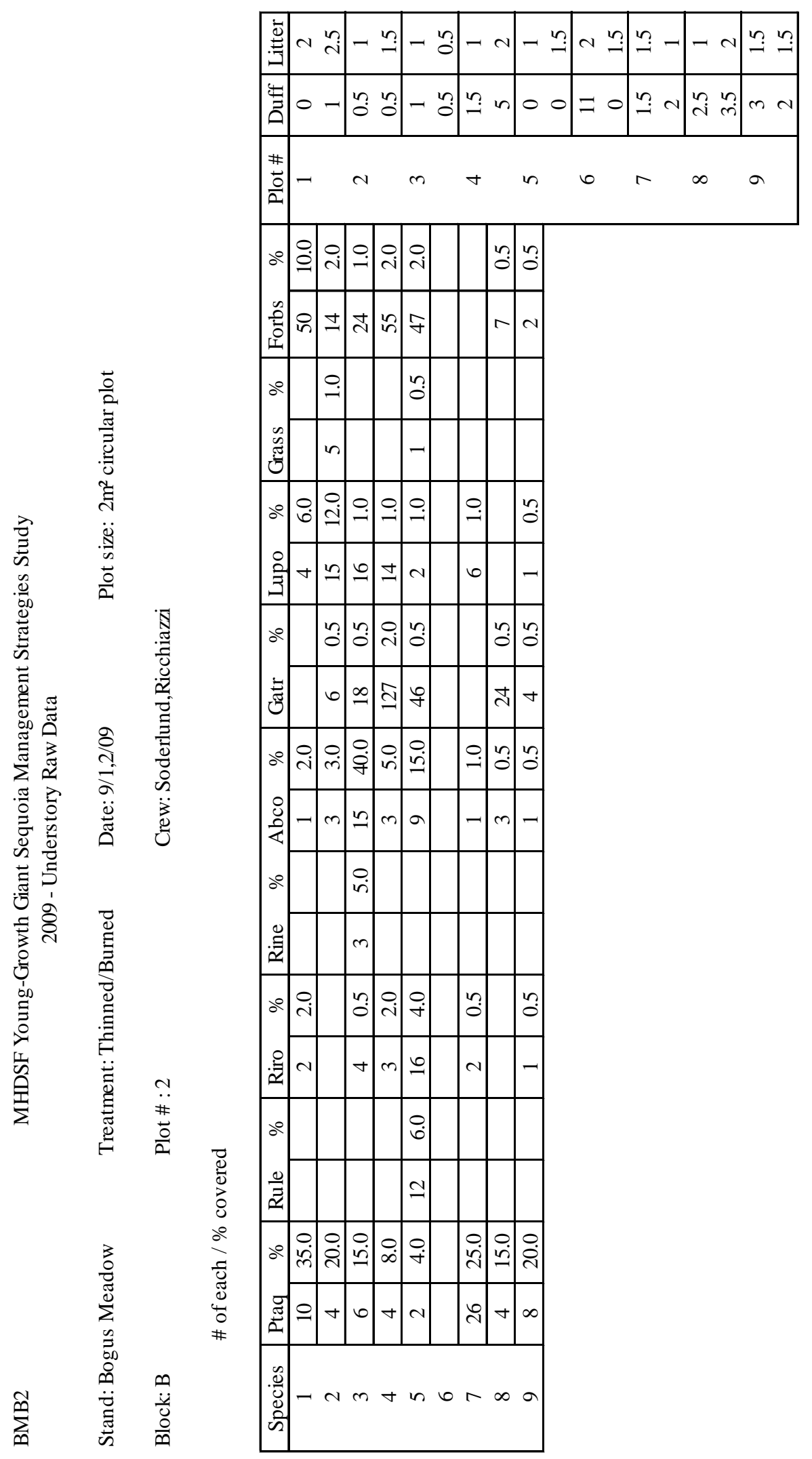

Page 180 


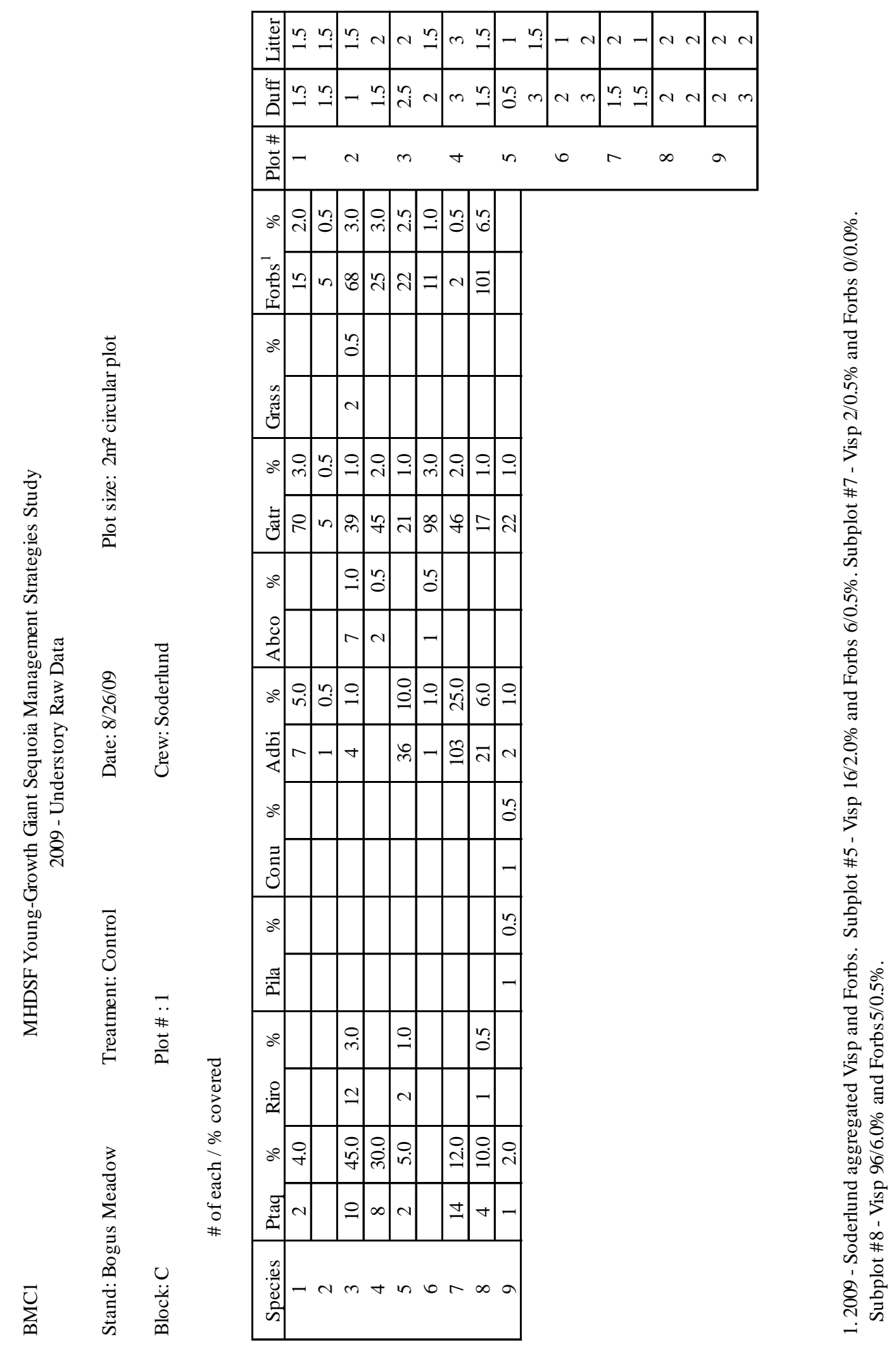

Page 181 


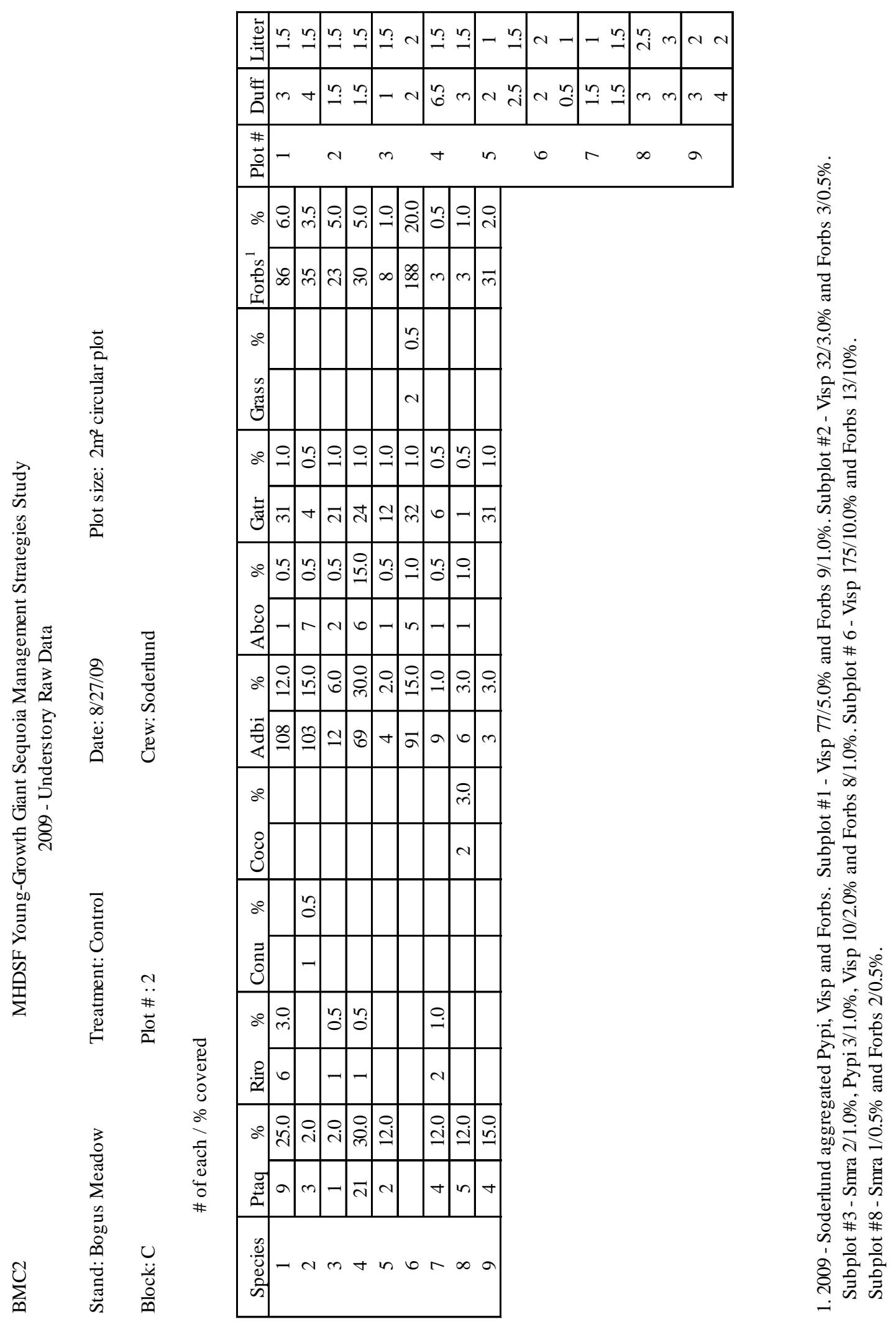

Page 182 


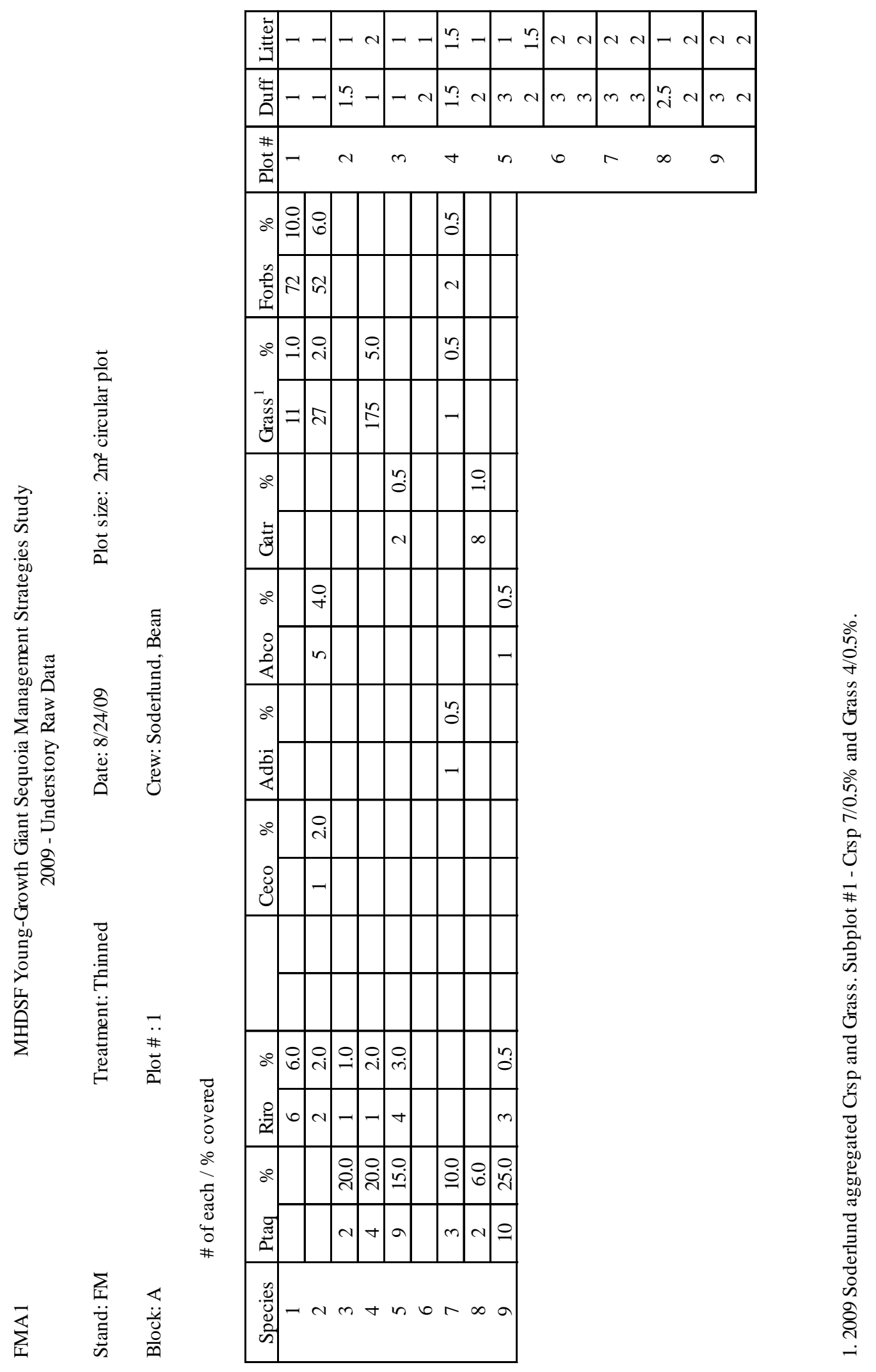

Page 183 


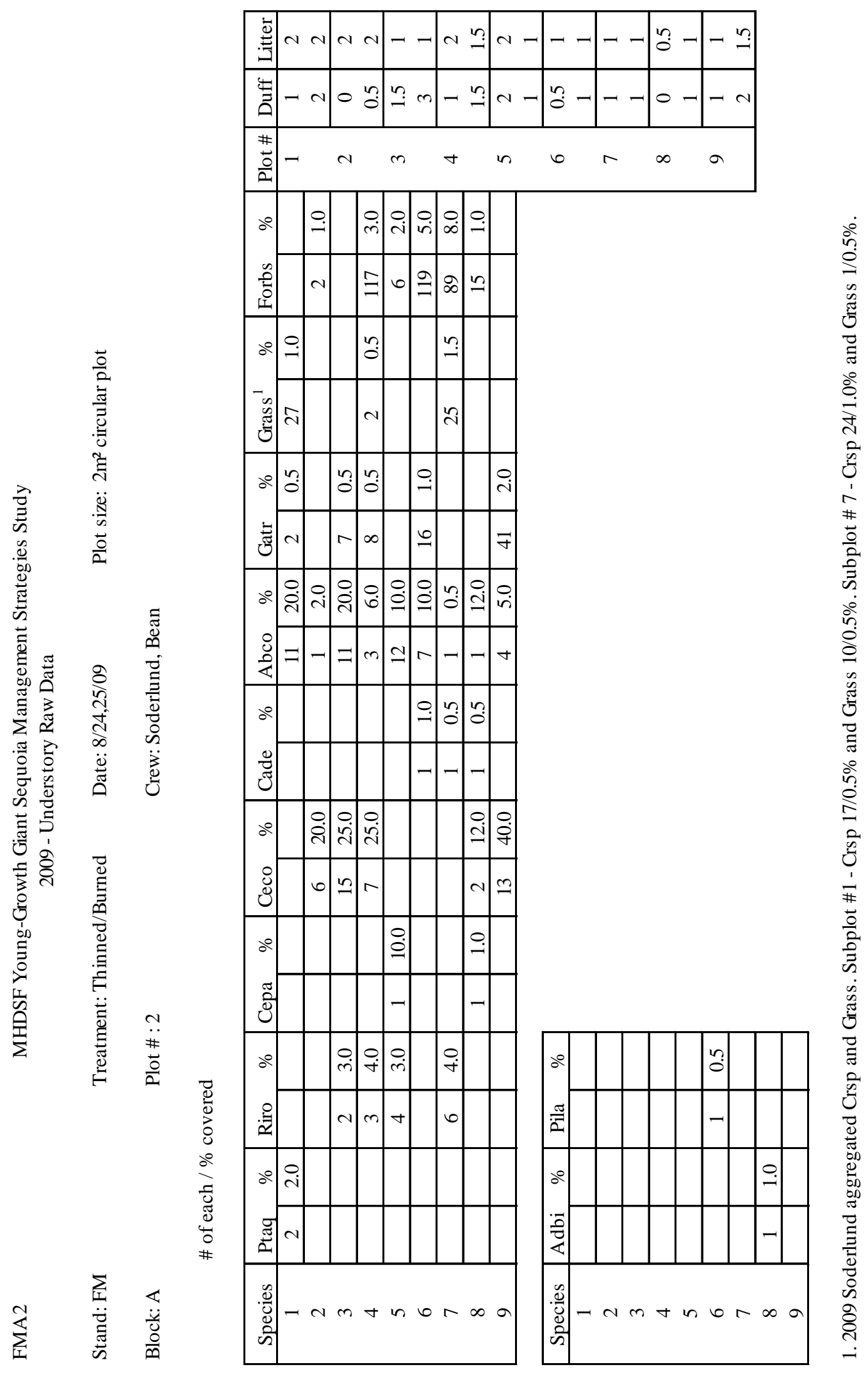

Page 184 


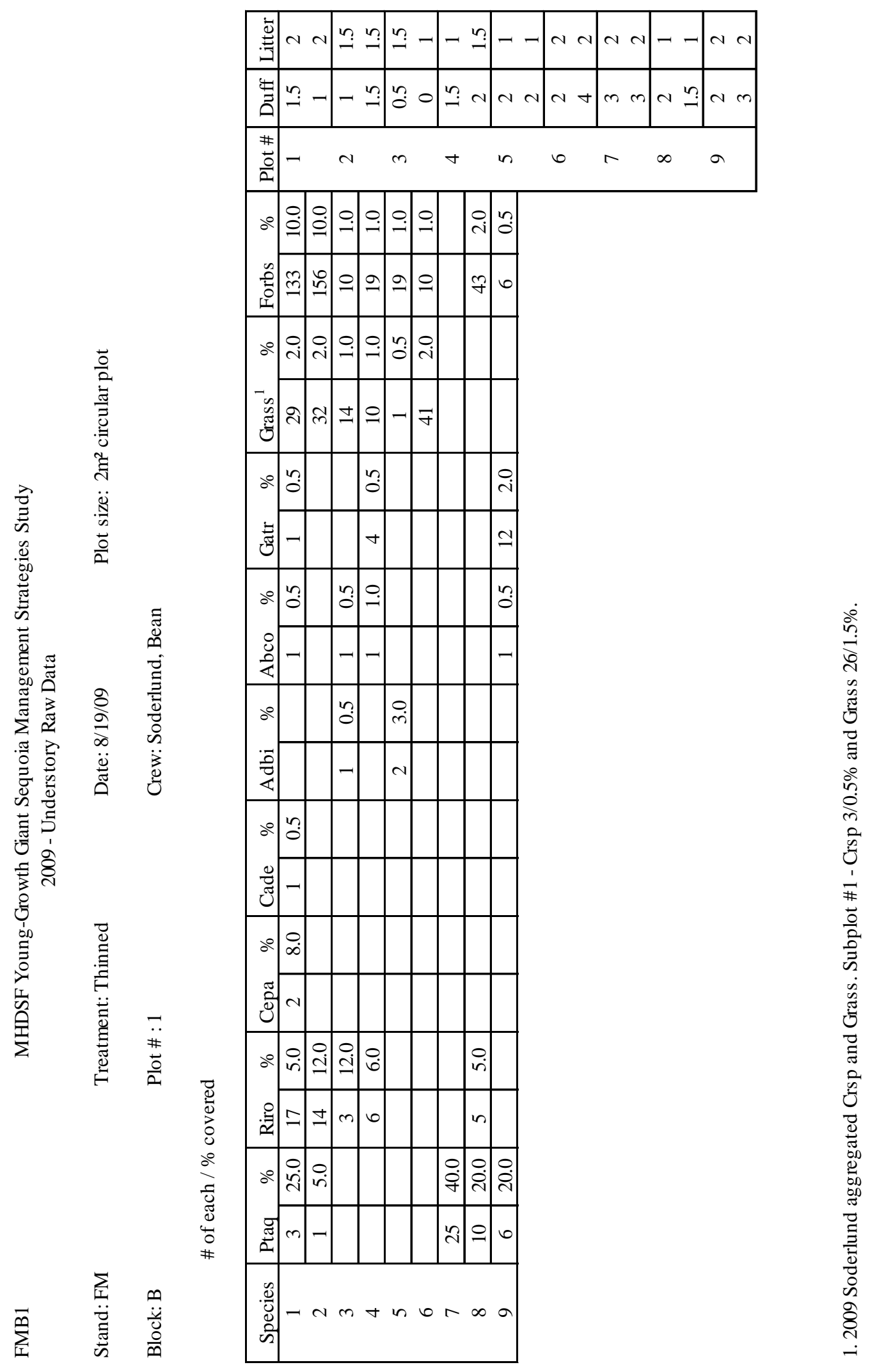

Page 185 


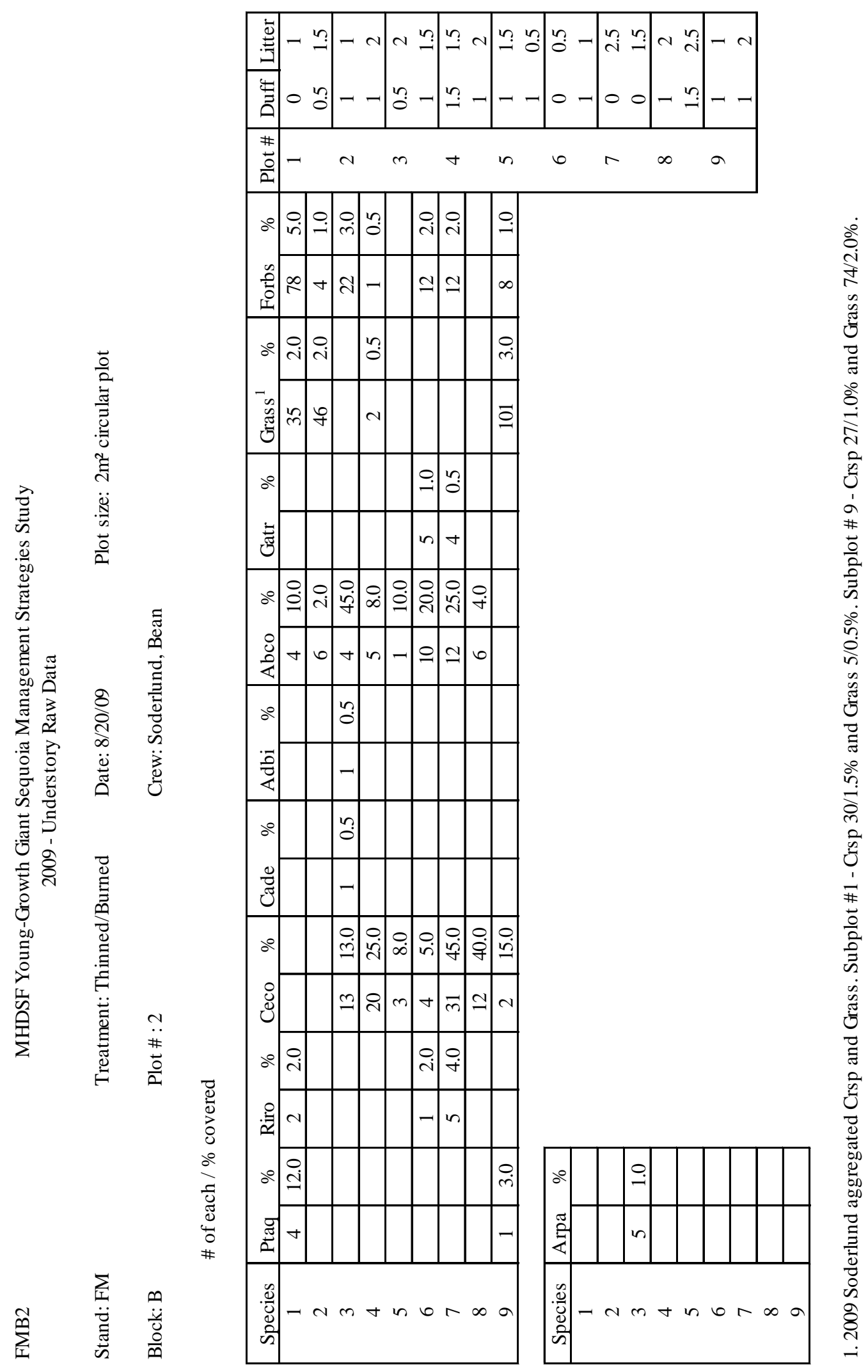

Page 186 


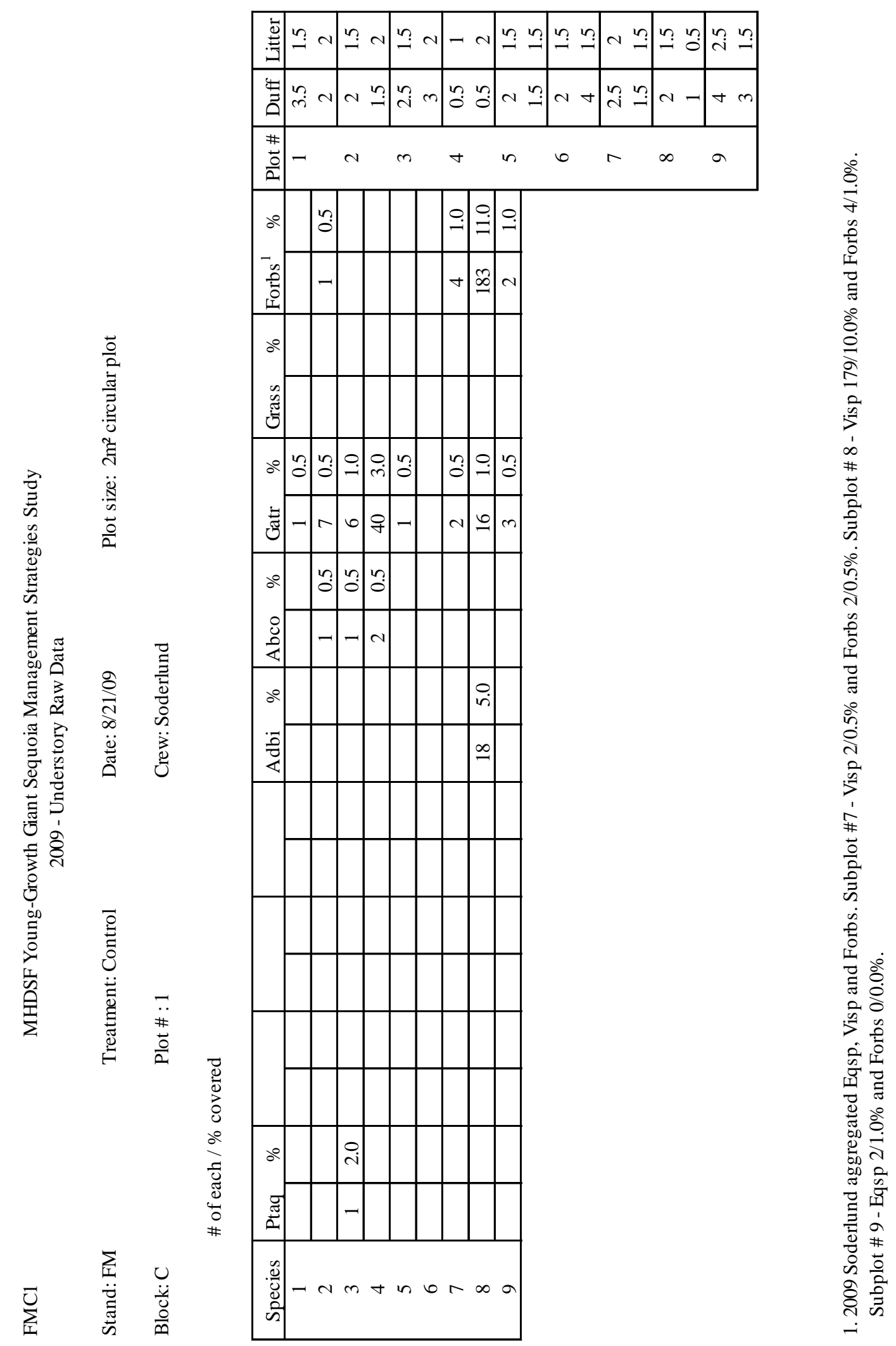

Page 187 


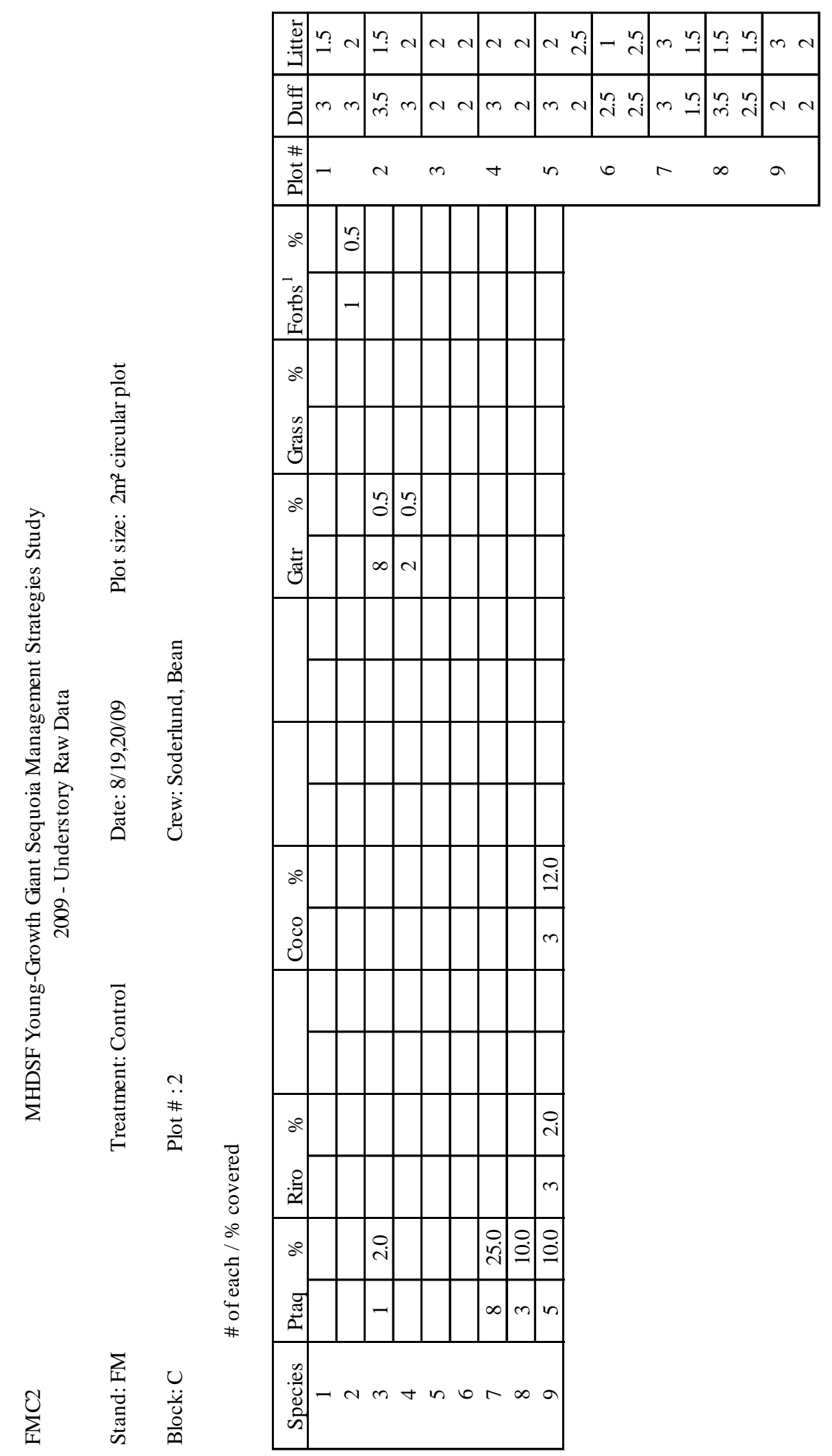

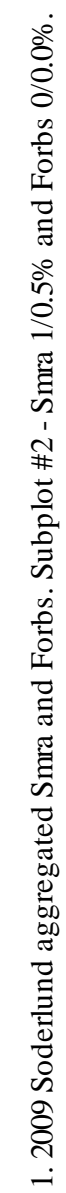

Page 188 


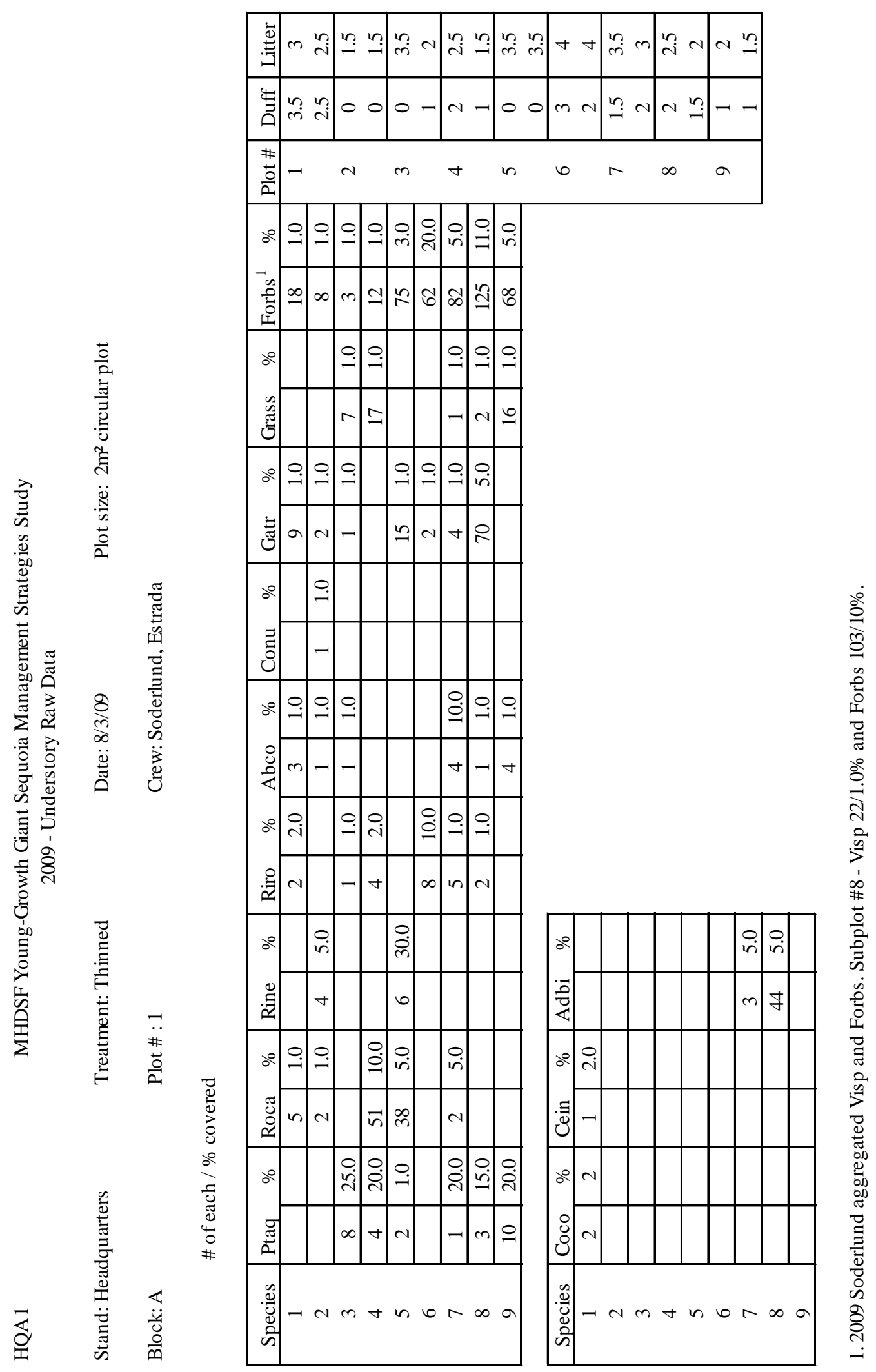

Page 189 


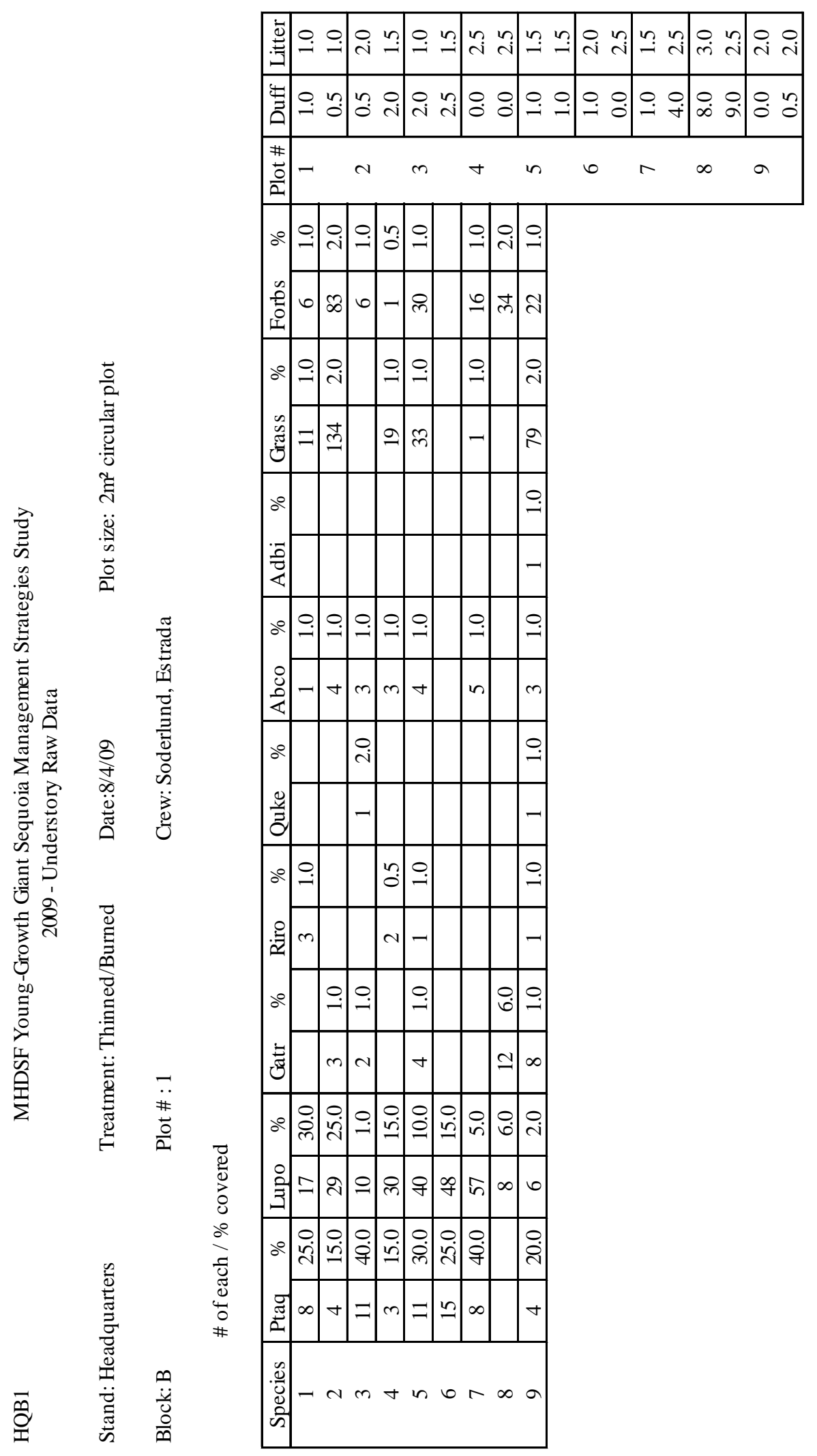

Page 190 


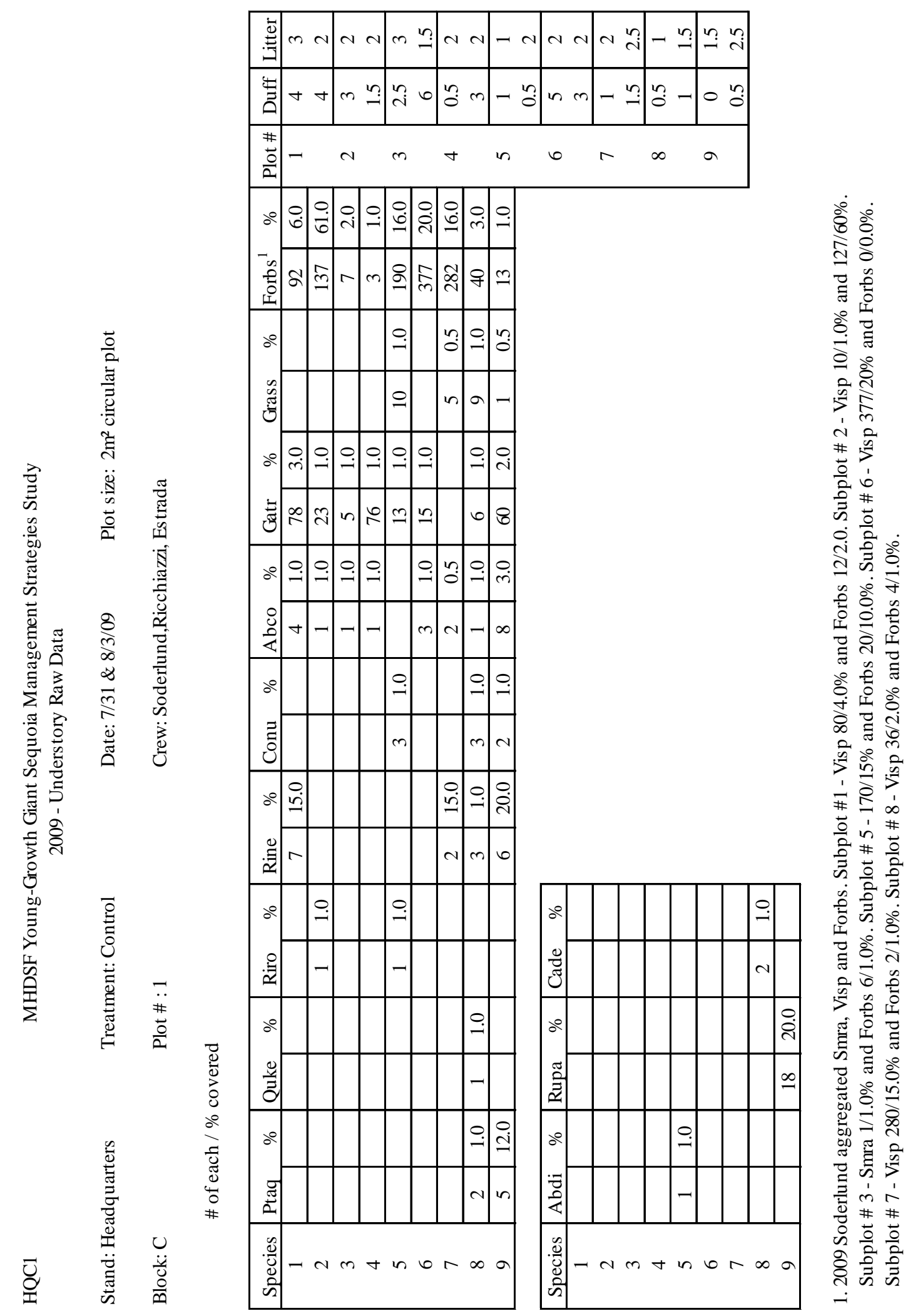

Page 191 


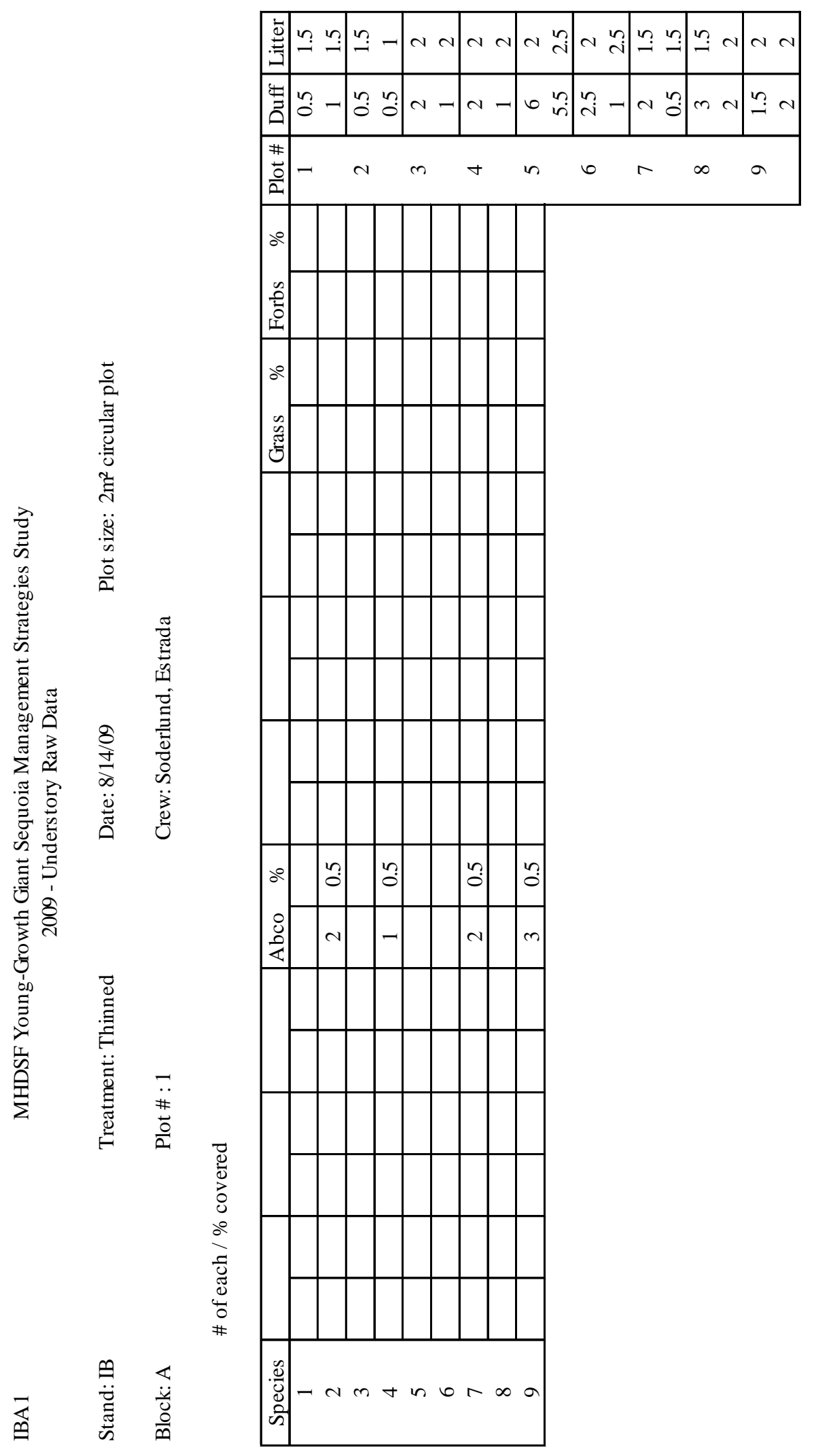

Page 192 


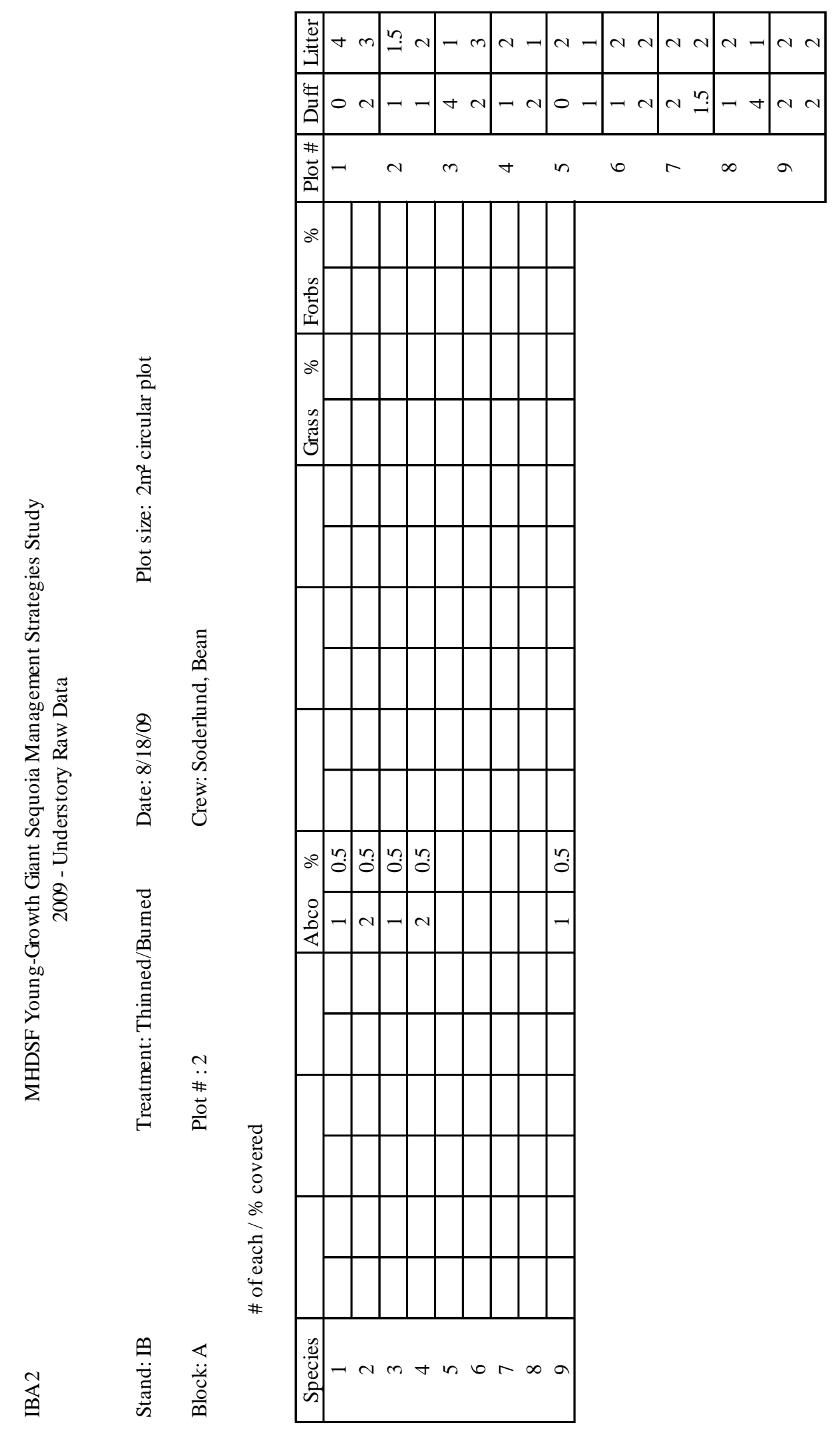

Page 193 


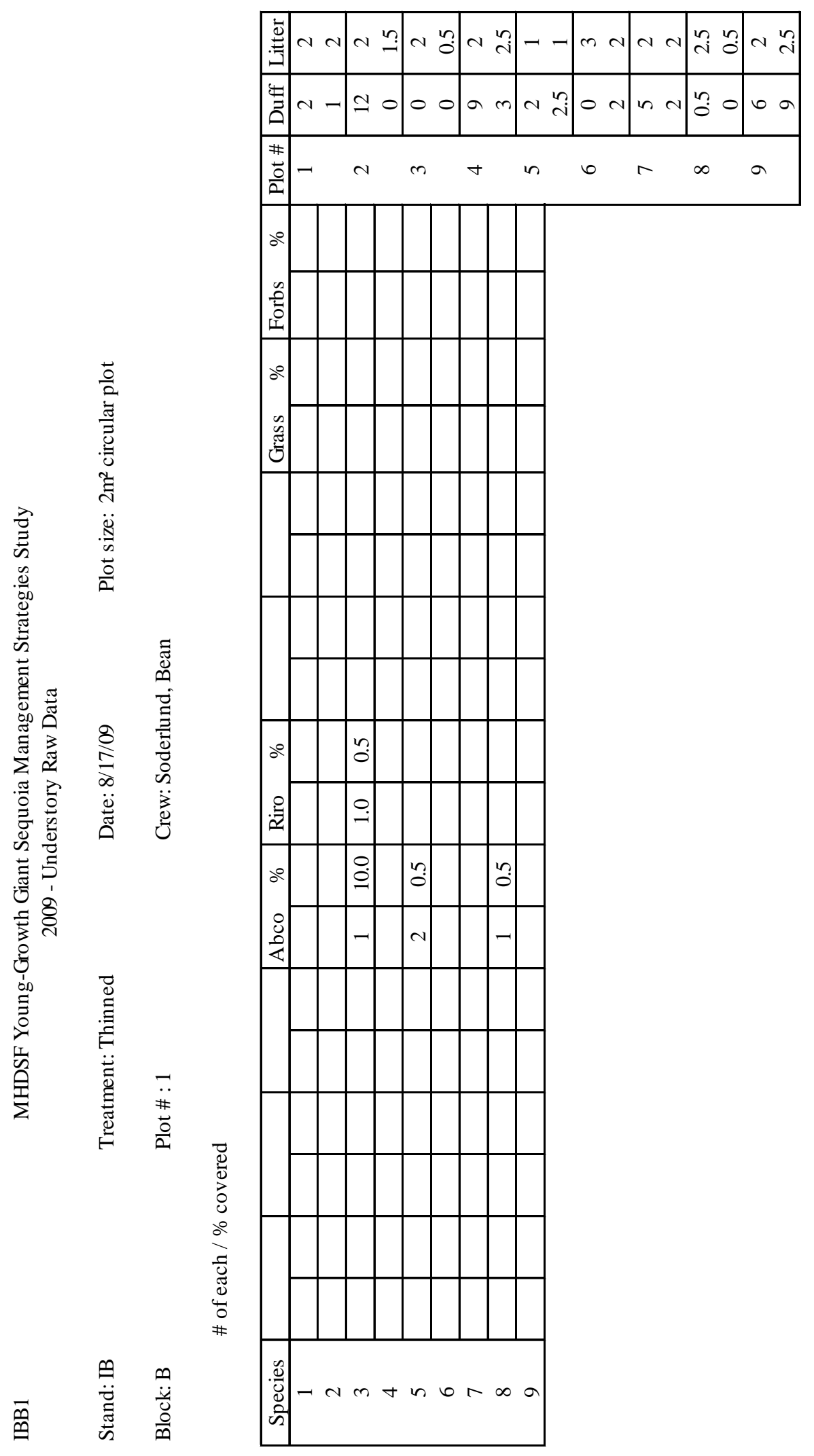

Page 194 


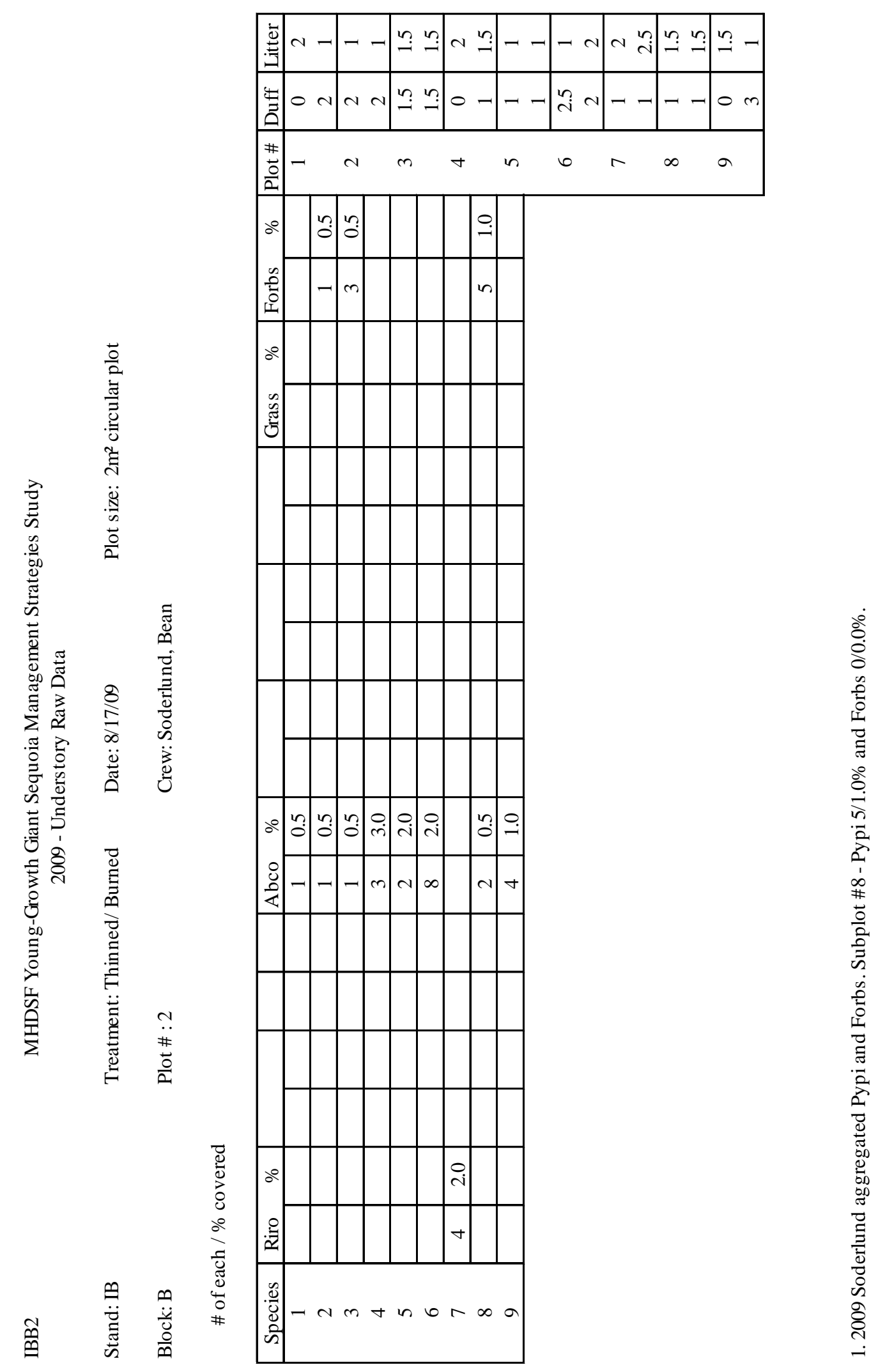

Page 195 


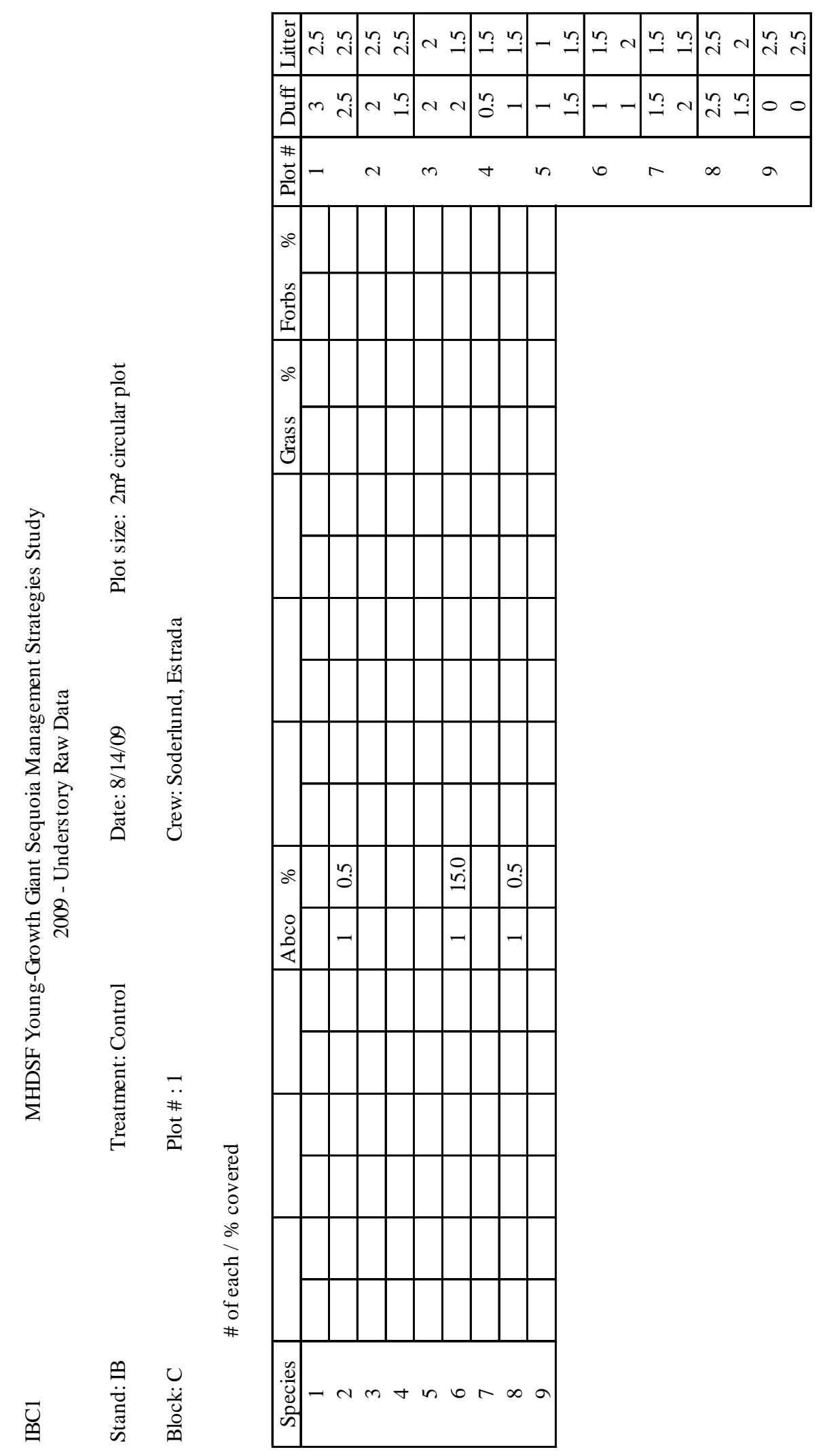

Page 196 


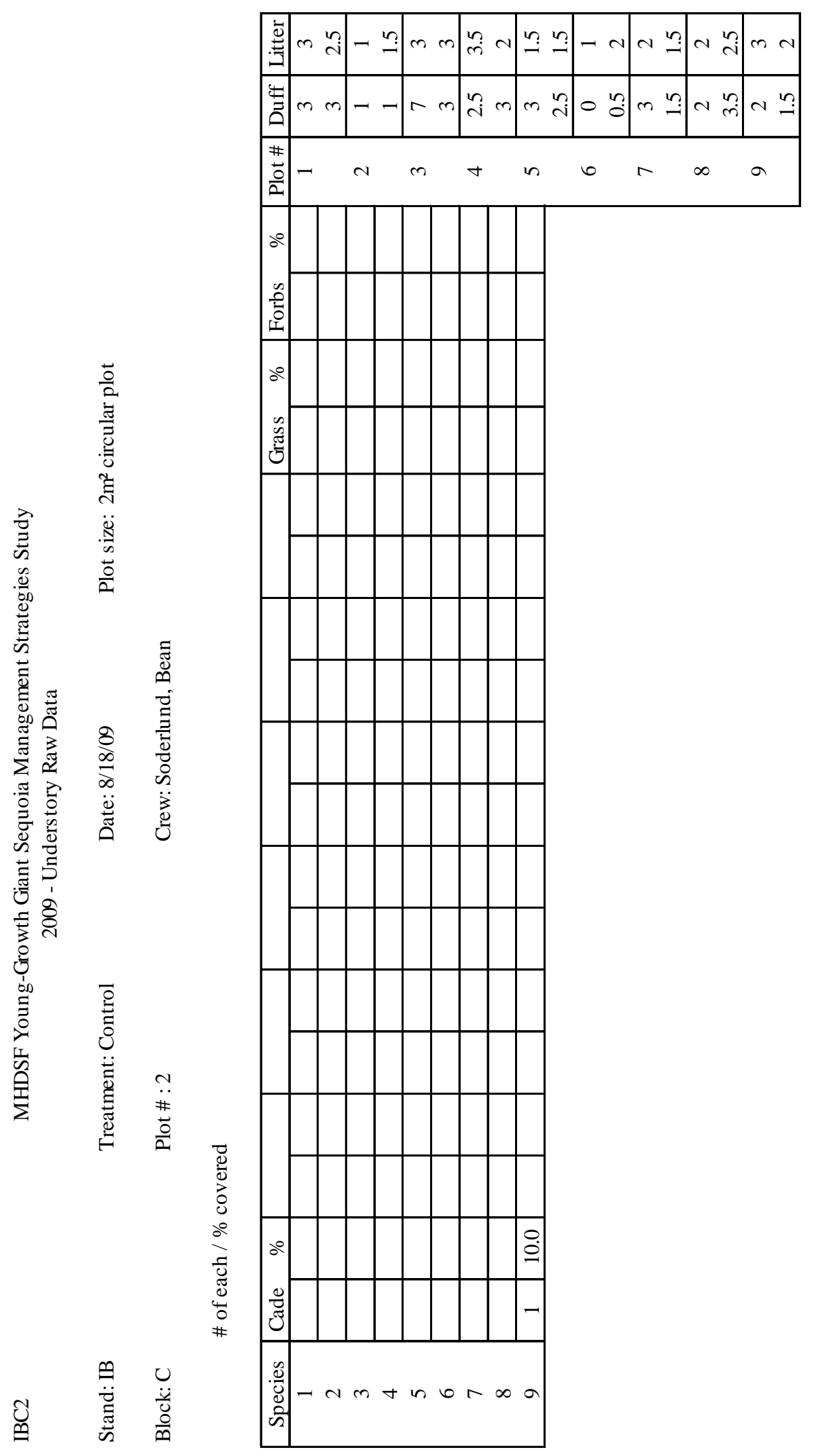

Page 197 


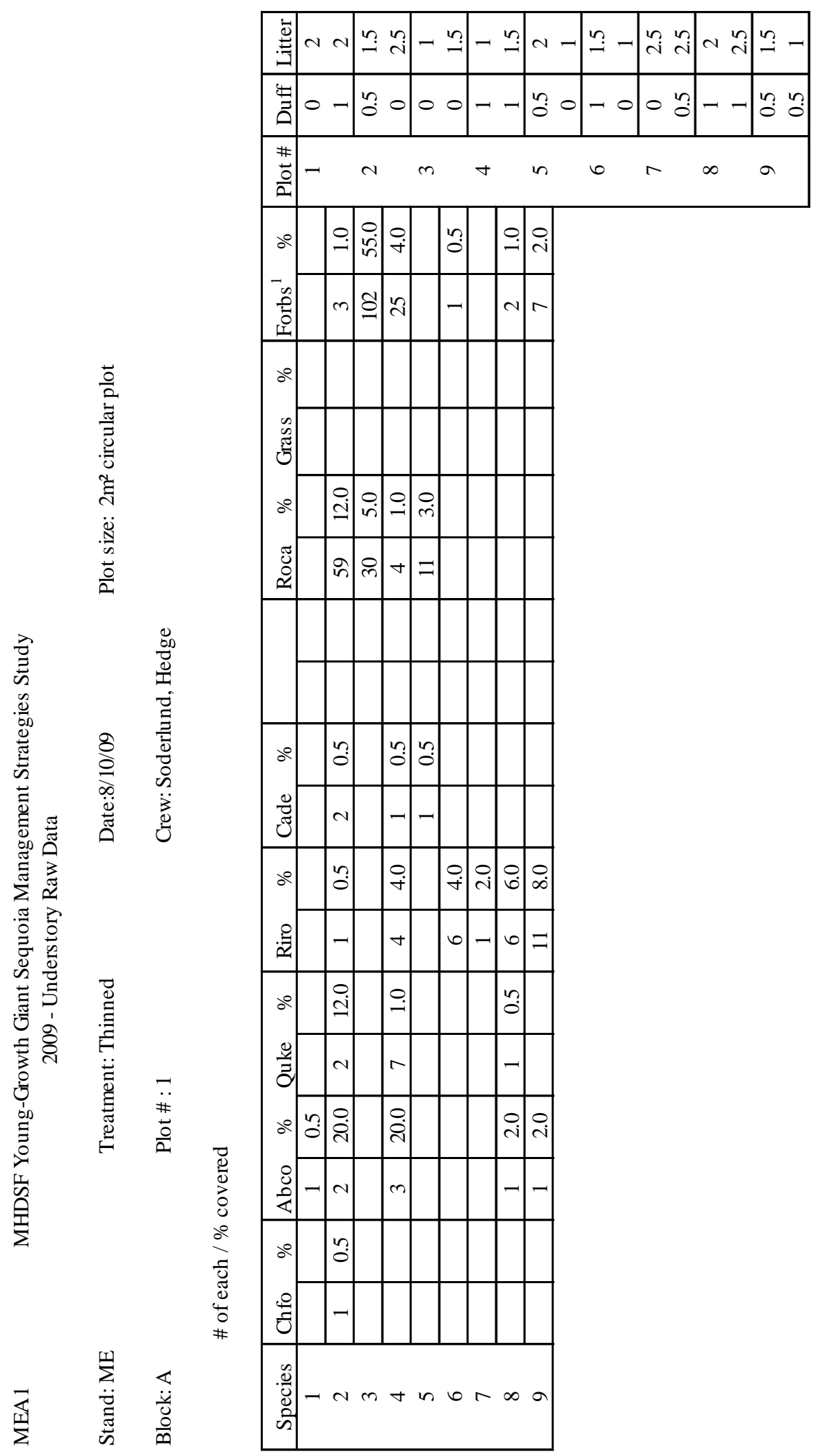

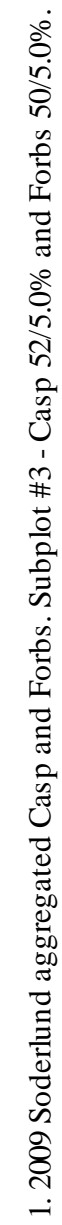

Page 198 


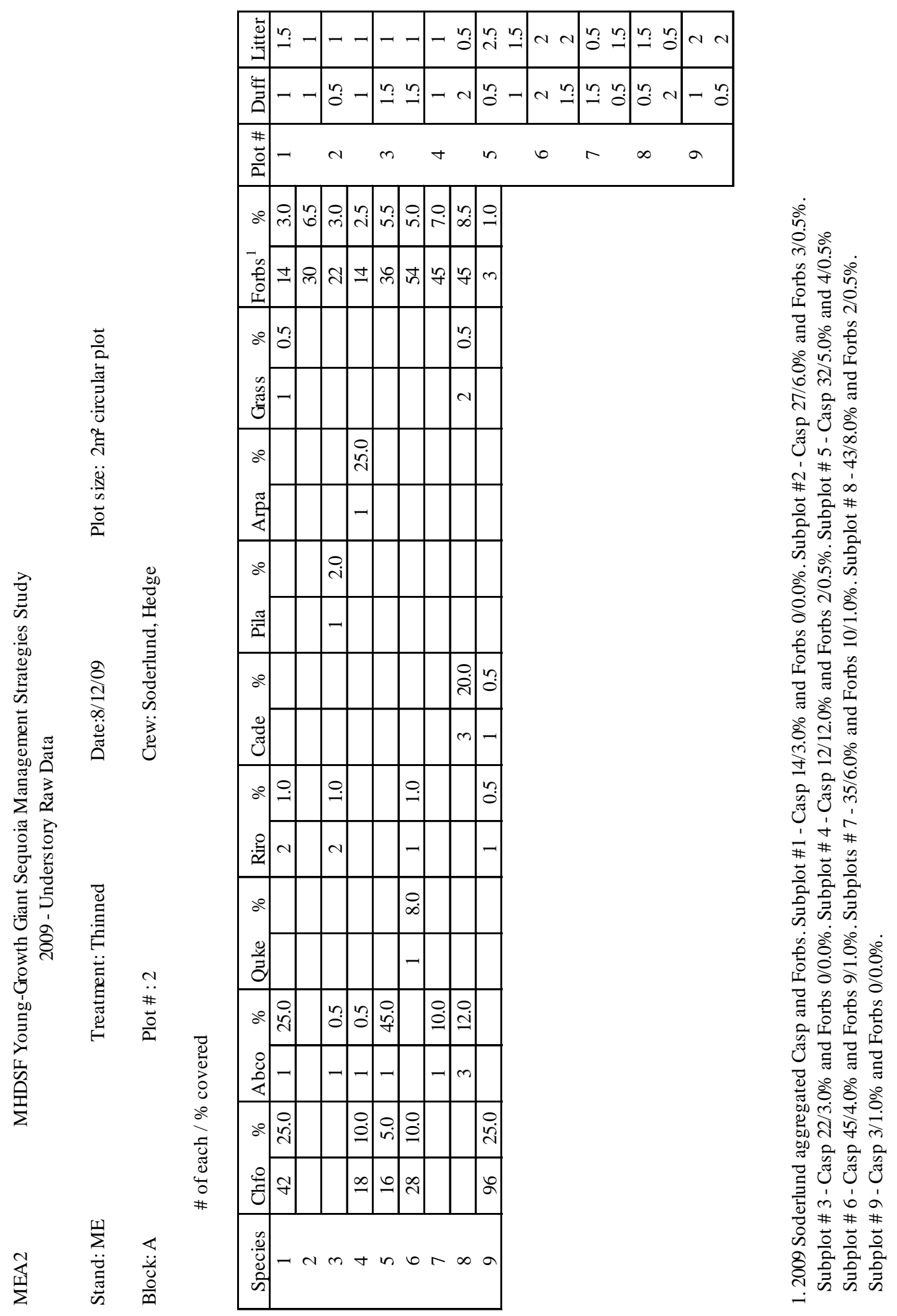

Page 199 


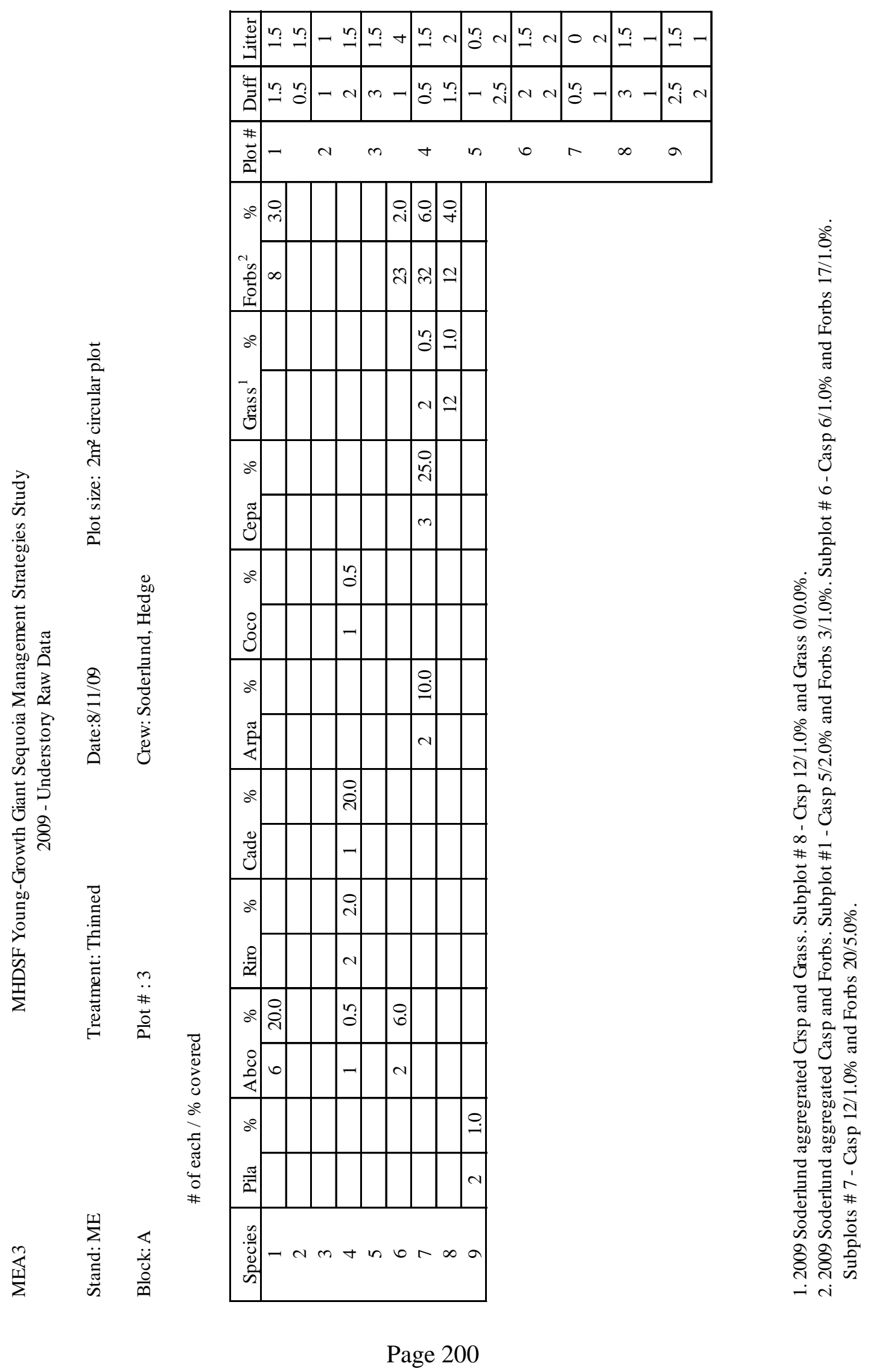




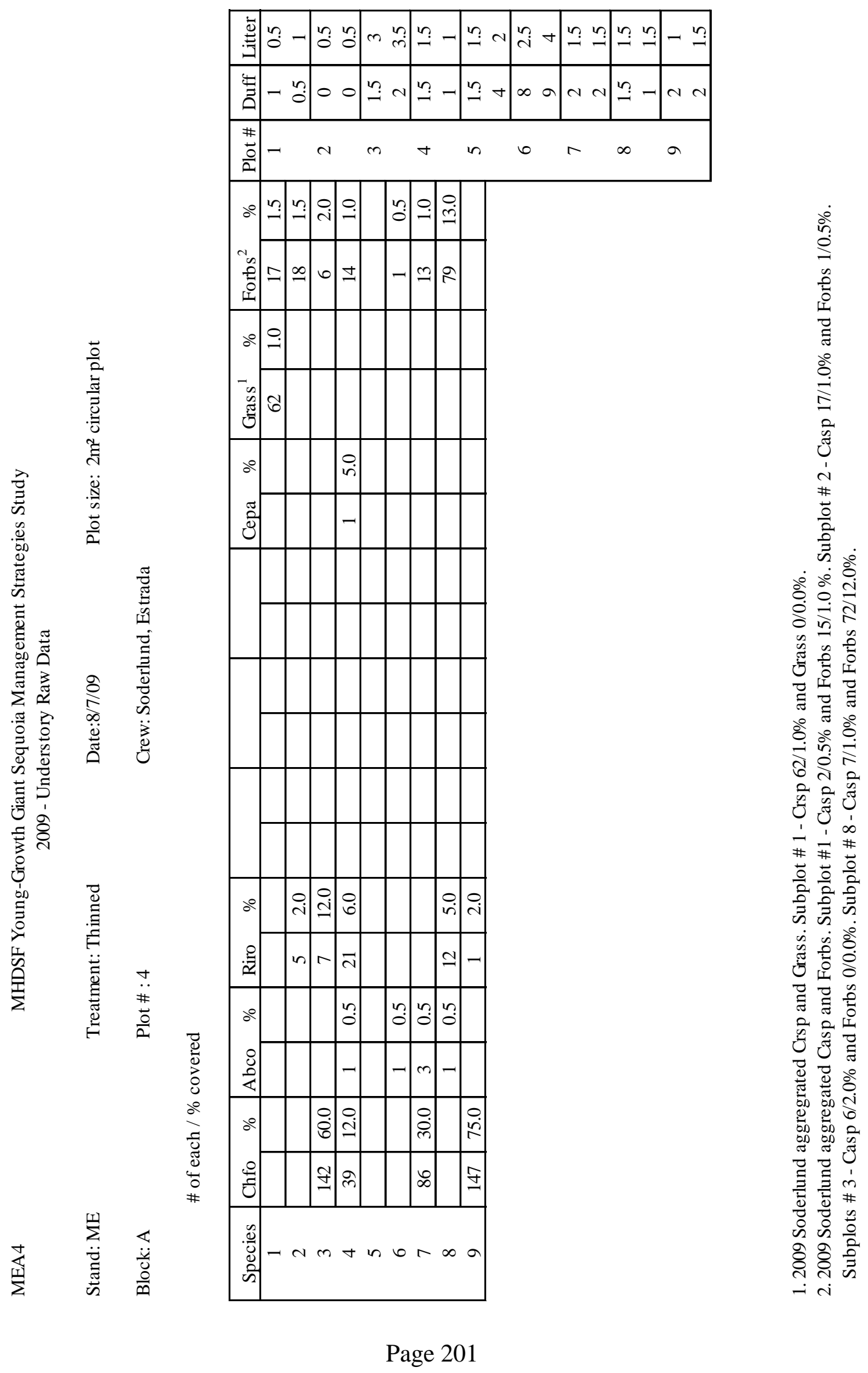




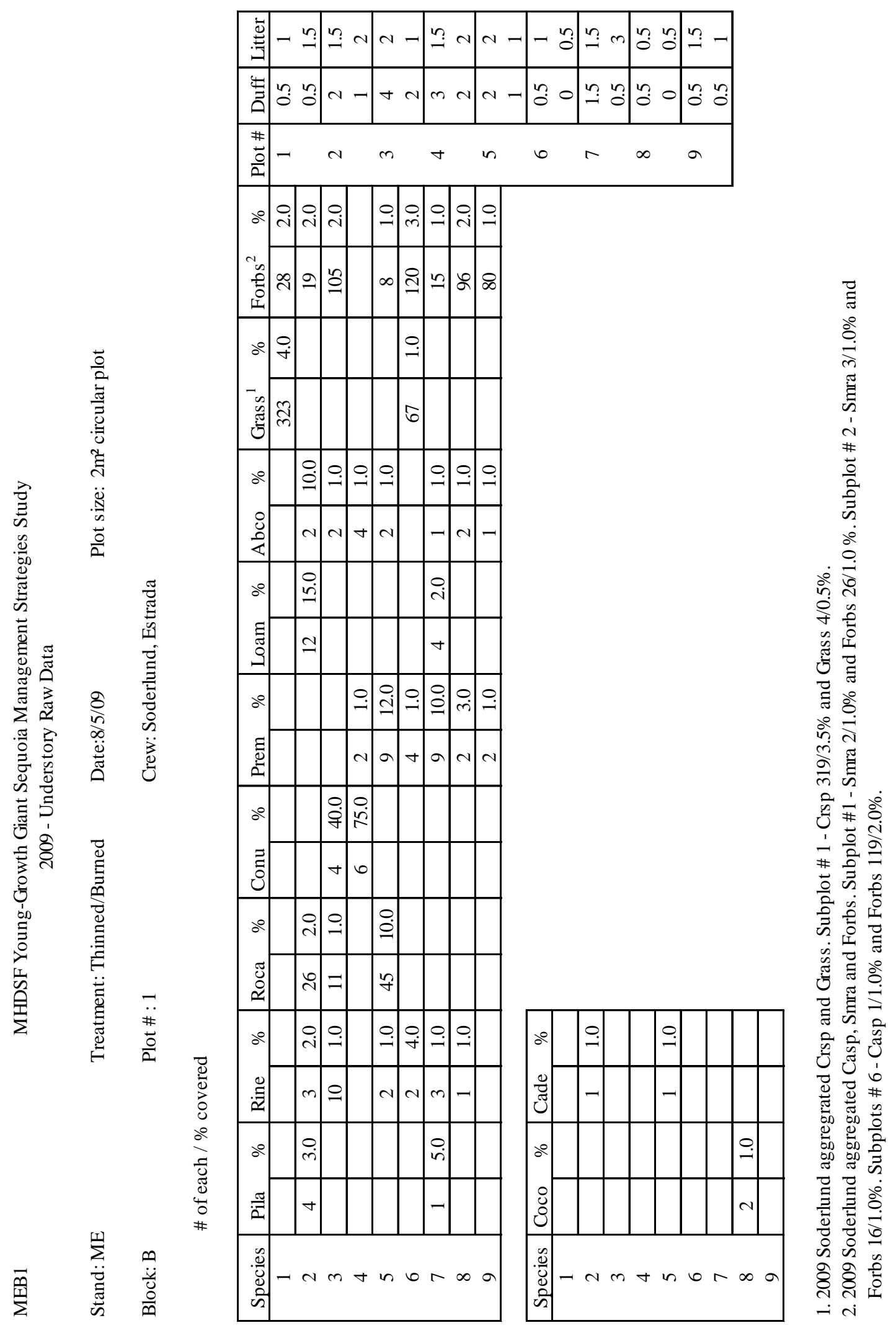

Page 202 


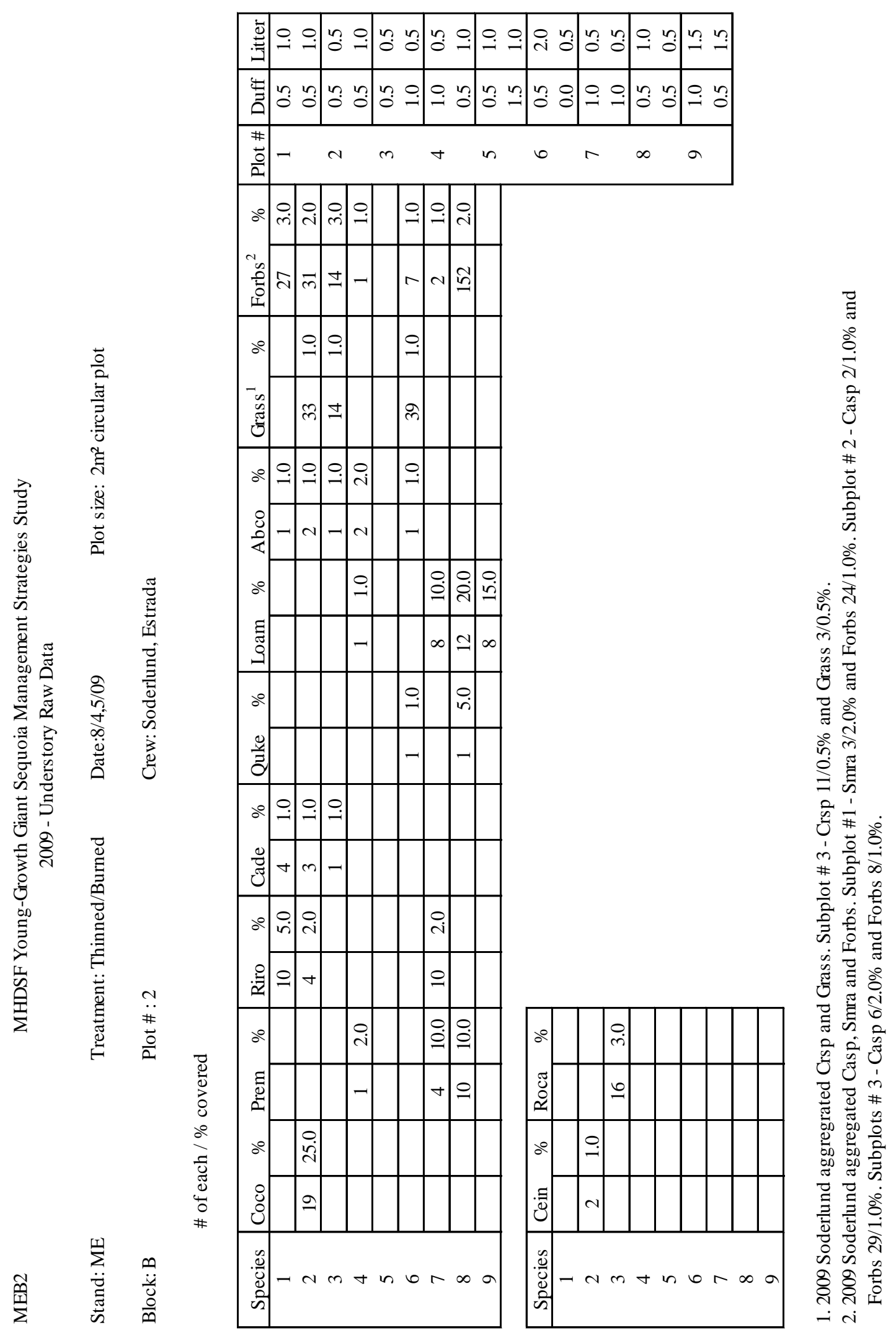

Page 203 


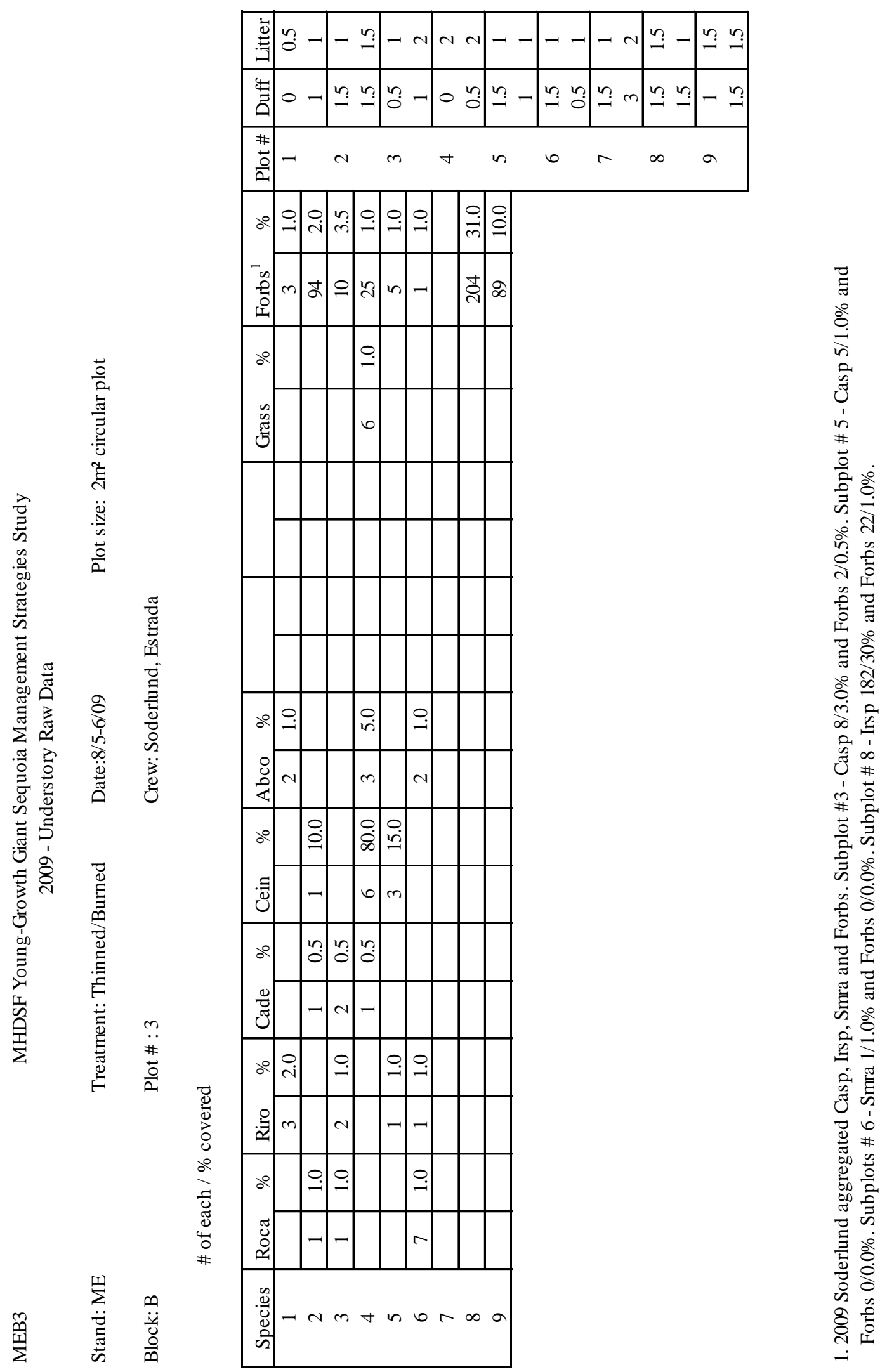

Page 204 


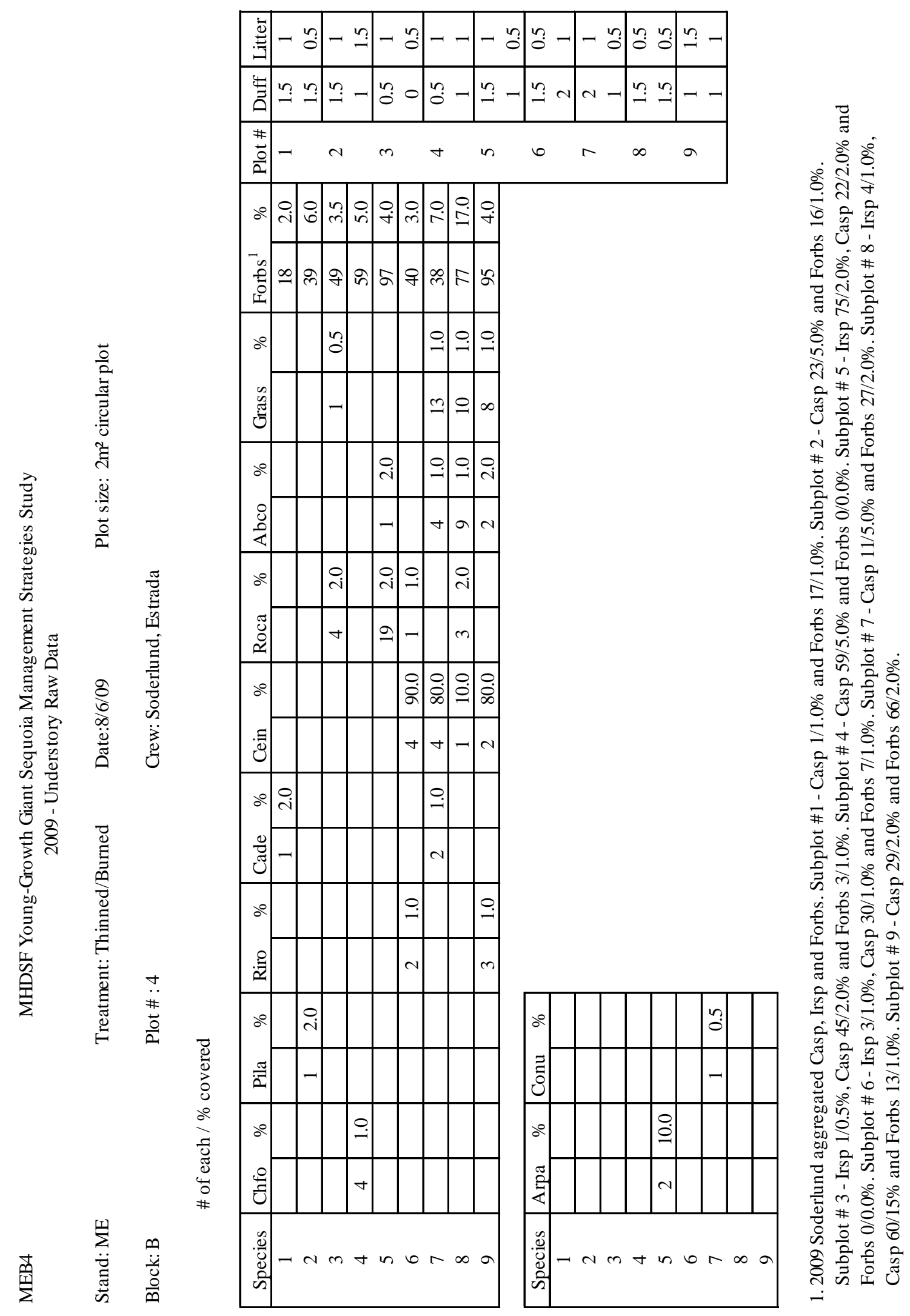

Page 205 


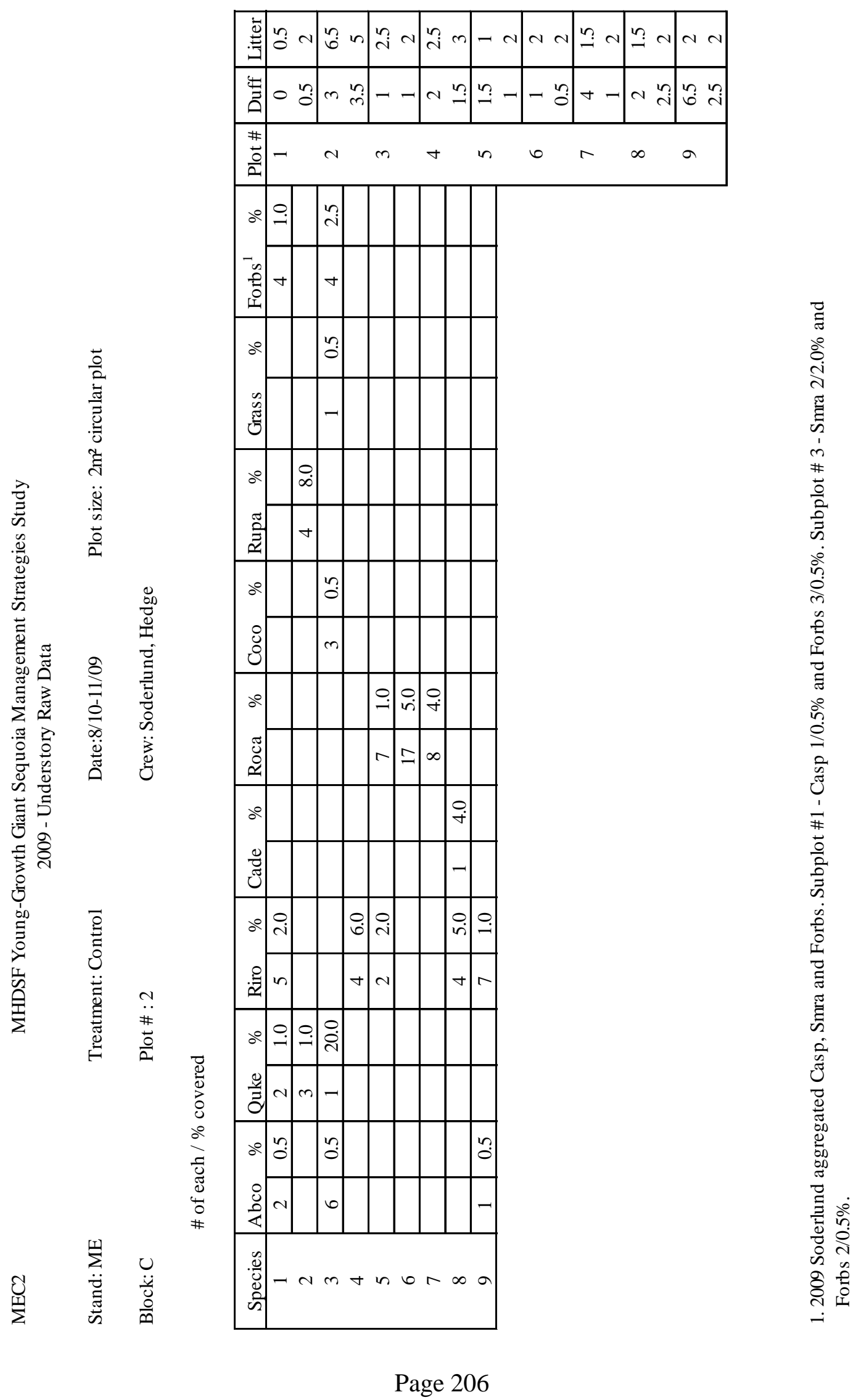




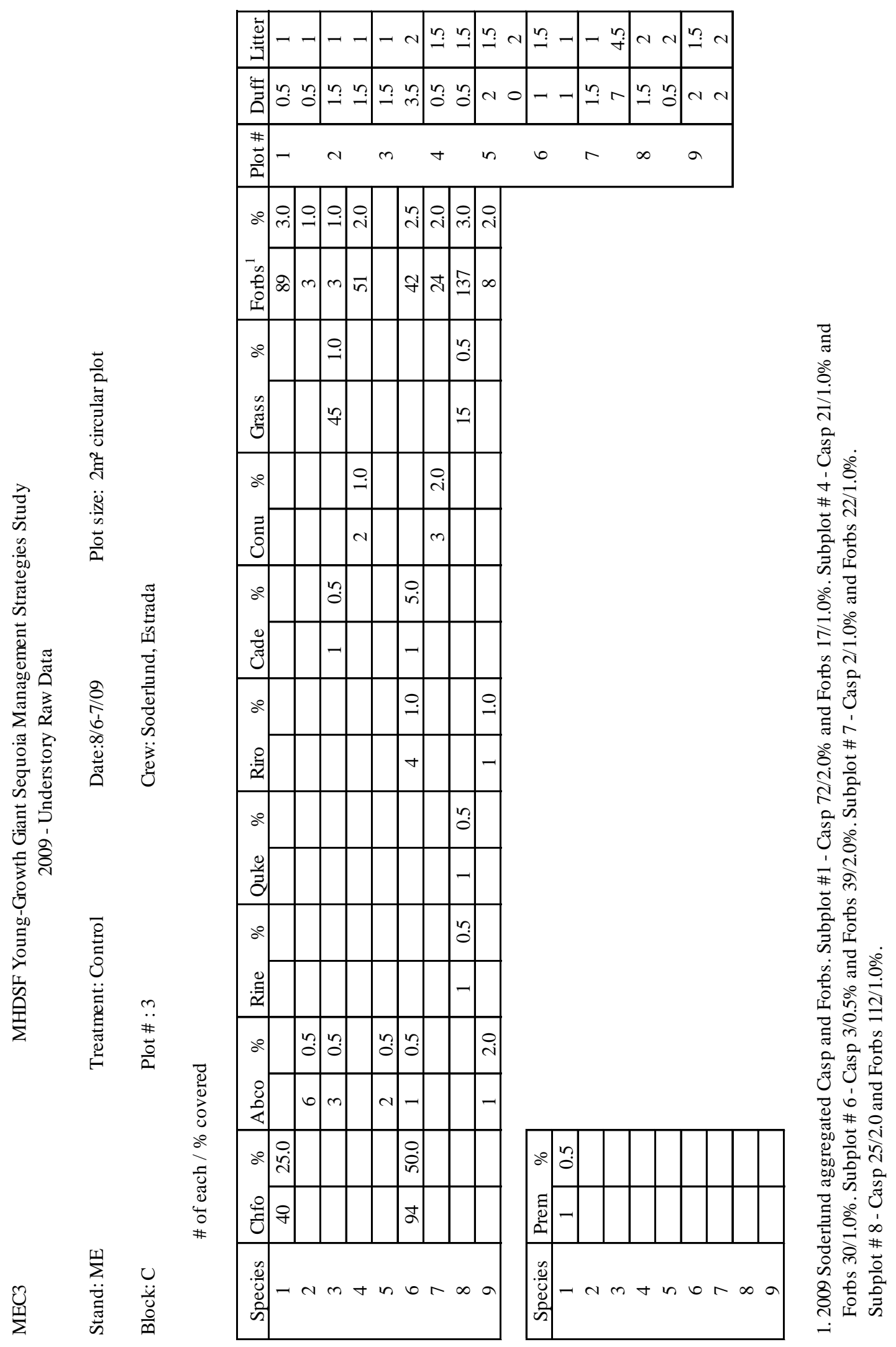

Page 207 


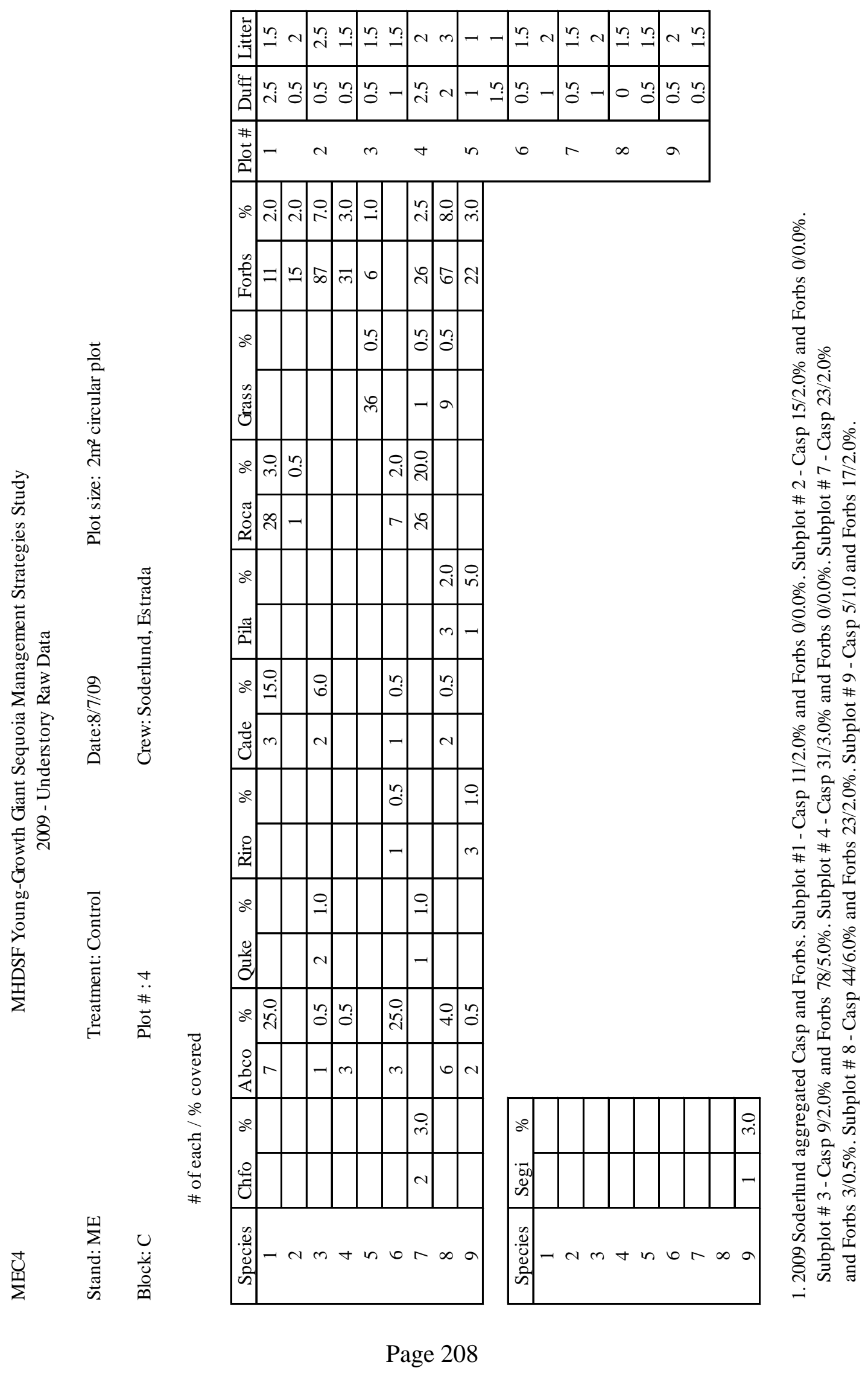




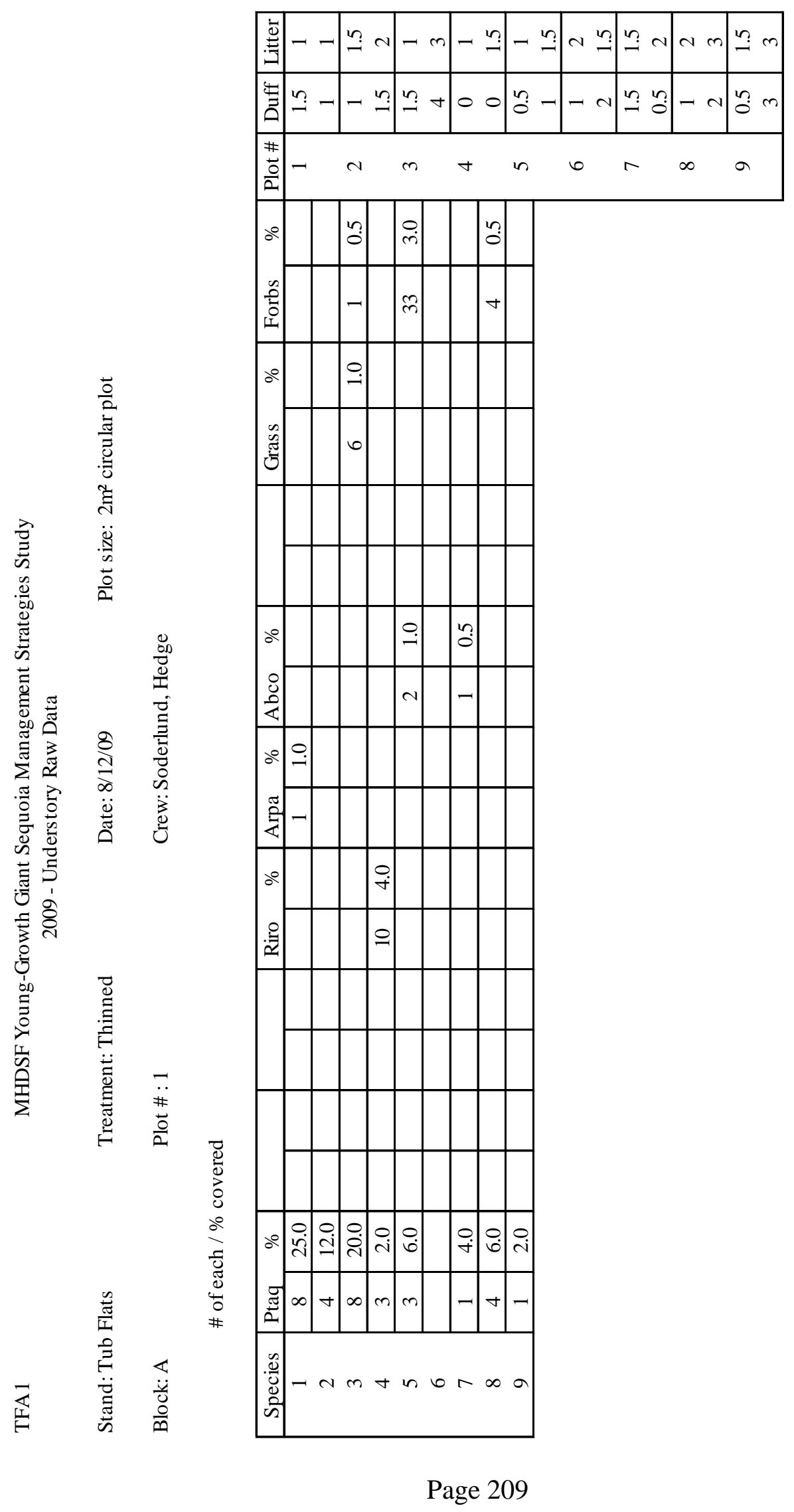




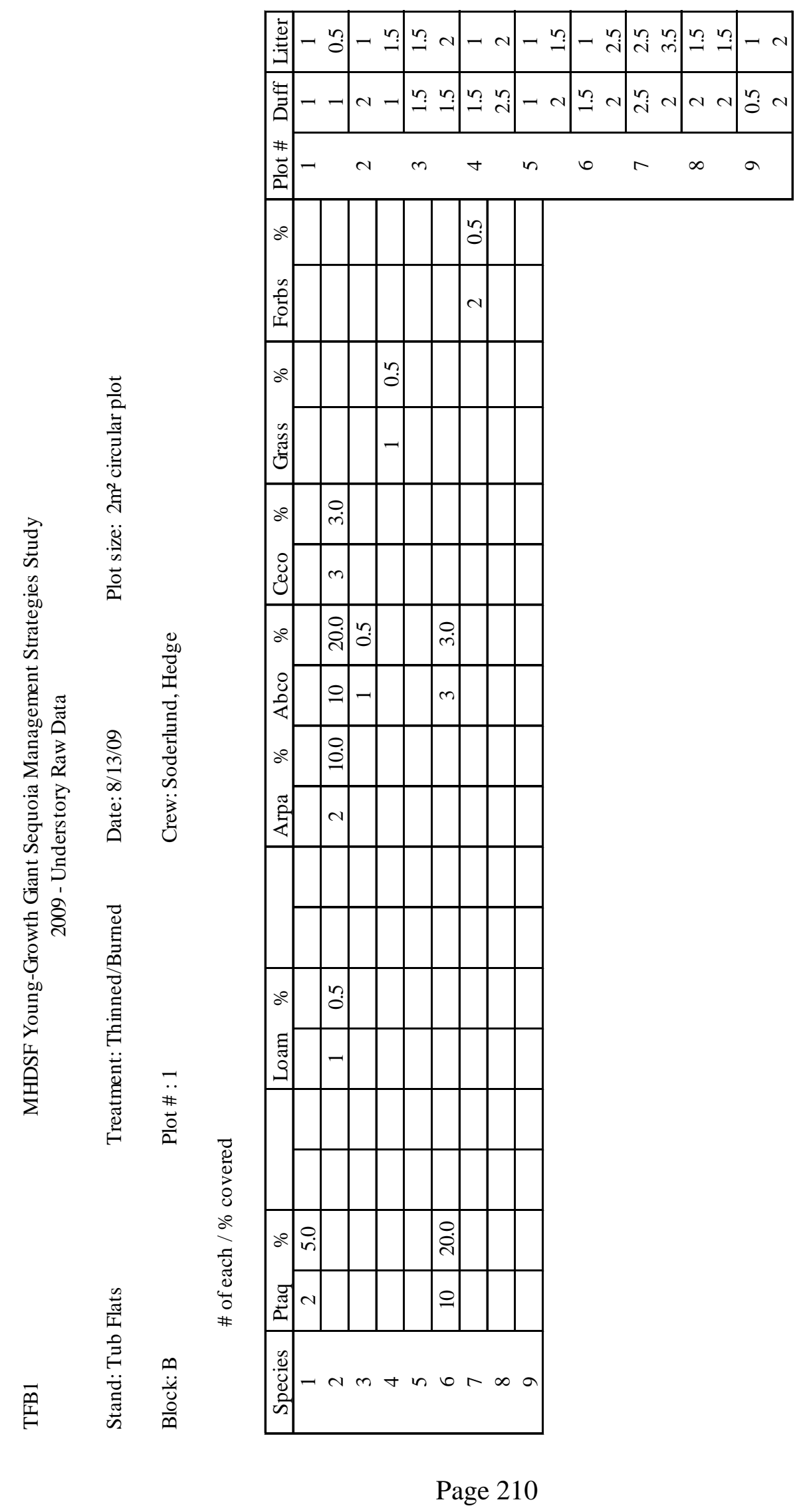




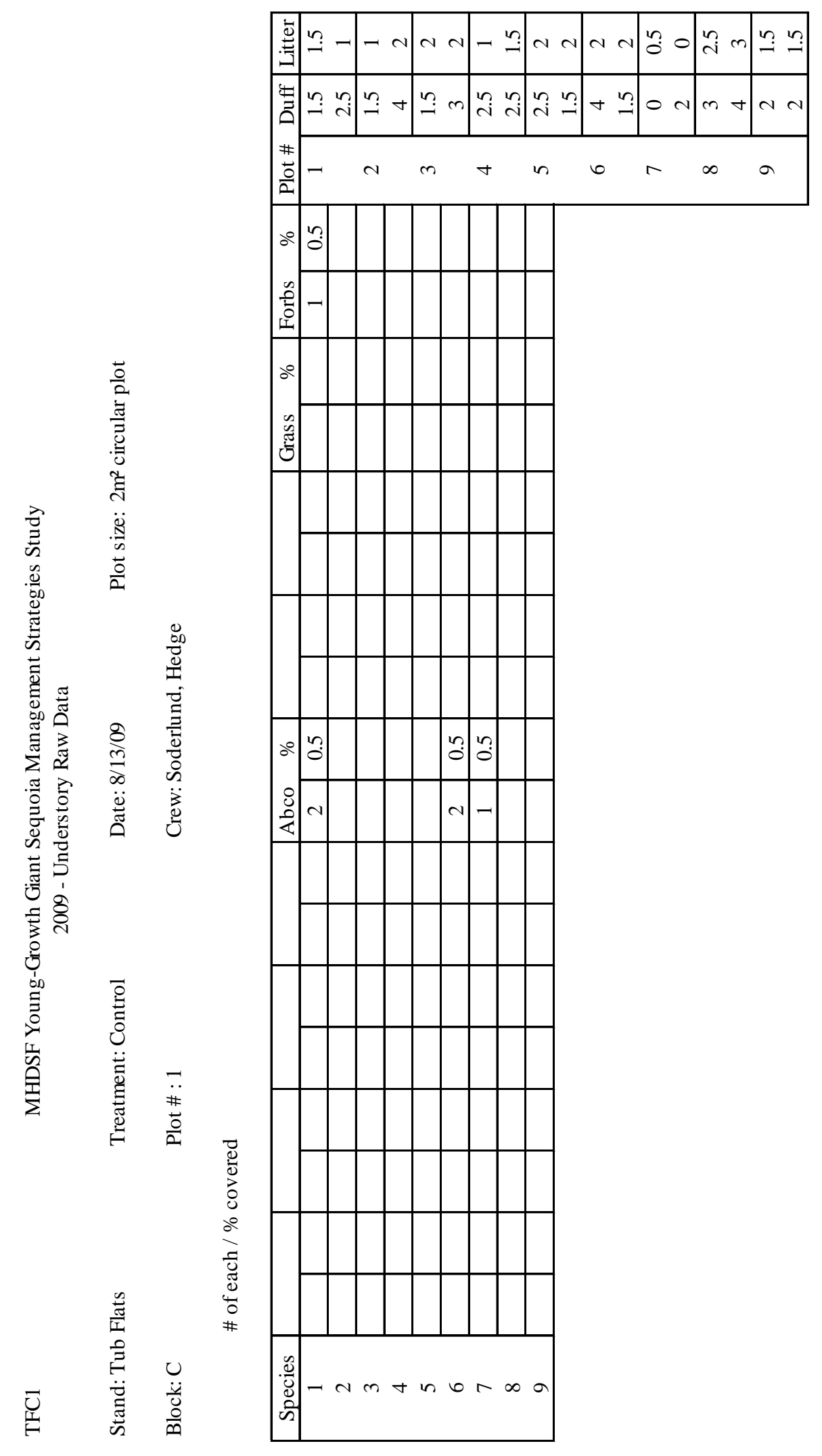

Page 211 
APPENDIX D

Understory Species List

Page 212 
Mountain Home Demonstration State Forest

List of Understory Tree and Shrub/Herbaceous Plant Species

2009

Code Scientific Name

Common Name

$\underline{\text { Trees }}$

$\begin{array}{lll}\text { Abco } & \text { Abies concolor } & \text { White Fir } \\ \text { Alrh } & \text { Alnus rhombifolia } & \text { White Alder } \\ \text { Cade } & \text { Calocedrus decurrens } & \text { Incense-cedar } \\ \text { Coco } & \text { Corylus cornuta var. californica } & \text { California Hazelnut } \\ \text { Conu } & \text { Cornus nuttallii } & \text { Western Dogwood } \\ \text { Pila } & \text { Pinus lambertiana } & \text { Sugar Pine } \\ \text { Quke } & \text { Quercus kelloggii } & \text { California Black Oak } \\ \text { Segi } & \text { Sequoiadendron giganteum } & \text { Giant Sequoia }\end{array}$


Mountain Home Demonstration State Forest

List of Understory Tree and Shrub/Herbaceous Species

2009

Code Scientific Name

Common Name

$\underline{\text { Shrubs/ Herbaceous Plants }}$

Adbi Adenocaulon bicolor

Arpa Arctostaphylos patula

Atfi Athyrum filix-femina var cyclosorum

Crsp Carex sp.

Case Chrysolepsis sempervirens

Casp Castilleja sp.

Ceco Ceanothus cordulatus

Cein Ceanothus integerrimus

Cepa Ceanothus parviflorus

Chfo Chamaebatia foliosa

Eqsp Equisetum sp.

Gatr Galium trifidum

Irsp Iris sp.

Loam Lotus crassifolius

Lupo Lupinus polyphyllus

Prem Prunus emarginata

Ptaq Pteridium aquilinum

Pypi Pyrola picta
Trail Plant

Greenleaf Manzanita

Lady Fern

Sedge

Evergreen Chinquapin

Paintbrush

Mountain Whitethorn

Deer Brush

Littleleaf Ceanothus

Mountain Misery

Horsetail

Threepetal Bedstraw

Iris

Big Deervetch

Big Leafed Lupine

Bitter Cherry

Bracken Fern

Wintergreen

Page 214 
Rine Ribes nevadense

Riro Ribes roezlii

Roca Rosa californica

Rule Rubus leucodermis

Rupa Rubus parviflorus

Smra Smilacina racemosa

Visp Viola sp.
Mountain Pink Currant

Sierra Gooseberry

California Wild Rose

Blackcap Raspberry

Thimbleberry

False Solomon’s Seal

Violet 


\section{APPENDIX E}

Downed Woody Debris Data

Page 216 
MHDSF Giant Sequoia Manipulation Study 2009 - Fuels Raw Data (4 Transects)

$\underline{\text { Stand: Bogus Meadow }}$

Depth and 1000 hour fuel diameters in inches.
Date: 8/26,27,28,31 \& 9/1/09

Crew: Soderlund, Hedge

\begin{tabular}{|c|c|c|c|c|c|c|c|c|}
\hline & & & & & \multirow{3}{*}{$\begin{array}{c}0-10 \mathrm{~m} \\
1000 \text { Hour } \\
\text { Sound }\end{array}$} & \multirow{3}{*}{$\begin{array}{c}0-10 \mathrm{~m} \\
1000 \text { Hour } \\
\text { Rotten }\end{array}$} & \multirow{3}{*}{$\begin{array}{c}\text { Litter } \\
\text { Depth 3m }\end{array}$} & \multirow{3}{*}{$\begin{array}{c}\text { Litter } \\
\text { Depth } 10 \mathrm{~m}\end{array}$} \\
\hline & Transect & $0-2 \mathrm{~m}$ & $0-2 \mathrm{~m}$ & $0-3 \mathrm{~m}$ & & & & \\
\hline Plot \# & Azimuth & 1 Hour & 10 Hour & 100 Hour & & & & \\
\hline \multirow[t]{4}{*}{ BM-A1 } & $\mathrm{N}$ & 7 & 5 & 1 & 0 & 0 & 2.0 & 3.0 \\
\hline & $\mathrm{E}$ & 5 & 3 & 2 & 0 & 0 & 1.0 & 1.0 \\
\hline & $\mathrm{S}$ & 4 & 4 & 0 & 8 & 0 & 1.0 & 2.0 \\
\hline & $\mathrm{W}$ & 7 & 10 & 1 & 0 & 0 & 1.5 & 2.5 \\
\hline \multirow[t]{4}{*}{ BM-A2 } & $\mathrm{N}$ & 7 & 5 & 2 & 0 & 5 & 2.0 & 3.0 \\
\hline & $\mathrm{E}$ & 7 & 2 & 0 & 0 & 6 & 2.0 & 3.0 \\
\hline & $\mathrm{S}$ & 3 & 3 & 0 & 0 & 8,6 & 4.0 & 2.5 \\
\hline & $\mathrm{W}$ & 6 & 4 & 1 & 0 & 0 & 3.0 & 3.0 \\
\hline \multirow[t]{4}{*}{ BM-B1 } & $\mathrm{N}$ & 1 & 2 & 0 & 9 & 7.5 & 2.0 & 1.0 \\
\hline & $\mathrm{E}$ & 2 & 0 & 0 & 8 & 0 & 1.5 & 3.0 \\
\hline & $\mathrm{S}$ & 3 & 1 & 0 & 0 & 29 & 2.0 & 2.0 \\
\hline & $\mathrm{W}$ & 1 & 2 & 0 & 0 & 0 & 2.0 & 3.0 \\
\hline \multirow[t]{4}{*}{ BM-B2 } & $\mathrm{N}$ & 6 & 2 & 0 & 0 & 0 & 2.0 & 3.0 \\
\hline & $E$ & 2 & 6 & 1 & 0 & 0 & 2.0 & 2.0 \\
\hline & $\mathrm{S}$ & 4 & 2 & 1 & 0 & 7 & 3.0 & 2.0 \\
\hline & $\mathrm{W}$ & 8 & 1 & 0 & 0 & 0 & 0.5 & 1.5 \\
\hline \multirow[t]{4}{*}{ BM-C1 } & $\mathrm{N}$ & 2 & 0 & 0 & $7.5,5$ & 4.5 & 1.5 & 2.0 \\
\hline & $E$ & 19 & 13 & 0 & 0 & 0 & 2.0 & 1.5 \\
\hline & $\mathrm{S}$ & 13 & 6 & 3 & 0 & 0 & 1.0 & 3.5 \\
\hline & $\mathrm{W}$ & 7 & 4 & 1 & 0 & 4.5 & 3.0 & 2.5 \\
\hline \multirow[t]{4}{*}{ BM-C2 } & $\mathrm{N}$ & 13 & 7 & 1 & 0 & 0 & 2.5 & 2.0 \\
\hline & $E$ & 11 & 10 & 1 & 0 & 0 & 2.0 & 2.0 \\
\hline & $\mathrm{S}$ & 15 & 4 & 0 & 0 & 0 & 2.5 & 2.0 \\
\hline & $\mathrm{W}$ & 13 & 9 & 1 & 9 & 4.5 & 2.5 & 0.5 \\
\hline
\end{tabular}


MHDSF Giant Sequoia Manipulation Study 2009 - Fuels Raw Data (4 Transects)

Stand: Frasier Mill

Depth and 1000 hour fuel diameters in inches.
Date: 8/13,19,24,25/09

Crew: Soderlund, Hedge, Bean

\begin{tabular}{|c|c|c|}
\hline \multirow{2}{*}{$\begin{array}{c}0-10 \mathrm{~m} \\
1000 \text { Hour } \\
\text { Rotten }\end{array}$} & & \\
\hline & $\begin{array}{c}\text { Litter } \\
\text { Depth 3m }\end{array}$ & $\begin{array}{c}\text { Litter } \\
\text { Depth } 10 \mathrm{~m}\end{array}$ \\
\hline $7,3.5,5.5,6$ & 4.0 & 1.5 \\
\hline 7 & 2.0 & 2.0 \\
\hline 7, 7, 3.5 & 4.0 & 3.0 \\
\hline 4 & 2.0 & 2.0 \\
\hline 0 & 2.5 & 3.0 \\
\hline $11.5,5$ & 0.5 & 2.0 \\
\hline 11,9 & 1.0 & 2.0 \\
\hline 9,9 & 3.0 & 2.0 \\
\hline 6 & 2.0 & 2.5 \\
\hline 12 & 3.5 & 3.0 \\
\hline 0 & 3.0 & 1.0 \\
\hline 3 & 2.5 & 3.0 \\
\hline 0 & 3.0 & 2.0 \\
\hline 13 & 2.0 & 1.0 \\
\hline 0 & 1.5 & 2.0 \\
\hline 0 & 2.0 & 3.0 \\
\hline 0 & 1.5 & 2.0 \\
\hline 14 & 2.0 & 3.0 \\
\hline 0 & 2.0 & 3.0 \\
\hline 0 & 1.5 & 2.0 \\
\hline 0 & 2.5 & 2.5 \\
\hline 0 & 3.0 & 3.0 \\
\hline 0 & 2.5 & 4.0 \\
\hline 0 & 4.5 & 6.5 \\
\hline
\end{tabular}




\section{MHDSF Giant Sequoia Manipulation Study \\ 2009 - Fuels Raw Data (4 Transects)}

Stand: Headquarters

Depth and 1000 hour fuel diameters in inches.
Date: 7/31 \& 8/3-4/09

Crew:Soderlund, Ricchaizzi,Estrada

\begin{tabular}{|c|c|c|}
\hline \multirow{2}{*}{$\begin{array}{c}0-10 \mathrm{~m} \\
1000 \text { Hour } \\
\text { Rotten }\end{array}$} & \multirow[b]{2}{*}{$\begin{array}{c}\text { Litter } \\
\text { Depth 3m }\end{array}$} & \multirow[b]{2}{*}{$\begin{array}{c}\text { Litter } \\
\text { Depth } 10 \mathrm{~m}\end{array}$} \\
\hline & & \\
\hline 11 & 3.5 & 12.0 \\
\hline 0 & 1.5 & 2.0 \\
\hline 36 & 1.5 & 4.5 \\
\hline $9,30,5,9$ & 3.5 & 2.0 \\
\hline $9,11.5$ & 2 & 2.0 \\
\hline 0 & 1.5 & 2.0 \\
\hline 0 & 2 & 3.5 \\
\hline 40 & 2 & 2.0 \\
\hline 0 & 2 & BG \\
\hline 0 & 3.5 & 2.5 \\
\hline 0 & 3 & 2.5 \\
\hline 0 & 2 & 2.0 \\
\hline
\end{tabular}


MHDSF Giant Sequoia Manipulation Study 2009 - Fuels Raw Data (4 Transects)

Stand: Indian Bath

Depth and 1000 hour fuel diameters in inches.
Date: 8/14,17,18/09

Crew: Soderlund, Estrada, Bean

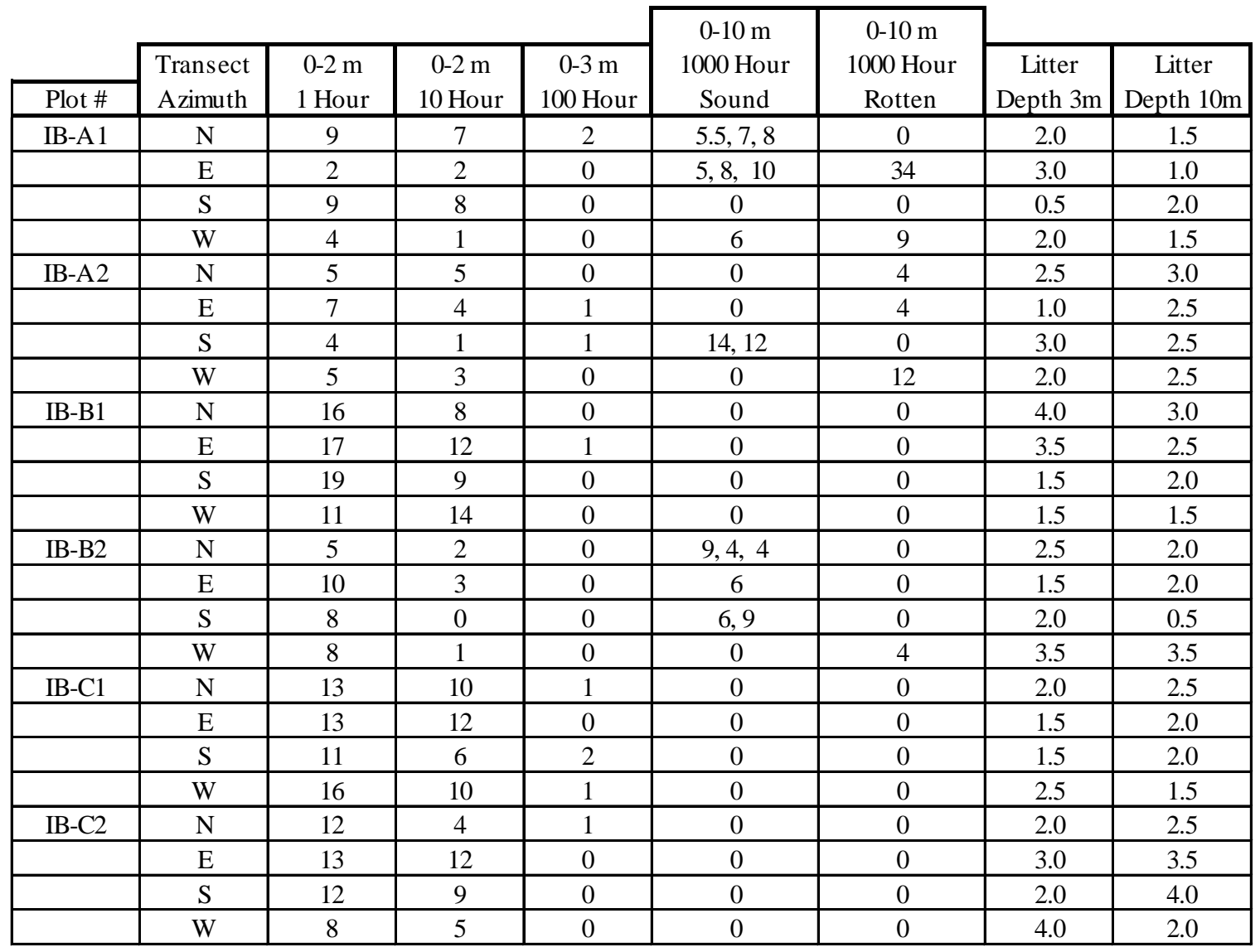

Page 220 
MHDSF Giant Sequoia Manipulation Study 2009 - Fuels Raw Data (4 Transects)

Stand: Methuselah

Depth and 1000 hour fuel diameters in inches.

Date:8/4,5,6,10,11,12/09

Crew:Soderlund, Estrada, Hedge

$0-10 \mathrm{~m}$ 1000 Hour Rotten Litter $\quad$ Litter Depth 3m Depth 10m Sound

\begin{tabular}{|c|c|c|}
\hline ME-A1 & $\mathrm{N}$ & 13 \\
\hline
\end{tabular}

\begin{tabular}{|c|c|c|c|c|c|c|c|c|}
\hline & & & & & & & & \\
\hline & $E$ & 13 & 13 & 2 & 0 & 4 & 1.5 & 2.0 \\
\hline & $\mathrm{S}$ & 9 & 7 & 1 & 0 & 0 & 1.5 & 2.0 \\
\hline & $\mathrm{W}$ & 8 & 8 & 0 & 0 & 4.3, 3.8 & 2.5 & 3.0 \\
\hline ME-A2 & $\mathrm{N}$ & 4 & 1 & 0 & 0 & 4,8 & 3.0 & 1.0 \\
\hline & $\mathrm{E}$ & 5 & 4 & 0 & 0 & 0 & 3.0 & 2.0 \\
\hline & $\mathrm{S}$ & 14 & 3 & 0 & 0 & 0 & 1.0 & 7.0 \\
\hline & $\mathrm{W}$ & 11 & 2 & 0 & 0 & 0 & 2.0 & 2.5 \\
\hline ME-A3 & $\mathrm{N}$ & 6 & 6 & 0 & 0 & 0 & 1.0 & 2.0 \\
\hline & $\mathrm{E}$ & 2 & 2 & 1 & 0 & 0 & 1.5 & 0.5 \\
\hline & $\mathrm{S}$ & 12 & 10 & 1 & 0 & 17 & 2.0 & 3.0 \\
\hline & $\mathrm{E}$ & 2 & 2 & 1 & 0 & 0 & 1.5 & 0.5 \\
\hline & $\mathrm{W}$ & 2 & 1 & 0 & 0 & 0 & 1.0 & 0.5 \\
\hline ME-A4 & $\mathrm{N}$ & 4 & 3 & 0 & 0 & 0 & 5.0 & 1.0 \\
\hline & $\mathrm{E}$ & 12 & 12 & 1 & 0 & 0 & 3.0 & 1.5 \\
\hline & $\mathrm{S}$ & 8 & 3 & 0 & 0 & 0 & 2.0 & 1.5 \\
\hline & $\mathrm{W}$ & 7 & 1 & 0 & 0 & 0 & 2.5 & 1.0 \\
\hline ME-B1 & $\mathrm{N}$ & 8 & 5 & 0 & 0 & 0 & 1.0 & 1.0 \\
\hline & $\mathrm{E}$ & 19 & 8 & 0 & 0 & 0 & 1.5 & 1.5 \\
\hline & $\mathrm{S}$ & 9 & 3 & 0 & 0 & 18 & 1.5 & 1.0 \\
\hline & W & 9 & 2 & 0 & 0 & 0 & 1.0 & 2.0 \\
\hline ME-B2 & $\mathrm{N}$ & 11 & 6 & 0 & 7,5 & 3.5 & 1.5 & 0.5 \\
\hline & $\mathrm{E}$ & 16 & 9 & 0 & 14 & 0 & 2.0 & 1.5 \\
\hline & $\mathrm{S}$ & 13 & 7 & 0 & 0 & 0 & 2.0 & 1.5 \\
\hline & W & 12 & 8 & 0 & 0 & 4 & 2.0 & 2.5 \\
\hline
\end{tabular}

Page 221 
MHDSF Giant Sequoia Manipulation Study

2009 - Fuels Raw Data (4 Transects)

Stand: Methuselah

Depth and 1000 hour fuel diameters in inches.

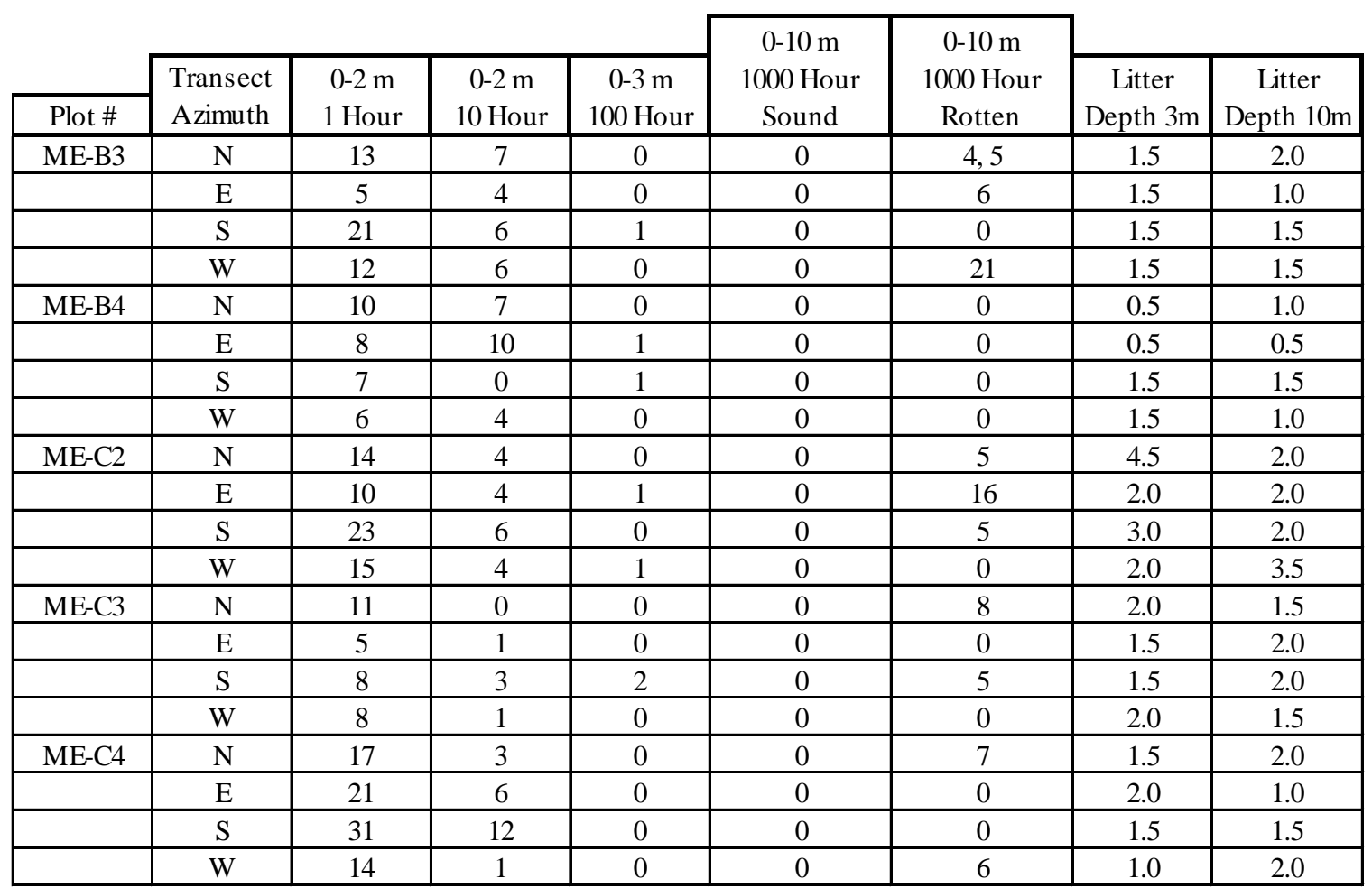

Date:8/4,5,6,10,11,12/09

Crew:Soderlund, Estrada, Hedge

Page 222 


\section{MHDSF Giant Sequoia Manipulation Study \\ 2009 - Fuels Raw Data (4 Transects)}

Stand: Tub Flats

Depth and 1000 hour fuel diameters in inches.

\begin{tabular}{|c|c|c|c|c|c|c|c|c|}
\hline & \multirow[b]{2}{*}{$\begin{array}{l}\text { Transect } \\
\text { Azimuth }\end{array}$} & \multirow[b]{2}{*}{$\begin{array}{c}0-2 \mathrm{~m} \\
1 \text { Hour }\end{array}$} & \multirow[b]{2}{*}{$\begin{array}{c}\text { 0-2 m } \\
10 \text { Hour }\end{array}$} & \multirow[b]{2}{*}{$\begin{array}{c}0-3 \mathrm{~m} \\
100 \text { Hour }\end{array}$} & \multirow{2}{*}{$\begin{array}{c}0-10 \mathrm{~m} \\
1000 \text { Hour } \\
\text { Sound }\end{array}$} & \multirow{2}{*}{$\begin{array}{c}\text { 0-10 m } \\
1000 \text { Hour } \\
\text { Rotten }\end{array}$} & \multirow[b]{2}{*}{$\begin{array}{c}\text { Litter } \\
\text { Depth 3m }\end{array}$} & \multirow[b]{2}{*}{$\begin{array}{c}\text { Litter } \\
\text { Depth } 10 \mathrm{~m}\end{array}$} \\
\hline Plot \# & & & & & & & & \\
\hline \multirow[t]{4}{*}{ TF-A1 } & $\mathrm{N}$ & 18 & 6 & 2 & 0 & 4 & 4.0 & 2.0 \\
\hline & $E$ & 9 & 2 & 1 & 0 & 61,4 & 3.0 & 2.0 \\
\hline & $\mathrm{S}$ & 6 & 0 & 0 & 20 & 0 & 2.5 & 2.0 \\
\hline & $\mathrm{W}$ & 3 & 0 & 0 & 0 & 0 & Rock & 4.0 \\
\hline \multirow[t]{4}{*}{ TF-B1 } & $\mathrm{N}$ & 31 & 5 & 1 & 0 & 8 & 2.5 & 1.0 \\
\hline & $E$ & 24 & 5 & 0 & 0 & 4 & 2.0 & 4.5 \\
\hline & $\mathrm{S}$ & 24 & 5 & 0 & 0 & $47,9,4$ & 1.5 & 1.0 \\
\hline & $\mathrm{W}$ & 33 & 6 & 0 & 0 & 5 & BG & 3.5 \\
\hline \multirow[t]{4}{*}{ TF-C1 } & $\mathrm{N}$ & 14 & 13 & 4 & 0 & 4 & 2.5 & 2.0 \\
\hline & $E$ & 12 & 6 & 1 & 0 & 0 & 2.0 & 3.0 \\
\hline & $\mathrm{S}$ & 7 & 3 & 0 & 0 & 0 & 2.0 & BG \\
\hline & $\mathrm{W}$ & 7 & 0 & 0 & 0 & 0 & 3.0 & 2.0 \\
\hline
\end{tabular}

Date: 8/12,13/09

Crew: Soderlund, Hedge 


\section{APPENDIX F}

Regeneration Data

Page 224 
MHDSF Giant Sequoia Manipulation Study

2009 - Seedling Raw Data Set (19.7ft (6m) Plot)

Stand: Bogus Meadow

Crew: Soderlund, Hedge

Date: 8/26,31 \& 9/1/09

BM-A1

Totals/ 1 Foot Height Class
BM-A2

Totals/ 1 Foot Height Class

\begin{tabular}{|c|c|c|c|c|}
\hline & WF & IC & BO & SP \\
\hline 0 & 32 & 0 & 0 & 0 \\
\hline 1 & 6 & 0 & 0 & 0 \\
\hline 2 & 9 & 0 & 0 & 0 \\
\hline 3 & 0 & 0 & 0 & 0 \\
\hline 4 & 0 & 0 & 0 & 0 \\
\hline 5[ & 0 & 0 & 0 & 0 \\
\hline \multicolumn{5}{|c|}{ TOTALS/SPECIES } \\
\hline & WF & IC & BO & SP \\
\hline & 47 & 0 & 0 & 0 \\
\hline
\end{tabular}

\begin{tabular}{|c|c|c|c|}
\hline WF & IC & $\mathrm{BO}$ & SP \\
\hline 10 & 0 & 0 & 0 \\
\hline 0 & 0 & 0 & 0 \\
\hline 0 & 0 & 0 & 0 \\
\hline 0 & 0 & 0 & 0 \\
\hline 1 & 0 & 0 & 0 \\
\hline 0 & 0 & 0 & 0 \\
\hline \multicolumn{4}{|c|}{ TOTALS/SPECIES } \\
\hline WF & IC & $\mathrm{BO}$ & SP \\
\hline 11 & 0 & 0 & 0 \\
\hline
\end{tabular}

BM-B1

Totals/ 1 Foot Height Class
BM-B2

Totals/ 1 Foot Height Class

\begin{tabular}{|c|c|c|c|c|}
\hline & WF & IC & $\mathrm{BO}$ & SP \\
\hline 0 & 23 & 0 & 0 & 0 \\
\hline 1 & 2 & 0 & 0 & 0 \\
\hline 2 & 2 & 0 & 0 & 0 \\
\hline 3 & 3 & 0 & 0 & 0 \\
\hline 4 & 4 & 1 & 0 & 0 \\
\hline 5 & 0 & 0 & 0 & 0 \\
\hline \multicolumn{5}{|c|}{ TOTALS/SPECIES } \\
\hline & WF & IC & $\mathrm{BO}$ & SP \\
\hline & 34 & 1 & 0 & 0 \\
\hline
\end{tabular}

\begin{tabular}{c|cccc|}
\multicolumn{1}{c}{ WF } & IC & BO & SP \\
\hline 0 & 23 & 0 & 0 & 0 \\
1 & 66 & 1 & 0 & 0 \\
2 & 117 & 0 & 0 & 0 \\
3 & 29 & 0 & 0 & 0 \\
4 & 7 & 0 & 0 & 0 \\
5 & 0 & 0 & 0 & 0 \\
\hline
\end{tabular}

BM-C1

Totals/ 1 Foot Height Class
BM-C2

Totals/ 1 Foot Height Class

\begin{tabular}{|c|c|c|c|c|c|c|c|c|c|}
\hline & WF & IC & $\mathrm{BO}$ & SP & & WF & IC & $\mathrm{BO}$ & SP \\
\hline 0 & 54 & 0 & 0 & 1 & 0 & 60 & 0 & 1 & 1 \\
\hline 1 & 0 & 0 & 0 & 0 & 1 & 0 & 0 & 0 & 0 \\
\hline 2 & 0 & 0 & 0 & 0 & 2 & 0 & 0 & 0 & 0 \\
\hline 3 & 0 & 0 & 0 & 0 & 3 & 0 & 0 & 0 & 0 \\
\hline 4 & 0 & 0 & 0 & 0 & 4 & 0 & 0 & 0 & 0 \\
\hline 5[ & 0 & 0 & 0 & 0 & 5 & 0 & 0 & 0 & 0 \\
\hline \multicolumn{5}{|c|}{ TOTALS/SPECIES } & \multicolumn{5}{|c|}{ TOTALS/SPECIES } \\
\hline & WF & IC & $\mathrm{BO}$ & SP & & WF & IC & $\mathrm{BO}$ & SP \\
\hline & 54 & 0 & 0 & 1 & & 60 & 0 & 1 & 1 \\
\hline
\end{tabular}


MHDSF Giant Sequoia Manipulation Study 2009 - Regeneration Summary Data (19.7ft (6m) Plot)

Stand: Bogus Meadow

Crew: Soderlund, Hedge

Date: $8 / 26,27,28,31$ \& 9/1/09

BM-A1, BM-A2 Treatment - Thinned

\begin{tabular}{r|cccc|c}
\multicolumn{1}{l}{} & WF & IC & BO & SP & TOTAL \\
\hline 0 & 42 & 0 & 0 & 0 & 42 \\
1 & 6 & 0 & 0 & 0 & 6 \\
2 & 9 & 0 & 0 & 0 & 9 \\
3 & 0 & 0 & 0 & 0 & 0 \\
4 & 1 & 0 & 0 & 0 & 1 \\
5 & 0 & 0 & 0 & 0 & 0 \\
\cline { 2 - 6 } TOTAL & 58 & 0 & 0 & 0 & $\mathbf{5 8}$
\end{tabular}

\begin{tabular}{cc}
\multicolumn{1}{c}{ Ht. Class } & \\
0 & $0-0.9$ feet \\
1 & $1-1.9$ feet \\
2 & $2-2.9$ feet \\
3 & $3-3.9$ feet \\
4 & $4-4.9$ feet \\
5 & Over 5 feet
\end{tabular}

BM-B1, BM-B2 Treatment - Thinned/Burned

\begin{tabular}{r|cccc|c}
\multicolumn{1}{r}{} & WF & IC & BO & SP & TOTAL \\
\hline 0 & 46 & 0 & 0 & 0 & 46 \\
1 & 68 & 1 & 0 & 0 & 69 \\
2 & 119 & 0 & 0 & 0 & 119 \\
3 & 32 & 0 & 0 & 0 & 32 \\
4 & 11 & 1 & 0 & 0 & 12 \\
5 & 0 & 0 & 0 & 0 & 0 \\
\cline { 2 - 6 } TOTAL & 276 & 2 & 0 & 0 & $\mathbf{2 7 8}$
\end{tabular}

BM-C1, BM-C2 Treatment - Control

\begin{tabular}{r|cccc|c}
\multicolumn{1}{l}{} & WF & IC & BO & SP & TOTAL \\
\hline 0 & 114 & 0 & 1 & 2 & 117 \\
1 & 0 & 0 & 0 & 0 & 0 \\
2 & 0 & 0 & 0 & 0 & 0 \\
3 & 0 & 0 & 0 & 0 & 0 \\
4 & 0 & 0 & 0 & 0 & 0 \\
5 & 0 & 0 & 0 & 0 & 0 \\
\cline { 2 - 7 } TOTAL & 114 & 0 & 1 & 2 & $\mathbf{1 1 7}$
\end{tabular}

Total Number of Seedlings/ Height Class/ Entire Stand

\begin{tabular}{c|ccccc|}
\multicolumn{1}{l}{} & WF & IC & BO & SP \\
\hline 0 & 202 & 0 & 1 & 2 \\
1 & 74 & 1 & 0 & 0 \\
2 & 128 & 0 & 0 & 0 \\
3 & 32 & 0 & 0 & 0 \\
4 & 12 & 1 & 0 & 0 \\
5 & 0 & 0 & 0 & 0 \\
\hline
\end{tabular}

Total Number of Seedlings for Entire Stand

\begin{tabular}{cccc} 
WF & IC & BO & SP \\
\hline 448 & 2 & 1 & 2
\end{tabular}


MHDSF Giant Sequoia Manipulation Study

2009 - Seedling Raw Data Set (19.7ft (6m) Plot)

Stand: Frasier Mill

Crew: Soderlund, Bean

Date: 8/19,20,21,24,25/09

FM-A1

Totals/ 1 Foot Height Class
FM-B1

Totals/ 1 Foot Height Class

\begin{tabular}{|c|c|c|c|c|c|}
\hline & WF & IC & $\mathrm{BO}$ & SP & GS \\
\hline 0 & 10 & 0 & 0 & 0 & 0 \\
\hline 1 & 3 & 0 & 0 & 0 & 0 \\
\hline 2 & 0 & 0 & 0 & 0 & 1 \\
\hline 3 & 0 & 0 & 0 & 0 & 0 \\
\hline 4 & 0 & 0 & 0 & 0 & 0 \\
\hline 5 & 0 & 0 & 0 & 0 & 0 \\
\hline \multicolumn{6}{|c|}{ TOTALS/SPECIES } \\
\hline & WF & IC & $\mathrm{BO}$ & SP & GS \\
\hline & 13 & 0 & 0 & 0 & 1 \\
\hline
\end{tabular}

\begin{tabular}{c|ccc|}
\multicolumn{1}{c}{ WF } & IC & SP \\
\hline 0 & 30 & 1 & 0 \\
1 & 1 & 1 & 1 \\
2 & 1 & 0 & 0 \\
3 & 0 & 0 & 0 \\
4 & 0 & 0 & 0 \\
5 & 0 & 0 & 0 \\
\hline
\end{tabular}

FM-A2

Totals/ 1 Foot Height Class
FM-B2

Totals/ 1 Foot Height Class

\begin{tabular}{|c|c|c|c|c|c|}
\hline & WF & IC & BO & SP & GS \\
\hline 0 & 24 & 5 & 0 & 1 & 0 \\
\hline 1 & 78 & 4 & 0 & 0 & 0 \\
\hline 2 & 66 & 1 & 0 & 1 & 0 \\
\hline 3 & 44 & 0 & 0 & 0 & 0 \\
\hline 4 & 23 & 0 & 0 & 0 & 0 \\
\hline 5[ & 10 & 0 & 0 & 0 & 0 \\
\hline \multicolumn{6}{|c|}{ TOTALS/SPECIES } \\
\hline & WF & IC & $\mathrm{BO}$ & SP & GS \\
\hline & 245 & 10 & 0 & 2 & 0 \\
\hline
\end{tabular}

\begin{tabular}{|c|c|c|}
\hline WF & IC & SP \\
\hline 69 & 0 & 0 \\
\hline 97 & 0 & 1 \\
\hline 36 & 0 & 0 \\
\hline 18 & 0 & 0 \\
\hline 6 & 0 & 0 \\
\hline 3 & 0 & 0 \\
\hline \multicolumn{3}{|c|}{ TOTALS/SPECIES } \\
\hline WF & IC & SP \\
\hline 229 & 0 & 1 \\
\hline
\end{tabular}

FM-C1

Totals/ 1 Foot Height Class
FM-C2

Totals/ 1 Foot Height Class

\begin{tabular}{|c|c|c|c|c|}
\hline WF & IC & $\mathrm{BO}$ & SP & GS \\
\hline 6 & 0 & 2 & 0 & 0 \\
\hline 1 & 0 & 0 & 0 & 0 \\
\hline 2 & 0 & 0 & 0 & 0 \\
\hline 0 & 0 & 0 & 0 & 0 \\
\hline 1 & 0 & 0 & 0 & 0 \\
\hline 0 & 0 & 0 & 0 & 0 \\
\hline \multicolumn{5}{|c|}{ TOTALS/SPECIES } \\
\hline WF & IC & BO & SP & GS \\
\hline 10 & 0 & 2 & 0 & 0 \\
\hline
\end{tabular}

\begin{tabular}{c|ccc|}
\multicolumn{1}{c}{ WF } & IC & SP \\
\hline 0 & 0 & 0 & 0 \\
1 & 0 & 0 & 0 \\
2 & 0 & 0 & 0 \\
3 & 0 & 0 & 0 \\
4 & 0 & 0 & 0 \\
5 & 0 & 0 & 0 \\
\hline \multirow{5}{*}{ TOTALS/SPECIES } \\
\multicolumn{5}{c}{ WF } & IC & SP \\
\hline & 0 & 0 & 0
\end{tabular}


MHDSF Giant Sequoia Manipulation Study 2009 - Regeneration Summary Data (19.7ft (6m) Plot)

Stand: Frasier Mill

Crew: Soderlund, Bean

Date: 8/19,20,21,24,25/09

FM-A1, FM-B1

Treatment: Thinned

\begin{tabular}{r|ccccc|c}
\multicolumn{1}{l}{} & WF & IC & BO & SP & GS & TOTAL \\
\hline 0 & 40 & 1 & 0 & 0 & 0 & 41 \\
1 & 4 & 1 & 0 & 1 & 0 & 6 \\
2 & 1 & 0 & 0 & 0 & 1 & 2 \\
3 & 0 & 0 & 0 & 0 & 0 & 0 \\
4 & 0 & 0 & 0 & 0 & 0 & 0 \\
5 & 0 & 0 & 0 & 0 & 0 & 0 \\
\cline { 2 - 7 } TOTAL & 45 & 2 & 0 & 1 & 1 & $\mathbf{4 9}$
\end{tabular}

Ht. Class

FM-A2, FM-B2 Treatment: Thinned/ Burned

\begin{tabular}{r|ccccc|c}
\multicolumn{1}{l}{} & WF & IC & BO & SP & GS & TOTAL \\
\hline 0 & 93 & 5 & 0 & 1 & 0 & 99 \\
1 & 175 & 4 & 0 & 1 & 0 & 180 \\
2 & 102 & 1 & 0 & 1 & 0 & 104 \\
3 & 62 & 0 & 0 & 0 & 0 & 62 \\
4 & 29 & 0 & 0 & 0 & 0 & 29 \\
5 & 13 & 0 & 0 & 0 & 0 & 13 \\
\cline { 2 - 7 } TOTAL & 474 & 10 & 0 & 3 & 0 & $\mathbf{4 8 7}$
\end{tabular}

FM-C1, FM-C2 Treatment: Control

\begin{tabular}{r|ccccc|c}
\multicolumn{1}{l}{} & WF & IC & BO & SP & GS & TOTAL \\
\hline 0 & 6 & 0 & 2 & 0 & 0 & 8 \\
1 & 1 & 0 & 0 & 0 & 0 & 1 \\
2 & 2 & 0 & 0 & 0 & 0 & 2 \\
3 & 0 & 0 & 0 & 0 & 0 & 0 \\
4 & 1 & 0 & 0 & 0 & 0 & 1 \\
5 & 0 & 0 & 0 & 0 & 0 & 0 \\
\hline \multirow{2}{*}{ TOTAL } & 10 & 0 & 2 & 0 & 0 & $\mathbf{1 2}$
\end{tabular}

Total Number of Seedlings/ Height Class/ Entire Stand

\begin{tabular}{c|ccccc|}
\multicolumn{1}{l}{} & WF & IC & BO & SP & GS \\
\hline 0 & 139 & 6 & 2 & 1 & 0 \\
1 & 180 & 5 & 0 & 2 & 0 \\
2 & 105 & 1 & 0 & 1 & 1 \\
3 & 62 & 0 & 0 & 0 & 0 \\
4 & 30 & 0 & 0 & 0 & 0 \\
5 & 13 & 0 & 0 & 0 & 0 \\
\hline
\end{tabular}

Total Number of Seedlings for Entire Stand

\begin{tabular}{ccccc} 
WF & IC & BO & SP & GS \\
\hline 529 & 12 & 2 & 4 & 1
\end{tabular}


MHDSF Giant Sequoia Manipulation Study 2009 - Regeneration Raw Data Set and Summary (19.7ft (6m) Plot)

Stand: Headquarters

Crew: Soderlund, Estrada

Date: 8/3,4/09

HQ-A1

Treatment - Thinned

Totals/ 1 Foot Height Class

\begin{tabular}{|c|c|c|c|c|c|}
\hline & WF & IC & $\mathrm{BO}$ & SP & TOTAL \\
\hline 0 & 34 & 6 & 1 & 0 & 41 \\
\hline 1 & 6 & 0 & 0 & 0 & 6 \\
\hline 2 & 2 & 0 & 0 & 0 & 2 \\
\hline 3 & 0 & 0 & 0 & 0 & 0 \\
\hline 4 & 1 & 0 & 0 & 0 & 1 \\
\hline 5 & 0 & 0 & 0 & 0 & 0 \\
\hline TOTAL & 43 & 6 & 1 & 0 & 50 \\
\hline
\end{tabular}

Ht. Class

HQ-B1 Treatment - Thinned/ Burned Totals/ 1 Foot Height Class

\begin{tabular}{|c|c|c|c|c|c|}
\hline & WF & IC & $\mathrm{BO}$ & SP & TOTAL \\
\hline 0 & 231 & 0 & 0 & 0 & 231 \\
\hline 1 & 6 & 1 & 0 & 0 & 7 \\
\hline 2 & 3 & 0 & 0 & 0 & 3 \\
\hline 3 & 4 & 0 & 0 & 0 & 4 \\
\hline 4 & 2 & 0 & 0 & 0 & 2 \\
\hline 5 & 1 & 0 & 0 & 0 & 1 \\
\hline TOTAL & 247 & 1 & 0 & 0 & 248 \\
\hline
\end{tabular}

HQ-C1

Treatment - Control

Totals/ 1 Foot Height Class

\begin{tabular}{r|cccc|c}
\multicolumn{1}{l}{} & WF & IC & BO & SP & TOTAL \\
\hline 0 & 25 & 6 & 4 & 0 & 35 \\
1 & 5 & 0 & 0 & 0 & 5 \\
2 & 1 & 0 & 0 & 0 & 1 \\
3 & 2 & 0 & 0 & 0 & 2 \\
4 & 1 & 0 & 0 & 0 & 1 \\
5 & 0 & 0 & 0 & 0 & 0 \\
\hline \multirow{2}{*}{ TOTAL } & 34 & 6 & 4 & 0 & $\mathbf{4 4}$
\end{tabular}

Total Number of Seedlings/ Height Class/ Entire Stand

\begin{tabular}{c|ccccc}
\multicolumn{1}{l}{} & WF & IC & BO & SP \\
\hline 0 & 290 & 12 & 5 & 0 \\
1 & 17 & 1 & 0 & 0 \\
2 & 6 & 0 & 0 & 0 \\
3 & 6 & 0 & 0 & 0 \\
4 & 4 & 0 & 0 & 0 \\
5 & 1 & 0 & 0 & 0 \\
\hline
\end{tabular}

Total Number of Seedlings for Entire Stand

\begin{tabular}{cccc} 
WF & IC & BO & SP \\
\hline 324 & 13 & 5 & 0
\end{tabular}


MHDSF Giant Sequoia Manipulation Study

2009 - Seedling Raw Data Set (19.7ft (6m) Plot)

Stand: Indian Bath

Crew: Soderlund, Estrada, Bean

Date: 8/14,17,18/09

IB-A1

Totals/ 1 Foot Height Class

IB-B1

Totals/ 1 Foot Height Class

\begin{tabular}{|c|c|c|c|c|}
\hline & WF & IC & $\mathrm{BO}$ & SP \\
\hline 0 & 7 & 0 & 0 & 0 \\
\hline 1 & 0 & 0 & 0 & 0 \\
\hline 2 & 0 & 0 & 0 & 0 \\
\hline 3 & 0 & 0 & 0 & 0 \\
\hline 4 & 0 & 0 & 0 & 0 \\
\hline 5 & 0 & 0 & 0 & 0 \\
\hline \multicolumn{5}{|c|}{ TOTALS/SPECIES } \\
\hline & WF & IC & $\mathrm{BO}$ & SP \\
\hline & 7 & 0 & 0 & 0 \\
\hline
\end{tabular}

\begin{tabular}{c|cccc|}
\multicolumn{1}{c}{ WF } & BO & SP & GS \\
\hline 0 & 3 & 1 & 2 & 0 \\
1 & 0 & 0 & 0 & 1 \\
2 & 0 & 0 & 0 & 0 \\
3 & 0 & 0 & 0 & 0 \\
4 & 0 & 0 & 0 & 0 \\
5 & 0 & 0 & 0 & 0 \\
\hline
\end{tabular}

IB-A2

Totals/ 1 Foot Height Class
IB-B2

Totals/ 1 Foot Height Class

\begin{tabular}{|c|c|c|c|c|}
\hline & WF & IC & $\mathrm{BO}$ & SP \\
\hline 0 & 28 & 0 & 1 & 0 \\
\hline 1 & 0 & 0 & 0 & 0 \\
\hline 2 & 0 & 0 & 0 & 0 \\
\hline 3 & 0 & 0 & 0 & 0 \\
\hline 4 & 0 & 0 & 0 & 0 \\
\hline 5[ & 0 & 0 & 0 & 0 \\
\hline \multicolumn{5}{|c|}{ TOTALS/SPECIES } \\
\hline & WF & IC & $\mathrm{BO}$ & SP \\
\hline & 28 & 0 & 1 & 0 \\
\hline
\end{tabular}

\begin{tabular}{c|cccc|}
\multicolumn{1}{c}{ WF } & BO & SP & GS \\
\hline 0 & 150 & 0 & 7 & 0 \\
1 & 13 & 0 & 0 & 0 \\
2 & 1 & 0 & 0 & 0 \\
3 & 0 & 0 & 0 & 0 \\
4 & 0 & 0 & 0 & 0 \\
5 & 0 & 0 & 0 & 0 \\
\hline
\end{tabular}

IB-C1

Totals/ 1 Foot Height Class
IB-C2

Totals/ 1 Foot Height Class

\begin{tabular}{|c|c|c|c|c|}
\hline & WF & IC & $\mathrm{BO}$ & SP \\
\hline 0 & 13 & 0 & 1 & 0 \\
\hline 1 & 1 & 0 & 0 & 0 \\
\hline 2 & 0 & 0 & 0 & 0 \\
\hline 3 & 0 & 0 & 0 & 0 \\
\hline 4 & 0 & 0 & 0 & 0 \\
\hline 5[ & 0 & 0 & 0 & 0 \\
\hline \multicolumn{5}{|c|}{ TOTALS/SPECIES } \\
\hline & WF & IC & $\mathrm{BO}$ & SP \\
\hline & 14 & 0 & 1 & 0 \\
\hline
\end{tabular}

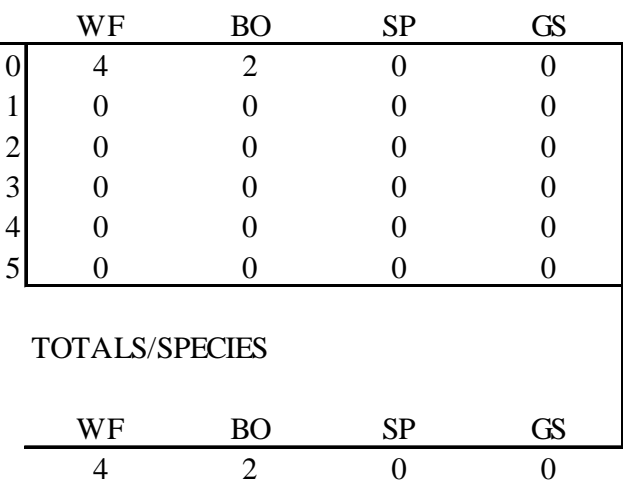


MHDSF Giant Sequoia Manipulation Study 2009 - Regeneration Summary Data (19.7ft (6m) Plot)

Stand: Indian Bath

Crew: Soderlund, Estrada, Bean

Date: 8/14,17,18/09

IB-A-1, IB-B1

\begin{tabular}{r|ccccc|c}
\multicolumn{1}{l}{} & WF & IC & BO & SP & GS & TOTAL \\
\hline 0 & 10 & 0 & 1 & 2 & 0 & 13 \\
1 & 0 & 0 & 0 & 0 & 1 & 1 \\
2 & 0 & 0 & 0 & 0 & 0 & 0 \\
3 & 0 & 0 & 0 & 0 & 0 & 0 \\
4 & 0 & 0 & 0 & 0 & 0 & 0 \\
5 & 0 & 0 & 0 & 0 & 0 & 0 \\
\cline { 2 - 7 } TOTAL & 10 & 0 & 1 & 2 & 1 & $\mathbf{1 4}$
\end{tabular}

Ht. Class

$\begin{array}{ll}0 & 0-0.9 \text { feet } \\ 1 & 1-1.9 \text { feet } \\ 2 & 2-2.9 \text { feet } \\ 3 & 3-3.9 \text { feet } \\ 4 & 4-4.9 \text { feet } \\ 5 & \text { Over } 5 \text { feet }\end{array}$

IB-A2, IB-B2

\begin{tabular}{r|cccccc|c}
\multicolumn{2}{l}{} & WF & IC & BO & SP & GS & TOTAL \\
\hline & 0 & 178 & 0 & 1 & 7 & 0 & 186 \\
1 & 13 & 0 & 0 & 0 & 0 & 13 \\
2 & 1 & 0 & 0 & 0 & 0 & 1 \\
3 & 0 & 0 & 0 & 0 & 0 & 0 \\
& 4 & 0 & 0 & 0 & 0 & 0 & 0 \\
TOTAL & 5 & 0 & 0 & 0 & 0 & 0 & 0 \\
\cline { 2 - 8 } & 192 & 0 & 1 & 7 & 0 & $\mathbf{2 0 0}$
\end{tabular}

IB-C1, IB-C2

\begin{tabular}{r|ccccc|c}
\multicolumn{1}{l}{} & WF & IC & BO & SP & GS & TOTAL \\
\hline 0 & 17 & 0 & 3 & 0 & 0 & 20 \\
1 & 1 & 0 & 0 & 0 & 0 & 1 \\
2 & 0 & 0 & 0 & 0 & 0 & 0 \\
3 & 0 & 0 & 0 & 0 & 0 & 0 \\
4 & 0 & 0 & 0 & 0 & 0 & 0 \\
5 & 0 & 0 & 0 & 0 & 0 & 0 \\
\cline { 2 - 7 } TOTAL & 18 & 0 & 3 & 0 & 0 & $\mathbf{2 1}$
\end{tabular}

Total Number of Seedlings/ Height Class/ Entire Stand

\begin{tabular}{c|cccccc|}
\multicolumn{1}{l}{} & WF & IC & BO & SP & GS \\
\hline 0 & 205 & 0 & 5 & 9 & 0 \\
1 & 14 & 0 & 0 & 0 & 1 \\
2 & 1 & 0 & 0 & 0 & 0 \\
3 & 0 & 0 & 0 & 0 & 0 \\
4 & 0 & 0 & 0 & 0 & 0 \\
5 & 0 & 0 & 0 & 0 & 0 \\
\hline
\end{tabular}

Total Number of Seedlings for Entire Stand

\begin{tabular}{ccccc} 
WF & IC & BO & SP & GS \\
\hline 220 & 0 & 5 & 9 & 1
\end{tabular}


MHDSF Giant Sequoia Manipulation Study 2009 - Regeneration Raw Data Set (19.7ft (6m) Plot)

Stand: Methuselah

Crew: Soderlund, Estrada, Hedge

Date: 8/4,5,6,7,10,11,12/09

ME-A1

Totals/ 1 Foot Height Class
ME-A2

Totals/ 1 Foot Height Class

\begin{tabular}{|c|c|c|c|c|}
\hline & WF & IC & $\mathrm{BO}$ & GS \\
\hline 0 & 37 & 14 & 18 & 0 \\
\hline 1 & 6 & 3 & 2 & 0 \\
\hline 2 & 1 & 1 & 0 & 0 \\
\hline 3 & 2 & 1 & 0 & 0 \\
\hline 4 & 0 & 0 & 1 & 0 \\
\hline 5 & 1 & 1 & 1 & 0 \\
\hline \multicolumn{5}{|c|}{ TOTALS/SPECIES } \\
\hline & WF & IC & $\mathrm{BO}$ & GS \\
\hline & 47 & 20 & 22 & 0 \\
\hline
\end{tabular}

\begin{tabular}{|c|c|c|c|c|}
\hline WF & IC & $\mathrm{BO}$ & SP & GS \\
\hline 20 & 10 & 0 & 2 & 0 \\
\hline 13 & 1 & 1 & 2 & 0 \\
\hline 5 & 5 & 1 & 0 & 0 \\
\hline 7 & 1 & 0 & 0 & 2 \\
\hline 3 & 3 & 0 & 0 & 1 \\
\hline 4 & 1 & 0 & 0 & 1 \\
\hline \multicolumn{5}{|c|}{ TOTALS/SPECIES } \\
\hline WF & IC & $\mathrm{BO}$ & SP & GS \\
\hline 52 & 21 & 2 & 4 & 4 \\
\hline
\end{tabular}

ME-A3

Totals/ 1 Foot Height Class
ME-A4

Totals/ 1 Foot Height Class

\begin{tabular}{|c|c|c|c|c|c|c|c|c|c|c|}
\hline & WF & IC & $\mathrm{BO}$ & SP & $\mathrm{PP}$ & & WF & IC & $\mathrm{BO}$ & GS \\
\hline 0 & 9 & 1 & 3 & 2 & 0 & 0 & 25 & 0 & 5 & 0 \\
\hline 1 & 3 & 1 & 1 & 0 & 0 & 1 & 2 & 1 & 0 & 0 \\
\hline 2 & 3 & 1 & 0 & 0 & 1 & 2 & 2 & 1 & 0 & 0 \\
\hline 3 & 2 & 1 & 0 & 1 & 0 & 3 & 1 & 0 & 0 & 0 \\
\hline 4 & 1 & 1 & 0 & 0 & 0 & 4 & 1 & 1 & 0 & 1 \\
\hline 5 & 0 & 2 & 0 & 0 & 0 & 5 & 0 & 2 & 0 & 0 \\
\hline \multicolumn{6}{|c|}{ TOTALS/SPECIES } & \multicolumn{5}{|c|}{ TOTALS/SPECIES } \\
\hline & WF & IC & $\mathrm{BO}$ & SP & PP & & WF & IC & $\mathrm{BO}$ & GS \\
\hline & 18 & 7 & 4 & 3 & 1 & & 31 & 5 & 5 & 1 \\
\hline
\end{tabular}

ME-B1

Totals/ 1 Foot Height Class
ME-B2

Totals/ 1 Foot Height Class

\begin{tabular}{|c|c|c|c|c|}
\hline & WF & IC & $\mathrm{BO}$ & SP \\
\hline 0 & 18 & 6 & 1 & 2 \\
\hline 1 & 16 & 0 & 0 & 3 \\
\hline 2 & 2 & 0 & 1 & 1 \\
\hline 3 & 0 & 0 & 0 & 0 \\
\hline 4 & 0 & 0 & 0 & 0 \\
\hline 5 & 0 & 0 & 0 & 0 \\
\hline \multicolumn{5}{|c|}{ TOTALS/SPECIES } \\
\hline & WF & IC & $\mathrm{BO}$ & SP \\
\hline & 36 & 6 & 2 & 6 \\
\hline
\end{tabular}

\begin{tabular}{|c|c|c|c|c|}
\hline WF & IC & $\mathrm{BO}$ & SP & GS \\
\hline 13 & 0 & 1 & 7 & 0 \\
\hline 15 & 1 & 0 & 0 & 0 \\
\hline 1 & 0 & 0 & 0 & 0 \\
\hline 2 & 0 & 1 & 0 & 0 \\
\hline 1 & 0 & 0 & 0 & 0 \\
\hline 0 & 0 & 0 & 0 & 0 \\
\hline \multicolumn{5}{|c|}{ TOTALS/SPECIES } \\
\hline WF & IC & $\mathrm{BO}$ & SP & GS \\
\hline 32 & 1 & 2 & 7 & 0 \\
\hline
\end{tabular}


MHDSF Giant Sequoia Manipulation Study 2009 - Regeneration Raw Data Set (19.7ft (6m) Plot)

Stand: Methuselah

Crew: Soderlund, Estrada, Hedge

Date: 8/4,5,6,7,10,11,12/09

ME-B3

Totals/ 1 Foot Height Class

\begin{tabular}{c|cccc}
\multicolumn{1}{l}{} & WF & IC & BO & SP \\
\hline 0 & 15 & 4 & 2 & 5 \\
1 & 9 & 0 & 1 & 2 \\
2 & 3 & 0 & 0 & 0 \\
3 & 2 & 0 & 0 & 0 \\
4 & 1 & 0 & 0 & 0 \\
5 & 0 & 0 & 0 & 0 \\
\cline { 4 - 5 } & & &
\end{tabular}

TOTALS/SPECIES

\begin{tabular}{cccc} 
WF & IC & BO & SP \\
\hline 30 & 4 & 3 & 7
\end{tabular}

ME-C2

Totals/ 1 Foot Height Class

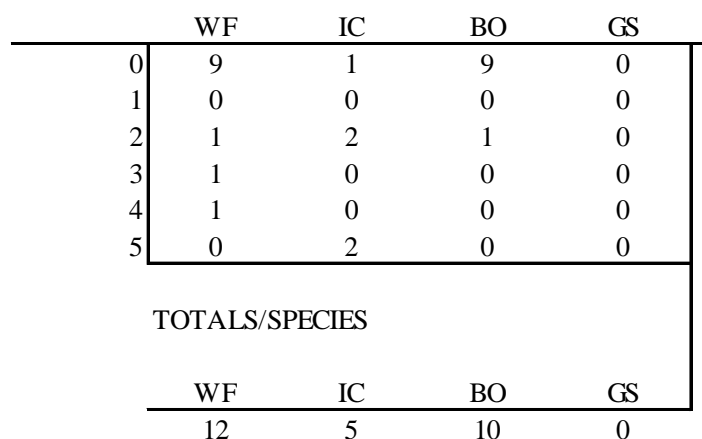

ME-B4

Totals/ 1 Foot Height Class

\begin{tabular}{|c|c|c|c|c|}
\hline WF & IC & $\mathrm{BO}$ & SP & PP \\
\hline 40 & 7 & 1 & 4 & 0 \\
\hline 11 & 1 & 0 & 2 & 0 \\
\hline 2 & 0 & 0 & 0 & 0 \\
\hline 0 & 0 & 0 & 0 & 1 \\
\hline 1 & 0 & 0 & 0 & 0 \\
\hline 0 & 0 & 0 & 0 & 0 \\
\hline \multicolumn{5}{|c|}{ TOTALS/SPECIES } \\
\hline WF & IC & $\mathrm{BO}$ & SP & PP \\
\hline 54 & 8 & 1 & 6 & 1 \\
\hline
\end{tabular}

ME-C3

Totals/ 1 Foot Height Class

\begin{tabular}{|c|c|c|c|c|}
\hline WF & IC & BO & SP & GS \\
\hline \begin{tabular}{l|l|}
0 & 70 \\
\end{tabular} & 3 & 15 & 8 & 0 \\
\hline 1 & 4 & 0 & 2 & 0 \\
\hline 0 & 3 & 0 & 1 & 0 \\
\hline 0 & 3 & 0 & 1 & 0 \\
\hline 0 & 0 & 0 & 0 & 0 \\
\hline 0 & 1 & 0 & 0 & 0 \\
\hline \multicolumn{5}{|c|}{ TOTALS/SPECIES } \\
\hline WF & IC & BO & SP & GS \\
\hline
\end{tabular}

ME-C4

Totals/ 1 Foot Height Class

\begin{tabular}{|c|c|c|c|c|c|}
\hline & WF & IC & $\mathrm{BO}$ & SP & GS \\
\hline 0 & 88 & 16 & 7 & 5 & 0 \\
\hline 1 & 6 & 10 & 2 & 5 & 0 \\
\hline 2 & 2 & 4 & 0 & 1 & 0 \\
\hline 3 & 2 & 0 & 0 & 2 & 0 \\
\hline 4 & 3 & 0 & 0 & 0 & 0 \\
\hline 5\lfloor & 2 & 1 & 0 & 0 & 0 \\
\hline \multicolumn{6}{|c|}{ TOTALS/SPECIES } \\
\hline & WF & IC & $\mathrm{BO}$ & SP & GS \\
\hline & 103 & 31 & 9 & 13 & 0 \\
\hline
\end{tabular}


MHDSF Giant Sequoia Manipulation Study 2009 - Regeneration Summary Data (19.7ft (6m) Plot)

Stand: Methuselah

Crew: Soderlund, Estrada, Hedge

Date: 8/4,5,6,7,10,11,12/09

ME-A1, ME-A2, ME-A3, ME-A4

Treatment: Thinned

\begin{tabular}{r|cccccc|c}
\multicolumn{1}{l}{} & WF & IC & BO & SP & GS & PP & TOTAL \\
\hline 0 & 91 & 25 & 26 & 4 & 0 & 0 & 146 \\
1 & 24 & 6 & 4 & 2 & 0 & 0 & 36 \\
2 & 11 & 8 & 1 & 0 & 0 & 1 & 21 \\
3 & 12 & 3 & 0 & 1 & 2 & 0 & 18 \\
4 & 5 & 5 & 1 & 0 & 2 & 0 & 13 \\
5 & 5 & 6 & 1 & 0 & 1 & 0 & 13 \\
\cline { 2 - 8 } TOTAL & 148 & 53 & 33 & 7 & 5 & 1 & $\mathbf{2 4 7}$
\end{tabular}

\begin{tabular}{cc} 
Ht. Class & \\
\cline { 1 - 1 } 0 & $0-0.9$ feet \\
1 & $1-1.9$ feet \\
2 & $2-2.9$ feet \\
3 & $3-3.9$ feet \\
4 & $4-4.9$ feet \\
5 & Over 5 feet
\end{tabular}

ME-B1, ME-B2, ME-B3, ME-B4

Treatment: Thinned/ Burned

\begin{tabular}{r|ccccc|c|c}
\multicolumn{1}{r}{} & WF & IC & BO & SP & GS & PP & TOTAL \\
\hline 0 & 86 & 17 & 5 & 18 & 0 & 0 & 126 \\
1 & 51 & 2 & 1 & 7 & 0 & 0 & 61 \\
2 & 8 & 0 & 1 & 1 & 0 & 0 & 10 \\
3 & 4 & 0 & 1 & 0 & 0 & 1 & 6 \\
4 & 3 & 0 & 0 & 0 & 0 & 0 & 3 \\
5 & 0 & 0 & 0 & 0 & 0 & 0 & 0 \\
\cline { 2 - 8 } TOTAL & 152 & 19 & 8 & 26 & 0 & 1 & 206
\end{tabular}

ME-C2, ME-C3, ME-C4

Treatment: Control

\begin{tabular}{rr|ccccc|c}
\multicolumn{2}{l}{} & WF & IC & BO & SP & GS & TOTAL \\
\hline 0 & 167 & 20 & 31 & 13 & 0 & 231 \\
1 & 7 & 14 & 2 & 7 & 0 & 30 \\
2 & 3 & 9 & 1 & 2 & 0 & 15 \\
2 & 3 & 3 & 0 & 3 & 0 & 9 \\
3 & 4 & 4 & 0 & 0 & 0 & 0 & 4 \\
& 4 & 2 & 4 & 0 & 0 & 0 & 6 \\
\cline { 2 - 8 } TOTAL & 5 & 186 & 50 & 34 & 25 & 0 & $\mathbf{2 9 5}$
\end{tabular}

Total Number of Seedlings/ Height Class/ Entire Stand

\begin{tabular}{c|ccccccc}
\multicolumn{1}{l}{} & WF & IC & BO & SP & GS & PP \\
\hline 0 & 344 & 62 & 62 & 35 & 0 & 0 \\
1 & 82 & 22 & 7 & 16 & 0 & 0 \\
2 & 22 & 17 & 3 & 3 & 0 & 1 \\
3 & 19 & 6 & 1 & 4 & 2 & 1 \\
4 & 12 & 5 & 1 & 0 & 2 & 0 \\
5 & 7 & 10 & 1 & 0 & 1 & 0 \\
\hline
\end{tabular}

Total Number of Seedlings for Entire Stand

\begin{tabular}{cccccc} 
WF & IC & BO & SP & GS & PP \\
\hline 486 & 122 & 75 & 58 & 5 & 2
\end{tabular}


MHDSF Young-Growth Giant Sequoia Management Strategies Study 2009 - Regeneration Raw Data Set and Summary (19.7ft (6m) Plot)

Stand: Tub Flats

Crew: Soderlund, Hedge

Date: $8 / 13 / 09$

TF-A1

Treatment - Thinned

Totals/ 1 Foot Height Class

\begin{tabular}{r|cccc|c}
\multicolumn{1}{l}{} & WF & IC & BO & SP & TOTAL \\
\hline 0 & 8 & 0 & 0 & 1 & 9 \\
1 & 6 & 0 & 0 & 0 & 6 \\
2 & 0 & 0 & 0 & 0 & 0 \\
3 & 0 & 0 & 0 & 0 & 0 \\
4 & 0 & 0 & 0 & 0 & 0 \\
5 & 0 & 0 & 0 & 0 & 0 \\
\hline \multirow{2}{*}{ TOTAL } & 14 & 0 & 0 & 1 & $\mathbf{1 5}$
\end{tabular}

Ht. Class

$\begin{array}{cc}0 & 0-0.9 \text { feet } \\ 1 & 1-1.9 \text { feet } \\ 2 & 2-2.9 \text { feet } \\ 3 & 3-3.9 \text { feet } \\ 4 & 4-4.9 \text { feet } \\ 5 & \text { Over } 5 \text { feet }\end{array}$

TF-B1

Treatment - Thinned/ Burned Totals/ 1 Foot Height Class

\begin{tabular}{rc|cccc|c}
\multicolumn{2}{l}{} & WF & IC & BO & SP & TOTAL \\
\hline 0 & 77 & 0 & 0 & 1 & 78 \\
1 & 6 & 0 & 0 & 0 & 6 \\
2 & 0 & 0 & 0 & 0 & 0 \\
3 & 0 & 0 & 0 & 0 & 0 \\
4 & 0 & 0 & 0 & 0 & 0 \\
& 5 & 0 & 0 & 0 & 0 & 0 \\
\hline \multirow{2}{*}{ TOTAL } & 53 & 0 & 0 & 1 & $\mathbf{8 4}$
\end{tabular}

TF-C1

Treatment - Control

Totals/ 1 Foot Height Class

\begin{tabular}{rc|cccc|c}
\multicolumn{2}{l}{} & WF & IC & BO & SP & TOTAL \\
\hline 0 & 33 & 0 & 0 & 2 & 35 \\
1 & 0 & 0 & 0 & 0 & 0 \\
2 & 1 & 0 & 0 & 0 & 1 \\
3 & 0 & 0 & 0 & 0 & 0 \\
4 & 0 & 0 & 0 & 0 & 0 \\
& 5 & 0 & 0 & 0 & 0 & 0 \\
\hline \multirow{2}{*}{ TOTAL } & 34 & 0 & 0 & 2 & 36
\end{tabular}

Total Number of Seedlings/ Height Class/ Entire Stand

\begin{tabular}{c|ccccc}
\multicolumn{2}{l}{} & WF & IC & BO & SP \\
\hline 0 & 118 & 0 & 0 & 4 \\
1 & 12 & 0 & 0 & 0 \\
2 & 1 & 0 & 0 & 0 \\
3 & 0 & 0 & 0 & 0 \\
4 & 0 & 0 & 0 & 0 \\
5 & 0 & 0 & 0 & 0 \\
\cline { 3 - 5 } & & &
\end{tabular}

Total Number of Seedlings for Entire Stand

\begin{tabular}{cccc} 
WF & IC & BO & SP \\
\hline 131 & 0 & 0 & 4
\end{tabular}


APPENDIX G

Regeneration TPA Graphs

Located in Supplementary Files

Page 236 


\section{APPENDIX H}

\section{Plot Maps}

Page 237 


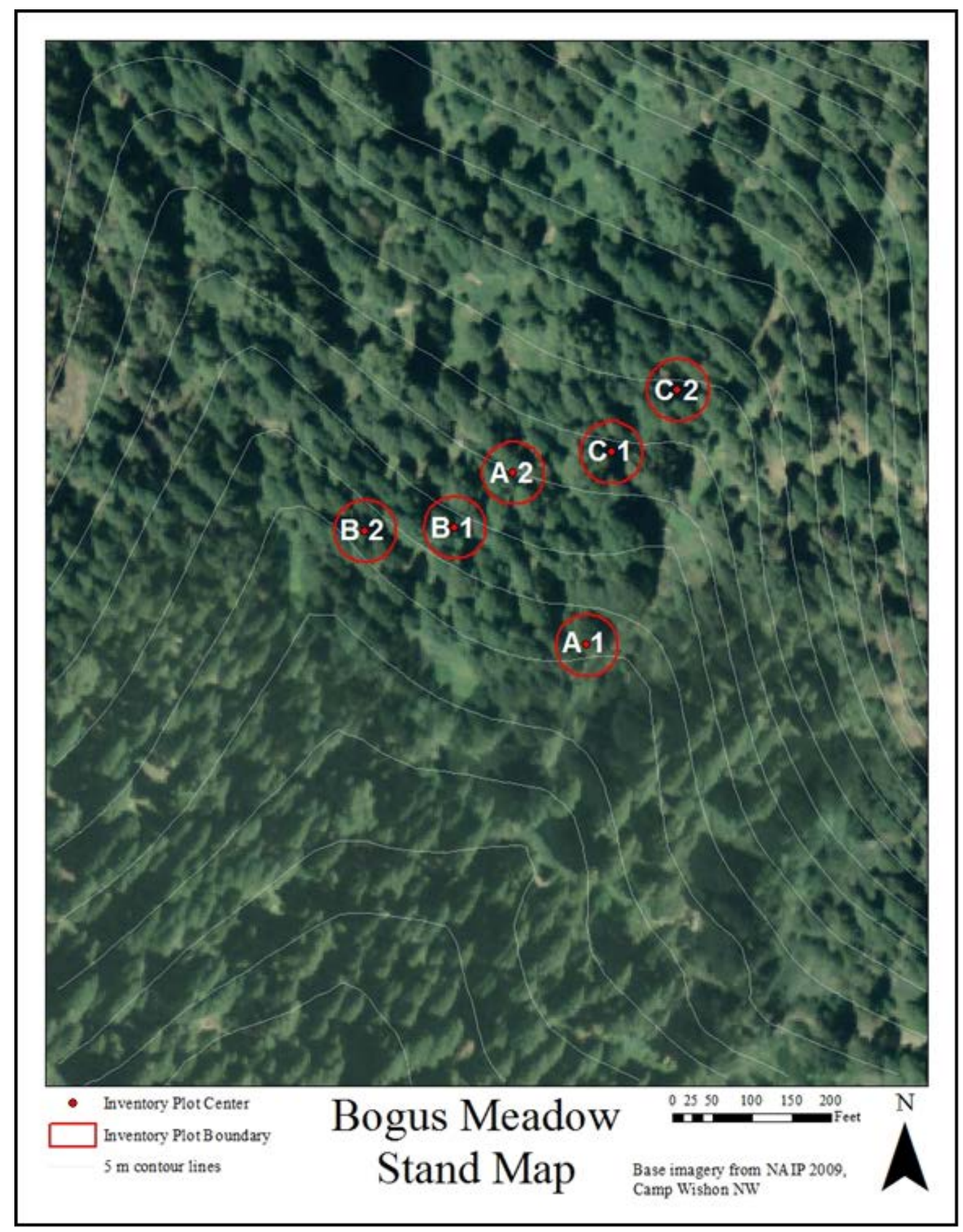

Page 238 


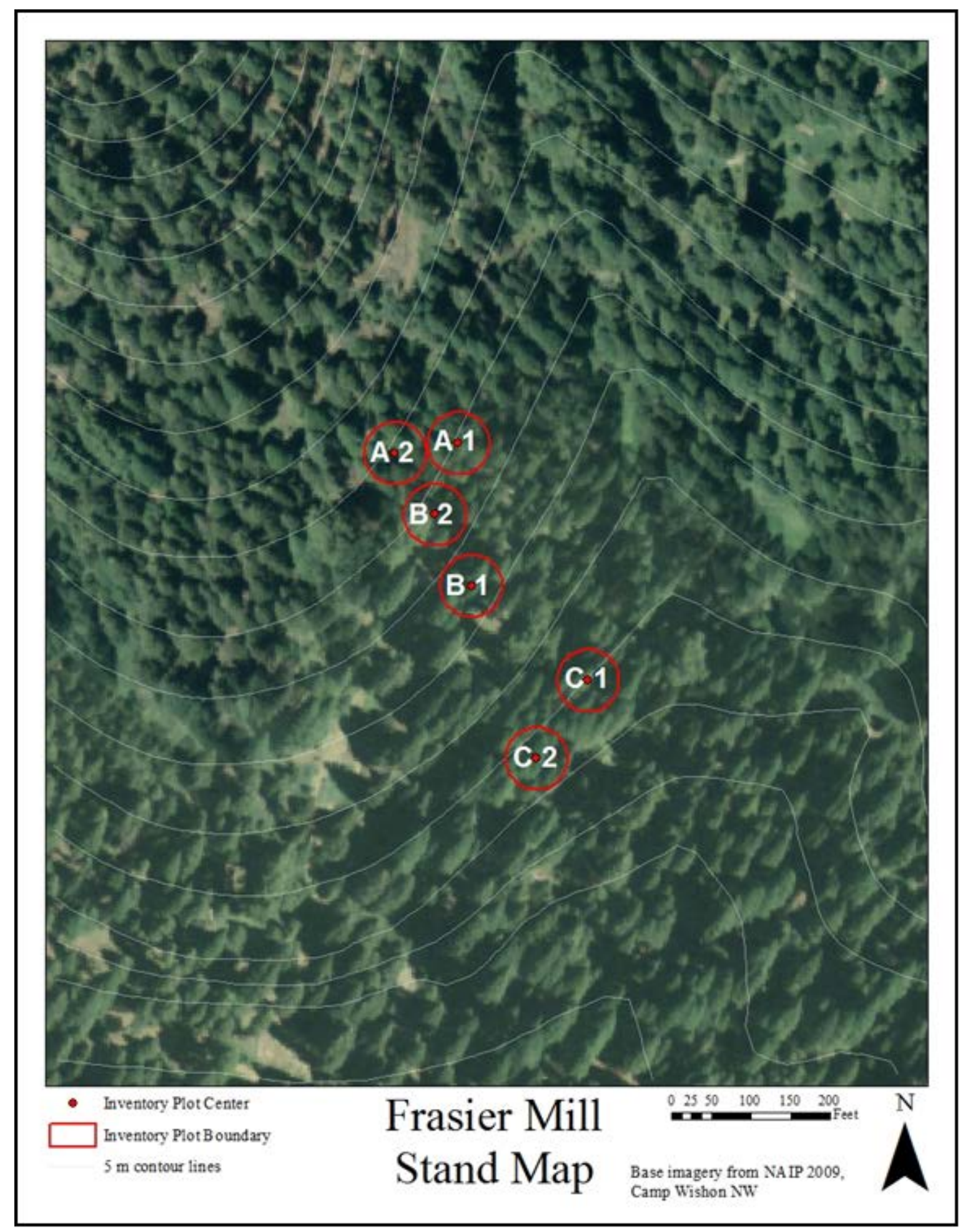

Page 239 


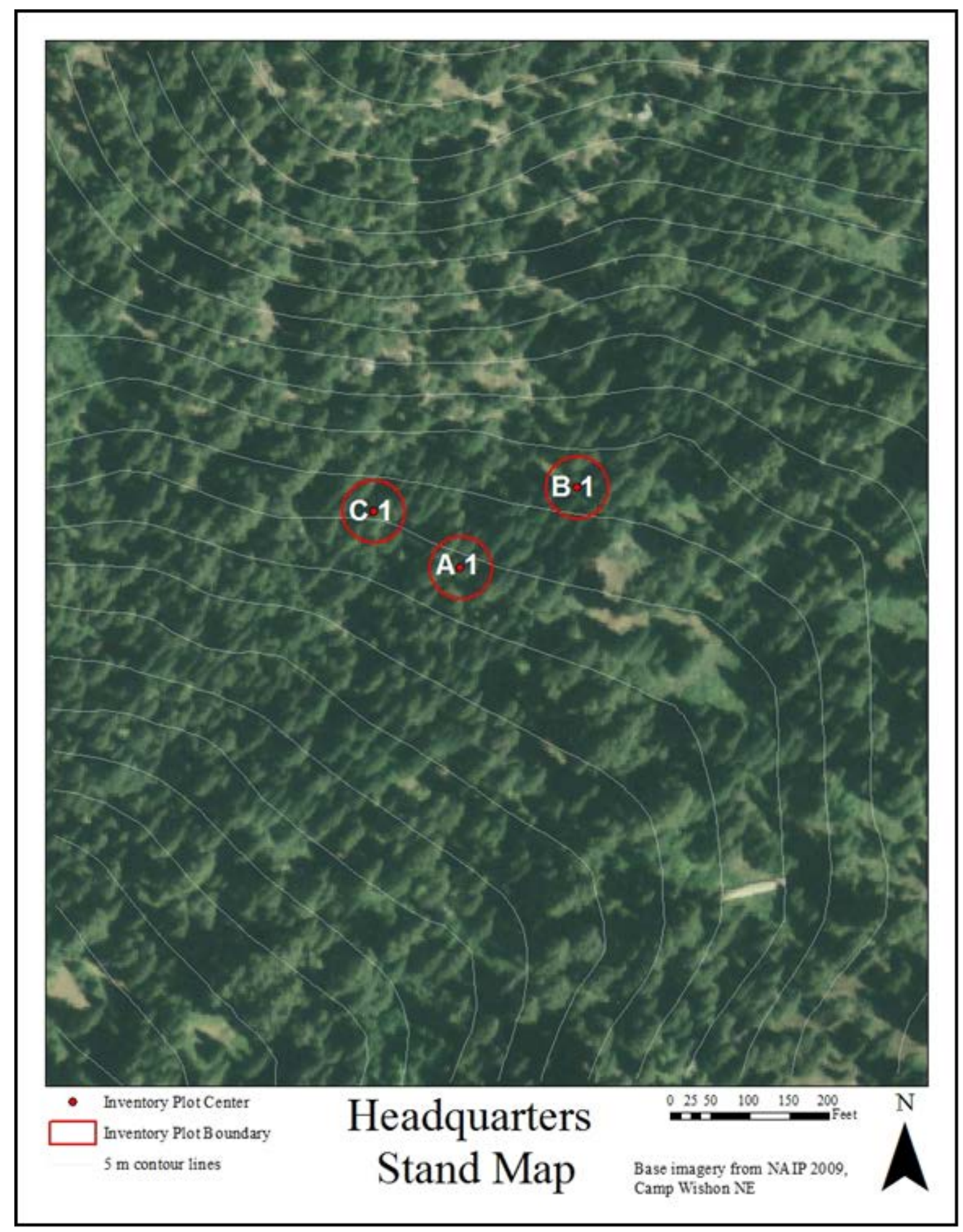

Page 240 


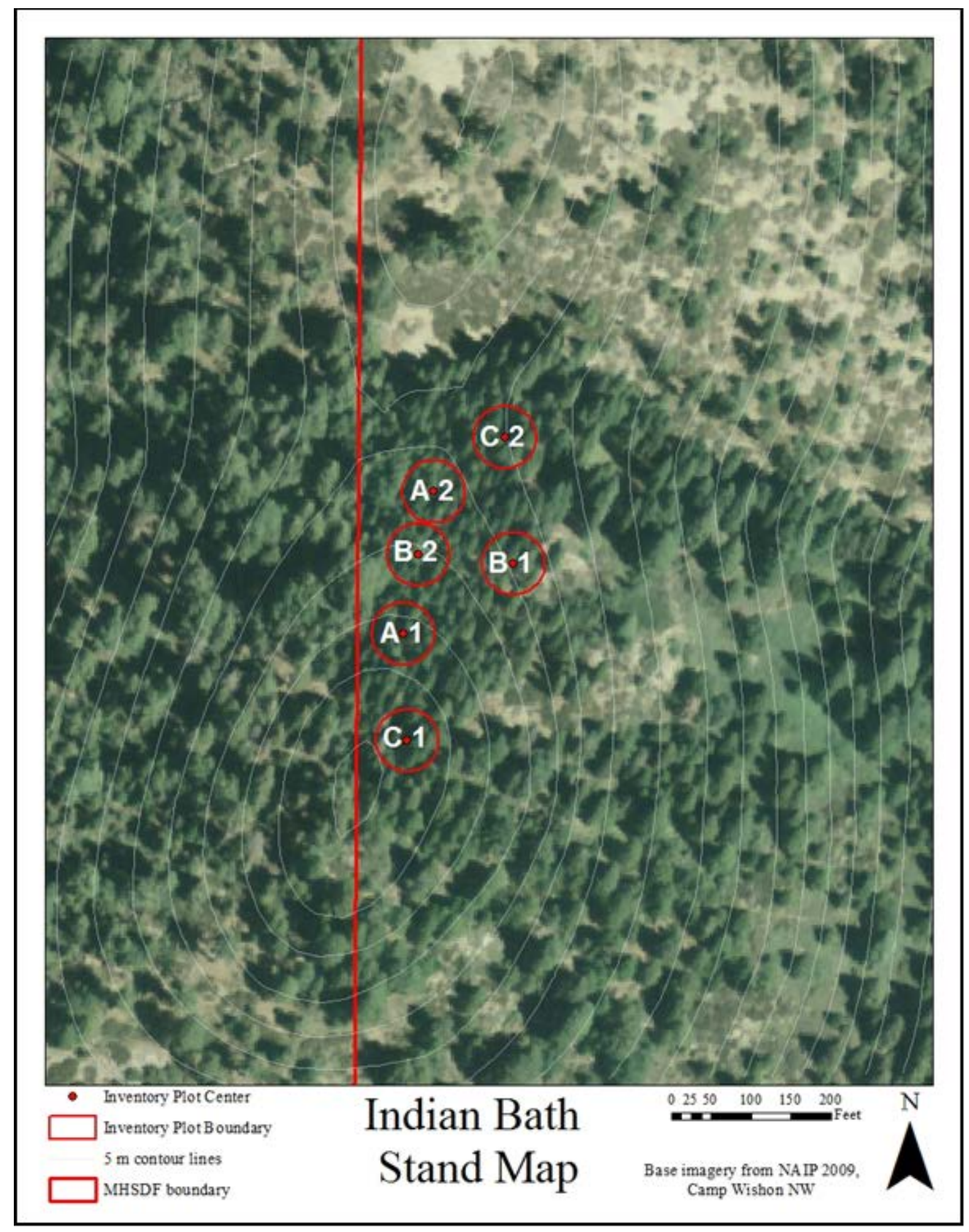

Page 241 


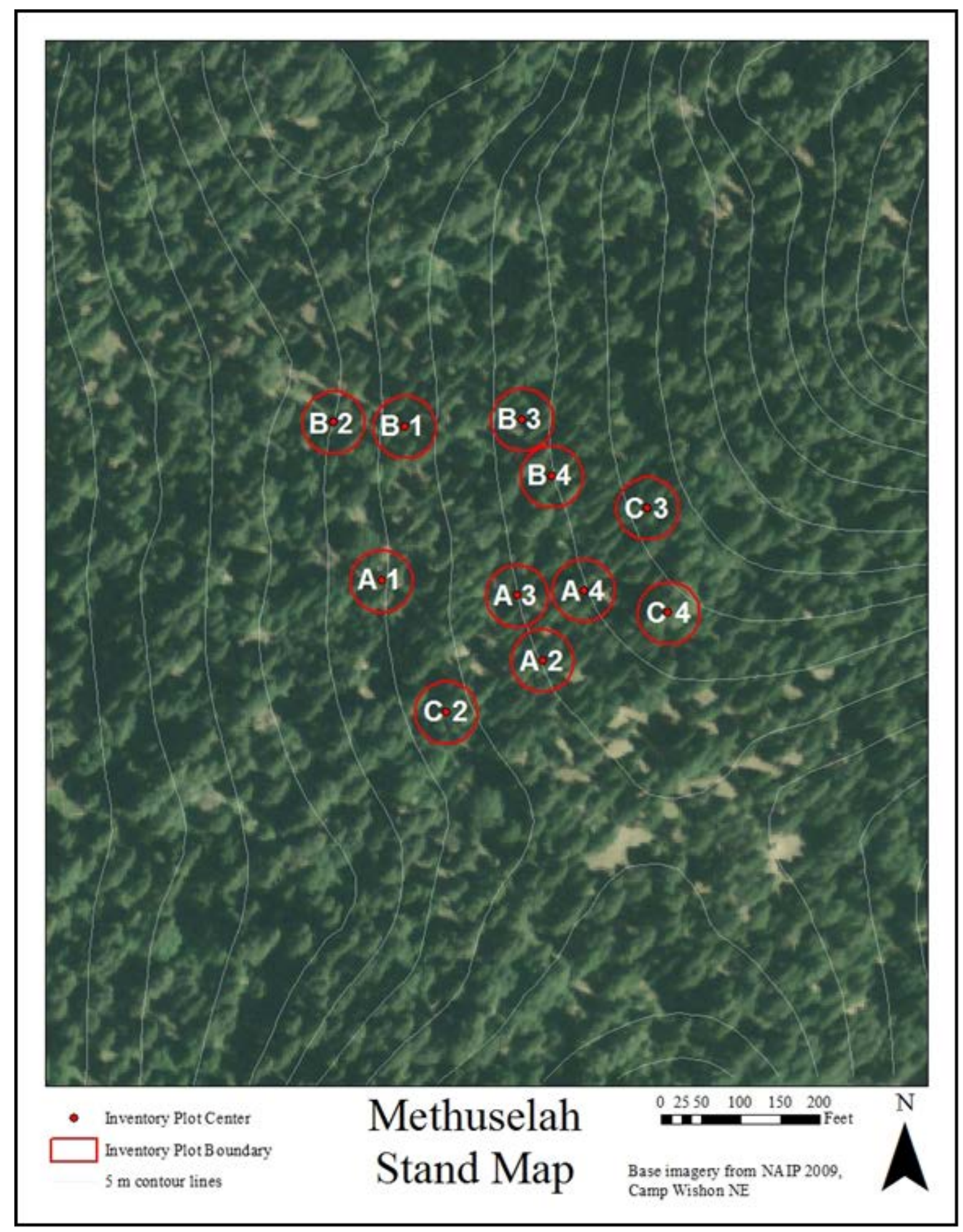

Page 242 


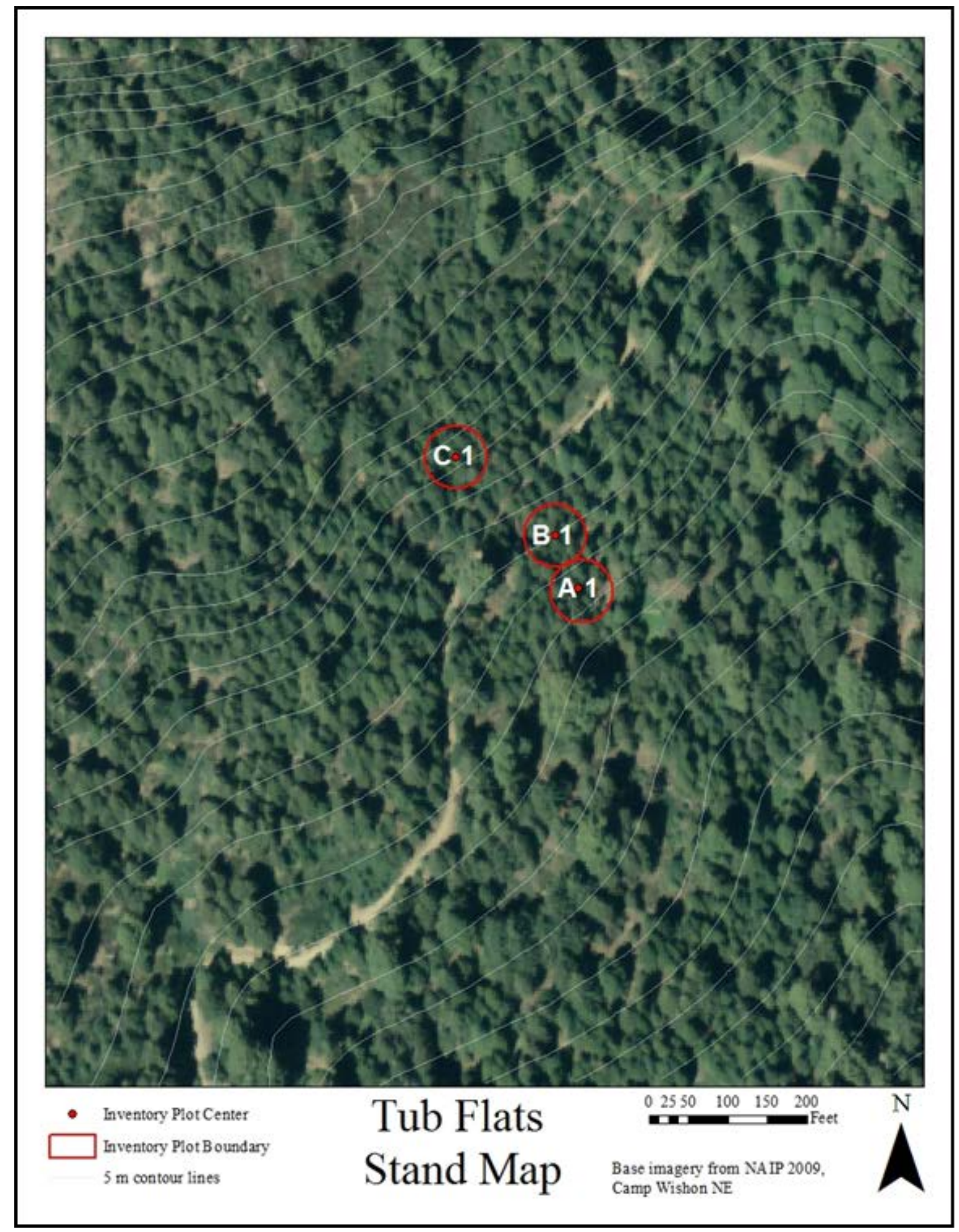

Page 243 


\section{APPENDIX I}

Pre/Post Treatment Plot Pictures

Located in Supplementary Files

Page 244 
APPENDIX J

MHDSF Volume Equations

Page 245 
Mountain Home Demonstration State Forest

Volume Equations

\begin{tabular}{|c|c|c|c|c|}
\hline & & $\mathrm{a}$ & $\mathrm{b}$ & $\mathrm{C}$ \\
\hline \multirow[t]{2}{*}{ Giant Sequoia } & $\mathrm{CF}$ & 0.002438339 & 1.694874 & 1.098957 \\
\hline & $\mathrm{BF}$ & 0.001682608 & 1.755956 & 1.490641 \\
\hline \multirow[t]{2}{*}{ Ponderosa Pine } & $\mathrm{CF}$ & 0.0046019 & 1.764829 & 0.951568 \\
\hline & $\mathrm{BF}$ & 0.0011752 & 2.139430 & 1.322741 \\
\hline \multirow[t]{2}{*}{ Sugar Pine } & $\mathrm{CF}$ & 0.0127581 & 2.115143 & 0.485265 \\
\hline & $\mathrm{BF}$ & 0.0042926 & 2.444471 & 0.833562 \\
\hline \multirow[t]{2}{*}{ Incense Cedar } & $\mathrm{CF}$ & 0.0075869 & 1.750414 & 0.838679 \\
\hline & $\mathrm{BF}$ & 0.0010465 & 1.935883 & 1.480513 \\
\hline \multirow[t]{2}{*}{ White Fir } & $\mathrm{CF}$ & 0.0141475 & 1.790957 & 0.731500 \\
\hline & $\mathrm{BF}$ & 0.0266830 & 1.765320 & 1.013663 \\
\hline
\end{tabular}

\begin{tabular}{|c|l|}
$\begin{array}{c}\text { Standard Volume } \\
\text { Equation }\end{array}$ & \multicolumn{1}{|c|}{$\mathrm{V}=\mathrm{a} \mathrm{D}^{\wedge} \mathrm{b} \mathrm{H}^{\wedge} \mathrm{C}$} \\
$\mathrm{V}=$ volume in cubic or board feet \\
$\mathrm{D}=$ diameter at breast height outside bark \\
$\mathrm{H}=$ total height in feet \\
a, b, c = regression coefficients
\end{tabular}


APPENDIX K

Special Investigation of Observed Second-Growth Giant Sequoia Mortality

Page 247 


\section{Special Investigation of Observed Second-Growth Giant Sequoia Mortality}

Two young-growth giant sequoia trees suddenly died during the summer of 2009 and 2010. The first tree was within an inventory plot for the long-term young-growth giant sequoia study which is the topic of this thesis. The tree was green and healthy on $7 / 14 / 09$, then on $8 / 4 / 09$ the crown was $2 / 3$ brown and by $9 / 2 / 09$ the entire crown was brown and likely dead. On 10/29/09 Dr. Douglas Piirto and Joshua Soderlund collected insects found at the base of the dead giant sequoia tree. Dr. David Wood identified Tenebrionidae and Lygaediae spp., and it was determined that neither insect caused the tree's death. The second tree was located along a road and on 8/2/10 the crown was $1 / 3$ brown and the bottom 6 feet $(1.8 \mathrm{~m})$ was wrapped in plastic to trap any emerging insects. On $8 / 24 / 10$ the crown was $2 / 3$ brown and the standing tree was investigated for insect colonization by Kim Camilli and Joshua Soderlund. Cal Fire felled the tree and cut the lower 6 feet $(1.8 \mathrm{~m})$ into one foot $(0.3 \mathrm{~m}) \log$ sections for further study. Sections were wrapped in plastic and then wire mesh and put in an office for rearing of insects. On 10/27/10 Serropalpus substriatus (Haldeman) was found in wire mesh. Serropalpus sp. specifically Serropalpus barbatus (Schall) has been recorded on coast redwood (Sequoia sempervirens) [D.Don] Engl.; it was collected as a larva that had bored into the sapwood of a recently dead tree (De Leon, 1952). Giant sequoia is potentially now a new record for S. substriatus after checking with nine separate entomology museums. On 8/13/11 the log sections were dissected and two distinct larvae were found, flat-headed and round-headed borers. Dr. Darren Polluck from Eastern New Mexico University identified them as cerambycid and buprestid from a picture provided by Kim Camilli. 
All insects collected and identified are secondary and not primary invaders. Cause of death for these young-growth giant sequoias is still not known and further investigation is needed. A poster was presented at the 2011 California Forest Pest Council $60^{\text {th }}$ Annual Meeting (Figure 17).

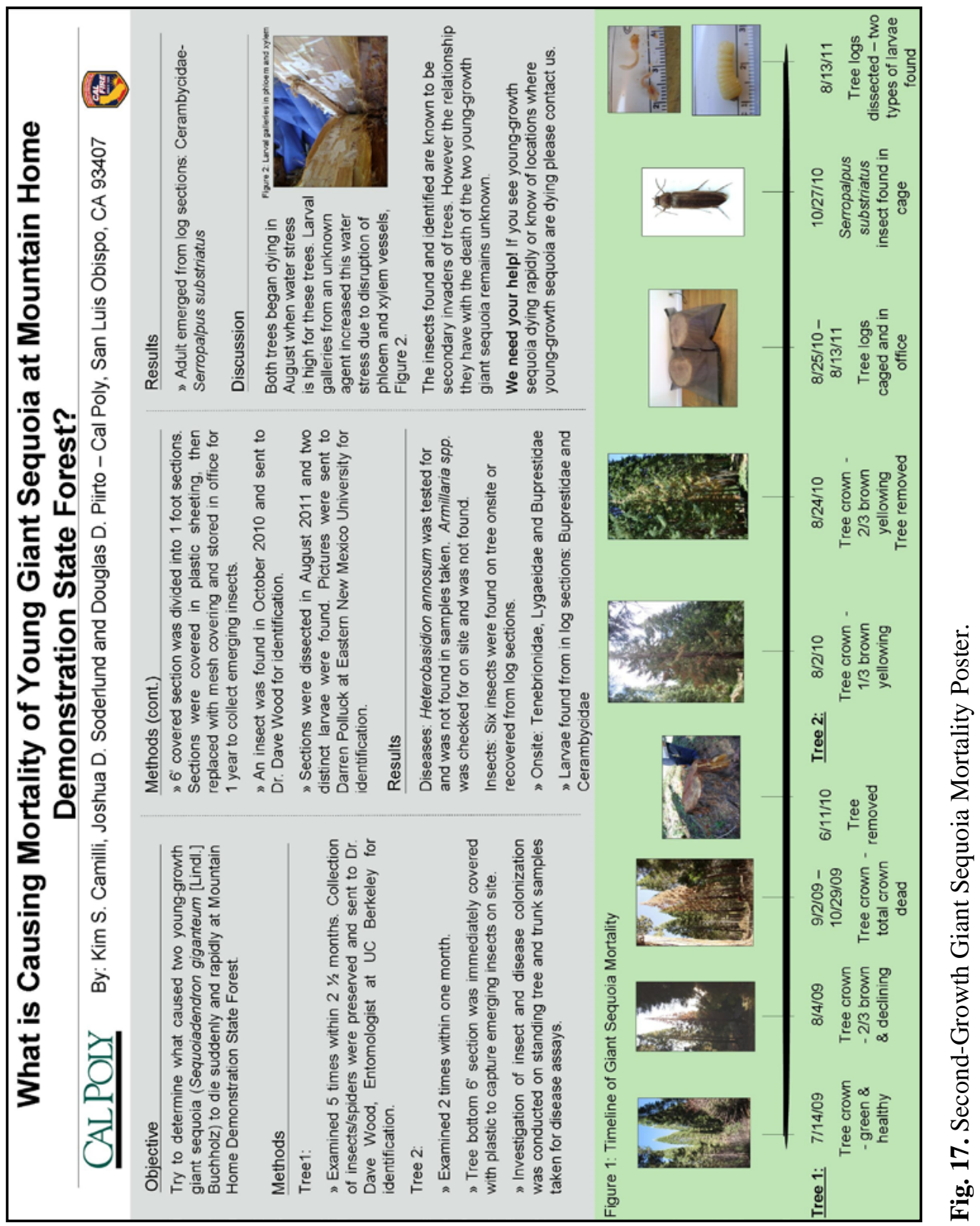

Page 249 
Page 250 